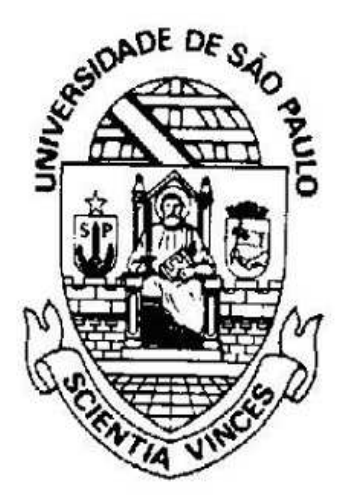

\author{
UNIVERSIDADE DE SÃO PAULO \\ ESCOLA DE COMUNICAÇÕES E ARTES \\ DEPARTAMENTO DE MÚSICA
}

ELIEL ALMEIDA SOARES

\title{
A utilização de elementos e figuras de retórica nos Ofertórios de André da Silva Gomes
}




\section{ELIEL ALMEIDA SOARES}

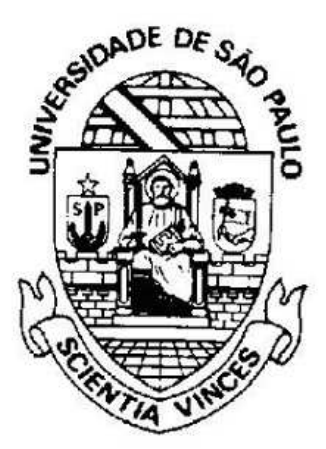

\section{A utilização de elementos e figuras de retórica nos Ofertórios de André da Silva Gomes}

Dissertação apresentada junto ao Programa de Pós-Graduação em Música, Área de Concentração: Musicologia, Linha de Pesquisa: História, Estilo e Recepção, da Escola de Comunicações e Artes da Universidade de São Paulo, como exigência parcial para obtenção do título de Mestre em Música, sob a orientação do Prof. Dr. Diósnio Machado Neto.

São Paulo, 2012 
Autorizo a reprodução e divulgação total ou parcial deste trabalho, por qualquer meio convencional ou eletrônico, para fins de estudo e pesquisa, desde que citada a fonte.

SOARES, Eliel Almeida. A utilização de elementos e figuras de retórica nos Ofertórios de André da Silva Gomes. 461 f. Dissertação (Mestrado) Programa de Pós-Graduação em Música, Escola de Comunicações e Artes, Universidade de São Paulo (USP), São Paulo, 2012.

\section{Catalogação na publicação Serviço de Biblioteca e Documentação Escola de Comunicações e Artes da Universidade de São Paulo}

Soares, Eliel Almeida

A utilização de elementos e figuras de retórica nos Ofertórios de André da Silva Gomes / Eliel Almeida Soares - São Paulo: E. A. Soares, 2012. 461 p. : il.

Dissertação (Mestrado) - Escola de Comunicações e Artes / Universidade de São Paulo.

Orientador: Diósnio Machado Neto

1. Retórica 2. Ofertórios 3. Música - Brasil 4. Análise musical 5. Gomes, André da Silva, 1752-1844 I. Machado Neto, Diósnio II. Título

CDD 21. ed. -780 
Nome: SOARES, Eliel Almeida.

Título: A utilização de elementos e figuras de retórica nos Ofertórios de André da Silva Gomes

Dissertação apresentada à Escola de Comunicações e Artes da Universidade de São Paulo para obtenção do título de Mestre em Música

Aprovado em:

\section{Banca Examinadora}

Prof. Dr. Instituição:

Julgamento: Assinatura:

Prof. Dr. Instituição:

Julgamento: Assinatura:

Prof. Dr. Instituição:

Julgamento: Assinatura: 
A Deus, que sempre me sustém com sua força e benevolência.

A meus pais, Valmir e Luzia, por proporcionar esse momento impar em minha vida. 


\section{AGRADECIMENTOS}

Ao meu orientador, Prof. Dr. Diósnio Machado Neto, pela amizade, pelas indicações, por incentivar sempre a pesquisa minuciosa, com critérios éticos, responsáveis e de qualidade, pelo estimulo ao processo criativo na dissertação pelo viés da contextualização seja das fontes ou referências bibliográficas. Enfim, pelas orientações e por avalizar e acreditar neste trabalho.

À Prof ${ }^{a}$. Dr ${ }^{\text {a }}$. Monica Isabel Lucas, pelos esclarecimentos e contributos nas questões relacionadas à retórica em geral e musical.

Ao Prof. Dr. Rubens Russomano Ricciardi, pelos apoios dados desde minha graduação e por seus ensinamentos.

Ao Prof. Dr. Mário Vieira de Carvalho, pela indicação da Profạ. Ana Paixão.

Ao Prof. Dr. Rodolfo Nogueira Coelho de Souza, pelos incentivos nas análises sejam harmônicas, tópicas, hermenêuticas e retóricas.

À Prof ${ }^{a}$. Drạ. Ana Margarida Madeira Minhós Paixão, pelas indicações bibliográficas e no auxílio sobre retórica em Portugal.

À Profa ${ }^{\text {. }}$ Dr ${ }^{a}$. Cristina Isabel Vieira Fernandes, pela cooperação em assuntos concernentes à formação dos músicos portugueses no Seminário da Patriarcal.

Ao Prof. Dr. Régis Duprat, por sua sapiência, fonte relevante dessa pesquisa.

A ajuda financeira da CAPES.

Aos meus amigos e colegas, em especial, a Ronaldo Novaes, companheiro desde a graduação, além dos trabalhos juntamente realizados e Juliano de Oliveira companhia certa nos estudos.

Em síntese, a todos aqueles que direta e indiretamente me ajudaram nesta investigação. 


\section{RESUMO}

SOARES, Eliel Almeida. A utilização de elementos e figuras de retórica nos Ofertórios de André da Silva Gomes. 461 f. Dissertação (Mestrado) Programa de Pós-Graduação em Música, Escola de Comunicações e Artes, Universidade de São Paulo (USP), São Paulo, 2012.

O presente trabalho tem como proposta apresentar elementos e figuras de retórica inseridas na música de André da Silva Gomes, ou seja, os mecanismos adotados pelo autor nas estruturas de sua obra, primeiramente partindo de investigações dos contextos históricos de épocas anteriores e de seus contemporâneos, passando pelos importantes tratadistas e compositores que estudaram e a utilizaram, sua origem, sistematização e seu ápice no Barroco e possíveis aplicações no Classicismo. Da mesma forma, na dissertação se encontrará uma observação minuciosa sobre a relação texto-música, tomando por base algumas obras compostas por Silva Gomes. Em síntese, através de análises das partituras do compositor luso-brasileiro, mostraremos a utilização da retórica como elo entre a eloquência e persuasão por via de um discurso altamente planejado, organizado, desenvolvido em seus ofertórios e que seu conhecimento retórico se alinha ao saber da época.

Palavras-chave: Retórica, Ofertórios, Música Brasileira, André da Silva Gomes, Análise Musical. 


\section{ABSTRACT}

SOARES, Eliel Almeida. The use of elements and rhetorical figures in the Offertories of André da Silva Gomes. 461 f. Dissertação (Mestrado) Programa de Pós-Graduação em Música, Escola de Comunicações e Artes, Universidade de São Paulo (USP), São Paulo, 2012.

This paper aims to present elements and rhetorical figures inserted in the music of André da Silva Gomes, in other words, the mechanisms adopted by the author in the structures of his work, starting from investigations of the historical contexts of earlier times and his contemporaries, then important writers and composers who had studied and used it, its origin, organization and its apex in the Baroque, and also the possible application in the Classicism. Likewise, in the dissertation it is going to be found a detailed observation on the relationship text-music, based on some works composed by Silva Gomes. In summary, through analysis of the scores of the composer Luso-Brazilian, we will show the use of rhetoric as a link between eloquence and persuasion by means of a speech highly planned, organized and developed in his offertories which his rhetorical knowledge aligns with the knowledge of that time.

Keywords: Rhetoric, Offertories, Brazilian Music, André da Silva Gomes, Musical Analysis. 


\section{LISTAS DE FIGURAS}

\section{Exemplos:}

Figura 1: Figura Alegórica da Retórica

Figura 2: Figuras Alegóricas representando o ensino da Retórica e Música em Portugal 54

Figura 3: Salmo Beatus Vir, do compositor e aluno do Seminário José Joaquim dos Santos; cópia de André da Silva Gomes, de 1775.

Figura 4: Figura Alegórica do lluminismo 80

Figura 5: Passaporte do terceiro bispo de São Paulo, cuja comitiva participava André da Silva Gomes. 83

Figura 6: Bispo Dom Frei Manuel da Ressurreição e o Governador Dom Luiz Antônio de Souza Botelho Mourão. 85

Figura 7: Fachada Principal do Adjuva nos Deus et Immutemur, autografo de André da Silva Gomes, 1781 87

Figura 8: Tratado El porque de lá Musica (1672) de André Lorene. 93

Figura 9: Partitura original de André da Silva Gomes, primeira página de um Ofertório, Domine Jesus Christe 101

\section{LISTAS DE TABELAS}

\section{Exemplos:}

Tabela 1: Estrutura retórica e suas etapas................................................... 50

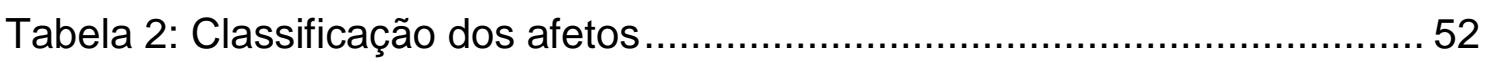

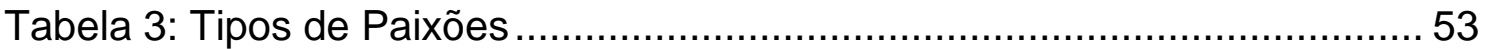

Tabela 4: Locus Topici encontrados no Ofertório da Missa de Quarta-feira de Cinzas de André da Silva Gomes 106 
Tabela 5: Figuras Retóricas encontradas no Ofertório da Missa de Quarta-feira de Cinzas de André da Silva Gomes.

Tabela 6: Curva Tonal do Ofertório da Missa de Quarta- feira de Cinzas...... 120

Tabela 7: Estrutura analítica do Ofertório.

Tabela 8: Locus Topici encontrados no Ofertório da Missa do Domingo da Paixão de André da Silva Gomes.

Tabela 9: Figuras Retóricas encontradas no Ofertório da Missa do Domingo da Paixão de André da Silva Gomes. 136

Tabela 10: Curva Tonal do Ofertório da Missa do Domingo da Paixão. 137

Tabela 11: Estrutura analítica do Ofertório. 138

Tabela 12: Locus Topici encontrados no Ofertório da Missa de Domingo de Ramos de André da Silva Gomes

Tabela 13: Figuras Retóricas encontradas no Ofertório da Missa de Domingo de Ramos de André da Silva Gomes 154

Tabela 14: Curva Tonal do Ofertório do Domingo de Ramos. 155

Tabela 15: Estrutura analítica do Ofertório. 157

Tabela 16: Locus Topici encontrados no Ofertório da Missa do Primeiro Domingo da Quaresma de André da Silva Gomes 159

Tabela 17: Figuras encontradas no Ofertório da Missa do Primeiro Domingo da Quaresma de André da Silva Gomes. 169

Tabela 18: Curva Tonal do Ofertório da Missa do Primeiro Domingo da Quaresma. 170

Tabela 19: Estrutura analítica do Ofertório. 171

Tabela 20: Locus Topici encontrados no Ofertório da Missa do Segundo Domingo da Quaresma de André da Silva Gomes 173 
Tabela 21: Figuras encontradas no Ofertório da Missa do Segundo Domingo da Quaresma de André da Silva Gomes.

Tabela 22: Curva Tonal do Ofertório da Missa do Segundo Domingo da Quaresma. 188

Tabela 23: Estrutura analítica do Ofertório 190

Tabela 24: Locus Topici encontrados no Ofertório da Missa do Terceiro Domingo da Quaresma de André da Silva Gomes. 193

Tabela 25: Figuras encontradas no Ofertório da Missa do Terceiro Domingo da Quaresma de André da Silva Gomes. 208

Tabela 26 Curva Tonal do Ofertório da Missa do Terceiro Domingo da Quaresma. 209

Tabela 27: Estrutura analítica do Ofertório 210

Tabela 28: Locus Topici encontrados no Ofertório da Missa do Quarto Domingo da Quaresma de André da Silva Gomes 212

Tabela 29: Figuras encontradas no Ofertório da Missa do Quarto Domingo da Quaresma de André da Silva Gomes. 234

Tabela 30: Curva Tonal do Ofertório da Missa do Quarto Domingo da Quaresma. 235

Tabela 31: Estrutura analítica do Ofertório. 237

Tabela 32: Locus Topici encontrados no Ofertório da Missa do Primeiro Domingo do Advento de André da Silva Gomes 239

Tabela 33: Figuras encontradas no Ofertório da Missa do Primeiro Domingo do Advento de André da Silva Gomes 259

Tabela 34: Curva Tonal do Ofertório da Missa do Primeiro Domingo do Advento 260

Tabela 35: Estrutura analítica do Ofertório. 262 
Tabela 36: Locus Topici encontrados no Ofertório da Missa do Segundo Domingo do Advento de André da Silva Gomes 264

Tabela 37: Figuras encontradas no Ofertório da Missa do Segundo Domingo do Advento de André da Silva Gomes 277

Tabela 38: Curva Tonal do Ofertório da Missa do Segundo Domingo do Advento 278

Tabela 39: Estrutura analítica do Ofertório 280

Tabela 40: Locus Topici encontrados no Ofertório da Missa do Terceiro Domingo do Advento de André da Silva Gomes 282

Tabela 41: Figuras encontradas no Ofertório da Missa do Terceiro Domingo do Advento de André da Silva Gomes 303

Tabela 42: Curva Tonal do Ofertório da Missa do Terceiro Domingo do Advento 304

Tabela 43: Estrutura analítica do Ofertório 306

Tabela 44: Locus Topici encontrados no Ofertório da Missa da Quarta-feira das Têmporas do Advento de André da Silva Gomes 308

Tabela 45: Figuras encontradas no Ofertório da Missa da Quarta-feira das Têmporas do Advento de André da Silva Gomes 329

Tabela 46: Curva Tonal do Ofertório da Missa da Quarta-feira das Têmporas do Advento 330

Tabela 47: Estrutura analítica do Ofertório 332

Tabela 48: Locus Topici encontrados no Ofertório da Missa de Natal de André da Silva Gomes (Primeiro Movimento) 334

Tabela 49: Locus Topici encontrados no Ofertório da Missa de Natal de André da Silva Gomes (Segundo Movimento)..... 335

Tabela 50: Figuras encontradas no Ofertório da Missa de Natal de André da Silva Gomes 364 
Tabela 51: Curva Tonal do Ofertório da Missa de Natal (Primeiro Movimento) 364

Tabela 52: Estrutura analítica do Ofertório (Primeiro Movimento)..... 366

Tabela 53: Curva Tonal do Ofertório da Missa de Natal (Segundo Movimento) 367

Tabela 54: Estrutura analítica do Ofertório (Segundo Movimento). 368

Tabela 55: Divisão Litúrgica da Missa da Ascenção do Senhor. 371

Tabela 56: Locus Topici encontrados no Ofertório da Missa da Ascenção do Senhor de André da Silva Gomes (Primeiro Movimento) 372

Tabela 57: Locus Topici encontrados no Ofertório da Missa da Ascenção do Senhor de André da Silva Gomes (Segundo Movimento). 373

Tabela 58: Figuras encontradas no Ofertório da Missa da Ascenção do Senhor de André da Silva Gomes 398

Tabela 59: Curva Tonal do Ofertório da Missa da Ascenção do Senhor (Primeiro Movimento) 399

Tabela 60: Estrutura analítica do Ofertório (Primeiro Movimento). 401

Tabela 61: Curva Tonal do Ofertório da Missa da Ascenção do Senhor (Segundo Movimento) 401

Tabela 62: Estrutura analítica do Ofertório (Segundo Movimento). 402

Tabela 63: Locus Topici encontrados no Ofertório da Missa da Conversão de São Paulo Apóstolo de André da Silva Gomes (Primeiro Movimento) 405

Tabela 64: Locus Topici encontrados no Ofertório da Missa da Conversão de São Paulo Apóstolo de André da Silva Gomes (Segundo Movimento). 405

Tabela 65: Figuras encontradas no Ofertório da Missa da Conversão de São Paulo Apóstolo de André da Silva Gomes 430 
Tabela 66: Curva Tonal do Ofertório da Missa da Conversão de São Paulo Apóstolo (Primeiro Movimento) 431

Tabela 67: Estrutura analítica do Ofertório (Primeiro Movimento). 433

Tabela 68: Curva Tonal do Ofertório da Missa da Conversão de São Paulo Apóstolo (Segundo Movimento) 433

Tabela 69: Estrutura analítica do Ofertório (Segundo Movimento). 434

\section{LISTAS DE EXEMPLOS MUSICAIS}

\section{Exemplos:}

Exemplo 1: Cum Sancto Spiritu da Missa a Cinco Vozes de André da Silva Gomes Preceito $2^{\circ}$-Todo Motivo, Tema, Tensão ou Passo em uma Fuga deve constar três partes ou Condições, a saber, Princípio, Meio e Fim 96

Exemplo 2: Parte introdutória do Kyrie // da Missa a Oito vozes de André da Silva Gomes e figuras de imitação, de inversão de motivos e de retórica como a Fuga Realis. 97

Exemplos 3 a 13: Figuras e Elementos Retóricos no Ofertório da Missa de Quarta -feira de Cinzas 107-116

Exemplos 14 a 22: Figuras e Elementos Retóricos no Ofertório da Missa do Domingo da Paixão 124-132

Exemplos 23 a 32: Figuras e Elementos Retóricos no Ofertório da Missa Ofertório da Missa de Domingo de Ramos $142-151$

Exemplos 33 a 38 : Figuras e Elementos Retóricos no Ofertório da Missa do Primeiro Domingo da Quaresma $160-166$

Exemplos 39 a 49: Figuras e Elementos Retóricos no Ofertório da Missa do Segundo Domingo da Quaresma. 174-183

Exemplos 50 a 61: Figuras e Elementos Retóricos no Ofertório da Missa do Terceiro Domingo da Quaresma 193-203 
Exemplos 62 a 75: Figuras e Elementos Retóricos no Ofertório da Missa do Quarto Domingo da Quaresma $214-228$

Exemplos 76 a 87: Figuras e Elementos Retóricos no Ofertório da Missa do Primeiro Domingo do Advento. $241-252$

Exemplos 88 a 98: Figuras e Elementos Retóricos no Ofertório da Missa do Segundo Domingo do Advento. 265-273

Exemplos 99 a 112: Figuras e Elementos Retóricos no Ofertório da Missa do Terceiro Domingo do Advento 284-297

Exemplos 113 a 125: Figuras e Elementos Retóricos no Ofertório da Missa da Quarta-feira das Têmporas do Advento. 309-322

Exemplos 126 a 150: Figuras e Elementos Retóricos no Ofertório da Missa de Natal. 337-358

Exemplos 151 a 170: Figuras e Elementos Retóricos no Ofertório da Missa da Ascenção do Senhor. 374-392

Exemplos 171 a 190: Figuras e Elementos Retóricos no Ofertório da Missa da Conversão de São Paulo Apóstolo. 406-426

\section{ABREVITURAS}

Bibliotecas e acervos de fontes primárias:

ACMSP - Arquivo da Cúria Metropolitana de São Paul

BNP - Biblioteca Nacional de Portugal

BNB - Biblioteca Nacional do Brasil

\section{Exemplos Musicais, Etimológicos e Gramaticais:}

Adj Adjetivo

Art Artigo

Coord. Coordenação 

D Dominante
D/D Dominante da Dominante
D/S Dominante da Subdominante

Ecles Eclesiástico

$\begin{array}{ll}\text { Ed } & \text { Edição } \\ \mathbf{f} & \text { Folha }\end{array}$

Filos Filosofia

fr- $\quad$ Francês

gr Grego

Hist História

Intr Introdução

lat Latim

Lóg Lógica

Mús Música (o)

Org. Organização

p Página

rel Relacionado

ret. Retórica

S Subdominante

Sp Subdominante Paralela (Relativa)

S/S Subdominante da Subdominante

S.f Substantivo Feminino

S.m Substantivo Masculino 


$\begin{array}{ll}\text { T } & \text { Tônica } \\ \text { Tp } & \text { Tônica Paralela (Relativa) } \\ \text { Trad } & \text { Tradução } \\ \text { Univ } & \text { Universidade } \\ \text { Var } & \text { Variação } \\ \text { Vb } & \text { Verbo } \\ \text { vol } & \text { Volume }\end{array}$

Instituições, Escolas e Departamentos Superiores de Pesquisa e Publicação:

ANPPOM Associação Nacional de Pesquisa e Pós-Graduação em Música

ECA Escola de Comunicações e Artes

EDUSP Editora da Universidade de São Paulo

EPU Editora Pedagógica e Universitária

FFLCH Faculdade de Filosofia, Letras e Ciências Humanas

FFCLRP Faculdade de Filosofia, Ciências e Letras de Ribeirão Preto

IA Instituto de Artes

IFCH Instituto de Filosofia, Ciências e História

PUC-RJ Pontifícia Universidade Católica do Rio de Janeiro

PUC-SP Pontifícia Universidade Católica de São Paulo

UBI Universidade Beira Interior

UC Universidade de Coimbra

UE Universidade de Évora

UEMG Universidade Estadual de Minas Gerais 
UERJ Universidade Estadual do Rio de Janeiro

UFBA Universidade Federal da Bahia

UFG Universidade Federal de Goiás

UFMG Universidade Federal de Minas Gerais

UFPR Universidade Federal do Paraná

UFRJ Universidade Federal do Rio de Janeiro

UFU Universidade Federal de Uberlândia

UL Universidade de Lisboa

UN Universidade de Nice

UnB Universidade de Brasília

UNESP Universidade Estadual Paulista "Júlio de Mesquita Filho"

UNICAMP Universidade Estadual de Campinas

Unirio Universidade Federal do Estado do Rio de Janeiro

UNL Universidade Nova de Lisboa

UP Universidade do Porto

USP Universidade de São Paulo

Localizações Geográficas:

BA Bahia

BRA Brasil

ESP Espanha

FRA França

GRE Grécia

ITA Itália

MG Minas Gerais 
PT Portugal

RJ Rio de Janeiro

SP São Paulo

Nomes e Indicações de Autoria:

ASG André da Silva Gomes

JMNG José Mauricio Nunes Garcia

MDO Manoel Dias de Oliveira

\section{Ofertórios}

Adv1. Ofertório da Missa do Primeiro Domingo do Advento

Adv2. Ofertório da Missa do Segundo Domingo do Advento

Adv3. Ofertório da Missa do Terceiro Domingo do Advento

Adv4. Ofertório da Missa da Quarta-Feira das Têmporas do Advento

Ascd. Ofertório da Missa da Ascensão do Senhor

Cinz. Ofertório da Missa da Quarta-Feira de Cinzas

Cvsp. Ofertório da Missa da Conversão de São Paulo Apóstolo

Natl. Ofertório da Missa de Natal

Pass. $\quad$ Ofertório da Missa do Domingo da Paixão

Qua1. Ofertório da Missa do Primeiro Domingo da Quaresma

Qua2. Ofertório da Missa do Segundo Domingo da Quaresma

Qua3. Ofertório da Missa do Terceiro Domingo da Quaresma

Qua4. Ofertório da Missa do Quarto Domingo da Quaresma

Rmos. Ofertório da Missa do Domingo de Ramos

Referências Bíblicas e Religiosas:

a.C Antes de Cristo

a.D Depois de Cristo

Anun. Anúncio 
At Livro de Atos dos Apóstolos

Cap. Capítulo

1Co 1a $^{\text {a }}$ epistola aos Coríntios

Dn. Livro de Daniel

Gn. Livro de Gênesis

Is Livro de Isaías

Jo Evangelho de João

Jr Livro de Jeremias

Lc Evangelho de Lucas

Mc Evangelho de Marcos

Mt Evangelho de Mateus

Of. Ofertório

Ps/Sal Livro dos Salmos

Prov Livro de Provérbios

Vers. Versículo 


\section{SUMÁRIO}

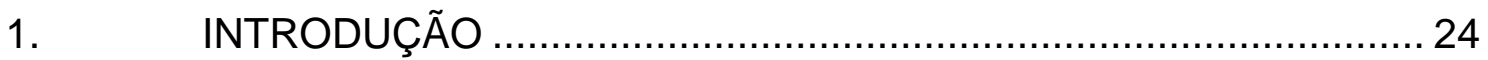

2. RETÓRICA: SUA EVOLUÇÃO .................................................. 30

2.1. Natureza da retórica e suas definições ………............................. 31

2.2. A retórica da Antiguidade até a Idade Média.................................. 34

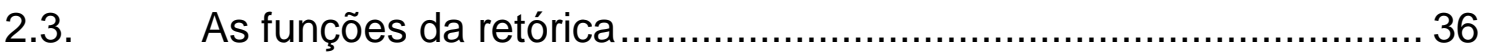

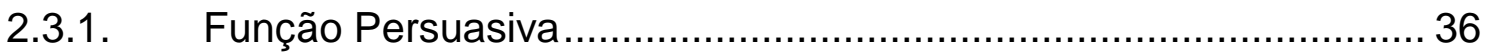

2.3.2. Função Hermenêutica ............................................................ 37

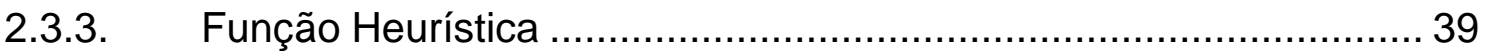

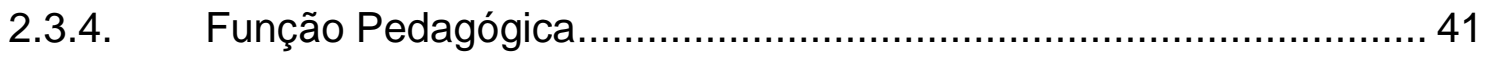

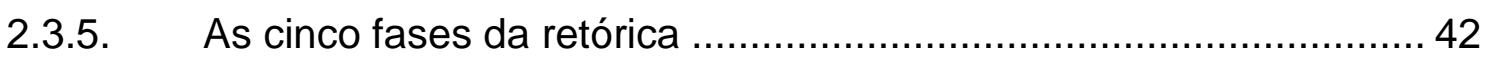

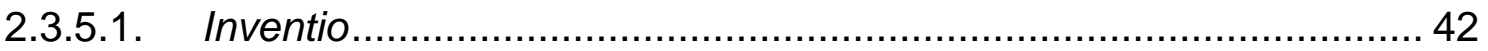

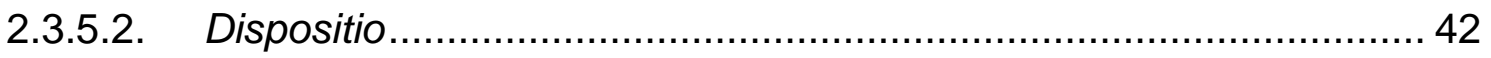

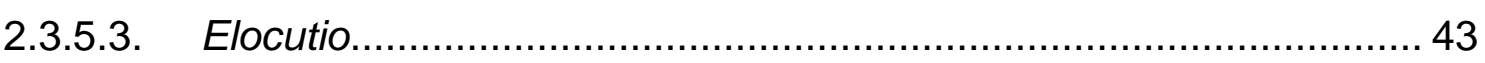

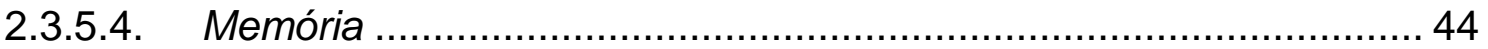

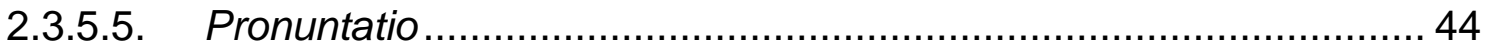

2.4. A retórica da Idade Média até a Idade Moderna ............................ 44

2.5. Retórica e Música.................................................................. 46

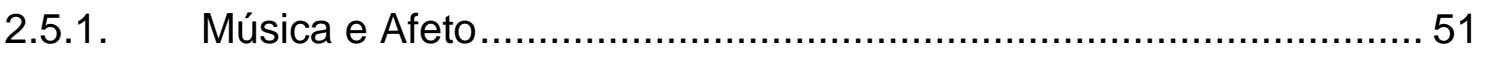

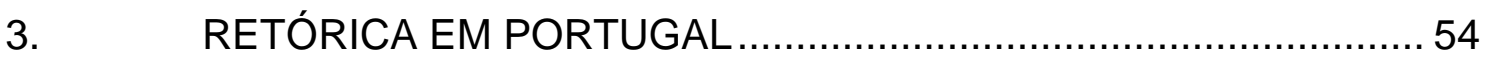

3.1. Arte Retórica Portuguesa ...................................................... 55

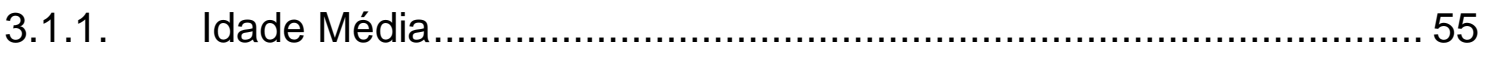




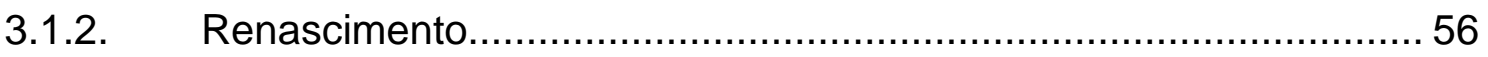

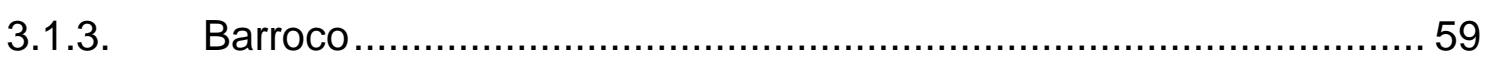

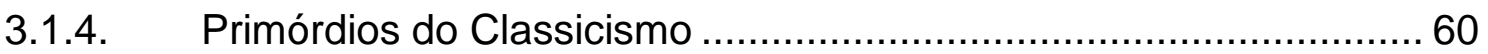

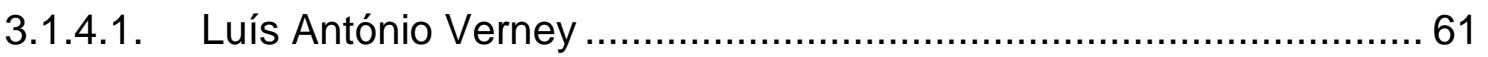

3.2. Relação entre música e retórica em Portugal.................................. 65

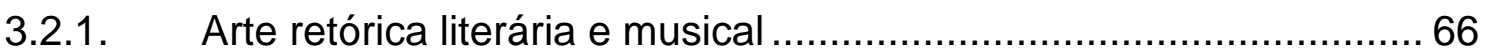

3.2.2. Paralelismos entre poesia, música e retórica ................................ 67

3.2.2.1. Proximidade destas relações com diferentes culturas......................69

3.3. O Sistema de formação musical em Portugal: o Real Seminário de

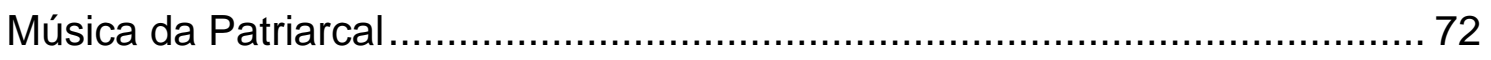

3.3.1. Organização e sistema de ensino: a partir dos Estatutos de

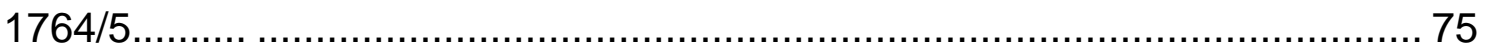

3.3.1.1. Alguns dos alunos ilustres do Seminário...................................... 78

4. RETÓRICA NA MÚSICA DE ANDRÉ DA SILVA GOMES ...............80

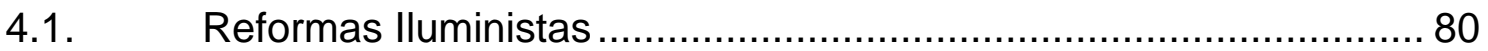

4.1.1. O Programa lluminista na Capitania de São Paulo ......................... 83

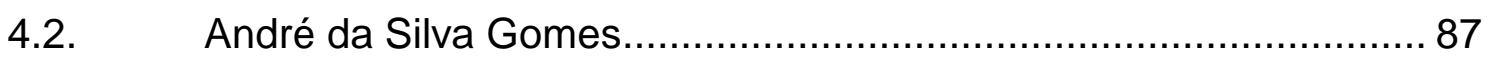

4.3. Consciência Retórica................................................................ 90

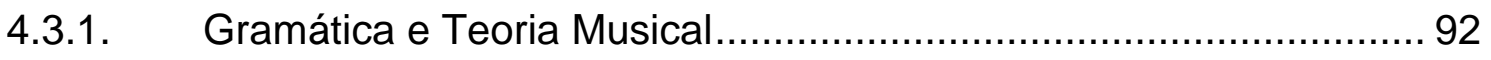

4.3.2. Discurso e Figuras Retóricas ………………............................. 94

5. ANÁLISE RETÓRICA EM ANDRÉ DA SILVA GOMES:

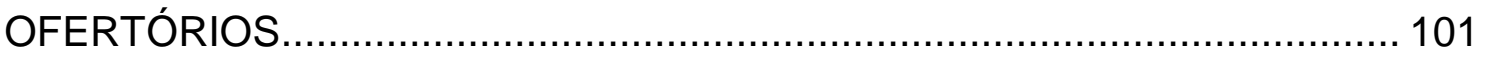

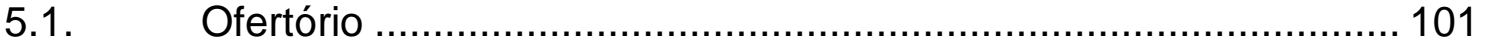

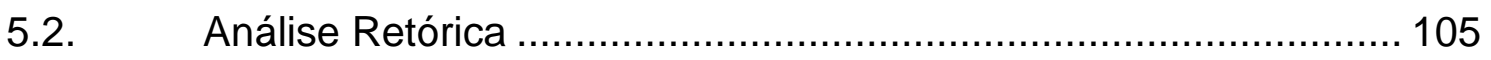


5.2.1. Ofertório da Missa de Quarta-Feira de Cinzas ............................ 105

5.2.2. Ofertório da Missa do Domingo da Paixão …………………....... 122

5.2.3. Ofertório da Missa de Domingo de Ramos................................... 139

5.2.4. Ofertório da Missa do Primeiro Domingo da Quaresma ................ 158

5.2.5. Ofertório da Missa do Segundo Domingo da Quaresma................ 172

5.2.6. Ofertório da Missa do Terceiro Domingo da Quaresma ................ 191

5.2.7. Ofertório da Missa do Quarto Domingo da Quaresma ................... 211

5.2.8. Ofertório da Missa do Primeiro Domingo do Advento..................... 238

5.2.9. Ofertório da Missa do Segundo Domingo do Advento................... 263

5.2.10. Ofertório da Missa do Terceiro Domingo do Advento .................... 281

5.2.11. Ofertório da Missa da Quarta-Feira das Têmporas do Advento .... 307

5.2.12. Ofertório da Missa de Natal ........................................................ 333

5.2.13. Ofertório da Missa da Ascensão do Senhor .................................. 369

5.2.14. Ofertório da Missa da Conversão de São Paulo Apóstolo.............. 403

6. CONCLUSÃO

7. REFERÊNCIAS BIBLIOGRAFICAS ........................................... 441

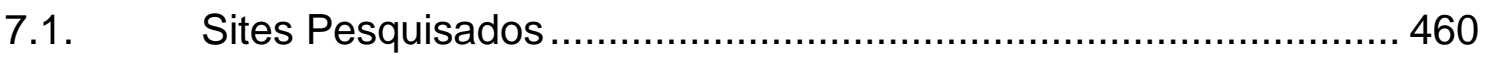




\section{INTRODUÇÃO}

Estudar história, estilo, e recepção musical, requer do pesquisador, dentre vários conhecimentos ${ }^{1}$, o da gramática e sua adequação na utilização da linguagem musical. Tal conhecimento não se dá meramente por exclusividades ou relatividades, mas pelo conjunto de fatores tais como: contextos sociais, políticos, históricos e até estéticos. Assim como o estudo da forma, harmonia e contraponto servem de acréscimo para quem compõe ou interpreta um instrumento, a aplicação da retórica nas músicas, que foram produzidas entre o final do século XVI e primórdios do XIX, servem de subsídio para compreender a invocação dos grandes mestres da composição aos recursos retóricos no enriquecimento do discurso musical, proporcionando, assim, a capacidade de despertar, mover e controlar os afetos do ouvinte ${ }^{2}$.

A teorização e sistematização retórico-musical, a partir do século XVI, deu-se através de uma série de conjunturas históricas relacionadas aos grandes pensadores, tratadistas e compositores, ocorridas desde Antiguidade, por exemplo, as ideias discursivas de Aristóteles, além de suas obras de cunho poético e retórico, do Manual de Oratória, de Cícero, fundamental para o esclarecimento de quem quer exercer o domínio da arte de falar em público e, ao mesmo tempo, objetiva maior sucesso em convencer o ouvinte, ou por Quintiliano que exaltava a virtude do bem-dizer e pensar (PLEBE, 1978, p.51). Posteriormente, pela relação entre retórica e educação, através do viés universitário na Idade Média, o qual seria muito propagado por Martin Lutero e pela música na Renascença, sob uma perspectiva humanística. No Barroco, por tratadistas e compositores preocupados em atentar não só na ordenação dos elementos, das figuras e sua vinculação com a música, mas, também para os sentimentos de quem está ouvindo, assim como no resultado em que esses

\footnotetext{
${ }^{1}$ Estes conhecimentos seriam além da gramática, os formais, estruturais e interpretativos, ou seja, práticos (práxis), teóricos (theoria) e de produção do compositor (poiesis).

${ }^{2}$ E importante destacar que na Europa do século XVIII e início do XIX, a representação de afetos, de um texto, de gestos até mesmo movimentos e fenômenos da natureza, por exemplo, era um aspecto relevante para a significação nas obras musicais, para Mattheson, por exemplo, o que ocorria [na música] sem ter afetos louváveis pode ser desconsiderado, ou seja, literalmente era considerado um nada, que não faz nada e não significa nada. "Everything that occurs without praiseworthy affections [in music] can be considered nothing and means nothing", (BUELOW, 1980, apud SCHREINER, 2007, p.1).
} 
afetos poderiam proporcionar seja no despertar das emoções ou na elevação para um plano espiritual, e, por fim, no Classicismo, onde alguns gêneros, estilos e composições mantinham essa tradição, além da preocupação dos autores no desempenho de suas obras perante o público.

Enfim, a utilização de elementos e figuras retóricas, aliados a um discurso altamente organizado, foram estruturas essenciais para a música Barroca e no início do Classicismo, não só pelo fato de elas disporem de instrumentos persuasivos e eloquentes, mas, igualmente, pela consumação de um parâmetro composicional, que, por sua vez, abrangeu toda a Europa e até mesmo o Brasil.

Da mesma forma, em Portugal, desde os tempos medievais, a retórica era exclusivamente um domínio da escolaridade. Como disciplina, a Retórica era dividida em duas frentes: uma preocupada com conceitos gramaticais, poéticos e retóricos, e a outra desenvolvia a arte de pregar, sempre amparada na palavra, ou seja, nos argumentos fundamentados nas estruturas retóricas pelos sacerdotes. Escolas como as de Coimbra e Alçobaça ${ }^{3}$ foram fundamentais para orientação e erudição do estudo retórico no país lusitano.

A partir da Renascença a Retórica torna-se mais elaborada no país lusitano, isto é, ela passa a ser vista de outra maneira pelos portugueses, devido ao fato de os humanistas desenvolverem uma metodologia, onde era relevante estudar os grandes autores clássicos, o que facilitava o conhecimento que se tornara mais direcionado e teorizado, tanto na prática da argumentação como na disposição do discurso. E, finalmente, no Barroco, onde os padres, sobretudo jesuítas, ensinavam a Retórica nas instituições superiores de Portugal e transmitiam-na com grande veemência. Por essa razão certamente, o compositor luso-brasileiro André da Silva Gomes deve ter sido influenciado por essas teorizações e sistematizações.

No Brasil Colonial, a retórica musical possivelmente esteve presente em obras de compositores como: Manoel Dias de Oliveira, José Maurício Nunes Garcia, José Joaquim Lobo de Mesquita, André da Silva Gomes, entre outros. Trabalhos, artigos e dissertações escritas por Maurício Dottori, Rodrigo Cardoso Affonso, Cláudia Schreiner, Robson Bessa Costa, Fausto Borém de

\footnotetext{
${ }^{3}$ No segundo capítulo sobre Retórica em Portugal dissertaremos com mais profundidade.
} 
Oliveira e Marcio Spartaco Landi, dentre alguns, investigam esse processo 4 . Dottori argumenta a possibilidade concreta da utilização de figuras retóricas por parte de Manoel Dias de Oliveira, através das frequentes cadências, com fins expressivos e pela linha do contraponto, somado a ênfase de afetos:

Se Manoel Dias de Oliveira fez ou não uso de alguma terminologia, é impossível de se determinar, e a resposta provável seria não, mas que ele enfatizava a retórica musical torna-se óbvio e evidente na análise de um moteto seu, "O vos omnes" [grifo nosso] (DOTTORI, 1992, p.53).

Já Cardoso Affonso afirma que José Maurício Nunes Garcia aplicava elementos retóricos na disposição de seu discurso musical em muitas de suas obras sacras. Ele continua dizendo que o uso das figuras retórico-musicais foi amplamente difundido como recurso analítico e ferramenta composicional. Cardoso Affonso conclui da seguinte maneira:

\begin{abstract}
Não podemos afirmar que o compositor tenha tido contato com algum tratado de retórica musical, ou qualquer outro que ao menos aproveitasse a terminologia e os conceitos de tal maneira. Contudo, é notável na escrita mauriciana uma forte relação entre texto litúrgico e música. Se não podemos localizar a origem de seus conhecimentos retórico-musicais, ou com que grau de sistematização os possuía, é certo que as partituras musicais ao seu alcance e sua intensa vivência musical lhe serviram de tratado vivo e dinâmico de retórica musical [grifos nossos] (AFFONSO, 2005, p.83).
\end{abstract}

Da mesma forma, Cláudia Schreiner desenvolve a linha de pensamento sobre a relação texto e música, fazendo analogias entre as representações musicais e o emprego da arte retórica no Salmo 112 Laudate Pueri de José Maurício Nunes Garcia.

Por sua vez, Robson Bessa Costa apresenta o uso de figuras retóricas simultaneamente com o baixo contínuo por Lobo de Mesquita:

Poderíamos nos reportar a inúmeros exemplos do Barroco europeu, mas um simples exemplo de Lobo de Mesquita pode nos mostrar a força e a complexidade das figuras rítmicas oriundas do Barroco. É o caso do Enem ergo, que, apesar de ser uma obra tardia, apresenta

\footnotetext{
${ }^{4}$ Artigo de Maurício Dottori: Ut Rhetorica Musica: análise do moteto O Vos Omnes a dois coros, de Manoel Dias de Oliveira (1992) pela Revista Música; Dissertação de Mestrado de Rodrigo Cardoso Affonso: Um Estudo sobre a Relação Texto-Música: os Ofícios Fúnebres de José Maurício Nunes Garcia (2005) pela UNIRIO; Dissertação de Mestrado de Robson Bessa Costa: O Baixo Contínuo no Ofício de Defuntos de Lobo de Mesquita (2006) pela UFMG; O livro de Marcio Spartaco Landi: Lições de Contraponto segundo a Arte Explicada de André da Silva Gomes (2006) pela Expressão Gráfica e Editora e a Dissertação de Mestrado de Cláudia Schreiner: Psalmo de anjinhos bem xibantes: representações musicais no salmo Laudate pueri (1813) de José Maurício Nunes Garcia (2008) pela UFBA.
} 
alguns aspectos comuns ao Barroco europeu, como o uso de violas em vez de violinos, o que proporciona uma sonoridade mais escura e doce, contrapostas a um ritmo pontuado e insistentes colcheias em notas repetidas do contínuo. Esse uso simultâneo de elementos contrastantes era uma figura de retórica musical [grifo nosso], chamada de Oxymoron $^{5}$ comumente usada pelos compositores barrocos (COSTA, 2006, p.24).

Fausto Borém e Cecilia Nazaré de Lima expõem a relação texto-música, além da localização de figuras retóricas na obra Recitativo e Ária:

No processo de transcrição musical, procurou-se não interferir nas figuras de retórica recorrentes em ambos os movimentos. Na entrada da voz na Ária, por exemplo, é mantida a ênfase da $4^{\text {a }}$ justa ascendente no salto símplice (um salto de intervalo consoante de $3^{\text {a }}$ ou maior; BARTEL, 1997, p.380) que sublinha "Se o canto. . ." (Ex.3, c.22). Ainda no Ex.3 (c.24-25), pode-se observar uma recorrência de synonymia (figura de repetição melódica; BARTEL, 1997, p.405-408) em uma progressão melódica descendente na qual é repetida a palavra ". . . enfraquecido. .." Também no Recitativo, muitas figuras retóricas potencializam a natureza pictórica de palavras ou ideias do texto. Por exemplo, a anabasis (ou ascensus; BARTEL, 1997, p.179180) que enfatiza a conotação ascendente do trecho "que por impulso do feliz destino" (Ex.4a; c.7) ou, ainda, o movimento para o grave da catabasis (ou descensus; BARTEL, 1997, p.214-215) que sublinha o trecho "Oh! se tivesse o canto grave" (Ex.4b; c.67) (BORÉM; LIMA, 2008, p.43).

Finalizando, Landi analisa e retrata a forte tradição retórica na maioria das composições de André da Silva Gomes e, muitas das vezes essa tradição se torna clara e evidente nas passagens canônicas ou nas fugas, onde figuras como Mimesis ou Fuga Realis ou Imaginaria $^{6}$ se complementavam e combinavam-se às demais partes, numa composição polifônica aparente ou imaginária (LANDI, 2006, p.20). Portanto, pode-se intuir que a retórica fora um veículo de comunicação, onde igreja, oradores, eruditos, políticos, artistas ligados à pintura, ao teatro e músicos, a empregaram e que sem ela, seria praticamente impossível uma convergência afetuosa e persuasiva de sucesso. Por isso, a necessidade de estudos profícuos nessa área, não se atendo somente às meras conjecturas, mas constructos enraizados na fonte dos

\footnotetext{
${ }^{5}$ Um dispositivo retórico em que duas palavras, aparentemente contraditórias, são usadas em conjunto para o efeito: Ela é apenas uma pobre menina rica. Fonte disponível: http://dictionary.reference.com/browse/oxymoron Acessado em: 10 de Maio de 2011.

$\mathrm{Na}$ retórica literária seria uma variante especial da antítese de palavras isoladas que se constitui entre os membros antitéticos, um paradoxo intelectual (LAUSBERG, 2004, p.230).

${ }^{6}$ Eram utilizadas para diferenciar entre a forma livre de fuga daquela escrita em cânone, respectivamente.
} 
argumentos discursivos das auctoritas ${ }^{7}$, tratadistas e compositores que se apropriaram dos recursos retóricos, e, concluindo, para que tais recursos fossem inseridos na música brasileira do século XVIII e primórdios do XIX, foram essências todas essas fases de teorização e sistematização, desde a Antiguidade greco-romana.

Não obstante, pode-se observar que, atualmente, a retórica musical se constitui num campo complexo e abrangente, onde inúmeras publicações e artigos especializados são editados anualmente, pelo fato de que os numerosos tratados, publicados entre 1535 e 1792, estabelecem um elo com o corpus teórico do sistema retórico-musical, servindo de embasamento às atuais pesquisas da musicologia contemporânea, acerca da poética musical Barroca e Clássica.

Em síntese, embora haja diversos tratados $^{8}$ que evidenciam a importância da retórica no âmbito musical, há pouquíssimas fontes brasileiras sobre o assunto ${ }^{9}$, o que, por si só, já justifica a elaboração de um trabalho mais sistematizado nessa área.

No que diz respeito à estrutura desta dissertação, foi dividida em cinco partes e quatro capítulos, na ordem mostrada a seguir.

O primeiro traz uma pequena exposição introdutória acerca da retórica e sua origem ${ }^{10}$, também da sua capacidade para influenciar, juntamente com a música, os sentimentos humanos ${ }^{11}$. Esses fenômenos passam por várias gerações, ou seja, desde a Antiguidade Clássica até seu apogeu no Barroco e com algumas reminiscências no Classicismo. No segundo tópico, será

\footnotetext{
${ }^{7}$ Pessoa que tem legitimação ou autoridade reconhecida.

8 Joachim Burmeister (1599/1606), Johann Christophe Gottsched (1729), Athanasius Kircher (1650), Mauritius Vogt (1719), Johann Mattheson (1721/1739), Johann David Heinichen (1728), Johann Adolph Sheibe (1745), Johann Nikolaus Forkel (1777), para citar apenas alguns.

${ }_{9}$ Rodrigo Cardoso Affonso destaca a importância da pesquisa e produção de trabalhos em torno do repertório colonial brasileiro e sua relação com o texto da seguinte maneira: "Até o momento, não temos notícia de trabalhos que tenham se dedicado exclusivamente, ou primordialmente, à investigação das relações entre texto litúrgico e música, no repertório colonial brasileiro. Faltam estudos [grifos nossos] que busquem perceber de que forma interagem essas duas forças em uma mesma obra, formando um só discurso" (AFFONSO, 2005, p.6).

${ }^{10}$ Para compreensão do por quê da utilização de elementos e figuras de retórica por parte do compositor luso-brasileiro, se faz necessária esta introdução, onde alguns conceitos da retórica e sua sistematização na música são discorridos em forma de linha cronologia, chegando a seu âmbito superior no Barroco e, obviamente, repercutindo-se em autores de nosso país como Manoel Dias de Oliveira, José Maurício Nunes Garcia e o próprio André da Silva Gomes.

${ }^{11}$ Alegria, tristeza, paixão, raiva, ódio, amor, entre outros.
} 
abordada a retórica da Idade Média até à Moderna, sua utilização em forma de doutrina inserida também na escolástica. Outro aspecto importante para essa inserção foi a instituição das universidades, assim, o saber retórico se torna público e mais acessível. No último tópico do capítulo, disserta-se sobre a relação entre música e retórica.

O segundo capítulo trata da retórica e sua teorização em Portugal, desde a Antiguidade até a transição do Barroco para o Classicismo. Posteriormente, há a contextualização dessa disciplina na arte musical e literária portuguesa, igualmente serão abordadas questões relativas ao aprendizado musical lusitano, no Seminário da Patriarcal.

No terceiro capítulo, disserta-se acerca de André da Silva Gomes. Primeiramente será retratado o processo pela qual se deu sua vida ao Brasil e sua biografia, posteriormente, se fará uma abordagem sobre seu conhecimento musical, gramatical e a consciência na utilização dos recursos e estruturas retóricas em suas obras.

No quarto capítulo tem-se uma introdução sobre o significado de ofertório e, logo depois, serão realizadas análises de elementos e figuras de retórica nos ofertórios de André da Silva Gomes.

A quinta e última parte trata-se da conclusão da dissertação, onde todos os tópicos e assuntos da pesquisa realizada estão sintetizados com critério, lisura e imparcialidade.

Feita esta introdução, espera-se, aqui, cumprir com o roteiro de investigação acerca das teorizações retóricas em Portugal e, também, sobre a possibilidade concreta da inserção da retórica na Música Colonial Brasileira, através de análise crítica e imparcial das obras do ilustre compositor lusobrasileiro, André da Silva Gomes. 


\section{RETÓRICA: SUA EVOLUÇÃO}

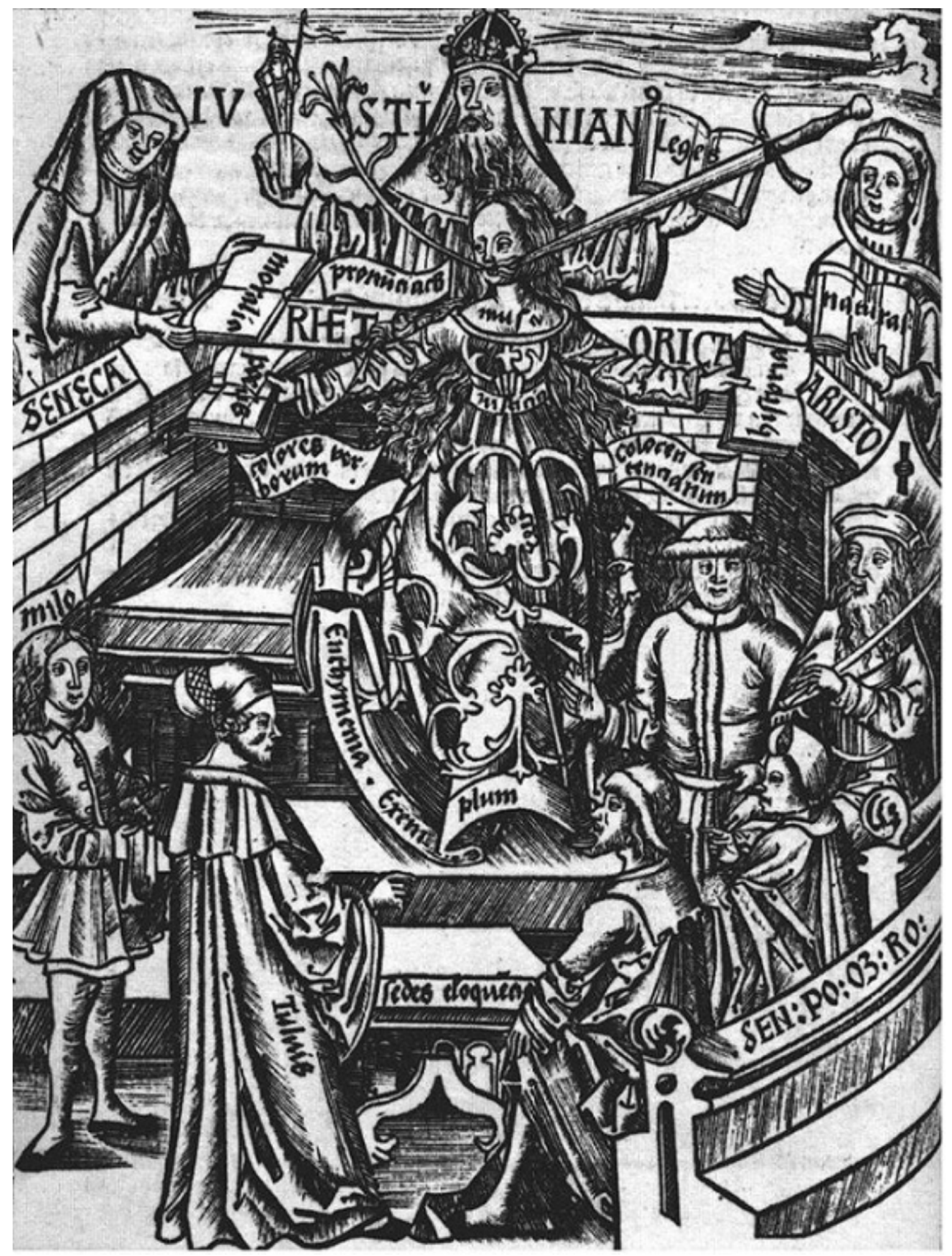

Figura 1: Figura Alegórica da Retórica ${ }^{12}$

${ }^{12}$ Nessa alegoria além das disposições retóricas, observa-se a presença de autores como: Aristóteles, Cícero e Sêneca. Fonte disponível: http://luminescencias.blogspot.com/uploaded images/Retorica-755280.jpg Acessado em: 17 de Abril de 2011. 


\subsection{Natureza da retórica e suas definições}

Definir retórica não é tarefa fácil pelo fato de nunca ter tido um sistema uniforme preciso, na retórica clássica e apesar da multiplicação dos esforços de apresentá-la como um sistema. Ela sempre se apresentou como disciplina flexível, mais preocupada com a persuasão dos ouvintes do que com a produção de formas de discurso. Em outras palavras, mais preocupada com a função retórica do que com a configuração do próprio texto (ARISTÓTELES [ALEXANDRE JÚNIOR], 2005, pp.21-22) ${ }^{13}$.

Em sua Instituo Oratoria, Quintiliano disserta sobre a natureza da retórica e, ao mesmo tempo, reflete a respeito das definições atribuídas a quatro convenções retóricas clássicas que são:

> Geradora de persuasão, segundo Córax, Tísias, Górgias e Platão;

A retórica parece ser capaz de descobrir os meios de persuasão relativos a um dado assunto, segundo Aristóteles;

A faculdade de falar bem no que concerne aos assuntos públicos, segundo Hermágoras;

A ciência de bem falar, segundo Quintiliano (QUINTILIANO, 1416, apud ARISTÓTELES [ALEXANDRE JÚNIOR], 2005, p.22).

Em um aspecto todas essas definições concordam:

Que a retórica e o seu estudo têm como objetivo a criação e elaboração de discursos com finalidades persuasivas. Embora idênticas no essencial, elas realçam quatro elementos retóricos importantes:

1. O seu estado metodológico, ou seja, um conhecimento organizado num sistema ou método, com a finalidade de atingir um determinado objetivo prático;

2. O seu propósito, que trata da finalidade do discurso, ou seja, dos oradores;

\footnotetext{
${ }^{13}$ Manuel Alexandre Júnior faz o prefácio e introdução do Livro Retórica cujo, autor é
} Aristóteles. 
3. O seu objeto, que visa a prática na oratória, em um horizonte retórico de três gêneros de discurso público: judicial, deliberativo e epidíctico ${ }^{14}$;

4. O seu conteúdo ético, a neutralidade ${ }^{15}$ (ARISTÓTELES [ALEXANDRE JÚNIOR], 2005, p.24).

Outra definição relevante é de Plutarco. Para ele, a retórica é a arte relativa aos discursos, que tem sua força no ser artífice de uma persuasão nos discursos políticos sobre todos os assuntos, arte criadora de uma crença e não de ensinamentos. Os seus argumentos próprios dizem respeito, sobretudo, ao justo e ao injusto, ao bem e ao mal, ao belo, e ao feio (PLUTARCO apud PLEBE, 1978, p.17).

Japiassú e Marcondes definem a retórica (gr. hretoriké: arte da oratória, de retor: orador) como uma disciplina que tem por objetivo de estudo a produção e análise dos discursos sob a perspectiva da eloquência até a persuasão, por meio do qual se visa convencer ${ }^{16}$ uma audiência sobre a verdade de algo, técnica argumentativa, baseada não na só na lógica ${ }^{17}$, nem

\footnotetext{
${ }^{14}$ Ostentoso e demonstrativo.

15 Platão sustenta que ela deve ser eticamente responsável e comprometida. Aristóteles defende a sua neutralidade e fez depender do orador, não do sistema retórico, o uso responsável das técnicas de persuasão. Finalizando, Quintiliano representa sua definição com uma posição intermediária, onde a eloquência é uma virtude com um lugar primordial e o orador é capaz de se expressar bem, ou seja, de forma eticamente aceitável (ARISTÓTELES [ALEXANDRE JÚNIOR], ibidem, p.24).

${ }_{16}$ Nesse caso, o termo convencer uma audiência para a verdade significa persuadir com razões e argumentos para um veredicto, seja ele positivo ou não. Já alguns estudiosos, acerca de retórica, afirmam que a verdade é objeto apenas das ciências, e a retórica não é uma ciência e sim arte. Portanto, como arte, a retórica trata das coisas possíveis, que podem ser de uma maneira ou de outra, e a verdade pode ser apenas de uma maneira, assim se conclui que o objeto da retórica não é a verdade. Porém, para outros mestres, essa era de fato uma arte, no entanto, também uma ciência e para os filósofos era apenas uma experiência de valor relativo (ARISTÓTELES [ALEXANDRE JÚNIOR], 2005, pp.22-25). Sob esses pontos de vista encerra-se com Tomás de Aquino, que caracteriza a prudência como recta ratioagibilium (reto proporcionamento do que é matéria de ação) e com Aristóteles na (Ética à Nicômaco, VI, 5, 1140 b 5 e 1140 b 20) citando a prudência como uma virtude entre a sabedoria prática e a ciência. Ou seja, a arte é a recta ratio factibilium e a ciência, recta ratio speculabilium. Portanto, tanto prudência como a arte e a ciência são recta ratio, isto é, visão de algum tipo de verdade. A prudência visa à verdade da vida; a ciência visa a verdade teórica e especulativa, e a arte visa a verdade da obra (SILVA, 1998, p.138).

${ }^{17}$ De fato, a retórica é uma técnica argumentativa, que possui uma lógica de expressão, diversa em alguns aspectos da lógica formal, ou seja, há uma lógica para estruturar um discurso, isso se dá pelo fato de a argumentação retórica ser respaldada pelo estudo e convencimento, no entanto, ela não se baseia somente nessa lógica, como afirmam Japiassú e Marcondes.
} 
no conhecimento, mas na habilidade em empregar a linguagem e impressionar favoravelmente os ouvintes ${ }^{18}$ (JAPIASSÚ; MARCONDES, 1999, p.235).

Aurélio descreve-a como capacidade de pôr em prática uma ideia através de estudo do uso persuasivo da linguagem, em especial para o treinamento de oradores (FERREIRA, 2004, p.1751). Houaiss, por sua vez, a define como: conjunto de regras que constituem a arte do bem-dizer, arte da eloquência, oratória e, por extensão, também o conjunto de regras que consistem e organizam a nossa arte (HOUAISS, 2001, p.2447). Seguindo uma linha de raciocínio semelhante, Reboul fala que a "retórica é a arte de persuadir pelo discurso" (REBOUL, 2000, p. XIV) e, por fim, Abbagnano completa ressaltando-a como "arte de persuadir com o uso de instrumentos linguísticos" (ABBAGNANO, 1998, p. 871).

Feitas todas essas ponderações, pode-se dizer que a retórica tem sido um instrumento de grande importância não só em sua origem na Antiguidade, mas para muitas gerações posteriores. Mesmo que para muitos ela seja uma mera manipulação linguística, ornato estilístico e discurso, servindo-se de artifícios irracionais e psicológicos, mais interessados à verbalização de discursos vazios de conteúdo do que fundamentados em princípios e valores que se nutrem de um raciocínio crítico, válido e eficaz. Seu restabelecimento ao antigo estatuto de teoria e prática da argumentação persuasiva como antiga e nova rainha das ciências humanas, vem corrigir essa noção enganosa, revalorizando-a como ciência e arte que, tão logicamente, opera na heurística e na hermenêutica dos dados que faz intervir no discurso.

Em suma, retórica é um saber que se inspira em vários saberes e se coloca a serviço de todos eles. É um conhecimento interdisciplinar no sentido pleno da palavra, na medida em que se afirmou como arte de pensar e arte de comunicar o pensamento. E, como tal, pode se multiplicar em interdisciplinar e transdisciplinar, ela está presente no direito, na filosofia, na oratória, na dialética, na literatura, na hermenêutica, na crítica literária, na ciência e nas artes (ARISTÓTELES [ALEXANDRE JÚNIOR], 2005, pp.9-10).

\footnotetext{
${ }^{18}$ Trata-se, como no caso de seu equivalente latino Oratória, da apropriação de um substantivo associado ao ato de discursar (VIDAL, 2002, p.16).
} 


\subsection{A retórica da Antiguidade até a Idade Média}

Quando diz Aristóteles, a tirania foi destruída na Sicília e as questões entre particulares, após um longo intervalo, foram novamente submetidas aos tribunais, pela primeira vez, nesse povo de espírito penetrante e naturalmente inclinado à discussão, viram-se os sicilianos Córax e Tisias dar um método e regras. Antes, ninguém seguia uma rota traçada, nem se submetia a uma teoria e, entretanto, a maioria se exprimia com cuidado e ordem ${ }^{19}$ (CICERO, Cap. X-XII $\S \S .41-45,1839$, p.34).

Sua origem remonta ao século $\mathrm{V}$ a.C. ${ }^{20}$ e seu desenvolvimento permeia toda a vida cultural, educativa, religiosa, social e, de especial maneira, a atividade artística na cultura ocidental. Sua influência abrange sobretudo a literatura, mas, também, se manifesta no teatro, artes plásticas, arquitetura e na música. Esse desenvolvimento se inicia com apresentação de um processo em dois estágios: primeiramente com a exibição adequada e coerente das partes performáticas do discurso e, segundo, em uma imitação da poética, onde se enfocava o fenômeno local da estrutura da sentença e questões de estilo, ou seja, figuras e elementos de retórica que poderiam ser empregadas como artifícios de persuasão, por exemplo, figuras de pensamento, figuras de discurso, entre elas palavras e sintaxe (VIDAL, 2002, p.17).

Desde a Grécia Antiga, a música é tida como poderosa e capaz de influenciar e modificar a natureza do homem e, consequentemente, da sociedade, constituindo-se um dos principais interesses na organização política do Estado Grego. Questões relativas aos princípios éticos e estéticos da música são tratadas por Platão, na República e nas Leis. Como se nota, a vinculação da música a estados emocionais específicos é fenômeno que se registra desde os tempos da cultura grega, passando pela Idade Média e

\footnotetext{
19 Ait Aristoteles, cum sublatis in Sicilia tyrannis res privatae longo intervallo iudiciis repeterentur, tum primum, quod esset acuta illa gens et controversiae nata, artem et praecepta Siculus Coracem et Tisiam conscripsisse: nam antea neminem solitum via nec arte,accurate tamen et descripte plerosque dicere.

20 Os tiranos sicilianos Hierón e Gelón haviam decretado uma abusiva expropriação das propriedades, distribuindo-as entre seus mercenários. Posteriormente, um movimento democrático conseguiu derrubar a ditadura. O novo regime se empenhou em devolver as propriedades a seus antigos donos, porém, surgiu um sério problema: como realizar a restituição dos bens, sendo que, devido aos conflitos internos, havia confusão e desordem nos antigos títulos de propriedade. A solução foi instaurar uma espécie de júri popular. A partir desse instante, cada demandante poderia solicitar a devolução de suas terras, não sendo necessária a apresentação de documentos, nem sequer testemunhas oficiais, para convencer as autoridades da legitimidade de seu crédito. Embasavam-se unicamente na argumentação, ou seja, na palavra. Dessa maneira, a retórica, desde seu nascimento esteve ligada a questões judiciárias (CANO, 2000, p.19).
} 
Renascença, no entanto, segundo Cano, "é no Barroco que estas preocupações alcançam algumas das mais refinadas e complexas teorizações da história da música" (CANO, 2000, p.24). Sendo que, no Classicismo, os elementos estilísticos herdados do Barroco se adaptaram e sobreviveram às significativas mudanças ocorridas na segunda metade do século XVIII (VIDAL, 2002, p.6).

A descoberta do poder da palavra e da importância de valer-se dela com desenvoltura e precisão constituiu deslumbrante revelação. Surgiram, assim, oradores profissionais que, cobrando somas exorbitantes, se dedicaram a ensinar aos neófitos os mistérios de sua arte. Empédocles de Agrigento, juntamente com seu discípulo Córax de Siracusa, Górgias, o famoso sofista ${ }^{21}$ questionado por Sócrates e Tísias, estão entre os primeiros mestres dessa antiquíssima disciplina.

Córax e Tísias defendiam uma retórica científica, baseada na demonstração técnica do verossímil. Outra escola contemporânea praticava e teorizava uma retórica não científica, mas pitagórica, fundada na sedução irracional que a palavra, sabiamente usada, exerceria sobre a alma dos ouvintes. Essa última corrente retórica liga-se estreitamente ao mundo pitagórico. Nas raízes dessa corrente "do irracional" estão os denominados "discursos de Pitágoras", cujas características são:

1. O propósito de usar estilos e argumentos diferentes conforme os diferentes ouvintes;

2. O emprego constante da figura retórica da antítese.

Para Pitágoras, "o belo participa do feio e o justo do injusto" e, portanto, "esta é a razão pela qual o discurso toma a sua direção ora em um ora em outro sentido" (PLEBE, 1978, p.4). Na segunda característica dos discursos, tem-se o emprego da antítese e a especial atenção que lhe é dirigida. Por exemplo, para mostrar às crianças que o acontecimento que antecede é mais

${ }^{21}$ [Do gr. sophistés, 'sábio', posteriormente 'impostor', pelo lat. sufixa.] Cada um dos personagens contemporâneos de Sócrates ( $v$. socratismo) que chamavam a si a profissão de ensinar a sabedoria e a habilidade, e entre os quais se destacam Protágoras (480-410 a.C.), que afirmava ser o homem a medida de todas as coisas, e Górgias (485-380 a.C.), que atribuía grande importância à linguagem. Os sofistas desenvolveram especialmente a retórica, a eloquência e a gramática. 
apreciado aquilo que se segue, contrapõe-se o oriente ao caso a aurora à noite, o princípio ao fim, o nascimento à morte. Para exortá-los à virtude, contrapõem-se os bons resultados de quem é bem-educado aos maus resultados de quem não é etc. (PLEBE, ibidem, p.4).

\subsection{As funções da retórica}

Na Antiguidade Clássica e durante a Idade Média, era conferida à retórica apenas uma função, a persuasiva, entretanto, com o advento de novas pesquisas, estudiosos contemporâneos atribuíram a ela até quatro funções diferentes. Por exemplo, Olivier Reboul ${ }^{22}$ trabalha com essas: função persuasiva, hermenêutica, heurística ${ }^{23}$ e pedagógica (BARROS, 2006, p.7).

\subsubsection{Função Persuasiva}

De acordo com Cassiano Barros:

Esta função decorre de uma das definições da retórica - arte de persuadir. Os meios de persuasão são três, o discurso, o orador e o público. Os modos de persuasão são dois: o da competência da razão e o da competência da emoção. À razão compete a argumentação do discurso. À emoção competem os caráteres do orador (ethos) ${ }^{24}$ e do público (pathos) ${ }^{25}$ (BARROS, 2006, p.8).

Já a emoção, para Aristóteles, é apresentada como todos os sentimentos que, ao se transformarem, fazem com que os indivíduos alterem seus julgamentos os quais são seguidos de prazer e dor. Das emoções devemse distinguir três pontos de vista:

1. em qual ordenação estão as pessoas;

2. contra quem se dispõem;

3. por quais razões; (BARROS, 2006, p.8).

\footnotetext{
${ }^{22}$ Filósofo canadense (1922-1995), suas principais áreas de atuação foram a retórica e a filosofia da educação.

${ }^{23}$ [Do lat. cient. heuristica (< gr. heuristiké [téchne], 'arte de encontrar', 'descobrir')]. Conjunto de regras e métodos que conduzem à descoberta, à invenção e à resolução de problemas.

${ }^{24}$ [Do gr. que significa 'costume', 'uso', 'característica'.] Caráter que o orador deve parecer ter, mostrando-se "sensato, sincero e simpático". Igualmente, caráter do auditório, ao qual o orador deve se adaptar (REBOUL, 2004, p.247).

${ }^{25}$ Ação do orador sobre as paixões, os desejos e as emoções do auditório, para facilitar a persuasão (REBOUL, 2004, p.251).
} 
Aristóteles continua sua tese afirmando que, através da emoção podem ser extraídos os argumentos para aconselhar e desaconselhar, louvar e censurar, acusar e defender-se, ou seja, por meio dessas opiniões e premissas, que são úteis para todas as provas, se convertem em matérias argumentais. Uma vez que a retórica tem por objetivo formar um juízo, seja deliberativo, por exemplo, se faz necessário não só procurar que o discurso seja demonstrativo e digno de crédito, mas, também, que o orador mostre possuir certas disposições e prepare favoravelmente o júri (ARISTÓTELES, 2005, p.159).

Em suma, Aristóteles admite como passageiras as emoções do público, pois se tornam manifestas apenas quando há deliberação ou escolha a se fazer. Nesse caso, o pathos é uma resposta, uma reação ao modo de ser do orador, ou seja, onde as disposições são conhecidas como seu modo de ser, seu ethos. Já as emoções devem ser dominadas pela razão e devem gerar ações virtuosas. Essas ordenações não são estados transitórios, mas fixos. Portanto, o orador deve ser virtuoso e ao mesmo tempo buscar sua virtude exercitando a razão contemplativa e prática, a qual influencia e domina suas paixões. Destarte, sua virtude se ordenará à reflexão e não à sucessão ininterrupta das emoções.

O pathos, por consequência, deve ser compreendido como o caráter coletivo assumido pelo público. Para obter domínio e adquirir aprovação, o orador deve discernir e apropriar seu discurso, isto é, adequar sua especificidade e postura, de maneira que possa adequar seu caráter e atitude a ele e ao seu discurso, de modo a incutir confiança e inspirar credibilidade (BARROS, ibidem, p.8).

\subsubsection{Função Hermenêutica}

Hermenêutica é a interpretação do sentido das palavras, isto é, a capacidade de interpretar textos. Ao conferir esse ofício à retórica, imputa a ela a capacidade de ser reversível, em outras palavras, uma técnica capaz de reunir um corpus de regras e ferramentas aplicadas na formação de estruturas literárias de caráter mais ou menos persuasivos, onde se utiliza um conjunto de processos não só de construção, mas, também, na desconstrução, com vistas à análise e interpretação. Demonstra-se, portanto, como um método analítico, 
que tem por objetivo a busca da metodologia do entendimento textual, pela atenção obtida graças aos efeitos das palavras dispostas no texto, em decorrência dos fenômenos hermenêuticos de recepção (BARROS, 2006, p.9).

Reboul observa da seguinte maneira:

Por mais primordial que seja a função persuasiva, ela não é a única, por isso, se a retórica é a arte de persuadir pelo discurso, é preciso ter em mente que o discurso não é e nunca foi um acontecimento isolado. Ao contrário, opõe-se a outros discursos que o precederam ou que the sucederão, que podem mesmo estar implícitos, como o protesto silencioso das massas às quais se dirige, por exemplo, um ditador, todavia, contribuem para dar sentido e alcance retórico ao discurso [grifos nossos] (REBOUL, 2004, p. XVIII).

Cassiano Barros, argumenta sobre as tendências dos mais recentes estudos sobre a análise retórica de um texto, onde o mesmo se assume como crítica cultural num contexto pós-moderno, método que necessariamente é composto por cinco passos fundamentais:

1. A identificação das unidades retóricas do texto;

2. A verificação da situação retórica que gerou o texto e o problema retórico que o orador enfrentou nessa situação;

3. A determinação do gênero retórico;

4. A identificação das características do estilo retórico;

5. A análise da estratégia retórica global (BARROS, ibidem, p.9).

Reboul salienta que, na universidade atual, a função hermenêutica é fundamental, para não dizer única. Ao mesmo tempo, ele ressalta que a retórica não é mais ensinada como arte de produzir discursos, mas uma arte de interpretá-los. O autor termina enfatizando que embora aí a retórica receba outra dimensão, ela não é mais uma arte que visa produzir, mas uma teoria que visa compreender (REBOUL, 2004, p. XIX).

Em síntese, esse modelo de análise pode ser conjecturado como um conjunto de elementos críticos retóricos na sociedade, onde é estudada a natureza pela qual se dão os fenômenos culturais, não admitindo apenas uma maneira válida de interpretação, similarmente convergindo às diversas metodologias de abordagens hermenêuticas na exploração da relação dos textos com a sociedade e a cultura em que se inserem (BARROS, ibidem, p.9). 


\subsubsection{Função Heurística}

A referida função traz à baila que a arte de persuadir pressupõe que não se está sozinho, por isso, ela só pode ser exercida quando se interpreta o discurso de outrem, ou seja, a retórica é utilizada não só para obtenção de poder, mas também para o saber ou o encontrar alguma coisa, portanto, essa função tem por objetivo investigar, pesquisar e descobrir (REBOUL, 2004, p. $X X)$. A argumentação se dá também de maneira escrita ou oral. Isso leva a pensar nas características específicas de cada uma delas.

Reboul prossegue destacando como se associa a função heurística com retórica nos dias atuais:

Na atualidade falar na palavra descoberta automaticamente nos
remete a pensar em ciência, que, por sua vez, parece não se
interessar por retórica, no entanto, isso pode revelar uma denegação
por parte dos cientistas de enxergar sua própria retórica. [...] Portanto,
mesmo em um mundo com poucas evidências, sem previsões certas,
torna-se preponderante a retórica, o que dá a ela realmente um
papel de descoberta [grifos nossos] (REBOUL, ibidem, pp. XX- XXI).

Afrânio Garcia, por sua vez, enfatiza que a metodologia da função heurística na pesquisa matemática foi relacionada por muito tempo aos modelos cognitivos, as quais eram baseadas em regras na experiência e no planejamento às anteriores, baseadas na procura algorítmica ${ }^{26}$, que chega a soluções corretas depois de ter combinado o problema com todas as soluções possíveis. Todavia, na pesquisa histórica, o conceito de heurística define 0 conjunto de métodos e procedimentos que garantem certo grau de certeza e nos rumos da investigação histórica, ao mesmo passo que na filosofia, principalmente na epistemologia, o termo heurística define não apenas a descoberta de novas concepções e soluções e a invenção de novas proposições, como também o próprio processo de elaboração do pensamento: sua constituição, sua disposição, seu inter-relacionamento, sua metodologia, seu valor de verdade etc. (GARCIA, 2008, p.4).

Garcia, posteriormente, pondera sobre a heurística no seu sentido amplo, tanto aristotélico quanto platônico, de ramo da filosofia, ou da retórica, que estuda os modos de elaboração e a constituição do pensamento. Ele

${ }^{26}$ Conjunto de regras e operações bem definidas e ordenadas, destinadas à solução de um problema, ou de uma classe de problemas, em um número finito de etapas. 
conclui esse tópico apresentando alguns fatores caracteristicamente heurísticos ligados à retórica:

1. Os métodos de indução e dedução, partindo de dados específicos para uma conclusão de caráter geral (indução) ou, inversamente, de partir de generalizações para chegar a conclusões que se aplicam a casos específicos (dedução);

2. O silogismo ${ }^{27}$, o entimema ${ }^{28}$ e o sofisma ${ }^{29}$, processos de elaboração do pensamento (e do discurso) em que se chega a uma conclusão a partir de duas premissas (proposições iniciais) ou de uma premissa que pressupõe uma segunda, respectivamente silogismo e entimema, ou através de premissas falsas, quando há o sofisma;

3. A relação de prótase ${ }^{30}$ (mais ou menos equivalente à precedente) e apódose $^{31}$ (aproximadamente igual à consequente), uma relação necessária dentro da elaboração do pensamento, já que praticamente todos os pensamentos são a origem de um pensamento subsequente (prótase) ou são a complementação de um pensamento anterior (apódose);

4. A estruturação aristotélica do texto (expressão do pensamento) em introdução, desenvolvimento e conclusão;

5. Outras estruturações do texto (expressão do pensamento), como tese e antítese, análise e síntese, associação e dissociação, correlação e concatenação, generalização e especificação;

6. As relações expressas pela coordenação e subordinação, que são maneiras de associarmos ou dissociarmos pensamentos (expressos sob a forma de orações, períodos ou parágrafos);

7. Os processos de denotação e conotação, inclusive as inúmeras figuras de linguagem, principalmente as semânticas (GARCIA, 2008, p.5).

Em meio a tais afirmações, pode-se convir que mesmo vivendo num mundo repleto de avanços e conhecimentos científicos, ainda se faz necessária a aplicação de recursos retóricos, como os das funções, dentre elas a heurística, como auxílio para o embasamento de ordem científica, jurídica, política, literária e no discurso realizado pelo orador.

\footnotetext{
${ }^{27}$ [Do gr. syllogismós, 'argumento' 'pelo lat. syllogismu.] Dedução formal tal que, postas duas proposições, chamadas premissas, delas, por inferência, se tira uma terceira, chamada conclusão.

${ }^{28}$ Silogismo no qual se subentende uma premissa; silogismo truncado, incompleto.

29 Do gr. sóphisma, 'sutileza de sofista', pelo lat. sophisma]. Argumento aparentemente válido, mas, na realidade, não conclusivo, e que supõe má-fé por parte de quem o apresenta; falácia, silogismo erístico. Também pode ser definido como um argumento que parte de premissas verdadeiras, ou tidas como verdadeiras, e chega a uma conclusão inadmissível, que não pode enganar ninguém, mas que se apresenta como resultante das regras formais do raciocínio; falácia. Por último, um argumento falso formulado de propósito para induzir outrem a um erro.

${ }^{30}$ No antigo teatro grego, a primeira parte da ação dramática, na qual o argumento é anunciado e se inicia o seu desenvolvimento.

${ }_{31}$ A segunda parte de um período gramatical, em relação à primeira, chamada prótase, cujo sentido é complemento.
} 


\title{
2.3.4. Função Pedagógica
}

A última função retórica abordada nesta dissertação pode ser relacionada aos programas escolares desde a época clássica na Antiguidade, passando pela Idade Média e pela Moderna, entretanto, muitos autores e estudiosos sobre o assunto, quando se reportam a esses programas verificam que a retórica só admitiu mais claramente a primeira dessas quatro funções, ou seja, a argumentativa, ficando a hermenêutica reservada à gramática e a heurística à dialética. Contudo, nessas escolas, gramática, retórica e dialética faziam parte de um mesmo todo, ou seja, a arte do discurso implica a arte de compreender, que, por sua vez, resulta na arte de inventar (REBOUL, 2004, p. XXII).

Na metade do século XIX, mesmo quando a retórica foi abolida dos programas curriculares nos principais centros de ensino da Europa, isto é, oficialmente retirada como disciplina, ela permaneceria sendo aplicada, porém com forma e configuração diferente. Reboul, por exemplo, descreve que os professores desta época como os da atualidade, quase sempre sem saber fazem retórica desta maneira:

\begin{abstract}
Ensinar a compor segundo um plano, a encadear os argumentos de modo coerente e eficaz, a cuidar do estilo, a encontrar as construções apropriadas e as figuras exatas, a falar distintamente e com vivacidade, não será retórica, no sentido mais clássico do termo? Demonstramos com facilidade que os critérios segundo os quais um professor de língua ou mesmo de filosofia, avalia uma redação de um determinado assunto ou quando examina um plano e sua argumentação, igualmente na observância do estilo utilizado, podem ser encontrados com outros nomes na retórica clássica, por exemplo, disposição com suas seis partes: exórdio, narração, pontos esboçados, digressão/refutação, confirmação e conclusão [grifos nossos] (REBOUL, ibidem, p. XXII).
\end{abstract}

Portanto, mesmo com a existência de diferentes métodos de ensino em variadas culturas, com formas particulares ou distintas de avaliação, assim como a observação dos planos de ordenação pedagógica buscando a excelência, coerência e a eficácia não só na argumentação, mas também em sua aplicação, torna-se indispensável à sua utilização, mesmo existindo outras culturas além da escolar, todavia como salienta Reboul: "não existe cultura sem formação retórica, porque, aprender a arte de bem-dizer é já também aprender a ser" (REBOUL, idem, ibidem p. XXII). 


\subsubsection{As cinco fases da retórica}

Aristóteles, transformou a retórica em um sistema, que, posteriormente, foi desenvolvido por seus sucessores, no entanto, sem perder a sua essência (BARROS, 2006, p.10). Para melhor compreensão do funcionamento da retórica e de sua sistematização, com o passar dos tempos, instituiu-se o que se conhece hoje como as cinco fases da retórica, distribuídas e mostradas a seguir.

\subsubsection{Inventio}

Descobrimento ou invenção das ideias e argumentos que sustentarão o discurso e sua tese. Nesse caso o orador tem como tarefa efetuar um argumento adequado para dar sustentação a um tema ou ideia a ser exposta (PERSONE, 1996, p.28). Igualmente a Inventio é um passo inicial, onde o tópico sobre o qual se vai discorrer, isto é, compor, será fundamento sobre o qual se construirá a representação e evocação do afeto correspondente (ASSUMPÇÃO, 2007, p.58). Bartel destaca que, na Inventio, é onde são determinados os sujeitos e, da mesma forma, nessa etapa acontecem as coletas das informações (BARTEL, 1997, p.66).

Tal processo vai ao encontro de uma definição de Aristóteles quando afirma que um dos papéis da retórica é de ver teoricamente o que, em cada caso, pode ser capaz de gerar a persuasão (ARISTÓTELES, s/d, p.33).

\subsubsection{Dispositio}

Distribuição ou arranjo das ideias e argumentos encontrados na Inventio, de forma apropriada e eficaz. Para que essa disposição seja orientada e organizada, acontece uma subdivisão tradicional da dispositio em seções. Tal subdivisão sofre pequenas variações desde a Antiguidade, no entanto, sua base, foi padronizada desde maneira: Exordium, Narratio, Propositio, Confutatio, Confirmatio e Perotatio, (ASSUMPÇÃO, 2007, p.60) sendo que Aristóteles enuncia quatro partes primeiramente: Exordium, Narratio, Confirmatio e Perotatio. Quintiliano, por sua vez, cinco, desdobrando a terceira parte em Confirmatio e Refutatio (Confutatio) (BARROS, 2006, p.12). 
Enfim, apropriando-se das partes expostas por Aristóteles e Quintiliano, os retóricos latinos dividiram o discurso nas seis partes como são conhecidas hoje, em poucas linhas, veja-se seus significados:

- Exordium: introdução;

- Narratio: Exposição do caso em discussão;

- Propositio: esboços dos pontos de um argumento;

- Confutatio: refutação dos argumentos expostos, ou seja, uma oposição ao tema inicial ou principal;

- Confirmatio: confirmação das ideias principais, expostas no início do discurso;

- Perotatio: conclusão do discurso.

\subsubsection{Elocutio}

Elocução do discurso, ou seja, base de sua organização; descoberta da expressão para cada ideia, e que inclui o estudo das figuras ou tropos ${ }^{32}$; onde as regras estilísticas são ensinadas. Também podem ser acrescidas ornamentações e junções entre partes e alterações de estilo. Nessa fase do discurso retórico o orador escolhe as palavras e as junta, para depois ordenálas, visando assim o melhor resultado tanto na compreensão do ouvinte, quanto do orador. Segundo Cícero, nessa fase, o orador enuncia seu discurso com maior peculiaridade (CíCERO, 1967, p.61).

Duas regras são as que orientam essa fase do discurso, são elas: as do decoro e a regra da clareza. A primeira tem por objetivo ajustar um assunto à função do discurso, ou seja, cada assunto e função exigem um estilo diferente, a segunda é uma solicitação para uma adequação do estilo ao auditório.

Enfim, é na Elocutio que as diversas ideais e pensamentos são traduzidos em palavras e sentenças, somando assim todos os dispositivos necessários para uma fundamentação e argumentação com maior ênfase (BARTEL, 1997, p.66).

\footnotetext{
${ }^{32}$ Tropo [Do gr. trópos, 'desvio', pelo lat. tropu]. É o emprego da palavra ou expressão em sentido figurado, na música medieval. Era empregado na ampliação de um canto litúrgico de formação melismática, mediante acréscimos ou substituições. A primeira manifestação dramática da Idade Média, e que se constituía de pequeno recitativo ou diálogo inserido na liturgia da missa, donde se originaram os dramas litúrgicos (v. drama litúrgico).
} 


\title{
2.3.5.4. Memória
}

Mecanismos e processos para memorizar o discurso, por extensão, o modo operativo de cada uma das fases retóricas. Esses instrumentos e processos de memorização, atribuídos ao orador, permitem que o mesmo possa realizar seu discurso com maior desenvoltura e confiança. Tendo 0 orador discursado e corretamente memorizado as ideias, argumentos, e da mesma forma demonstrando domínio em sua execução, ia ganhando, com o tempo, maior credibilidade e autoridade.

\subsubsection{Pronuntatio}

Realização do discurso ante o público, onde são revisados os princípios fonéticos e gestuais que se devem observar durante a execução pública. Quintiliano afirma que:

\begin{abstract}
A escrita, a leitura e a fala estão intimamente relacionadas e são inseparáveis: se uma delas falta, empregaremos todos os nossos esforços em vão. Por isso, a oratória só será eficaz se apenas retirar suas forças do exercício escrito. Sem o exemplo dado pela leitura, o objetivo do trabalho escrito (na falta de um guia) será vago e instável. Portanto, aquele que não sabe falar adequadamente e sem sensibilidade aguçada, isto é, com nenhum aprimoramento na oratória, será como um guarda de um tesouro fechado (QUINTILIANO, 1416, livro X, cap.1,§ 1,2 apud LUCAS, 2010, p.5).
\end{abstract}

Há de se ressaltar, ainda, que os teóricos da retórica dedicam também grandes espaços ao estudo da origem e funcionamento dos afetos. Despertar, mover e controlar as paixões nos ouvintes é uma tarefa fundamental no trabalho persuasivo do orador.

\subsection{A retórica da Idade Média até a Idade Moderna}

A retórica, como doutrina, acompanhou e serviu a gregos e romanos em suas expansões territoriais. Com o domínio da cultura clássica na Antiguidade, novos tratamentos e rumos foram aprimorando o discurso e argumentação, entre os quais está o texto poético. Assim, o fenômeno da poesia converteu a retórica em criação literária, e essa para as demais artes.

No início da Idade Média, Santo Agostinho (354-430) impulsionou uma releitura cristã de Platão, Aristóteles e Cícero. Mas adiante, São Gregório de Naciazo (330-390), Cassidoro (480? -575?) e finalmente Beda, o Venerável 
(673-735), solidificaram a teoria da retórica medieval. Ao interpretar as escrituras se descobriu que a Bíblia estava repleta de figuras retóricas. Assim a retórica se converteu em instrumento capital para futuras evangelizações ao mesmo tempo em que se ampliava o campo de ação a análises e interpretação de textos já existentes (CANO, 2000, p.23).

Outro fator de transformação surgiu com a instituição da Universidade. 0 saber retórico se tornou público. Nesse momento, a disciplina foi colocada ao lado da gramática e da dialética, formando assim o TRIVIUM que, junto com o QUADRIVIUM ${ }^{33}$, constituiu a base acadêmica da educação universitária durante aproximadamente dez séculos. Assim a retórica deixou de ser uma disciplina hermética reservada só para alguns interessados e passou a ser um pilar da educação.

Entre o florescimento da Idade Média até o Renascimento, a retórica foi à base da articulação da Escolástica ${ }^{34}$, e, através dessa a filosofia continua ligada à religião, uma vez que são as questões teológicas que suscitam a discussão filosófica.

Com o desenvolvimento da cultura humanista do Renascimento, desde sempre aristocrática, várias disciplinas clássicas foram reguladoras, entre elas a oratória e a poética. Com a primeira ressurgiu a retórica como princípio construtor do discurso falado. Com a segunda, reapareceram os princípios criadores do texto poético. Nikolaus Listemis foi o primeiro teórico musical a introduzir um conceito de retórica musical em seu tratado Música (1537). Já na época da Reforma e Contrarreforma, o cristianismo revitalizou a retórica como instrumento primordial da eloquência. Segundo Luís Morales:

\footnotetext{
A Contrarreforma surgiu como defesa contra o Luteranismo, não só para rechaçá-lo mais também para uma alternativa para a grande massa, sem falar da manifestação contra a pressão material e psíquica da igreja e da aristocracia. Já a arte Barroca foi um meio de persuasão da igreja para reconverter a massa. Os jesuítas
}

\footnotetext{
${ }^{33} \mathrm{Na}$ Idade Média, nome dado à divisão das artes liberais, a qual abrangia a gramática, a retórica e a dialética (Trivium). Conjunto das quatro disciplinas matemáticas, a saber: aritmética, geometria, música e astronomia (Quadrivium).

${ }^{34}$ Conjuntos de doutrinas filosóficas e teológicas desenvolvidas em escolas eclesiásticas e universidades da Europa. Caracteriza-se pela tentativa de conciliar a fé cristã com a razão, representada pelos princípios da filosofia clássica grega, em especial os ensinamentos de Platão e Aristóteles. Desenvolve-se a partir da filosofia patrística, que faz a primeira aproximação entre o cristianismo e uma forma racional de organizar a fé e seus princípios, baseada no platonismo.
} 
foram os encarregados de tal tarefa [grifos nossos] (Morales, 1990, apud CANO, 2000, p.25).

E assim, pleno desse caráter comunicativo forjado nos instrumentos retóricos, o espírito persuasivo que se pretendeu imprimir na arte Barroca requereu profundo conhecimento da natureza e funcionamento dos afetos e paixões da alma. Uma vez mais, a retórica constituiu-se na disciplina que podia oferecer conhecimento pleno e mais ou menos sistematizado a esse respeito. Este fenômeno, ligado à forte tradição das poéticas artísticas, iniciadas no século $\mathrm{XVI}$, foi inevitável para que princípios e mecanismos próprios da retórica fossem assimilados pela arte. Efetivamente, se um dos objetivos da arte Barroca era a persuasão, os artistas aspiravam imprimir em suas obras a eloquência e o mover dos afetos dos próprios oradores. Nikolaus Harnoncourt afirma: "a retórica, como um todo e sua complexa termologia era uma disciplina ensinada em todas as escolas e formada, em parte, igual à música e cultura geral" (apud CANO, 2000, p.27).

\title{
2.5. Retórica e Música
}

\begin{abstract}
Johann Sebastian Bach conhece de uma forma tão completa o papel e as portas da retórica e à hora de compor música que não só é um prazer escutar ou falar das similitudes e concordâncias entre os dois, sendo que resulta admirável observar a habilidade com que aplica estes princípios em suas obras. Birnbaum (amigo intimo de Bach apud CANO, 2000, p.99).
\end{abstract}

Na história da civilização ocidental, a música foi, durante considerável tempo, vocal e ligada às palavras. As relações entre retórica e música foram assim e, desde a Antiguidade, bastante estreitas. No Barroco, essa relação chegou a um ponto sofisticado de aplicação. Aqui as influências dos princípios básicos da retórica afetaram profundamente os elementos mais íntimos da linguagem musical. Porém, as inter-relações entre música e as artes (artes dicendi), gramática, retórica e dialética são ao mesmo tempo óbvias e confusas para que se possa compreendê-las. Os compositores eram influenciados por doutrinas retóricas que governavam a adequação dos textos e da música e, também, depois do crescimento da música instrumental independente, os princípios retóricos continuaram a ser utilizados por algum tempo não só na música vocal, mas também na música instrumental. A partir do princípio do 
século XIX, os músicos e estudiosos "modernos" não estavam tão interessados nas disciplinas retóricas (BUELOW, 2001, p.260).

É necessário ainda reiterar, em parte, e acrescentar na área musical, que todos os conceitos musicais relacionados à retórica procedem de extensa literatura sobre oratória e retórica dos antigos escritores gregos e romanos, especialmente Aristóteles, Cícero e Quintiliano. O redescobrimento, em 1416, do Institutuio Oratoria proporcionou uma das fontes primárias sobre o qual se baseou a nascente união entre retórica e música no século XVI.

Quintiliano, como anteriormente Aristóteles, havia destacado as similitudes entre a música e a oratória. O propósito de sua obra e de todos os outros estudos da oratória, desde a Antiguidade, havia sido o mesmo: instruir o orador sobre os meios para controlar e dirigir as respostas emocionais de sua audiência, ou, em que linguagem da retórica clássica e também de todos os tratados musicais posteriores, capacitar o orador (é decidir, sobre o compositor e intérprete) para mover os "afetos" (as emoções) de seus ouvintes.

Em 1563, Gallus Dressler (1533-1589), em um manuscrito intitulado Praecepta Music Poeticae, desenvolveu uma forma de música que iria tomar as divisões em um discurso Exordium (Introdução/Ouverture), Medium (Médio/Meio) e Finis (Final). Um regime semelhante aparece no tratado Burmeister, de 1606. Em ambos os escritos a terminologia retórica é levada ao ponto de definir a estrutura de uma composição, uma abordagem que permanecerá válida até bem dentro do século XVIII (BUELOW, 2001, p.261).

Em 1739, na sua Der Vollkommene Capellmeister (O Perfeito Mestre de Capela), Johann Mattheson (1681-1764) deu um esboço de composição musical completamente organizada e racional, modelado com partes da teoria e da retórica, podendo ser encontrando argumentos para apresentar um discurso de forma coerente. Pode-se observar que Mattheson utiliza-se das cinco fases da retórica, seguindo os cânones clássicos, porém, acrescenta partes novas, fazendo, assim, uma ligação entre o discurso e a música ${ }^{35}$ :

1. Inventio - ou invenção de ideias, abrangendo o ato de criação e de recolha fundamentos expostos, ideias musicais etc.;

\footnotetext{
${ }^{35}$ Segundo Cano, a Memoria é a única parte que não foi transmitida para as outras artes (a não ser na literatura): "a memoria é a única parte do sistema retórico que não foi sequer mencionada pelos tratadistas musicais do Barroco" (CANO, 2000, p.94).
} 
2. Dispositio - Atual estágio das ideias em seis partes do discurso, para o próprio processo de composição, formulário;

3. Elocutio (Decoratio) - Elaboração ou decoração de cada ideia para o desenvolvimento tanto dos itens quanto na sua ornamentação, também chamado elaboratio por outros autores;

4. Pronuntatio - Apresentação de expressão ou de ação, para a interpretação em frente ao público.

A estrutura de Dressler (Exordium, Médium e Finis) foi apenas uma versão simplificada da mais usual divisão em seis partes do Dispositio. Porém, Mattheson ampliou esse esquema para estabelecer um plano racional e organizado para a composição musical ${ }^{36}$ (BUELOW, 2001, p.262). Mattheson afirma a respeito desse plano:

Nossa disposição musical difere do arranjo retórico de um discurso apenas em tema, assunto ou objeto: mas ainda assim ela observa aquelas seis partes que são prescritas a um orador, nomeadamente introdução, relato, discurso, corroboração, confutação e conclusão (MATTHESON, 1739, parte II, cap.4,§ 4, p.235 apud VIDAL, 2002, p.62).

Mattheson prossegue com uma explicação detalhada de cada etapa e suas aplicações na composição musical, bem desenvolvida, como uma ária:

1. Exordium - "é a introdução e começo de uma melodia, na qual o seu propósito e inteira intenção devem ser mostrados, de forma que o ouvinte é preparado e sua atenção captada. Frequentemente, quando examinamos uma obra sem instrumentos, apenas com a parte vocal e o baixo, esta introdução ocorre na passagem do baixo contínuo que antecede a entrada da voz; se um acompanhamento maior está presente, [essa introdução ocorre] no ritornello. Pois nós chamamos a parte que ocorre no começo e com instrumentos de ritornello: porque posteriormente ela é repetida, e a obra pode facilmente tanto terminar quanto começar com ela".

2. Narratio - "é por assim dizer, um relato, uma narração, através do qual o sentido e o caráter do discurso aqui são sugeridos. Ocorre com a entrada ou começo da parte vocal ou da parte concertada [instrumental] mais importante, e é relacionada ao Exordium, que o precedeu, por meio de uma hábil conexão" ${ }^{37}$.

\footnotetext{
${ }^{36}$ Mark Evan Bonds explica que os teóricos de música do século XVIII recorriam a imagens e ao vocabulário da retórica, isto é, eles se fundamentavam naquilo que poderia ser compreendido, na atualidade, como uma metáfora da música (linguagem/discurso), de modo que a base lógica, por trás da estrutura do discurso musical, revelaria certos paralelos com a base lógica por trás das convenções formais da retórica verbal (BONDS, 1991, pp.4-5).

${ }^{37}$ Mattheson faz referência à entrada do solo vocal e instrumental da Narratio, nas árias, porém, a narração do discurso dependendo do texto e contexto, não necessariamente acontece na voz preponderante, ela pode ser realizada em todas as vozes.
} 
3. Divisio - ou Propositio - "é quando o discurso propriamente dito contém de forma sucinta o conteúdo e propósito do discurso musical, e é de duas variedades: simples ou composto [...] Tal discurso ocorre imediatamente depois do primeiro inciso da melodia, nomeadamente quando o baixo toma a frente e apresenta a melodia tão simples e brevemente. Depois a parte vocal começa sua propositio nem variatam, une-se com 0 baixo contínuo e realiza o discurso combinado".

4. Confutatio - "é a clarificação das objeções [isso é, ideias musicais oponentes ou contrastantes], e pode ser expressa na melodia tanto através da combinação, ou mesmo citação ou refutação de elementos estranhos à música que se precedeu".

5. Confirmatio-"é a corroboração artística do discurso, e em melodias é comumente encontrado em repetições imaginativas e inesperadas; o que não deve ser entendido como uma reprise normal. Nos referimos à introdução de certas passagens vocais agradáveis ornamentadas com todos os tipos de boas variações [...]".

6. Perotatio - "finalmente, é o final ou conclusão de nossa oração musical, que deve produzir uma impressão especialmente enfática, mais do que as outras partes. $E$ isto ocorre não apenas no curso ou progresso da própria melodia, mas especialmente no epílogo, seja ele tocado pelo baixo contínuo ou por um forte acompanhamento; tenha ou não alguém ouvido este ritornello antes" (MATTHESON, 1739, parte II, cap.14,§ 7-12, p.236 apud VIDAL, 2002, p.63).

Veja-se na tabela abaixo, essa estrutura formulada por Dietrich Bartel, em seu livro Música Poética Musical - Rhetorical Figures in German Baroque Music, onde são expostas e reforçadas essas partes da Dispositio, assim como as fases retóricas ${ }^{38}$ :

\begin{tabular}{|l|}
\hline \multicolumn{1}{|c|}{ Etapas } \\
\hline a) Inventio, incluem o Loci topici $^{39}$ \\
\hline b) Dispositio \\
i. Exordium
\end{tabular}

\footnotetext{
${ }^{38}$ Observa- se nessa tabela todas as cinco fases retóricas, entretanto, na música as mais empregadas são as três primeiras (Inventio, Dispositio e Elocutio).

${ }^{39} \mathrm{Na}$ Loci Topici, encontram-se cerca de 15 lócus diferentes: Notationis (desenho das notas, na oratória, nas letras que geram ideais); Descriptionis (descrições, descobertas) Generis ou Antecedenita (lugar de gênero e da espécie); Totius (semelhança do instrumento ou da voz com matéria); Casue Effcintis (a história ou a ação é a causa principal); Cause Materialis (a matéria musical é o som; não sujeito de palavras, também não haverá intenção expressiva com relação ao afeto específico); Cause Formalis (a forma e norma de cada obra e melodia); Cause Finalis ou Causorum (final); Effectorum (efeito específico da composição, de acordo com a ocasião); Adjunctorum (representação de determinados personagens como em: ofertórios, óperas e cantatas); Circumstantiarum (diferentes circunstâncias de tempo, do lugar e de acontecimentos anteriores); Comparatorum (comparação de coisas semelhantes e dessemelhantes, pequenas e grandes); Oppositorum (contraste de compassos, movimentos contrários, agudo e grave, lento e rápido, calmo e agitado etc.); Exemplorum (emulação de outros compositores); Testimoniorum (utilização de exemplos conhecidos como: canções de igrejas, para testemunhos ou reforço) (MATTHESON, 1739, apud, LUCAS, 2010, p.1).
} 


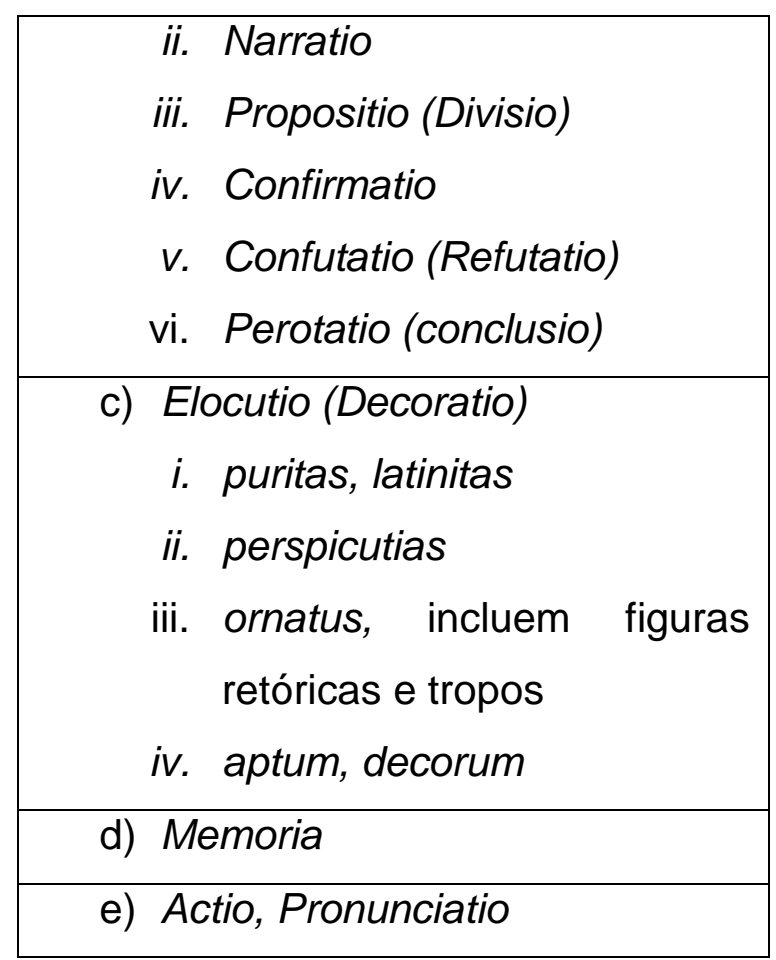

Tabela 1: Estrutura retórica e suas etapas (BARTEL, 1997, p.68).

Em síntese, os tratados de Burmeister, Dressler e Mattheson foram de grande relevância para os compositores contemporâneos e posteriores a eles. Por esse motivo houve maior preocupação em relação ao discurso e à música, além de sua ordenação distribuída primeiramente em três partes e posteriormente em seis partes dentro da Dispositio, todas essas tinham também como integrantes figuras retórico-musicais, inseridas em cada parte. Compositores como: Ludovico Viadana, Cláudio Monteverdi, Heinrich Schütz, Dietrich Buxtehude, Antônio Vivaldi, Johann Sebastian Bach, George Friedrich Haendel, Carl Philipp Emanuel Bach, até mesmo Joseph Haydn, entre outros utilizaram-se desses mecanismos na formulação de estruturas em suas composições. No entanto, no século XIX, com o Classicismo, inicia-se o "enfraquecimento" na inserção da retórica como elemento discursivo ou na elaboração da composição, ou seja, na relação texto e música. Por essa razão, os autores empregavam a retórica em gêneros sacros e em óperas, preferencialmente, embora existam alguns trabalhos que dissertam sobre a 
possibilidade de se encontrar elementos retóricos em obras instrumentais no final do século XVIII e início do XIX ${ }^{40}$.

\subsubsection{Música e Afeto}

A vinculação da música a estados emocionais específicos é fenômeno que se registra desde os tempos da cultura grega. No entanto, é no Barroco onde acontece a maior expansão e detalhamento, haja vista as grandes teorizações, que foram de suma importância para o desenvolvimento das figuras de retórica inseridas na música.

Desde o princípio, a teoria das paixões ou afetos foi parte integral da música Barroca, a qual tinha como objetivo transmitir o mover desses sentimentos aos ouvintes. O compositor barroco planejava o conteúdo da cada obra, seção ou movimento da mesma e do mesmo modo esperava uma resposta de sua audição baseada na apresentação racional do significado afetivo de sua música (BUELOW, 1980, p.800).

Descartes, Bacon, Leibitz, Spinoza e Hulme foram filósofos que abordaram o assunto dos afetos. René Descartes, por exemplo, em seu tratado Les Passions de lâme (1649), trouxe uma perspectiva retórica para os músicos e artistas do período. Nessa obra, o filosofo francês retoma muito das tradições antigas do estudo nesse campo. Ele define as paixões da alma como "as percepções dos sentimentos, ou das emoções" da alma, que se referem particularmente e ela, que são causadas, sustentadas e fortificadas por um movimento dos espíritos (CANO, 2000, p.47). Esses espíritos a qual se refere Descartes são os espíritos animais ${ }^{41}$.

O ódio para Descartes se origina quando um indivíduo persegue um objetivo que causa aversão e seus espíritos animais conduzem imediatamente aos músculos do estômago e do intestino. Assim há impedimento onde os

\footnotetext{
${ }^{40}$ Leonard G. Ratner: Texture, a rhetorical element in Beethoven's quartets (1980). Mark Evan Bonds: Wordless Rhetoric. Musical Form and Metaphor of the Oration (1991). No Brasil: Mônica Isabel Lucas: Humor e Agudeza nos Quartetos de Cordas Op.33 de Joseph Haydn, Tese de Doutorado UNICAMP (2005). João Vicente Vidal. A Ideia do 'Clássico' no Classicismo. Retórica e Música no Final do Século XVIII, Dissertação de Mestrado UFRJ (2002). Sérgio Eduardo Martinelli de Assumpção: Ascendência Retórica das Formas Musicais. Dissertação de Mestrado USP (2006). Cassiano de Almeida Barros: A orientação retórica no processo de composição do Classicismo, observada a partir do tratado VERSCH EINER ANLEITUNG ZUR COMPOSITION (1782-1793) de H.C. Koch (2006). Dissertação de Mestrado, para citar alguns.

${ }^{41}$ Os espíritos animais são as partes mais liberais do sangue. Os movimentos dos espíritos animais provocam as reações corporais características que acompanham cada paixão e tipo de movimento que corresponde a uma paixão.
} 
alimentos não se misturam com o sangue. A alegria estimula mais os nervos pelos espíritos animais que estão em torno dos orifícios do coração, há maior volume nas artérias do coração. Já na tristeza se encontram grande abundância de sangue no coração. No desejo há uma grande força que pode controlar o cérebro que é a vontade. Em síntese, para Descartes, o movimento dos espíritos animais é uma relação entre nossa alma e corpo (que gera os afetos).

Para Descartes, "nenhum sujeito vai mais imediatamente contra nossa alma do que o corpo à qual está unida, como consequência, devemos pensar que ela é paixão, é geralmente uma ação" (CANO, 2000, p.51). Essa identidade alma/corpo, expressada em termos de paixão/ação ou afeto/efeito é um princípio reitor para a descrição musical dos afetos. Segundo o filósofo, teólogo e teórico musical francês Marin Mersene (1588-1648), em um texto de 1636 (Harmonie Universelle), enunciou que, quando a alma se vê afetada por uma paixão, produz dois tipos distintos de movimentos de espíritos animais: 0 fluxo e refluxo. O primeiro move os afetos, o coração, alegria, já o segundo, concentração, tristeza, dor.

- LAETITIA: causa agrado, prazer, amor, devoção, esperteza, confiança, alegria, atenção, orgulho, etc.

- TRISTITIA: desagrado, desprazer, ódio, aversão, susto, decepção, indignação, humildade.

- DESEO: crueldade, temor, cortesia, ambição, lascívia.

Tabela 2: Classificação dos afetos 
Já, segundo David Hulme (CANO, 2000 p. 57), em seu tratado $A$ Natureza Humana (1739), existem somente dois tipos de paixões:

\begin{tabular}{|l|l|}
\hline As diretas & As indiretas \\
\hline $\begin{array}{l}\text { Nascem imediatamente do bem ou } \\
\text { do mal, prazer ou dor, desejo, pena, } \\
\text { alegria, esperança, medo, }\end{array} \begin{array}{l}\text { Produzem as mesmas ou mesmos } \\
\text { princípios, porém, têm combinação } \\
\text { segurança, piedade, malícia, } \\
\text { generosidade. }\end{array}$ & $\begin{array}{l}\text { humildade, ambição, vaidade, amor } \\
\text { e ódio. }\end{array}$ \\
\hline
\end{tabular}

Tabela 3: Tipos de Paixões

O princípio básico e fundamental na representação musical dos afetos na música reside na imitação. Há como elementos suscetíveis à representação do afeto, o desenho melódico, escalas, ritmo, estrutura harmônica, tempo, tonalidade, forma e estilo. Para Marin Mersene (1636), só acontece uma correta expressão na música se os acentos musicais expressarem ou imitarem o fluxo do sangue e o espírito com refluxos. A representação musical desse afeto partirá, do princípio da imitação analógica e efeitos corporais. Tem-se três níveis de intensidade para esse afeto: o ritmo, a melodia e a velocidade. Para Athanasius Kircher (1650), "música é o som que possui força natural como uma corda da alma que vibra". Já Coliisani acredita que a música não pode comover qualquer sujeito senão aquele cujo humor natural esteja conforme a música (COLLISANI, 1988, pp. 64-66). 


\section{RETÓRICA EM PORTUGAL}

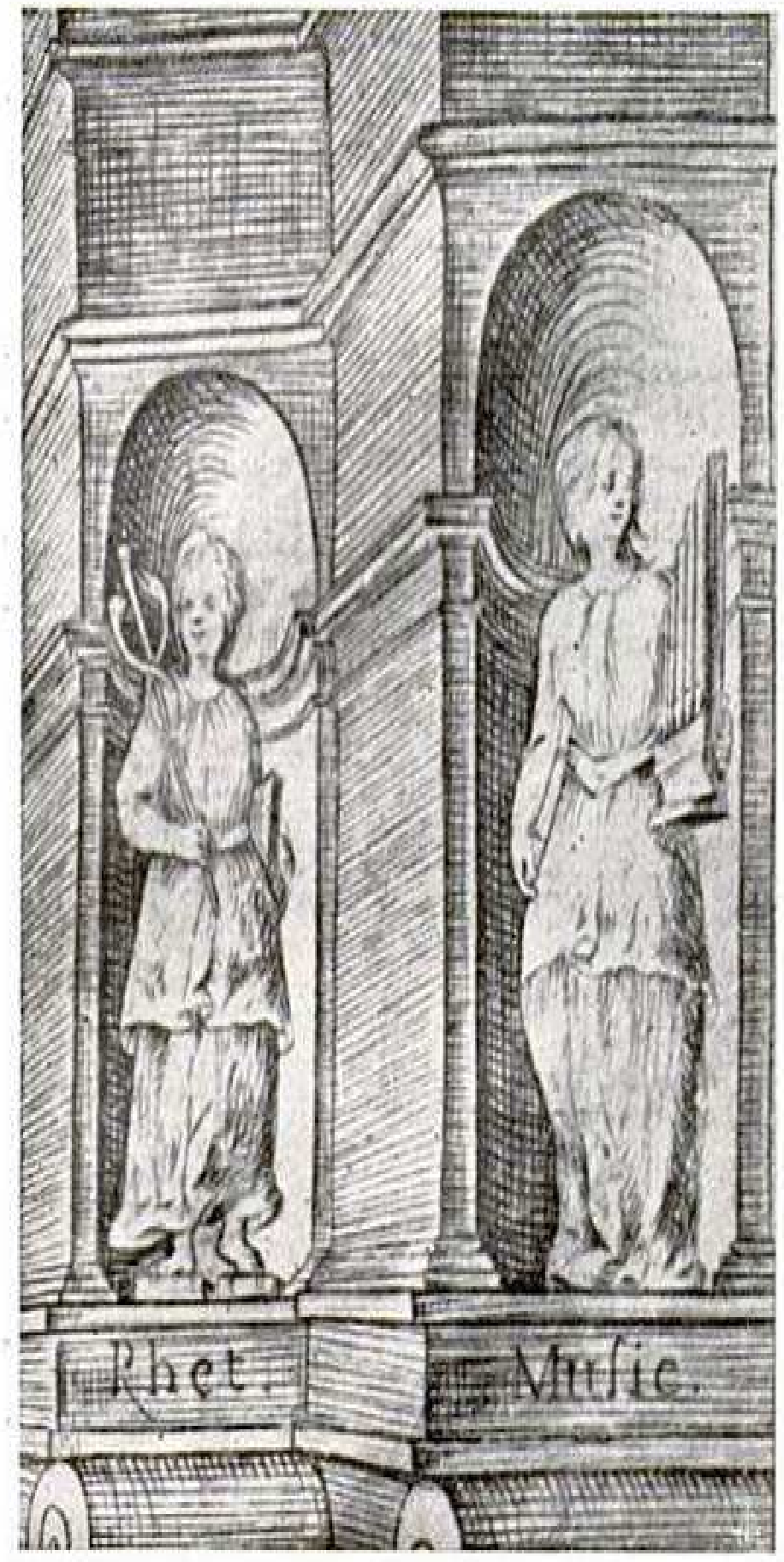

Figura 2: Figuras Alegóricas representando o ensino da Retórica e Música, existentes nos nichos da direita, por parte inferior do pórtico dos estatutos impressos em 1654

(Repr. de A. Hipólito) (BANDEIRA, 1947, p. 204) 


\subsection{Arte Retórica Portuguesa}

É evidente a tradição da retórica na Península Ibérica, acompanhando, evidentemente, a evolução das letras latinas ${ }^{42}$. Entre os séculos I e VII d.C, escritores e filósofos, como Sêneca e Santo Isidoro de Servilha, escreveram e compilaram tratados sobre a oratória e as sete artes liberais ${ }^{43}$. Posteriormente a esses acontecimentos, nas escolas romanas da Península, existia um substrato retórico residente, continuado pelas escolas monacais cristãs, onde se afirma com particular fulgor as obras desses autores.

\subsubsection{Idade Média}

Em Portugal, circunscreveu-se a retórica dos tempos medievais, ao exclusivo domínio da escolaridade. Esta disciplina era dividida em duas frentes ${ }^{44}$ a primeira de ordem profana onde era mesclada retórica e poética imbuída de conceitos gramaticais e a segunda que tinha conexão com a arte de pregar, fundamentada na técnica da palavra, necessária para tornar aptos os sacerdotes na propagação da fé (LAUSBERG, 2004, p.14).

Para melhor compreender em que direção se orientou o ensino da retórica em Portugal, durante o período medieval, há que se observar, logo de início, quais as espécies bibliográficas que chegaram até os dias de hoje. Os dois grandes centros de ensino que melhor se conhecem na história da cultura portuguesa medieval são os mosteiros de Santa Cruz de Coimbra e de Alcobaça (ibidem, p.14). Nesses mosteiros, eram compilados tratados que permitiam aos clérigos aumentarem o seu cabedal de conhecimentos gramaticais e retóricos, tendo-se que gramática, retórica e dialética, conjuntamente, formavam o que se conhece por Trivium.

Nas livrarias de ambos os mosteiros, podem ser encontradas obras de Cícero, entre elas os Duo Libri de Retorjca scilicet Tulij, mencionados num inventário de Santa Cruz de Coimbra. Esses correspondem aos dois livros que

\footnotetext{
${ }^{42}$ Essa tradição não é exclusivamente Ibérica pelo fato dessa também ser parte integrante dos modelos europeus, sobretudo greco-latina, entretanto, esse tópico aborda a retórica literária em Portugal e sua evolução dada pela transmissão dos ensinos dessa disciplina, desde a Antiguidade até os primórdios do Classicismo.

${ }^{43}$ Isidoro, bispo de Hispalis (Servilha), 570-636, compilou, nas suas Origines ou Etyniologie (ED.Lindsay, Oxford, 1911, 1957), todo o saber do seu tempo, desde as sete artes liberais até a geografia, agricultura etc. A retórica está compreendida no livro-II, 1-21 e é uma compilação valiosa, onde se trata, com brevidade exemplar, da teoria do discurso e das figuras.

${ }^{44}$ Essas duas frentes faziam parte da retórica escolar.
} 
constituem o tratado ciceroniano do De inventione, e datam, segundo especialistas, do fim do século XII e princípio do XIII. Por outro, lado encontrase, entre os manuscritos alcobacenses, um códice do século XV, copiado em gótico, da Rhetorica ad Herennium, atribuído a Cícero ${ }^{45}$. Esse texto, bem conhecido na Idade Média, constituía o que se chamava a Retórica Nova e contrapunha-se ao De Inventione, ou Retórica Velha, ou seja, ambos os textos eram frequentemente utilizados durante a época medieval e foram realmente traduzidos por eruditos italianos e franceses (LAUSBERG, 2004, p.15).

Tratados gramaticais dedicados às palavras latinas eram utilizados pelos alcobacenses para compreender questões relativas aos tropos e sua inserção na composição latina ${ }^{46}$. Embora muitos deles sejam responsórios gramaticais, neles podem ser encontradas ligações com a matéria retórica, pelo fato de serem trabalhadas as figuras ornamentais, e isso ajudava os estudantes a formarem o seu estilo, unindo correção gramatical com a beleza estilística. Ainda se pode considerar como elemento secundário para a aprendizagem da retórica o Dicionário de Pápias, que figura tanto na biblioteca de Santa Cruz como na de Alcobaça, sendo fundamental para os estudantes de latinidade. Nesse léxico encontram-se explicações de algumas figuras de retórica.

Enfim, as obras desses autores foram essenciais para o estudo da retórica na Idade Média e as escolas monásticas por dispor de meios suficientes para o ensino de uma das disciplinas mais importantes do Trivium, servindo de subsídio para aprimoramento da técnica oratória dos pregadores e, também, dos preceitos para a sua aplicação prática, tendo por finalidade convencer os ouvintes às verdades eternas cristãs. Igualmente as escolas e suas bibliotecas auxiliavam tanto a pesquisa como a observação minuciosa da gramática e poética e sua relação com a retórica.

\subsubsection{Renascimento}

$\mathrm{Na}$ Renascença, Portugal tratou a retórica como um novo incremento, através dos humanistas, ensinando os textos clássicos de Homero, Demóstenes, Virgílio, Aristóteles e Cícero, assim, estreitando o contato com a

\footnotetext{
${ }^{45}$ Essa anteriormente fora atribuída a Cícero, no entanto, posteriormente, ela seria atribuída a Confúcio (CASTRO, 2008, p.25).

${ }^{46}$ Obras de Prisciano e Grecismus de Eberhard de Béthune.
} 
Antiguidade. Como resultado de tal ligação, textos literários que eram resultados práticos de um conhecimento transformado em arte, por meio do talento individual, eram melhorados e polidos pelos humanistas, no entanto, o conhecimento dos pensadores e tratadistas antigos facilitava uma teorização mais orientada ${ }^{47}$.

Esse movimento humanístico se afirmava, com vigor, ao longo do segundo quartel do século XVI, consagrando a retórica para uma atenção mais solícita e ao mesmo tempo, tornando premente sua inclusão no plano de estudos oficiais, de modo a obter um lugar independente e basilar. Assim, superando o organismo medieval, que lhe atribuía importância relativamente modesta no quadro das disciplinas do Trivium. Portanto, o Humanismo faz da retórica uma ligação estreita entre a invenção dialética e uma base de um método novo de filosofar, ou seja, aos poucos iam sendo despojados de abandonar a especulação abstrata, para procurar uma aproximação da realidade humana através da comunicação, tratando de problemas de ordem moral, política, religiosa ou mesmo filosófica. Em síntese, aliando-se à dialética simplificada a retórica transforma-se no desenvolvimento progressivo do Humanismo (CASTRO, 2008, pp.17-18).

A retórica ensinada nas escolas por professores nacionais e estrangeiros foi um instrumento de intercâmbio verdadeiramente europeu, onde lecionar nas principais universidades europeias, desde a Espanha, França e Itália, consistia não só em objeto de seus estudos, mas muitas vezes como ensino genérico das humanidades. Portugal, por sua vez, não fugiu a esse processo de movimentos intelectuais de constructos, onde as relações eram expressamente ligadas a um sincretismo retórico ${ }^{48}$ (LAUSBERG, 2004, p.20).

No século $X V I$, era a retórica ministrada em todas os estabelecimentos escolares portugueses, desde o colégio de Santo Antão, em Lisboa, como das Artes em Coimbra, à escola de Braga, onde lecionou Clenardo e depois Vaseu, e à Universidade de Évora. No reinado de Dom João III, ensinava-se retórica no colégio fundado pelos Jerônimos no Mosteiro de Penha Longa, que depois foi transferido para o Mosteiro da Marinha da Costa, nas proximidades de

\footnotetext{
${ }^{48}$ Obras retóricas de autores portugueses eram impressas em países estrangeiros, geralmente nas cidades em que esses professores ensinavam, assim acontecia com os humanistas estrangeiros que, porventura, interessavam, pelas suas obras, ao ensino das escolas portuguesas.
} 
Guimarães. Essa instituição tinha, em 1534, o privilégio de conferir graus em artes. Em 1543, foi incorporado à Universidade de Coimbra. Também, no Primeiro Regimento, referente ao Colégio das $\mathrm{Artes}^{49}$, promulgado em 1552 por Dom João III, a retórica passa a ser considerava parte integrante das disciplinas de estudo. Seguido essa mesma orientação, observa-se, nos Estatutos da Universidade de Coimbra, de 1559, eram partes obrigatórias do programa dessa instituição de ensino superior, para os alunos que fossem admitidos na graduação de licenciatura em artes, as cadeiras de gramática e retórica:

Acabados os exames dos bacharéis para licenciados, o Reitor, na tarde do dia, se ajuntava com o Chancelário e a outros examinadores e ali examinavam todos os bacharéis, um a um, analisando seus conhecimentos de gramática e retórica (LAUSBERG, 2004, p.23).

Rosado Fernandes termina sua exposição, acerca da trajetória percorrida pela retórica como disciplina nos estabelecimentos educacionais superiores em Portugal do século XVI, da seguinte forma:

Vemos, por conseguinte, que, muito embora não nos fosse possível traçar um panorama circunstanciado dos programas escolares do século $\mathrm{XVI}$, o ensino da retórica deve ter feito parte integrante do ensino pré-universitário incorporando-se, certamente, no ensino das universidades que formavam os espíritos da época (LAUSBERG, ibidem, p.23).

Pinto de Castro ressalta que muitas dessas escolas tinham como manual de base para a disciplina ensinamentos das obras do padre Cipriano Soares (1524-1593 $)^{50}$, que, embora espanhol, ocupara grande influência em todas as instituições escolares da Companhia de Jesus, não apenas em Portugal, mas em toda a Europa e no Brasil (CASTRO, 2008, p.36).

Tais aplicações deram-se não só na Renascença, mas igualmente em pleno Barroco, entretanto, os professores fazem algumas modificações ao

\footnotetext{
${ }^{49}$ Primeiro Requerimento que El-Rei D. João III deu ao Collegio das Artes no tempo em que nelle leram os Francezes (1552) - (Documentos dos Jesuítas- apud- LAUSBERG, ibidem, p.23).

50 A partir de 1552, as referidas instituições de ensino passaram por uma modificação substancial, isto é, a retórica não seria apenas uma disciplina literária ou de cunho oracional, mas ela seria uma espécie de ponte para outras áreas como: pedagogia, teologia, história, ética, entre outros. Como momento significativo dessa transformação é o primeiro compêndio De Arte Rhetorica libri tres ex Aristotele recogniti, Cicerone et Quintiliano praecipue deprompti ab eodem Auctore recogniti, et multis in locis locupletati - "A Arte de três das obras retóricas reconhecidas de Aristóteles, Cícero e Quintiliano" (1562) de Cipriano Soares (CASTRO, 2008 p.35).
} 
exporem essa obra para seus alunos, isto é, eles reduzem o seu conteúdo a metáforas e as adaptam conforme a demanda e gostos da época, por exemplo, a supracitada obra (De Arte Rhetorica libri) de Soares era introduzida com alterações de relevo, como a recorrência a um manual elaborado com várias finalidades e diferentes conceitos culturais, em vez só da leitura comentada dos tratadistas latinos, porém, não despiciendo no ensino da retórica (CASTRO, 2008, pp.36-37).

\subsubsection{Barroco}

Já no Barroco, nos grandes centros de ensino se estudou aplicadamente retórica e poética ${ }^{51}$. Entre eles destacam-se Évora, Coimbra e Lisboa. Os jesuítas ensinaram nas escolas e universidades de Portugal a Oratória de Cícero e de Quintiliano, traduziram a obra Poética de Aristóteles e transmitiram com grande erudição, a retórica para seus alunos, fazendo dessa um elo entre aplicação prática e teoria escolar ${ }^{52}$ (LAUSBERG, 2004, p.24).

Com isso, nos estabelecimentos de ensino, ocorria verdadeiro alargamento de informações tanto do discurso como no domínio de seus diferentes argumentos. Desse modo, abria-se campo vastíssimo à invenção, apoiada em raciocínios tirados dos lugares comuns, intrínsecos e extrínsecos, por exemplo, a prática oratória e as disposições de inúmeros tratados e sermões, como os do padre Francisco de Mendonça e do padre Antônio Vieira, os quais iriam fortalecer os pregadores barrocos (CASTRO, 2008, pp.72-73).

Segundo Aníbal Pinto de Castro:

O exame das obras que, do Renascimento ao Romantismo, fixaram a teorização retórica em Portugal, traz um contributo de inegável valor para o conhecimento histórico e genérico de uma parte importantíssima, pela qualidade e pela quantidade da produção literária [grifo nosso] (CASTRO, 2008, p. 6).

\footnotetext{
${ }^{51}$ Pinto de Castro afirma que a disciplina retórica atingira, nessa época, um status universal, seja pelas obras escritas por diferentes tratadistas de regiões variadas da Europa, da ampliação do conhecimento acerca do assunto, na importância da matéria na formação educacional e social do cidadão, isto é, aristocrático ou religioso, nos assuntos deliberativos e judiciais com a ampliação das possibilidades nas alegações de provas, com suas respectivas fundamentações, entre outros (CASTRO, 2008, p.72).

52 Juntamente com a retórica e poética, o ensino da gramática, através do latim, era imprescindível para o sistema jesuíta de ensino, em outras palavras, o conhecimento estava sujeito tanto central no sistema jesuíta de ensino, ou seja, seu conhecimento dependia tanto da transparência dos estudos quanto da compreensão lógica dos temas, cuja imprescindibilidade revelou a afirmação de um código universal, embora restrito, para a cultura letrada da Europa Ocidental e seus territórios de influência, até metade do século XVIII (DURAN, 2009, p.13).
} 
Esse autor afirma que, através da obra de Victor Hugo, "O grito no poema, contemplações resposta a uma acusação" ${ }^{53}$, novamente era lembrada aquela antiga e prestigiosa disciplina literária, outrora esquecida, a qual viria a emergir renovada, em nossos dias.

À medida que nos estudos literários o historicismo positivista se viu substituído pela análise do texto, na sua estrutura linguística entendida como expressão de uma literalidade, a retórica, interpretada como uma teoria das figuras e, por consequência, como um fundamento do estilo, viu-se progressivamente redescoberta e valorizada no quadro desses estudos e procurada como objeto de pesquisa pelas correntes ligadas ao estruturalismo, à nova crítica, à teoria da literatura e à semiologia.

\subsubsection{Primórdios do Classicismo}

Após a aplicabilidade da retórica nas grandes instituições de ensino, nos séculos XVII e primórdios do XVIII, manifestar-se-ia em Portugal uma renovação e reformulação nas estruturas da disciplina, não só de ordem escolar, mas também na metodologia e didática, seja deliberativa, religiosa e judicial. Desse modo, ao lado de tratados e métodos gramáticos e retóricos com finalidade profana e eclesiástica, encontram-se tentativas de esclarecimento quanto à matéria em questão, visando tal como os humanistas uma aproximação das fontes (LAUSBERG, 2004, p.25).

Para Lausberg (2006) essa aproximação se dá por meio das edições em latim ou em vernáculo dos autores antigos, sobretudo Cícero e Quintiliano. No entanto, esse movimento não para por ai, pois a Poética de Aristóteles e o Tratado Sublime de Pseudo-Longuino ${ }^{54}$ viriam ampliar as possibilidades de conhecimento dos textos antigos, traduzidos na mesma época.

\footnotetext{
${ }^{53}$ Victor Hugo, nesse poema, traz à tona um pensamento de grande relevância à palavra e as suas várias significações. Ele encerra o trecho da poesia citando um conhecido texto bíblico que se encontra no livro João 1:1; "Por que a palavra era o verbo, e o verbo era Deus".

${ }^{54}$ (Longinos em grego, Cassius Longinus em latim) foi professor de retórica, crítico literário, político e orador grego no século I. Ele é o autor do tratado mais antigo sobre a estética e estilo sublime, ou elevado. Sua primeira publicação é de 1554, editado por Francesco Robortello. O livro se enquadra na categoria de numerosos textos sobre a formação retórica dos oradores, de acordo com o estilo atual de aticismo (atitude purista em relação à língua grega), mas exalta o valor da imitação dos grandes escritores do passado, destacando a necessidade do espírito de grandeza da alma e uma paixão forte e sincera como um elemento essencial da poesia.
} 
Paralelamente, professores como Leitão Ferreira e Lourenço Botelho Soto-Maior iniciaram cursos retóricos baseados nas obras dos autores conceptistas $^{55}$. Esses por sua vez, foram publicados posteriormente, entre 1718 e 1721, assim constituindo valoroso documento desse movimento na formação literária lusitana, todavia, essa tendência não encontrará boa acolhida e, por isso, nos meados do século XVIII, alguns autores voltam a considerar como fundamental o retorno aos textos clássicos. Essa nova reação tem como seu mais ilustre representante Luís António Verney (LAUSBERG, 2004, p.26).

Como se pode notar, a cultura portuguesa era cônscia da arte retórica. Essa tradição é observada na obra do compositor luso-brasileiro, André da Silva Gomes, que se utiliza de figuras e elementos de retórica para enriquecer o seu discurso musical, proporcionando-Ihe a capacidade de despertar, mover e controlar os afetos do ouvinte, tal como os oradores faziam com o discurso falado.

\subsubsection{Luís António Verney}

O ensino lusitano nesse período seguia pela égide de um novo sistema, o qual era direcionado para as camadas da sociedade responsáveis pela manutenção da ordem do reino. Todavia, devido à crescente expansão do saber retórico tornou-se necessário, no segundo quartel do século XVIII, a língua vernácula e os diversos conhecimentos voltados à prosperidade material da população passaram a ser valorizados. Entre os que se direcionaram para a efetivação desse processo de reformulação da transmissão nas metodologias instrutivas lusitanas, estavam os mestres de uma das mais importantes universidades do reino, isto é, em Coimbra. A referida mudança teve como escopo a introdução da disciplina retórica em todos os cursos da instituição, além do processo seletivo dessa como prerrogativa para ingressar nesse

\footnotetext{
${ }^{55}$ Uma corrente da literatura espanhola barroca, baseada na associação engenhosa das palavras e suas ideias. Ou seja, são caracterizados pela concisão de expressão e intensidade semântica das palavras, significados que são carregados por meio de vários sentidos. Assim, a linguagem cria muitas vezes múltiplos significados. Por todas essas razões, os recursos formais mais comuns são as elipses(omissão de parte de uma sentença, subentendida com base na estrutura gramatical), zeugma (figura pela qual uma palavra, expressa em determinada parte do período, é subentendida em outra parte, posterior ou anterior àquela), a ambiguidade(existência de dois ou mais estados de equilíbrio), polissemia (o ter uma palavra muitas significações), antítese (Figura pela qual se salienta a oposição entre duas palavras ou ideias). Enfim, o conceito de estilo é lacônico e sentencioso.
} 
estabelecimento de ensino. Com isso, os estudantes tiveram que se submeter à nova disposição da universidade, a qual se fundamentava na obra de Luís Antônio Verney $(1713-1792)^{56}$, O Verdadeiro Método de Estudar (1746) (DURAN, 2009, p.19).

Foi a publicação desse método, que trouxe orientação mais segura aos estudos da retórica em Portugal e mesmo à sua aplicação prática, isto é, Verney estabelece uma visão diferenciada acerca da disciplina com novos parâmetros. Entretanto, esse autor por ter tido formação oratoriana, a qual era diferente à dos jesuítas, faz críticas à maneira pela qual se direcionava o ensino contemporâneo da retórica (LAUSBERG, ibidem, p.26). Ou seja, ele fazia um juízo crítico das metodologias aplicadas pelos jesuítas ${ }^{57}$, evidenciando que os mesmos se restringiam à instrução de um grupo limitado de pessoas, os quais não direcionavam seus estudos para o bem coletivo, mas sim no favorecimento pessoal. Além disso, Verney ressaltava a necessidade da aplicação de uma linguagem mais acessível para a instrução dos estudantes, ou seja, a língua portuguesa:

\begin{abstract}
Ensinar a retórica em latim é um erro, pelo fato de seus preceitos compreenderem e se exercitarem em todas as línguas, fato que pode ser considerado como um primeiro problema nas instituições escolares portuguesas. Pois alunos estudando retórica sem entender o latim, resultaria em uma interpretação de que a mesma só serviria para as orações latinas, o que não seria uma definição correta. Portanto, da mesma forma em que a retórica nascida na Grécia se espalhara por toda a Europa, isto é, seu conteúdo fora compartilhado e transmitido em diferentes nações, deveria também difundir o ensino da disciplina em línguas diferentes, tais como a do país lusitano [grifos nossos] (VERNEY, 1746, pp.124-125).
\end{abstract}

Nesse propósito, a retórica poderia popularizar uma linha de raciocínio baseada em uma lógica à qual permitiria exprimir opiniões em português e, ao mesmo tempo, conduziria os atributos do saber e do estudo para o cotidiano

${ }^{56}$ Segundo Maria Cruz Duran (2009), Verney estudou no Colégio de Santo Antão e na Congregação do Oratório, posteriormente, forma-se em Teologia pela Universidade de Évora. Obtém o título de doutor em Teologia e Jurisprudência, em Roma. Publica, em 1746, $O$ Verdadeiro Método de Estudar, em seguida, a pedido do rei $\mathrm{D}$. João $\mathrm{V}$, dá início à reforma pedagógica no país lusitano, a qual tem continuidade com D. José I e pelo Marquês de Pombal, com quem se desentendeu, e, por essa razão, fixou residência na capital italiana, até seu falecimento (DURAN, 2009, p.20).

${ }^{57}$ Verney discorre sobre a necessidade da utilização de um novo método de ensino para a retórica em Portugal, sem vícios, como aqueles praticados pelos pregadores. Ele continua dizendo que os mesmos poderiam ser considerados ignorantes no assunto e, por sua vez, devem deixar o estilo antigo para então realmente conhecer a maneira correta da aplicação da retórica (VERNEY, 1746, p.124). 
das pessoas, modificando assim os princípios organizacionais do conhecimento, colocando num mesmo patamar tanto os que ensinavam quanto os que aprendiam.

Para Verney, o conhecimento da retórica poderia contribuir para 0 entendimento do aluno, isto é, através dela os estudantes saberiam organizar e transmitir melhor suas ideias a número maior de pessoas. Semelhantemente, o latim não seria a única língua oficial a ser ensinada e a retórica lograria o posto de disciplina central nessa forma de instruir. Mesmo tendo mudado o processo de ensino em Portugal, era mantido o conteúdo formal do objeto estudado (DURAN, ibidem, p.20).

Verney continua sua crítica aos "métodos antigos" dizendo que muitos dos indivíduos defendem uma ideia errônea acerca da utilidade dessa arte:

Retórica é a arte de persuadir e essa, por consequência, que se acha e serve para o comércio humano e mais necessário para ele. Quem diz que a mesma só serve para persuadir na cadeira ou no púlpito, conhece pouco, o que é retórica. Confesso, que nos púlpitos e nas cadeiras se faz a retórica gala, com seus ornamentos, mas ela não se limita neles, pois todo o lugar é teatro para a retórica [grifos nossos] (VERNEY, 1746, p.125).

Justificando essa afirmação pode-se entender que o método barroco de pregar, baseado nesses conceitos, estava condenado pelo consenso geral dos bons teorizadores. Essa condenação implicava logicamente à não aceitação das metodologias pedagógicas ou das obras didáticas, difundidas pelos defensores do estilo anterior, assim como a dos pregadores que as utilizavam, ou seja, fica clara sua posição antibarroca (CASTRO, 2008, p.454).

Para ele, todo exercício da língua necessita de uma direção retórica, seja a filosofia que se serve da sua elegância, igualmente a teologia pela necessidade de explicar as verdades espirituais que são seu objeto, a justiça com suas leis e cânones, às quais não se pode dispensar e, por fim, o advogado que, em sua arguição, deverá informar ao juiz ou defender o rei sabendo o lugar correto das provas, isto é, o momento exato de utilizá-las, para, assim, aclarar a verdade de sua causa e exercitar os afetos tanto do juiz quanto do júri (VERNEY, 1746, p.126).

Tais constructos aferidos a esse uso persuasivo da linguagem traduziriam em um novo sistema elaborado por Verney, onde matérias como 
história, geografia e gramática viriam acompanhadas da retórica, ou seja, ela se alinhava a esses saberes disponibilizando, assim, distintas aplicações do discurso, além de auxiliar o aluno na elaboração e opinião das disciplinas estudadas:

[O mestre de Retórica] Logo mandará compor alguma coisa em Português, começando por assuntos breves nos três gêneros de Eloquência. Começará, primeiro, pelas cartas portuguesas, dando somente aos rapazes o argumento delas, e emendando-lhes ao depois os defeitos que podem fazer contra a sua própria língua e contra a Gramática. E por esta razão é supérfluo neste ano ler mais autores portugueses, porque esta composição é o melhor estudo que se pode fazer da língua portuguesa. Depois, passará ao estilo histórico, e tirará algum argumento da mesma História que se explica pela manhã, para que os estudantes a dilatem, escrevendo o dito caso mui circunstanciado, e variando isto segundo o arbítrio do Mestre, ou também a descrição de um lugar e de uma pessoa, ou coisa semelhante. Em terceiro lugar, segue-se dar-lhe algum argumento declamatório, mas breve. Para facilitar isto, o melhor meio é este: Quando o mestre propõe algum argumento que se deve provar, perguntará ao rapaz que razões ele dá sobre aquele ponto. Ouça as que ele dá, e ajude-o a produzi-las, pois desta sorte acostuma-se a responder de repente e escrever com facilidade (VERNEY, 1952, apud, DURAN, 2009, p.21).

Portanto, a retórica se tornara não só um exercício mais elaborado de comunicação e de autonomia, auxiliando no pensamento do aluno, mas era essencial porque se estendia para as diversas áreas dos saberes e estudos, inclusive no cotidiano.

No que tange à aplicabilidade de figuras retóricas, Luís António Verney afirma que elas devem ser empregadas em toda ocasião, seja em discursos grandes, simples, medíocres, ou na conversação familiar (VERNEY, 1746, p.161). Ele divide os estilos os quais devem ser utilizados em um discurso, mostrado a seguir.

1. Estilo Sublime: este é aplicado a expressões grandiosas, harmoniosas, com ornamentos. Seu próprio lugar estaria nas orações, nos sermões, na poesia heroica e trágica e na história.

2. Estilo Simples: também conhecido como Humilde, seria exprimir o natural. As expressões desse estilo são tratadas na maneira comum de falar a língua. 
3. Estilo Baixo: não confundir com o Simples, o mesmo seria o modo de falar dos ignorantes e pouco cultos, já o Simples, é a maneira de falar com naturalidade, sem ornamentos, mas com palavras próprias e puras.

4. Estilo Medíocre: é aquele que participa de um e outro estilo (VERNEY, 1746, pp.163-168).

Em suma, para Verney, quem entendesse a maneira de usar esses elementos retóricos estruturados nas fases retóricas, ficaria perfeitamente instruído do modo que deveriam se aplicar às diferentes matérias ${ }^{58}$ (VERNEY, 1746, p.169).

\title{
3.2. Relação entre música e retórica em Portugal
}

Em Portugal, nas artes musicais, a retórica surge a par da gramática como um dos principais elementos de comparação com a música. Aliás, como bem sublinha Rita Copland, "desde o período romano a retórica e gramática se encontravam interligadas, fundindo-se numa disciplina única" (COPLAND, 1991, apud, PAIXÃO, 2008, p.113).

Ana Margarida Madeira Minhós da Paixão destaca que, independente da sua contiguidade e associação retórica e gramática há desde a Antiguidade um conjunto metódico e sistemático que ao longo dos séculos se consolidaria:

\begin{abstract}
Independente dos seus graus de proximidade e de fusão, retórica e gramática dispõem, desde a Antiguidade, de um código normativo bastante difundido e historicamente consolidado, o que justifica 0 recurso aos seus princípios por parte da música que procura precisamente codificar, regulamentar e nomear os seus elementos e princípios, de modo a constituir-se como um todo coeso. A apropriação de princípios oratórios ou gramaticais por parte da música assumirá ainda maior relevo nas artes musicais portuguesas do período que se segue à implementação do sistema tonal (PAIXÃO, 2008, p.114).
\end{abstract}

Dessa forma, a teoria musical portuguesa embasava suas metodologias e aplicabilidade no ensino utilizando a retórica e a gramática. Em virtude disso, surge a necessidade da criação de normas de estabilização para um sistema ainda que embrionário, de maneira a notabilizar as duas disciplinas que figurariam nas obras musicais portuguesas desde o início do século XVII. Por exemplo, em 1618, Pedro Talésio, à semelhança do que se pode encontrar nas

\footnotetext{
${ }^{58}$ Por exemplo, a Geometria, a Lógica, Física e Metafísica, Filosofia, Teologia, na Poesia, entre outras áreas do conhecimento (VERNEY, 1746, p.170).
} 
Etimologias de Isidoro de Sevilha, apresenta um compasso Grammatical, o qual pode ser formando de três maneiras: igual, desigual ou ternário (PAIXÃO, ibidem, p.114).

Dentre os diversos tratadistas portugueses, António Fernandes justifica a necessidade de uma elaboração mais profícua em suas obras por meio da criação e sistematização de regras que, à semelhança da gramática e da retórica, possa estabelecer um quadro teórico subjacente a todo o ensino da música, tal afirmação é sustentada com uma citação de Cícero. Salienta o autor precisamente que:

O Grammatico, o Rhetorico, \& os demais não saem hum ponto daquillo que lhe manda \& ensina a Arte, \& isto he proprio de qualquer Arte ou sciencia, que he terem hum caminho certo \& seguro por onde qualquer principiante que scientifico ser deseja com seguridade poßa caminhar; \& faltando isto não seria sciencia, senão confusam. Para intelligencia disto diz Marco Tullio Cicero no primeiro de Oratore que todas as cousas que agora estão enserradas em Arte foram primeiro derramadas \& em algữa maneira dißipadas, aßi como na Musica estiveram os numeros, vozes, \& modos, \& por causa dessa confusam foi inventada a Arte pellos doutos: pera que as cousas que estavam aßi derramadas as ajuntassem e puzessem em rezam, que de outra maneira não fora Arte (FERNANDES, 1626, apud, PAIXÃO, 2008, p.115).

Assim Fernandes, deixa claro seu atento para a criação deste quadro conceitual para a música, amparado na gramática e na retórica cujas artes se alinham como modelos para a aplicação de um sistema notacional para a música.

\subsubsection{Arte retórica literária e musical}

As artes musicais evidenciam uma vasta área de contato com a literatura. Segundo Ana Paixão, "as artes literárias e musicais portuguesas apresentam-se como espaços privilegiados para a identificação e análise desses elementos de Ante-Escrita e de Escrita, frequentemente baseadas em técnicas retóricas" (PAIXÃO, 2008, p.80). Através dos códices retóricos e estabilizados desde a Antiguidade Clássica as obras de Cícero, Quintiliano, Platão e Aristóteles se mantêm inalterados em muitas das obras portuguesas de teoria literária e musical ${ }^{59}$. Diante disso, as divisões da retórica, assim como

\footnotetext{
${ }^{59}$ Sublinha-se a redescoberta de Instituto Oratoria de Fábio Quintiliano por Poggio Bracciolini, em 1416, ou do De Oratore de Cícero, feita por Gherardo Landarini, em 1432, os comentários
} 
o plano e as partes do discurso, surgem como princípios orientadores de AnteEscrita e de Escrita nas Artes literárias e musicais portuguesas e serão fundamentalmente categorias e princípios retóricos que permitirão identificar os modos de produção discursiva comuns, na música e na literatura.

Tanto as artes de retórica como a poética em análise evidenciam vasta área de contato com a música, seja em obras de teoria literária onde se destacam as origens comuns entre literatura e música ou em modos de relacionamento entre textos literários e musicais, que resultam em efeitos de recepção idênticos ou gêneros partilhados. Essa comparação entre as relações surgiram por meio de um grande campo de intersecção temático, onde analogias e imagens são frequentes, assim como citações de autores musicais e reflexões elaboradas em torno de aspectos musicais específicos, dentre elas a música portuguesa (PAIXÃO, 2008, p.84). Tais constructos comparativos trazem reflexões sobre o exame da maneira do relacionamento da música e seus respectivos modos de integração que, segundo Paixão (ibidem), "são possíveis, graças ao reconhecimento dos aspectos musicais nas línguas, gerando assim uma distribuição e adaptação da terminologia, além dos conselhos ao poeta, orador ou para quem estuda música".

Em síntese, como ressalta Áron Kibédi Varga:

\begin{abstract}
A retórica se apresenta como uma disciplina de abrangência geral, que abarca modos e processos de produção e emissão discursivos que englobam todo o tipo de textos independentemente e de signos que os integram. O que a torna operativa para os princípios de criação e enunciação dos discursos literários e musicais (VARGA, 1983 apud PAIXÃO, 2008, p.82).
\end{abstract}

\title{
3.2.2. Paralelismos entre poesia, música e retórica
}

Autores portugueses como Francisco Freire de Carvalho salienta que a música e a poesia têm em comum a mesma origem, pelo fato de haverem nascido nas mesmas circunstâncias, ou seja, poetas cantavam suas próprias

de Pietro d`Abano à obra de Aristóteles em 1475, as traduções das obras completas de Platão por Marsílio Ficino, publicadas em 1491. Como bem salienta Peter Mack, nos textos humanistas: "as expectativas estavam dominadas pela Rhetorica ad Hernnium e pela recente descoberta da Instituo Oratoria de Quintiliano, a Retórica de Aristóteles, outras obras como De inventione, que são fundamentais para o período medieval". Nas obras portuguesas, a preponderância do pensamento retórico de Cícero e, sobretudo, de Quintiliano será mais do que a de quaisquer outros autores (PAIXÃO, 2008, p.81). 
composições e essas por sua vez, eram acompanhadas de métrica e melodia, resultando em palavras trabalhadas, ornamentadas ${ }^{60}$. Bernardino Carneiro evidencia também a relação entre a poesia e música, justificando precisamente a existência da versificação poética a partir dessa gênese musical. Para Duarte de Vasconcelos, os princípios geradores da poesia são também comuns, todavia, ele apresenta mais um componente o qual serve de condutor e impulsionador para a criação do poema e da melodia, que é a emoção (PAIXÃO, 2008, p.86).

Por consequência, o conjunto dos modos de complementaridade, no estabelecimento entre texto das duas artes (música e poesia), ajustado às palavras e a um discurso organizado, alinhados à emoção, corrobora para a manifestação do despertar dos afetos e como instrumento central na consolidação dessa reação, está a retórica, que pode apresentar esses efeitos.

Autores como Filipe das Chagas, Jerónimo Rodrigues e João Francisco Branco analisam questões relativas a gêneros partilhados pela música, poética e retórica. Tanto canções como ópera são enfatizadas em suas obras e ao mesmo tempo, estabelecidas pela proximidade entre o músico e o poeta, ressaltando os efeitos que o poema e a música poderão provocar e a maneira de sua disposição nas relações entre os textos das duas partes. Finalizando, Antonio da Costa, na sua obra Conclusões de Rhetorica e Poetica, tece comentários acerca da poesia lírica para posteriormente aplicar reflexões ao gênero operístico, abordando também a questão da representatividade musical (PAIXÃO, 2008, p.88).

Os mesmos paralelismos nas artes retóricas e de poética são apresentados e comparados entre os domínios da literatura e da música, por João de Barros, no século XVI, na Grammatica da Lingua Portuguesa, onde as comparações com a música a propósito da duração e das alturas sonoras das sílabas são estabelecidas:

\footnotetext{
${ }^{60}$ Por exemplo, António Fernandes explicita da seguinte forma a origem da música métrica: "Assi que nam das letras, mas do som da voz vem a nascer a Musica Metrica: porque acompanhandoa com o som dos artificiais instrumentos se forma o Metro, como antigamente 0 faziam os Poetas Lyricos, que ao som da Lyra ou da Cytara cantavam os seus versos: donde igualmente os Poetas \& os seus versos cantados vinham a chamarse Lyricos; \& porque assi do principio andavam pouco \& pouco buscando acompanhar os versos com harmonia ao som da Lyra, ou da Cythara, he opiniam de muitos que os dittos acharam as leys ou regras dos versos os quais se chamam Metricos" (FERNANDES, 1636, apud, PAIXÃO, 2008, p.105).
} 
Toda syllaba tem tres acidentes, Numero de leteras, Espaço de tempo, Acẽto alto ou baixo. O numero de leteras, ia ô vimos pelos exemplos atrás. Espaço de tẽpo, por q hũas sam curtas e outras lõgas, como nesta diçã Bárbora, q a primeira e lõga. \& as duas sã breves. Por que tãto tẽpo se gásta na primiera, como nas duas seguintes, à semelhança dos músicos, os quáes tanto se detẽ no ponto desta primeira figura bar, como nas duas derradeiras, bo, ra. [...] O terceiro acidente da Syllaba, e canto álto ou baixo: por que como os músicos alevantam \& abaixã a voz cantando, assy nos temos a mesma ordem (BARROS, 1540, apud, PAIXÃO, 2008, p.89).

No século XVII, em uma obra anônima intitulada Orphea Rhetorices Cithara in quinque Cordas seu partes distributa et eloquentiae plectro emodulata, a retórica é equiparada a uma cítara que contém cinco cordas assim como as partes da retórica, ou seja, suas cinco partes. Já no século XVIII, José de São Lourenço estabelece igualmente paralelismo entre retórica e música ao ressaltar "que as persuasões e provas retóricas deviam variar pela razão dos ouvintes; assim como o músico precisaria acomodar-se pela diversidade do ouvir" (PAIXÃO, 2008, p.89). No mesmo período, Antonio das Neves Pereira considerava que a música era uma área privilegiada de intersecção com a literatura e, sobretudo com a retórica, ou seja, pela eloquência ordenada que se traduzira em uma música articulada, por exemplo. Além dessa relação entre eloquência e música, Neves Pereira estabelece outro paralelismo ao evidenciar que "o movimento no discurso produz o mesmo efeito que faz na música". Portanto, na composição das palavras, como na ação ou gesto, ele pode ser encontrado, porém, na ação é bem mais perceptível (PAIXÃO, 2008, p.90).

Em síntese, através das comparações e paralelismos entre poesia, música e retórica, por parte de autores portugueses, pode-se intuir que a música é uma área privilegiada que serve como uma linha de intersecção com a literatura e, sobretudo, com a retórica, ou seja, um elo onde a eloquência se apresenta através da qualidade do pensamento e discurso expresso pelo autor, compositor, orador ou poeta, com a finalidade de persuadir o ouvinte.

\subsubsection{Proximidade destas relações com diferentes culturas}

Aníbal Pinto de Castro descreve a importância de teorizadores da retórica literária de países como França e Itália. Segundo ele, os teóricos 
franceses dos séculos XVII e XVIII contribuíram para a fundamentação de certos aspectos da estética pré-romântica na ação formativa da retórica ${ }^{61}$, defendida por M.Klaus Dockhorn, com base no estudo de fontes inglesas e germânicas, completadas. Igualmente no conhecimento de tratados de retórica, publicados na Itália desde os alvores do Renascimento e divulgados modernamente por Eugênio Garin, Paolo Rossi, Cesare Vasoli e, sobretudo, Bernard Weiberg, o que propiciou a permitir um estudo estruturado sobre fundamentos renovados e mais sólidos de toda a estética literária italiana, nas fases sucessivas da sua história, num movimento de crescente entusiasmo e labor (CASTRO, 2008, p.7).

Castro conclui, destacando e relacionando esse intercâmbio de saberes em Portugal, da mesma forma o que era produzido e ao mesmo tempo recebido de outras nações europeias, ou seja, Portugal obteve fortes influências de inegável valor no campo da literatura comparada. E no quadro de todas essas influências merece referência especial a presença permanente do predomínio de teorizadores greco-latinos como Aristóteles, Cícero e Quintiliano (CASTRO, 2008, p.9).

Ana Paixão completa expondo que essa proximidade de relações entre gramática, retórica e a poética com a música não se limita à teoria alemã, mas ela pode ser encontrada igualmente nos quadros teórico-musicais italianos, franceses ou flamengos ${ }^{62}$ que, embora nem sempre apresentem a designação música poética, adotam e adaptam terminologias ou técnicas para o domínio musical, sobretudo ao longo do Barroco (PAIXÃO, 2008, pp.32-35).

Reforçando ainda mais essa argumentação, na Idade Média, Santo Agostinho, em seu tratado $A$ Doutrina Cristã, faz uma observação sobre a

61 A professora Marina Machado Rodrigues (UERJ) destaca que: "a estética pré-romântica tinha como características a expressão da profunda melancolia, o desespero, a angústia, da mesma forma o sentimento da natureza inaugura uma nova visão da paisagem: entre a natureza e o eu estabelecem-se relações afetivas; os lagos, as árvores, as montanhas etc., associam-se intimamente aos estados de alma; o poeta submete todas as visões do universo às suas emoções e aos seus sonhos. À literatura pré-romântica se deve à revelação da beleza melancólica do outono, como tempo de folhas caídas, do sol pálido dos crepúsculos magoados, das paisagens montanhosas e selvagens" (RODRIQUES, 2004, p.125).

${ }_{62}$ Exemplos podem ser vistos em: Le Instituione Harmoniche, de Geosefio Zarlino, em 1558 (cf. Zarlino, 1562), Elementa musicalia, de Jabus Faber Stapulenis (cf. Stapulenis, 1500), Compendium musicae de René Descartes, em 1618 (cf. Descartes, 1987), Traité de I'harmonie universelle, de Martin Mersenne, em 1627 (cf.Mersenne, 2003), Essai d'une méthode pour apprendre à jouer la flûte tranversière, de Jean Joachim Quantz, em 1752 (cf.Quantz, 1975), Compediolum musicae pro incipientibus, de Heinrich Faber (cf. Faber, 1980) ou Compedium musices, de Adrianus Petit Coclico (cf.Coclico, 1954) (PAIXÃO, op.cit, p.35). 
questão da necessidade do conhecimento dos tropos ou das figuras de pensamento, seja para os autores e eruditos ou para quem pratica a fé cristã, no entanto, esse conhecimento não se limita a uma só via, mas pode ser adquirido de várias formas:

Sabem os literatos que nossos autores usaram de todos os modos de expressão chamados pelos gramáticos com a palavra grega de tropos. Eles os empregavam com maior frequência do que podem pensar ou crer os que não conhecem as obras literárias, mas que os aprenderam de outra maneira. Contudo, os que estudaram os tropos encontram-se nos Livros santos e esse conhecimento lhes é de bastante utilidade para o seu entendimento [...] Pois as letras das quais a gramática tirou seu nome - já que os gregos as chamam gramata - são signos escritos dos sons que fazemos com a voz articulada ao falar. Ora, encontram-se nos Livros santos não somente exemplos desses tropos, como de todas as outras coisas, como ainda o nome declarado de alguns deles, tais como: alegoria, enigma, parábola. Ademais, quase todos esses tropos, que se pretende aprender nos estudos liberais, encontram-se até na linguagem comum dos que nunca estudaram com os retóricos e contentam-se em falar a linguagem vulgar. De fato, quem não diz: "Assim floresças"? Aí está um tropo chamado metáfora. Quem não diz "piscina", ainda que a propósito de um reservatório que não possua peixes, nem tenha sido feito para isso, e que, contudo, tira seu nome de piscis (peixe)? Esse tipo de tropo é chamado de catacrese [grifos nossos] (AGOSTINHO, [397-426] 2002, livro III, cap.29 § 40, pp.185186).

Tendo em vista essa afirmação, fica claro que o saber não é propriedade exclusiva de uma pessoa ou etnia, mas ele é universal e como tal deve ser expandido para além das fronteiras. Mesmo no caso da retórica onde seu nascimento e desenvolvimento se deram, primeiramente na Grécia e depois em Roma, percorreu por toda a Europa no final da Antiguidade e Idade Média, contribuindo para o enriquecimento tanto da oratória, do vocabulário e da gramática, como da música, nos tratados musicais, a partir do século XVI. Enfim, pode-se dizer que a consciência no uso dos elementos retóricos, por exemplo, na música, não está baseado somente em uma escola ou seguimento, mas em uma diversidade de tratados, cujos autores são de nações diferentes.

Evidentemente que a teoria alemã, através de tratadistas como Johannes Lippius, Johannes Nucius, Michael Praetorius, Joachim Burmeister e Johann Mattheson, entre muitos outros, foi importante para a teorização e 
sistematização entre gramática, retórica, poética com a música, com elaboração de estruturas retórico-musicais, por exemplo, formas de se encontrar figuras retóricas, elementos retóricos e análises dos discursos, no entanto, deve-se levar em conta a teorização retórica, na península ibérica que se deu desde a Antiguidade, além das contribuições de teóricos citados anteriormente nesse subtópico.

\subsection{O Sistema de formação musical em Portugal: o Real Seminário de Música da Patriarcal}

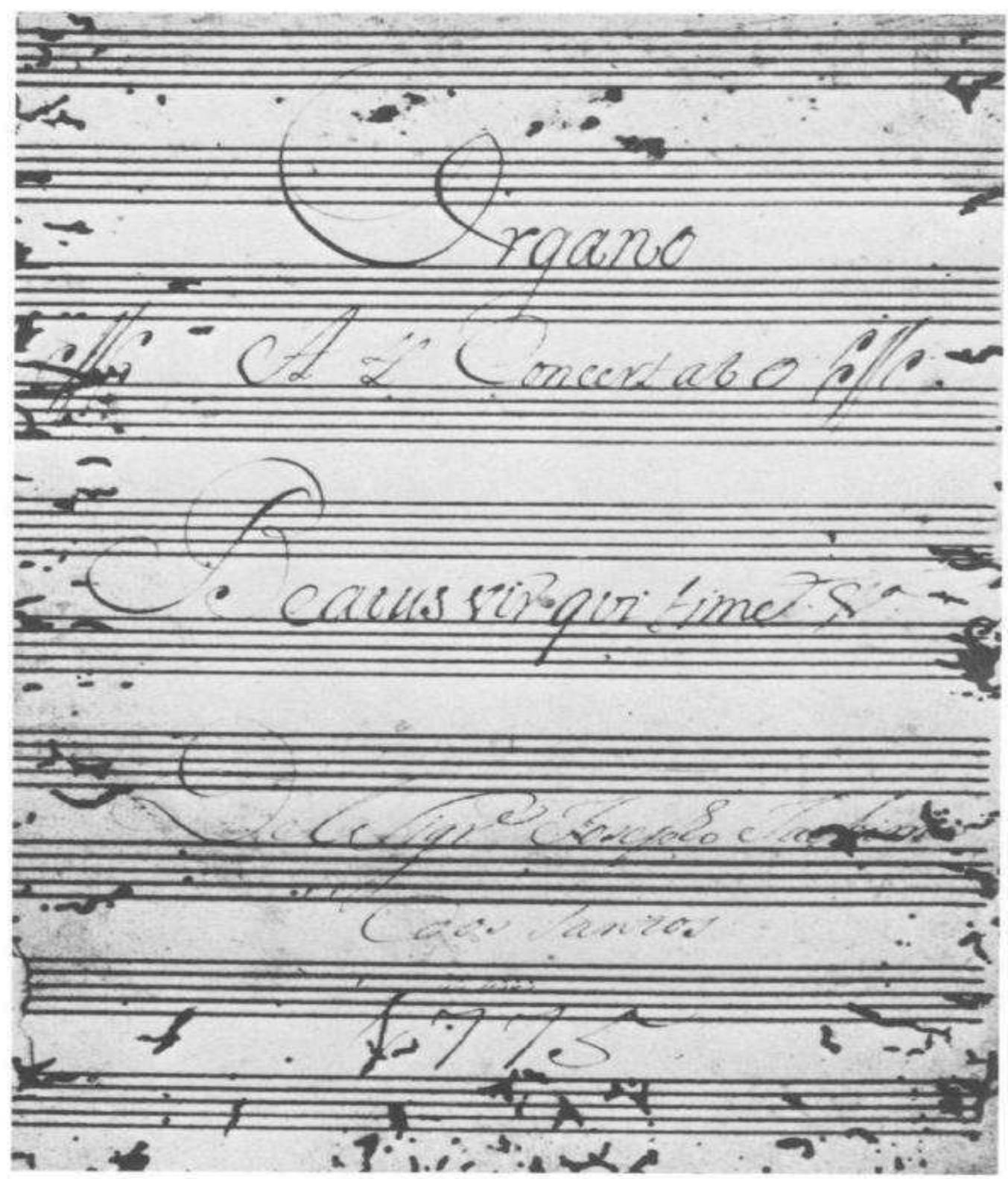

Figura 3: Salmo Beatus Vir, do compositor e aluno do Seminário José Joaquim dos Santos; cópia de André da Silva Gomes, de 1775. (ACMSP- Arquivo da Cúria Metropolitana de São Paulo- apud - DUPRAT, 1975, p.24). 
Em decorrência do crescente interesse das instituições portuguesas em proporcionar a seus alunos melhor formação musical, o rei Dom João $V$ outorga a efetivação de uma escola específica no ensino da música, segundo destaca Cristina Fernandes:

$A$ criação por Dom João $V$ de um estabelecimento especializado no ensino da música anexo à Capela Real, seguindo uma tradição próxima das escolas que há vários séculos formavam os meninos de coro das grandes catedrais e de outras capelas de cortes europeias se deu em 1713, precedendo em três anos a instituição oficial do Patriarcado de Lisboa ${ }^{63}$. O Rei procurou desde o início de seu reinado incentivar a formação de músicos com qualidade, através de investimentos, fazendo assim uma estratégia de, a longo prazo, garantir à instituição os melhores profissionais nacionais, em paralelo com os músicos estrangeiros qualificados que viriam a ser contratados nas décadas seguintes (FERNANDES, 2009, p.1 do capítulo-3) $^{64}$.

Fernandes (2009) prossegue afirmando que o Real Seminário de Música

da Patriarcal "funcionava como uma escola de modelo eclesiástico, onde um grupo seleto de colegiais vivia em regime de internato bastante rigoroso, mas que abria algumas das suas aulas a estudantes exteriores à instituição"65 (FERNANDES, ibidem, pp.1-2). Entre as disciplinas estudadas no Seminário Patriarcal havia lições de música e gramática ${ }^{66}$ (latim e italiano a partir do segundo quartel do século XVIII) ${ }^{67}$, os alunos internos estavam sujeitos a um

\footnotetext{
${ }^{63}$ Academia Real de Música do Seminário da Patriarcal.

${ }^{64}$ Foi obtido da autora da tese um excerto de 15 páginas e a mesma se encontra sem paginação original, por essa razão a citação está com esses números de páginas.

65 Segundo a Profa . Cristina Isabel Vieira Fernandes, da Universidade de Évora, em Portugal, pesquisadora há anos sobre a relação entre ensino e música portuguesa e o seu desenvolvimento nos séculos XVII a primórdios do XIX no país lusitano, muitos alunos e compositores estudaram no Seminário Patriarcal no regime de externato, por esse fato seus nomes nem sempre aparecem nos livros ou documentos da época. Ela, atendendo um pedido nosso a respeito do compositor luso-brasileiro, esclarece sobre uma questão bastante peculiar desse músico, já que pouco se sabe sobre sua infância ou de um detalhamento de sua formação em Portugal, dito isso, veja-se sua descrição literal: "O nome de André da Silva Gomes não consta do Livro de Matrículas do Seminário da Patriarcal que se encontra na Biblioteca Nacional de Portugal, o que não quer dizer que não tenha estudado lá, pois eu sei que o próprio André da Silva Gomes afirma ter sido aluno de José Joaquim dos Santos, que era mestre do Seminário. No Livro de Matrículas constam só os alunos internos, ele poderá ter sido aluno externo, pois havia bastante ou por algum motivo o nome não foi registrado no livro". ${ }^{66} \mathrm{Na}$ Idade Média, o objetivo da gramática associada à retórica, é o ensino do latim, por isso 0 termo de gramática latina (FAVERO, 2008, p.1).

${ }^{67}$ Ernesto Vieira, informa, da seguinte maneira, sobre a forma e conteúdos do ensino no citado Seminário: "a excellente escola do Seminario Patriarchal educava-os completamente ensinando-Ihes não só música, mas tambem grammatica portuguesa, latim e italiano; os numerosos solfejos de Perez, Luciano, João Jorge, Solano, e tantos outros, faziam d'elles leitores imperturbaveis que liam à primeira vista e sem o menor embaraço toda a musica que se the apresentasse; os exemplos dos melhores cantores italianos estabelecidos em Lisboa
} 
intenso plano de atividades diárias, que incluía o estudo da doutrina cristã, a assistência à Missa e ao Ofício Divino e à colaboração em várias cerimônias da Patriarcal como cantores, ou prestando pequenos serviços. Segundo Cristina Fernandes, a principal missão do seminário era:

Fornecer músicos especializados para os quadros da Patriarcal, mas o alcance desta ação pedagógica acabaria por ser muito mais amplo. Das suas classes saíram quase todos os compositores portugueses setecentistas mais importantes e numerosos músicos (sobretudo cantores e organistas) que viriam a ocupar cargos relevantes em múltiplas instituições luso-brasileiras ${ }^{68}$ (FERNANDES, 2009, p.2).

Não obstante, em 1759, depois da expulsão dos jesuítas, a instituição tem novo endereço, isto é, se situa no antigo Noviciado dessa congregação na Cotavia, nas proximidades da Igreja Patriarcal. Cristina enfatiza que a edificação da escola fora entregue ao Patriarca mediante uma carta régia ${ }^{69}$, sendo objeto de obras em 1761, supervisionadas pelo arquiteto Matheus Vicente de Oliveira. Já o processo de intervenções nas dependências e anexos destinados ao Seminário foi adverso, pelo fato de a edificação ter sido destinada por ordem régia, ao recém-criado Colégio dos Nobres. Todavia, "a descrição dos espaços na documentação que se guarda na Torre do Tombo $14^{70}$ coincide com as características das instalações da escola de música enunciadas pelos Estatutos do Seminário de 1764" (FERNANDES, 2009, p.5).

Imediatamente após, o início da década de 1760 seria marcado pelo investimento no reforço da qualidade da instituição e na sua organização. Por exemplo, alguns dos discípulos mais dotados foram enviados para Nápoles com a finalidade de aperfeiçoarem a sua formação. Em decorrência desse expressivo aumento qualitativo, Dom José I aprovaria novos estatutos, os quais resultariam em uma sistematização e na aplicação de um Livro de Admissões (FERNANDES, ibidem, p.5).

eram-Ihes util lição para adquirirem um bello methodo de canto, cuja tradicção se conservou por muitos annos" (VIEIRA,1900, apud SOTUYO,2003,p.112).

${ }^{68}$ Entre tais compositores, André da Silva Gomes, discípulo de José Joaquim dos Santos, que chegou ao Brasil no final de 1773 e início de 1774.

${ }^{69}$ A localização do Seminário da Patriarcal no antigo Noviciado dos Jesuítas é mencionada em diversos documentos. Um Aviso do Patriarca, datado de 28 de Outubro de 1759, refere que, por sua ordem, "se acha transportado o Seminário Patriarcal das casas em que se achava para a que foy do Noviciado dos Jesuítas no sítio da Cotovia" ( $P$-Lant, Patriarcal-Igreja e Fábrica, Avisos, Cx. 59-apud- FERNANDES, ibidem, p.5).

${ }^{70}$ Constitui-se no arquivo central do Estado Português desde a Idade Média. Com mais de 600 anos, é uma das mais antigas instituições portuguesas ainda ativas. 
Nos anos ulteriores, o Seminário passaria por diversas mudanças, entre elas a hipótese de sua possível transferência em 1774, por causa da ocupação do Colégio dos Nobres no Noviciado de Cotovia para São Vicente de Fora:

\begin{abstract}
Não sabemos se o Seminário continuou a funcionar nas mesmas instalações até a década de 1770, uma vez que o Colégio dos Nobres passou a ocupar o antigo Noviciado da Cotovia, em 1766. Poderiam ter coexistido no mesmo local, mas a bibliografia sobre o assunto é omissa em relação a essa questão, bem como a documentação arquivística consultada $^{71}$. Como se disse atrás, na sequência do incêndio criminoso que destruiu a Igreja Patriarcal da Cotovia, em 1769, esta viria a ocupar por um breve período a Igreja de São Roque e a Igreja do Convento de São Bento, antes de ser instalada na Igreja de São Vicente de Fora, onde permaneceu entre 1772 e 1792. O Seminário deveria acompanhá-la, mas é possível que a transferência só tenha ocorrido em 1774 como se depreende de um Aviso que manda "satisfazer os gastos com a acomodação e mudança do Seminário" 19. Em 1776 e 1777 são solicitadas obras de manutenção e melhoramentos nas salas e dormitórios dos Seminaristas, nos quais chovia e não havia móveis suficientes (FERNANDES, 2009, p.7).
\end{abstract}

Enfim, o Real Seminário de Música da Patriarcal pôde-se manter em uma localidade estável, a partir de 1797, na Tapada da Ajuda, transformandose mais tarde, em 1835, no Conservatório Nacional de Lisboa, por decreto da rainha Dona Maria II, continuando a formar importantes músicos portugueses.

\title{
3.3.1. Organização e sistema de ensino: a partir dos Estatutos de $1764 / 5^{72}$
}

O terceiro quartel do século XVIII ficou assinalado por uma série de reformas educativas praticadas pelo Marquês de Pombal, das quais podem ser destacadas: a secularização e reforma da Universidade de Coimbra, subtraída à influência dos jesuítas, a criação de uma escola para a nobreza (Colégio dos Nobres) e de outra para a burguesia (Aula de Comércio) (FERNANDES, 2010, p.9). Já a área do ensino da música continuou confinada à esfera religiosa.

\footnotetext{
${ }^{71}$ A fundação e os Estatutos do Colégio Real dos Nobres de Lisboa datam de 1761, mas a escola só começou a funcionar em 1766. Nem a História do Ensino em Portugal, de Rómulo de Carvalho (Lisboa: Fundação Gulbenkian, 2001), nem na História da Fundação do Colégio Real dos Nobres de Lisboa (Coimbra: Atlântida, 1959), do mesmo autor fazem menção à passagem do Seminário de Música da Patriarcal pelo edifício. O livro de José Lopes Ribeiro, O Edifício da Faculdade de Ciências - Quatro Séculos de Retratos Institucionais (Lisboa: Edições 70, 1987) é também omisso em relação a essa questão (FERNANDES, ibidem, p.7).

72 Os Estatutos são de 1764, no entanto, o Rei os referendou em 1765.
} 
Porém, diversas normas de regulamentação do Seminário da Patriarcal foram executadas, através dos Estatutos de 23 de Agosto de 1765, assinados por Dom José I. No seu Dicionário Biográfico de Músicos Portugueses, Ernesto Vieira afirma que esses eram ordenados em quinze capítulos, divididos em grande número de artigos, sem grandes diferenças dos estatutos de Vila Viçosa, ou seja, o modelo inspirador seria o mesmo (VIEIRA, 1900, p.548). Enfim, Vieira faz uma descrição aprofundada dos Estatutos do Seminário da Patriarcal, apresentando cada item e os aspectos mais relevantes desse documento de maneira que o pesquisador possa compreender melhor tanto a estrutura quanto o funcionamento da instituição, além de suas particularidades e sistema de ensino (FERNANDES, 2009, p.9).

Semelhantemente como o que sucedera na generalidade dos colégios eclesiásticos, os mestres, alunos e o restante do pessoal auxiliar encontravamse na dependência do Reitor e do Inspetor e esse, por sinal, deveria ser eclesiástico, e conhecedor de música, ornado de virtudes, respeito e autoridade. Dentre suas obrigações contam-se a visita semanal às instalações do Seminário, a revisão da contabilidade e o processo de admissão dos novos alunos, cuja avaliação era feita em conjunto com o Reitor, o Mestre de Solfa ou outras pessoas entendidas sobre $\mathrm{o}$ assunto.

Para admissão de novos discípulos, era requisito essencial ter voz clara, suave e agudíssima, em outras palavras, uma exigência não delimitada apenas à futura carreira musical, mas, também, a objetivar os Seminaristas a cantar em diferentes tessituras vocais, por exemplo, que eles cantassem as partes de soprano em determinadas cerimônias da Patriarcal. Fernandes revela que, além dos Estatutos, o livro de matrículas é bem claro quanto a essa incumbência:

(...) entrou para este Real Seminário para aprender música e cantar tiple no Serviço da Santa Igreja Patriarcal, conforme as ordens de Sua Majestade e determinação dos Estatutos, sendo caso que dentro dos seis meses primeiros lhe sobrevenha alguma queixa grave, se prezuma trazer da casa dos ditos seus pais, e perca o tiple, e se conheça nele inactidão para os fins que se tomão, e S. Majestade os quer, se entregará aos ditos seus pais sem estes se escandalizarem (apud FERNANDES, 2009, p.10). 
Ernesto Vieira relata, em seu dicionário, que a idade ideal para ingressar na escola era de 8 anos e para ser aprovado pedia-se que os futuros discentes já tivessem "luz de solfa para se fazer conceito da voz no exame" e soubessem "suficientemente ler e escrever". Da mesma forma, podiam ser admitidos candidatos mais velhos (em teoria, até 10 anos) caso possuíssem formação musical anterior ou se fossem castrados, com voz de soprano ou, alto. Já o Reitor tinha a incumbência de averiguar informações a respeito da "particular informação da pureza de sangue ${ }^{73}$ e verificar se os pais não tinham "ocupações indignas" (CAPÍTULO I, apud VIEIRA, 1900, p.548).

O cargo de Reitor deveria ser ocupado por um presbítero secular com capacidade, maturidade, bom procedimento, prudente e ciente na música. Esse tinha como missão e responsabilidade a obrigação de "garantir os meios necessários para que os seminaristas se tornassem peritos na música, gramática, leitura, escrita e na interpretação do órgão, além de educá-los nas obrigações dos católicos e na política civil" (CAPÍTULO II, apud VIEIRA, 1900, pp.548-549).

Por fim, no capítulo 5 são fornecidas relevantes informações a respeito do Mestre de Solfa, o qual seria nomeado pelo monarca, em virtude de seus conhecimentos aprofundados em música do ponto de vista prático e teórico:

Art.1- O mestre de Solfa será eleito por mim, tendo em vista a sciencia necessaria da Musica, assim pratica como theorica; e será Compositor de gosto e fundamento, saberá tocar órgão e acompanhar, tudo muito preciso para ensinar e presidir a uma Aula situada na Capital do meu Reyno; será Presbytero secular, morigerado, agradável e prudente; e tendo sido alunno do mesmo seminário, preferirá a outros de iguais prendas; mas não havendo Presbytero com os requesitos necessarios, occupará o dito magisterio algum secular Portugues, ou Estrangeiro, que tenha ventagem em prendas; e terá o ordenado que eu lhe mandar fazer segundo o seu merecimento.

Art.2- Ensinará aos seminaristas Musica e a cantar bem; e aos que forem já destros, ou antes se lhe parecer conveniente, lhes ensinará contraponto, tocar órgão e acompanhar; pondo todo o cuidado e actividade no adiantamento dos discípulos, para que possão servir a Igreja, e esta utilisar-se dos seus prestimos. (D.JOSÉ I 1764/5, apud VIEIRA, 1900, p.549).

${ }^{73} \mathrm{O}$ estatuto de pureza de sangue, que fazia a distinção entre cristãos novos e velhos, viria a ser abolido pelas Reformas Pombalinas de 1772. 
Apesar de nos Estatutos haver referência sempre ao Mestre de Solfa no singular, a instituição possuía diversos docentes, para ministrarem as aulas de música. Segundo Fernandes, no fim da década de 1760, o número de mestres era de 5 , podendo um deles ser ajudante ou substituto. Já a constituição de um corpo docente mais vasto e a divisão mais compartimentada das tarefas administrativas e do governo do seminário estaria mais próxima aos dos conservatórios napolitanos (FERNANDES, 2009, p.11).

\subsubsection{Alguns dos alunos ilustres do Seminário}

O Seminário, desde a época da outorga dos Estatutos, viveu um período florescente onde pode afirmar-se, sem receio de exageros, como ocorria nos institutos italianos do mesmo gênero, ou seja, os conservatórios que, por sua vez, ensinavam contraponto e acompanhamento da mais alta qualidade. Compositores habilíssimos aprenderam nesse estabelecimento variadas metodologias aplicadas no ensino e as formas composicionais da célebre escola napolitana, como as obras de Niccolò Jommelli (1714-1774), por exemplo, e ao mesmo tempo estudantes eram enviados para Nápoles pela coroa portuguesa. Dentre os alunos compositores do estabelecimento português podem ser citados alguns nomes como: Antônio da Silva, José Joaquim dos Santos, Luciano Xavier dos Santos, João Cordeiro da Silva, João de Souza Carvalho, Leal Moreira, Marcos António da Fonseca Portugal, João de Souza Carvalho, Frei José Marques, António José Soares e Xavier Migone (VIEIRA, 1900, p.552), entre muitos outros alunos em regime de internato e externato, como o caso do compositor luso-brasileiro André da Silva Gomes.

Todavia, como descreve Vieira em sua obra, o Seminário sofre declínio tanto na produção artística como nos investimentos de ordem material, isso motivado pela vinda da família real e sua corte em princípios do século XIX:

\footnotetext{
Em 1808 sofreu grande abalo por causa da invasão francesa e guerra peninsular. Dom João VI mandou-o restaurar em 1815, mas ausente no Rio de Janeiro a sua proteção pouco eficaz podia ser. Além disso, as rendas do Patriarcado, extremamente minguadas, iam em parte para o Rio; Marcos Portugal recebia lá o ordenado de mestre do Seminário, e em Lisboa era preciso pagar a outros que realmente 0 fossem. O mesmo sucedia com os italianos (VIEIRA, ibidem, p.552).
}

Nesse afã, viu-se obrigada a escola fixar o número de alunos, fazer uma restauração de suas dependências (edifício, capela e anexos), delinear um 
limite no tempo do curso, isto é, a duração do mesmo, seja internato ou externato.

Enfim, a partir de 1818, com a nomeação do cônego José Barba Alando de Menezes para inspetor, procurou-se estabelecer uma nova metodologia e planejamento ao Seminário, objetivando a busca de novos talentos e da mesma forma zelar pelo nome da instituição escolar, como na formação de seus alunos:

Em 1818 tinha o Seminário dezenove alunos e dois anos depois vinte, que era o máximo número admissível. Eram mestres Leal Moreira, Franco Leal e Angelelli, desempenhando as funções de substituto o aluno Bertozzi. [...] Em 1824, por decreto de 3 de novembro, foram reformados os estatutos de 1764, ficando 0 Seminário considerado um estabelecimento régio de utilidade pública, sustentado pelo cofre da Patriarcal com um subsídio fixo de $400 \$ 000$ réis mensais, pagos adiantados. Assim, o ensino recebeu maior latitude, criando-se também aulas de música instrumental (VIEIRA, 1900, p.553). 


\section{RETÓRICA NA MÚSICA DE ANDRÉ DA SILVA GOMES}

\subsection{Reformas lluministas}

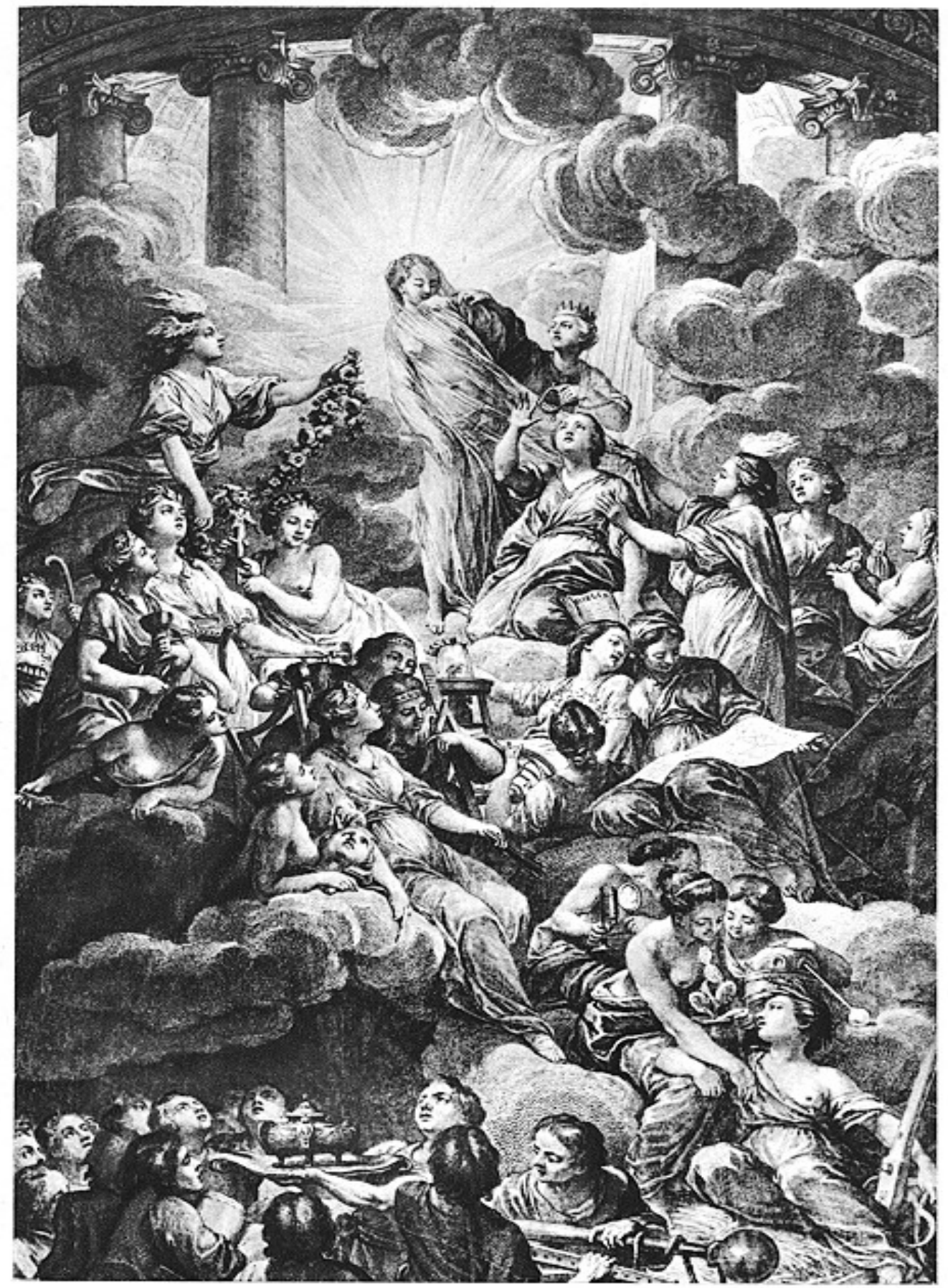

Figura 4: Figura Alegórica do lluminismo ${ }^{74}$

${ }^{74}$ Observa-se no centro dessa figura a verdade, sob intensa luz. Igualmente duas figuras: a direita que simbolizam a razão e a filosofia, estão a retirar o manto sobre a verdade. Esse racionalismo também chegou ao campo das Artes - da música, pintura, escultura, arquitetura e da literatura. Fonte disponível: http://profstellerdepaula.wordpress.com Acessado em: 18 de Março de 2011. 
A partir da segunda metade do século XVIII, iniciou-se uma série de manifestações no movimento lluminista na Europa, todavia, esse fenômeno tinha em comum o entendimento de que eram necessárias profundas reformas desde a base até o topo da estrutura social cristã. O musicólogo Diósnio Machado Neto destaca que essas reformas de grande intensidade, deram-se a partir do momento em que a estrutura socioeconômica e geopolítica era cada vez mais influenciada por meio de um modelo, cuja estrutura era arraigada em um sistema capitalista de produção, o qual desconsiderava paulatinamente, antigos fundamentos da sociedade do Antigo Regime (MACHADO NETO, 2008, p.207).

Por essas e outras modificações na estrutura socioeconômica europeia, o Antigo Regime não se sustentaria sem que houvesse amplas negociações nas diversas esferas da sociedade. Sendo assim, as boas administrações teriam que passar por uma adequação direcionada a métodos de racionalização, cuja organização governamental seguiria gestão ajustada aos fundamentos de uma política que iniciava uma marcha baseada nas estruturas de desenvolvimento econômico industrial, sustentada na visão política de que cada vez menos seria admitida a interferência religiosa nas suas resoluções paradigmáticas (MACHADO NETO, 2008, p.208).

\footnotetext{
Por volta de 1780 , todos os governos continentais com qualquer pretensão a uma política racional estavam consequentemente fomentando o crescimento econômico, e especialmente o desenvolvimento industrial, embora com sucesso muito variável. As ciências dedicavam-se à solução de problemas produtivos [...] $\mathrm{A}$ grande Enciclopédia de Diderot e d'Alambert não era simplesmente um compêndio do pensamento político e social progressista, mas do progresso científico e tecnológico. Pois, de fato, o lluminismo, a convicção no progresso do conhecimento humano, na racionalidade, na riqueza e no controle da natureza derivou sua força primordialmente do evidente progresso da produção, do comércio e da racionalidade econômica e científica que se acreditava estarem associadas a ambos (HOBSBAWM, 2002 apud, MACHADO NETO, ibidem, p.208).
}

Enfim, através dessas modificações, países conservadores e de grande tradição, como Portugal, tiveram que prover os cargos administrativos não mais obedecendo às antigas reservas coorporativas, ou seja, sem licitação justa, mas sim pelo mérito. 
Dando prosseguimento a esses acontecimentos, setores da aristocracia portuguesa buscavam avançar na política de processo no conhecimento humano com a criação da Academia Real de História fundada em 1720, entretanto, a eminente catástrofe econômica que se aproximava, a partir do último período do reinado de Dom João $\mathrm{V}$, fruto de seu procedimento insensato e fanatismo religioso, que envolveu a nação num descaminho institucional, estimulou a queda da economia do Império, ou seja, nas colônias, o comércio debilitava-se e a política exterior era visto com desprezo pelos ingleses (AZEVEDO, 2004, apud MACHADO NETO, 2008, p.209).

A solução para esse problema deu-se em princípio por meio do Testamento Político de Dom Luís da Cunha escrito em 1747 e oferecido ao Príncipe do Brasil, Dom José, herdeiro da Coroa. Nesse documento, era tratada a necessidade radical de mudança de mentalidade, no melhor estilo erudito da época e suas inúmeras citações históricas. Da mesma forma, era exposta a ideia da incorporação da terra pela nobreza, além dos poderes atribuídos do Rei para a mesma, contudo, quem governaria seriam os secretários de estado e não as cortes, o que acarretaria em estratégia política a qual perpetuaria o Rei como senhor benevolente e promotor da justiça, que interviria, através de sua autoridade, somente quando acontecessem dissensões entre os estados. Enfim, estava traçado um plano para a afirmação do Rei com poderes absolutos (MACHADO NETO, 2008, pp.210-211).

$O$ resultado do plano referido e da reforma imposta gerou um processo de transformação com inúmeras variantes aplicadas pelo sucessor de Dom João V, Dom José I:

1. A diminuição na influência da igreja na determinação da política real;

2. A renovação do quadro administrativo como agente de um servilismo da nova nobreza que, consequentemente, resultaria no processo de expulsão dos jesuítas;

3. A transformação de paradigmas filosóficos tais como: a prática e teoria do direito, da economia, da ciência e das artes.

Em face dessa renovação socioeconômica e cultural em Portugal, a música brasileira começaria a trilhar por um caminho cujo sistema 
organizacional com que, suas linguagens e funcionalidades, além de suas convenções, teria como norte o ensino, representado pela sua principal forma de delegação: a religião, o que resultaria em um confronto de ordem cultural. Portanto, para compreender o processo pela qual se estrutura a música brasileira entre o século XVIII e o início do XIX, se faz necessária uma observação da estabilidade e consolidação do cargo de mestre de capela, ou seja, sua relação com a administração geopolítica luso-brasileira, sua inteiração com os alunos, a maneira pela qual ele elaborava não só a música executada, mas igualmente sua linha de raciocínio, com suas ideologias, o que poderia constituir os conjuntos de características culturais.

\subsubsection{O Programa lluminista na Capitania de São Paulo}

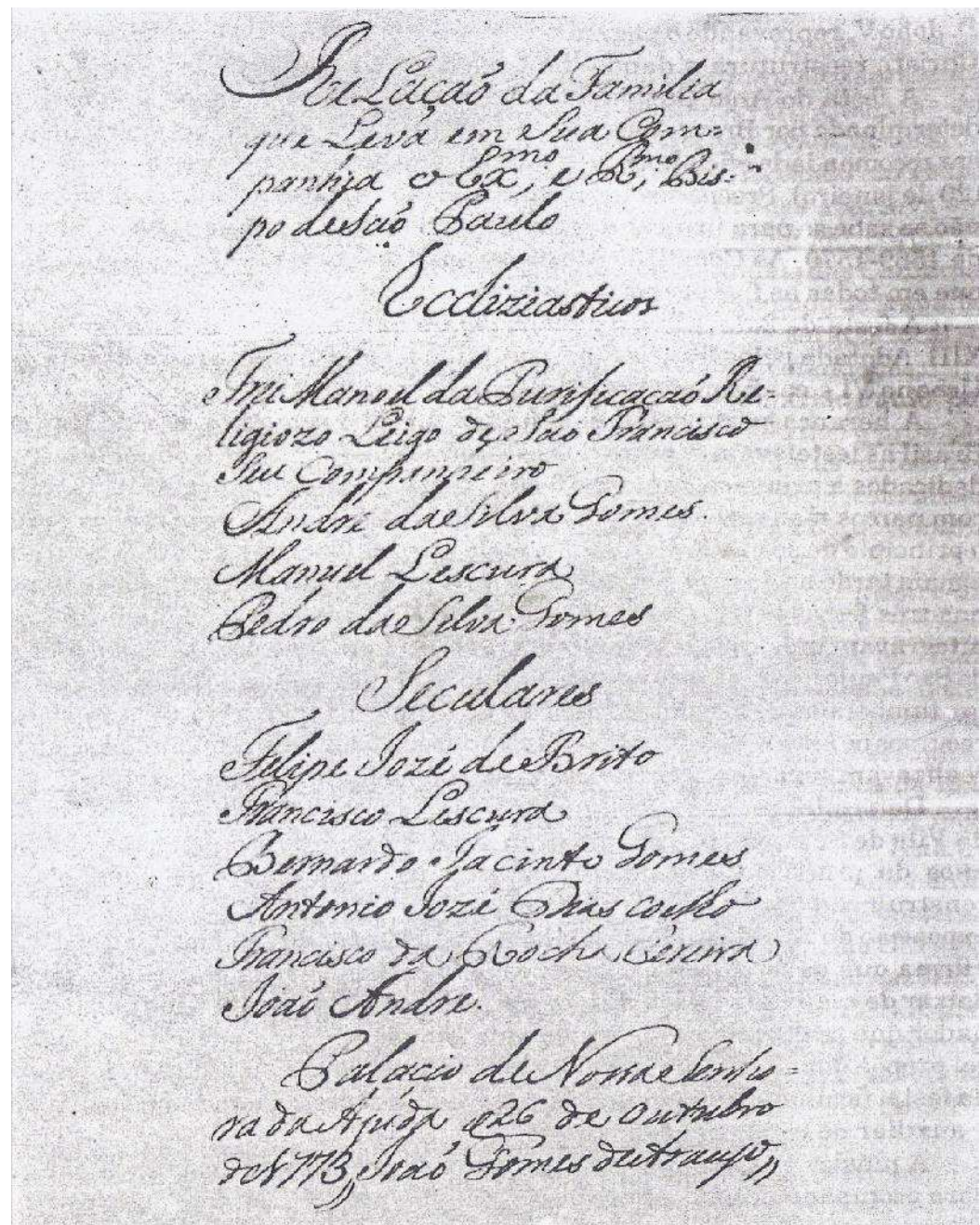

Figura 5: Passaporte do terceiro bispo de São Paulo, cuja comitiva participava André da Silva Gomes (AHUL- Arquivo Histórico Ultramarino de Lisboa- apud- DUPRAT, 1995, p.33). 
Com a morte do segundo Bispo da Sé de São Paulo, Dom Antônio da Madre de Deus, em 1764, a igreja episcopal foi dirigida por um Vigário Capitular até a chegada de Dom Manuel da Ressurreição (1718-1789), em 1774. Evidentemente, esse padre não tinha a mesma autoridade de um Bispo, por essa razão, o então Governador Dom Luiz Antônio censurou desde o primeiro momento a maneira pela qual era feito o cerimonial da Sé paulista, assim desatando um libelo com o Cabido que se estendeu em arguições que perscrutaram inúmeros livros de cerimônias e decretos canônicos e que, por fim, resultaria num documento intitulado "As etiquetas da Sé" (CAMARGO, 1953, apud, MACHADO NETO, 2008, p.359).

Por conseguinte, observa-se que o projeto iluminista chegaria a São Paulo para modificar as antigas estruturas, por exemplo, na música. Régis Duprat ressalta que o mestre de capela da Sé, em 1765, padre Matias Álvares Torres, era julgado pelo Governador por apresentar uma música tão antiga quanto sua pessoa (DUPRAT, 1995, p.50). Diante desse quadro, o Governador nomeia Antônio Manso da Mota, músico recém-chegado da Bahia, como diretor da casa da ópera, justificando que o mesmo era provido das melhores músicas escritas, isto é, de bom gosto e atuais. No entanto, o Governador estava concentrado com a condução e aplicação do cerimonial religioso, o que, naturalmente, acarretaria em marco divisório entre as fronteiras nebulosas das nomeações dos cargos paralitúrgicos, como o mestre de capela. Enfim, valendo-se da ausência de uma autoridade episcopal, promoveu o seu desejo modernizador nomeando para o comando da capela da Sé Manso da Mota, o terceiro mestre de capela entre 1768 e 1773 (DUPRAT, 1995, apud MACHADO NETO, 2008, p.359). 


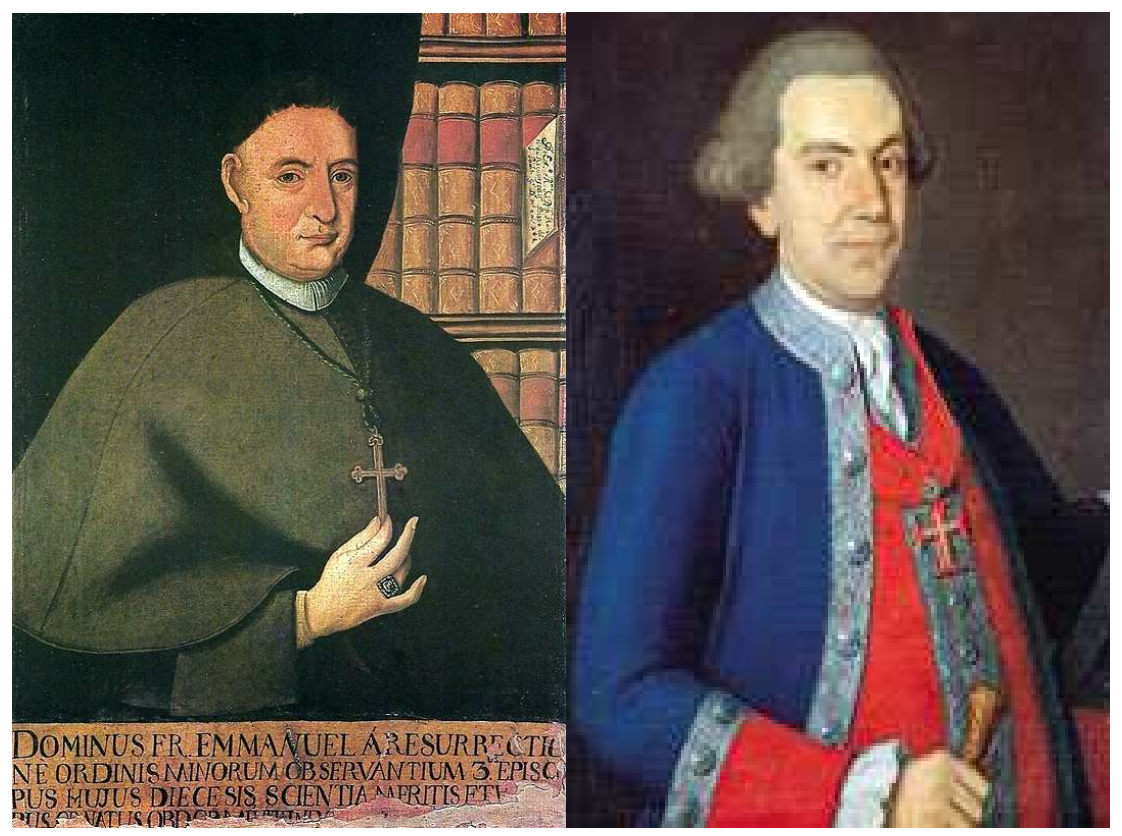

Figura 6: Bispo Dom Frei Manuel da Ressurreição e o Governador Dom Luiz Antônio de Souza Botelho Mourão ${ }^{75}$.

Todo esse processo, partindo da revitalização da querela do estanco ${ }^{76}$, ocorre a partir da chegada do terceiro Bispo de São Paulo: Dom Frei Manuel da Ressurreição, em 1774, o que traria uma série de discussões e embates, ou seja, o Bispo provocaria inúmeras disputas jurisdicionais com o governador (DUPRAT, 1995, pp.55-56). Ambos solicitavam vários direitos, dentre deles o de prover professores de primeiras letras e mestres de capela. Alegando que esse direito era historicamente outorgado às autoridades seculares, o Morgado

\footnotetext{
${ }^{75}$ Fonte: Bispo Dom Frei Manoel da Ressurreição, disponível em: http://pt.wikipedia.org/wiki/Ficheiro:An\%C3\%B4nimo Retrato de D. Frei Manoel da Ressur rei\%C3\%A7\%C3\%A30.JPG Acessado em: 21 de Março de 2011. Fonte Governador Luiz Antônio de Souza Botelho Mourão, disponível em: http://velhariasdoluis.blogspot.com/2010/02/d-luis-antonio-de-sousa-botelho-mourao.html Acessado em: 21 de Março de 2011.

${ }^{76}$ Monopólio comercial instituído pelo Estado sobre um produto de forma legal. Pode-se citar o que ocorria no Brasil Colonial, onde Portugal arrendava o direito de exploração de diversas mercadorias, como o pau-brasil, por exemplo. Já no período conhecido como a do reformismo luso-brasileiro na segunda metade do século XVIII, algumas formas de estanco foram removidas, como as do sal e do contrato da pesca.

Régis Duprat, em o Estanco na Música Colonial, ressalta que, no caso da música, o empreendedor do estanco era a autoridade eclesiática local, o qual efetivava algo contra as determinações do Conselho Ultramarino, portanto, da administração portuguesa no Brasil. Dessa forma, o estanco na música não era uma medida legal ou providenciada e emanada do poder público metropolitano ou de seus representantes no Brasil. Pelo contrário, era uma medida ilegal, vedada, e só como tal praticada, o que servia de pretexto para quem o aplicava de governar o que deveria ser cantado nas igrejas, igualmente estancar com diversos modos e meios os músicos e, por fim, tirar dos seculares a liberdade de poderem ter e conservar a música que queriam (DUPRAT, 1968, p.100).
} 
de Mateus $^{77}$, denuncia o Bispo de passar provisões para o mestre de capela de todas as vilas e freguesias, sendo assim, com esta declaração do Governador, fica evidente e explícito o intenso movimento de nomeações a partir da chegada do terceiro Bispo (MACHADO NETO, 2008, p.360).

Mesmo com a resistência das autoridades civis, o Bispo atuava, também, na direção de reformas estruturais, só que no âmbito religioso, o que incluiria as contestadas nomeações. Então, no exercício de sua atividade e influência, Dom Frei Manuel da Ressurreição reagiu contrariamente ao Governador, enfrentando-o trazendo consigo de Lisboa para a Sé em São Paulo o compositor André da Silva Gomes para assumir o lugar de Antônio Manso da Mota. Silva Gomes tinha como missão reestruturar a capela da catedral paulista (DUPRAT, 1995, p.57), não na incorporação explícita do estilo operístico da música de Manso, mas na restauração do estilo romano, "principalmente através da prevalência da textura polifônica, reafirmada pela preponderância da música coral” (MACHADO NETO, 2008, p.360).

Dada as novas conjunturas e processos de nomeação para mestre de capela no Brasil, portanto, em particular na Capitania de São Paulo, pode-se afirmar que elas passaram por um estado de renovação e resistência ao mesmo tempo, onde o ponto de convergência nas articulações das ideias é a comunicação organizada e estabelecida pelo discurso musical. No mesmo sentido, em meio a essas reformulações, aconteceram diversos embates antagônicos entre o Governador de São Paulo, Dom Luís Antônio de Souza Botelho Mourão ${ }^{78}$ com o recém-nomeado bispo de São Paulo, Dom Manuel da Ressurreição, que trouxera de Lisboa André da Silva Gomes. Gerando assim um conflito que se manifestaria através do programa iluminista defendido pelo governador, como se viu anteriormente, aqui. Nesse conflito entre os dois

\footnotetext{
${ }^{77}$ Fora uma forma de organização familiar que cria uma linhagem, bem como um código para designar os seus sucessores, estatutos e comportamentos. Nesse regime de morgadio, os domínios senhorais eram inalienáveis, indivisíeis e inusceptíveis de partilha do seu titular, ou seja, havia uma transmissão desses poderes para o filho primogênito, mantendo assim, a vitalicidade e perpetuação do poder econômico das famílias as quais faziam parte, por sucessivas gerações. Por exemplo, no Brasil, teve-se, como detentores do título nobilárquico Morgado de Mateus, António Álvares Coelho, Matias Álvares Mourão (1696-1730), António José Botelho Mourão (1688-1746), Luís Antônio de Sousa Botelho Mourão (1722-1798), Governador da capitania de São Paulo, José Maria de Sousa Botelho Mourão e Vasconcelos (1758-1825), José Luís de Sousa Botelho Mourão e Vasconcelos (1785-1855), que tornou-se o primeiro Conde de Vila Real, entre outros.

${ }^{78}$ Esse fora Governador da capitania de São Paulo entre (1765 e 1774).
} 
máximos agentes régios na capitania paulista, é possível observar por um lado o programa iluminista vinculado à superação dos modelos figurativos pela música de métrica pela síntese e, por outro, a resistência aferrada na persistência da retórica barroca, ou seja, na linguagem figurativa (MACHADO NETO, 2010, p.62).

\subsection{André da Silva Gomes}

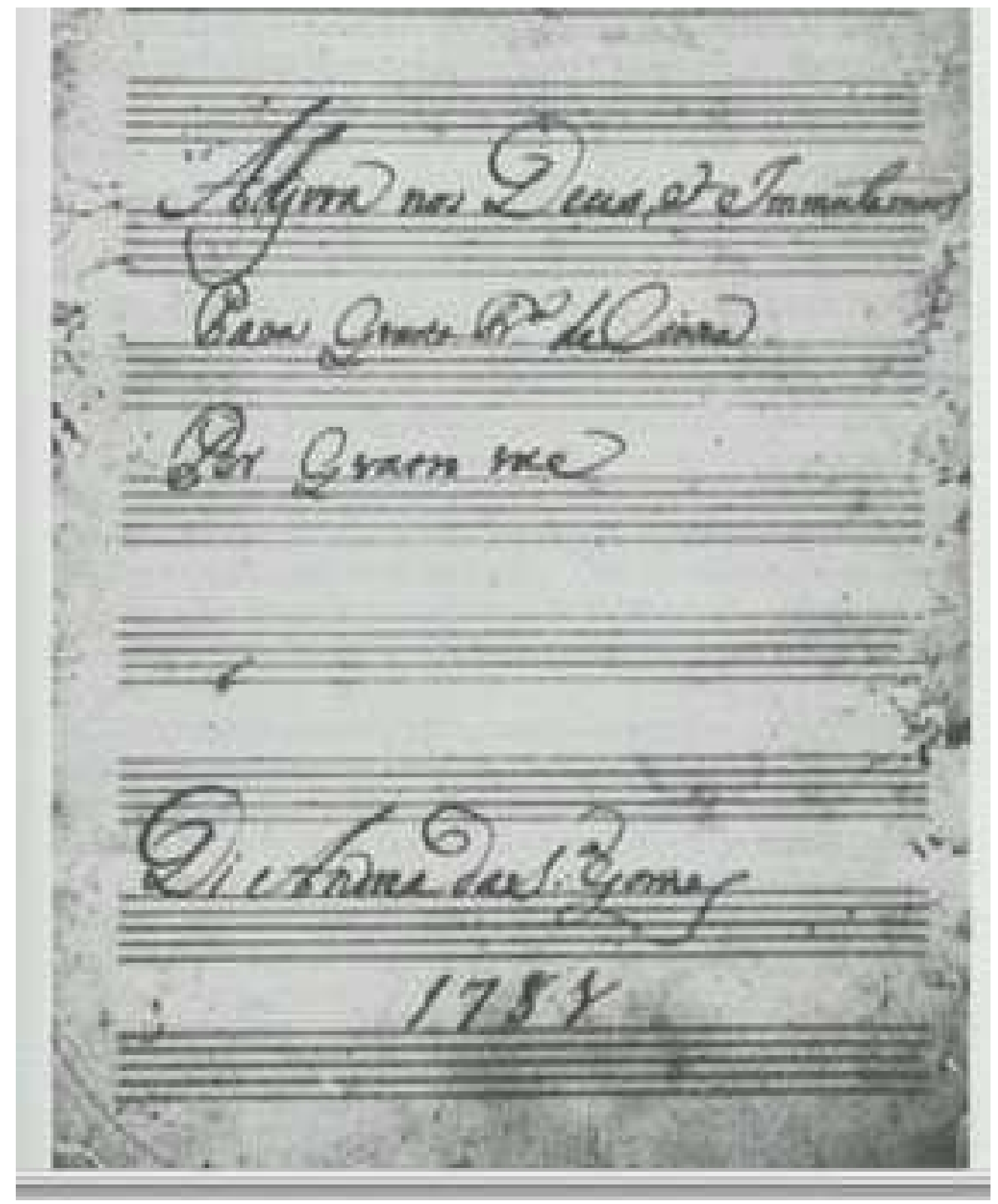

Figura 7: Fachada Principal do Adjuva nos Deus et Immutemur; autografo de André da Silva Gomes, 1781 (ACMSP- Arquivo da Cúria Metropolitana de São Paulo- apudDUPRAT, 1995, p.37). 
Em Música na Sé de São Paulo Colonial, de 1995, o musicólogo Régis Duprat revelou importantes aspectos da vida e obra de André da Silva Gomes. Assim, não há como falar do mestre de capela luso-brasileiro sem haver referência ao trabalho supracitado.

Segundo a historiografia consolidada, e principalmente amparado em Duprat (1995), o compositor luso-brasileiro, nascido em Lisboa, no dia 15 de dezembro de 1752, quarto mestre de capela de São Paulo, era filho de Francisco da Silva Gomes e Inácia Rosa, naturais de Lisboa. André chegou ao Brasil bastante jovem, com 21 anos de idade, nos fins de 1773, para organizar e reger o coro de música da catedral em princípios de 1774, dando início a uma nova fase na atividade musical da Sé de São Paulo. Sua vinda foi articulada pelo terceiro bispo de São Paulo, Dom Frei Manoel da Ressurreição, inserindose numa conjuntura de mitigação do projeto de administração colonial iluminista desenvolvido com considerável autonomia pela Capitania de São Paulo $^{79}$, cujo Governador era dom Luís Antônio de Souza Botelho Mourão $(1722-1789)^{80}$, como visto detalhadamente no tópico anterior (DUPRAT, 1995, p.57).

Sempre orientado em Duprat (1995), as condições iniciais de sua formação cultural e musical permanecem ignoradas, salvo o fato de ter sido aluno, no Seminário Patriarcal de Lisboa, do compositor e mestre de capela José Joaquim dos Santos (1747-1801). Nessa época revolucionaria, dominava o ambiente musical português a figura do napolitano David Perez (1711-1780), dedicado à composição lírica e religiosa, interessado pelas edições didáticas para o ensino da teoria da música, solfejo, baixo cifrado, acompanhamento etc., influenciou compositores portugueses dentre os quais João Cordeiro da Silva, João de Souza Carvalho, José Joaquim dos Santos, Luciano Xavier dos

\footnotetext{
${ }^{79}$ Tal conjuntura de mitigação e administração colonial iluminista era denominada Morgado de Mateus. Nessa época, o Governador estabelecia um padrão estético referenciado na corte portuguesa e, sempre, objetivando o estabelecimento dos paradigmas do iluminismo católico, tais como: as imponências das festas públicas e religiosas, com o objetivo de não só cumprir o afeto, mas, também, para imprimir nos corações do povo dessa corte uma veneração e obediência a seu soberano. Em síntese, o Morgado de Mateus sempre tinha em mente edificar pelas festas, como propunham inúmeros protocolos das doutrinas iluministas que se espalhavam pela Europa (MACHADO NETO, 2008, p.313).

${ }^{80}$ Machado Neto ressalta que: "Esse Governador impulsionou o "divertimento da ópera" por um envolvimento pessoal e singular conferindo a ela até mesmo um caráter revelador de sua visão de mundo em que a arte, de um modo geral, figurava num papel de representação e afirmação de poder" (MACHADO NETO, 2008, p.309).
} 
Santos e o próprio André da Silva Gomes, outros compositores italianos como Niccolò Piccinni (1728-1800) e Giovanni Battista Pergolesi (1710-1736), da mesma forma, serviram de modelo para esses autores musicais. David Perez veio para Lisboa em 1752, por convite de Dom José I, ali permaneceu até a sua morte ocorrida em 1780. Diretor da Capela Patriarcal dedicou-se inicialmente à educação musical dos filhos do rei e por publicações didáticas.

Obras religiosas desses autores italianos citados acima, eram conhecidas por André da Silva Gomes, e peças de João Cordeiro da Silva, José Joaquim dos Santos e outros portugueses são copiadas do próprio punho de André.

Conforme o catálogo das obras de André da Silva Gomes, apresentado por Duprat (1995), já no ano de sua chegada a São Paulo (1774) esse compositor produziu intensamente. A sua proficuidade foi ao encontro das preocupações do bispado por obter a desejada estabilidade da capela de música, até então dificultada pela módica remuneração, disputas civileclesiásticas citadas, modesta solicitação e recursos do meio social ${ }^{81}$. André da Silva Gomes já exercia as funções de mestre de capela, logo após sua chegada em 1774, porém, somente em 1789, o seu nome aparece citado nos documentos de confraria, nas referidas funções, em 1781, seu nome é citado na documentação remanescente, e ali permanece até 1801, quando abandonou todos os serviços eventuais fora a capela da Sé.

$O$ ambiente musicalmente restrito antepunha-lhe dificuldades consideráveis por não dispor de instrumentistas e cantores. Não obstante característica geral da época no Brasil, é pequena a variedade de instrumentos nas orquestrações de suas obras; a reduzida quantidade de músicos no ambiente obstaculizava a ampliação das atividades musicais. Após 1797, o mestre se dedicou integralmente ao ensino de latim (DUPRAT, 1995, p.71-72).

Uma questão interessante que comprova o conhecimento da caba retórica de André da Silva Gomes é que, depois de requerer diversas posições que the permitissem melhor situação econômica, foi nomeado interinamente para o cargo de mestre régio de Gramática Latina da cidade de São Paulo, em

81 O mestre de capela ganhava, em média, cerca de 40.000 réis anuais, com tal salário o mestre obrigava-se a escrever música, financiar sua execução, com o coro e eventualmente com orquestra. 
decorrência do falecimento de Pedro Homem da Costa, seu antecessor no cargo. Passou então a receber ordenado dez vezes superior ao de mestre de capela da Sé. Em 1813, ingressa na Irmandade do Santíssimo Sacramento na qualidade de irmão. Posteriormente, em 1820, com 68 anos de idade, André ainda exercia efetivamente 0 cargo de mestre de latim, remetendo matriculas e relações semanais dos alunos de sua classe à secretaria do governo (DUPART, 1995, p.101).

André da Silva Gomes faleceu em 1844 com aproximadamente 92 anos. Seu corpo foi envolto em hábito de São Francisco, acompanhado por todos os capelães da Sé em enterro solene. Enquanto viveu, foi a personalidade mais destacada da música de São Paulo, pátria adotada por ele, na qual viveu por 70 anos (DUPRAT, 1995, p.102).

\subsection{Consciência Retórica}

Daqui pode concluir que o Compositor instruído, não só como Filósopho, a entidade differente de cada hum dos sobreditos empregos; podendo justamente distinguir o Contraponto Harmonia Docente, e a Composição Harmonia Utente, isto he, parte que dá preceitos; e parte, que os apprezenta em execução; mas também pode observar como Rhetorica; aqui se observa o Contraponto relativo à parte da Invenção e a Composição relativa à Disposição e à Elocução. Na Dissertação, que serve de principio a esta obra, fica [após?] demonstrando, quanto He precioza ao Compositor a Instrução Literária [grifos nossos]. (André da Silva Gomes, lição no. 1 f 2. Nota do original, apud DUPRAT, 1998, pp.1718).

Dando prosseguimento à exposição sobre a consciência retórica de André da Silva Gomes, manifestada em sua Arte Explicada do Contraponto, Landi (2006) afirma que os adjetivos docente e utente são, respectivamente, formas participais dos verbos latinos doceo, docui, doctum, docere (instruir, ensinar); e utor, usus, sum, uti (usar, servir-se). Nota-se que Silva Gomes preferiu atribuir à harmonia um significado bastante peculiar. O termo é empregado como um elemento comum ou mediador: a doutrina utente, ou seja, a composição serve-se dos preceitos da doutrina docente, o contraponto (LANDI, 2006, p. 32). 
Seguindo seu raciocínio, a analogia com a faculdade retórica torna-se evidente e precisa: "[...] aqui se observa o contraponto relativo à parte da invenção e a composição relativa à disposição e à elocução" (Lição 1aㅗ f.2 do original). O autor fará, no decorrer de todo o tratado, repetidas alusões à importância da instrução literária e, mais especificamente, da oratória na formação do compositor, dando continuidade a uma tradição que tem início com o pensamento de Aristóteles, de Cícero e Quintiliano, cujos traços racionais estarão definitivamente expostos na musica practica com 0 nascimento do Barroco, sobretudo, com o gênero operístico. O compositor, tal qual o orador, tem por objetivo atuar diretamente sobre as paixões, ou afetos, dos seus ouvintes. A essa "paixão" já havia Cícero se referido em sua obra Partitiones Oratoriae, 54 a.C: "Procura descobrir de maneira ele (o orador) possa gerar confiança naqueles que irá querer persuadir e, de que maneira possa provocar as paixões nos espíritos deles"82.

Enfim, André da Silva Gomes demonstra os princípios contidos na doutrina desses antigos mestres, como se fez referência, no entanto, ele evita polemizar em resposta a eventuais argumentações por parte dos modernos, sobretudo, no que diz respeito a certas liberdades que esses últimos, judiciosamente, passam a consentir. Todavia, ele conduz um pensamento e posição com uma representação de alguns aspectos, por exemplo, a importância da instrução literária e, especificamente, da retórica na prática musical, a qual remete à visão do autor à tradição medieval e barroca de se encerrar a própria essência da teoria musical no conjunto das disciplinas das sete artes liberais (Quadrivium e Trivium). Essas, por sua vez, consistiam nas duas áreas do conhecimento humano na Idade Média (LANDI, 2006, p. 55). Portanto, mesmo não enunciando esses conceitos com maior amplitude, já que o considerava um saber de domínio universal, obrigação de qualquer indivíduo ligado ao discurso público, Silva Gomes, como professor régio de Gramática Latina, posto que assumiu em 1797, seguramente os tem muito em conta (LANDI, 2006, apud SOARES; MACHADO NETO, 2011, p.394).

\footnotetext{
82 "Ut ueniat quem ad modum fidem faciat eis quibus uolet persuadere, et quem ad modum motum eorum animis adferat” (LANDI, ibidem, p.32).
} 


\subsubsection{Gramática e Teoria Musical}

Como artista e com considerável erudição, André da Silva Gomes acompanhava atentamente os progressos da ciência e da música; em outras palavras, era um compositor, mestre de capela e gramático, com consciência do anacronismo da linguagem adotada para modelar suas composições. $\mathrm{Na}$ prática, atuou como um mestre contrapontístico e conservador, influenciado pela música barroca ${ }^{83}$, contudo, colaborou com a evolução da atividade musical na Colônia, introduzindo procedimentos teóricos inauditos no final do século XVIII. Mesmo com o gradativo esquecimento das lições do Discurso Apologético, de Caetano de Melo de Jesus, Silva Gomes estabeleceu um novo paradigma racionalista para a análise e o desempenho da música: sua Arte Explicada de Contraponto ${ }^{84}$ e mais de 130 peças sacras (GIRON, 2004, p.50).

Segundo Luís Antônio Giron, possivelmente Silva Gomes tenha estudado séries ibéricas de obras avançadas da teoria musical, que abordavam assuntos concernentes à sintaxe harmônica sequencial e de modulação como: El Porque de La Musica (1672), de André Lorene, Llaves de La Modulación (1762), de Antônio Soler e Del Origen y Reglas de La Musica (1796), de Antonio Eximenio. Em síntese, essas obras certamente ajudaram ao compositor luso-brasileiro a formular seu Tratado de Contraponto, além de algumas composições próprias. Giron continua sua exposição destacando a colaboração leiga de Silva Gomes para a igreja, seja ministrando aulas particulares ou hospedando diversos discípulos seus, como Manuel José Gomes, pai de Antônio Carlos Gomes (DUPRAT, 1990, apud GIRON, 2004, p.52).

\footnotetext{
${ }^{83}$ Esse conservadorismo deve-se ao fato de ele ser um mestre de capela e, como tal, deveria seguir os cânones nos quais a música religiosa era escrita, ou seja, com os modelos composicionais tradicionais da época. Paulo Castagna, em um artigo seu, designa essa maneira composicional de estilo antigo. Ele descreve desta forma: "De acordo com Karl Gustav Fellerer, o estilo [antigo] se atém, principalmente, às instruções canônicas da velha polifonia" (CASTAGNA, 2001, p.202).

${ }^{84}$ A Arte Explicada de Contraponto, apresenta-se em cópia escrita de 1830 por Jerônimo Pinto Rodrigues, constituída de 150 p., entretanto, não há uma data precisa sobre a versão original do tratado (DUPRAT et al, 1998, p.9).
} 


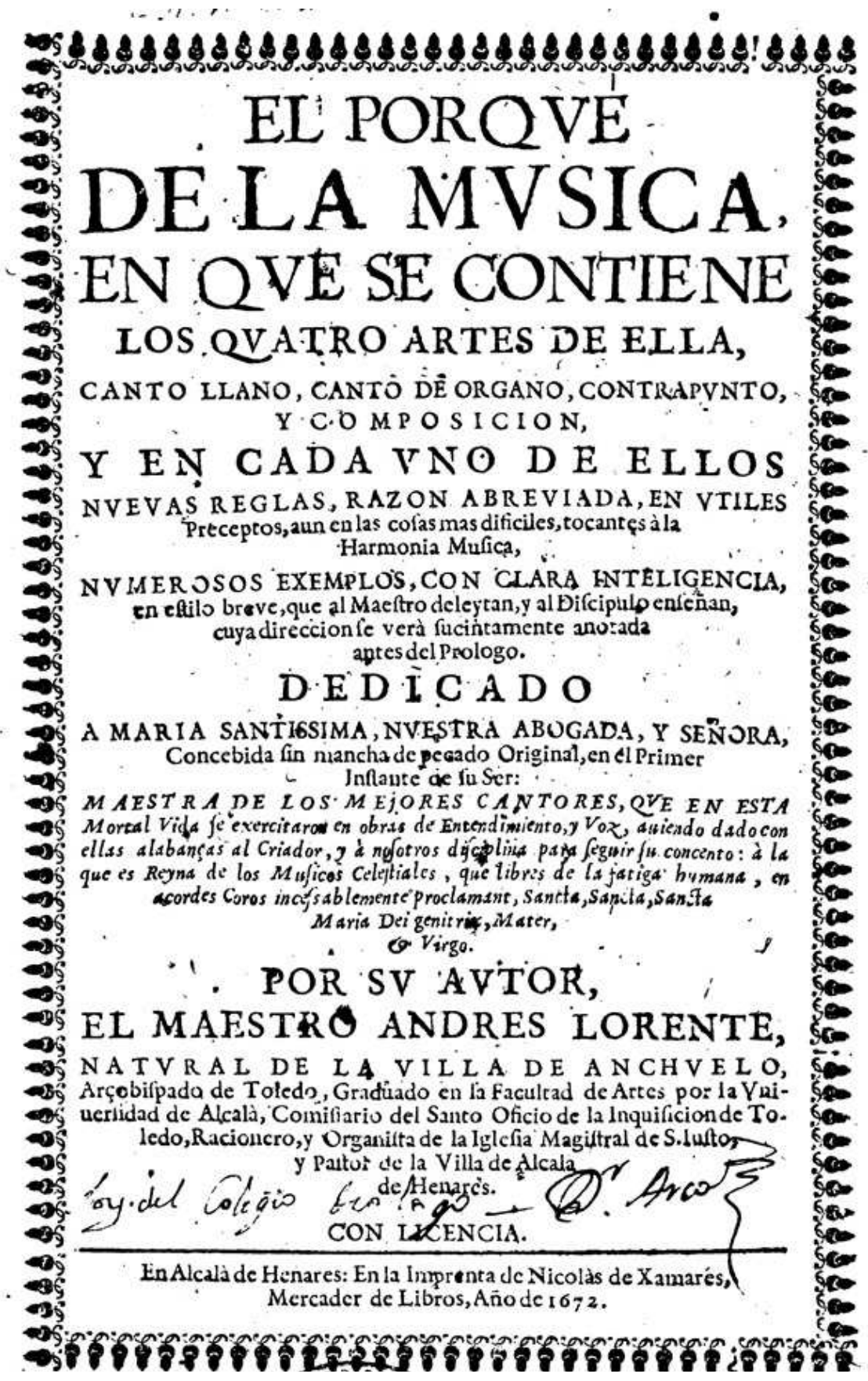

Figura 8: Tratado El porque de lá Musica (1672) de André Lorene

Seu tratado de contraponto foi considerado por diversas gerações de estudantes de música. Duprat nota que a obra de Silva Gomes foi executada regularmente na Sé até 1911 (DUPRAT, 1995, p.99). Na Arte Explicada... André demonstra sua preocupação didática e seu conhecimento acerca da linguagem musical e retórica. No primeiro capítulo, trata dos conceitos e princípios dos tipos de contraponto, na segunda lição salienta o conceito de harmonia e consonâncias e na terceira lição há influências do pensamento 
pitagórico. Esse por sinal, se dará até a $20^{\underline{a}}$ lição. $O$ modelo dogmático de exposição vem da gramática latina. Já os preceitos do conhecimento musical situam-se na Grécia Antiga. Para Silva Gomes, o contraponto exerce papel ponderável para criação musical.

Por fim, apesar de pitagórico, o teórico abre um postigo à imaginação. Seus conhecimentos de retórica e gramática o conduzem a associar faculdade harmônica e faculdade retórica, sugerindo que o músico se instrua também pela literatura. Gomes, através de sua afirmação, na primeira lição da Arte de Contraponto postula que a elocução opera tanto na música como na escrita verbal, e que sem instrução literária o compositor está em desvantagem, por não conhecer os preceitos literários (GIRON, 2004, p.53), ou seja, o autor de uma obra musical tem que ser cônscio das possibilidades do emprego da harmonia, do contraponto, da fraseologia, da sintaxe, da relação entre texto e música e, por último, da gramática em sua macroestrutura e da faculdade retórica, tudo isso a serviço da música e persuasão.

\title{
4.3.2. Discurso e Figuras Retóricas
}

\begin{abstract}
Além desta imitação harmônica que se acaba de tratar, é preciso ao compositor outra qualidade de imitação, e é aquela por meio da qual ele se propõe a imitar o gênio, o estilo e a demarcha harmoniosa daqueles mestres que foram reconhecidos grandes e famosos nesta faculdade, aos quais há toda a necessidade de imitar (André da Silva Gomes - Lição 17ª , Nota, f.124 do original apud LANDI, 2006, p.20).
\end{abstract}

Conforme a faculdade retórica, Mimesis (Ethophonia ou Imitatio) significa imitar, e, na oração, a fala e maneirismos de alguém. Porém, não no sentido de uma personificação seja por palavras ou gestos, como deseja a prosopopeia, ela é empregada apenas para representar uma pessoa ausente. É com esse sentido que se vê, pela primeira vez, conscientemente aplicada à terminologia das figuras retóricas na música, mais precisamente na composição da fuga e do cânone no século XVII. Nesse sentido, a antiga nomenclatura seiscentista dada para o termo fuga, ou seja, uma forma de cânone estrito ${ }^{85} \mathrm{em}$ oposição ao contraponto imitativo ${ }^{86}$, seria invertida por Burmeister em novos termos:

\footnotetext{
${ }^{85}$ Fuga Ligata (integra, mera ou totalis).

${ }^{86}$ Fuga Soluta (libera, partialis ou semifuga).
} 
Fuga Realis ${ }^{87}$ e Imaginaria $^{88}$, para diferenciar a forma livre de fuga do cânone estrito, respectivamente. Consequentemente, em sua Música Poética (1606)

Burmeister utilizaria um total de 26 figuras de retórica, dentre elas as fugas Realis, Imaginaria e a Mimesis ${ }^{89}$ (LANDI, 2006, p.20). Da mesma forma, André da Silva Gomes utiliza-se de recursos retóricos de figuras como a imitação e da fuga na 16 e $17^{\mathrm{a}}$ lições de seu Tratado de Contraponto.

Silva Gomes, nas folhas de ㄲ‥ 124 a 126 do original na sua $17^{a}$ lição, conclui esse assunto, não só referindo-se da importância de "imitar" os grandes mestres, o que demostra seu sentimento em relação à tradição, mas, também, revela que o conhecimento retórico transmitido de forma natural é inevitável para quem compõe:

É verdade que todos os nossos esforços tornariam inúteis, uma vez que nos considerássemos destituídos dos dons da natureza, mas igualmente esses mesmos dons da natureza, ainda que modificados pela Arte, não poderão avançar um dilatado terreno sem que sejam acompanhados, ajustados e socorridos pelos ótimos exemplares de insignes Mestres, aos quais nos comunicam em não sei que virtude particular e oculta, que é só a que nos desembaraça na mesma execução dos preceitos da Arte; muitos deles rigorosamente estabelecidos pelos Antigos Mestres que nestes tempos têm elevado ao mais alto ponto de perfeição a Composição da Música, sendo também inegável que estes mesmos Mestres tiveram a precisão de imitar outros famosos Modelos, e polidos também por este Meio os seus felizes talentos, aumentando e ainda polindo, por meio de novas descobertas, aquelas científicas produções, nos transmitem e expõem a nossa admiração autorizados Modelos, que imitemos; e em que igualmente aperfeiçoemos e dilatemos as nossas ideias [...] $\mathrm{Na}$ experiência de todos os dias, nós vemos a grande utilidade que resulta da Imitação e que longe de enfraquecer e sufocar; pelo contrário, ela corrobora, aumenta, dilata e faz realçar a mesma natureza. Revela, pois, saber manejar, define um empréstimo de ideias de pensamentos, de sentimentos e passagens dos escolhidos exemplares que nos propomos a imitar ou aproximandoos ou diferenciando-os, ou diminuindo ou aumentando, os quais preceitos, próprios da Faculdade Retórica e Poética, nos quais supomos o nosso aluno de Composição de Música bem instruído, como preparatórios desta Faculdade que tratamos; por isto deixamos aqui de os explicar [grifos nossos] (SILVA GOMES, apud DUPRAT et al, 1998, pp.179-180).

\footnotetext{
87 "Fuga Realis (fuge ousiodes) é aquela disposição da harmonia, na qual todas as vozes imitam - através do uso de intervalos idênticos ou similares - um determinado sujeito [affectio], desenhado a partir de uma voz na combinação" (BURMEISTER [1606], 1993 p.159).

${ }_{88}$ Fuga Imaginaria é a que todas as partes das vozes podem ser imaginadas mesmo com somente uma parte escrita. $\mathrm{Na}$ anterior, todas seriam de fato escritas por extenso (BURMESITER, ibidem, p.159).

${ }^{89}$ Mimesis ocorre em uma combinação de muitas vozes, onde algumas delas estão próximas umas das outras para introduzir uma Noema (BURMEISTER, ibidem, p.167). Também pode ser uma repetição de um fragmento superior.
} 
Vistas essas ponderações pode-se considerar a utilização da Inventio pelo compositor luso-brasileiro atribuída ao contraponto, não só pelas invenções das ideias ou dos argumentos, mas também na importância de produzir um fundamento no qual será constituída a representação e evocação do afeto correspondente. Analogamente o emprego da Dispositio e Elocutio conferida à composição, motivadas pela coerência e ordenação das ideias originarias da Inventio, assim como a expressão de cada concepção, seja afetiva, de clareza ou de ênfase por meio das figuras retóricas.

\section{Cam Sancto Spiriu, Nissa a Cinco Vozes, CT Duprai $n^{2}(1)+$, comp. I-9 $d=881$}

$\mathrm{S}$

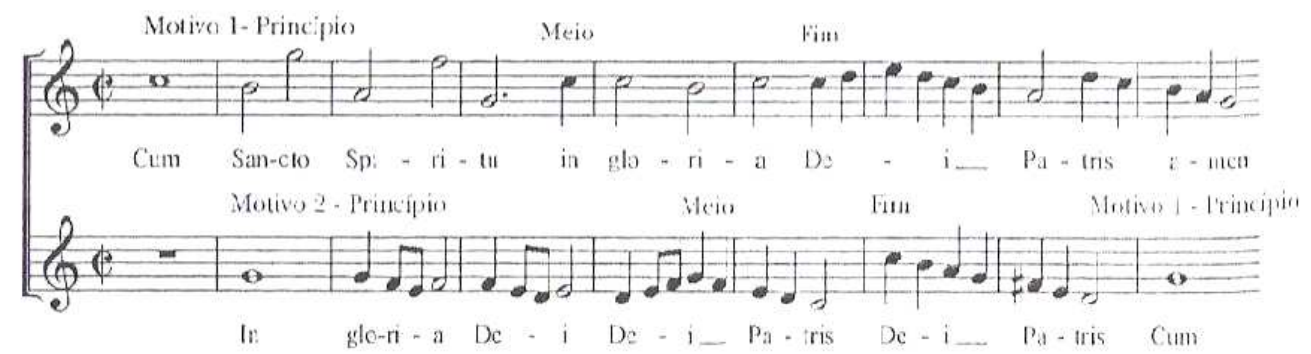

Exemplo 1: Cum Sancto Spiritu da Missa a Cinco Vozes de André da Silva Gomes Preceito $2^{\circ}$-Todo Motivo, Tema, Tensão ou Passo em uma Fuga deve constar três partes ou Condições, a saber, Princípio, Meio e Fim ${ }^{90}$ (apud LANDI, ibidem, p.127).

${ }^{90}$ Burmeister aplica figuras retóricas como Fugas Realis ou Imaginária em sua estrutura discursiva retórica onde o Princípio seria o (Exordium), o Meio (Medium) e o Fim (Finis). 


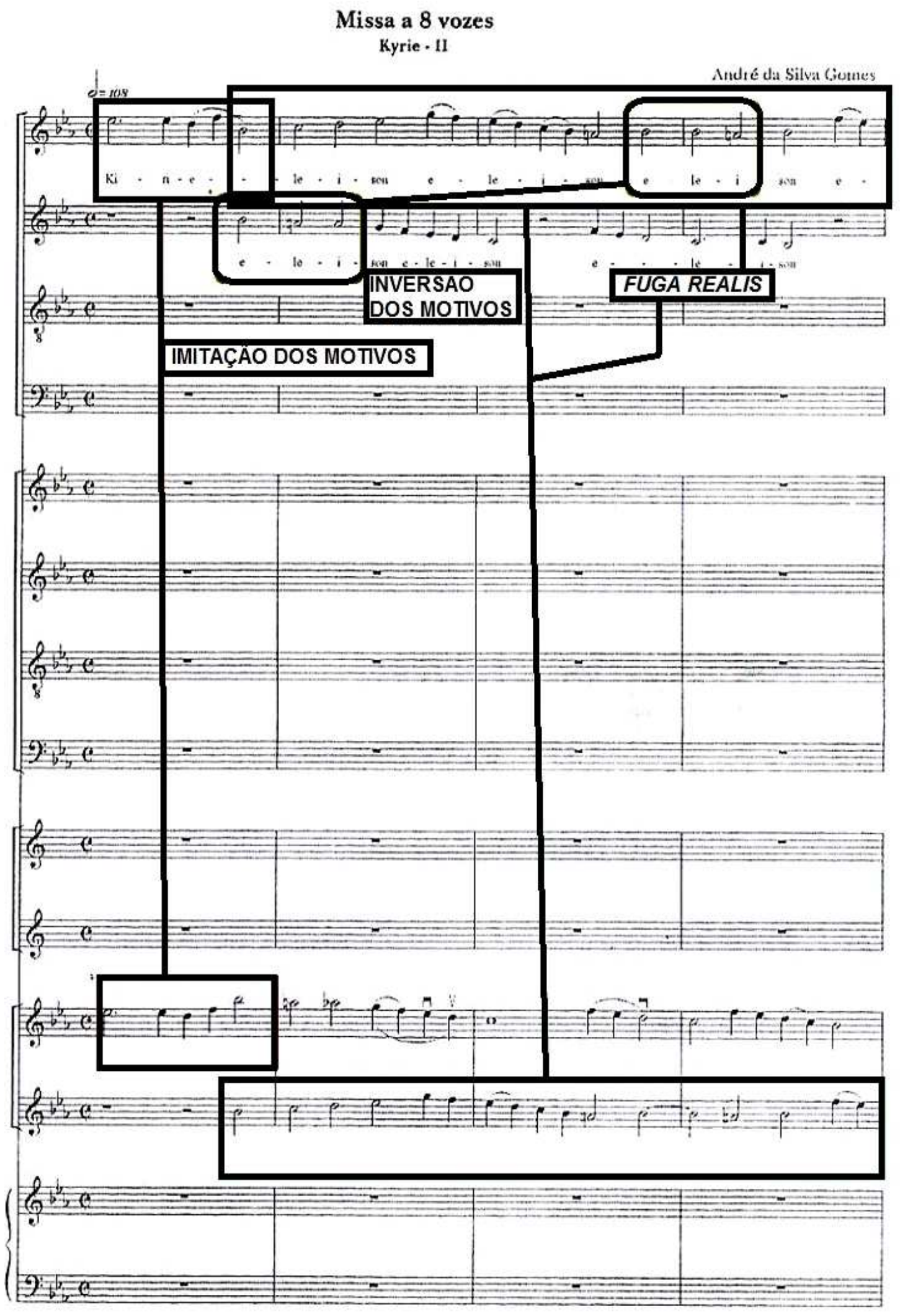

Exemplo 2: (do Exemplo 76, f.105 do original de ASG). Parte introdutória do Kyrie II da Missa a Oito vozes de André da Silva Gomes e figuras de imitação, de inversão de motivos e de retórica como a Fuga Realis (apud LANDI, ibidem, p.239). 
Outro aspecto relevante seja na imitação ou na composição é a do discurso que, juntamente com as figuras e elementos retóricos, traz maior eloquência, afetividade e dramaticidade à obra. Régis Duprat faz comparações sobre o discurso barroco e do clássico da seguinte maneira:

O discurso Barroco é um discurso fundamentado inteiramente nas varietas permanente, oferecidas pela harmonia sequencial e pela continuidade modulatória. O Classicismo, por sua vez, se estrutura na articulação frasística, compartimentando o processo modulatório em seção dramática específica. Outros parâmetros introduzem-se no discurso para garantir o princípio da varietas que, preocupação essencial da retórica do Barroco, passa a integra o discurso musical na sua totalidade (DUPRAT, 2001, p.250).

Duprat continua sua explanação, da afirmação acima, ressaltando a instabilidade nas seções pelos processos modulatórios e a concentração dramática, além do equilíbrio e a racionalidade no Classicismo, contrastando com a afetividade e a sedução emotiva que é reforçada pela varieta, no Barroco, entretanto, ele encerra esse excerto dizendo que o gênero sacro é onde o compositor do período clássico pode utilizar e expressar, através do discurso, elementos da retórica como: pathos; todavia, o autor poderá buscar novas possibilidades na produção de sua obra.

Como se pode notar, o discurso musical no século XVIII e primórdios do XIX, principalmente no que se refere à música sacra, era tratado pelo compositor com critério, ou seja, esse tinha consciência e preocupação em relação à ordenação e disposição das ideias tangíveis ao texto litúrgico, por intermédio da retórica que, por sua vez, conduzia o discurso e ao mesmo tempo era o elo entre o orador (intérprete/autor) e o ouvinte, onde se transmitia a expectativa, as emoções e as paixões intrínsecas.

Silva Gomes estava inserido em uma conjuntura apropriada para o emprego de elementos e figuras de retórica, por algumas razões, mostradas abaixo.

1. Pelo fato de a maioria das composições no Brasil serem de caráter ou de estilo sacro, isto é religioso. ${ }^{91}$

\footnotetext{
${ }^{91}$ Rubens Ricciardi em sua tese: Manoel Dias de Oliveira: um compositor em tempos coloniais, descreve sobre a preponderância das obras sacras em relação às profanas no Brasil da seguinte maneira: "é muito rara a localização de obras profanas dos tempos coloniais. 0
} 
2. Por suas obras serem na maioria sacras, são baseadas em textos bíblicos e utilizadas na liturgia cristã.

3. No possível contato com a retórica literária, já que ele estudou como aluno externo em Lisboa, no Real Seminário de Música da Patriarcal.

4. Por ter sido professor régio de Gramática Latina entre 1797 a 1827, ou seja, por 30 anos.

5. Profundo conhecedor da teoria musical e da escrita musical, o que resultaria obras dentro dos repertórios litúrgicos importantes como: Antífonas, Hinos, Ladainha, Matinas, Missas, Motetos, Ofertórios, Salmos, Semana Santa. Sequências, Te Deum, além-claro de seu Tratado de Contraponto.

6. Pela consciência da necessidade do compositor ter relações interdisciplinares, como o conhecimento da filosofia, literatura e retórica.

7. Suas obras são na maior parte no estilo Barroco, e as que são de transição (estilo galante) são vocais, ou seja, utilização de texto, ordenação de ideias e do discurso, o que é próprio do sistema retórico.

8. Da influência europeia nos estilos e gêneros.

9. O Brasil era um país cristão, em sua maioria.

10. No emprego dos textos bíblicos nas obras, se aplicava o uso também de figuras como metáforas (tropos), hipérbole, prosopopeia, entre outras.

11.0 fato da reforma lusitana de 1759 , fixando o exame da retórica como parâmetro do saber.

repertório era minoritário em relação à produção geral, e quase tudo se perdeu [...] Para uma melhor compreensão desse fato, basta compararmos a proporção entre exemplares sacros e profanos em meio ao número total de obras existentes em arquivos brasileiros, a maioria deles situados no triângulo São Paulo, Minas Gerais e Rio de Janeiro. A maioria absoluta destas composições musicais ainda não foi editada e nem sequer transcrita em partitura, mas boa parte já consta pelo menos dos principais catálogos (CT-ASG, CT-CG, CT-JMNG, CT-OP e CT-PUC). Se muitas obras profanas teriam-se perdido, talvez se perderiam também igual proporção as obras sacras. Portanto, a quantidade mínima de obras profanas catalogadas comprova a já incontestável predominância do caráter sacro na produção musical colonial brasileira como um todo. Soma-se a isso ainda o fato de que não há informações consistentes em documentos (fontes primárias) que apontem para o emprego sistemático de obras compostas por brasileiro em qualquer outra ocasião fora das atividades católicas, ao logo do período colonial" (RICCIARDI,2000,p.48). 
Portanto, com a exposição de todas essas razões e fatos argumentados, fica evidenciado o exercício e a aplicação de elementos retóricos na estrutura da obra do compositor luso- brasileiro, não só objetivado por ele para mover os afetos do ouvinte, mas igualmente na busca de um discurso coerente e eloquente, classificado e distribuído em fases, na forma que ele mesmo descreve em sua Arte Explicada do Contraponto, onde a invenção deve ser realizada no contraponto, a disposição e a elocução na composição musical. 


\section{ANÁLISE RETÓRICA EM ANDRÉ DA SILVA GOMES: OFERTÓRIOS}

\subsection{Ofertório}

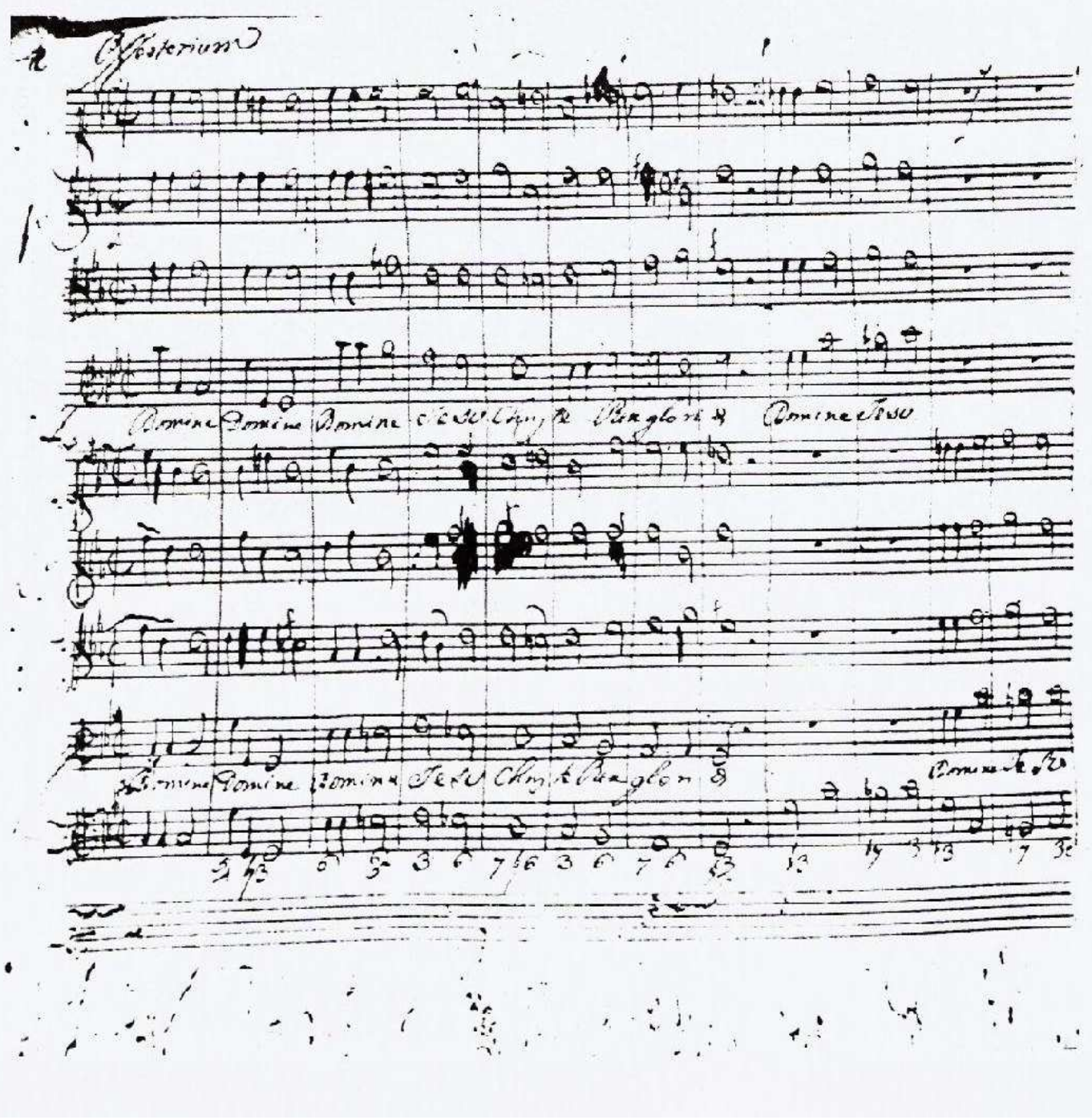

Figura 9: Partitura original de André da Silva Gomes, primeira página de um Ofertório, Domine Jesus Christe (ACMSP apud- Duprat, 1995, p.61) ${ }^{92}$.

\footnotetext{
${ }^{92}$ Relação dos 14 Ofertórios de André da Silva Gomes: Ofertório Ad te Domine, da Missa do 1ำ Domingo do Advento, Ofertório Ascendit Deus, da Missa da Ascensão do Senhor, Ofertório Benedixisti Domine, da Missa do $3^{\circ}$ Domingo do Advento, Ofertório Confitebor tibi... in toto, da Missa do $1^{\circ}$ Domingo da Paixão, Ofertório Confortamini, da Missa de $4^{\underline{a}}$ feira das têmporas do Advento, Ofertório Deus tu conversus, da Missa do 20 Domingo do Advento, Ofertório Domine Jesu Christe, da Missa de Defuntos, Ofertório Exaltabo te, da Missa de 4⿳亠丷厂 feira de Cinzas, Ofertório Justiae Domini, da Missa do $3^{\circ}$ Domingo da Quaresma, Ofertório Laetentur caeli, da Missa de Natal, Ofertório Lautede Dominum, da Missa do 4ํDomingo da Quaresma, Ofertório Meditabor, da Missa do $2^{\circ}$ Domingo da Quaresma, Ofertório Mihi Autem nimis, da Missa da Conversão de São Paulo e Ofertório Suis, da Missa do 1ํDomingo da Quaresma.
} 
Ofertório é um dos seguimentos do ritual da missa cristã. Segundo Paulo Augusto Soares:

\begin{abstract}
É o momento de reflexão-ação do fiel que imediatamente precede a Eucaristia, o fundamento mais significativo do cristianismo. Por olhos descompromissados, a Eucaristia é o momento em que o sacerdote ergue um receptáculo que contém hóstias - uma espécie de pão, consagrando-as, na exposição se dá por meio de uma sequência de orações em voz baixa, em atitude contrita; ao final delas estará consumado o sacramento. (SOARES, 2000, p.14).
\end{abstract}

A tradição explica a Eucaristia como a materialização do corpo e sangue do Cristo nas hóstias e no vinho, respectivamente. Num quadro genérico de interpretações históricas, diz a tradição que, na última refeição realizada junto aos apóstolos, Cristo teria repartido um pão entre os presentes e distribuído vinho, afirmando serem esses o seu corpo e seu sangue, criando um clima testamentário, de alerta e despedida (SOARES, ibidem, p.14):

$E$, dando graças, o partiu e disse: "Isto é o meu corpo que é entregue por vós; fazei isto em memória de mim". Semelhantemente, depois de cear, tomou o cálice, dizendo: "Este cálice é a Nova Aliança no meu sangue; fazei isto todas as vezes que beberdes, em memória de mim" (1ํㅡㅁíntios 11,24-25; ALMEIDA, 1999, p.972).

Tal episódio, abordando o prenúncio dos fatos a serem ocorridos na sua captura, sofrimento e morte, insistindo, ao fim, para que a conduta e os ensinamentos que disseminaria até então não fossem esquecidos, ficou conhecido como Santa Ceia ${ }^{93}$ (SOARES, ibidem, pp.14-15).

Esse cerimonial, associado à múltipla confraternização, alimentação, princípios éticos e misticismo, de caráter altamente dramático e memorável, certamente foi levado muito em conta pelos cristãos da igreja primitiva; em outras palavras, sua estratégia de doutrinação tinha como fundamento esse ato litúrgico. Enfim, os cristãos se valeram da ordenação dos episódios da Santa Ceia para elaborar uma composição metafórica dos acontecimentos, agrupando seus elementos de modo a utilizá-los como fundamento em um ritual que prolongasse o estado de espírito de revelação e urgência, vivido pelos primeiros mártires do cristianismo (SOARES, 2000, p.15).

\footnotetext{
${ }^{93}$ Tal passagem bíblica também pode ser encontrada em Mateus Cap. 26,versos, 26 a 29.
} 
Paulo Augusto Soares, em sua investigação, chega a esta definição sobre as etapas, atributos e características do ofertório:

\begin{abstract}
Derivado do latim offertorium, o ato remete à offerta (oferta), offerre (oferecer), offerenda (oferenda, coisa oferecida) e offerens (oferente); também com ferre, que tem interessantes características: sendo verbo irregular, necessita de outros radicais (tulu, latum) para sua conjugação e resume as etapas da Eucaristia em seus vários significados- erguer, dar, oferecer, contemplar. O ofertório, entretanto, cristalizou-se na figura do oferente, aquele que oferece alguma coisa; houve uma contaminação semântica do termo com a espórtula, o donativo feito pelo cristão para a conversação do recinto onde se pratica a missa (SOARES, 2000, pp.17-18).
\end{abstract}

Antônio Houaiss, destaca que essa seção da missa é a que o celebrante oferece o pão e o vinho aos fiéis, também são realizadas as orações que antecedem ou acompanham essa fase da cerimônia e, por fim, acontece o recebimento das ofertas para as festividades da igreja (HOUAISS, 2001, dicionário eletrônico). Mesma ênfase e explicação apresentada por Aurélio Buarque de Holanda Ferreira (FERREIRA, 2006, p.1429).

Já o início da prática do canto do ofertório não é preciso. Todavia, seu primeiro registro pode ser encontrado nas Confissões de Santo Agostinho, escritas no século V. Tal manuscrito cristão faz referência a certo Hilarius que teria criticado a prática da congregação de Cartago em cantar um salmo durante a cerimônia das ofertas. Não, há, todavia, nenhuma indicação do caráter ou estrutura desse canto (BAROFIO, 1964, apud, SOARES, 2000, p.19).

O uso litúrgico dos salmos é comum a todos os ritos da igreja: gregoriano, ambrosiano ou milanês, hispânico ou moçárabe, copta, etiópico, armênio, maronita, bizantino, siríaco, galicano, celta e africano. É executado em três formas:

1. Continuada (in directum), não há interpretação, o solista, coro ou assembleia apenas faz a leitura do mesmo;

2. Alternada a comunidade é divida em dois coros, cantando alternadamente os versículos do salmo;

3. Responsorial é recitado ou cantado por um solista e a assembleia interrompe em alguns momentos, repetindo um ou mais versículos. 
Soares afirma que: "alguns autores, como Wagner, acreditam que o ofertório era, no princípio, como a comunhão, um salmo executado na forma alternada" (WAGNER, 1962, apud, SOARES, 2000, p.19).

Os ofertórios da tradição gregoriana, a partir do século VIII, são os cantos mais elaborados do repertório. Esses iniciam com uma antífona seguida de dois ou três versos, cujas melodias são ornamentadas, isto é, cada verso é seguido por um refrão, que é a própria frase de abertura ou seu trecho final. Melismas ocorrem com frequência e há repetição na segunda vez. São ornamentos que chamam a atenção para si, ou seja, simples veículos para o texto (SOARES, 2000, p.20).

Nos ofertórios gregorianos muitos textos expressam alegria e louvor; vários exemplificam isso:

1. Jubilate

2. Benedicite

3. Laudate

Algumas vezes o texto é relevante à festa do dia (Elegerunt Apostoli, para festa de Santo Estevão), e alguns textos têm conexão com o Intróito ou Evangelho. $\mathrm{Na}$ tradição ambrosiana, cerca da metade vem do Velho Testamento; o mesmo ocorre no rito Moçárabe que, diferente dos outros ritos, trata com frequência de sacrifícios e oferendas, fazendo, aí, um interessante balanço dos significados que a expressão ofertório adotou durante a gênese da tradição cristã (SOARES, 2000, pp.20-21). 


\subsection{Análise Retórica}

\subsubsection{Ofertório da Missa de Quarta-Feira de Cinzas}

\section{Estudo semântico}

\subsection{Inventio}

O texto deste ofertório foi extraído do Salmo (Ps.29,1-3/ 30,1-3) ${ }^{94}$, cujo tema é: Ação de Graças pela Libertação da Morte.

Exaltabo te Domine, quoniam suscepiste me, et nec [non] dilectasti Inimicos meos super me/ Domine clamavi ad te sanasti me.

Exalto-te, Senhor, por que me livrou/ e não permitiu que se alegrassem a Minha custa meus inimigos/ Senhor, meu Deus, a ti clamei e me sarou.

(SOARES, 2000, p.25).

Este excerto descrito acima, expressa uma fé autêntica não só do autor do salmo, mas igualmente dos fiéis no Senhor. Davi, nesta passagem, louva a Deus por tê-lo livrado de três coisas terríveis:

1. De seus inimigos;

2. De uma doença;

3. Da morte.

Tal sentimento manifesta uma aclamação à figura do criador pelo fato deste ter concedido as graças rogadas e alcançadas sob sua influência. A mesma devoção e gratidão são partilhadas no ofertório, onde o cristão faz uma reflexão sobre a fragilidade da vida humana, a qual é sujeita à morte. De sorte que esse profundo pensar é destacado pela conversão e mudança de vida, necessária para quem professa a Cristo como salvador e responsável pela remissão dos pecados.

Essa obra, portanto, é composta por trinta e três compassos na tonalidade Sol Maior, em andamento Moderato, proporcionando ao ouvinte audição clara e perspicaz. Em suma, a intenção nos tópicos seguintes, é revelar a existência de aspectos relevantes da linguagem adotada pelo autor,

\footnotetext{
${ }^{94}$ Salmos 29,1-3 seriam o número e versículo na bíblia católica, já na bíblia protestante o texto está escrito no número 30 versículo 1 a 3 .
} 
observando a aplicação de figuras e elementos retóricos, além dos materiais e das funções harmônicas.

\subsection{Locus observados na Inventio do Ofertório}

\begin{tabular}{|c|c|c|c|}
\hline INVENTIO & DESCRIÇÃO & UTILIZAÇÃO NA OBRA & $\begin{array}{l}\text { COMPASSO/ } \\
\text { VOZ }\end{array}$ \\
\hline $\begin{array}{l}\text { Locus } \\
\text { Notationis } \\
\text { (MATTHESON, } \\
\text { [1739],1954, } \\
\text { Parte II,Cap.4, } \\
\S 23, \text { p.123). }\end{array}$ & $\begin{array}{l}\text { Aspecto } \\
\text { externo e } \\
\text { desenho das } \\
\text { notas } \\
\text { (Duração das } \\
\text { notas, } \\
\text { alteração, } \\
\text { repetição e } \\
\text { procedimento } \\
\text { s canônicos). }\end{array}$ & $\begin{array}{l}\text { Vários motivos rítmicos e } \\
\text { diferentes durações de } \\
\text { notas (mínimas, mínimas } \\
\text { pontuadas, semínimas, } \\
\text { semínima pontuadas, } \\
\text { colcheias, colcheias } \\
\text { pontuadas,semicolcheias, } \\
\text { repetições, ligaduras, } \\
\text { pausas, fermata entre } \\
\text { outros). }\end{array}$ & $\begin{array}{l}1-5 \text { S-A-T-B } \\
6-8 \text { S-A-T-B } \\
17-26 \text { S-A-T-B } \\
27-33 \text { S-A-T-B }\end{array}$ \\
\hline $\begin{array}{l}\text { Locus } \\
\text { Oppositorum } \\
\text { (MATTHESON, } \\
\text { [1739],1954, } \\
\text { Parte II,Cap.4, } \\
\text { § 80,p.131). }\end{array}$ & $\begin{array}{l}\text { Contraste de } \\
\text { compassos, } \\
\text { movimentos } \\
\text { contrários, } \\
\text { agudos e } \\
\text { graves, lento } \\
\text { e rápido, } \\
\text { calmo e } \\
\text { agitado. }\end{array}$ & $\begin{array}{l}\text { Movimento contrário entre } \\
\text { contralto e baixo. } \\
\text { Também entre soprano e } \\
\text { baixo e tenor. }\end{array}$ & $\begin{array}{l}21 \mathrm{~A}-\mathrm{B} \\
28 \mathrm{~S}-\mathrm{B} \\
29-\mathrm{S}-\mathrm{T}\end{array}$ \\
\hline 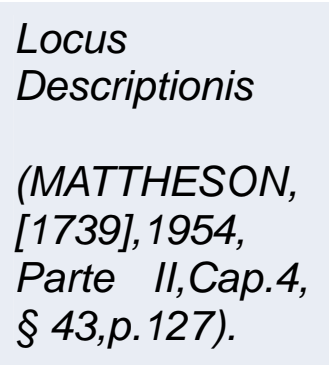 & $\begin{array}{l}\text { Disposições } \\
\text { da alma }\end{array}$ & $\begin{array}{l}\text { Louvor, Júbilo, Alegria, } \\
\text { Celebração (Exalto-te, } \\
\text { Senhor, por que me } \\
\text { livrou). } \\
\text { Expectativa, Resposta (A } \\
\text { ti clamei e me sarou). }\end{array}$ & 1-21 S-A-T-B \\
\hline
\end{tabular}

Tabela 4: Locus Topici encontrados no Ofertório da Missa de Quarta-feira de Cinzas de André da Silva Gomes 


\subsection{Dispositio}

\subsubsection{Exordium}

O Exordium é apresentado nos três primeiros compassos da peça, tendo como figura central a Anabasis, a qual é trabalhada por Silva Gomes tanto na ordenação quanto na preparação dos argumentos iniciais, dos quais se fundamentará o discurso. Por meio dessa figura, observa-se a caracterização de louvor e agradecimento por parte do salmista a um ser superior, o qual está num lugar elevado: Exaltabo te Domine (Exalto-te, Senhor), evidenciado pelas notas que se movimentam de forma ascendente. No terceiro compasso, o autor emprega a figura da Synaeresis, destacando esse efusivo momento, igualmente, o mesmo aplicativo se dá para destacar o repouso da frase na Tônica, como das notas cantadas na mesma silaba.

DIPOSITIO

Ofertório da Missa de Quarta-feira de Cinzas

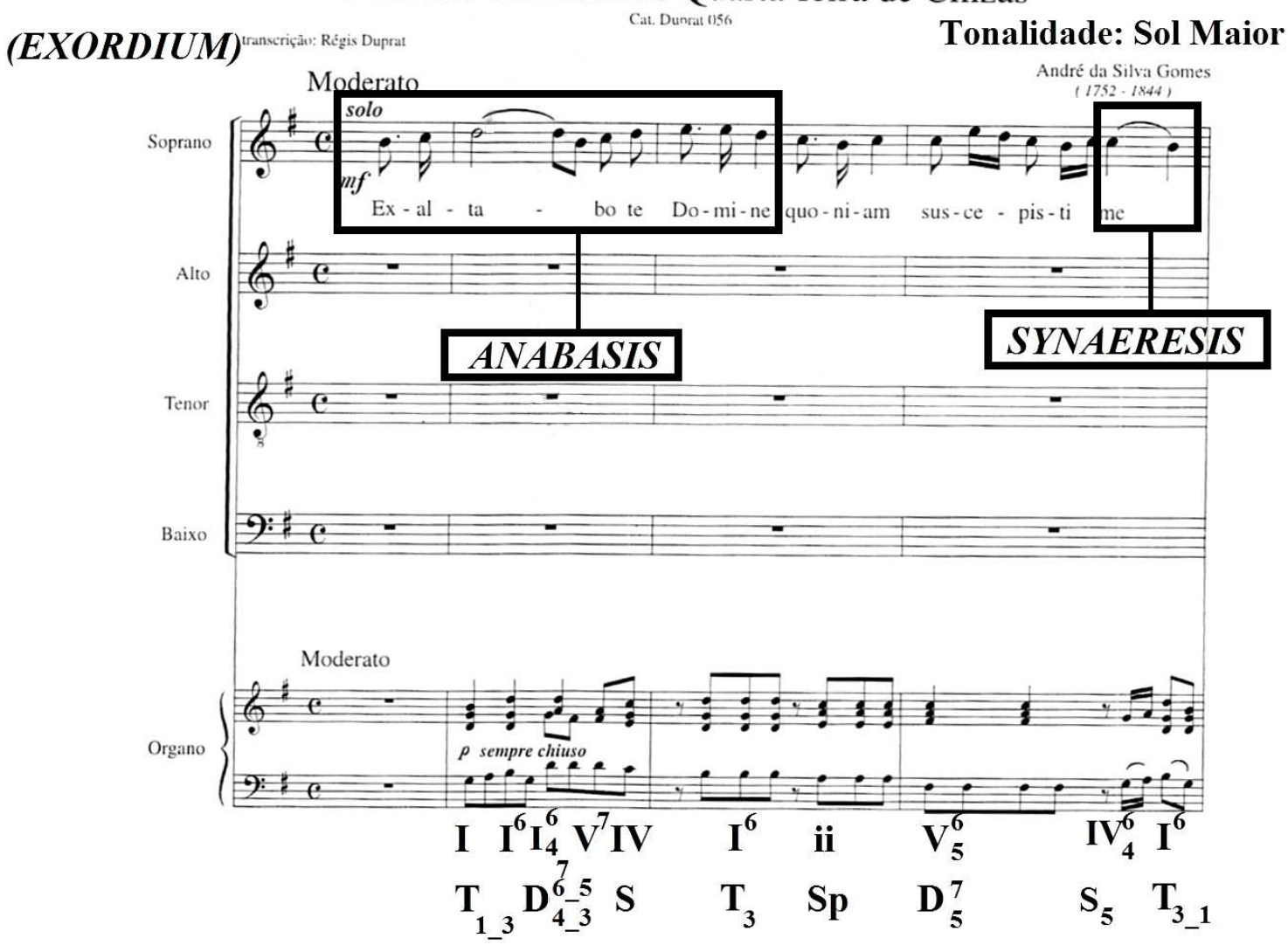

Exemplo 3: Ofertório da Missa de Quarta -feira de Cinzas de André da Silva GomesCatalogação e Organização Régis Duprat (DUPRAT, 1999, p.175). 


\subsubsection{Narratio}

$\mathrm{Na}$ segunda fase da Dispositio, continua a serem empregadas pelo compositor as figuras da Anabasis e da Synaeresis, mantendo a mesma relação de exaltação e louvor estabelecida anteriormente no Exordium, entretanto, no compasso 5, na voz do tenor, pode-se observar o uso da Anticipatio, antecipando a entrada das outras vozes na reiteração do encômio dado. A junção desses elementos procura despertar a atenção do ouvinte para o estabelecimento entre elevação e reflexão. A Narratio termina no terceiro tempo do compasso 8 , ou seja, bem na passagem da primeira para a segunda seção da obra, delimitada pelo efeito suspensivo da Cadência na Dominante (Semicadência) $^{95}$.

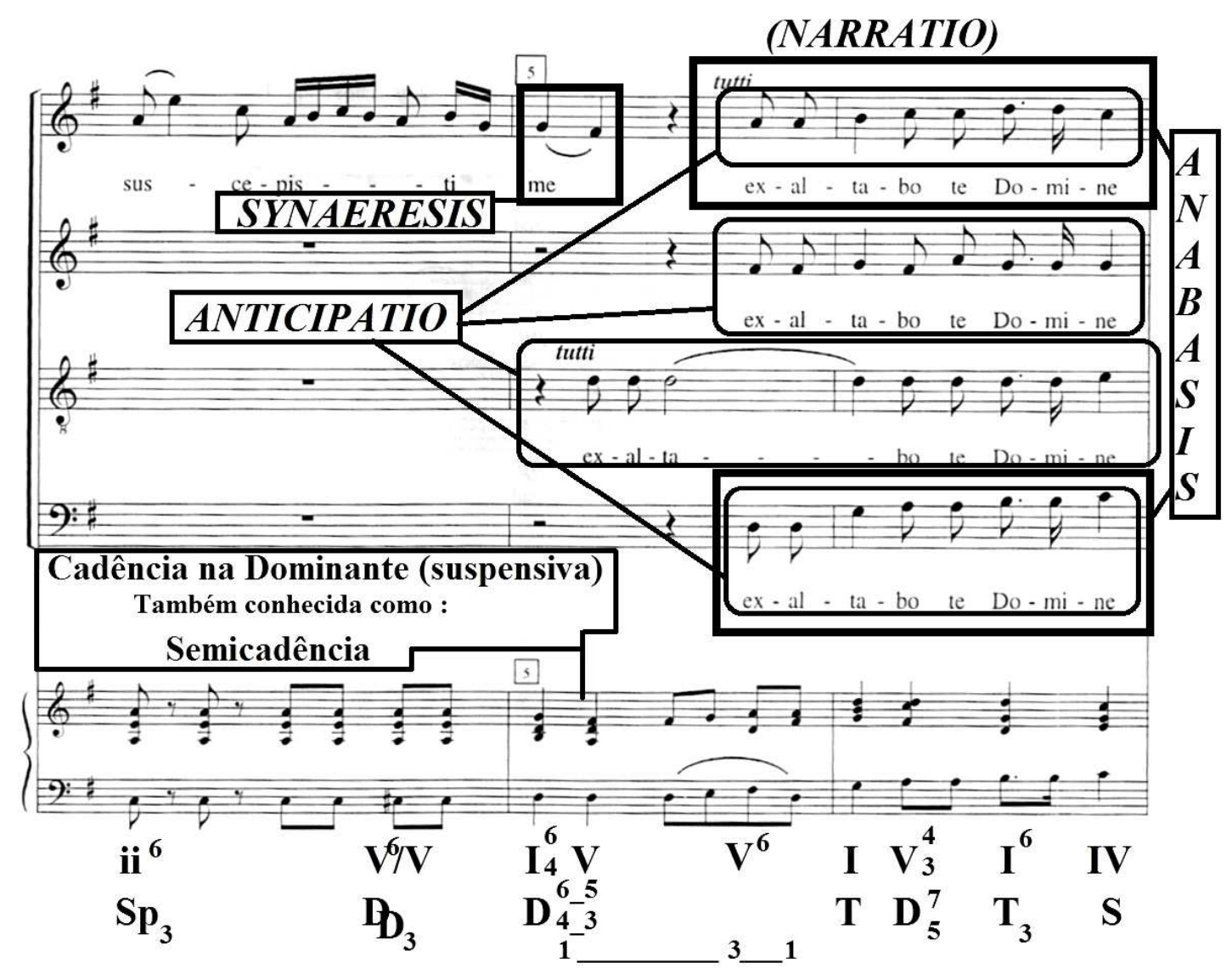

Exemplo 4: Ofertório da Missa de Quarta -feira de Cinzas de André da Silva GomesCatalogação e Organização Régis Duprat (DUPRAT, 1999, p.175).

$95 \mathrm{O}$ termo Semicadência, outro nome dado à Cadência que termina na Dominante, pode ser localizada em vários autores tais como Arnold Schoenberg (Fundamentos da Composição Musical, 2008, p.68-73), Diether da la Motte (Armonía, 2006, p.28), Walter Piston (Armonía, 1998, p.168-170), William Earl Caplin (Classical Form, 2001, p.128-130), entre outros. 


\subsubsection{Propositio}

No momento em que se encerra, tanto a primeira seção como a Narratio, inicia-se a Propositio, no final do compasso 8, na voz da soprano. Da mesma forma, Silva Gomes utiliza a figura da Pausa com o intuito de obter repouso após uma suspensão no final da seção anterior na Dominante de Mi Menor.

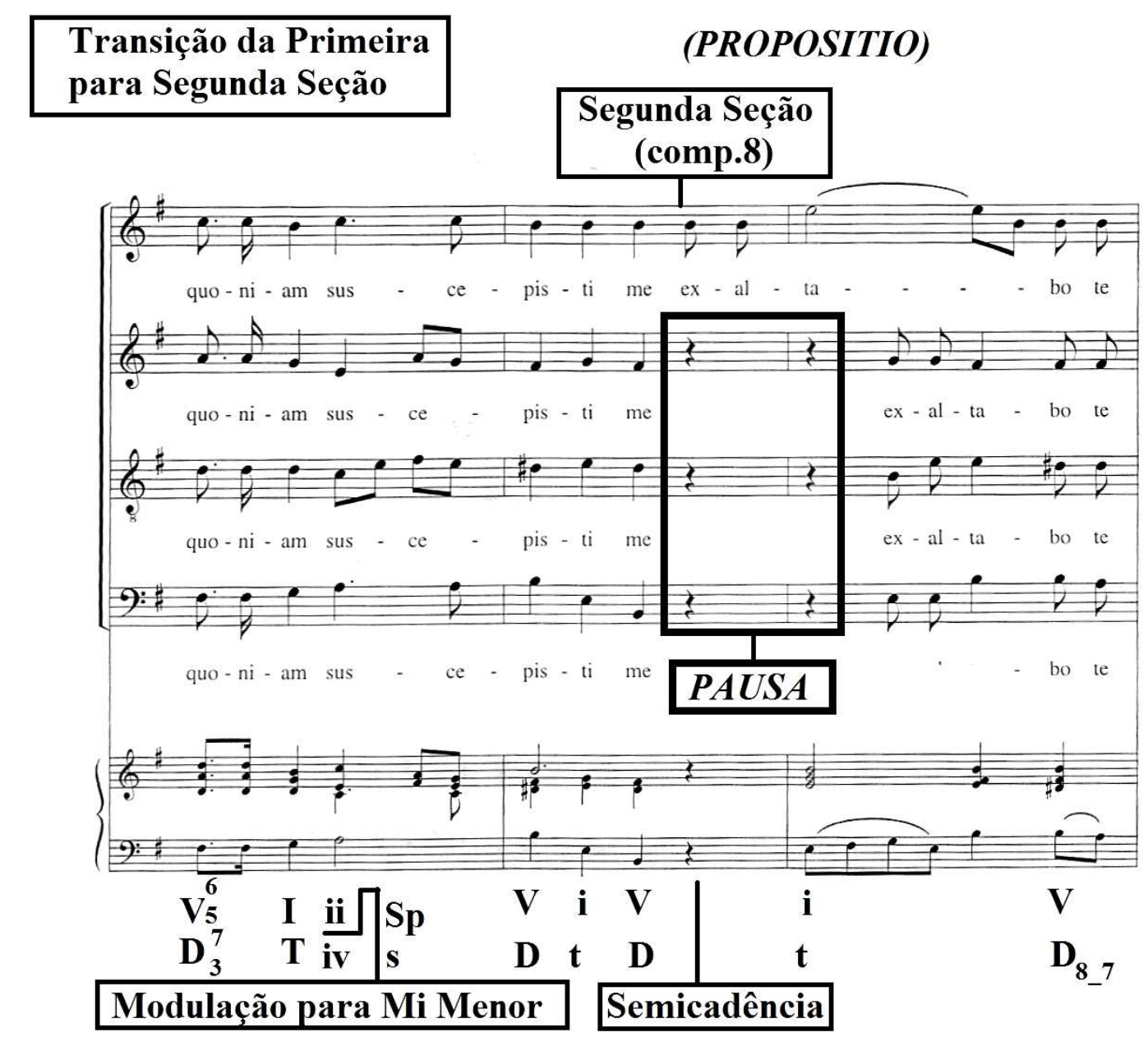

Exemplo 5: Ofertório da Missa de Quarta -feira de Cinzas de André da Silva GomesCatalogação e Organização Régis Duprat (DUPRAT, 1999, p.175).

Como peculiar dessa parte do discurso, o autor novamente faz menção às palavras: Exaltabo te Domine (Exalto-te, Senhor), destacando-as de maneira enfática. Auxiliando essas aplicações no texto, estão as figuras retóricas inseridas por Silva Gomes como a Noema, trazendo equilíbrio nas vozes e também valorizando a Cadência Autêntica Imperfeita, concretizada no compasso 11, em condução homofônica e a Anaphora, repetindo tanto as 
frases e motivos dessa passagem, como a palavra Suscepiste (amparo, ajuda, livramento).

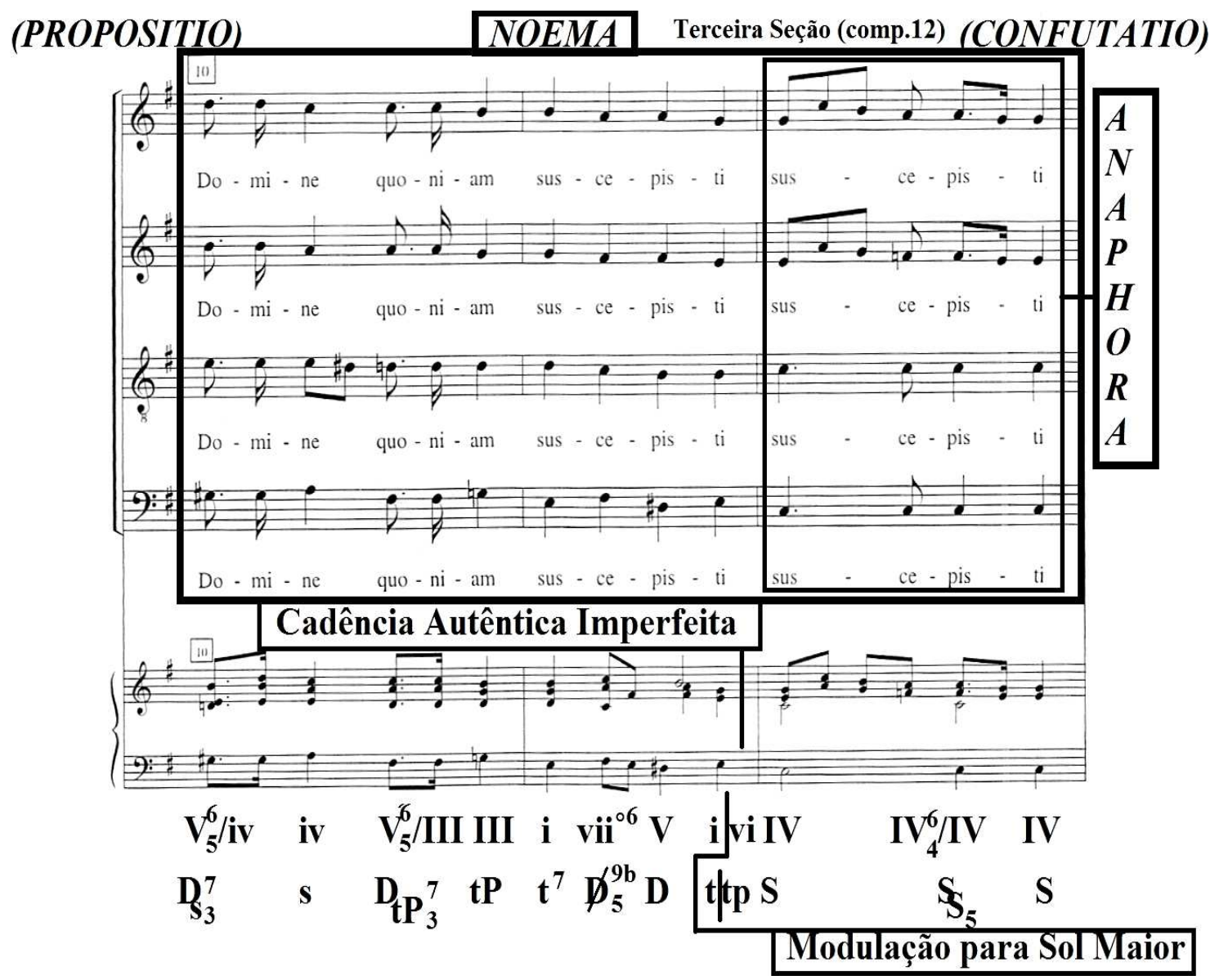

Exemplo 6: Ofertório da Missa de Quarta -feira de Cinzas de André da Silva GomesCatalogação e Organização Régis Duprat (DUPRAT, 1999, p.175).

\subsubsection{Confutatio}

A Confutatio é empregada na transição da modulação de Mi Menor para Sol Maior. Já a terceira fase da disposição é concluída no compasso 14, ainda na terceira seção da obra, em sua tonalidade principal. Semelhantemente, o compositor continua a empregar a Anaphora, ressaltando a importância do livramento concedido por Deus para seu servo. 


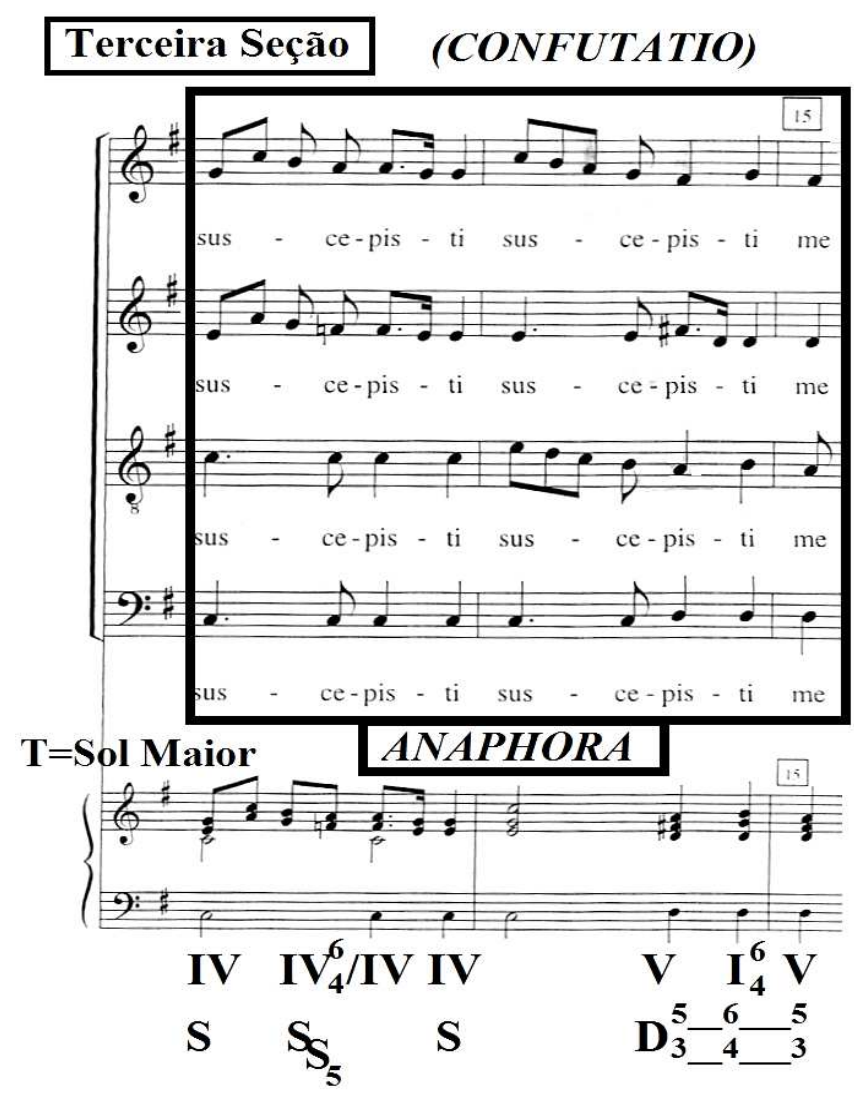

Exemplo 7: Ofertório da Missa de Quarta -feira de Cinzas de André da Silva GomesCatalogação e Organização Régis Duprat (DUPRAT, 1999, p.176).

Apesar de conservar o uso da figura supracitada (Anaphora), nessa parte da Dispositio, o autor se preocupa em cumprir o objetivo e plano estabelecidos para a execução da mesma, inserindo novos elementos de ordem textual e motívica. Por exemplo, a partir do compasso 19, na terceira seção, é empregada pela primeira vez na peça uma fermata, valorizando tanto a repetição da exposição melódica como a valoração das vozes da soprano e contralto, entoando duas notas em uma sílaba, realizadas pela Anaphora e Synaeresis, igualmente antecedendo a figura da Aposiopesis, descrita por uma pausa geral em todas as vozes, aplicada posteriormente no compasso 20. Também é observável o contraste alcançado com êxito através da intersecção desses mecanismos, sem se esquecer das dinâmicas forte e piano entre a Aposiopesis. Identicamente, o texto retrata a questão da não permissão da alegria dos inimigos à custa do sofrimento anterior, por parte de Deus $(E t$ nec [non] dilectasti inimicos meos super me). 
Em síntese, todo esse sentido converge para a organização das contestações às quais são expostas a partir desse trecho do ofertório, ou seja, a oposição das ideias musicais.
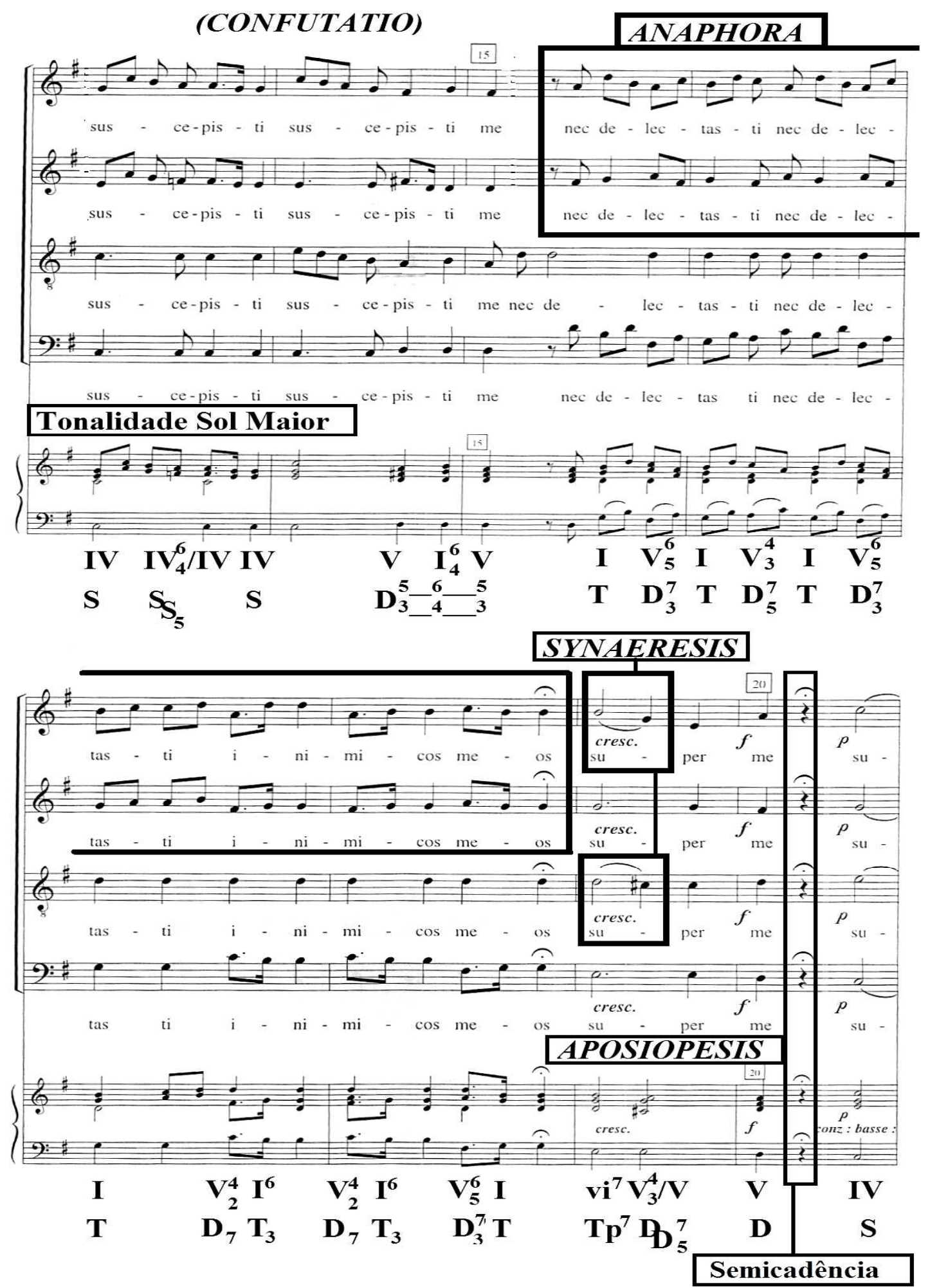

Exemplo 8: Ofertório da Missa de Quarta -feira de Cinzas de André da Silva GomesCatalogação e Organização Régis Duprat (DUPRAT, 1999, p.176). 


\subsubsection{Confirmatio}

A reafirmação do discurso inicial ocorre pela repetição imediata e enfática das notas, como da palavra Domine (Senhor), efetuada pela figura da Epizeuxis. Igualmente pode-se destacar o emprego da pausa como elemento de transição da terceira para a quarta seção e a modulação obtida no compasso 22 de Sol Maior para Mi Menor, respaldada anteriormente pela Cadência Autêntica Imperfeita.

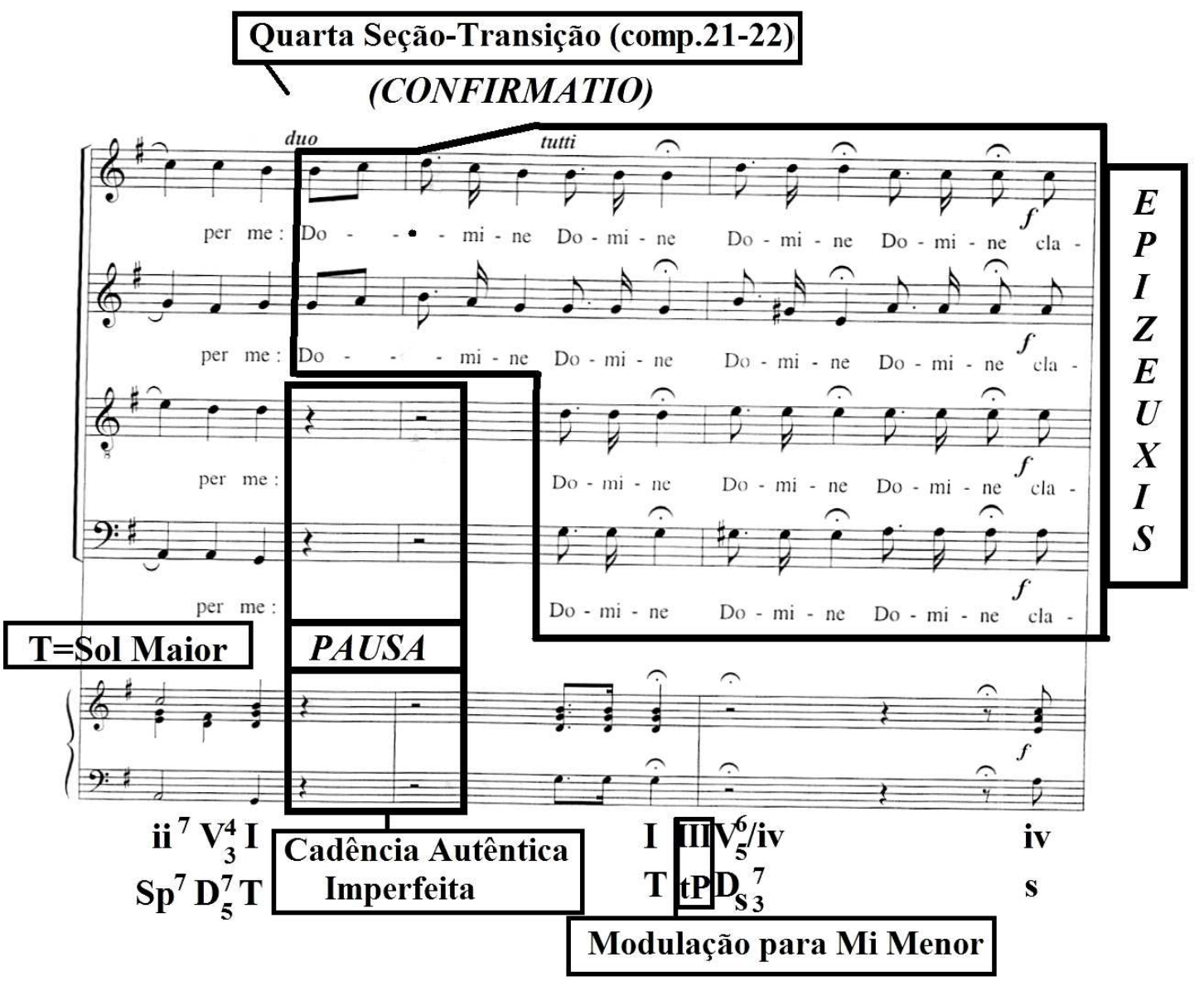

Exemplo 9: Ofertório da Missa de Quarta -feira de Cinzas de André da Silva GomesCatalogação e Organização Régis Duprat (DUPRAT, 1999, p.177).

No exemplo a baixo podem ser observadas as mesmas figuras empregadas anteriormente pelo autor, no entanto, o mesmo insere uma nova: Palilogia que, por sua vez, repete as mesmas notas e palavras temáticas do texto. 
(CONFIRMATIO)

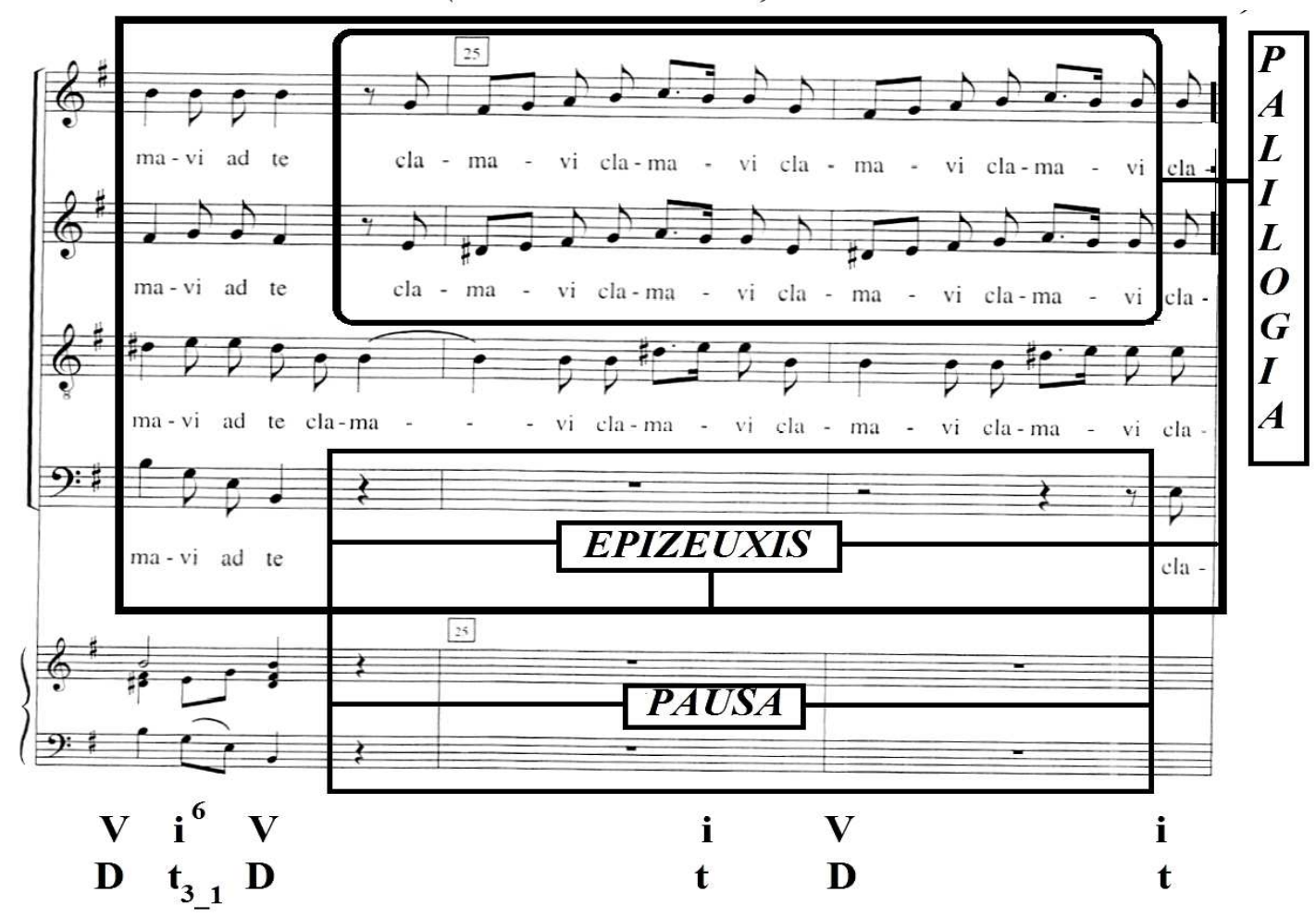

Exemplo 10: Ofertório da Missa de Quarta -feira de Cinzas de André da Silva GomesCatalogação e Organização Régis Duprat (DUPRAT, 1999, p.177).

A Confirmatio termina coincidentemente com a quarta seção no compasso 27.

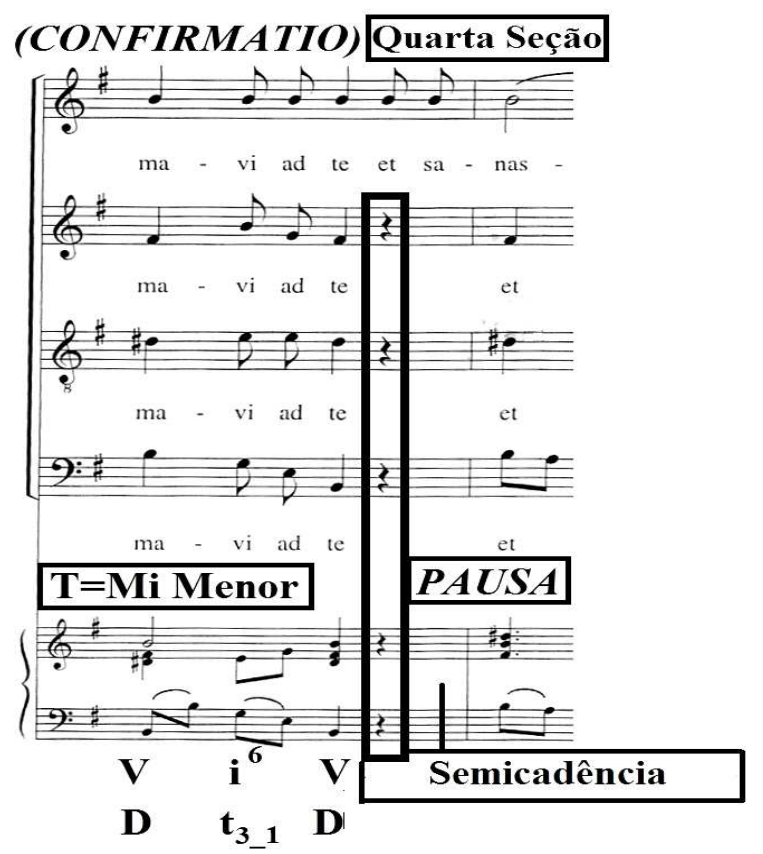

Exemplo 11: Ofertório da Missa de Quarta -feira de Cinzas de André da Silva GomesCatalogação e Organização Régis Duprat (DUPRAT, 1999, p.178). 


\subsubsection{Perotatio}

Tanto a Perotatio quanto a quinta e última seção iniciam-se no final do compasso 27. Como característica dessa parte do discurso, é trabalhado pelo autor tanto o texto quanto as figuras de maneira enfática, ou seja, repetindo e destacando a palavra Et sanasti (Me sarou), através da Epizeuxis e Anaphora.

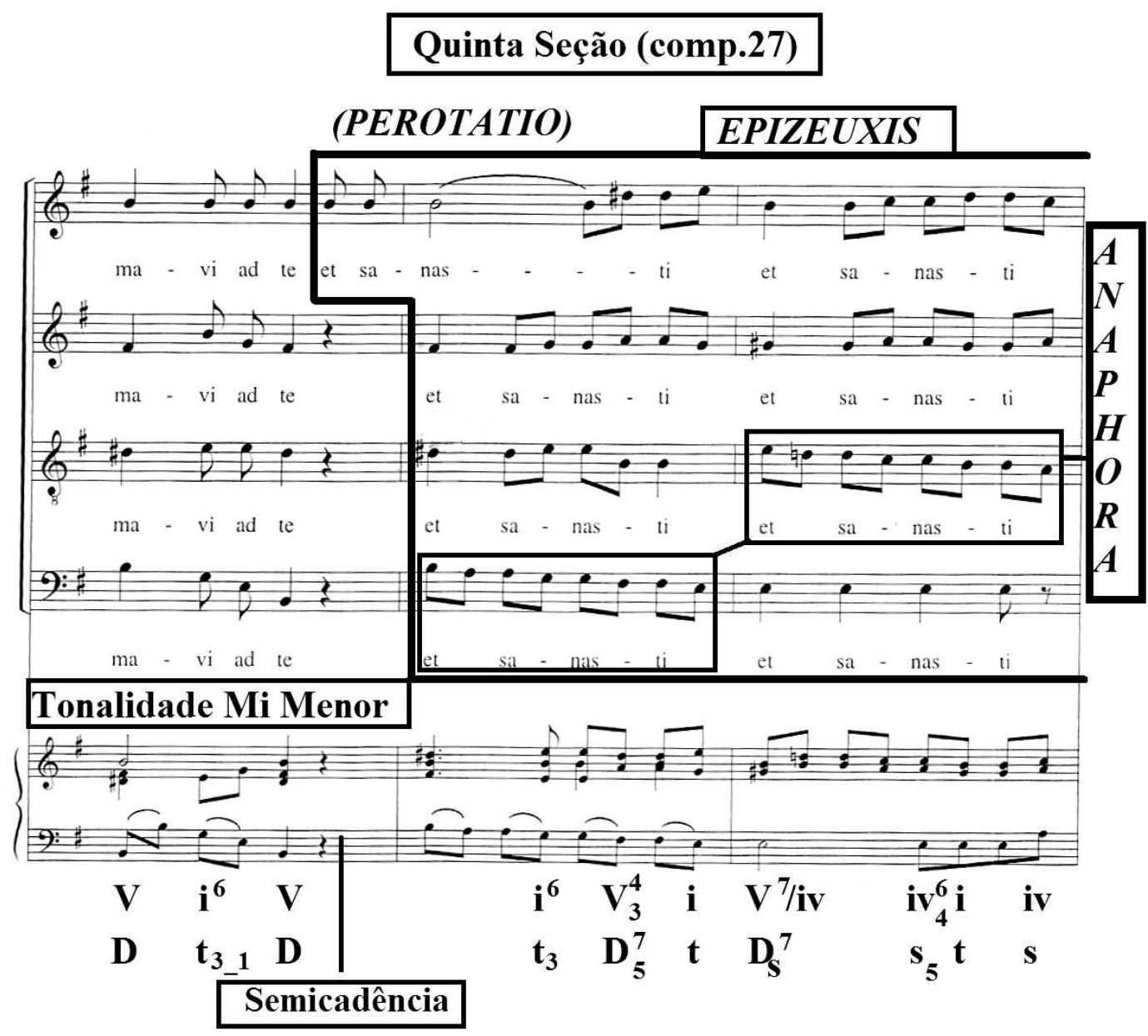

Exemplo 12: Ofertório da Missa de Quarta -feira de Cinzas de André da Silva GomesCatalogação e Organização Régis Duprat (DUPRAT, 1999, p.178).

Silva Gomes conclui o discurso desse ofertório na tonalidade de Sol Maior, utilizando a Aposiopesis e Anaphora, empregadas desde a Propositio na segunda seção, ou seja, ele reúne partes integrantes da fundamentação da tese. Entretanto, entre os compassos 32 e 33, pode-se notar a aplicação, além da Synaeresis, de outra figura: a Syncope na voz da soprano, que num primeiro momento é consonante ao acorde da Subdominante e, posteriormente, resulta em uma dissonância da Subdominante Paralela, isto é, 
a nota Sol que, no compasso anterior, era a quinta passa a ser a sétima, criando assim uma tensão para a função que virá com a Dominante.

Enfim, é finalizada a peça com uma dinâmica contrastante semelhante à que fora apresentada na Confutatio, no entanto, com uma diferença de forte para pianíssimo e com uma frase bem definida, reflexiva e suave para, em seguida, acabar na Cadência Autêntica Imperfeita.

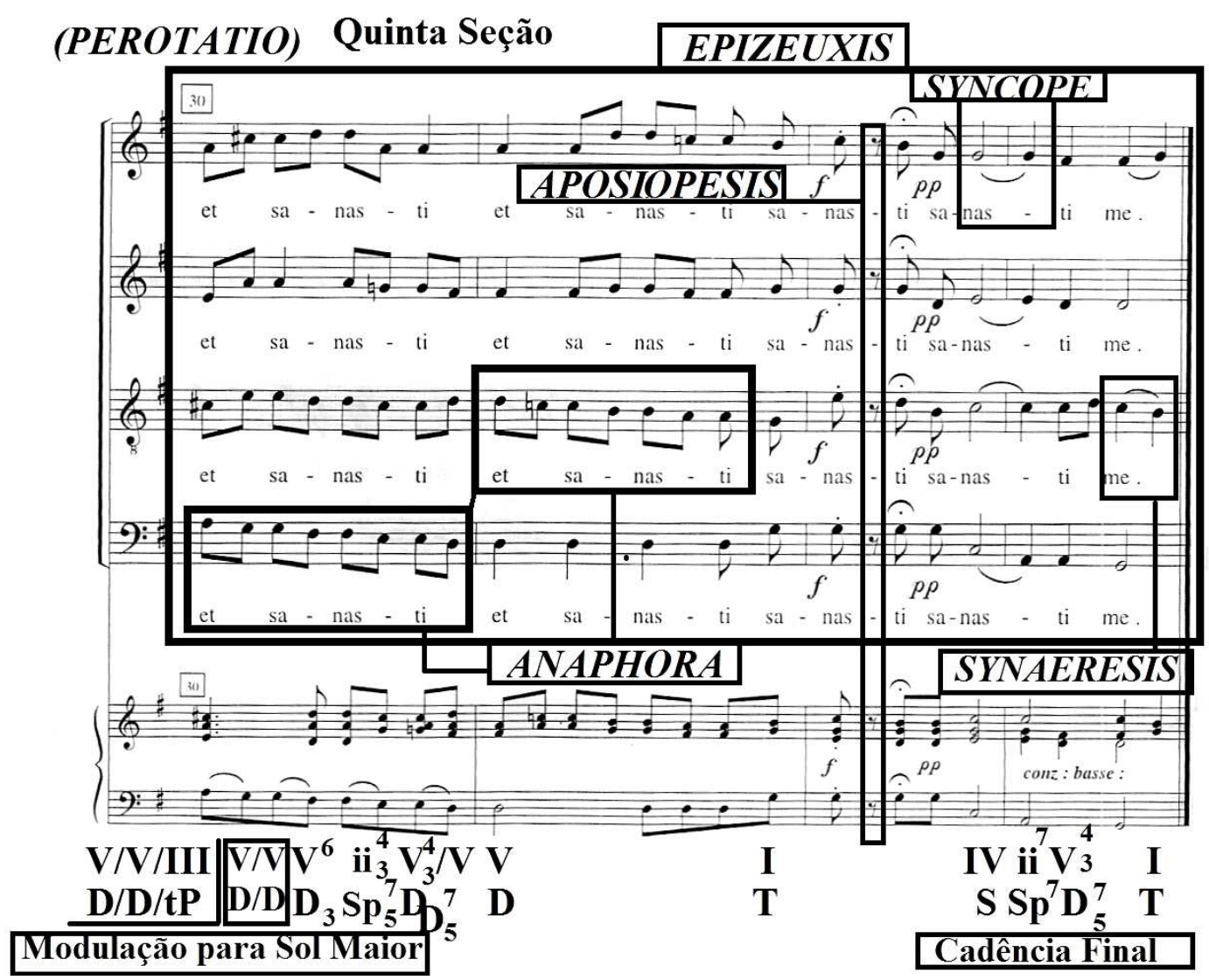

Exemplo 13: Ofertório da Missa de Quarta -feira de Cinzas de André da Silva GomesCatalogação e Organização Régis Duprat (DUPRAT, 1999, p.178).

\subsection{Figuras observadas no Ofertório (Elocutio/Decoratio)}

\begin{tabular}{|c|c|c|c|}
\hline FIGURAS & TIPO & DESCRIÇÃO & TRATADISTA \\
\hline $\begin{array}{l}\text { ANABASIS } \\
\text { (BARTEL, 1997, } \\
\text { pp.179-180). }\end{array}$ & $\begin{array}{l}\text { Representação e } \\
\text { Descrição }\end{array}$ & $\begin{array}{l}\text { Uma passagem } \\
\text { musical } \\
\text { ascendente, que } \\
\text { expressa } \\
\text { exaltação ou } \\
\text { imagens } \\
\text { positivas dos } \\
\text { afetos. }\end{array}$ & $\begin{array}{l}\text { Walther: Anabasis, } \\
\text { de anabaino, } \\
\text { ascendo é uma } \\
\text { passagem musical } \\
\text { por meio do qual } \\
\text { algo subindo às } \\
\text { alturas é expressa. } \\
\text { Por exemplo, nas } \\
\text { palavras: Ele é }\end{array}$ \\
\hline
\end{tabular}




\begin{tabular}{|c|c|c|c|}
\hline & & & $\begin{array}{l}\text { ressuscitado, Deus } \\
\text { subiu, e textos } \\
\text { similares. } \\
\text { Kircher: A } \\
\text { Anabasis ou } \\
\text { ascentio é uma } \\
\text { passagem musical } \\
\text { através do qual } \\
\text { expressamos } \\
\text { sentimentos de } \\
\text { exaltação, ascenso } \\
\text { ou pensamentos } \\
\text { elevados e } \\
\text { eminentes, } \\
\text { exemplificado na } \\
\text { ascensão de Cristo. }\end{array}$ \\
\hline $\begin{array}{l}\text { ANAPHORA } \\
\text { (BARTEL, 1997, } \\
\text { pp.184-190). }\end{array}$ & $\begin{array}{l}\text { Repetição } \\
\text { Melódica }\end{array}$ & $\begin{array}{l}\text { (1) É uma linha } \\
\text { do baixo repetida } \\
\text { em forma de } \\
\text { solo. (2) A } \\
\text { repetição de uma } \\
\text { exposição } \\
\text { melódica sobre } \\
\text { notas e partes } \\
\text { diferentes. } \\
\text { Também pode } \\
\text { ocorrer no início } \\
\text { das repetições } \\
\text { de frases e } \\
\text { motivos em uma } \\
\text { série de } \\
\text { passagens } \\
\text { sucessivas; (3) } \\
\text { Uma repetição } \\
\text { em geral. }\end{array}$ & $\begin{array}{lr}\text { Vogt: } & \text { Ocorre } \\
\text { quando nós } & \text { nós } \\
\text { frequentemente } & \\
\text { repetimos } & \text { um } \\
\text { seguimento } & \text { ou } \\
\text { determinada } & \text { figura } \\
\text { por causa } & \text { da } \\
\text { intensidade. } & \\
\text { A Anáfora é a } \\
\text { repetição ras que } \\
\text { acontece } \\
\text { apenas em parte } \\
\text { de uma passagem, } \\
\text { mas também nas } \\
\text { figurae símplices. }\end{array}$ \\
\hline $\begin{array}{l}\text { ANTICIPATIO } \\
\text { (BARTEL, } 1997, \\
\text { pp.192-195) }\end{array}$ & $\begin{array}{l}\text { Ornamentação } \\
\text { Melódica e } \\
\text { Harmônica }\end{array}$ & $\begin{array}{lr}\text { Uma } & \text { nota } \\
\text { superior } & \text { ou } \\
\text { inferior, vizinha e } \\
\text { adicionada } \\
\text { uma } \\
\text { principal, } \\
\text { prematuramente } \\
\text { introduzida } \\
\text { uma de } \\
\text { pertencente nota } \\
\text { harmonia ou de } \\
\text { acordes } \\
\text { posteriores. }\end{array}$ & $\begin{array}{l}\text { Spiess: A } \\
\text { Anticipatio é a } \\
\text { antecipação ou } \\
\text { reprodução } \\
\text { prematura de uma } \\
\text { nota. Trata-se de } \\
\text { uma figura muito } \\
\text { comum e ocorre } \\
\text { quando uma voz } \\
\text { entra mais cedo } \\
\text { que as demais. }\end{array}$ \\
\hline
\end{tabular}




\begin{tabular}{|c|c|c|c|}
\hline $\begin{array}{l}\text { APOSIOPESIS } \\
\text { (BARTEL, 1997, } \\
\text { pp.202-206) }\end{array}$ & $\begin{array}{l}\text { Interrupção } \\
\text { Silêncio }\end{array}$ & $\begin{array}{l}\text { Um descanso em } \\
\text { uma ou todas as } \\
\text { vozes de uma } \\
\text { composição: } \\
\text { pausa geral. }\end{array}$ & $\begin{array}{l}\text { Walther: } \\
\text { Aposiopesis se } \\
\text { refere a uma pausa } \\
\text { generalis ou um } \\
\text { completo silêncio } \\
\text { em todas as vozes } \\
\text { e nas partes da } \\
\text { composição } \\
\text { simultaneamente. }\end{array}$ \\
\hline $\begin{array}{l}\text { EPIZEUXIS } \\
\text { (BARTEL, 1997, } \\
\text { pp.263-265) }\end{array}$ & $\begin{array}{l}\text { Repetição } \\
\text { Melódica }\end{array}$ & $\begin{array}{l}\text { Uma repetição } \\
\text { imediata e } \\
\text { enfática de uma } \\
\text { palavra, nota, } \\
\text { motivo ou frase. }\end{array}$ & $\begin{array}{l}\text { Walther: } \\
\text { Epizeuxis é uma } \\
\text { figura de retórica } \\
\text { pela qual uma ou } \\
\text { mais palavras são } \\
\text { imediatamente e } \\
\text { enfaticamente } \\
\text { repetidas. }\end{array}$ \\
\hline $\begin{array}{l}\text { NOEMA } \\
\text { (BARTEL, 1997, } \\
\text { p.339-342). }\end{array}$ & $\begin{array}{l}\text { Representação e } \\
\text { Descrição }\end{array}$ & $\begin{array}{l}\text { Uma passagem } \\
\text { homofônica em } \\
\text { uma textura } \\
\text { contrapontística } \\
\text { e polifônica. }\end{array}$ & $\begin{array}{l}\text { Burmeister: A } \\
\text { Noema representa } \\
\text { o afeto harmônico, } \\
\text { onde as vozes } \\
\text { combinadas têm } \\
\text { valores e números } \\
\text { de notas } \\
\text { semelhantes. } \\
\text { Quando introduzida } \\
\text { adequadamente, } \\
\text { isto é, no momento } \\
\text { certo, ela afeta } \\
\text { docemente os } \\
\text { ouvidos do } \\
\text { ouvinte, produzindo } \\
\text { uma sensação de } \\
\text { calma e } \\
\text { serenidade. } \\
\text { Seção homofônica, } \\
\text { dentro da polifonia } \\
\text { utilizada para } \\
\text { enfatizar o texto. }\end{array}$ \\
\hline $\begin{array}{l}\text { PALILOGIA } \\
\text { (BARTEL, } 1997 \\
\text { pp.342-344). }\end{array}$ & $\begin{array}{l}\text { Repetição } \\
\text { Melódica }\end{array}$ & $\begin{array}{l}\text { Repetição de } \\
\text { um tema no } \\
\text { mesmo nível de } \\
\text { altura, também } \\
\text { pode ocorrer em } \\
\text { alturas diferentes } \\
\text { na mesma ou em } \\
\text { várias vozes. }\end{array}$ & $\begin{array}{l}\text { Burmeister: A } \\
\text { Palilogia é uma } \\
\text { repetição de uma } \\
\text { inteiração ou } \\
\text { apenas o começo } \\
\text { da estrutura dos } \\
\text { meios e temas } \\
\text { sobre a mesma }\end{array}$ \\
\hline
\end{tabular}




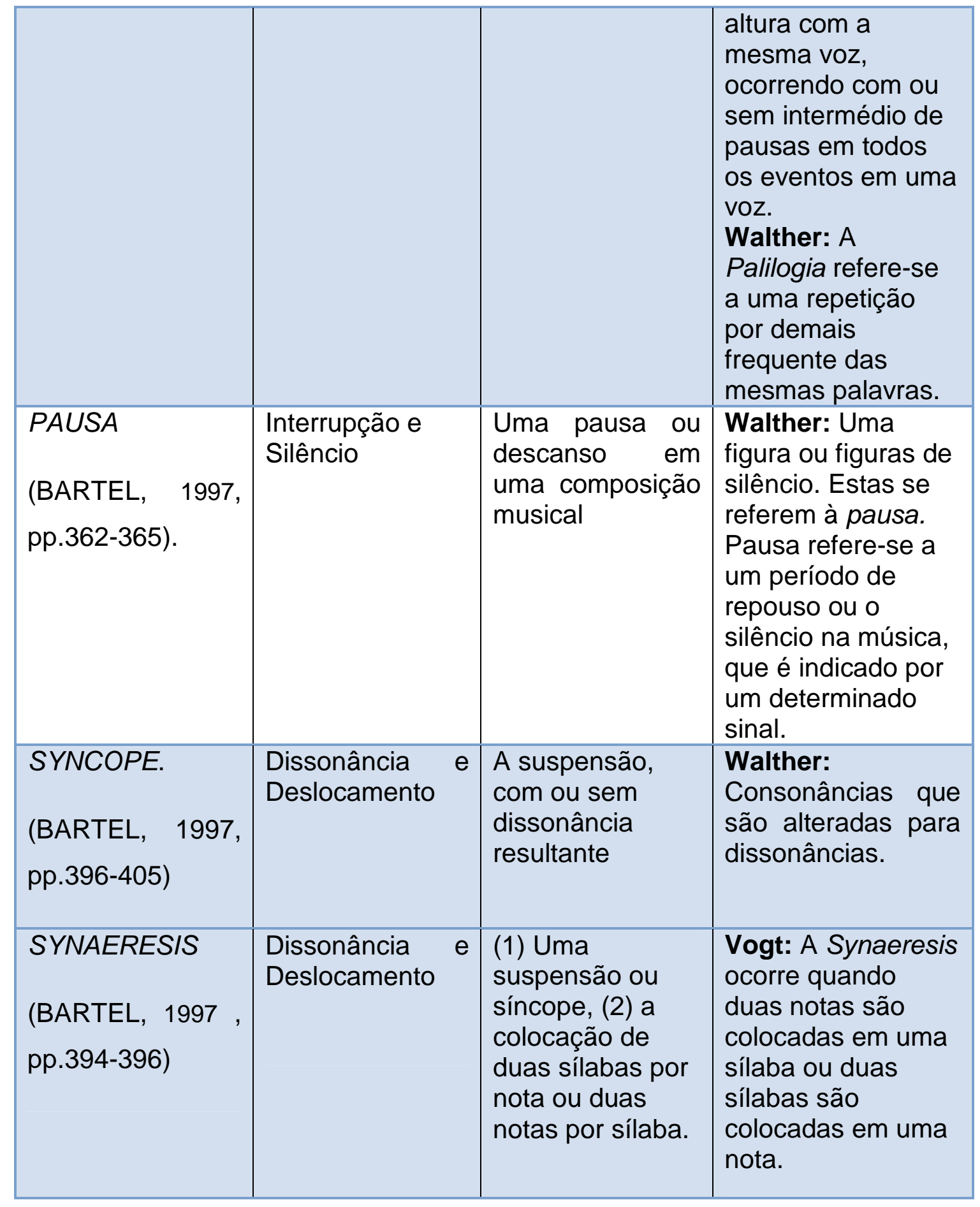

Tabela 5: Figuras Retóricas encontradas no Ofertório da Missa de Quarta-feira de Cinzas de André da Silva Gomes

\section{Análise Harmônica}

\subsection{Curva Tonal}

Tonalidade: Sol Maior

Andamento: Moderato 4/4 
Esquema das Progressões Harmônicas

\begin{tabular}{|l|c|l|}
\hline Compassos & $\begin{array}{l}\text { Função em relação a } \\
\text { tonalidade principal }\end{array}$ & Tonalidade (Acorde) \\
\hline $1-4$ & $\mathrm{~T}-\mathrm{I}$ & Sol Maior \\
\hline $4-5$ & $\mathrm{D}-\mathrm{V}$ & Ré Maior \\
\hline $5-7$ & $\mathrm{~T}-\mathrm{I}$ & Sol Maior \\
\hline $7-9$ & $\mathrm{Tp}-\mathrm{vi}$ & Mi Menor \\
\hline $9-10$ & $\mathrm{D} / \mathrm{Sp}-\mathrm{V} / \mathrm{ii}$ & Mi Maior \\
\hline 10 & $\mathrm{Sp}-\mathrm{ii}$ & Lá Menor \\
\hline 11 & $\mathrm{Tp}-\mathrm{vi}$ & Mi Menor \\
\hline $12-13$ & $\mathrm{~S}-\mathrm{IV}$ & Dó Maior \\
\hline $12-19$ & $\mathrm{~T}-\mathrm{I}$ & Sol Maior \\
\hline $19-20$ & $\mathrm{D}-\mathrm{V}$ & Ré Maior \\
\hline $20-22$ & $\mathrm{~T}-\mathrm{I}$ & Sol Maior \\
\hline 23 & $\mathrm{Sp}-\mathrm{ii}$ & Lá Menor \\
\hline $23-28$ & $\mathrm{Tp}-\mathrm{vi}$ & Mi Menor \\
\hline 29 & $\mathrm{Sp}-\mathrm{ii}$ & Lá Menor \\
\hline $30-31$ & $\mathrm{D}-\mathrm{V}$ & Ré Maior \\
\hline $31-33$ & $\mathrm{~T}-\mathrm{I}$ & Sol Maior \\
\hline
\end{tabular}

Tabela 6: Curva Tonal do Ofertório da Missa de Quarta- feira de Cinzas

Números de compassos: 33

Regiões abordadas: 6

Variações: 16

Ritmo Harmônico: 2,06 (divisão dos números de compassos e variações)

Média ideal: (divisão dos números de compassos e regiões tonais abordadas $=5,5$ )

Esquema Formal

$(1-7)(7-11)(12-22)(23-29)(30-33)$

$\begin{array}{lllll}T & \text { Tp } & T & \text { Tp } & T\end{array}$

l vi l vi I 


\subsection{Estrutura Analítica do Ofertório: Retórica e Harmônica}

\begin{tabular}{|c|c|c|c|c|c|}
\hline $\begin{array}{l}\text { RETÓRICA } \\
\text { DISPOSITIO }\end{array}$ & $\begin{array}{l}\text { FIGURA } \\
\text { ELOCUTIO }\end{array}$ & COMP. & $\begin{array}{l}\text { HARMÔNICA } \\
\text { SEÇÃO }\end{array}$ & TONALIDADE & FUNÇÃO \\
\hline EXORDIUM & $\begin{array}{l}\text { Anabasis } \\
\text { Synaeresis }\end{array}$ & $\begin{array}{l}1-2 \\
3\end{array}$ & $\begin{array}{l}1^{\text {a Seção }} \\
1^{\text {a Seção }}\end{array}$ & $\begin{array}{l}\text { Sol Maior } \\
\text { Sol Maior }\end{array}$ & $\begin{array}{l}\mathrm{T}-\mathrm{I} \\
\mathrm{T}-\mathrm{I}\end{array}$ \\
\hline NARRATIO & $\begin{array}{l}\text { Synaeresis } \\
\text { Anabasis } \\
\text { Anticipatio }\end{array}$ & $\begin{array}{l}5 \\
5 \text { e } 6 \\
5 \text { e } 6\end{array}$ & $\begin{array}{l}\text { 1ª Seção } \\
\text { 1ª Seção } \\
\text { 1' Seção }\end{array}$ & $\begin{array}{l}\text { Só Maior } \\
\text { Só Maior } \\
\text { Sol Maior }\end{array}$ & $\begin{array}{l}\mathrm{T}-\mathrm{I} \\
\mathrm{T}-\mathrm{I} \\
\mathrm{T}-\mathrm{I}\end{array}$ \\
\hline PROPOSITIO & $\begin{array}{l}\text { Pausa } \\
\text { Noema }\end{array}$ & $\begin{array}{l}8-9 \\
10-12\end{array}$ & $\begin{array}{l}2^{a} \text { Seção } \\
2^{\underline{a}} \text { Seção }\end{array}$ & $\begin{array}{l}\text { Mi Menor } \\
\text { Mi Menor }\end{array}$ & $\begin{array}{l}\text { Tp-vi } \\
\text { Tp-vi }\end{array}$ \\
\hline CONFUTATIO & $\begin{array}{l}\text { Anaphora } \\
\text { Aposiopesis }\end{array}$ & $\begin{array}{l}12-17 \\
20\end{array}$ & $\begin{array}{l}\text { 3ª Seção } \\
\text { 3ª Seção }\end{array}$ & $\begin{array}{l}\text { Sol Maior } \\
\text { Sol Maior }\end{array}$ & $\begin{array}{l}\mathrm{T}-\mathrm{I} \\
\mathrm{T}-\mathrm{I}\end{array}$ \\
\hline CONFIRMATIO & $\begin{array}{l}\text { Pausa } \\
\text { Epizeuxis } \\
\text { Palilogia }\end{array}$ & $\begin{array}{l}21-22 \\
24-27 \\
21-27 \\
\\
24-26\end{array}$ & $\begin{array}{l}4^{a} \text { Seção } \\
4^{\text {a }} \text { Seção } \\
4^{\text {a }} \text { Seção }\end{array}$ & $\begin{array}{l}\text { Mi Menor } \\
\text { Mi Menor } \\
\text { Mi Menor }\end{array}$ & $\begin{array}{l}\text { Tp-vi } \\
\text { Tp-vi } \\
\text { Tp-vi }\end{array}$ \\
\hline PEROTATIO & $\begin{array}{l}\text { Epizeuxis } \\
\text { Anaphora } \\
\text { Aposiopesis } \\
\text { Syncope }\end{array}$ & $\begin{array}{l}27-31 \\
28-32 \\
31 \\
32-33\end{array}$ & $\begin{array}{l}\text { 5ª Seção }^{\text {5a Seção }} \\
\text { 5ª Seção }^{\text {5ª Seção }}\end{array}$ & $\begin{array}{l}\text { Mi Menor } \\
\text { Mi Menor e } \\
\text { Sol Maior } \\
\text { Sol Maior } \\
\text { Sol Maior }\end{array}$ & $\begin{array}{l}\text { Tp-vi } \\
\text { Tp-vi } \\
\text { T-I } \\
\text { T-I } \\
\text { T-I }\end{array}$ \\
\hline
\end{tabular}

Tabela 7: Estrutura analítica do Ofertório 


\subsubsection{Ofertório da Missa do Domingo da Paixão}

\section{Estudo Semântico}

\subsection{Inventio}

Esta obra fora escrita a partir de dois diferentes salmos: "Obras Magnificas de Deus em Israel" (Ps.110,1/111,1), e Elogio da Lei Divina (Ps. $118,17 ; 25 / 119,17 ; 27)$.

Confitebor tibi Domine, in toto corde meo:

Retribue servo tuo: vivam et custodiam sermones tuos:

Vivifica me secundum verbum tuum, Domine.

Quero louvar o Senhor de todo o meu coração:

Concedei ao teu servo o beneficio da vida, e guardarei a tua palavra:

Restitui-me a vida, segundo a tua palavra.

(SOARES, 2000, p.34).

O primeiro texto é um louvor que faz lembrar o êxodo das peregrinações pelo deserto e a conquista da terra prometida. O segundo, representa a dependência do cristão em guardar e obedecer à palavra de Deus, para lograr êxito, isto é, ser- Ihe outorgada à vida. Outro aspecto interessante são suas elaborações denominadas pelos teólogos e estudiosos como acróstico ${ }^{96}$, característica comum entre os poemas de sabedoria (ALMEIDA, 1999, p.697).

Assim como no Domingo de Ramos o da Paixão abre à Semana Santa. No que tange a sua liturgia, pode-se verificar uma celebração de dois aspectos fundamentais, a paixão e a magnificência, a morte e ressurreição, os quais forma o mistério pascal, refletidos de maneira introspectiva pelo cristão.

Enfim, o ofertório é composto de quarenta e dois compassos, num andamento Grave na tonalidade de Sol Maior, distribuídos em seis seções com grande intensidade, sejam emocionais ou afetivas, trabalhadas pelo compositor com o propósito de atrair a atenção do ouvinte.

\footnotetext{
${ }^{96}$ Composição poética na qual o conjunto das letras iniciais (e por vezes as mediais ou finais) dos versos compõe verticalmente uma palavra ou frase. No caso desses salmos a cada meia linha eles são iniciados com letras sucessivas do alfabeto hebraico e se complementam em seu conteúdo.
} 


\subsection{Locus observados na Inventio do Ofertório}

\begin{tabular}{|c|c|c|c|}
\hline INVENTIO & DESCRIÇÃO & $\begin{array}{c}\text { UTILIZAÇÃO NA } \\
\text { OBRA }\end{array}$ & $\begin{array}{l}\text { COMPASSO/ } \\
\text { VOZ }\end{array}$ \\
\hline $\begin{array}{l}\text { Locus } \\
\text { Notationis } \\
\text { (MATTHESON, } \\
\text { [1739],1954, } \\
\text { Parte II,Cap.4, } \\
\text { § 23,p.123). }\end{array}$ & $\begin{array}{l}\text { Aspecto externo } \\
\text { e desenho das } \\
\text { notas (Duração } \\
\text { das notas, } \\
\text { alteração, } \\
\text { repetição e } \\
\text { procedimentos } \\
\text { canônicos). }\end{array}$ & $\begin{array}{l}\text { Vários motivos } \\
\text { rítmicos e diferentes } \\
\text { durações de notas } \\
\text { (mínimas, semínimas, } \\
\text { semínimas } \\
\text { pontuadas, colcheias, } \\
\text { colcheias pontuadas, } \\
\text { semicolcheias } \\
\text { repetições, } \\
\text { apogiaturas, } \\
\text { ligaduras, fermatas, } \\
\text { pausas, entre outros). }\end{array}$ & $\begin{array}{l}1-4 \quad S \\
5-14 \text { S-A-T-B } \\
15-19 \text { S } \\
20-29 \text { S-A-T-B } \\
30-32 \text { S } \\
33-42 \text { S-A-T-B }\end{array}$ \\
\hline $\begin{array}{l}\text { Locus } \\
\text { Oppositorum } \\
\text { (MATTHESON, } \\
\text { [1739],1954, } \\
\text { Parte II,Cap.4, } \\
\text { § 80,p.131). }\end{array}$ & $\begin{array}{l}\text { Contraste de } \\
\text { compassos, } \\
\text { movimentos } \\
\text { contrários, } \\
\text { agudos e } \\
\text { graves, lento e } \\
\text { rápido, calmo e } \\
\text { agitado. }\end{array}$ & $\begin{array}{l}\text { Movimento contrário } \\
\text { entre soprano e baixo. }\end{array}$ & S-B \\
\hline $\begin{array}{l}\text { Locus } \\
\text { Descriptionis } \\
\text { (MATTHESON, } \\
\text { [1739],1954, } \\
\text { Parte II,Cap.4, } \\
\S 43, \text { p.127). }\end{array}$ & $\begin{array}{l}\text { Disposições da } \\
\text { alma }\end{array}$ & $\begin{array}{l}\text { Celebração e } \\
\text { Exaltação (Quero } \\
\text { louvar o Senhor de } \\
\text { todo o meu coração). }\end{array}$ & $\begin{array}{ll}1-4 & S \\
5-14 & \text { S-A-T-B }\end{array}$ \\
\hline
\end{tabular}

Tabela 8: Locus Topici encontrados no Ofertório da Missa do Domingo da Paixão de André da Silva Gomes 


\subsection{Dispositio}

\subsubsection{Exordium}

A presente seção inicia-se com o emprego de duas figuras de repetição melódica, Synonimia e Palilogia, destacando as ornamentações, o solo executado pela soprano e a expressão de louvor manifesta pelo salmista, Confitebor tibi Domine (Quero louvar o Senhor). Também, nota-se a presença da Pausa, cuja função é oferecer um período de descanso as outras vozes.

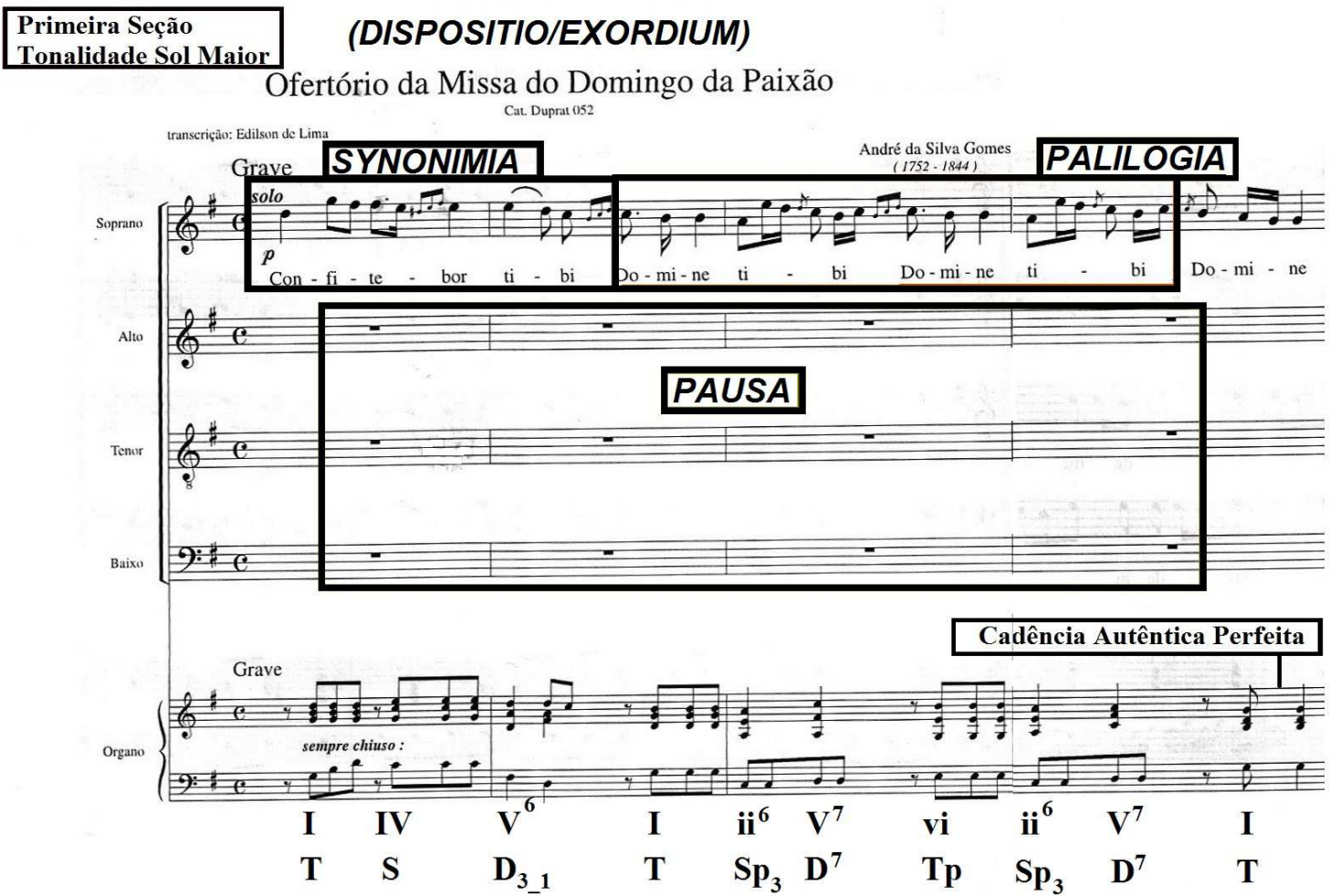

Exemplo 14: Ofertório da Missa do Domingo da Paixão de André da Silva GomesCatalogação e Organização Régis Duprat (DUPRAT, 1999, p.213).

\subsubsection{Narratio}

Logo após o desfecho da Exordium, na Cadência Autêntica Perfeita, a narração dos fatos iniciais se dá por meio do tutti, isto é, com todas as vozes entoando a mesma frase da introdução do discurso, porém é observável a aplicação da Anaphora, ressaltando as notas como as palavras, por meio de repetição. 


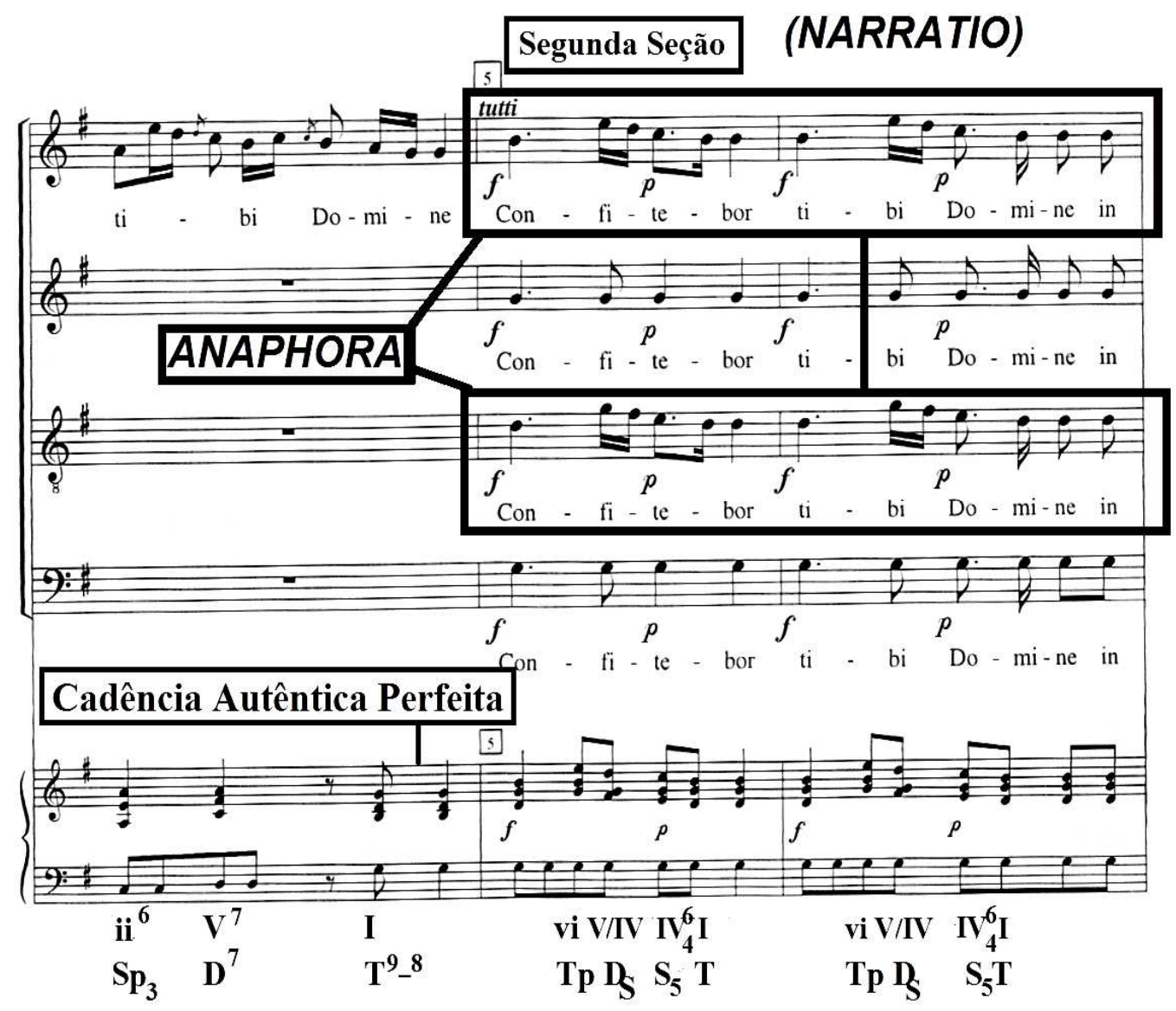

Exemplo 15: Ofertório da Missa do Domingo da Paixão de André da Silva GomesCatalogação e Organização Régis Duprat (DUPRAT, 1999, p.213).

Entre os compassos 7 e 12, o compositor continua utilizando figuras de repetição tais como Auxesis e Gradatio, sendo a primeira uma sucessão de repetições tanto melódica quanto das palavras, já a segunda além do mesmo caráter repetitivo, enfatiza a complementação da primeira frase do salmo, in toto corde meo (de todo meu coração) através das terças paralelas entre soprano e contralto, além da sequência das notas nessas vozes e do baixo.

Outro aspecto relevante é a modulação para a tonalidade de Mi Menor no compasso 6 , onde o autor trabalha com alguns tipos de dinâmicas, crescendo, forte e piano valorando tanto as funções harmônicas, quanto as representações dos afetos de celebração e devoção. 
(NARRATIO)
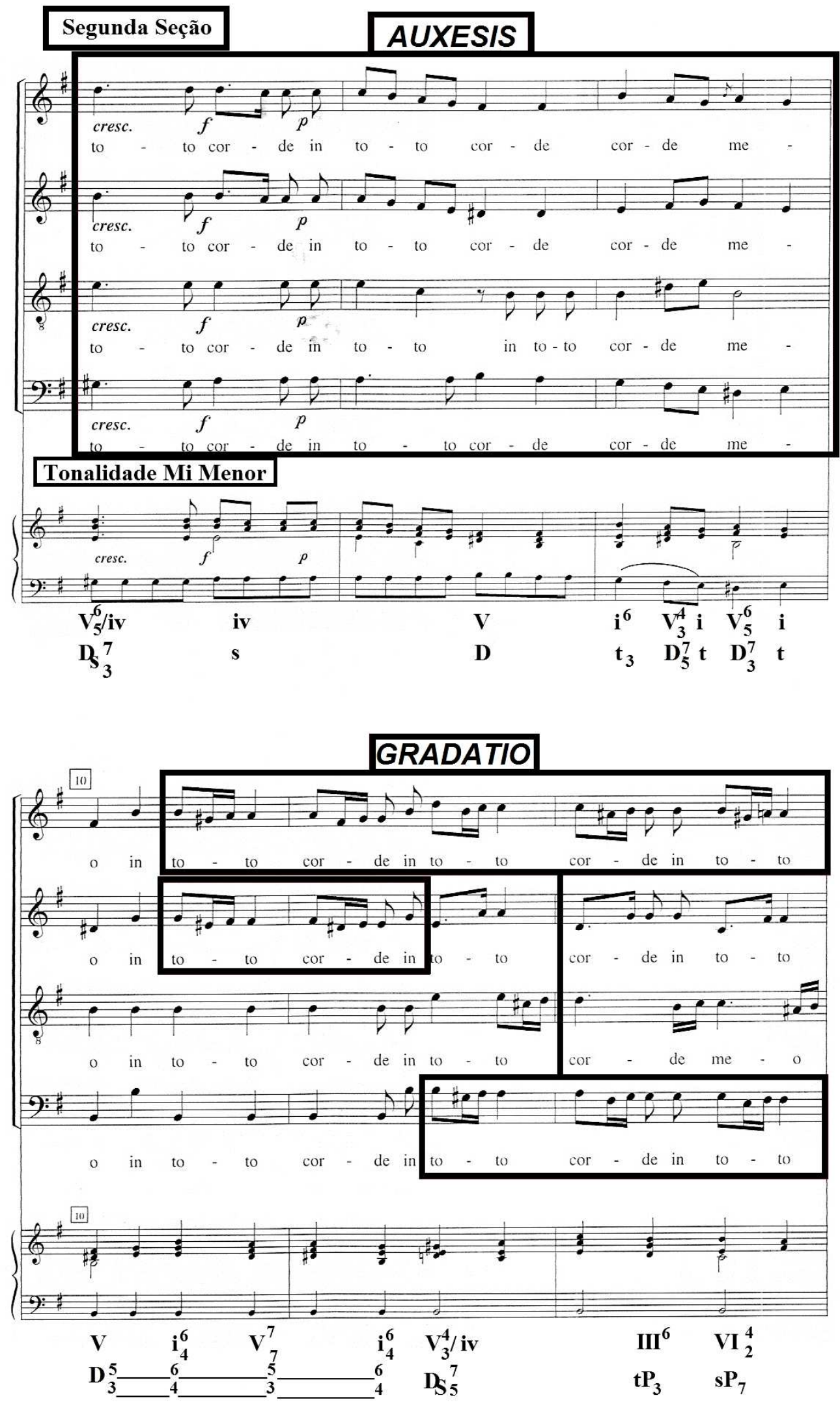

Exemplo 16: Ofertório da Missa do Domingo da Paixão de André da Silva GomesCatalogação e Organização Régis Duprat (DUPRAT, 1999, p.214). 


\subsubsection{Propositio}

Depois da conclusão da Narratio numa Semicadência, pode-se examinar nessa nova parte do discurso o emprego da Synonimia ressaltando a expressão Retribue, por meio de repetição realizado pelo solo da soprano, a qual novamente narra os fatos advindos das seções anteriores, no entanto, numa argumentação sucinta, o que caracteriza uma Narratio dentro da Propositio.

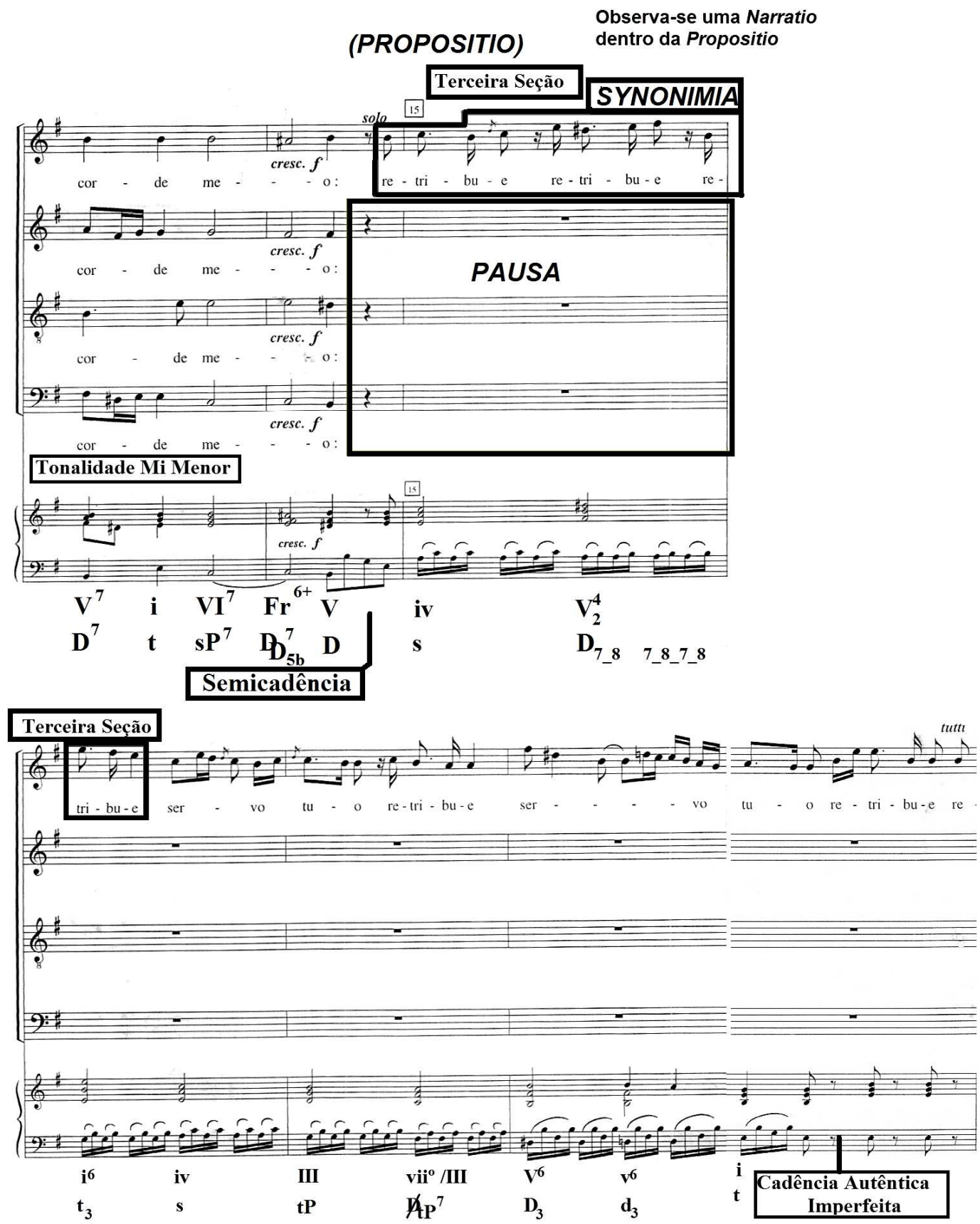

Exemplo 17: Ofertório da Missa do Domingo da Paixão de André da Silva GomesCatalogação e Organização Régis Duprat (DUPRAT, 1999, p.214). 


\subsubsection{Confutatio}

A Confutatio começa com a utilização da Anaphora, destacando as repetições da expressão retribue, no mesmo contexto, o autor apropria-se da Epizeuxis para enfatizar a prédica feita pelo salmista, o qual espera receber do Senhor o beneficio da vida Retribue servo tuo: vivam, et custodiam.

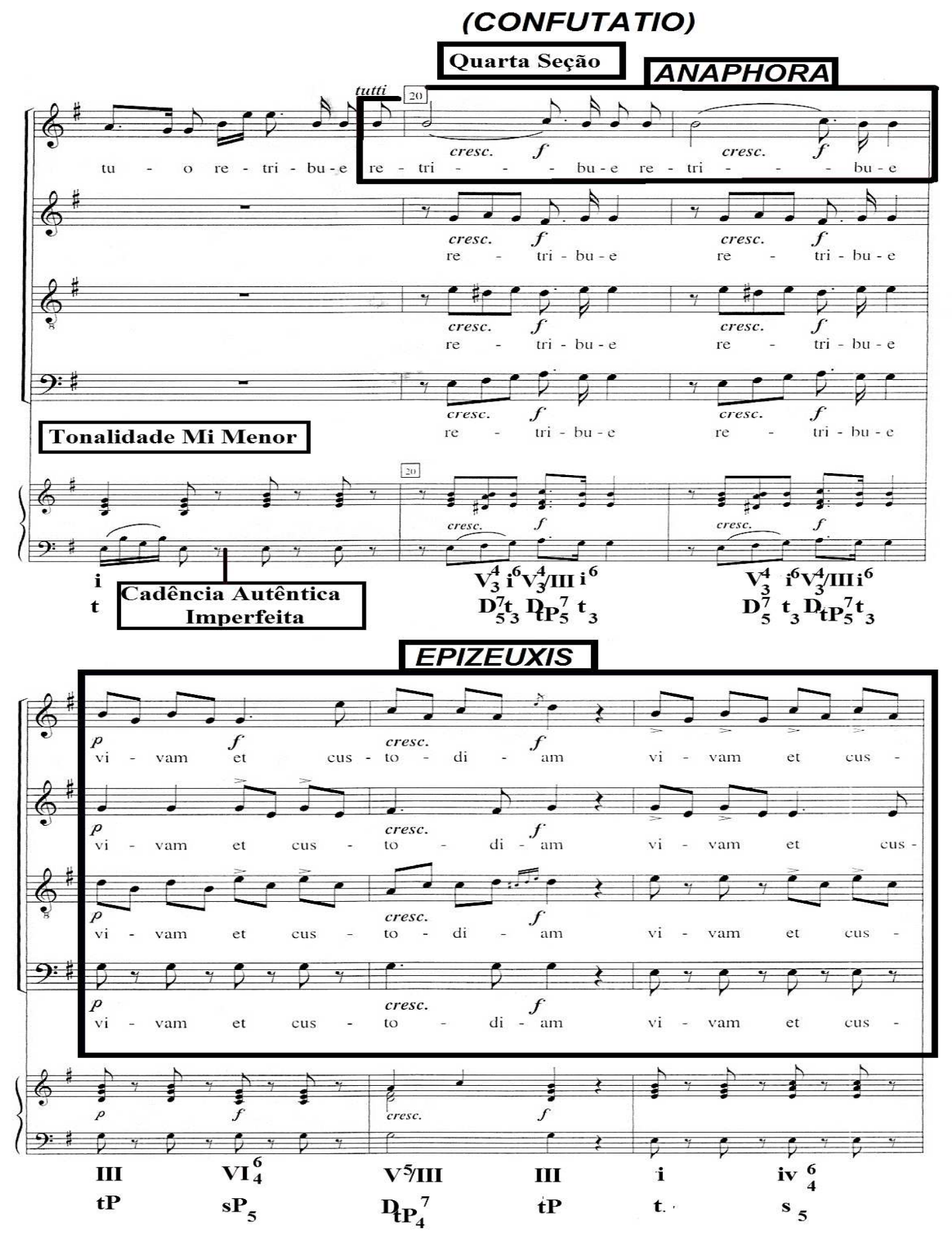

Exemplo 18: Ofertório da Missa do Domingo da Paixão de André da Silva GomesCatalogação e Organização Régis Duprat (DUPRAT, 1999, p.216). 
A caracterização tanto dos elementos de contraste, como na refutação da tese inicial se evidência através das inúmeras funções harmônicas empregas pelo compositor no presente excerto, por exemplo, a progressão dos acordes menores (Em, Dm, Cm) entre os compassos 26 a 29, a inserção de Dominantes menores e da Sexta Napolitana, dentro da tonalidade de Sol Maior e a modulação para Dó Maior, gerando maior dramaticidade e expectativa.

Enfim, Silva Gomes trabalha com figuras de silêncio e repetição, Aposiopesis, Anaphora e Pausa adaptando-as conforme a necessidade e circunstância do discurso sejam no final de cada frase, nas resoluções das Cadências ou no destaque do solo da soprano enfatizando as repetições da palavra vivifica me, com veemência.

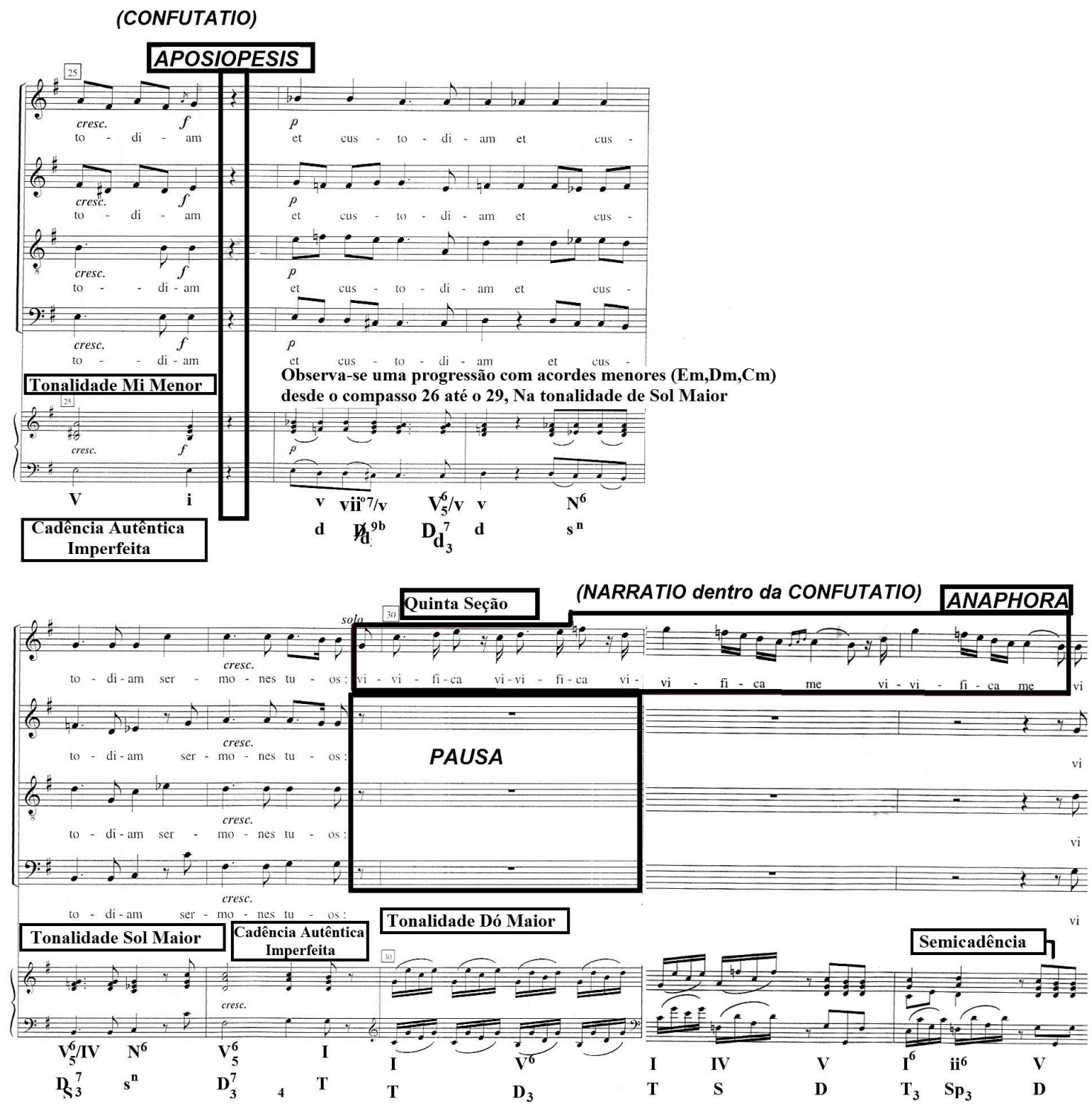

Exemplo 19: Ofertório da Missa do Domingo da Paixão de André da Silva GomesCatalogação e Organização Régis Duprat (DUPRAT, 1999, pp.217-218). 


\subsubsection{Confirmatio}

A confirmação da tese inicial é perceptível através da expressão secundum vebum tuum, ou seja, a petição pela concessão da vida eterna mediante a obediência dos estatutos bíblicos. Silva Gomes como profundo conhecedor do texto sacro e da liturgia cristã, utiliza a Epizeuxis como figura de repetição e ênfase para reforçar essa premissa, na tonalidade de Sol Menor.

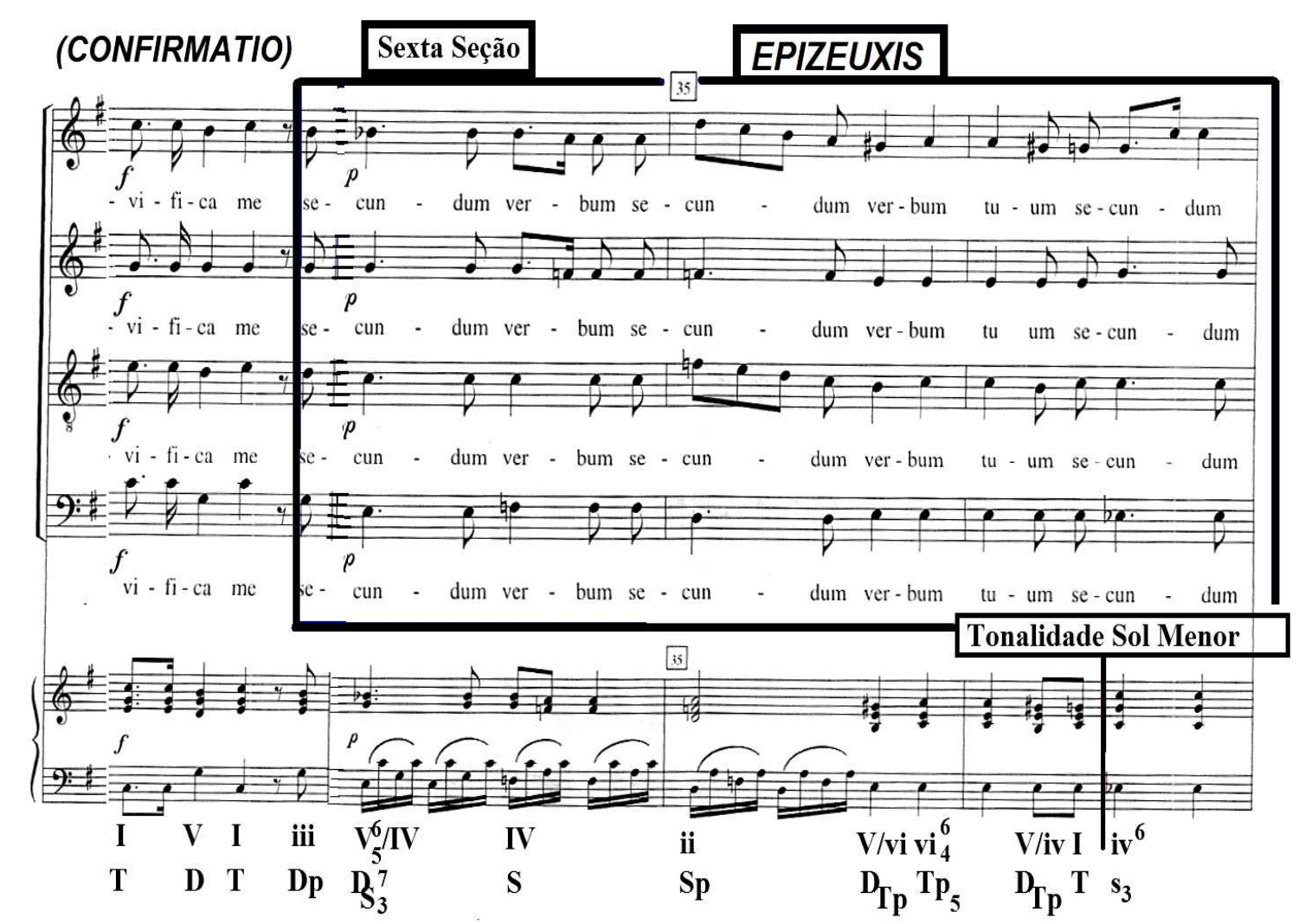

Exemplo 20: Ofertório da Missa do Domingo da Paixão de André da Silva GomesCatalogação e Organização Régis Duprat (DUPRAT, 1999, p.218).

Observa-se o uso da Gradatio, valorando as palavras e notas, por meio de repetições em forma de sequência, também, é verificável o pedal de Dominante, dando sustentação seja na voz do baixo como no acompanhamento instrumental. 


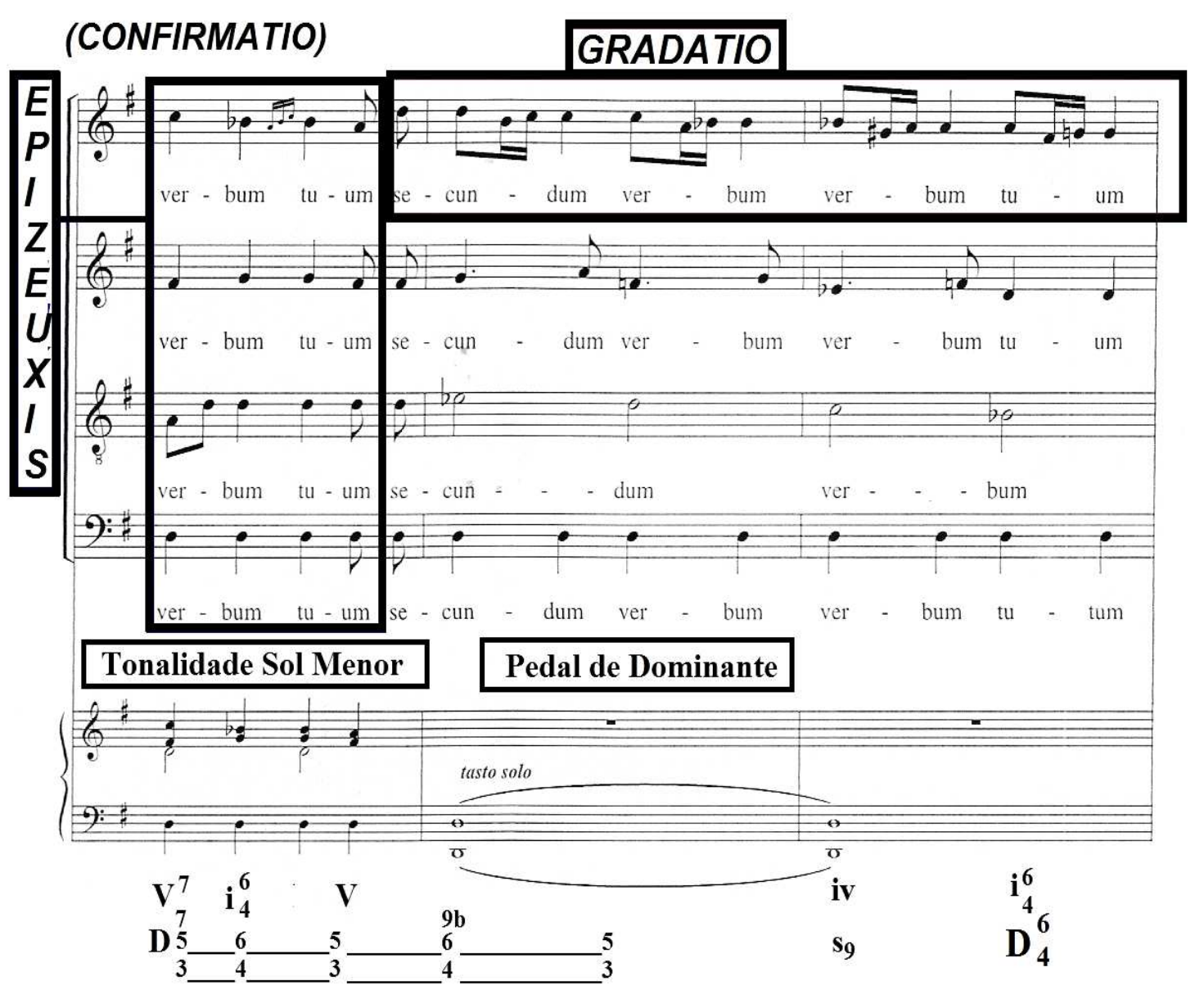

Exemplo 21: Ofertório da Missa do Domingo da Paixão de André da Silva GomesCatalogação e Organização Régis Duprat (DUPRAT, 1999, p.219).

\subsubsection{Perotatio}

Com o fechamento da Confirmatio na Cadência Autêntica Imperfeita, tem-se a conclusão do discurso numa pequena Coda de dois compassos, onde o autor sacramenta mais uma vez o pedido da oração feita em forma de louvor, através do uso da dinâmica forte representando o afeto de intensidade consubstanciada pela fé e devoção e da dinâmica pianíssimo, reproduzindo o afeto de certeza, serenidade e convicção da resposta positiva da súplica dirigida ao Senhor (Domine), somada pela aplicação da Synaeresis, a qual antecede o termino da obra no acorde de Sol Maior. 
(CONFIRMATIO)

(PEROTATIO)

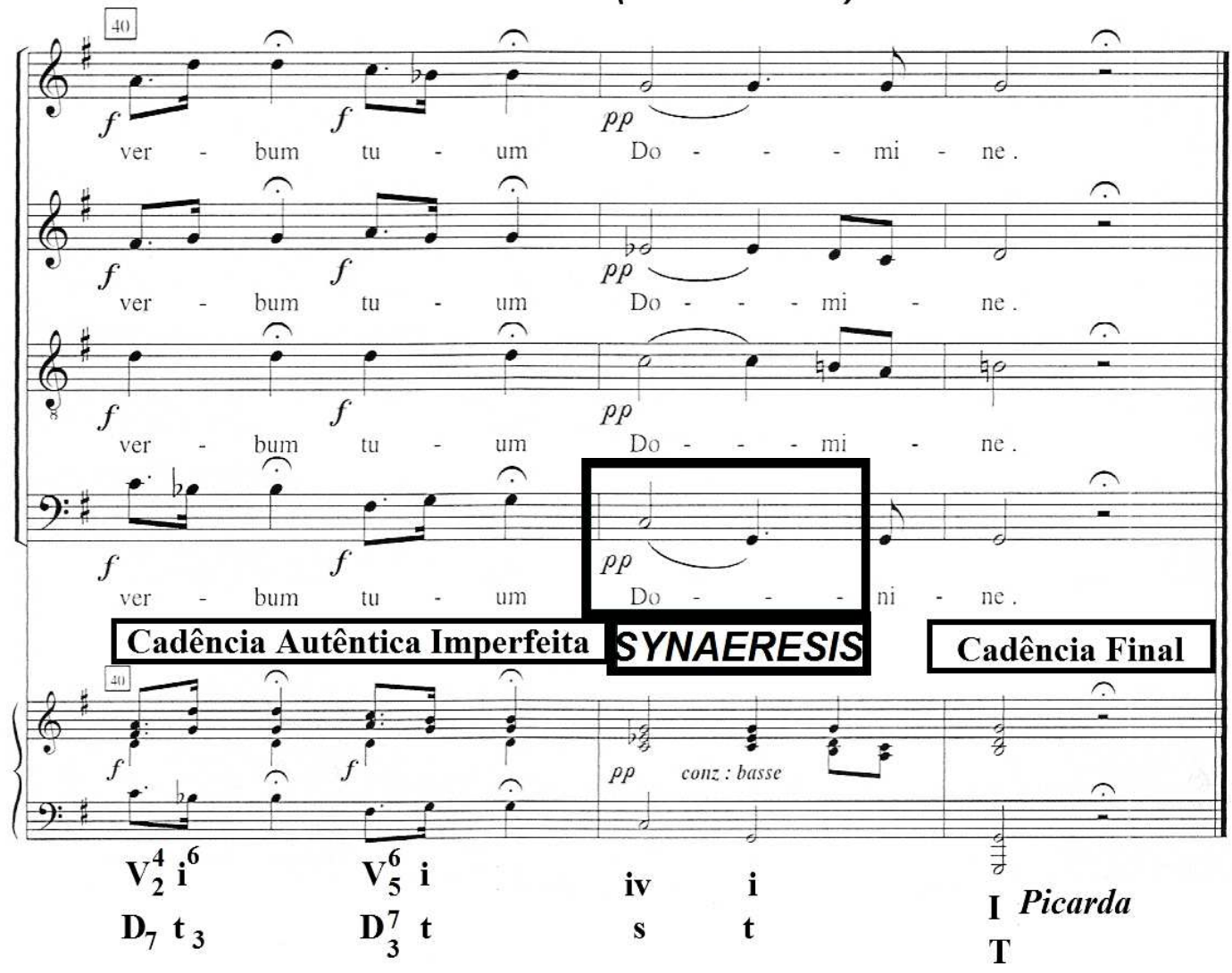

Exemplo 22: Ofertório da Missa do Domingo da Paixão de André da Silva GomesCatalogação e Organização Régis Duprat (DUPRAT, 1999, p.219).

\subsection{Figuras observadas no Ofertório (Elocutio/Decoratio)}

\begin{tabular}{|c|c|c|c|}
\hline FIGURAS & TIPO & DESCRIÇÃO & TRATADISTA \\
\hline $\begin{array}{l}\text { ANAPHORA } \\
\text { (BARTEL, } \\
\text { pp.184-190). }\end{array}$ & $\begin{array}{l}\text { Repetição } \\
\text { Melódica }\end{array}$ & $\begin{array}{l}\text { (1) É uma linha } \\
\text { do baixo repetida } \\
\text { em forma de solo. } \\
\text { (2) A repetição de } \\
\text { uma exposição } \\
\text { melódica sobre } \\
\text { notas e partes } \\
\text { diferentes. } \\
\text { Também pode } \\
\text { ocorrer no início } \\
\text { das repetições de } \\
\text { frases e motivos } \\
\text { em uma série de } \\
\text { passagens } \\
\text { sucessivas; (3) } \\
\text { Uma repetição }\end{array}$ & $\begin{array}{l}\text { Thuringus: } \\
\text { que é uma } \\
\text { Anáfora? É a } \\
\text { repetição } \\
\text { continuada } \\
\text { apenas no Baixo. } \\
\text { Walther: É uma } \\
\text { figura } \\
\text { repetição e pode } \\
\text { ocorrer de duas } \\
\text { maneiras: } \\
\text { 1. Quando uma } \\
\text { palavra é } \\
\text { repetida } \\
\text { frequentemen } \\
\text { te em uma }\end{array}$ \\
\hline
\end{tabular}




\begin{tabular}{|c|c|c|c|}
\hline & & em geral. & $\begin{array}{l}\text { composição } \\
\text { para dar } \\
\text { maior ênfase. } \\
\text { 2. Quando as } \\
\text { notas graves } \\
\text { são repetidas } \\
\text { inúmeras } \\
\text { vezes (como } \\
\text { o caso das } \\
\text { Chaconne). }\end{array}$ \\
\hline $\begin{array}{l}\text { APOSIOPESIS } \\
\text { (BARTEL, 1997, } \\
\text { pp.202-206). }\end{array}$ & $\begin{array}{l}\text { Interrupção e } \\
\text { Silêncio }\end{array}$ & $\begin{array}{l}\text { Um descanso em } \\
\text { uma ou todas as } \\
\text { vozes de uma } \\
\text { composição: } \\
\text { pausa geral. }\end{array}$ & $\begin{array}{l}\text { Walther: } \\
\text { Aposiopesis se } \\
\text { refere a uma } \\
\text { pausa generalis } \\
\text { ou um completo } \\
\text { silêncio em todas } \\
\text { as vozes e nas } \\
\text { partes r da } \\
\text { composição r } \\
\text { simultaneamente. }\end{array}$ \\
\hline $\begin{array}{l}\text { EPIZEUXIS } \\
\text { (BARTEL, 1997, } \\
\text { pp.263-265). }\end{array}$ & $\begin{array}{l}\text { Repetição } \\
\text { Melódica }\end{array}$ & $\begin{array}{l}\text { Uma repetição } \\
\text { imediata e } \\
\text { enfática de uma } \\
\text { palavra, nota, } \\
\text { motivo ou frase. }\end{array}$ & $\begin{array}{l}\text { Walther: A } \\
\text { Epizeuxis é uma } \\
\text { figura de retórica } \\
\text { pela qual uma ou } \\
\text { mais palavras } \\
\text { são } \\
\text { imediatamente e } \\
\text { enfaticamente } \\
\text { repetidas. }\end{array}$ \\
\hline $\begin{array}{l}\text { GRADATIO } \\
\text { (BARTEL, 1997, } \\
\text { pp.220-224). }\end{array}$ & $\begin{array}{l}\text { Repetição } \\
\text { Melódica }\end{array}$ & $\begin{array}{l}\text { (1) Sequência de } \\
\text { notas em uma só } \\
\text { voz repetida em } \\
\text { qualquer } \\
\text { tonalidade maior } \\
\text { ou menor, (2) } \\
\text { Duas vozes que } \\
\text { se deslocam em } \\
\text { movimento } \\
\text { ascendente ou } \\
\text { descendente } \\
\text { paralelo, (3) Um } \\
\text { aumento gradual } \\
\text { na intensidade e } \\
\text { altura do som. }\end{array}$ & $\begin{array}{l}\text { Walther: Climax } \\
\text { ou gradatio } \\
\text { podem ser } \\
\text { interpretadas } \\
\text { das seguintes } \\
\text { formas: } \\
\text { 1. Quando há } \\
\text { palavras que } \\
\text { falam sobre } \\
\text { alegria, } \\
\text { glorificação } \\
\text { louvor. } \\
2 . \quad \text { Em uma } \\
\text { figura musical } \\
\text { que ocorre } \\
\text { quando duas } \\
\text { vozes se } \\
\text { movimentam }\end{array}$ \\
\hline
\end{tabular}




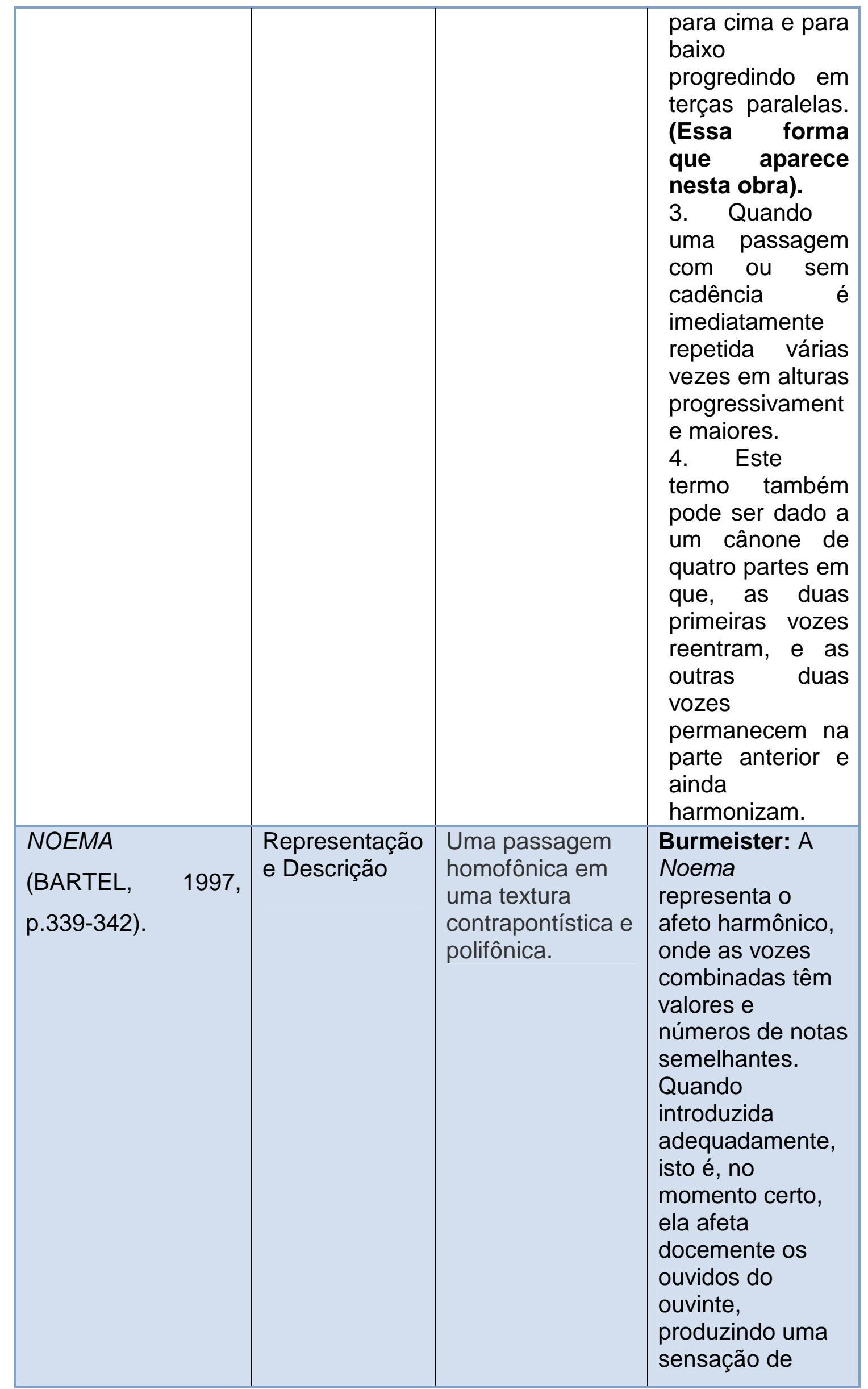




\begin{tabular}{|c|c|c|c|c|}
\hline $\begin{array}{l}\text { (BUELOW, } \\
\text { p.799). }\end{array}$ & 1980 & & & $\begin{array}{l}\text { calma e } \\
\text { serenidade. } \\
\text { Seção } \\
\text { homofônica, } \\
\text { dentro da } \\
\text { polifonia utilizada } \\
\text { para enfatizar o } \\
\text { texto. }\end{array}$ \\
\hline $\begin{array}{l}\text { PALILOGIA } \\
\text { (BARTEL, } \\
\text { pp.342-344). }\end{array}$ & 1997 & $\begin{array}{l}\text { Repetição } \\
\text { Melódica }\end{array}$ & \begin{tabular}{lr}
\multicolumn{2}{c}{ Repetição de um } \\
tema no mesmo \\
nível de altura, \\
também pode \\
ocorrer rem \\
alturas diferentes \\
na mesma ou em \\
várias vozes.
\end{tabular} & $\begin{array}{lr}\text { Burmeister: } & \text { A } \\
\text { Palilogia é uma } \\
\text { repetição de uma } \\
\text { inteiração ou } \\
\text { apenas o começo } \\
\text { da estrutura dos } \\
\text { meios e temas } \\
\text { sobre a mesma } \\
\text { altura com a a } \\
\text { mesma voz, } \\
\text { ocorrendo com } \\
\text { ou } \\
\text { intermédio sem } \\
\text { pausas em todos } \\
\text { os eventos em } \\
\text { uma voz. } \\
\text { Walther: } \\
\text { Palilogia refere- } \\
\text { se a uma } \\
\text { repetição por } \\
\text { demais frequente } \\
\text { das mesmas } \\
\text { palavras. }\end{array}$ \\
\hline $\begin{array}{l}\text { PAUSA } \\
\text { (BARTEL, } \\
\text { pp.362-365). }\end{array}$ & 1997 & $\begin{array}{l}\text { Interrupção e } \\
\text { Silêncio }\end{array}$ & $\begin{array}{lr}\text { Pausa } & \text { ou } \\
\text { descanso em } \\
\text { uma composição } \\
\text { musical }\end{array}$ & $\begin{array}{lrr}\text { Walther: } & \text { Uma } \\
\text { figura ou figuras } \\
\text { de silêncio. Estas } \\
\text { se referem à } \\
\text { Pausa. Pausa } \\
\text { refere-se a um } \\
\text { período } & & \text { de } \\
\text { repouso ou o } \\
\text { silêncio ró na } \\
\text { música, que é } \\
\text { indicado por um } \\
\text { determinado } \\
\text { sinal. }\end{array}$ \\
\hline
\end{tabular}




\begin{tabular}{|c|c|c|c|}
\hline $\begin{array}{l}\text { SYNAERESIS } \\
\text { (BARTEL, 1997, } \\
\text { pp.394-396). }\end{array}$ & $\begin{array}{l}\text { Dissonância e } \\
\text { Deslocamento }\end{array}$ & $\begin{array}{l}\text { (1) Uma } \\
\text { suspensão ou } \\
\text { síncope, (2) A } \\
\text { colocação de } \\
\text { duas sílabas por } \\
\text { nota ou duas } \\
\text { notas por sílaba. }\end{array}$ & $\begin{array}{lr}\text { Vogt: } & \text { A } \\
\text { Synaeresis } & \\
\text { ocorre quando } \\
\text { duas notas são } \\
\text { colocadas } & \text { em } \\
\text { uma sílaba ou } \\
\text { duas sílabas são } \\
\text { colocadas } & \text { em } \\
\text { uma nota. } & \end{array}$ \\
\hline $\begin{array}{l}\text { SYNONYMIA } \\
\text { (BARTEL, 1997, } \\
\text { pp.405-407). }\end{array}$ & $\begin{array}{l}\text { Repetição } \\
\text { Melódica }\end{array}$ & $\begin{array}{l}\text { É a repetição de } \\
\text { uma ideia musical } \\
\text { em forma } \\
\text { alterada ou } \\
\text { modificada. }\end{array}$ & $\begin{array}{l}\text { Walther: Um } \\
\text { compositor } \\
\text { também pode } \\
\text { empregar muito } \\
\text { bem diferentes } \\
\text { figuras retóricas } \\
\text { na elaboração de } \\
\text { um texto. Por } \\
\text { exemplo, além da } \\
\text { Epizeuxis, que é } \\
\text { a mais comum e } \\
\text { enfática, pode } \\
\text { usar, Anaphora, } \\
\text { Synonimia, } \\
\text { Epistrophe, } \\
\text { Epanalepsis e } \\
\text { assim por diante. }\end{array}$ \\
\hline
\end{tabular}

Tabela 9: Figuras Retóricas encontradas no Ofertório da Missa do Domingo da Paixão de André da Silva Gomes

\section{Análise Harmônica}

\subsection{Curva Tonal}

Tonalidade: Sol Maior

Andamento: Grave 4/4

Esquema das Progressões Harmônicas

\begin{tabular}{|l|c|l|}
\hline Compassos & $\begin{array}{l}\text { Função em relação a } \\
\text { tonalidade principal }\end{array}$ & Tonalidade (Acorde) \\
\hline $1-6$ & T-I & Sol Maior \\
\hline $7-11$ & Tp-vi & Mi Menor \\
\hline 11 & Sp-ii & Lá Menor \\
\hline $12-13$ & Tp-vi & Mi Menor \\
\hline $13-14$ & $\mathrm{D} / \mathrm{Tp}-\mathrm{V} / \mathrm{vi}$ & Si Maior \\
\hline
\end{tabular}




\begin{tabular}{|l|c|l|}
\hline $15-16$ & Tp-vi & Mi Menor \\
\hline 17 & T-I & Sol Maior \\
\hline $18-21$ & Tp-vi & Mi Menor \\
\hline $22-23$ & S-IV & Dó Maior \\
\hline $24-25$ & Tp-vi & Mi Menor \\
\hline $26-27$ & d-v & Ré Menor \\
\hline $27-29$ & N6/sn & Dó Menor \\
& Menor) & \\
\hline $30-33$ & S-IV & Dó Maior \\
\hline 34 & S/S- IV/IV & Fá Maior \\
\hline 35 & Sp-ii & Lá Menor \\
\hline $36-37$ & D-V & Ré Maior \\
\hline $38-41$ & t-i (Tonalidade Homônima) & Sol Menor \\
\hline 42 & T-I & Sol Maior \\
\hline
\end{tabular}

Tabela 10: Curva Tonal do Ofertório da Missa do Domingo da Paixão

Números de compassos: 42

Regiões abordadas: 10

Variações: 18

Ritmo Harmônico: 2,33 (divisão dos números de compassos e variações)

Média ideal: (divisão dos números de compassos e regiões tonais abordadas $=4,2)$

Esquema Formal

(1-6) (7-25) (26-29) (30-36) (36-41) (42)

$\begin{array}{llllll}\mathrm{T} & \mathrm{Tp} & \mathrm{T} & \mathrm{S} & \mathrm{t} & \mathrm{T}\end{array}$

l vi l vi $\quad$ i $\quad$ l 
2.2. Estrutura Analítica do Ofertório: Retórica e Harmônica

\begin{tabular}{|c|c|c|c|c|c|}
\hline $\begin{array}{l}\text { RETÓRICA } \\
\text { DISPOSITIO }\end{array}$ & $\begin{array}{l}\text { FIGURA } \\
\text { ELOCUTIO }\end{array}$ & COMP. & $\begin{array}{l}\text { HARMÔNICA } \\
\text { SEÇÃO }\end{array}$ & TONALIDADE & FUNÇĀO \\
\hline EXORDIUM & $\begin{array}{l}\text { Synonimia } \\
\text { Palilogia } \\
\text { Pausa }\end{array}$ & $\begin{array}{l}1-2 \\
2-4 \\
1-4\end{array}$ & $\begin{array}{l}\text { 1ª Seção } \\
\text { 1ª Seção } \\
1^{\text {a Seção }}\end{array}$ & $\begin{array}{l}\text { Sol Maior } \\
\text { Sol Maior } \\
\text { Sol Maior }\end{array}$ & $\begin{array}{l}\text { T-I } \\
T-I \\
T-I\end{array}$ \\
\hline NARRATIO & $\begin{array}{l}\text { Anaphora } \\
\text { Auxesis } \\
\text { Gradatio }\end{array}$ & $\begin{array}{l}5-6 \\
7-9 \\
10-12\end{array}$ & $\begin{array}{l}2^{\text {a }} \text { Seção } \\
2^{\text {a }} \text { Seção } \\
2^{2} \text { Seção }\end{array}$ & $\begin{array}{l}\text { Sol Maior } \\
\text { Mi Menor } \\
\text { Mi Menor }\end{array}$ & $\begin{array}{l}\text { T-I } \\
\text { Tp-vi } \\
\text { Tp-vi }\end{array}$ \\
\hline PROPOSITIO & $\begin{array}{l}\text { Synonimia } \\
\text { Pausa }\end{array}$ & $\begin{array}{l}14-16 \\
14-19\end{array}$ & $\begin{array}{l}\text { 3a Seção } \\
\text { 3a Seção }\end{array}$ & $\begin{array}{l}\text { Mi Menor } \\
\text { Mi Menor }\end{array}$ & $\begin{array}{l}\text { Tp-vi } \\
\text { Tp-vi }\end{array}$ \\
\hline CONFUTATIO & $\begin{array}{l}\text { Anaphora } \\
\text { Epizeuxis } \\
\text { Aposiopesis } \\
\text { Pausa }\end{array}$ & $\begin{array}{l}19-21 \\
\text { e } 29-32 \\
22-24 \\
25 \\
29-32\end{array}$ & $\begin{array}{l}4^{\text {a }} \text { Seção } \\
5^{\text {a }} \text { Seção } \\
4^{\text {a }} \text { Seção } \\
4^{\text {a }} \text { Seção } \\
5^{\text {a Seção }}\end{array}$ & $\begin{array}{l}\text { Mi Menor } \\
\text { Dó Maior } \\
\text { Mi Menor } \\
\text { Mi Menor } \\
\text { Dó Maior }\end{array}$ & $\begin{array}{l}\text { Tp-vi } \\
\text { S-IV } \\
\text { Tp-vi } \\
\text { Tp-vi } \\
\text { S-IV }\end{array}$ \\
\hline CONFIRMATIO & $\begin{array}{l}\text { Epizeuxis } \\
\text { Gradatio }\end{array}$ & $\begin{array}{l}33-37 \\
37-39\end{array}$ & $\begin{array}{l}\text { 6 Seção } \\
\text { 6" Seção }\end{array}$ & $\begin{array}{l}\text { Sol Menor } \\
\text { Sol Menor }\end{array}$ & $\begin{array}{c}t-i \\
(\text { Homo }) \\
t-i \\
(\text { Homo) }\end{array}$ \\
\hline PEROTATIO & Synaeresis & 41 & 6 Seção & Sol Menor & $\begin{array}{c}\mathrm{t}-\mathrm{i} \\
\text { (Homo) }\end{array}$ \\
\hline
\end{tabular}

Tabela 11: Estrutura analítica do Ofertório 


\title{
5.2.3. Ofertório da Missa de Domingo de Ramos
}

\section{Estudo Semântico}

\subsection{Inventio}

O Ofertório da Missa de Domingo de Ramos foi escrito a partir do texto do Salmo (Ps. 68,21-22/69, 21-22). - "A Oração de um justo em extrema aflição pela causa de Deus".

\author{
Improperium expectavit cor meum et miseriam \\ Et sustinui qui simulmecum \\ Contristaretur et non fuit. \\ Consolantem me quaesivit et non in veni \\ Et dederunt in escam meam fel \\ Et in mea protaverunt me aceto.
}

A injuria partiu-me o coração, e desfaleci;

Esperei quem de mim se compadecesse

E ninguém houve

Quem me consolasse, e não me encontrei.

E no meu alimento puseram fel,

$\mathrm{Na}$ minha sede deram-me beber vinagre.

(SOARES, 2000, p.41).

Esta oração de Davi retrata uma série de humilhações, semelhantes às sofridas pelo próprio Cristo ${ }^{97}$. Nesta longa descrição dos terríveis sofrimentos de um justo também revela a dor do Salvador ao sofrer perseguições pelos ímpios, ou seja, a agonia da cruz. Do mesmo modo, o Domingo de Ramos apresenta em sua liturgia, uma reflexão para que os fiéis creiam nos acontecimentos da paixão, morte e ressurreição de Jesus, isto é, crer no mistério central da fé cristã: em que a vida vence a morte e o mal e por fim, a vida eterna.

\footnotetext{
${ }^{97}$ Era desprezado e o mais indigno entre os homens, homem de dores, experimentado nos trabalhos e, como um de quem os homens escondiam o rosto, era desprezado, e não fizemos dele caso algum. Verdadeiramente, ele tomou sobre si as nossas enfermidades e as nossas dores levou sobre si; e nós o repudiamos por aflito, ferido de Deus e oprimido. Mas ele foi ferido pelas nossas transgressões e moído pelas nossas iniquidades; o castigo que noz traz a paz estava sobre ele, e pelas suas pisaduras, fomos sarados. (Isaías 53, 3 a 5). E logo um deles, correndo, tomou uma esponja, e embebeu-a em vinagre, e, pondo-a numa cana, davaIhe de beber (Mateus 27,48).
} 
Dos ofertórios compostos pelo compositor luso-brasileiro, esse é o que tem o texto mais longo, composto em sessenta e sete compassos, num Andante em Lá Menor, onde cada elemento e figura retórica são inseridos detalhadamente e com cuidado. Em síntese veremos por meio das análises retóricas, harmônicas e motívicas a habilidade de André da Silva Gomes na aplicação das fases retóricas onde cada afeto é trabalhado e moldado, despertando e movendo o ouvinte.

\subsection{Locus observados na Inventio do Ofertório}

\begin{tabular}{|c|c|c|c|}
\hline INVENTIO & DESCRIÇÃO & $\begin{array}{c}\text { UTILIZAÇÃO NA } \\
\text { OBRA }\end{array}$ & $\begin{array}{l}\text { COMPASSO/ } \\
\text { VOZ }\end{array}$ \\
\hline $\begin{array}{l}\text { Locus } \\
\text { Notationis } \\
\text { (MATTHESON, } \\
\text { [1739],1954, } \\
\text { Parte II,Cap.4, } \\
\text { § 23,p.123). }\end{array}$ & $\begin{array}{l}\text { Aspecto externo } \\
\text { e desenho das } \\
\text { notas (Duração } \\
\text { das notas, } \\
\text { alteração, } \\
\text { repetição e } \\
\text { procedimentos } \\
\text { canônicos). }\end{array}$ & $\begin{array}{l}\text { Vários motivos } \\
\text { rítmicos e diferentes } \\
\text { durações de notas } \\
\text { (semibreves, } \\
\text { mínimas, mínimas } \\
\text { pontuadas, } \\
\text { semínimas, colcheias, } \\
\text { repetições, ligaduras, } \\
\text { pausas, fermata entre } \\
\text { outros). }\end{array}$ & $\begin{array}{l}1-15 \text { S-A-T-B } \\
20-29 \text { S-A-T-B } \\
30-36 \text { S-A-T-B } \\
36-47 \text { S-A-T-B } \\
48-56 \text { S-A-T-B } \\
56-67 \text { S-A-T-B }\end{array}$ \\
\hline $\begin{array}{l}\text { Locus } \\
\text { Oppositorum } \\
\text { (MATTHESON, } \\
\text { [1739],1954, } \\
\text { Parte II,Cap.4, } \\
\text { § 80,p.131). }\end{array}$ & $\begin{array}{l}\text { Contraste de } \\
\text { compassos, } \\
\text { movimentos } \\
\text { contrários, } \\
\text { agudos e } \\
\text { graves, lento e } \\
\text { rápido, calmo e } \\
\text { agitado. }\end{array}$ & $\begin{array}{l}\text { Movimento contrário } \\
\text { entre soprano e baixo. } \\
\text { Também entre } \\
\text { soprano e contralto }\end{array}$ & $\begin{array}{l}1-2 \text { S-B } \\
5-6 \text { S-B } \\
7 \text { S-A } \\
10-11 \text { S-B } \\
15 \text { S-B } \\
22 \text { S-B } \\
40-41 \text { S-B } \\
51 \text { S-B }\end{array}$ \\
\hline $\begin{array}{l}\text { Locus } \\
\text { Descriptionis } \\
\text { (MATTHESON, } \\
\text { [1739],1954, } \\
\text { Parte II,Cap.4, } \\
\text { § 43,p.127). }\end{array}$ & $\begin{array}{l}\text { Disposições da } \\
\text { alma }\end{array}$ & $\begin{array}{l}\text { Tristeza, Angústia (A } \\
\text { injúria partiu-me o } \\
\text { coração, e desfaleci. } \\
\text { Ansiedade, } \\
\text { Expectativa (Esperei } \\
\text { quem de mim se } \\
\text { compadecesse e } \\
\text { ninguém houve, quem } \\
\text { me consolasse, e não } \\
\text { encontrei). }\end{array}$ & $\begin{array}{l}\text { 1-17 S-A-T-B } \\
17-46 \text { S-A-T-B }\end{array}$ \\
\hline
\end{tabular}




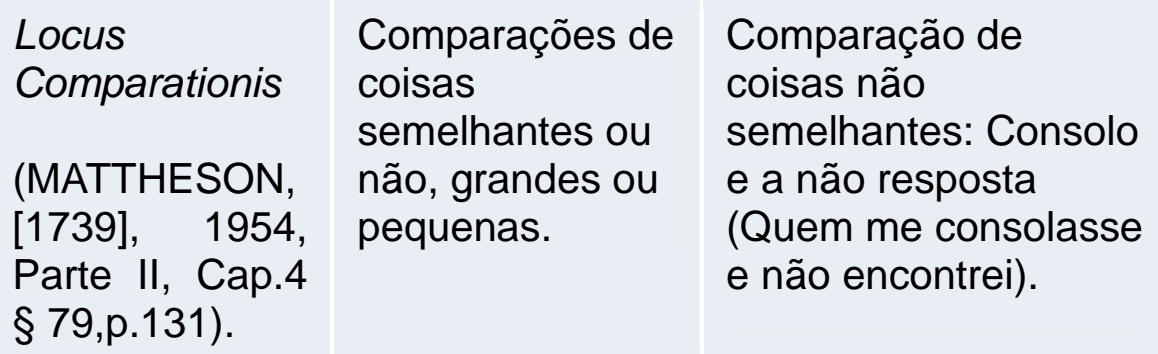

Tabela 12: Locus Topici encontrados no Ofertório da Missa de Domingo de Ramos de André da Silva Gomes

\subsection{Dispositio}

\subsubsection{Exordium}

O Exordium é exposto, nos cinco primeiros compassos, onde as notas e vozes iniciais caracterizam uma tristeza de quem fora injustiçado e humilhado através da expressão Improperium. No primeiro compasso observa-se 0 emprego da Noema pelo compositor, ressaltando a dor e a angústia do salmista, da mesma forma, o autor reitera este estado de espírito através da passagem homofônica na Tônica e Dominante. Outra figura utilizada pelo o autor é a Synaeresis na voz da soprano e contralto cantando duas notas na mesma silaba, ou seja, destacando a passagem da Dominante e também as notas longas. Paralelamente o uso da Aposiopesis no compasso 4, gera expectativa maior pelo fato do silêncio imposto a todas as vozes. 


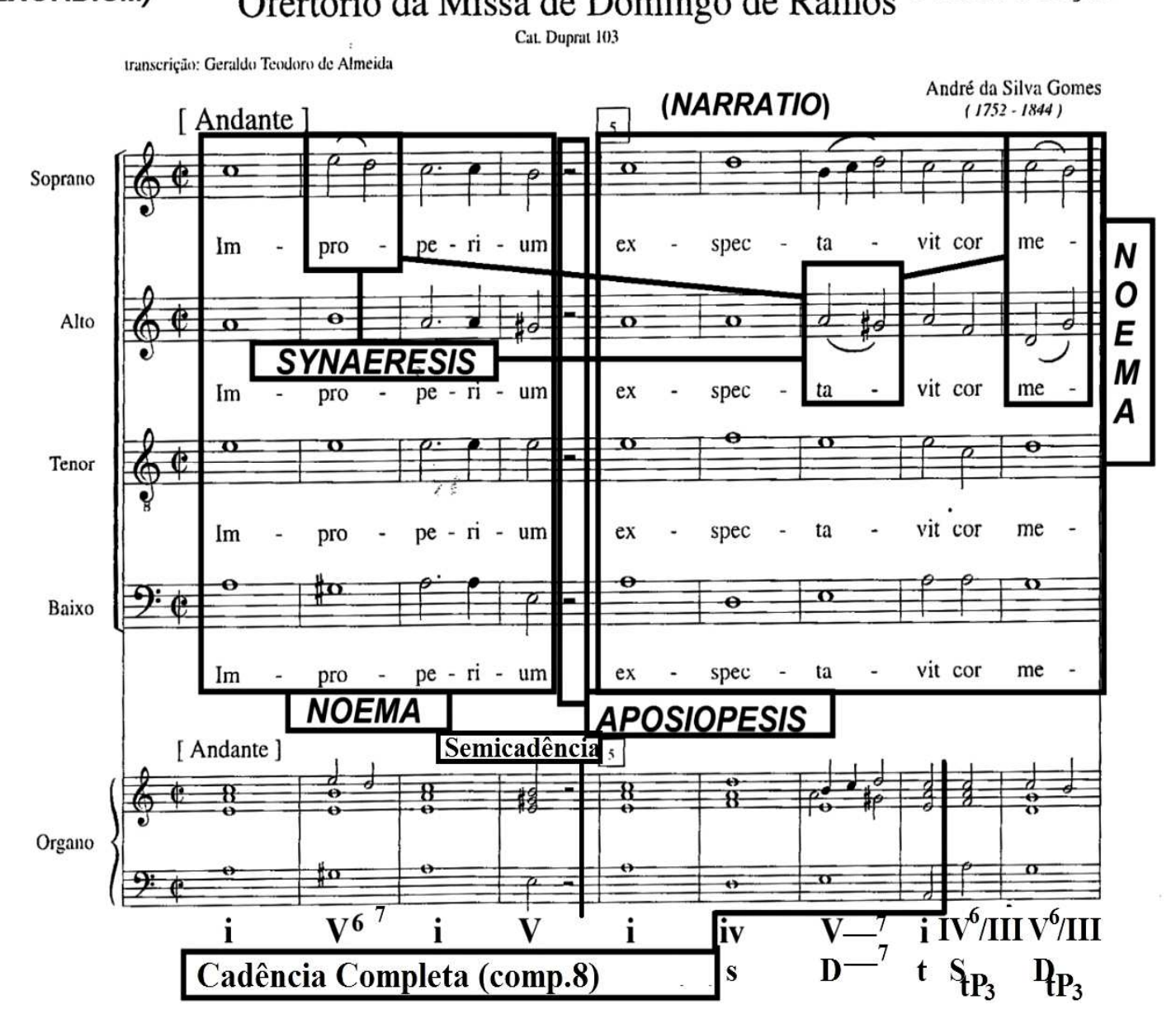

Exemplo 23: Ofertório da Missa de Domingo de Ramos de André da Silva GomesCatalogação e Organização Régis Duprat (DUPRAT, 1999, p.179).

\subsubsection{Narratio}

A figura da Noema ainda é utilizada pelo autor como transição da Narratio para a Propositio, a partir do compasso 10, mantendo sua função homofônica e, ao mesmo tempo provocando um efeito de suavidade devido ao confronto entre a polifonia vocal e a harmonia vertical do instrumento. Semelhantemente, o compositor aplica a Synaeresis reforçando a expressão das frases. A Narratio ainda está na primeira seção da obra onde ocorrem alternâncias entre Tônica e na região da Dominante, culminando com uma terminação na Tônica Relativa (Dó Maior). 


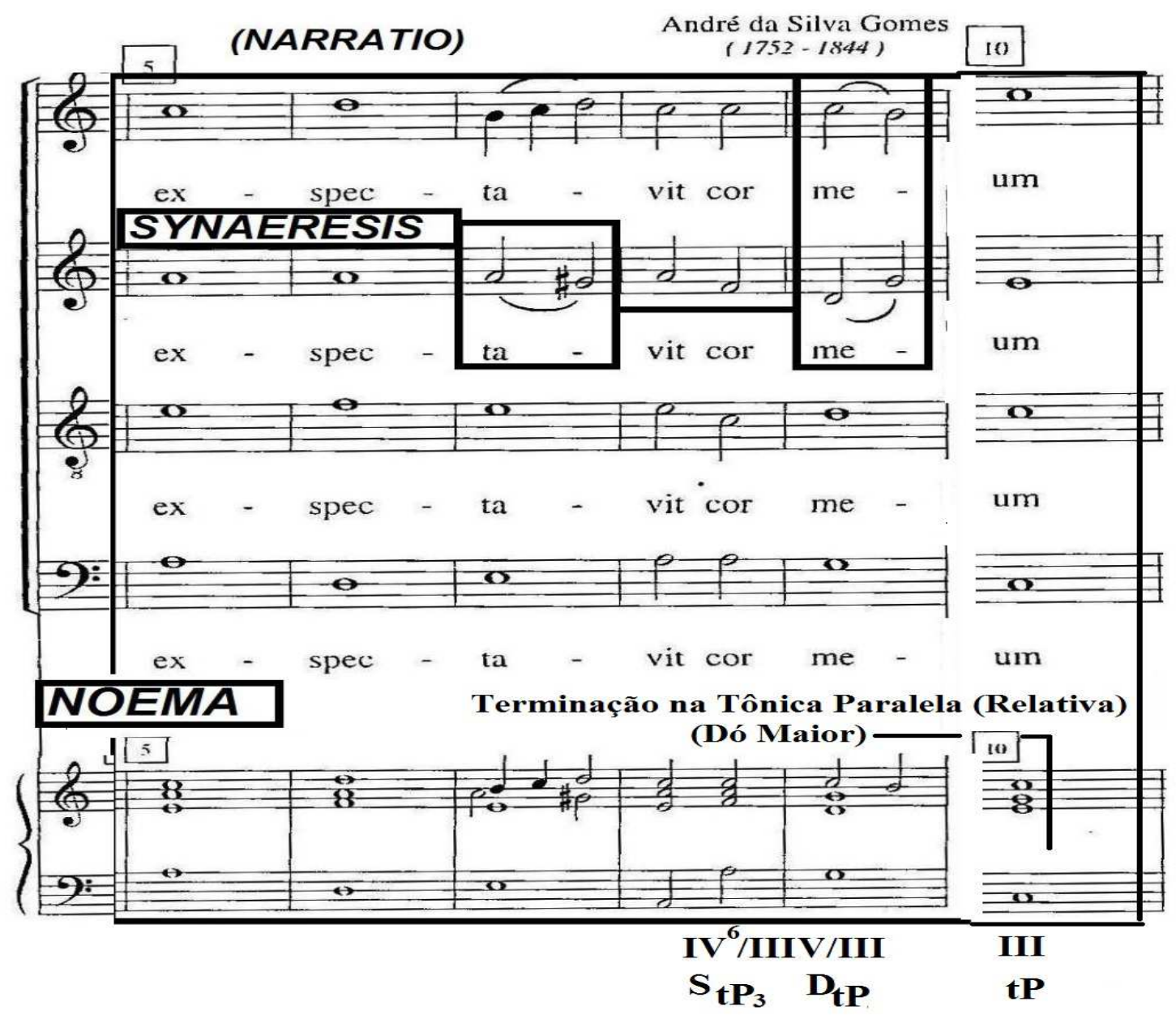

Exemplo 24: Ofertório da Missa de Domingo de Ramos de André da Silva GomesCatalogação e Organização Régis Duprat (DUPRAT, 1999, p.179).

\subsubsection{Propositio}

A manifestação de tristeza e angústia é evidenciada pela continuidade de elementos retóricos como a Noema, Synaeresis e por novas figuras tais como: Passus Duriusculus, a partir do compasso 18, com alteração cromática da linha melódica na voz da soprano, e no compasso 22 na voz da contralto (exemplos 25 e 26 ) e a Epizeuxis tornando mais intensa a palavra "Et Sustiui" (esperar), corroborando com o apelo de humilhação feita pelo salmista que faz uma prece pedindo por compaixão, sem haver, contudo, ninguém que o ajudasse. Esta figura afeta a harmonia através da dissonância, representada por intervalos cromáticos, enfatizando ainda mais os sentimentos de decepção e dor, através das notas Lá e Sol \# culminando na Dominante Mi Maior e também a nota Ré que, ligada, forma uma Syncope, antecipando a dissonância 
e tensão, se transformando num acorde de sétima, que, anteriormente, era consonante, ou seja, ao mesmo tempo é inserida uma escrita contrapontística que atrela a dois novos procedimentos musicais: a dissonância preparada e o prolongamento da escrita pela harmonia sequencial. A Propositio termina no mesmo compasso, já na terceira seção da música com uma Cadência Autêntica Perfeita na tonalidade de Dó Maior.

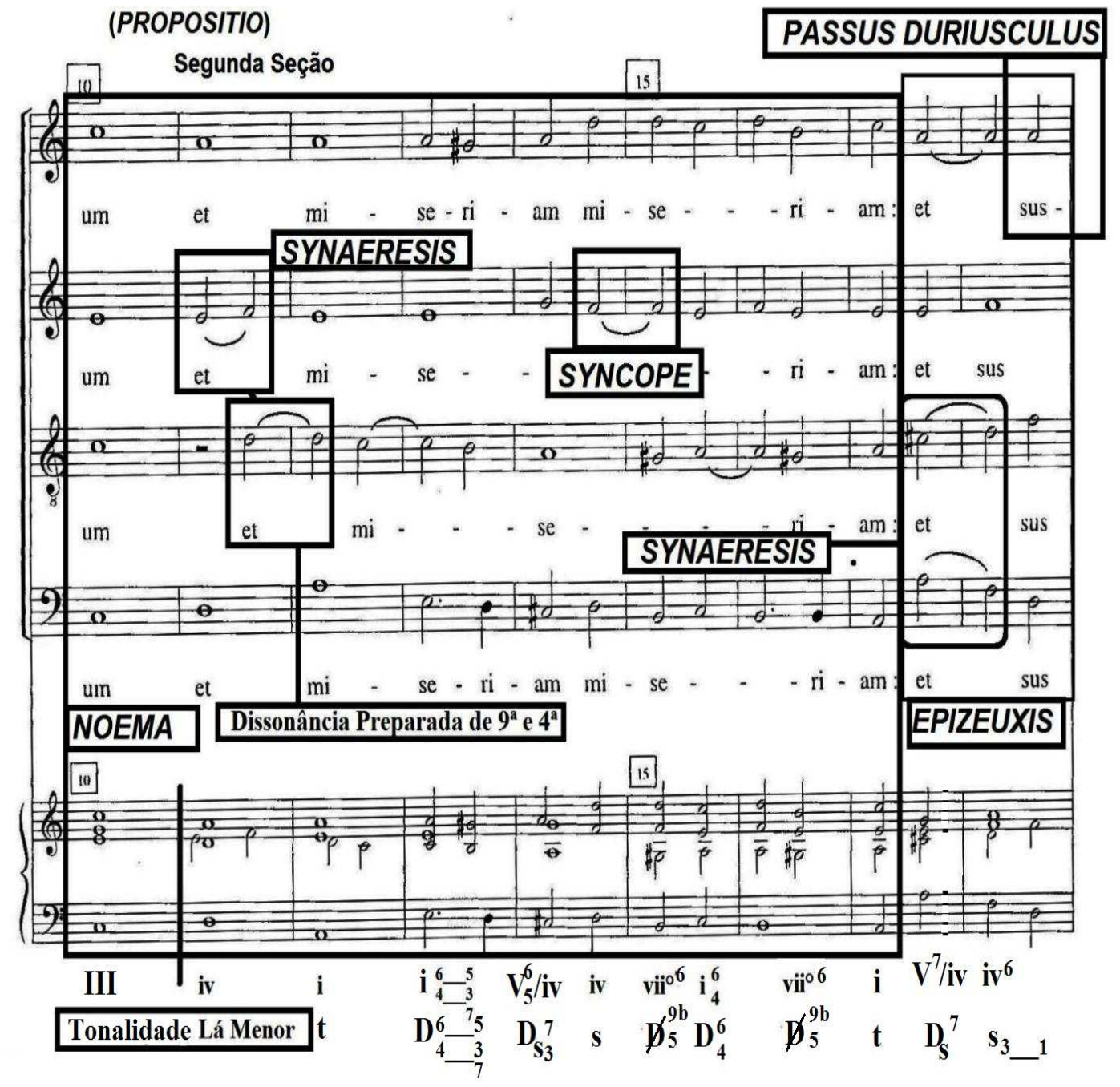

Exemplo 25: Ofertório da Missa de Domingo de Ramos de André da Silva GomesCatalogação e Organização Régis Duprat (DUPRAT, 1999, p.179). 


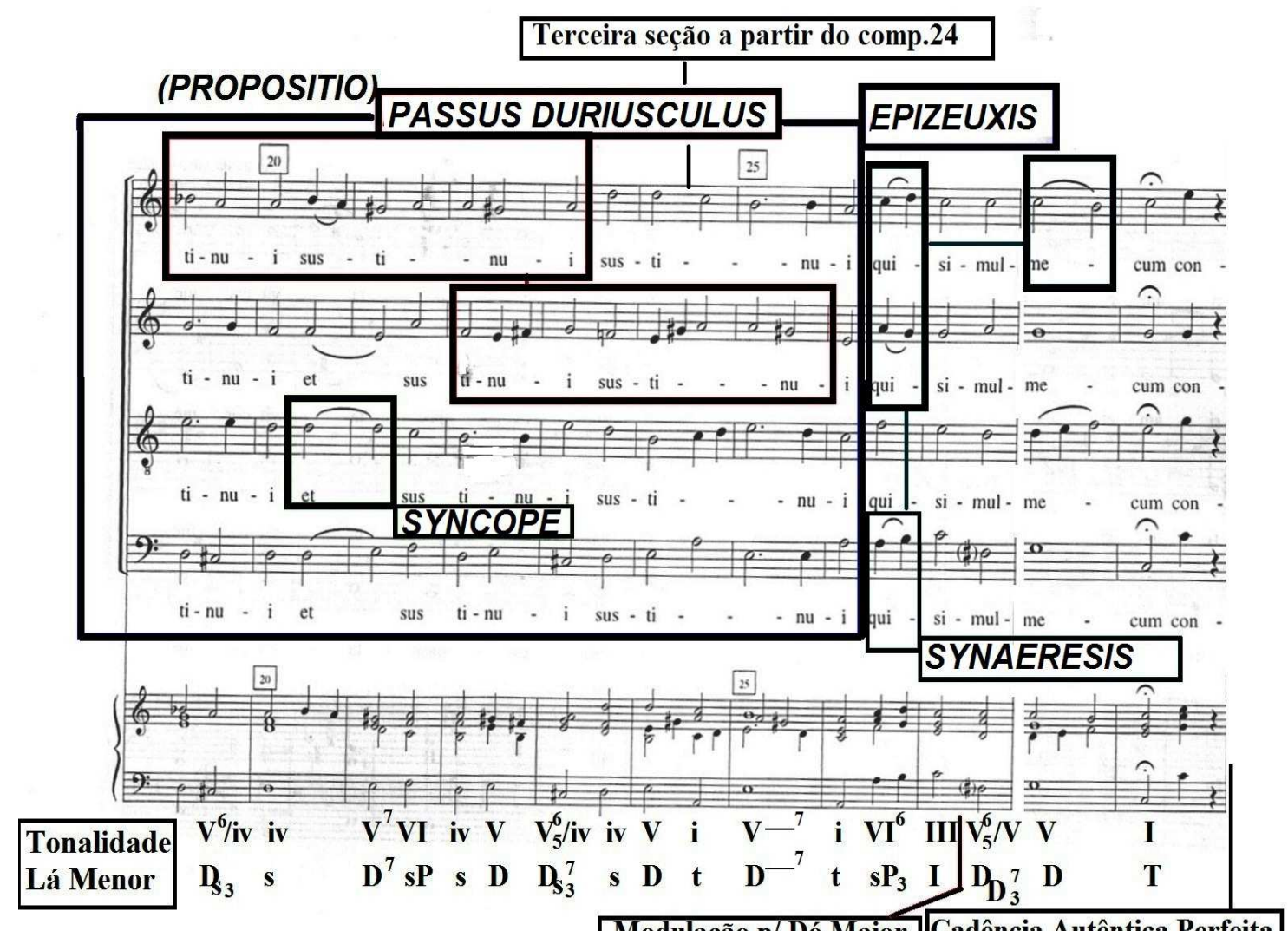

Exemplo 26: Ofertório da Missa de Domingo de Ramos de André da Silva GomesCatalogação e Organização Régis Duprat (DUPRAT, 1999, p.180).

\subsubsection{Confutatio}

Nessa parte da Dispositio são inseridos novos e contrastantes elementos, a partir do compasso 29 na terceira seção, onde as objeções e refutações são clarificadas, ou seja, há uma oposição das ideias musicais até então expostas, todavia, o discurso se mantém coerente e com seu curso natural. A Suspiratio é empregada pelo compositor no compasso 29 reforçando essa ideia de contraste e contestação, onde a expressão Contristaretur (mágoa, tristeza) é enfatizada com suspiros gerados pelas pausas entre as notas, resultando em uma alteração na articulação vocal de todas as vozes, inclusive no acompanhamento instrumental. Igualmente há uma reflexão no estado emocional decorrente da situação apresentada na introdução do salmo, em que a mágoa provoca injustiça. Além disso, o autor acentua ainda mais esta enorme carga afetiva modulando da tonalidade de Dó Maior para Lá Menor, no compasso 32. 


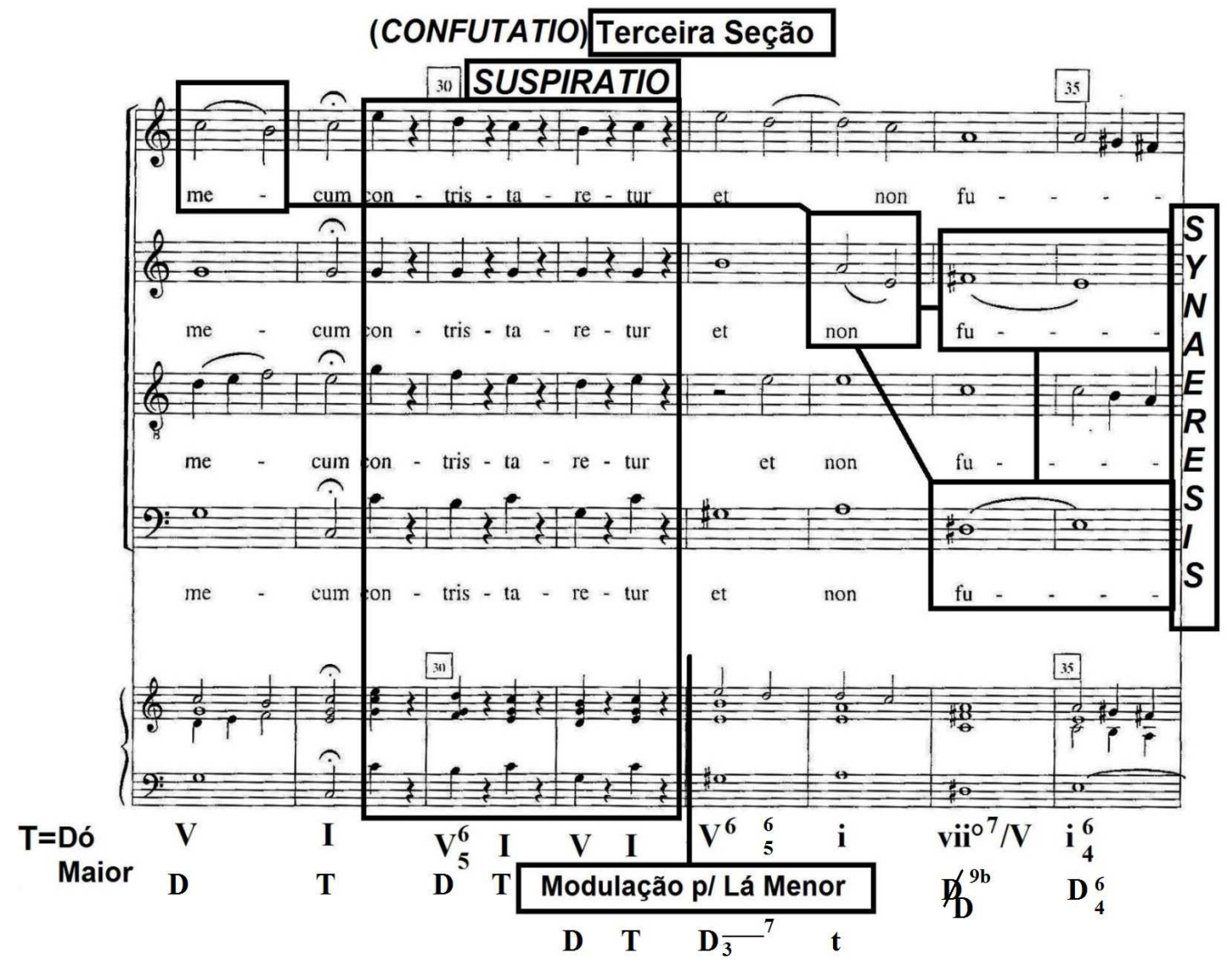

Exemplo 27: Ofertório da Missa de Domingo de Ramos de André da Silva GomesCatalogação e Organização Régis Duprat (DUPRAT, 1999, p.180).

O compositor trabalha com a expectativa do ouvinte dando continuidade às modulações, como as ocorridas no compasso 37 e 41 de Dó Maior para fá Maior, percorrendo regiões da Tônica, Tônica Paralela, Subdominante e Dominante e Dominante Paralela. Nesse excerto musical são inseridas figuras já utilizadas anteriormente, como a Noema e a Synaeresis, além de uma nova, Anticipatio onde uma nota na voz do tenor (Ré) pertencente também ao acorde posterior é introduzida antecipadamente dentro da Dominante de Dó Maior no compasso 39 e 40. Da mesma forma, o valor da nota subsequente (Dó) no compasso 40 é subtraído para possa ser adicionado o dobro da mesma à próxima nota. 
(CONFIRMATIO)

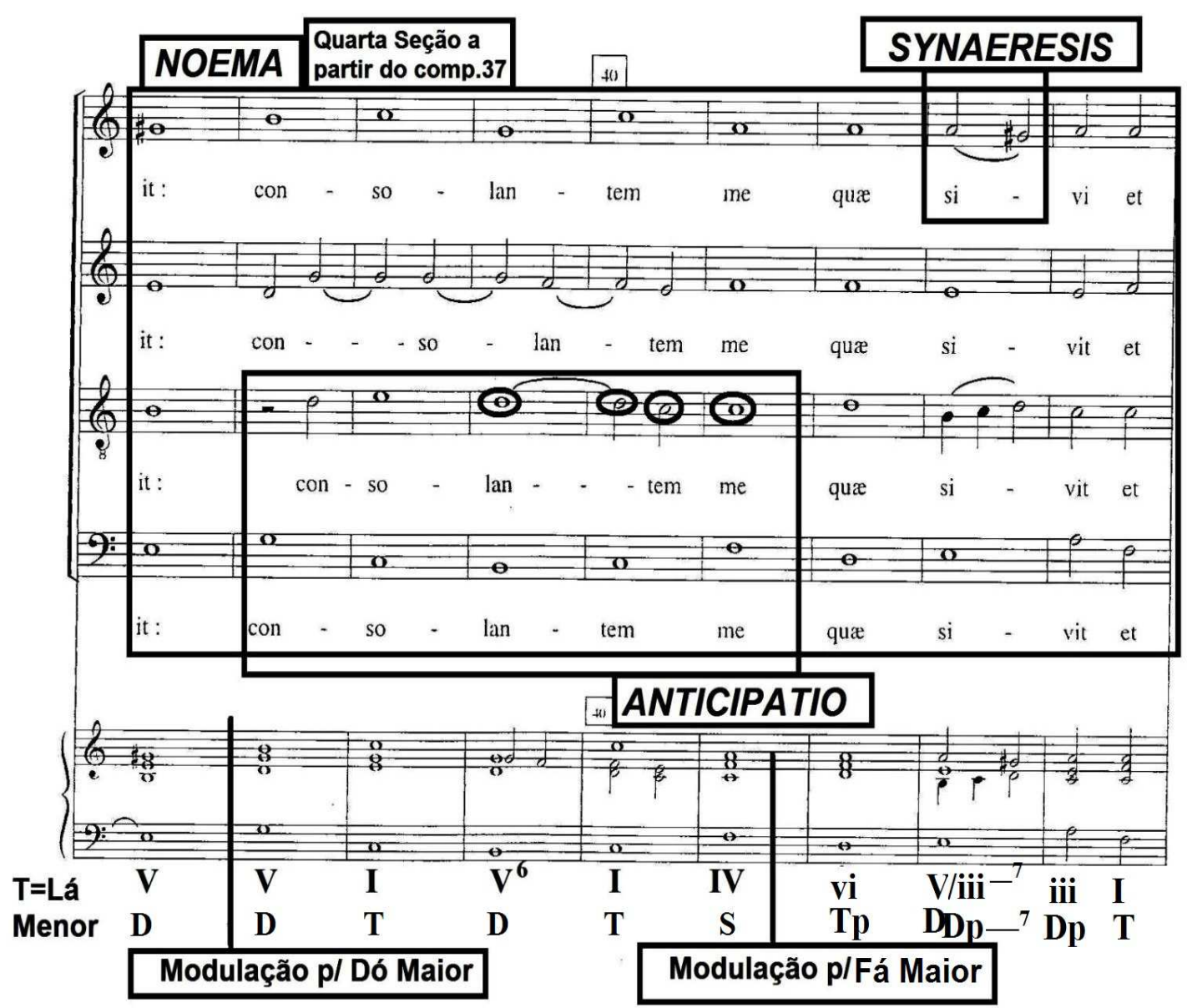

Exemplo 28: Ofertório da Missa de Domingo de Ramos de André da Silva GomesCatalogação e Organização Régis Duprat (DUPRAT, 1999, p.181).

\subsubsection{Confirmatio:}

A Confirmatio inicia-se na quarta seção no compasso 48 , ao mesmo tempo, observa-se a reiteração dos elementos iniciais aplicados deste o início do ofertório como, repetições dos motivos rítmicos e a enfatização das palavras pelas vozes, confirmando a tese principal.

No trecho a seguir, o autor continua com o emprego da Synaeresis reiterando o estado de angústia através da expressão: et non in veni (e não encontrei) também nas palavras: et dederunt in escam (e no meu alimento), assim corroborando na confirmação do texto salmódico. Outro aspecto relevante são as modulações ocorrentes de Fá Maior e desta para Dó Maior, em um espaço de apenas seis compassos. 


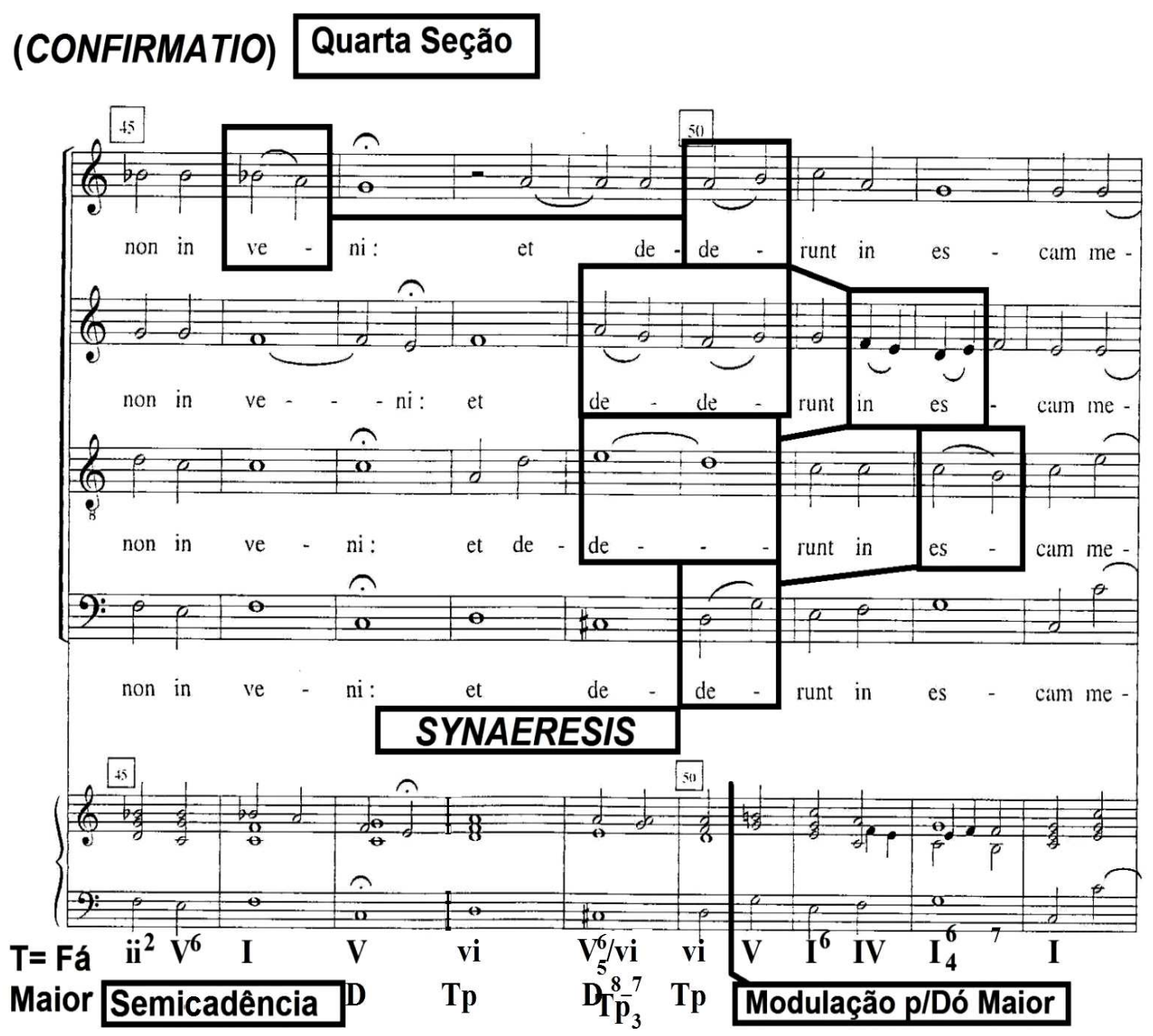

Exemplo 29: Ofertório da Missa de Domingo de Ramos de André da Silva GomesCatalogação e Organização Régis Duprat (DUPRAT, 1999, p.181).

Tanto a Confirmatio quanto a quarta seção se encerram no compasso 56 na tonalidade de Dó Maior, ao mesmo tempo, é aplicada a Aposiopesis onde é produzido um grande grau de expectativa através do silencio imposto a todas as vozes. 


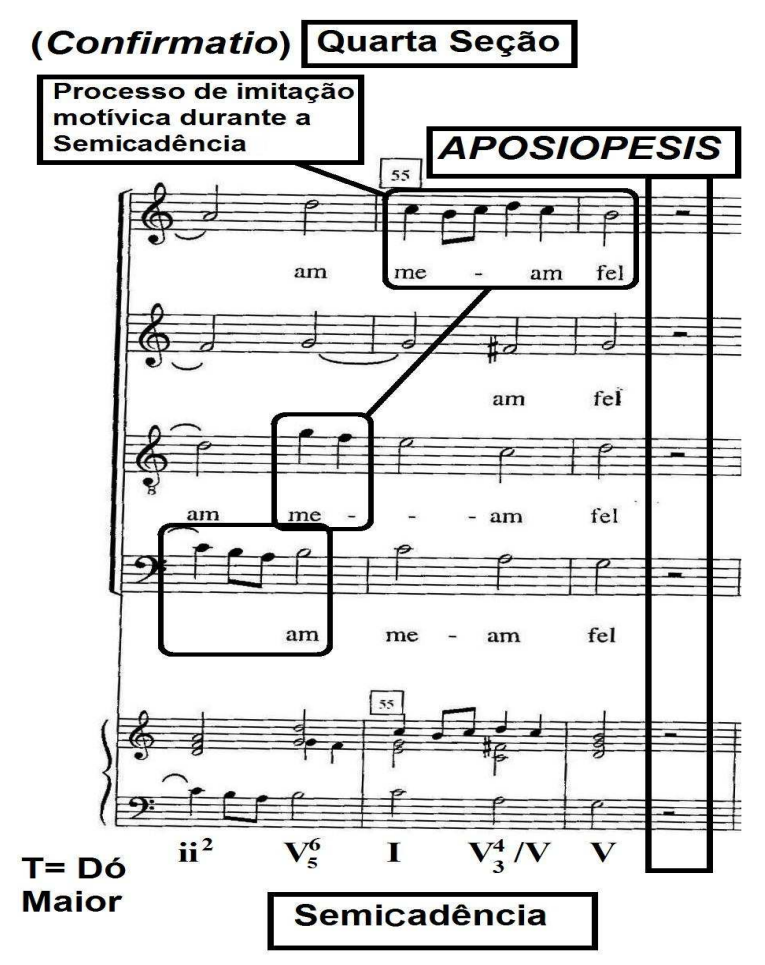

Exemplo 30: Ofertório da Missa de Domingo de Ramos de André da Silva GomesCatalogação e Organização Régis Duprat (DUPRAT, 1999 , p.182).

\subsubsection{Perotatio:}

O discurso se encerra de forma melancólica, por meio da pronunciação da frase Et in siti mea protaverunt me aceto (Na minha sede deram-me a beber vinagre), enfatizando novamente a dor e o sofrimento causado pela injustiça e desprezo. A Synaeresis mais uma vez é utilizada, assim como a Syncope evidenciando as palavras et in siti ( $\mathrm{Na}$ minha sede) nos compassos 57 a 60 . Também, dentro da Perotatio inicia-se a quinta e última seção, onde a tese central da peça e a mensagem reflexiva, abordada no Ofertório, de que a aflição do justo sofrida pelo cristão, além da falta de justiça, podem ser vencidas, por meio da esperança de uma vida eterna, são trabalhadas com diligência pelo compositor. 


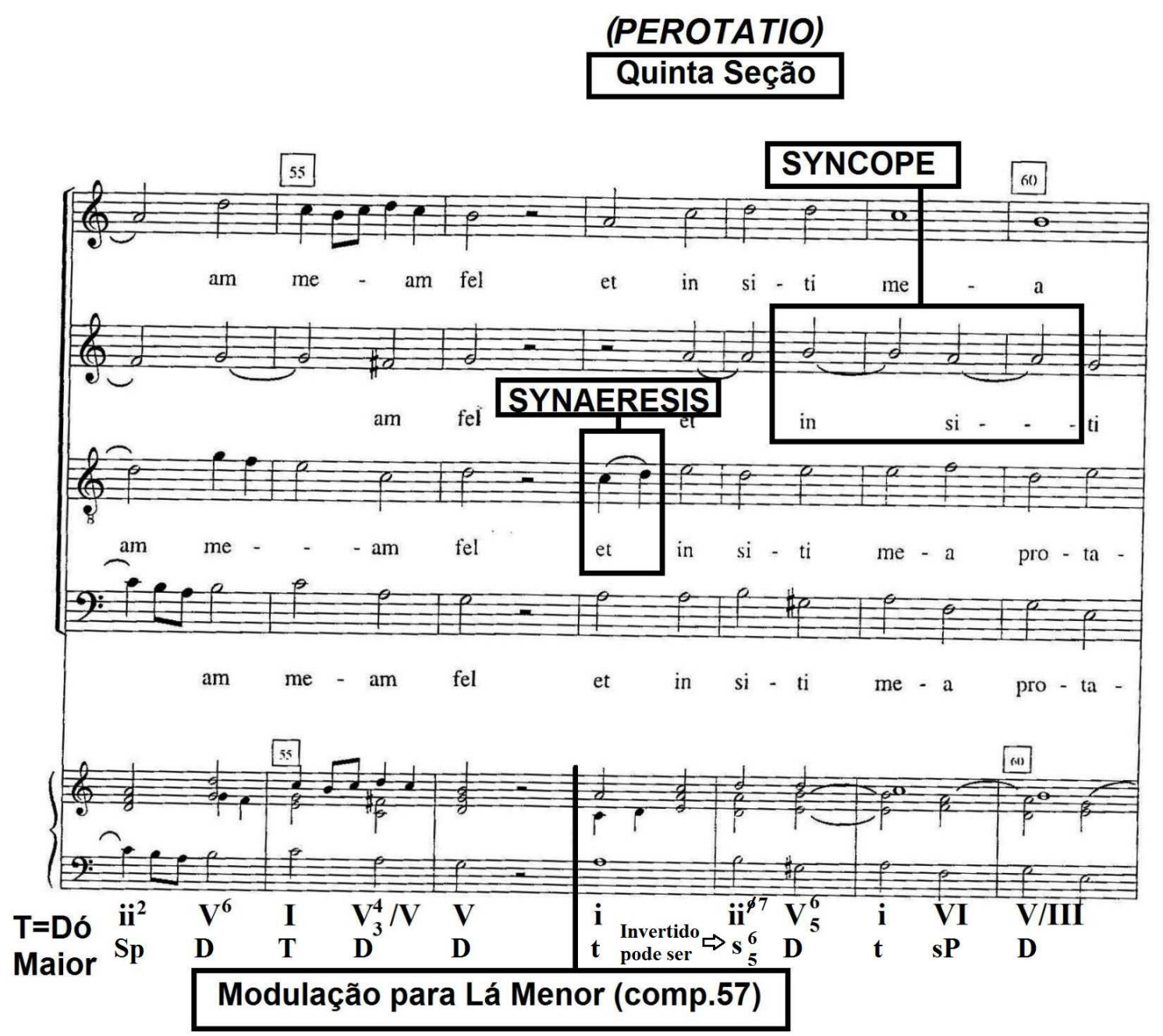

Exemplo 31: Ofertório da Missa de Domingo de Ramos de André da Silva GomesCatalogação e Organização Régis Duprat (DUPRAT, 1999, p.182).

A seção é concluída na mesma tonalidade utilizada no início da obra (Lá Menor), também é empregada pelo autor uma nova figura: Retardatio na voz da soprano, produzindo um efeito de suspensão prolongada na Dominante, ou seja, há uma relação de retardo entre as notas Sol \# e Lá com resolução na Tônica no compasso 67. Em síntese, o ofertório é finalizado com uma dinâmica suave, introspectiva, destacando a palavra "aceto" (azedo, que no contexto significaria vinagre) em uma linha fraseológica bem extensa e ligada gerando um grande grau de expectativa até a Cadência Final. 


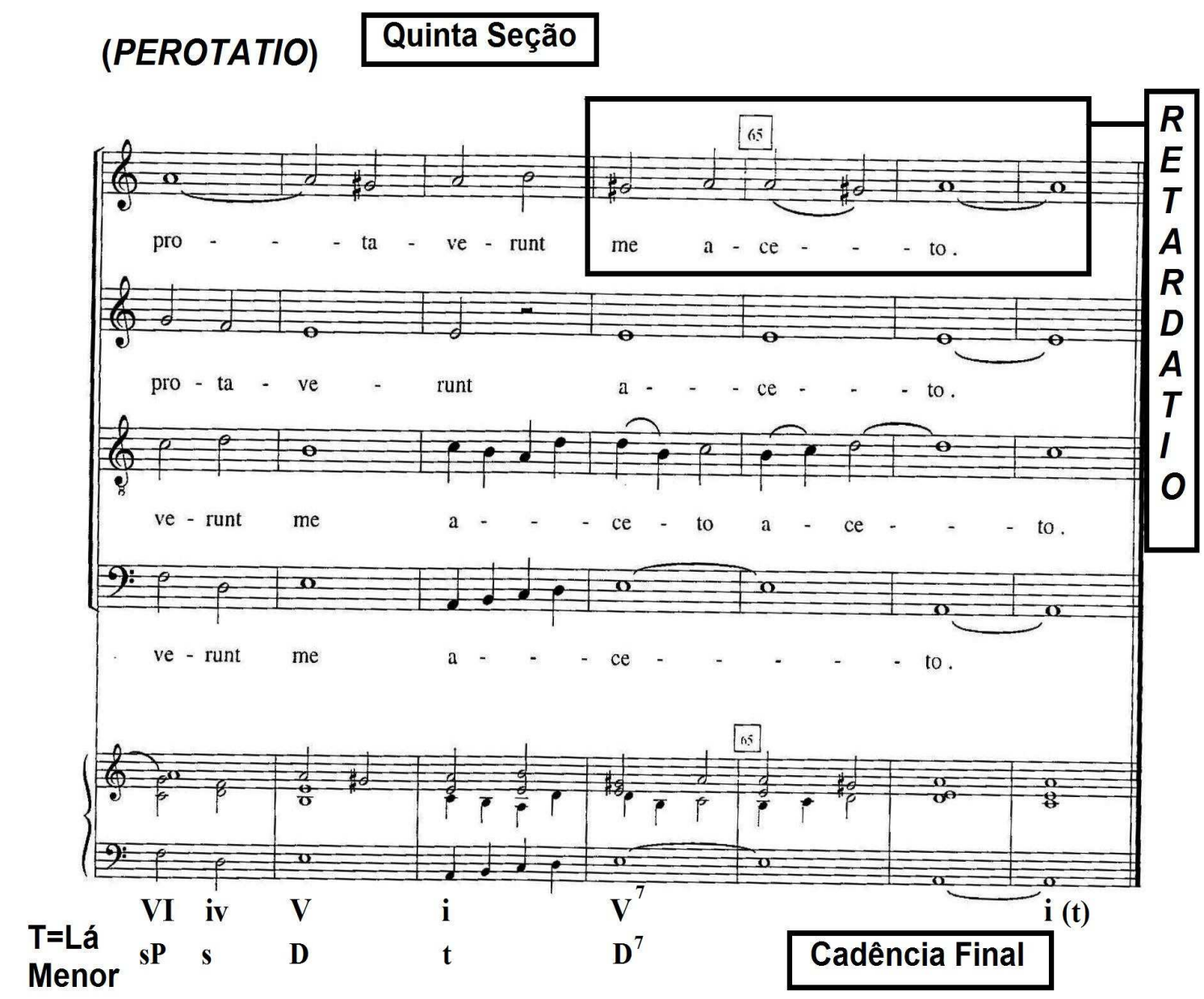

Exemplo 32: Ofertório da Missa de Domingo de Ramos de André da Silva GomesCatalogação e Organização Régis Duprat (DUPRAT, 1999, p.182).

\subsection{Figuras observadas no Ofertório (Elocutio/Decoratio)}

\begin{tabular}{|c|c|c|c|}
\hline FIGURAS & TIPO & DESCRIÇÃO & TRATADISTA \\
\hline $\begin{array}{l}\text { ANTICIPATIO } \\
\text { (BARTEL, } \\
\text { pp.199-195). }\end{array}$ & $\begin{array}{l}\text { Ornamentação } \\
\text { Melódica e } \\
\text { Harmônica }\end{array}$ & $\begin{array}{lr}\text { Uma nota } \\
\text { superior } \\
\text { inferior, vizinha } \\
\text { adicionada após } \\
\text { uma nota } \\
\text { principal, isto é, } \\
\text { prematuramente } \\
\text { introduzida de } \\
\text { uma nota } \\
\text { pertencente à } \\
\text { harmonia ou de } \\
\text { acordes } \\
\text { posteriores. }\end{array}$ & $\begin{array}{lr}\text { Walther: } & \text { A } \\
\text { Anticipatio é a } \\
\text { antecipação ou } \\
\text { reprodução } \\
\text { prematura de } \\
\text { uma nota. Trata- } \\
\text { se de uma figura } \\
\text { muito comum e } \\
\text { ocorre quando } \\
\text { uma voz entra } \\
\text { mais cedo que as } \\
\text { demais. }\end{array}$ \\
\hline
\end{tabular}




\begin{tabular}{|c|c|c|c|c|}
\hline $\begin{array}{l}\text { APOSIOPES } \\
\text { (BARTEL, } \\
\text { pp.202-206) }\end{array}$ & $\begin{array}{l}\text { S } \\
1997,\end{array}$ & \begin{tabular}{|l|} 
Interrupção e \\
Silêncio
\end{tabular} & $\begin{array}{l}\text { Um descanso em } \\
\text { uma ou todas as } \\
\text { vozes de uma } \\
\text { composição: } \\
\text { pausa geral. }\end{array}$ & $\begin{array}{l}\text { Walther: } \\
\text { Aposiopesis se } \\
\text { refere a uma } \\
\text { pausa generalis } \\
\text { ou um completo } \\
\text { silêncio em todas } \\
\text { as vozes e nas } \\
\text { partes } \\
\text { composição da } \\
\text { simultaneamente. }\end{array}$ \\
\hline $\begin{array}{l}\text { EPIZEUXIS } \\
\text { (BARTEL, } \\
\text { pp.263-265) }\end{array}$ & 1997, & $\begin{array}{l}\text { Repetição } \\
\text { Melódica }\end{array}$ & $\begin{array}{l}\text { Uma repetição } \\
\text { imediata e } \\
\text { enfática de uma } \\
\text { palavra, nota, } \\
\text { motivo ou frase. }\end{array}$ & $\begin{array}{l}\text { Walther: } \\
\text { Epizeuxis é uma } \\
\text { figura de retórica } \\
\text { pela qual uma ou } \\
\text { mais palavras são } \\
\text { imediatamente e } \\
\text { enfaticamente } \\
\text { repetidas. }\end{array}$ \\
\hline $\begin{array}{l}\text { NOEMA } \\
\text { (BARTEL, } \\
\text { p.339-342). }\end{array}$ & 1980, & $\begin{array}{l}\text { Representação } \\
\text { e Descrição }\end{array}$ & $\begin{array}{l}\text { Uma passagem } \\
\text { homofônica em } \\
\text { uma textura } \\
\text { contrapontística e } \\
\text { polifônica. }\end{array}$ & $\begin{array}{l}\text { Burmeister: A } \\
\text { Noema } \\
\text { representa o } \\
\text { afeto harmônico, } \\
\text { onde as vozes } \\
\text { combinadas têm } \\
\text { valores e } \\
\text { números de } \\
\text { notas } \\
\text { semelhantes. } \\
\text { Quando } \\
\text { introduzida } \\
\text { adequadamente, } \\
\text { isto é, no } \\
\text { momento certo, } \\
\text { ela afeta } \\
\text { docemente os } \\
\text { ouvidos do } \\
\text { ouvinte, } \\
\text { produzindo uma } \\
\text { sensação de } \\
\text { calma e } \\
\text { serenidade. } \\
\text { Seção } \\
\text { homofônica, } \\
\text { dentro da } \\
\text { polifonia utilizada } \\
\text { para enfatizar o } \\
\text { texto. }\end{array}$ \\
\hline
\end{tabular}




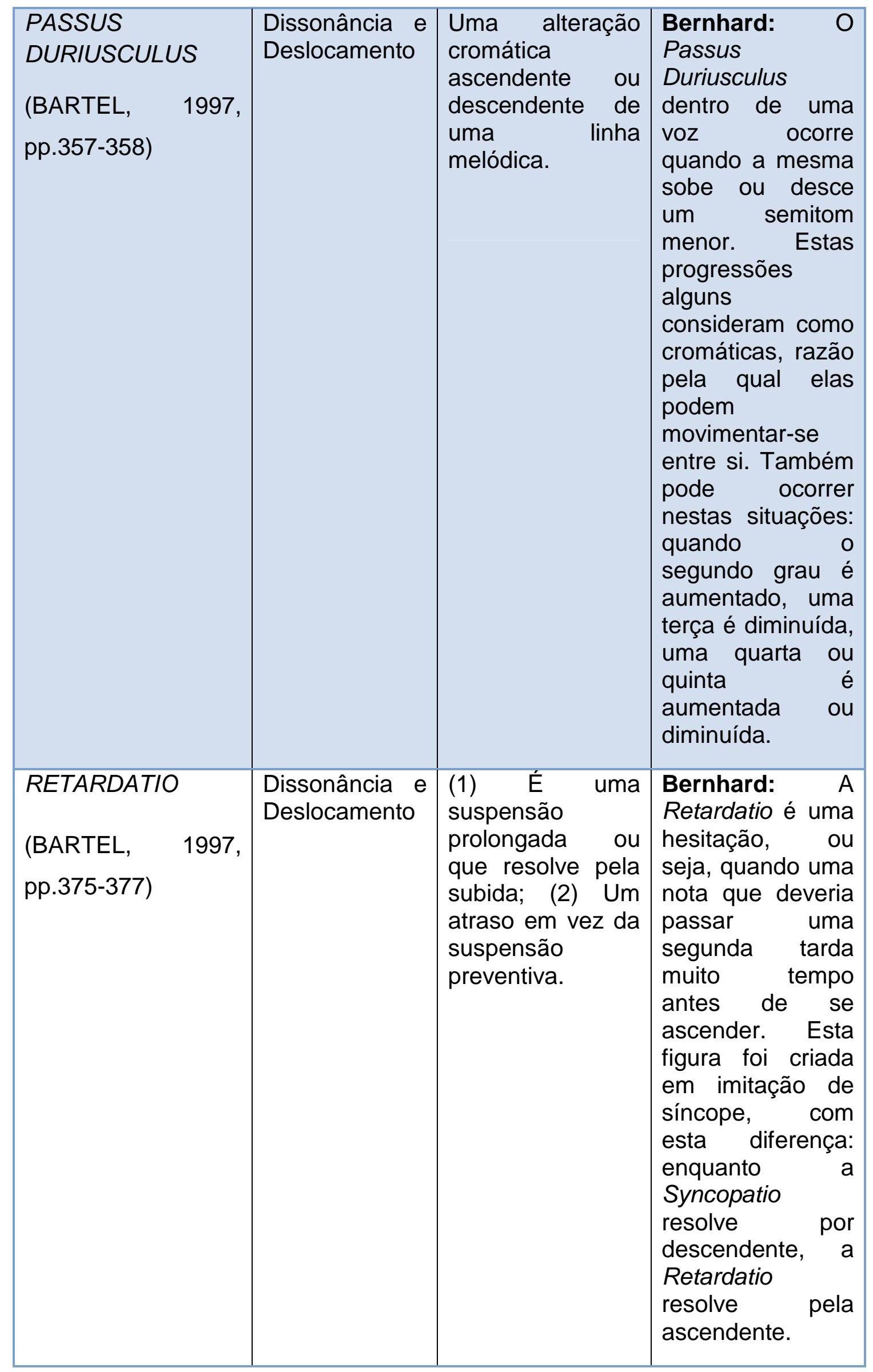




\begin{tabular}{|c|c|c|c|}
\hline $\begin{array}{l}\text { SUSPIRATIO } \\
\text { (BARTEL, 1997, pp. } \\
\text { 392-394) }\end{array}$ & $\begin{array}{l}\text { Interrupção e } \\
\text { Silêncio }\end{array}$ & $\begin{array}{l}\text { Expressão } \\
\text { musical de um } \\
\text { suspiro, através } \\
\text { de pausas. }\end{array}$ & $\begin{array}{l}\text { Kircher: } \\
\text { Stenasmus ou } \\
\text { Suspiratio } \\
\text { lembram os } \\
\text { afetos } \\
\text { naturalmente } \\
\text { expressados por } \\
\text { vários suspiros } \\
\text { criados através } \\
\text { de pausas. }\end{array}$ \\
\hline $\begin{array}{l}\text { SYNCOPE } \\
\text { (BARTEL, 1997, } \\
\text { pp.396-405) }\end{array}$ & $\begin{array}{l}\text { Dissonância e } \\
\text { Deslocamento }\end{array}$ & $\begin{array}{l}\text { Suspensão, com } \\
\text { ou sem } \\
\text { dissonância } \\
\text { resultante. }\end{array}$ & $\begin{array}{l}\text { Walther: } \\
\text { Consonâncias } \\
\text { que são alteradas } \\
\text { para } \\
\text { dissonâncias. }\end{array}$ \\
\hline $\begin{array}{l}\text { SYNAERESIS } \\
\text { (BARTEL, 1997, } \\
\text { pp.394-396) }\end{array}$ & $\begin{array}{l}\text { Dissonância e } \\
\text { Deslocamento }\end{array}$ & $\begin{array}{l}\text { (1) Uma } \\
\text { suspensão ou } \\
\text { síncope, (2) A } \\
\text { colocação de } \\
\text { duas sílabas por } \\
\text { nota ou duas } \\
\text { notas por sílaba. }\end{array}$ & $\begin{array}{lr}\text { Vogt: } & \text { A } \\
\text { Synaeresis ocorre } \\
\text { quando } & \text { duas } \\
\text { notas } & \text { são } \\
\text { colocadas } & \text { em } \\
\text { uma sílaba } & \text { ou } \\
\text { duas sílabas } & \text { são } \\
\text { colocadas } & \text { em } \\
\text { uma nota. } & \end{array}$ \\
\hline
\end{tabular}

Tabela 13: Figuras Retóricas encontradas no Ofertório da Missa de Domingo de Ramos de André da Silva Gomes

\section{Análise Harmônica}

\subsection{Curva Tonal}

Tonalidade: Lá Menor

Andamento: Andante 2/2

Esquemas das Progressões Harmônicas

\begin{tabular}{|l|c|l|}
\hline Compassos & $\begin{array}{l}\text { Função em relação a } \\
\text { tonalidade principal }\end{array}$ & Tonalidade (Acorde) \\
\hline $1-8$ & $\mathrm{t}-\mathrm{i}$ & Lá Menor \\
\hline $8-10$ & $\mathrm{tP}-\mathrm{III}$ & Dó Maior \\
\hline $11-13$ & $\mathrm{t}-\mathrm{i}$ & Lá Menor \\
\hline 14 & $\mathrm{~s}-\mathrm{i} \mathrm{i}$ & Ré Menor \\
\hline $15-17$ & $\mathrm{t}-\mathrm{i}$ & Lá Menor \\
\hline
\end{tabular}




\begin{tabular}{|l|c|l|}
\hline $18-20$ & $\mathrm{~s}-\mathrm{i}$ & Ré Menor \\
\hline $21-22$ & $\mathrm{sP}-\mathrm{VI}$ & Fá Maior \\
\hline $24-26$ & $\mathrm{t}-\mathrm{i}$ & Lá Menor \\
\hline $26-27$ & $\mathrm{tP}-\mathrm{III}$ & Dó Maior \\
\hline $27-28$ & $\mathrm{D} / \mathrm{tP}-\mathrm{V} / \mathrm{III}$ & Sol Maior \\
\hline $28-31$ & $\mathrm{tP}-\mathrm{III}$ & Dó Maior \\
\hline $32-33$ & $\mathrm{t}-\mathrm{i}$ & Lá Menor \\
\hline $34-36$ & $\mathrm{D}-\mathrm{V}$ & Mi Maior \\
\hline $37-40$ & $\mathrm{tP}-\mathrm{III}$ & Dó Maior \\
\hline $41-43$ & $\mathrm{t}-\mathrm{i}$ & Lá Menor \\
\hline $44-47$ & $\mathrm{sP}-\mathrm{VI}$ & Fá Maior \\
\hline $48-50$ & $\mathrm{~s}-\mathrm{i} \mathrm{I}$ & Ré Menor \\
\hline $51-55$ & $\mathrm{tP}-\mathrm{III}$ & Dó Maior \\
\hline $55-56$ & $\mathrm{D} / \mathrm{tP}-\mathrm{V} / \mathrm{III}$ & Sol Maior \\
\hline $57-67$ & $\mathrm{t}-\mathrm{i}$ & Lá Menor \\
\hline
\end{tabular}

Tabela 14: Curva Tonal do Ofertório do Domingo de Ramos

Números de compassos: 67

Regiões abordadas: 6

Variações: 21

Ritmo Harmônico: 3,19 (divisão dos números de compassos e variações)

Média ideal: (divisão dos números de compassos e regiões tonais abordadas $=9,57)$

Esquema Formal

$(1-27)(27-31)(31-42)(42-50)(51-57)(57-67)$

$\begin{array}{llllll}t & t P & t & s & t P & t\end{array}$

i III i iv III i 


\subsection{Estrutura Analítica do Ofertório: Retórica e Harmônica}

\begin{tabular}{|c|c|c|c|c|c|}
\hline $\begin{array}{l}\text { RETÓRICA } \\
\text { DISPOSITIO }\end{array}$ & $\begin{array}{l}\text { FIGURA } \\
\text { ELOCUTIO }\end{array}$ & COMP. & $\begin{array}{l}\text { HARMOÔNICA } \\
\text { SEÇÃOO }\end{array}$ & TONALIDADE & FUNÇĀO \\
\hline EXORDIUM & $\begin{array}{l}\text { Noema } \\
\text { Synaeresis } \\
\text { Aposiopesis }\end{array}$ & $\begin{array}{l}1-4 \\
2 \\
4\end{array}$ & $\begin{array}{l}1^{a} \text { Seção } \\
1^{\text {a }} \text { Seção } \\
1^{\text {a Seção }}\end{array}$ & $\begin{array}{l}\text { Lá Menor } \\
\text { Lá Menor } \\
\text { Lá Menor }\end{array}$ & $\begin{array}{l}t-i \\
t-i \\
t-i\end{array}$ \\
\hline NARRATIO & $\begin{array}{l}\text { Noema } \\
\text { Synaeresis }\end{array}$ & $\begin{array}{l}5-10 \\
5 \text { e } 7\end{array}$ & $\begin{array}{l}1 \text { a Seção } \\
1 \text { a Seção }\end{array}$ & $\begin{array}{l}\text { Lá Menor } \\
\text { Lá Menor }\end{array}$ & $t-i$ \\
\hline PROPOSITIO & $\begin{array}{l}\text { Noema } \\
\text { Synaeresis } \\
\text { Epizeuxis } \\
\text { Syncope } \\
\text { Passus } \\
\text { Duriusculus }\end{array}$ & $\begin{array}{l}10-17 \\
11,17,18 \\
\text { e } 28 \\
17-26 \\
14-15 \text { e } \\
20-21 \\
18-25\end{array}$ & 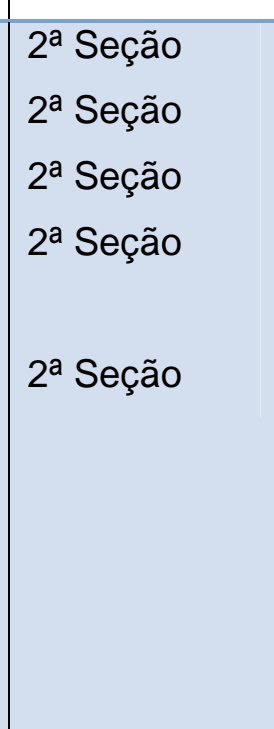 & $\begin{array}{l}\text { Lá Menor } \\
\text { Lá Menor } \\
\text { Dó Maior } \\
\text { Lá Menor } \\
\text { Lá Menor } \\
\text { Lá Menor }\end{array}$ & $\begin{array}{l}t-i \\
t-i \\
t-i\end{array}$ \\
\hline CONFUTATIO & $\begin{array}{l}\text { Suspiratio } \\
\text { Synaeresis } \\
\text { Noema } \\
\text { Anticipatio }\end{array}$ & $\begin{array}{l}29-31 \\
33-35 \\
43,46 \\
36-44\end{array}$ & $\begin{array}{l}3^{\text {a }} \text { Seção } \\
3^{\text {a }} \text { e } 4^{a} \text { Seção } \\
3^{\text {a }} \text { e 4a Seção }\end{array}$ & $\begin{array}{l}\text { Dó Maior } \\
\text { Dó Maior e } \\
\text { Fá Maior } \\
\text { Dó Maior e } \\
\text { Fá Maior } \\
\text { Dó Maior e } \\
\text { Fá Maior }\end{array}$ & $\begin{array}{l}\text { tP-III } \\
t-i \\
s P-V I \\
t P-I I I \\
s P-V I \\
t P-I I I \\
s P-V I\end{array}$ \\
\hline CONFIRMATIO & $\begin{array}{l}\text { Synaeresis } \\
\text { Aposiopesis }\end{array}$ & $\begin{array}{l}49-52 \\
56\end{array}$ & $\begin{array}{l}4^{a} \text { Seção } \\
4^{a} \text { Seção }\end{array}$ & $\begin{array}{l}\text { Fá Maior e } \\
\text { Dó Maior } \\
\text { Dó Maior }\end{array}$ & $\begin{array}{l}\text { sP-VI } \\
\text { Tp-III } \\
\text { tP-III }\end{array}$ \\
\hline
\end{tabular}




\begin{tabular}{|l|l|l|l|l|l|}
\hline PEROTATIO & Syncope & $58-60$ & 5 Seção & Lá Menor & $\mathrm{t}-\mathrm{i}$ \\
& Synaeresis & 57 & 5 - Seção & Lá Menor & $\mathrm{t}-\mathrm{i}$ \\
& Retardatio & $64-67$ & 5 - Seção & Lá Menor & $\mathrm{t}-\mathrm{i}$ \\
\hline
\end{tabular}

Tabela 15: Estrutura analítica do Ofertório 


\title{
5.2.4. Ofertório da Missa do Primeiro Domingo da Quaresma
}

\section{Estudo Semântico}

\subsection{Inventio}

O Ofertório da Missa do Primeiro Domingo da Quaresma foi escrito a partir do texto do Salmo (Ps.90,4/Ps.91,4). - "Deus Protetor dos Justos".

\author{
Scapulis suis obumbradit tibi Dominus \\ Et sub pennis ejus sperabis: \\ Scuto circumbadit te veritas ejus. \\ Com suas asas o Senhor te cobrirá \\ E sob suas penas estará protegido \\ Qual escudo te envolverá a sua verdade. ${ }^{98}$
}

(SOARES, 2000, pp.52).

Trata-se de uma oração de Moisés, onde ele retrata a esperança e a segurança daqueles que confiam no Deus dos Hebreus que, após serem libertados da escravidão no Egito, meditavam em preparação à festa da Páscoa. Esta tradição se perpetuou na liturgia cristã renovando seu sentido através da ressurreição de Cristo. $O$ primeiro domingo da quaresma traz em sua liturgia, um apelo à reflexão e a mudança de vida. Todas as leituras são estrategicamente organizadas para mover os afetos do ouvinte. O Ofertório é, então, o ápice da relação de entrega e partilha entre o Cristo que se oferece como um cordeiro imolado e o cristão que oferece seu propósito de uma nova vida. Todo este sentido de profunda devoção e humildade é a expressão do afeto que deverá ser trabalhado pela obra do compositor em cinco seções inteiramente ligadas entre si (SOARES; NOVAES, 2008, p.101).

\footnotetext{
${ }^{98}$ Assim como o texto descrito pelo salmista retrata sobre a proteção e segurança atribuída por Deus na forma metafórica de uma ave mãe, a qual é bem conhecida pela proteção que oferece aos filhotes, sobretudo debaixo das próprias asas, Jesus emprega metáfora semelhante quando ansiava por recolher Jerusalém debaixo de suas asas: "Jerusalém, Jerusalém, que mata os profetas e apedrejas os que te foram enviados! Quantas vezes quis eu reunir teus filhos como a galinha ajunta os do seu próprio ninho debaixo de suas asas, e vós não os quisestes." Lc. (Lucas) 34:34.
} 


\subsection{Locus observados na Inventio do Ofertório}

\begin{tabular}{|c|c|c|c|}
\hline INVENTIO & DESCRIÇÃO & $\begin{array}{l}\text { UTILIZAÇÃO } \\
\text { NA OBRA }\end{array}$ & $\begin{array}{l}\text { COMPASSO/ } \\
\text { VOZ }\end{array}$ \\
\hline $\begin{array}{l}\text { Locus } \\
\text { Notationis } \\
\text { (MATTHESON, } \\
\text { [1739],1954, } \\
\text { Parte II,Cap.4, } \\
\text { § 23,p.123). }\end{array}$ & $\begin{array}{l}\text { Aspecto externo e } \\
\text { desenho das notas } \\
\text { (Duração das notas, } \\
\text { alteração, repetição } \\
\text { e procedimentos } \\
\text { canônicos). }\end{array}$ & $\begin{array}{l}\text { Vários Motivos } \\
\text { Rítmicos e } \\
\text { diferentes } \\
\text { durações de } \\
\text { notas } \\
\text { (colcheias, } \\
\text { colcheias } \\
\text { pontuadas, } \\
\text { mínimas, } \\
\text { semínimas, } \\
\text { repetições, } \\
\text { mordente, } \\
\text { fermata entre } \\
\text { outros). }\end{array}$ & $\begin{array}{l}1-5 \text { S-A-T-B } \\
10-14 \text { S-A-T-B } \\
20-30 \text { S-A-T-B }\end{array}$ \\
\hline $\begin{array}{l}\text { Locus } \\
\text { Oppositorum } \\
\text { (MATTHESON, } \\
\text { [1739],1954, } \\
\text { Parte II,Cap.4, } \\
\text { § 80,p.131). }\end{array}$ & $\begin{array}{l}\text { Contraste de } \\
\text { compassos, } \\
\text { movimentos } \\
\text { contrários, agudos e } \\
\text { graves, lento e } \\
\text { rápido, calmo e } \\
\text { agitado. }\end{array}$ & $\begin{array}{l}\text { Movimento } \\
\text { contrário entre } \\
\text { soprano e } \\
\text { baixo. }\end{array}$ & $15-\mathrm{S}-\mathrm{B}$ \\
\hline $\begin{array}{l}\begin{array}{l}\text { Locus } \\
\text { Descriptionis }\end{array} \\
\text { (MATTHESON, } \\
\text { [1739],1954, } \\
\text { Parte II,Cap.4, } \\
\text { § 43,p.127). }\end{array}$ & $\begin{array}{l}\text { Disposições da } \\
\text { alma. }\end{array}$ & $\begin{array}{l}\text { Proteção, } \\
\text { Segurança } \\
\text { (Com suas } \\
\text { asas o Senhor } \\
\text { te cobrirá e } \\
\text { sob suas } \\
\text { penas estará } \\
\text { seguro). }\end{array}$ & $15-18$ S-A-T-B \\
\hline $\begin{array}{l}\text { Locus } \\
\text { Comparationis } \\
\text { (MATTHESON, } \\
\text { [1739], 1954, } \\
\text { Parte II, Cap.4 } \\
\text { § 79,p.131). }\end{array}$ & $\begin{array}{l}\text { Comparações de } \\
\text { coisas semelhantes } \\
\text { ou não, grandes ou } \\
\text { pequenas. }\end{array}$ & $\begin{array}{l}\text { Comparação } \\
\text { de coisas } \\
\text { grandes e } \\
\text { pequenas, por } \\
\text { exemplo, asas } \\
\text { e penas e } \\
\text { semelhantes } \\
\text { cobrir e } \\
\text { proteger. }\end{array}$ & $\begin{array}{l}\text { 1-4 S-A-T-B } \\
16-19 \text { S-A-T-B }\end{array}$ \\
\hline
\end{tabular}

Tabela 16: Locus Topici encontrados no Ofertório da Missa do Primeiro Domingo da Quaresma de André da Silva Gomes 


\subsection{Dispositio}

\subsubsection{Exordium}

É apresentado nos dois primeiros compassos, na primeira seção da música, onde os acordes iniciais exaltam a proteção divina através da expressão Scapulis! Scapulis suis..., esta invocação é um forte apelo ao ouvinte para que tenha plena confiança neste amparo. O primeiro compasso se inicia com uma combinação de repetição e aumentação nos valores rítmicos (nas quatro vozes); além disso, observa-se a utilização da Epizeuxis, na Tônica e Dominante reiterando a oração. A repetição imediata do fragmento musical tem o objetivo de persuadir o ouvinte de que somente Deus poderá protegê-lo. A seção é finalizada com uma Cadência Autêntica Imperfeita que, por sua vez, reitera a posse e o controle exercido pelo Deus de Israel: su-is (sua) (compasso 2).

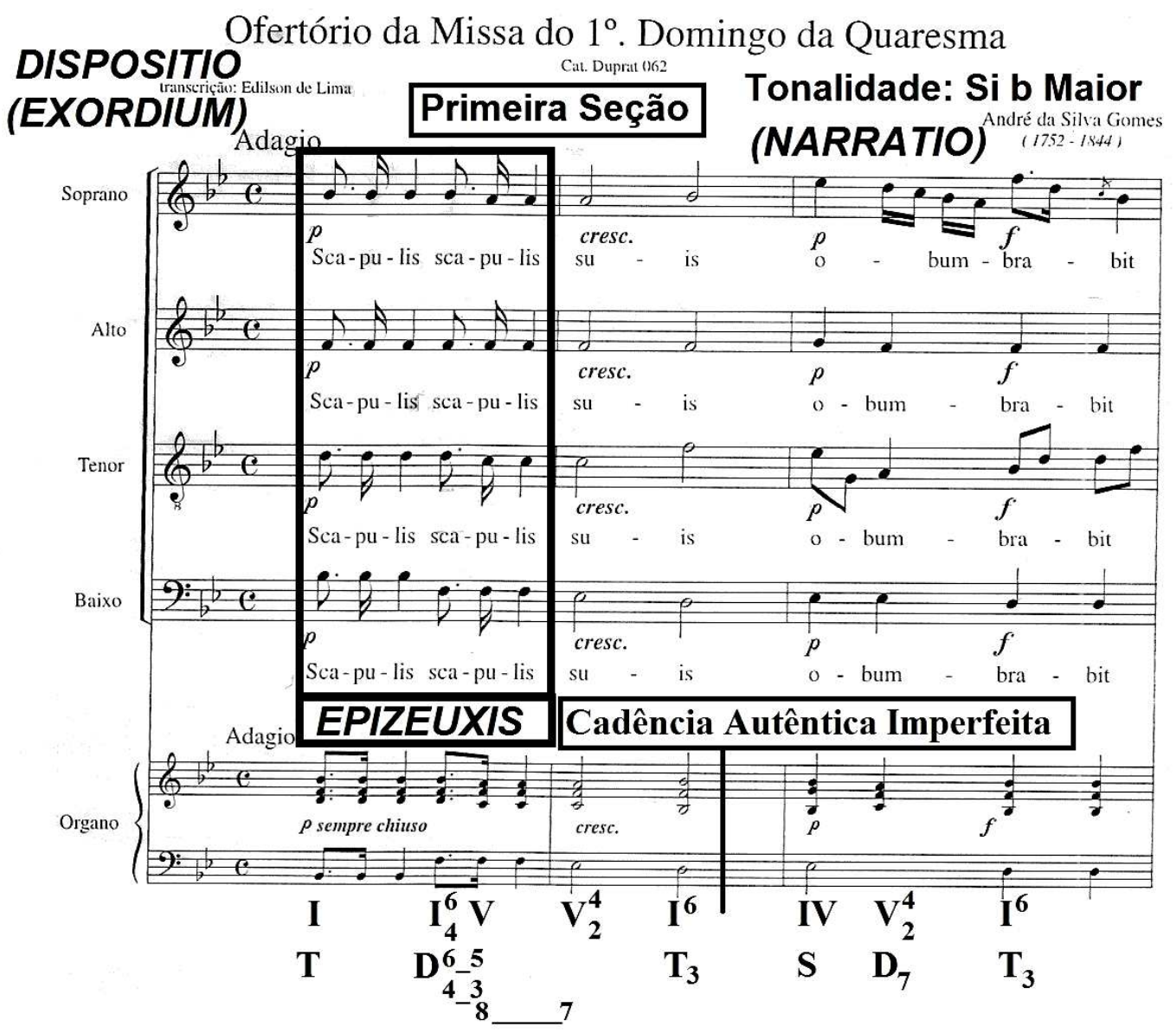

Exemplo 33: Ofertório da Missa do Primeiro Domingo da Quaresma de André da Silva Gomes- Catalogação e Organização Régis Duprat (DUPRAT, 1999, p.88). 


\subsubsection{Narratio}

No compasso 5, a figura da Noema é introduzida em passagem homofônica na Subdominante tanto nas vozes como no contraponto simples do instrumento, com a narrativa de que "os filhos do Senhor estarão seguros sob proteção do Altíssimo e assim, debaixo de suas asas, encontrarão refúgio". A Noema provoca, desta forma, um efeito de suavidade devido ao confronto entre a polifonia vocal e a harmonia vertical do instrumento. A Narratio está ainda na primeira seção da obra, onde ocorrem alternâncias entre Tônica e na região da Dominante, ela termina justamente quando é finalizada a primeira seção com uma suspensão, ou seja, uma Semicadência que juntamente com a Noema é o elo utilizado por Silva Gomes gerando maior expectativa para mover os afetos mais intrínsecos nesse importante momento da missa, que é o ofertório.

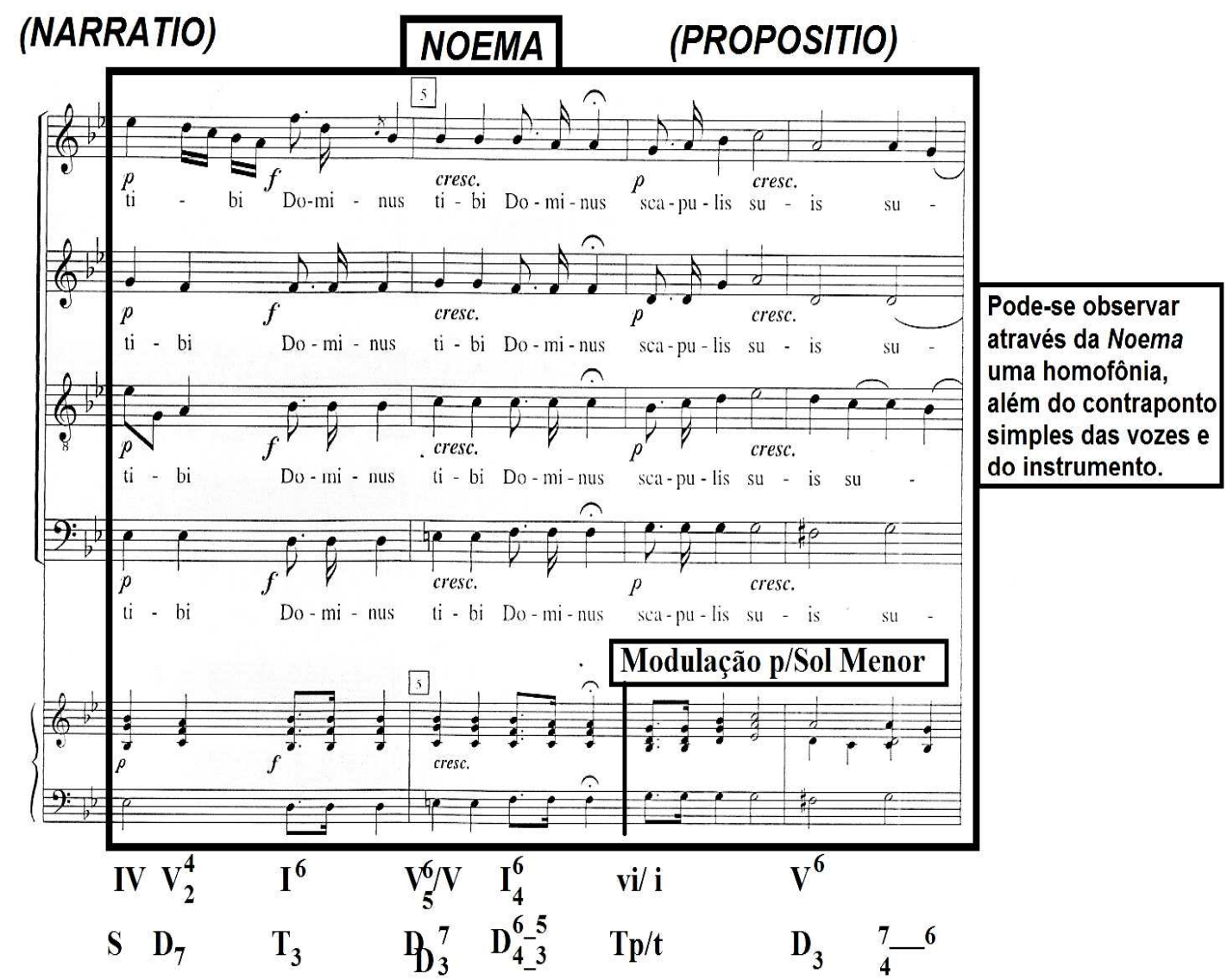

Exemplo 34: Ofertório da Missa do Primeiro Domingo da Quaresma de André da Silva Gomes- Catalogação e Organização Régis Duprat (DUPRAT, 1999, p.88). 


\subsubsection{Propositio}

O espírito de segurança, confiança em Deus é evidenciado pela utilização de novos elementos retóricos, tal como: Exclamatio, que no compasso 8, na soprano; é empregada com um salto inesperado de sexta menor ascendente, entre as notas Fá sustenido e Ré na Dominante de Sol Menor; Abruptio, ainda no oitavo compasso, terminando a frase nas três vozes de forma súbita ao mesmo tempo em que a voz da soprano continua a ser executada. Estes elementos enunciam a tese fundamental da peça, ou seja, "sob as penas de suas asas há proteção". A Propositio continua nos compassos seguintes, da mesma forma a segunda seção, no compasso 10 novamente o autor emprega a figura da Epizeuxis enfatizando e reiterando a palavra Dominus tibi, ao mesmo tempo, nessa parte do ofertório há uma alternância entre Dominantes e Subdominante em Sol Menor. Novamente como o ocorrido na Narratio, a Propositio é concluída conjuntamente com a segunda seção, além das Cadências suspensivas (Semicadências), esta solução empresta grande intensidade emotiva a esta parte discursiva retórica e estrutural da peça. 
(PROPOSITIO)

Segunda Seção
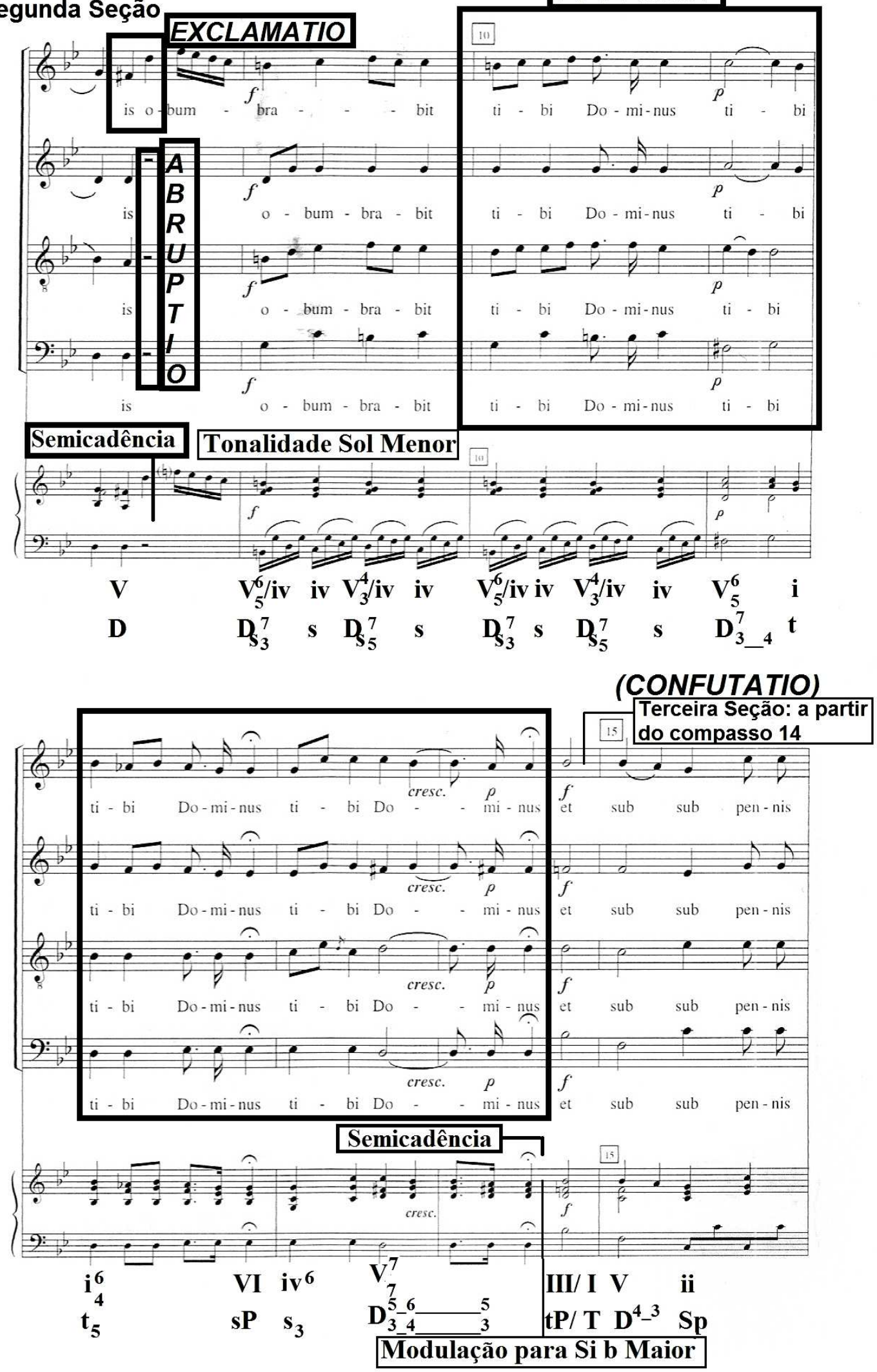

Exemplo 35: Ofertório da Missa do Primeiro Domingo da Quaresma de André da Silva Gomes- Catalogação e Organização Régis Duprat (DUPRAT, 1999, p.89). 


\subsubsection{Confutatio}

A inclusão de novos e contrastantes elementos a partir do compasso 16 na terceira seção, confirma a tese inicial. Figuras como a Epizeuxis, Syncope e Aposiopesis, que, nesse caso específico, são utilizados para preparar afirmação que virá em seguida: Scuto circumdabit te veritas ejus. Com isso o autor cria uma atmosfera de expectativa serena, prendendo a atenção do ouvinte através de mecanismos tanto retóricos, motívicos e estruturais, por exemplo, repetições insistentes das palavras sperabis e circumbabit, com auxílio da Epizeuxis, no compasso 20, reforçando a expectativa. Também da interação entre Tônica e Dominante em toda esta parte, a ênfase do silêncio empregado a todas as vozes pela Aposiopesis em conjunto a Cadência Autêntica Perfeita e por fim, o acorde consonante que se transforma em dissonante através da Syncope, no início da quarta seção.

(CONFUTATIO) Terceira Seçăo
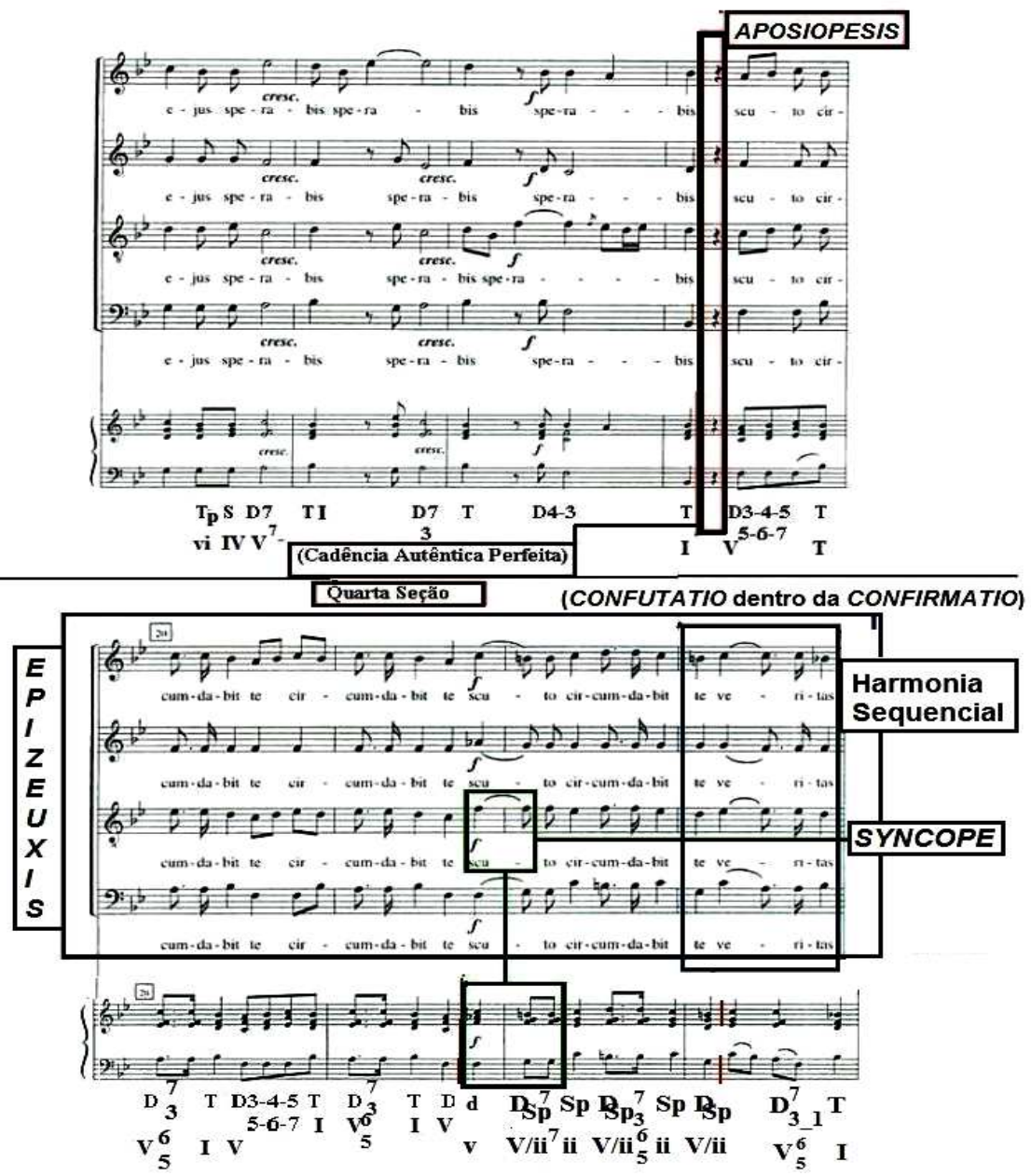

Exemplo 36: Ofertório da Missa do Primeiro Domingo da Quaresma de André da Silva Gomes- Catalogação e Organização Régis Duprat (DUPRAT, 1999, p.90). 


\subsubsection{Confirmatio}

A reiteração de elementos iniciais como as repetições dos motivos rítmicos, a ênfase das palavras, confirma a tese fundamental. Desde modo, André da Silva Gomes novamente como na Confutatio trabalha com a expectativa do ouvinte, no entanto, aumentando as progressões por intermédio da utilização da harmonia sequencial nos compassos 23 a 25, além das inúmeras reiterações que ele faz percorrendo regiões da Tônica, Subdominante, Dominante da Dominante, Dominante da Dominante da Tônica Relativa, até ao final deste compasso culminando em uma Cadência de Engano, pretendo ainda mais a atenção do ouvinte, valendo-se de uma maior carga afetiva. Por esta razão temos uma Confutatio dentro da Confirmatio.

\section{(CONFUTATIO dentro da CONFIRMATIO)}

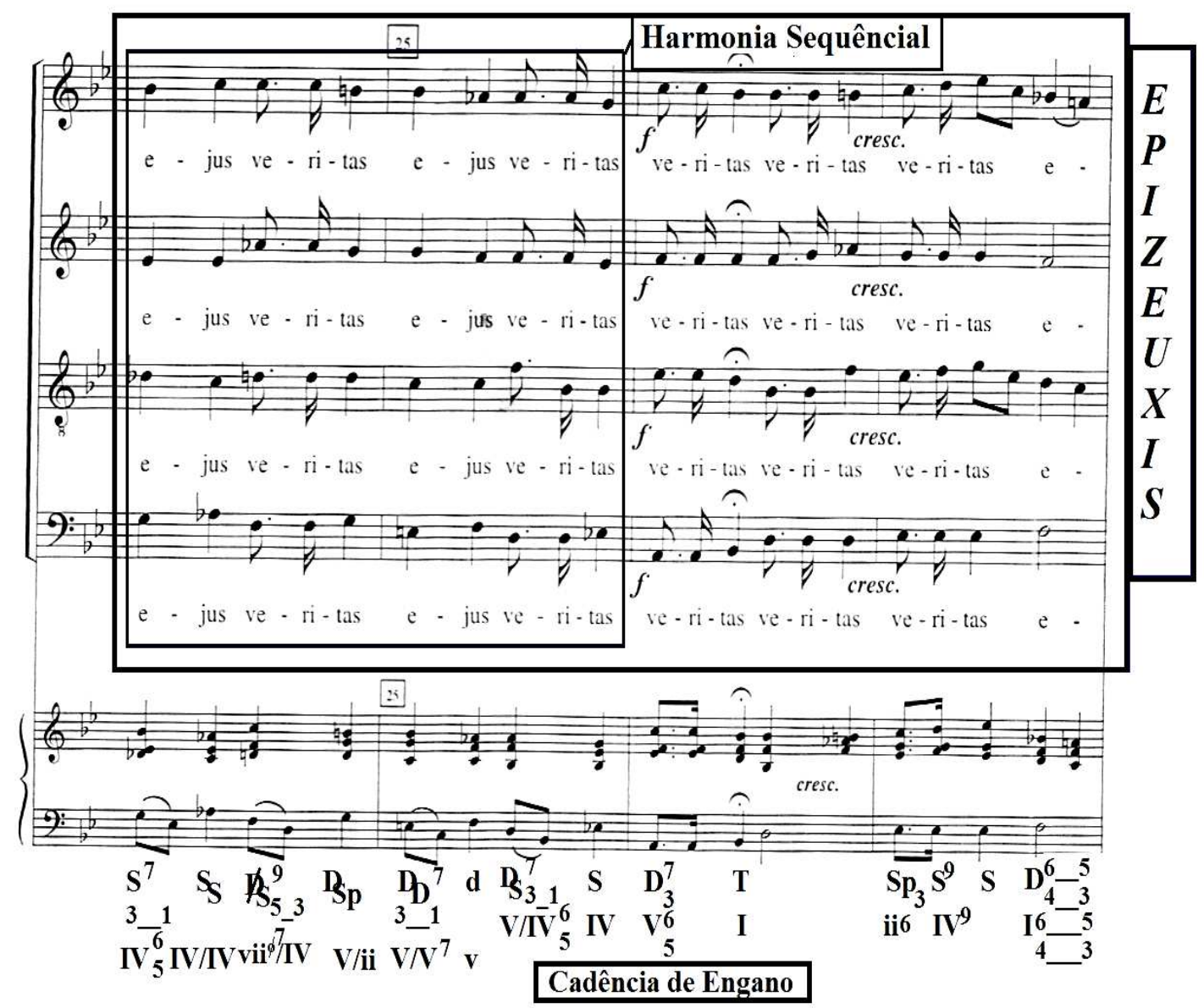

Exemplo 37: Ofertório da Missa do Primeiro Domingo da Quaresma de André da Silva Gomes- Catalogação e Organização Régis Duprat (DUPRAT, 1999, p.91). 


\subsubsection{Perotatio}

O discurso se encerra enfático, assim como a quinta e última seção, através da repetição das palavras veritas ejus (sua verdade), a tese central da peça e a lição significante do ofertório: a verdade de Deus é um escudo que envolve e protege o cristão. Sem dúvida alguma, trata-se de uma menção ao próprio Cristo, que disse: "Eu sou o caminho, e a verdade, e a vida; ninguém vem ao Pai, senão por mim. ${ }^{, 99}$. Na liturgia da missa, o ofertório dá início à Celebração Eucarística, onde é reproduzido o acontecimento central da Última Ceia, ou seja, o sacrifício de Cristo.

A seção é concluída na tonalidade de Si bemol Maior, ou seja, a mesma utilizada no início da obra, onde outra figura é utilizada pelo o autor: a Synaeresis na voz da soprano e do tenor cantando duas notas na mesma silaba, isto é, destacando a passagem da Dominante e também a dinâmica forte, ressaltando pela última vez a palavra veritas (verdade), enfim, o ofertório acaba com uma dinâmica piano com uma linha fraseológica bem ligada suave, na Cadência Final (Autêntica Perfeita).

\section{(PEROTATIO)}

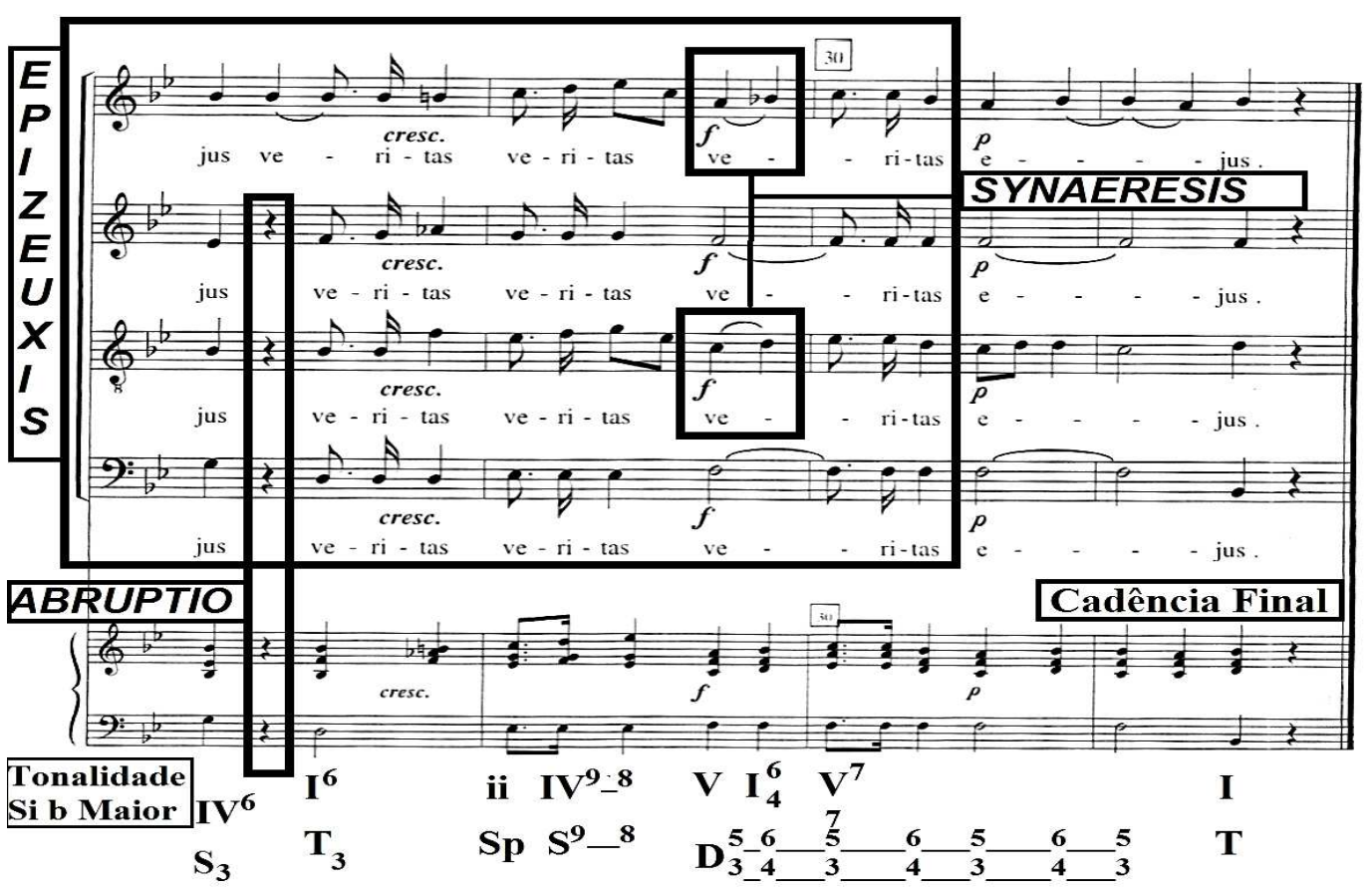

Exemplo 38: Ofertório da Missa do Primeiro Domingo da Quaresma de André da Silva Gomes- Catalogação e Organização Régis Duprat (DUPRAT, 1999, p.91).

${ }^{99}$ João $14,6$. 


\subsection{Figuras observadas no Ofertório (Elocutio/Decoratio)}

\begin{tabular}{|c|c|c|c|}
\hline FIGURAS & TIPO & DESCRIÇÃO & TRATADISTA \\
\hline $\begin{array}{l}\text { ABRUPTIO } \\
\text { (BARTEL, 1997, } \\
\text { pp.168-170). }\end{array}$ & $\begin{array}{l}\text { Interrupção e } \\
\text { Silêncio }\end{array}$ & $\begin{array}{l}\text { Uma quebra } \\
\text { súbita e } \\
\text { inesperada na } \\
\text { composição } \\
\text { musical. }\end{array}$ & $\begin{array}{lr}\text { Vogt: A } & \text { Abruptio } \\
\text { ocorre } & \text { quando } \\
\text { um } & \text { trecho } \\
\text { musical } & \text { é } \\
\text { interrompido } & \text { no } \\
\text { final } & \text { pela } \\
\text { colocação r de } & \text { de } \\
\text { algumas pausas. }\end{array}$ \\
\hline $\begin{array}{l}\text { APOSIOPESIS } \\
\text { (BARTEL, } \\
\text { pp.202-206). }\end{array}$ & $\begin{array}{l}\text { Interrupção e } \\
\text { Silêncio }\end{array}$ & $\begin{array}{l}\text { Um descanso em } \\
\text { uma ou todas as } \\
\text { vozes de uma } \\
\text { composição: } \\
\text { pausa geral. }\end{array}$ & $\begin{array}{l}\text { Walther: } \\
\text { Aposiopesis se } \\
\text { refere a uma } \\
\text { Pausa Generalis } \\
\text { ou um completo } \\
\text { silêncio em todas } \\
\text { as vozes e nas } \\
\text { partes ra da } \\
\text { composição r } \\
\text { simultaneamente. }\end{array}$ \\
\hline $\begin{array}{l}\text { EPIZEUXIS } \\
\text { (BARTEL, 1997, } \\
\text { pp.263-265). }\end{array}$ & $\begin{array}{l}\text { Repetição } \\
\text { Melódica }\end{array}$ & $\begin{array}{l}\text { Uma repetição } \\
\text { imediata e } \\
\text { enfática de uma } \\
\text { palavra, nota, } \\
\text { motivo ou frase. }\end{array}$ & $\begin{array}{l}\text { Walther: A } \\
\text { Epizeuxis é uma } \\
\text { figura de retórica } \\
\text { pela qual uma ou } \\
\text { mais palavras } \\
\text { são } \\
\text { imediatamente e } \\
\text { enfaticamente } \\
\text { repetidas. }\end{array}$ \\
\hline $\begin{array}{l}\text { EXCLAMATIO } \\
\text { (BARTEL, 1997, } \\
\text { pp.265-269). }\end{array}$ & $\begin{array}{l}\text { Representação } \\
\text { e Descrição }\end{array}$ & $\begin{array}{l}\text { Exclamação } \\
\text { musical, } \\
\text { frequentemente } \\
\text { associada com } \\
\text { uma exclamação } \\
\text { no texto. }\end{array}$ & $\begin{array}{l}\text { Walther: A } \\
\text { Exclamatio ou } \\
\text { Ecphonisis é uma } \\
\text { figura de retórica } \\
\text { que significa uma } \\
\text { exclamação } \\
\text { agitada. Isto pode } \\
\text { ser realizado de } \\
\text { forma muito } \\
\text { apropriada na } \\
\text { música através } \\
\text { de um salto para } \\
\text { cima, em sexta } \\
\text { menor. } \\
\text { Scheibe: Suas } \\
\text { propriedades são }\end{array}$ \\
\hline
\end{tabular}




\begin{tabular}{|c|c|c|c|c|}
\hline & & & & $\begin{array}{l}\text { tão diversas } \\
\text { quanto as suas } \\
\text { origens, causas } \\
\text { ou efeitos. Deve- } \\
\text { se notar que } \\
\text { geralmente ela é } \\
\text { expressa através } \\
\text { de rem uma } \\
\text { passagem } \\
\text { ascendente, } \\
\text { utilizando as } \\
\text { consonâncias nos } \\
\text { afetos e } \\
\text { acontecimentos } \\
\text { alegres e } \\
\text { dissonâncias nos } \\
\text { tristes. Isto se } \\
\text { aplica em conta } \\
\text { tanto a melodia e } \\
\text { harmonia. }\end{array}$ \\
\hline $\begin{array}{l}\text { NOEMA } \\
\text { (BARTEL, } \\
\text { p.339-342). }\end{array}$ & 1997 & $\begin{array}{l}\text { Representação } \\
\text { e Descrição }\end{array}$ & $\begin{array}{l}\text { Uma passagem } \\
\text { homofônica em } \\
\text { uma textura } \\
\text { contrapontística e } \\
\text { polifônica. }\end{array}$ & $\begin{array}{l}\text { Burmeister: A } \\
\text { Noema } \\
\text { representa o } \\
\text { afeto harmônico, } \\
\text { onde as vozes } \\
\text { combinadas têm } \\
\text { valores e } \\
\text { números de notas } \\
\text { semelhantes. } \\
\text { Quando } \\
\text { introduzida } \\
\text { adequadamente, } \\
\text { isto é, no } \\
\text { momento certo, } \\
\text { ela afeta } \\
\text { docemente os } \\
\text { ouvidos do } \\
\text { ouvinte, } \\
\text { produzindo uma } \\
\text { sensação de } \\
\text { calma e } \\
\text { serenidade. }\end{array}$ \\
\hline $\begin{array}{l}\text { (BUELOW, } \\
\text { p.799). }\end{array}$ & 1980, & & & $\begin{array}{l}\text { Seção } \\
\text { homofônica, } \\
\text { dentro da } \\
\text { polifonia utilizada } \\
\text { para enfatizar o } \\
\text { texto. }\end{array}$ \\
\hline
\end{tabular}




\begin{tabular}{|c|c|c|c|}
\hline $\begin{array}{l}\text { SYNCOPE. } \\
\text { (BARTEL, } \\
\text { pp.396-405). }\end{array}$ & $\begin{array}{l}\text { Dissonância e } \\
\text { Deslocamento }\end{array}$ & $\begin{array}{l}\text { Suspensão, com } \\
\text { ou sem } \\
\text { dissonância } \\
\text { resultante. }\end{array}$ & $\begin{array}{l}\text { Walther: } \\
\text { Consonâncias } \\
\text { que são alteradas } \\
\text { para } \\
\text { dissonâncias. }\end{array}$ \\
\hline $\begin{array}{l}\text { SYNAERESIS } \\
\text { (BARTEL, } \\
\text { pp.394-396). }\end{array}$ & $\begin{array}{l}\text { Dissonância e } \\
\text { Deslocamento }\end{array}$ & $\begin{array}{l}\text { (1) Uma } \\
\text { suspensão ou } \\
\text { síncope, (2) A } \\
\text { colocação de } \\
\text { duas sílabas por } \\
\text { nota ou duas } \\
\text { notas por sílaba. }\end{array}$ & $\begin{array}{lr}\text { Vogt: } & \mathrm{A} \\
\text { Synaeresis } \\
\text { ocorre quando } \\
\text { duas notas são } \\
\text { colocadas em } \\
\text { uma sílaba ou } \\
\text { duas sílabas são } \\
\text { colocadas em } \\
\text { uma nota. }\end{array}$ \\
\hline
\end{tabular}

Tabela 17: Figuras encontradas no Ofertório da Missa do Primeiro Domingo da Quaresma de André da Silva Gomes

\section{Análise Harmônica}

\subsection{Curva Tonal}

Tonalidade: Si bemol Maior

Andamento: Adagio 4/4

Esquema de Progressões Harmônicas

\begin{tabular}{|l|c|l|}
\hline Compassos & $\begin{array}{l}\text { Função em relação a } \\
\text { tonalidade principal }\end{array}$ & Tonalidade (Acorde) \\
\hline $1-4$ & T-I & Si b Maior \\
\hline 5 & D-V & Fá Maior \\
\hline $6-8$ & Tp-vi & Sol Menor \\
\hline $9-10$ & Sp-ii & Dó Menor \\
\hline $11-12$ & Tp-vi & Sol Menor \\
\hline 12 & S-IV & Mi b Maior \\
\hline $13-14$ & Tp-vi & Sol Menor \\
\hline $14-21$ & T-I & Si b Maior \\
\hline $21-23$ & Sp-ii & Dó Menor \\
\hline 24 & SS- IV/IV & Lá b Maior \\
\hline 24 & Sp-ii & Dó Menor \\
\hline 25 & d-v & Fá Menor \\
\hline 25 & S & Mi b Maior \\
\hline 26 & T-I & Si b Maior \\
\hline
\end{tabular}




\begin{tabular}{|l|c|l|}
\hline $26-27$ & Sp-ii & Dó Menor \\
\hline $27-28$ & T-I & Si b Maior \\
\hline 29 & Sp- ii & Dó Menor \\
\hline $29-31$ & T-I & Si b Maior \\
\hline
\end{tabular}

Tabela 18: Curva Tonal do Ofertório da Missa do Primeiro Domingo da Quaresma

Números de compassos: 31

Regiões abordadas: 7

Variações: 18

Ritmo Harmônico: 1,72 (divisão dos números de compassos e variações)

Média ideal: (divisão dos números de compassos e regiões tonais abordadas = 4,42)

Esquema Formal

$(1-5)(6-14)(14-31)$

$\begin{array}{lll}\text { T } & \text { Tp } & \text { T } \\ \text { I } & \text { vi } & \text { I }\end{array}$

2.2. Estrutura Analítica do Ofertório: Retórica e Harmônica

\begin{tabular}{|c|c|c|c|c|c|}
\hline $\begin{array}{l}\text { RETÓRICA } \\
\text { DISPOSITIO }\end{array}$ & $\begin{array}{l}\text { FIGURA } \\
\text { ELOCUTIO }\end{array}$ & COMP. & $\begin{array}{l}\text { HARMÔNICA } \\
\text { SEÇÃO }\end{array}$ & TONALIDADE & FUNÇÃO \\
\hline EXORDIUM & Epizeuxis & 1 & 1a Seção & Si b Maior & T-I \\
\hline NARRATIO & Noema & $4-6$ & $\begin{array}{l}1^{\mathrm{a}} \quad \mathrm{e} \quad 2^{\mathrm{a}} \\
\text { Seção }\end{array}$ & $\begin{array}{l}\text { Si b Maior } \\
\text { Sol Menor }\end{array}$ & $\begin{array}{l}\text { T-I } \\
\text { Tp-vi }\end{array}$ \\
\hline PROPOSITIO & Exclamatio & 8 & $2^{\mathrm{a}}$ Seção & Sol Menor & Tp-vi \\
\hline
\end{tabular}




\begin{tabular}{|c|c|c|c|c|c|}
\hline & $\begin{array}{l}\text { Abruptio } \\
\text { Epizeuxis }\end{array}$ & $\begin{array}{l}8 \\
10-14\end{array}$ & $\begin{array}{l}2^{a} \text { Seção } \\
2^{\text {a }} \text { Seção }\end{array}$ & $\begin{array}{l}\text { Sol Menor } \\
\text { Sol Menor }\end{array}$ & $\begin{array}{l}\text { Tp-vi } \\
\text { Tp-vi }\end{array}$ \\
\hline CONFUTATIO & $\begin{array}{l}\text { Aposiopesis } \\
\text { Epizeuxis } \\
\text { Syncope }\end{array}$ & $\begin{array}{l}19 \\
20-22 \\
21-22\end{array}$ & 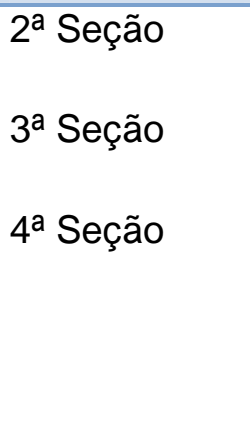 & $\begin{array}{l}\text { Si b Maior } \\
\text { Si b Maior } \\
\text { Si b Maior } \\
\text { Para as duas } \\
\text { figuras }\end{array}$ & $\begin{array}{l}\text { T-I } \\
\text { T-I } \\
\text { T-I }\end{array}$ \\
\hline CONFIRMATIO & Epizeuxis & $23-27$ & $4^{a}$ e e $5^{a}$ Seção & Si b Maior & T-I \\
\hline PEROTATIO & $\begin{array}{l}\text { Epizeuxis } \\
\text { Abruptio } \\
\text { Synaeresis }\end{array}$ & $\begin{array}{l}28-30 \\
28 \\
29\end{array}$ & $\begin{array}{l}\text { 5 Seção }^{\text {a }} \\
\text { 5 Seção }^{\text {a }} \\
5^{\text {a Seção }}\end{array}$ & $\begin{array}{l}\text { Si b Maior } \\
\text { Si b Maior } \\
\text { Si b Maior }\end{array}$ & $\begin{array}{l}\text { T-I } \\
\text { T-I } \\
\text { T-I }\end{array}$ \\
\hline
\end{tabular}

Tabela 19: Estrutura analítica do Ofertório 


\subsubsection{Ofertório da Missa do Segundo Domingo da Quaresma}

\section{Estudo Semântico}

\subsection{Inventio}

A presente obra foi escrita a partir dos versos de um salmo sapiencial alfabético, "Elogio da Lei Divina" (Ps.118,47-48/ 119,47-48).

Meditabor in mandatis tuis, quæ dilexi valde

Et levabo mnus meas ad mandata tua, quæ dilexi.

Meditarei em seus mandamentos, que muito estimo.

E levantarei as mãos para os seus honrados mandamentos.

(SOARES, 2000, p.58).

Esse que é o maior salmo da Bíblia constituído de 176 versículos, essa passagem ressalta o prazer que o salmista tem na Palavra de Deus, e seu devotado amor por ela. Assim o cristão que lê e observa os estatutos das Escrituras Sagradas, terá maior compreensão e desejo em guardar os Mandamentos de Cristo (ALMEIDA, 1996, p. 903). O Segundo Domingo da Quaresma, apresenta-nos em sua liturgia duas características: a primeira que define a Palavra de Deus como bussola e fundamento auxiliando o caminho que os seguidores da fé cristã devem seguir até alcançarem à vida eterna e a segunda que se consubstancia na Transfiguração de Cristo $^{100}$, o qual anteriormente venceu a tentação no deserto utilizando como sua defesa e argumento os Mandamentos de Deus, isto é, sua Palavra.

Em suma, Silva Gomes desenvolve essa linha de pensamento reflexivo em quarenta e dois compassos, distribuídos em seis seções, num Adagio, em Ré Menor, enfatizando os afetos e figuras apropriadas para cada trecho da obra.

\footnotetext{
${ }^{100} \mathrm{Na}$ sua transfiguração, Jesus foi transformado na presença de três discípulos (Pedro, Tiago e João), que viram a sua glória celestial. Entretanto a experiência da transfiguração foi: um alento para Jesus ante a sua iminente morte na cruz, um comunicado de que ele sofreria pelos pecados da humanidade e uma confirmação, por Deus, que ele era verdadeiramente seu Filho (ALMEIDA, 1996, p.1524).
} 


\subsection{Locus observados na Inventio do Ofertório}

\begin{tabular}{|c|c|c|c|}
\hline INVENTIO & DESCRIÇÃO & $\begin{array}{c}\text { UTILIZAÇÃO NA } \\
\text { OBRA }\end{array}$ & $\begin{array}{l}\text { COMPASSO/ } \\
\text { VOZ }\end{array}$ \\
\hline $\begin{array}{l}\text { Locus } \\
\text { Notationis } \\
\text { (MATTHESON, } \\
\text { [1739],1954, } \\
\text { Parte II,Cap.4, } \\
\S 23, \text { p.123). }\end{array}$ & $\begin{array}{l}\text { Aspecto externo e } \\
\text { desenho das notas } \\
\text { (Duração das } \\
\text { notas, alteração, } \\
\text { repetição } \\
\text { procedimentos } \\
\text { canônicos). }\end{array}$ & $\begin{array}{l}\text { Vários motivos } \\
\text { rítmicos e } \\
\text { diferentes durações } \\
\text { de notas (mínimas, } \\
\text { semínimas, } \\
\text { semínimas } \\
\text { pontuadas, } \\
\text { colcheias, } \\
\text { colcheias } \\
\text { pontuadas, } \\
\text { semicolcheias, } \\
\text { repetições, } \\
\text { ligaduras, pausas, } \\
\text { fermata, } \\
\text { apogiaturas, entre } \\
\text { outros). }\end{array}$ & $\begin{array}{l}1-5 \quad \text { S-A-T-B } \\
6-16 \text { S-A-T-B } \\
17-26 \text { S-A-T-B } \\
26-28 \text { S-A-T-B } \\
36-39 \text { S-A-T-B }\end{array}$ \\
\hline $\begin{array}{l}\text { Locus } \\
\text { Oppositorum } \\
\text { (MATTHESON, } \\
\text { [1739],1954, } \\
\text { Parte II, Cap.4, } \\
\text { § 80,p.131). }\end{array}$ & $\begin{array}{l}\text { Contraste de } \\
\text { compassos, } \\
\text { movimentos } \\
\text { contrários, agudos } \\
\text { e graves, lento e } \\
\text { rápido, calmo e } \\
\text { agitado. }\end{array}$ & $\begin{array}{l}\text { Movimento } \\
\text { contrário entre } \\
\text { soprano, contralto } \\
\text { e baixo. }\end{array}$ & 23 S-A-B \\
\hline $\begin{array}{l}\text { Locus } \\
\text { Descriptionis } \\
\text { (MATTHESON, } \\
\text { [1739],1954, } \\
\text { Parte II,Cap.4, } \\
\S 43, \text { p.127). }\end{array}$ & $\begin{array}{l}\text { Disposições da } \\
\text { alma }\end{array}$ & $\begin{array}{l}\text { Apreciar, Prezar, } \\
\text { Regozijar } \\
\text { (Meditarei em seus } \\
\text { mandamentos, que } \\
\text { muito estimo). } \\
\text { Celebração e } \\
\text { Exaltação (E } \\
\text { levantarei as mãos } \\
\text { para os seus } \\
\text { honrados } \\
\text { mandamentos). }\end{array}$ & 30-42 S-A-T-B \\
\hline
\end{tabular}

Tabela 20: Locus Topici encontrados no Ofertório da Missa do Segundo Domingo da Quaresma de André da Silva Gomes 


\subsection{Dispositio}

\subsubsection{Exordium}

Nos cinco primeiros compassos, na primeira seção, são aplicadas pelo autor figuras de repetição melódica, tais como Anaphora, Epizeuxis e Palilogia, repetindo e enfatizando, a primeira frase do texto, Meditabor in mandatis tuis (Meditarei em seus mandamentos), igualmente observa-se o emprego da Circulatio descrevendo uma formação circular das notas, destacando o Mi, Sol e Si bemol, valorando as funções da Tônica, Subdominante e Dominante até sua resolução na Cadência Autêntica Imperfeita.

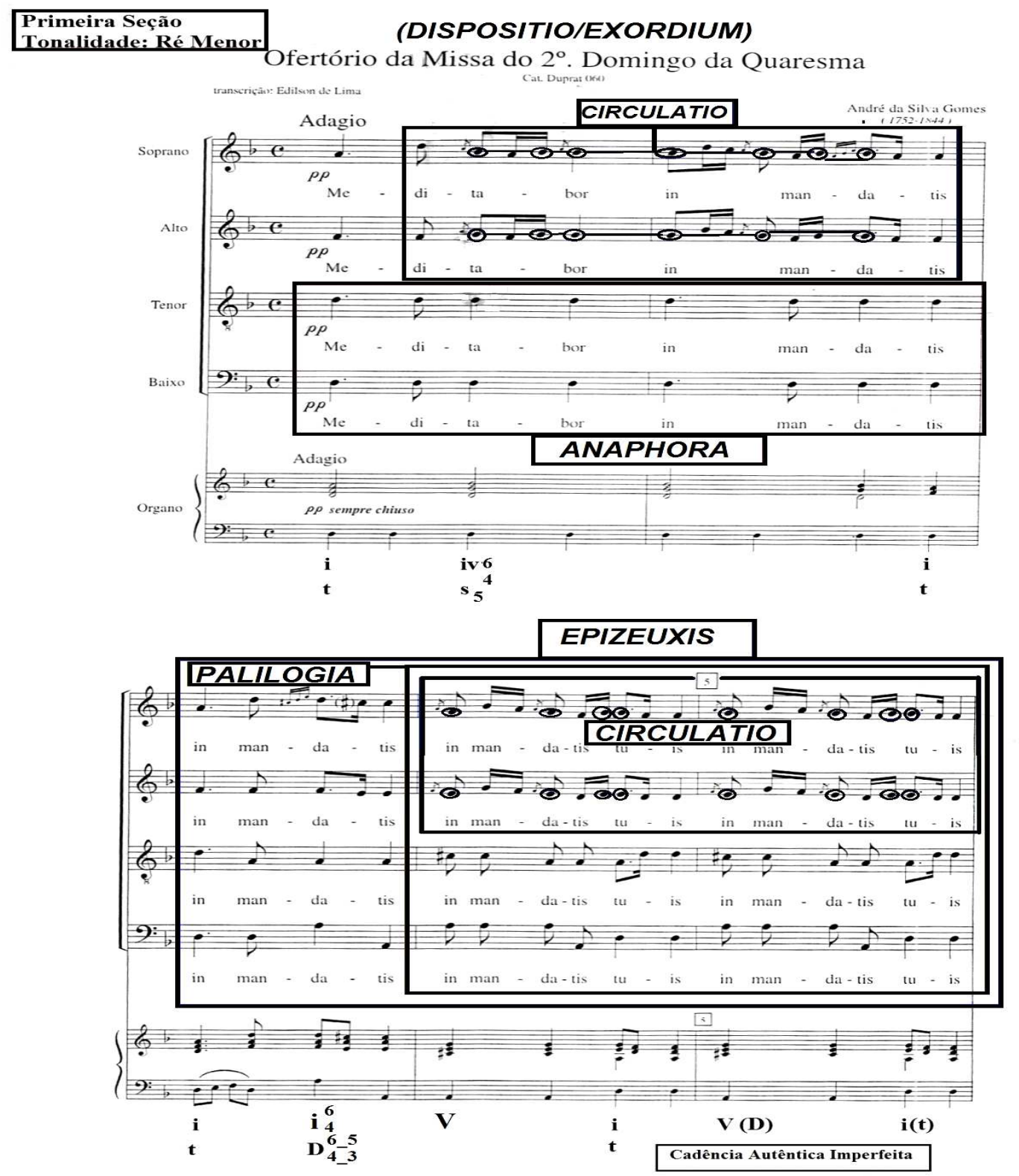

Exemplo 39: Ofertório da Missa do Segundo Domingo da Quaresma de André da Silva Gomes- Catalogação e Organização Régis Duprat (DUPRAT, 1999, p.92). 


\subsubsection{Narratio}

A Narratio inicia com a inserção da Variatio, no solo da soprano, com o intuito de variar a ornamentação melódica, por meio de apogiaturas curtas, também nota-se o uso da Pausa determinando um período de repouso as outras vozes e por fim a Synonimia ressaltando com sua repetição, as palavras in mandatis tuis.
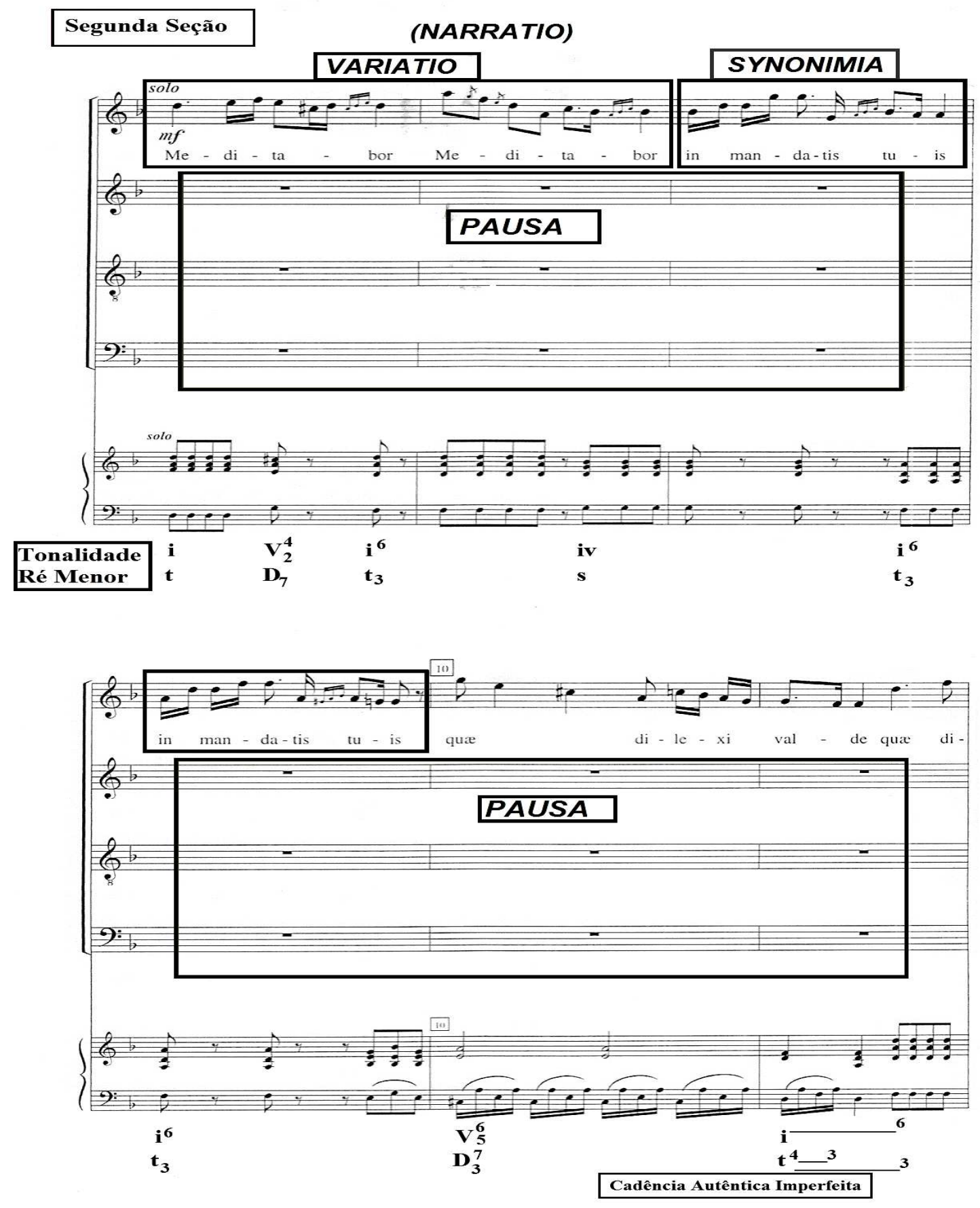

Exemplo 40: Ofertório da Missa do Segundo Domingo da Quaresma de André da Silva Gomes- Catalogação e Organização Régis Duprat (DUPRAT, 1999, p.93). 
É observável a mesma figura utilizada anteriormente nos compassos 6 e 7 , variando melodicamente e ritmicamente as notas.

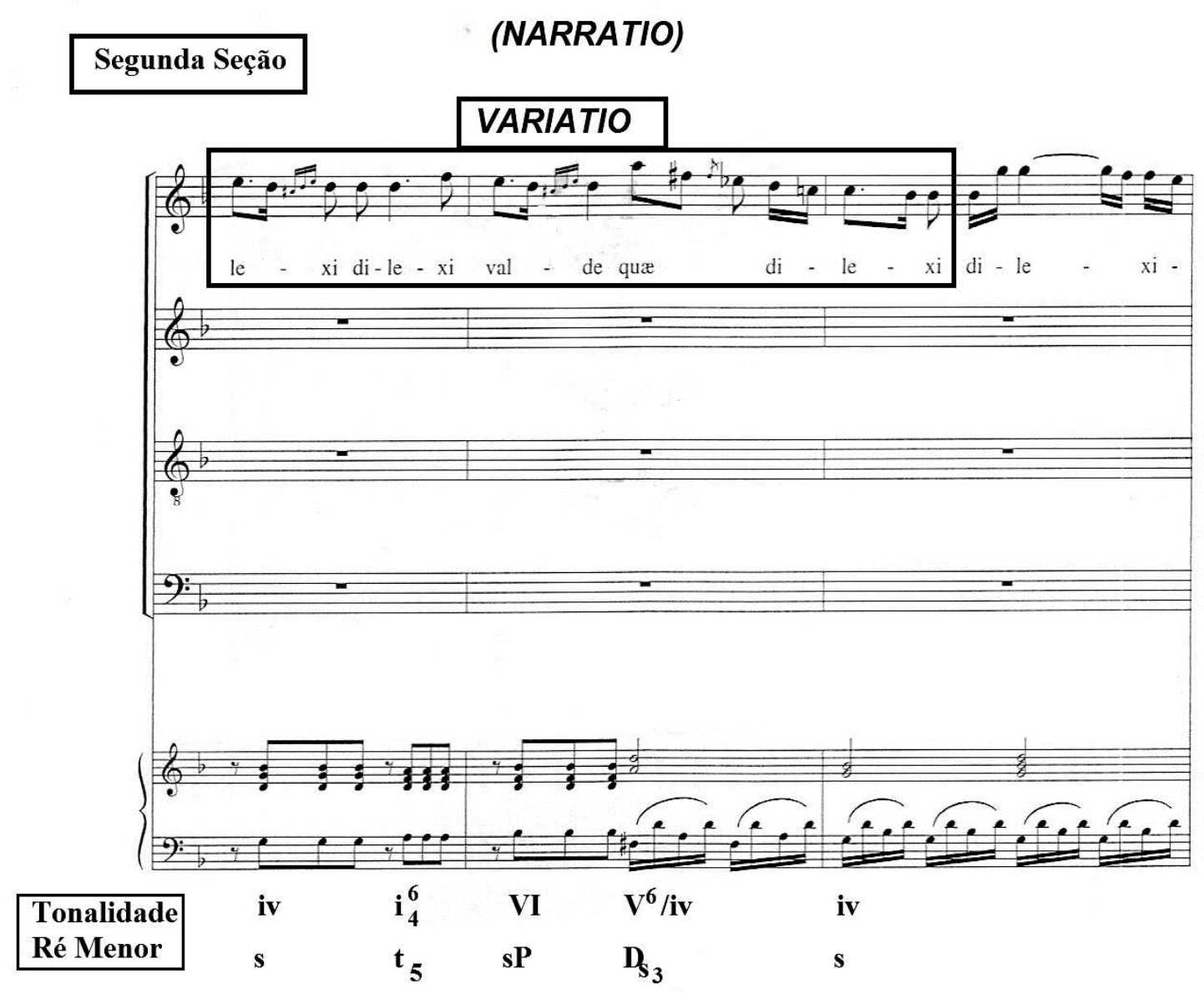

Exemplo 41: Ofertório da Missa do Segundo Domingo da Quaresma de André da Silva Gomes- Catalogação e Organização Régis Duprat (DUPRAT, 1999, p.94).

A segunda fase da Dispositio se encerra com a introdução de mais duas novas figuras, Synaeresis onde duas notas são entoadas na mesma silaba e a Acciaccatura, que além de representar as breves apogiaturas, é usada por Silva Gomes na resolução das notas dissonantes em consonantes após sua execução, de Dó para Si bemol na Dominante da Subdominante (Ré Maior), depois resolvida na Subdominante (Sol Menor) e Si bemol para Lá na Tônica (Ré Menor), tendo por objetivo não apenas em apresentar ao ouvinte todos esses mecanismos persuasivos através dos elementos retóricos, mas transmitir a ideia da Laetitia representada pelos afetos de devoção, meditação e atenção. 


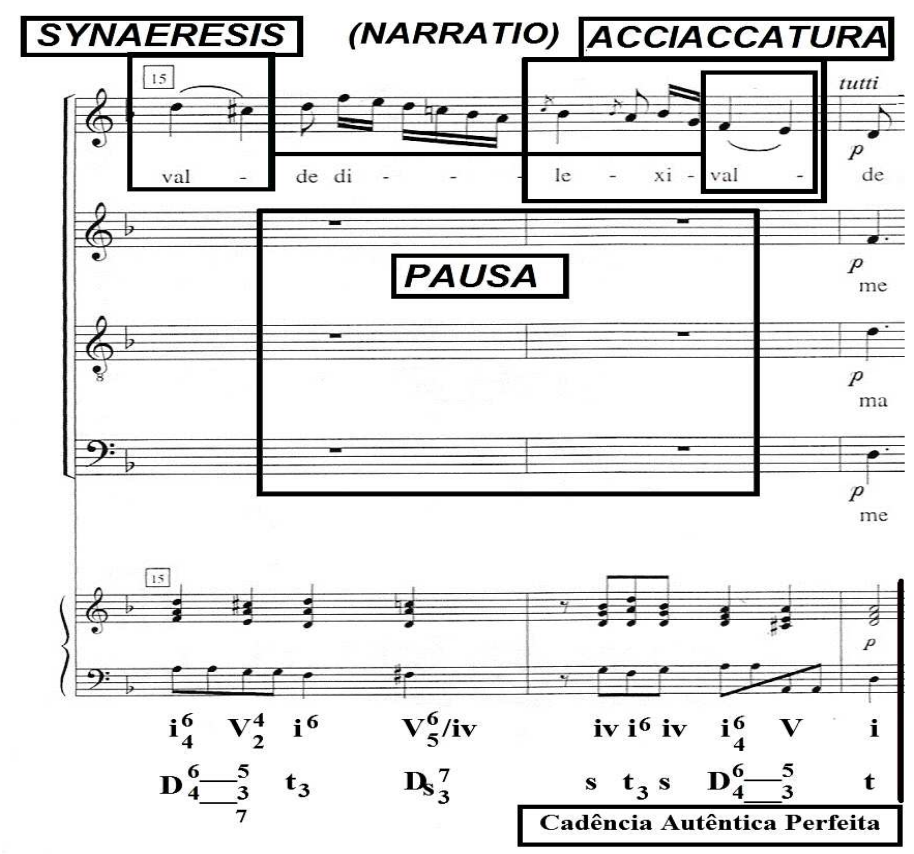

Exemplo 42: Ofertório da Missa do Segundo Domingo da Quaresma de André da Silva Gomes- Catalogação e Organização Régis Duprat (DUPRAT, 1999, p.94).

\subsubsection{Propositio}

Depois da conclusão da Narratio no início do compasso 16 na Cadência Autêntica Perfeita, pode-se verificar o uso da Circulatio, destacando as notas $\mathrm{Si}$ bemol e Sol, ou seja, as que formam o acorde da Subdominante. Igualmente é usada a Acciaccatura, dessa vez, além de serem entoadas as notas do acorde de Sol Menor, Ré, Sol, Si bemol, temos a presença do Fá sustenido, reforçando a dissonância até sua resolução em Sol.

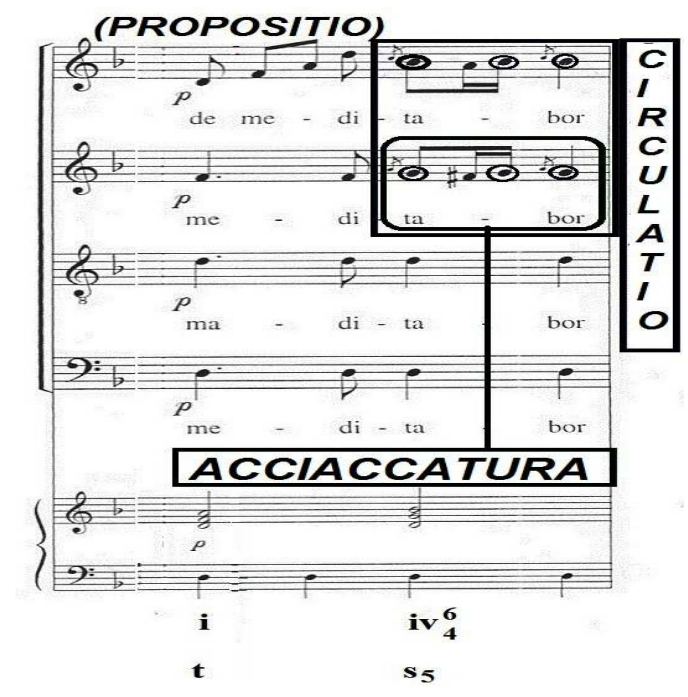

Exemplo 43: Ofertório da Missa do Segundo Domingo da Quaresma de André da Silva Gomes- Catalogação e Organização Régis Duprat (DUPRAT, 1999, p.94). 
Próprio da Propositio, o autor de forma sucinta esboça a tese inicial, utilizando as mesmas figuras: Epizeuxis, Circulatio e Anaphora, ressaltando três vezes a palavra, in mandatis tuis (teus mandamentos), estabelecendo desse modo, consonância ao sentimento cristão de ler, observar, prezar os estatutos e os mandamentos das Escrituras Sagradas, demostrando sua habilidade na manutenção da coesão e disposição do discurso.
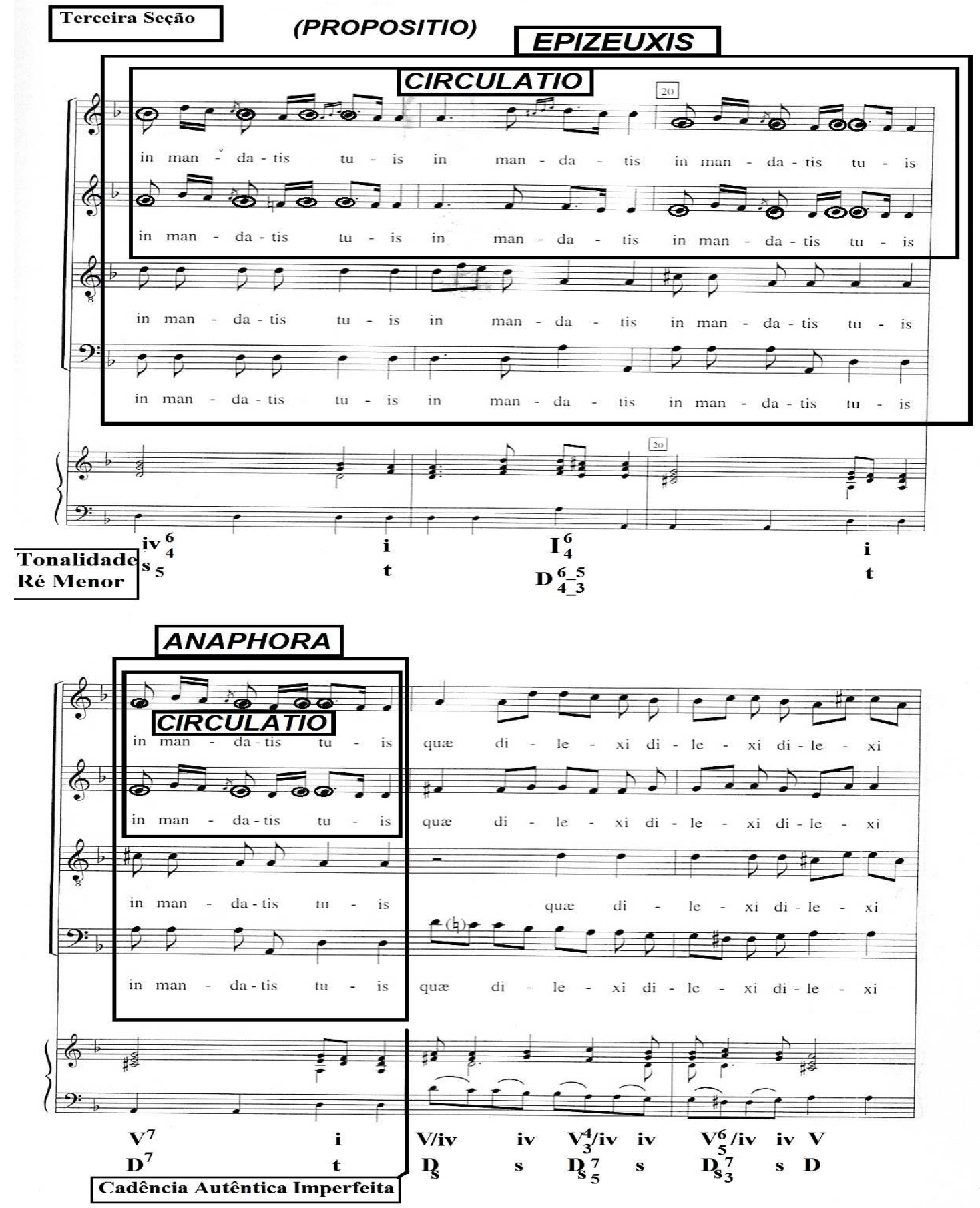

Exemplo 44: Ofertório da Missa do Segundo Domingo da Quaresma de André da Silva Gomes- Catalogação e Organização Régis Duprat (DUPRAT, 1999, p.95). 


\subsubsection{Confutatio}

Além da quarta seção e parte discursiva da obra, é tangível o emprego da Synaeresis no final da Pronuntatio, como o uso da Sexta Aumentada Italiana, não só antecipando a Dominante na Semicadência, mas já preparando os materiais contrastantes, além da refutação dos argumentos expostos anteriormente no ofertório. Há de se ressaltar também o emprego das figuras de Palilogia, Circulatio e da supracitada Synaeresis.

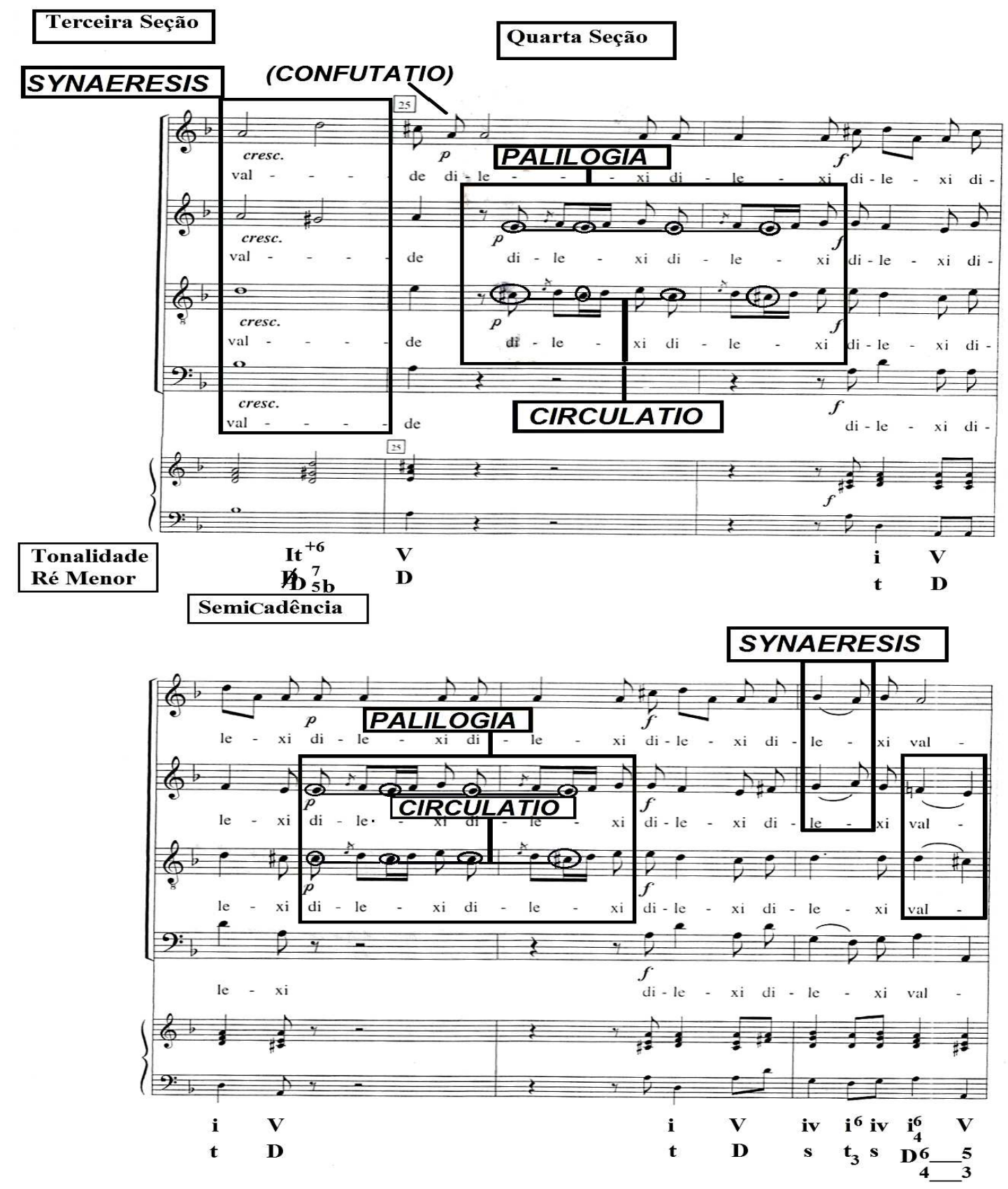

Exemplo 45: Ofertório da Missa do Segundo Domingo da Quaresma de André da Silva Gomes- Catalogação e Organização Régis Duprat (DUPRAT, 1999, p.96). 
Observa-se na Confutatio, o incremento da Anabasis em passagem melódica ascendente expressando o afeto de pensamentos elevados, $E t$ levabo manus (E levantarei as mãos). Semelhantemente é visível a Synaeresis na voz da contralto e do tenor, a Pausa no baixo, como a modulação para a relativa maior (Fá Maior) e a quinta seção.

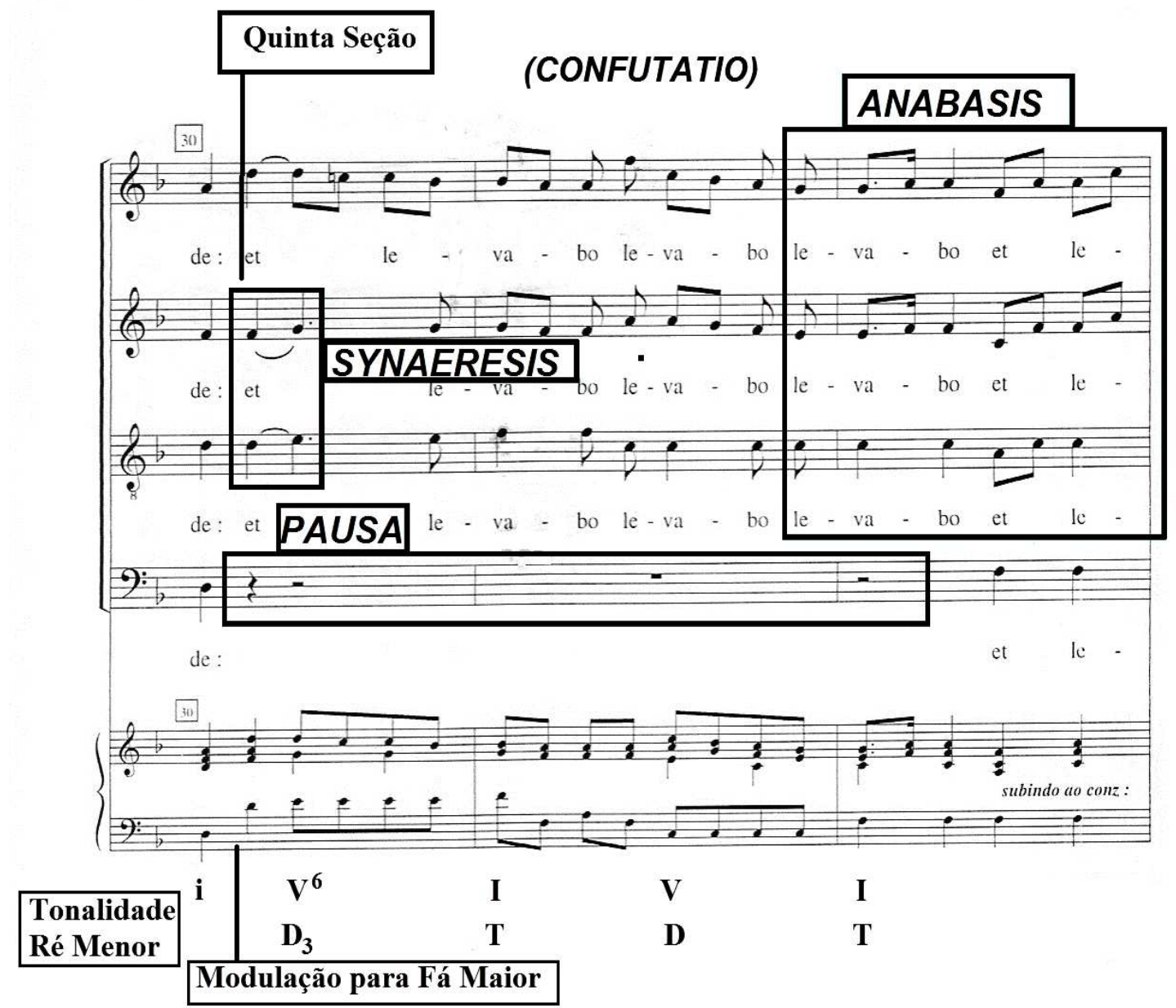

Exemplo 46: Ofertório da Missa do Segundo Domingo da Quaresma de André da Silva Gomes- Catalogação e Organização Régis Duprat (DUPRAT, 1999, p.97).

Entre os compassos 33 e 35, Silva Gomes continua a aplicar à figura da Anabasis, enfatizado a ideia de exultação e celebração, igualmente verifica-se o retorno à tonalidade principal da obra, por meio de modulação. 


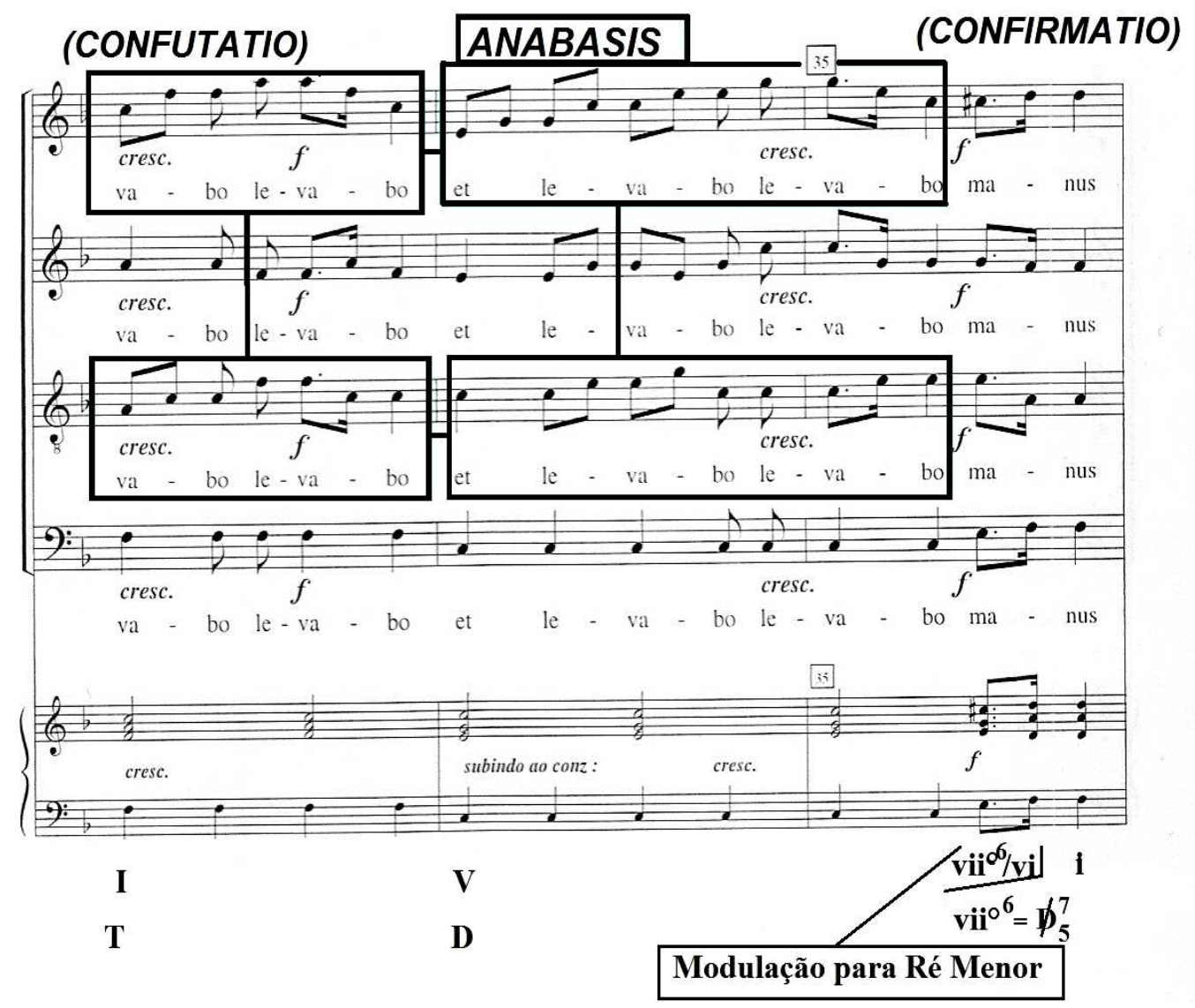

Exemplo 47: Ofertório da Missa do Segundo Domingo da Quaresma de André da Silva Gomes- Catalogação e Organização Régis Duprat (DUPRAT, 1999, p.97).

\subsubsection{Confirmatio}

$\mathrm{Na}$ Confirmatio, têm-se a confirmação das ideias iniciais já expostas desde as quatro fases anteriores, através da frase manus meas ad mandata tua (as mãos para os seus mandamentos), representada pela Auxesis, repetindo sucessivamente as notas dessa passagem musical, culminando em numa suspensão na Semicadência. 


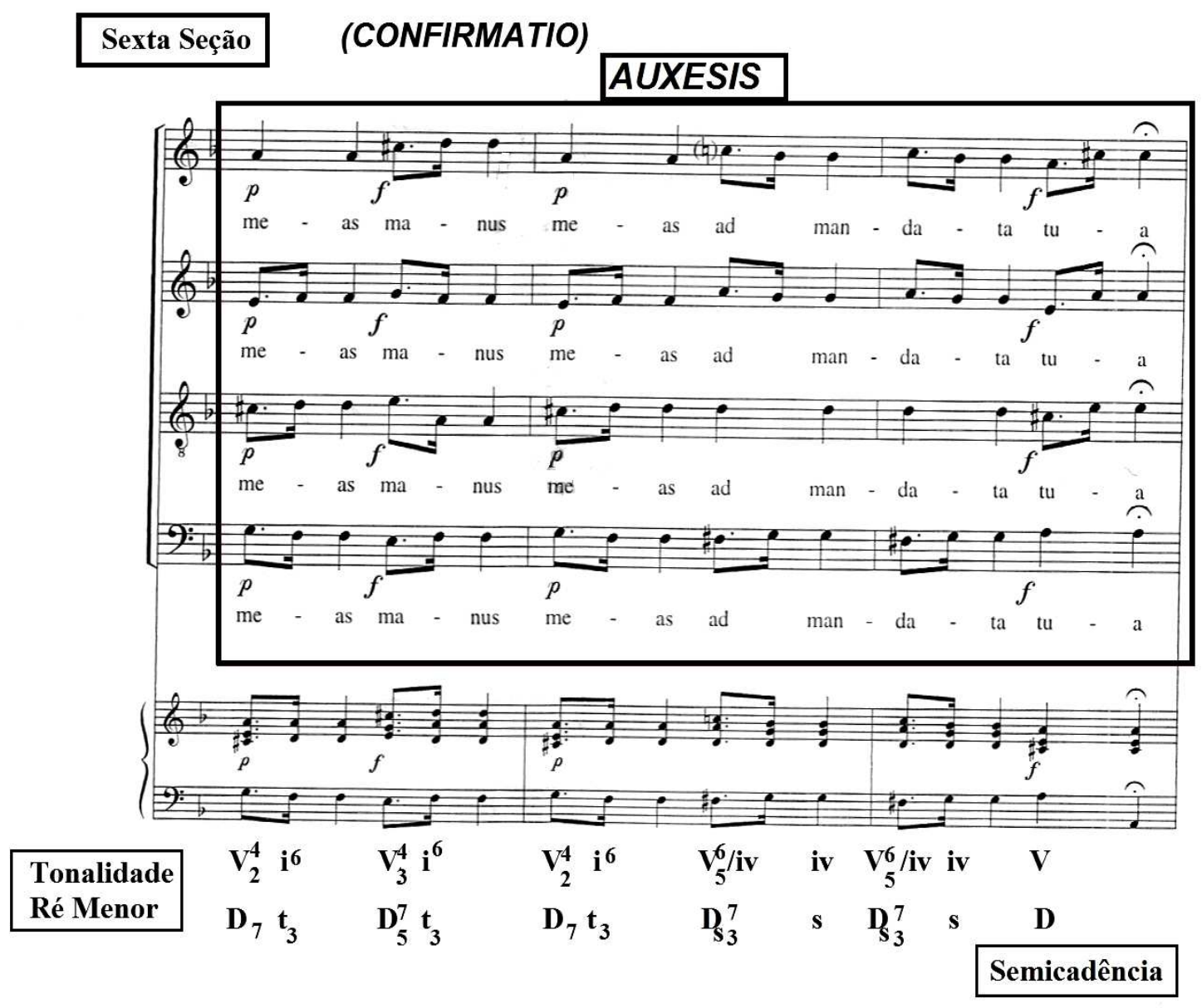

Exemplo 48: Ofertório da Missa do Segundo Domingo da Quaresma de André da Silva Gomes- Catalogação e Organização Régis Duprat (DUPRAT, 1999, p.98).

\subsubsection{Perotatio}

$\mathrm{Na}$ conclusão do ofertório, há a ocorrência de algo inesperado, o uso da Suspiratio, que, através de suspiros enfatiza as notas, por meio das pausas, como também da Cadência de Engano, no compasso 39, na Subdominante paralela rompendo com a formulação do raciocínio lógico da resolução terminativa na Tônica, assim caracterizando uma pequena Confutatio dentro da Perotatio, todavia, André da Silva Gomes, conduz o discurso de maneira mais enfática, destacando três vezes a frase quae dilexi, inserindo a Synaeresis com o intento de finalizar o discurso em forma de epílogo, apropriando-se de uma Coda, nos compassos 41-42 na Cadência Final em Ré Maior (Picarda). 
(CONFUTATIO dentro da PEROTATIO) SUSPIRATIO Molto Adagio SYNAERESIS

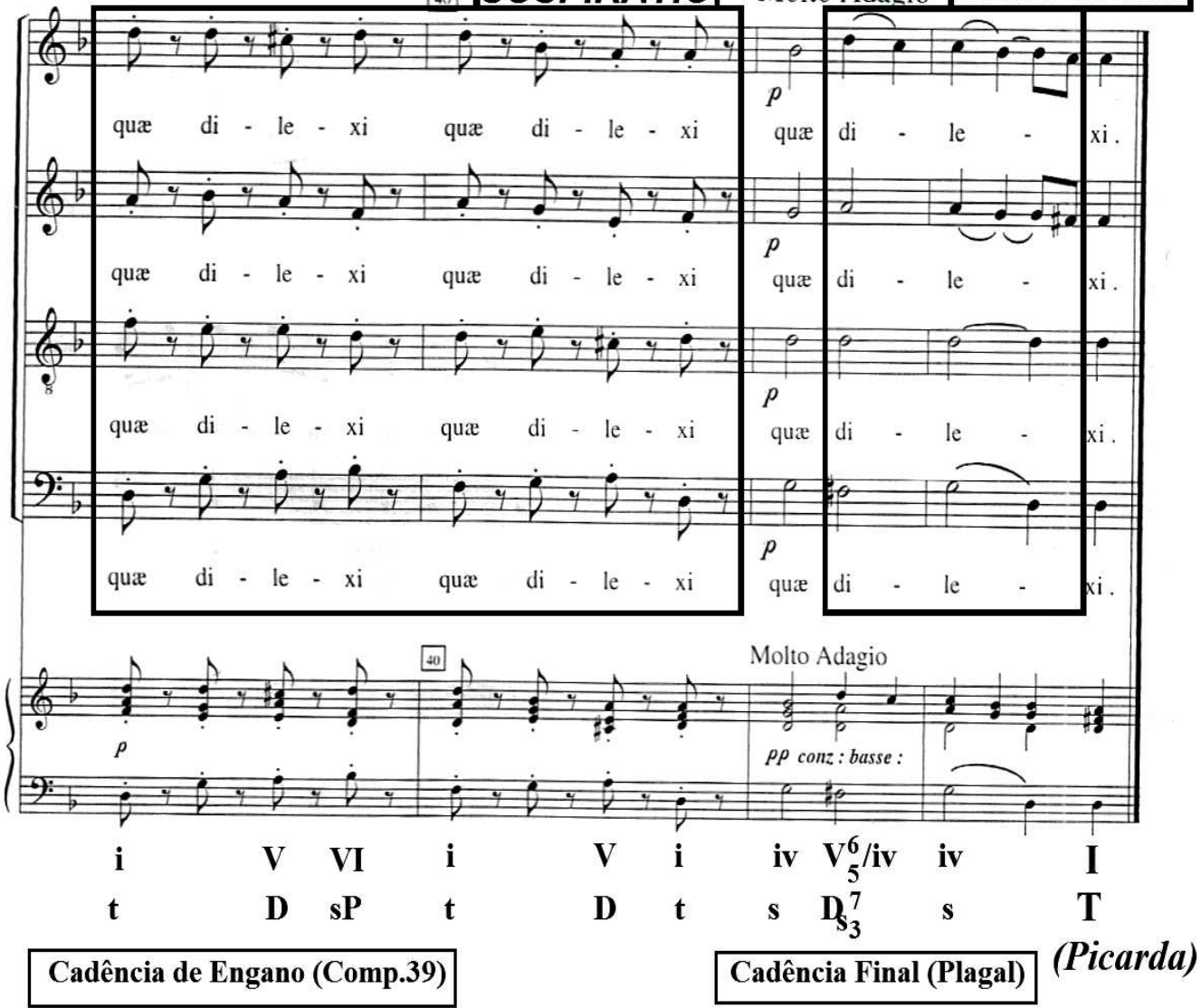

Exemplo 49: Ofertório da Missa do Segundo Domingo da Quaresma de André da Silva Gomes- Catalogação e Organização Régis Duprat (DUPRAT, 1999, p.98).

\subsection{Figuras observadas no Ofertório (Elocutio/Decoratio)}

\begin{tabular}{|c|c|c|c|c|}
\hline \multicolumn{2}{|l|}{ FIGURAS } & TIPO & DESCRIÇÃO & TRATADISTA \\
\hline \multicolumn{2}{|c|}{ ACCIACCATURA } & Ornamentação & Uma nota & Walther: \\
\hline $\begin{array}{l}\text { (BARTEL, } \\
\text { pp.176-178). }\end{array}$ & 1997 & $\begin{array}{ll}\text { Melódica } & \text { e } \\
\text { Harmônica }\end{array}$ & $\begin{array}{l}\text { dissonante } \\
\text { adicionada ao } \\
\text { acorde, que é } \\
\text { imediatamente } \\
\text { resolvida após } \\
\text { sua execução. }\end{array}$ & $\begin{array}{l}\text { Acciaccatura ocorre } \\
\text { quando, por } \\
\text { exemplo, além de } \\
\text { tocar as notas } \\
\text { pertencentes ao } \\
\text { acorde de Sol (d, g, } \\
\text { b) o Fá sustenido } \\
\text { poderá } \\
\text { incluído tal como o } \\
\text { mordente. }\end{array}$ \\
\hline $\begin{array}{l}\text { ANAPHORA } \\
\text { (BARTEL, }\end{array}$ & 1997, & $\begin{array}{l}\text { Repetição } \\
\text { Melódica }\end{array}$ & $\begin{array}{l}\text { (1) É uma linha } \\
\text { do baixo } \\
\text { repetida em } \\
\text { forma de solo. } \\
\text { (2) A repetição }\end{array}$ & $\begin{array}{l}\text { Thuringus: } \mathrm{O} \text { que } \\
\text { é uma Anáfora? É a } \\
\text { repetição } \\
\text { continuada apenas } \\
\text { no Baixo. }\end{array}$ \\
\hline
\end{tabular}




\begin{tabular}{|c|c|c|c|}
\hline pp.184-190). & & $\begin{array}{l}\text { de uma } \\
\text { exposição } \\
\text { melódica sobre } \\
\text { notas e partes } \\
\text { diferentes. } \\
\text { Também pode } \\
\text { ocorrer no iní́io } \\
\text { das repetições } \\
\text { de frases e } \\
\text { motivos em } \\
\text { uma série de } \\
\text { passagens } \\
\text { sucessivas; (3) } \\
\text { Uma repetição } \\
\text { em geral. }\end{array}$ & $\begin{array}{l}\text { Walther: É uma } \\
\text { figura de repetição } \\
\text { e pode ocorrer de } \\
\text { duas maneiras: } \\
\text { 1. Quando uma } \\
\text { palavra é } \\
\text { repetidaran } \\
\text { frequentemente } \\
\text { em a uma } \\
\text { composição para } \\
\text { dar maior ênfase. } \\
\text { 2. Quando as notas } \\
\text { graves sano } \\
\text { repetidas sas } \\
\text { inúmeras vezes } \\
\text { (como o caso } \\
\text { das Chaconne). }\end{array}$ \\
\hline $\begin{array}{l}\text { ANABASIS } \\
\text { (BARTEL, 1997, } \\
\text { pp.179-180). }\end{array}$ & $\begin{array}{l}\text { Representação } \\
\text { e Descrição }\end{array}$ & $\begin{array}{l}\text { Uma passagem } \\
\text { musical } \\
\text { ascendente, } \\
\text { que expressa } \\
\text { exaltação ou } \\
\text { imagens } \\
\text { positivas dos } \\
\text { afetos. }\end{array}$ & $\begin{array}{l}\text { Vogt: A Anabasis é } \\
\text { uma passagem } \\
\text { musical da qual } \\
\text { expressamos } \\
\text { pensamentos } \\
\text { elevados através } \\
\text { da voz e texto ou } \\
\text { de ascensão como } \\
\text { em: Ele subiu ao } \\
\text { céu. } \\
\text { (No caso desta } \\
\text { obra ro os } \\
\text { pensamentos } \\
\text { elevados podem } \\
\text { ser observados na } \\
\text { frase: "Et levado } \\
\text { manus"E levantarei } \\
\text { minhas mãos. }\end{array}$ \\
\hline $\begin{array}{l}\text { AUXESIS } \\
\text { (BARTEL, 1997, pp. } \\
\text { 209-212). }\end{array}$ & $\begin{array}{l}\text { Repetição } \\
\text { Melódica }\end{array}$ & $\begin{array}{l}\text { São repetições } \\
\text { sucessivas de } \\
\text { uma passagem } \\
\text { musical. }\end{array}$ & $\begin{array}{l}\text { Burmeister: A } \\
\text { Auxesis ocorre } \\
\text { quando uma } \\
\text { harmonia composta } \\
\text { por combinações } \\
\text { consonantes se } \\
\text { desenvolve de } \\
\text { forma crescente em } \\
\text { um texto que é } \\
\text { repetido uma, duas, } \\
\text { três ou mais vezes. } \\
\text { Portanto, ela pode } \\
\text { ser caracterizada } \\
\text { por uma elevação }\end{array}$ \\
\hline
\end{tabular}




\begin{tabular}{|c|c|c|c|c|}
\hline & & & & $\begin{array}{l}\text { com incremento na } \\
\text { altura de um } \\
\text { Noema repetido. }\end{array}$ \\
\hline $\begin{array}{l}\text { CIRCULATIO } \\
\text { (BARTEL, } \\
\text { pp.216-219). } \\
\text { (BUELOW, } \\
\text { p.798). }\end{array}$ & 1997 & $\begin{array}{l}\text { Representação } \\
\text { e Descrição }\end{array}$ & $\begin{array}{l}\text { Uma série de } \\
\text { notas } \\
\text { (geralmente } \\
\text { oito) em uma } \\
\text { formação } \\
\text { circular ou de } \\
\text { ondas } \\
\text { senoidais. } \\
\text { Também pode } \\
\text { ser definida } \\
\text { como uma linha } \\
\text { melódica que } \\
\text { oscila ao redor } \\
\text { de uma nota }\end{array}$ & $\begin{array}{l}\text { Walther: O circulo } \\
\text { que ocorre de duas } \\
\text { maneiras: } \\
\text { 1. Como uma forma } \\
\text { dupla, que ainda } \\
\text { é encontrada nas } \\
\text { composições } \\
\text { antigas, isto é, } \\
\text { como uma } \\
\text { assinatura de } \\
\text { tempo após a } \\
\text { clave. a dois } \\
\text { 2. Quando a } \\
\text { Circoli Mezzi são } \\
\text { combinados e } \\
\text { seguem um ao } \\
\text { outro de tal forma } \\
\text { que, eles devem } \\
\text { ser sobrepostos } \\
\text { entre si, eles } \\
\text { representam } \\
\text { visualmente um } \\
\text { círculo completo. }\end{array}$ \\
\hline $\begin{array}{l}\text { EPIZEUXIS } \\
\text { (BARTEL, } \\
\text { pp.263-265). }\end{array}$ & 1997 & $\begin{array}{l}\text { Repetição } \\
\text { Melódica }\end{array}$ & $\begin{array}{l}\text { Uma repetição } \\
\text { imediata e } \\
\text { enfática de uma } \\
\text { palavra, nota, } \\
\text { motivo ou frase. }\end{array}$ & $\begin{array}{l}\text { Walther: } \\
\text { epizeuxis é uma } \\
\text { figura de retórica } \\
\text { pela qual uma ou } \\
\text { mais palavras são } \\
\text { imediatamente e } \\
\text { enfaticamente } \\
\text { repetidas. }\end{array}$ \\
\hline $\begin{array}{l}\text { NOEMA } \\
\text { (BARTEL, } \\
\text { p.339-342). }\end{array}$ & 1997, & $\begin{array}{l}\text { Representação } \\
\text { e Descrição }\end{array}$ & $\begin{array}{l}\text { Uma passagem } \\
\text { homofônica em } \\
\text { uma textura } \\
\text { contrapontística } \\
\text { e polifônica. }\end{array}$ & $\begin{array}{l}\text { Burmeister: A } \\
\text { Noema representa } \\
\text { o afeto harmônico, } \\
\text { onde as vozes } \\
\text { combinadas têm } \\
\text { valores e números } \\
\text { de notas } \\
\text { semelhantes. } \\
\text { Quando introduzida } \\
\text { adequadamente, } \\
\text { isto é, no momento } \\
\text { certo, ela afeta }\end{array}$ \\
\hline
\end{tabular}




\begin{tabular}{|c|c|c|c|}
\hline $\begin{array}{l}\text { (BUELOW, 1980, } \\
\text { p.799). }\end{array}$ & & & $\begin{array}{l}\text { docemente os } \\
\text { ouvidos do ouvinte, } \\
\text { produzindo uma } \\
\text { sensação de calma } \\
\text { e serenidade. } \\
\text { Seção homofônica, } \\
\text { dentro da polifonia } \\
\text { utilizada para } \\
\text { enfatizar o texto. }\end{array}$ \\
\hline $\begin{array}{l}\text { PALILOGIA } \\
\text { (BARTEL, } \\
\text { pp.342-344). }\end{array}$ & $\begin{array}{l}\text { Repetição } \\
\text { Melódica }\end{array}$ & $\begin{array}{l}\text { Repetição de } \\
\text { um tema no } \\
\text { mesmo nível de } \\
\text { altura, também } \\
\text { pode ocorrer } \\
\text { em alturas } \\
\text { diferentes na } \\
\text { mesma ou em } \\
\text { várias vozes. }\end{array}$ & 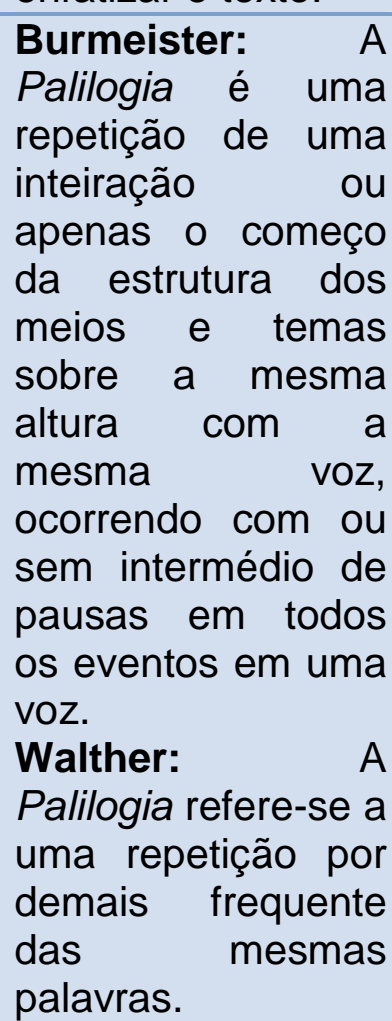 \\
\hline $\begin{array}{l}\text { PAUSA } \\
\text { (BARTEL, } \\
\text { pp.362-365). }\end{array}$ & $\begin{array}{l}\text { Interrupção e } \\
\text { Silêncio }\end{array}$ & $\begin{array}{l}\text { Uma pausa ou } \\
\text { descanso em } \\
\text { uma } \\
\text { composição } \\
\text { musical }\end{array}$ & $\begin{array}{l}\text { Walther: Uma } \\
\text { figura ou figuras de } \\
\text { silêncio. Pausa } \\
\text { refere-se a um } \\
\text { período de repouso } \\
\text { ou o silêncio na } \\
\text { música, que é } \\
\text { indicado por um } \\
\text { determinado sinal. }\end{array}$ \\
\hline $\begin{array}{l}\text { SUSPIRATIO } \\
\text { (BARTEL, 1997, pp. } \\
\text { 392-394) }\end{array}$ & $\begin{array}{l}\text { Interrupção e } \\
\text { Silêncio }\end{array}$ & $\begin{array}{l}\text { Expressão } \\
\text { musical de um } \\
\text { suspiro, através } \\
\text { de pausas. }\end{array}$ & $\begin{array}{lr}\text { Kircher: } & \text { A } \\
\text { Stenasmus ou } \\
\text { Suspiratio lembram } \\
\text { os afetos } \\
\text { naturalmente } \\
\text { expressados por } \\
\text { vários suspiros } \\
\text { criados através de } \\
\text { pausas. }\end{array}$ \\
\hline
\end{tabular}




\begin{tabular}{|c|c|c|c|c|}
\hline $\begin{array}{l}\text { SYNAERESIS } \\
\text { (BARTEL, } \\
\text { pp.394-396). }\end{array}$ & 1997, & $\begin{array}{l}\text { Dissonância e } \\
\text { Deslocamento }\end{array}$ & $\begin{array}{l}\text { (1) Uma } \\
\text { suspensão ou } \\
\text { síncope, (2) a } \\
\text { colocação de } \\
\text { duas sílabas } \\
\text { por nota ou } \\
\text { duas notas por } \\
\text { sílaba. }\end{array}$ & $\begin{array}{llr}\text { Vogt: A Synaeresis } \\
\text { ocorre quando duas } \\
\text { notas } & \text { são } \\
\text { colocadas em uma } \\
\text { sílaba ou duas } \\
\text { sílabas r são } \\
\text { colocadas em uma } \\
\text { nota. }\end{array}$ \\
\hline $\begin{array}{l}\text { SYNONYMIA } \\
\text { (BARTEL, } \\
\text { pp.405-407). }\end{array}$ & 1997 & $\begin{array}{l}\text { Repetição } \\
\text { Melódica }\end{array}$ & $\begin{array}{l}\text { É a repetição } \\
\text { de uma ideia } \\
\text { musical em } \\
\text { forma alterada } \\
\text { ou modificada. }\end{array}$ & 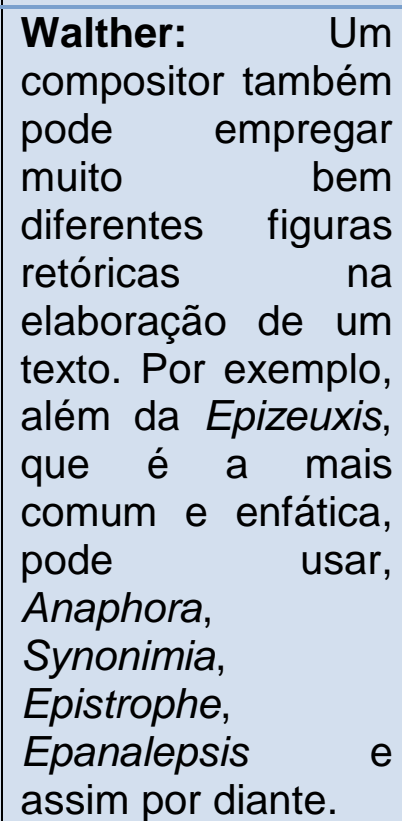 \\
\hline $\begin{array}{l}\text { VARIATIO } \\
\text { (BARTEL, } \\
\text { pp.432-438). }\end{array}$ & 1997, & $\begin{array}{l}\text { Ornamentação } \\
\text { Melódica e } \\
\text { Harmônica }\end{array}$ & $\begin{array}{l}\text { Ornamentação } \\
\text { de uma } \\
\text { passagem } \\
\text { melódica com } \\
\text { uma variedade } \\
\text { de } \\
\text { embelezamento } \\
\text { s (decorações). }\end{array}$ & $\begin{array}{l}\text { Printz: A palavra } \\
\text { Variatio é usada de } \\
\text { duas r maneiras } \\
\text { pelos músicos, ou } \\
\text { seja, tanto no } \\
\text { sentido amplo e } \\
\text { estrito. Em um } \\
\text { sentido estrito, } \\
\text { variatio refere-se a } \\
\text { uma alteração } \\
\text { artística (figuração) } \\
\text { de } 5 \text { uma } \\
\text { determinada r } \\
\text { passagem rer } \\
\text { melódica, mas em } \\
\text { que a melodia } \\
\text { original é sempre } \\
\text { percebida ra e } \\
\text { reconhecida. Em } \\
\text { um sentido amplo, } \\
\text { Variatio significa } \\
\text { qualquer tipo de } \\
\text { alteração de um } \\
\text { trecho melódico se }\end{array}$ \\
\hline
\end{tabular}




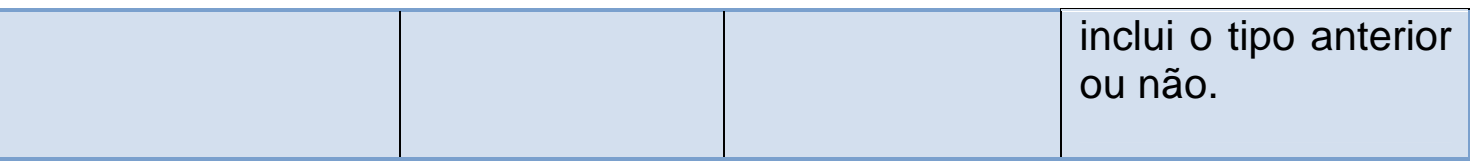

Tabela 21: Figuras encontradas no Ofertório da Missa do Segundo Domingo da Quaresma de André da Silva Gomes

\section{Análise Harmônica}

\subsection{Curva Tonal}

Tonalidade: Ré Menor

Andamento: Adagio 4/4

Esquema de Progressões Harmônicas

\begin{tabular}{|l|c|l|}
\hline Compassos & $\begin{array}{l}\text { Função em relação a } \\
\text { tonalidade principal }\end{array}$ & Tonalidade (Acorde) \\
\hline $1-13$ & $\mathrm{t}-\mathrm{i}$ & Ré Menor \\
\hline $13-14$ & $\mathrm{~s}-\mathrm{iv}$ & Sol Menor \\
\hline 15 & $\mathrm{t}-\mathrm{i}$ & Ré Menor \\
\hline $15-16$ & $\mathrm{~s}-\mathrm{iv}$ & Sol Menor \\
\hline $16-21$ & $\mathrm{t}-\mathrm{i}$ & Ré Menor \\
\hline $22-23$ & $\mathrm{~s}-\mathrm{i} \mathrm{V}$ & Sol Menor \\
\hline $24-25$ & $\mathrm{D}-\mathrm{V}$ & Lá Maior \\
\hline $26-30$ & $\mathrm{t}-\mathrm{i}$ & Ré Menor \\
\hline $30-35$ & $\mathrm{tP}-\mathrm{III}$ & Fá Maior \\
\hline $35-37$ & $\mathrm{t}-\mathrm{i}$ & Ré Menor \\
\hline $37-38$ & $\mathrm{~s}-\mathrm{iv}$ & Sol Menor \\
\hline $39-41$ & $\mathrm{t}-\mathrm{i}$ & Ré Menor \\
\hline $41-42$ & $\mathrm{~s}-\mathrm{iv}$ & Sol Menor \\
\hline 42 & $\mathrm{~T}-\mathrm{I}$ (Picarda) & Ré Maior \\
\hline
\end{tabular}

Tabela 22: Curva Tonal do Ofertório da Missa do Segundo Domingo da Quaresma

Números de compassos: 42

Regiões abordadas: 5

Variações: 14

Ritmo Harmônico: 3 (divisão dos números de compassos e variações)

Média ideal: (divisão dos números de compassos e regiões tonais abordadas = $8,4)$ 
Esquema Formal

$(1-30)(30-35)(35-42)$

$t \quad t P \quad T$

i III I

2.2. Estrutura Analítica do Ofertório: Retórica e Harmônica

\begin{tabular}{|c|c|c|c|c|c|}
\hline $\begin{array}{l}\text { RETÓRICA } \\
\text { DISPOSITIO }\end{array}$ & $\begin{array}{l}\text { FIGURA } \\
\text { ELOCUTIO }\end{array}$ & COMP. & $\begin{array}{l}\text { HARMÓNICA } \\
\text { SEÇÃO }\end{array}$ & TONALIDADE & FUNÇĀO \\
\hline EXORDIUM & $\begin{array}{l}\text { Anaphora } \\
\text { Circulatio } \\
\text { Epizeuxis } \\
\text { Palilogia }\end{array}$ & $\begin{array}{l}1-2 \\
1-2 ; 4-5 \\
3-5 \\
4-5\end{array}$ & $\begin{array}{l}1^{\text {a }} \text { Seção } \\
1^{\text {a }} \text { Seção } \\
1^{\text {a }} \text { Seção } \\
1^{\text {a Seção }}\end{array}$ & $\begin{array}{l}\text { Ré Menor } \\
\text { Ré Menor } \\
\text { Ré Menor } \\
\text { Ré Menor }\end{array}$ & $\begin{array}{l}t-i \\
t-i \\
t-i \\
t-i\end{array}$ \\
\hline NARRATIO & $\begin{array}{l}\text { Pausa } \\
\text { Variatio } \\
\text { Synonimia } \\
\text { Synaeresis } \\
\text { Acciaccatura }\end{array}$ & $\begin{array}{l}6-16 \\
6-7 \text { e } \\
13-14 \\
8-9 \\
15-16 \\
16\end{array}$ & 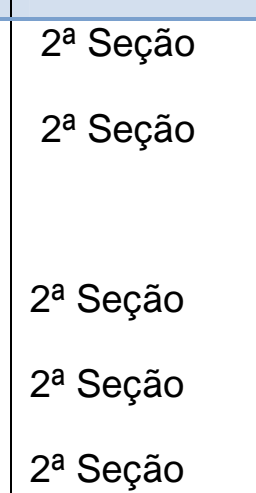 & $\begin{array}{l}\text { Ré Menor } \\
\text { Ré Menor } \\
\text { Ré Menor } \\
\text { Ré Menor } \\
\text { Ré Menor }\end{array}$ & $\begin{array}{l}t-i \\
t-i \\
t-i\end{array}$ \\
\hline PROPOSITIO & $\begin{array}{l}\text { Circulatio } \\
\text { Acciaccatura } \\
\text { Epizeuxis } \\
\text { Anaphora } \\
\text { Synaeresis }\end{array}$ & $\begin{array}{l}17-21 \\
18 \\
18-20 \\
21 \\
24\end{array}$ & $\begin{array}{l}3^{a} \text { Seção } \\
3^{a} \text { Seção } \\
3^{a} \text { Seção } \\
3^{a} \text { Seção } \\
3^{\text {a Seção }}\end{array}$ & $\begin{array}{l}\text { Ré Menor } \\
\text { Ré Menor } \\
\text { Ré Menor } \\
\text { Ré Menor } \\
\text { Ré Menor }\end{array}$ & $\begin{array}{l}t-i \\
t-i \\
t-i \\
t-i \\
t-i\end{array}$ \\
\hline CONFUTATIO & $\begin{array}{l}\text { Circulatio } \\
\text { Palilogia }\end{array}$ & $\begin{array}{l}25-26 \text { e } \\
27-28 \\
25-26 e \\
27-28\end{array}$ & $\begin{array}{l}4^{a} \text { Seção } \\
4^{a \underline{a}} \text { Seção } \\
4^{a} \text { Seção }\end{array}$ & $\begin{array}{l}\text { Ré Menor } \\
\text { Ré Menor }\end{array}$ & $t-i$ \\
\hline
\end{tabular}




\begin{tabular}{|l|l|l|l|l|c|}
\hline & Synaeresis & $29-30$ & $4^{\underline{a}}$ e 5a Seção & Ré Menor & t-i e tP-III \\
& e Fá Maior & \\
& Anabasis & $31-35$ & $5^{\underline{a}}$ Seção & Fá Maior & tP-III \\
\hline CONFIRMATIO & Auxesis & $36-38$ & $6^{\underline{a}}$ Seção & Ré Menor & $\mathrm{t}-\mathrm{i}$ \\
\hline PEROTATIO & Suspiratio & $39-40$ & $6^{\text {a }}$ Seção & Ré Menor & $\mathrm{t}-\mathrm{i}$ \\
& Synaeresis & $41-42$ & & Ré Menor & $\mathrm{t}-\mathrm{i}$ \\
\hline
\end{tabular}

Tabela 23: Estrutura analítica do Ofertório 


\subsubsection{Ofertório da Missa do Terceiro Domingo da Quaresma}

\section{Estudo Semântico}

\subsection{Inventio}

O texto utilizado neste ofertório é intitulado "Glória de Deus Criador e Legislador" (Ps. 18,9; 11-12/ Ps. 19,9-11).

Justitiae Domini rectae, laetificantes corda

Et judicia dulciosa super mel et favum

(Etenin) nam et servas [tuus] custodit ea.

Retos os preceitos do Senhor, que alegram os corações

Mais justos e mais doces que o mel e os favos

Ainda que neles atente o vosso servo.

(SOARES, 2000, p.68).

Davi expressa nesse salmo a natureza, os benefícios e valores da Palavra de Deus, abordando cinco aspectos relevantes em seu louvor:

1. A Lei- a qual exprime para a vontade revelada de Deus, e que direciona a pessoa num correto relacionamento com Ele.

2. O testemunho- que simboliza a verdadeira Palavra de Deus dando a Ela testemunho de seu caráter e vontade.

3. Os preceitos- regras específicas a respeito da vida em retidão, que são uma alegria para os justos.

4. O mandamento- a fonte verdadeira de luz para orientar os fiéis que buscam os seus caminhos.

5. Os juízos- leis reguladoras da vida social que levam à justiça e á retidão. (ALMEIDA, 1996, p.830).

O Terceiro Domingo da Quaresma em sua liturgia mostra a eterna preocupação de Deus em conduzir os homens ao encontro da vida eterna. Nesse sentido, sua Palavra oferece inúmeras condições para conversão e renovação, por exemplo, os estatutos estabelecidos em seus Mandamentos que devem permear a caminhada do cristão, o relacionamento do fiel com Deus e seus semelhantes e por fim, a busca de uma conversão lógica, não 
baseada no poder, autoridade, riqueza, mas no sacrifício de Cristo na cruz do Calvário. Destarte, Jesus apresenta-se como o Novo Templo onde Deus se revela a seus súditos de maneira diferente Ihes propiciando seu amor.

Em síntese, esse ofertório é organizado em quarenta e três compassos, num Adagio em Sol Menor, trabalhado pelo compositor com um discurso balizado pela égide normativa da arte retórica, como veremos a partir dos exemplos analíticos a seguir.

\subsection{Locus observados na Inventio do Ofertório}

\begin{tabular}{|c|c|c|c|}
\hline INVENTIO & DESCRIÇÃO & $\begin{array}{c}\text { UTILIZAÇÃO NA } \\
\text { OBRA }\end{array}$ & $\begin{array}{l}\text { COMPASSO/ } \\
\text { VOZ }\end{array}$ \\
\hline $\begin{array}{l}\text { Locus } \\
\text { Notationis } \\
\text { (MATTHESON, } \\
\text { [1739],1954, } \\
\text { Parte II,Cap.4, } \\
\text { § 23,p.123). }\end{array}$ & $\begin{array}{l}\text { Aspecto externo e } \\
\text { desenho das notas } \\
\text { (Duração das notas, } \\
\text { alteração, repetição } \\
\text { e procedimentos } \\
\text { canônicos). }\end{array}$ & $\begin{array}{l}\text { Vários motivos } \\
\text { rítmicos e } \\
\text { diferentes durações } \\
\text { de notas } \\
\text { (mínimas, } \\
\text { semínimas, } \\
\text { semínimas } \\
\text { pontuadas, } \\
\text { colcheias, } \\
\text { colcheias } \\
\text { pontuadas, } \\
\text { semicolcheias, } \\
\text { repetições, } \\
\text { ligaduras, pausas, } \\
\text { apogiatura,entre } \\
\text { outros). }\end{array}$ & $\begin{array}{l}\text { 1-2 S-A-T-B } \\
2-11 \text { A-T-B } \\
11-21 \text { S-A-T-B } \\
27-43 \text { S-A-T-B }\end{array}$ \\
\hline $\begin{array}{l}\text { Locus } \\
\text { Oppositorum } \\
\text { (MATTHESON, } \\
\text { [1739],1954, } \\
\text { Parte II,Cap.4, } \\
\text { § 80,p.131). }\end{array}$ & $\begin{array}{l}\text { Contraste de } \\
\text { compassos, } \\
\text { movimentos } \\
\text { contrários, agudos e } \\
\text { graves, lento e } \\
\text { rápido, calmo e } \\
\text { agitado. }\end{array}$ & $\begin{array}{l}\text { Movimento } \\
\text { contrário entre } \\
\text { soprano e } \\
\text { contralto. Também } \\
\text { entre soprano e } \\
\text { baixo. }\end{array}$ & $\begin{array}{r}16-18 \text { S-A } \\
38-41 S-B\end{array}$ \\
\hline $\begin{array}{l}\begin{array}{l}\text { Locus } \\
\text { Descriptionis }\end{array} \\
\text { (MATTHESON, } \\
\text { [1739], 1954, } \\
\text { Parte II,Cap.4, } \\
\text { § 43,p.127). }\end{array}$ & Disposições da alma & $\begin{array}{l}\text { Alegria (que } \\
\text { alegram os } \\
\text { corações) }\end{array}$ & $\begin{array}{l}5-11 \text { S } \\
16-20 \text { S-A-T-B }\end{array}$ \\
\hline
\end{tabular}




\begin{tabular}{l|l|l|l}
$\begin{array}{l}\text { Locus } \\
\text { Comparationis }\end{array}$ & $\begin{array}{l}\text { Comparações de } \\
\text { coisas semelhantes } \\
\text { ou não, grandes ou }\end{array}$ & $\begin{array}{l}\text { Comparação da } \\
\text { Palavra de Deus } \\
\text { como mais doce }\end{array}$ & $\begin{array}{l}21-27 \text { S } \\
\text { 28-35S-A-T-B }\end{array}$ \\
$\begin{array}{ll}\text { (MATTHESON, } \\
\text { pequenas. }\end{array}$ & $\begin{array}{l}\text { qustos e mel. (Mais } \\
\text { [1739], 1954, }\end{array}$ & $\begin{array}{l}\text { que o mel e os } \\
\text { favos) }\end{array}$ \\
$\begin{array}{l}\text { Parte II, Cap.4 } \\
\text { f9,p.131). }\end{array}$ & &
\end{tabular}

Tabela 24: Locus Topici encontrados no Ofertório da Missa do Terceiro Domingo da Quaresma de André da Silva Gomes

\subsection{Dispositio}

\subsubsection{Exordium}

Todo o sentimento de servidão e devoção são expressos na introdução dessa música, onde as palavras Justitiae Domini rectae (Retos os preceitos do Senhor), são enfatizados numa dinâmica forte sugerindo a quem ouve uma serenidade e ao mesmo tempo previdente em relação ao julgamento de Deus. Outro aspecto relevante é que essa parte do discurso retórico tem apenas dois compassos, sendo em seguida empregada já na Narratio a Pausa determinando o repouso das outras vozes, para entrada do solo na voz da soprano no compasso 3 .

Primeira Seção

Tonalidade Sol Menor

Ofertório da Missa do $3^{\circ}$. Domingo da Quaresma Cat. Duprat 057

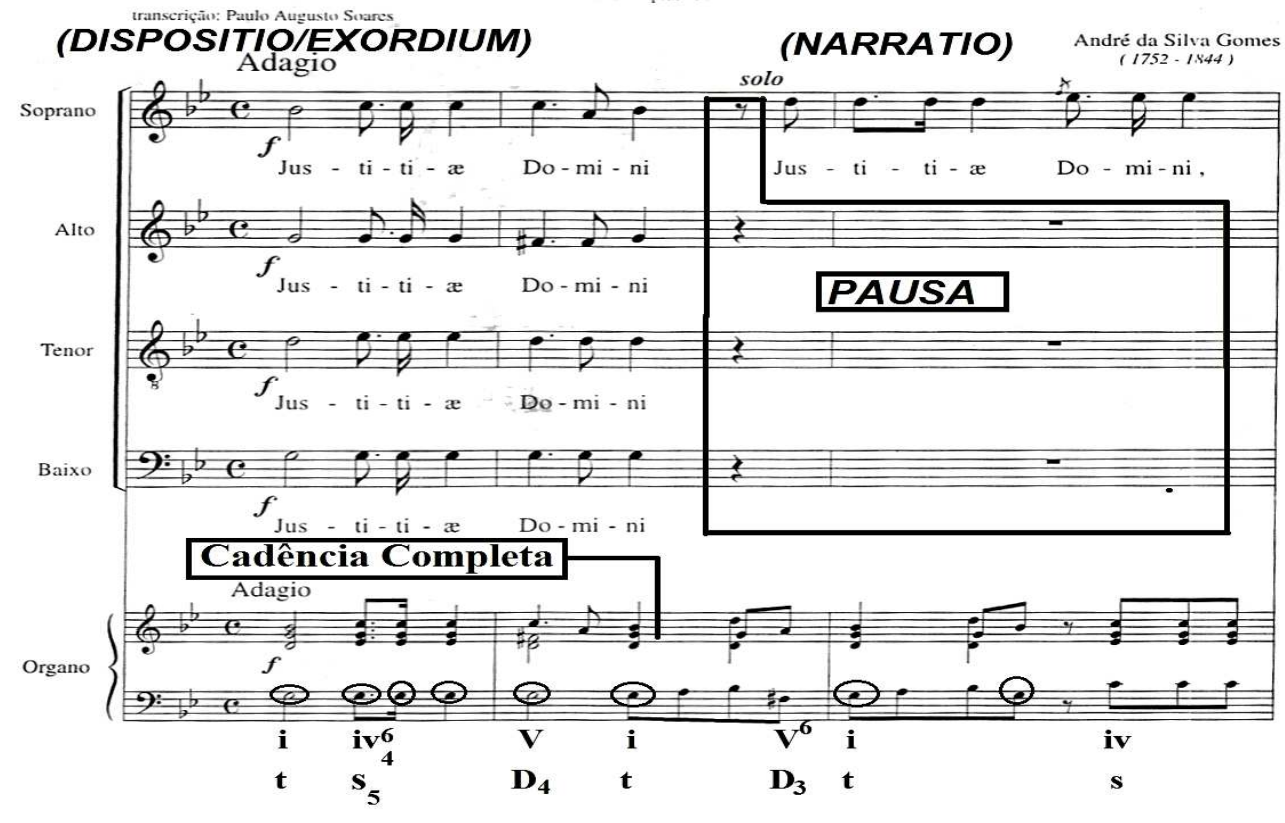

Observa-se o emprego do Pedal de Tônica no início da obra

Exemplo 50: Ofertório da Missa do Terceiro Domingo da Quaresma de André da Silva Gomes- Catalogação e Organização Régis Duprat (DUPRAT, 1999, p.99). 


\subsubsection{Narratio}

Dando prosseguimento a narração dos fatos, o autor utiliza a Synonimia, com o objetivo de enfatizar por meio de repetição da palavra laetificantes (alegria), como a repetência de uma ideia motívica, no entanto, com algumas alterações. Evidenciam-se, igualmente, as funções aplicadas nesse trecho da peça, tais como, Dominante sem fundamental, Dominante, Dominante da Subdominante, Subdominante, além da Tônica em Sol Menor, valorizando tanto o solo, quanto o recurso da figura adotada.

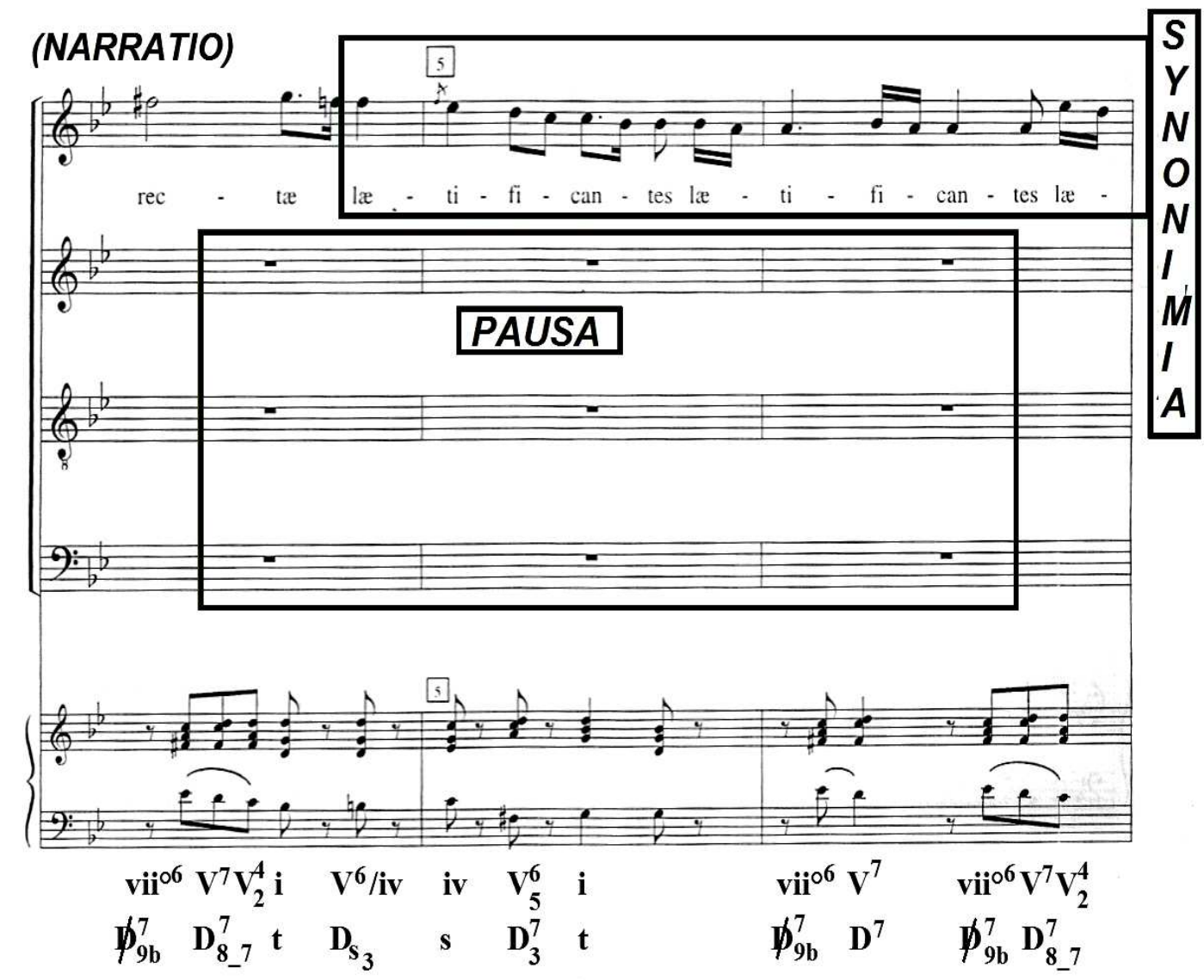

Exemplo 51: Ofertório da Missa do Terceiro Domingo da Quaresma de André da Silva Gomes- Catalogação e Organização Régis Duprat (DUPRAT, 1999, p.99).

$\mathrm{Na}$ mesma fase temos o emprego da mesma figura, assim como das funções, contudo, verifica-se a conclusão da primeira seção, numa Cadência Autêntica Perfeita no compasso 11. 
(NARRATIO)

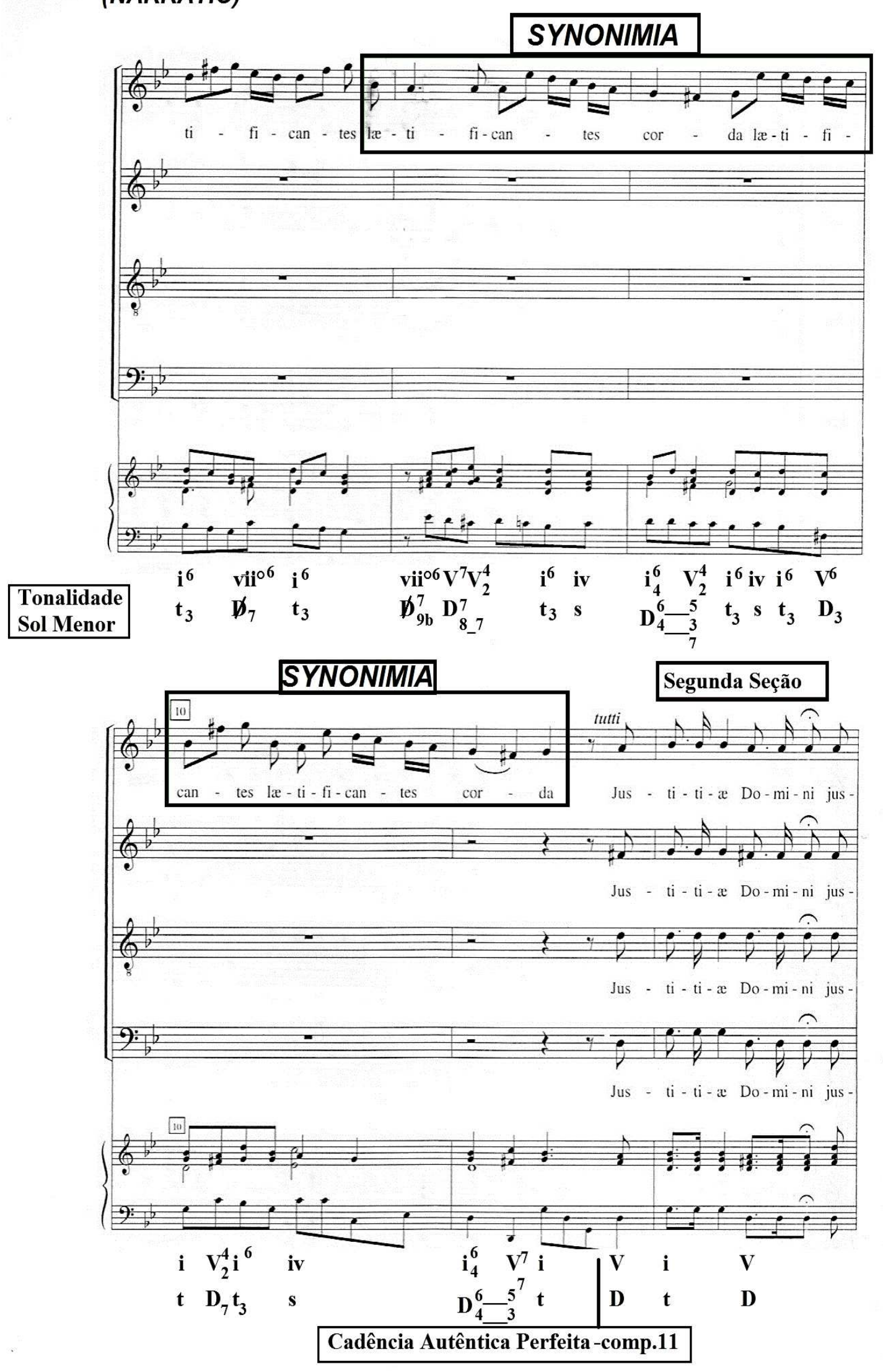

Exemplo 52: Ofertório da Missa do Terceiro Domingo da Quaresma de André da Silva Gomes- Catalogação e Organização Régis Duprat (DUPRAT, 1999, p.11). 


\subsubsection{Propositio}

$\mathrm{Na}$ Propositio é iniciada a segunda seção, também é cabível de observação à aplicação da Epizeuxis, por parte do compositor luso-brasileiro, objetivando maior ênfase a frase Justitiae Domini reforçando a ideia de justiça e retidão de quem julga, em outras palavras, o equilíbrio do juiz que arbitra com sensatez, nesse caso o Senhor de Israel.

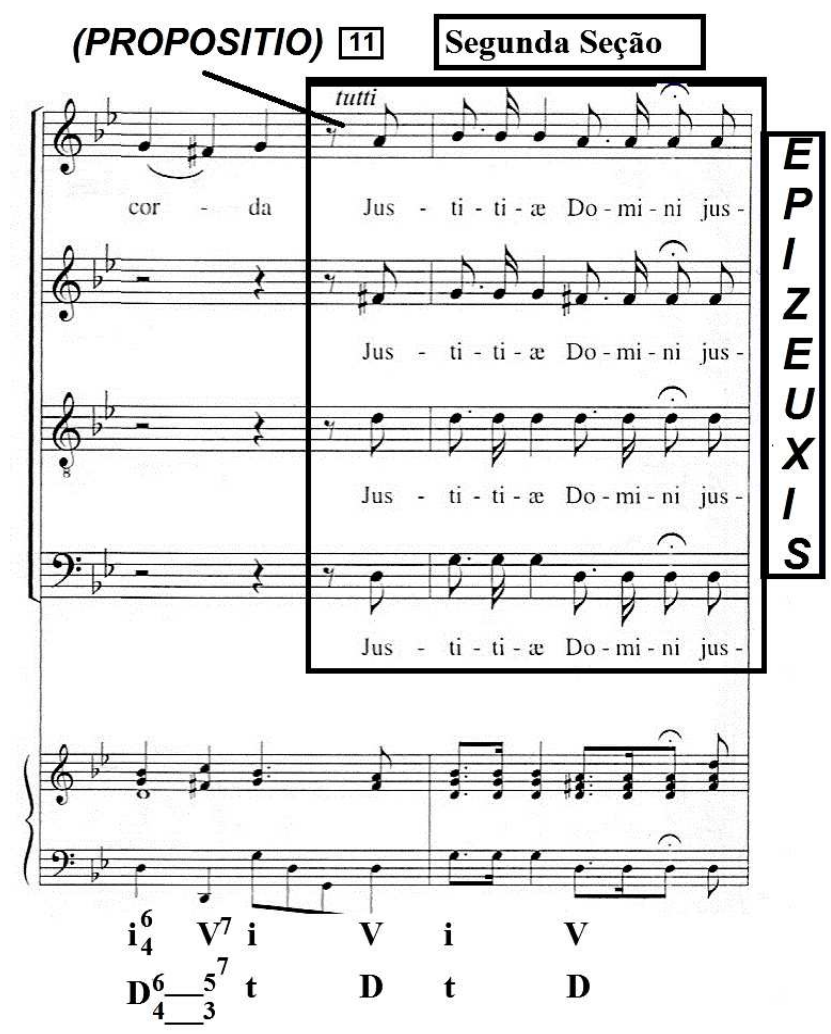

Exemplo 53: Ofertório da Missa do Terceiro Domingo da Quaresma de André da Silva Gomes- Catalogação e Organização Régis Duprat (DUPRAT, 1999, p.100).

Outras figuras são usadas na concepção dessa parte do discurso, tais como Synaeresis e Syncope, a primeira destacando a voz da contralto, cantando duas notas em uma silaba, a segunda ressaltando as notas Dó e Mi bemol que no compasso 15, dentro do acorde da Subdominante (Dó Menor), são consonantes e inseridas na Dominante (Ré Maior), compasso 16, tornamse dissonantes. Não podemos deixar de mencionar o uso da Epizeuxis, na terminação da frase anterior advinda desde o compasso 11, como da Pausa nas vozes do tenor e baixo. 


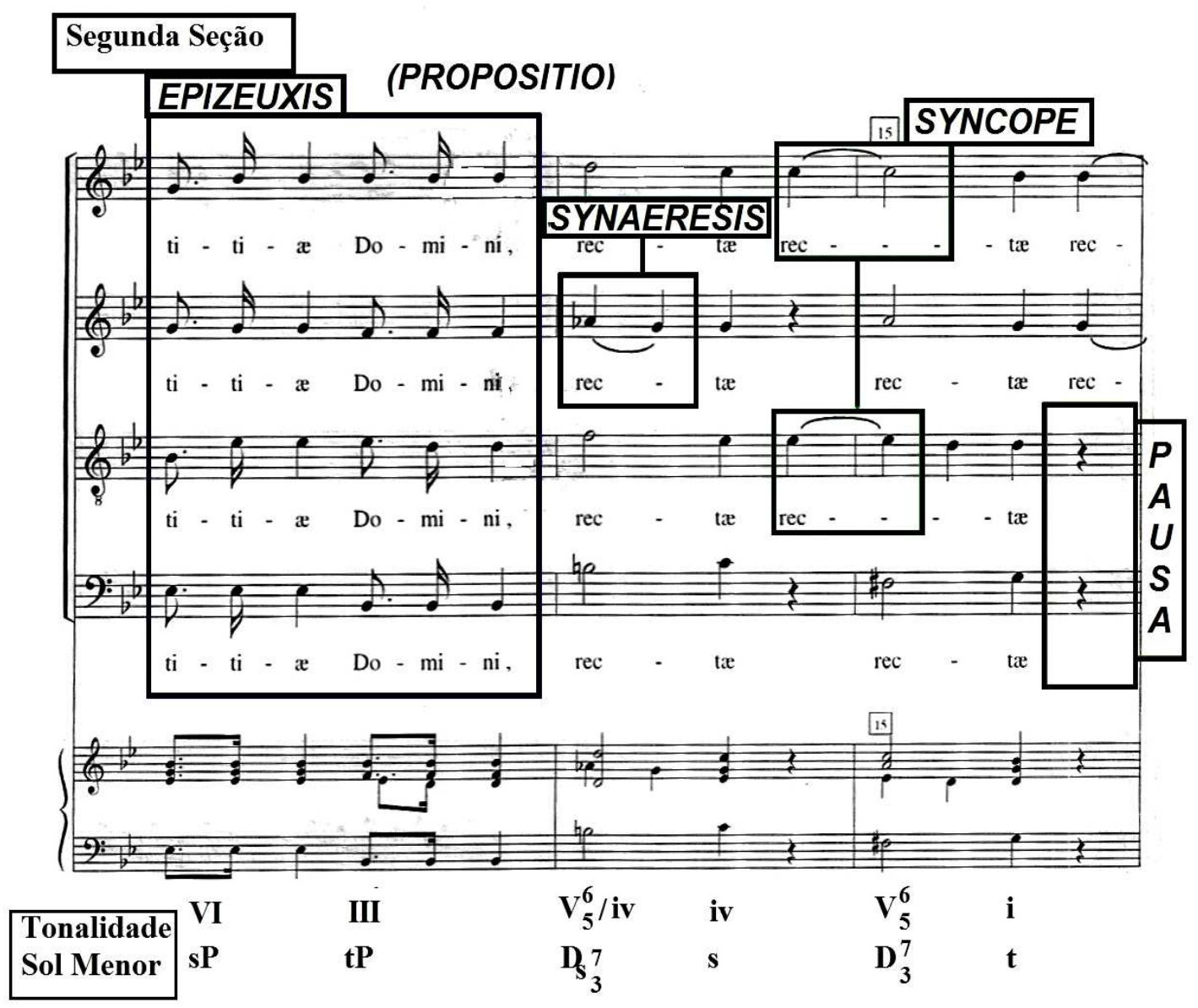

Exemplo 54: Ofertório da Missa do Terceiro Domingo da Quaresma de André da Silva Gomes- Catalogação e Organização Régis Duprat (DUPRAT, 1999, p.101).

\subsubsection{Confutatio}

Peculiar dessa parte, o compositor trabalha com materiais contrastantes, da mesma forma, insere novas figuras, dentre elas a Gradatio, que tem por finalidade repetir as notas, motivos ou frases, através de sequências, nesse caso, também por terças paralelas, seja entre as vozes da soprano e contralto, como no baixo, entre os compassos 16 e 18. 


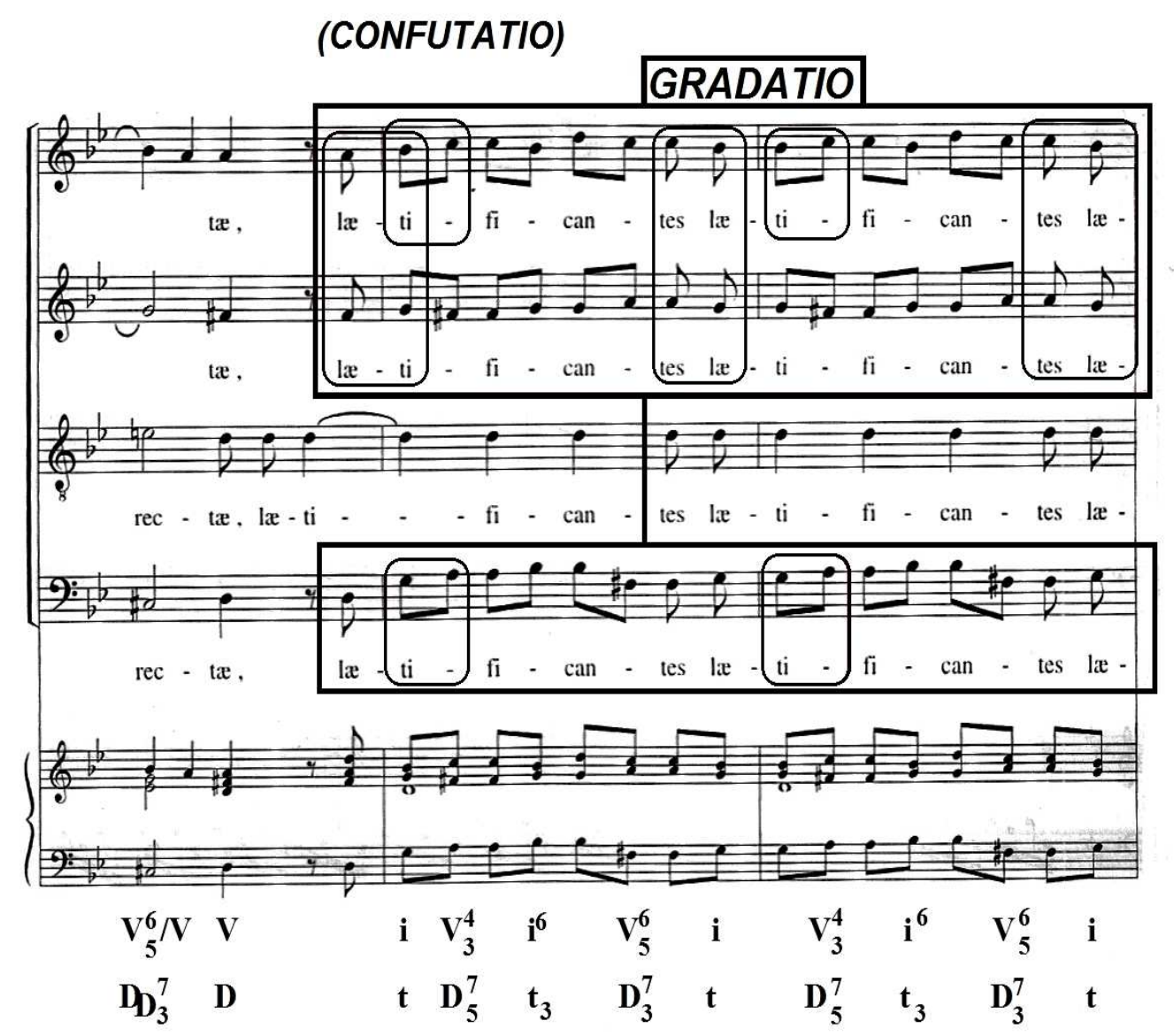

Exemplo 55: Ofertório da Missa do Terceiro Domingo da Quaresma de André da Silva Gomes- Catalogação e Organização Régis Duprat (DUPRAT, 1999, p.101).

É notável de apreciação a modulação realizada no compasso 19 para a tonalidade de Si bemol Maior, isto é, paralela a principal, como o termino da segunda seção em uma Semicadência, a utilização da Anaphora, ressaltando as palavras Et judiciosa (Mais justos), no solo da soprano e a Pausa, delimitando as outras vozes a aguardarem em silêncio, ficando em repouso por algum tempo, assim caracterizando uma Narratio dentro da Confutatio. 


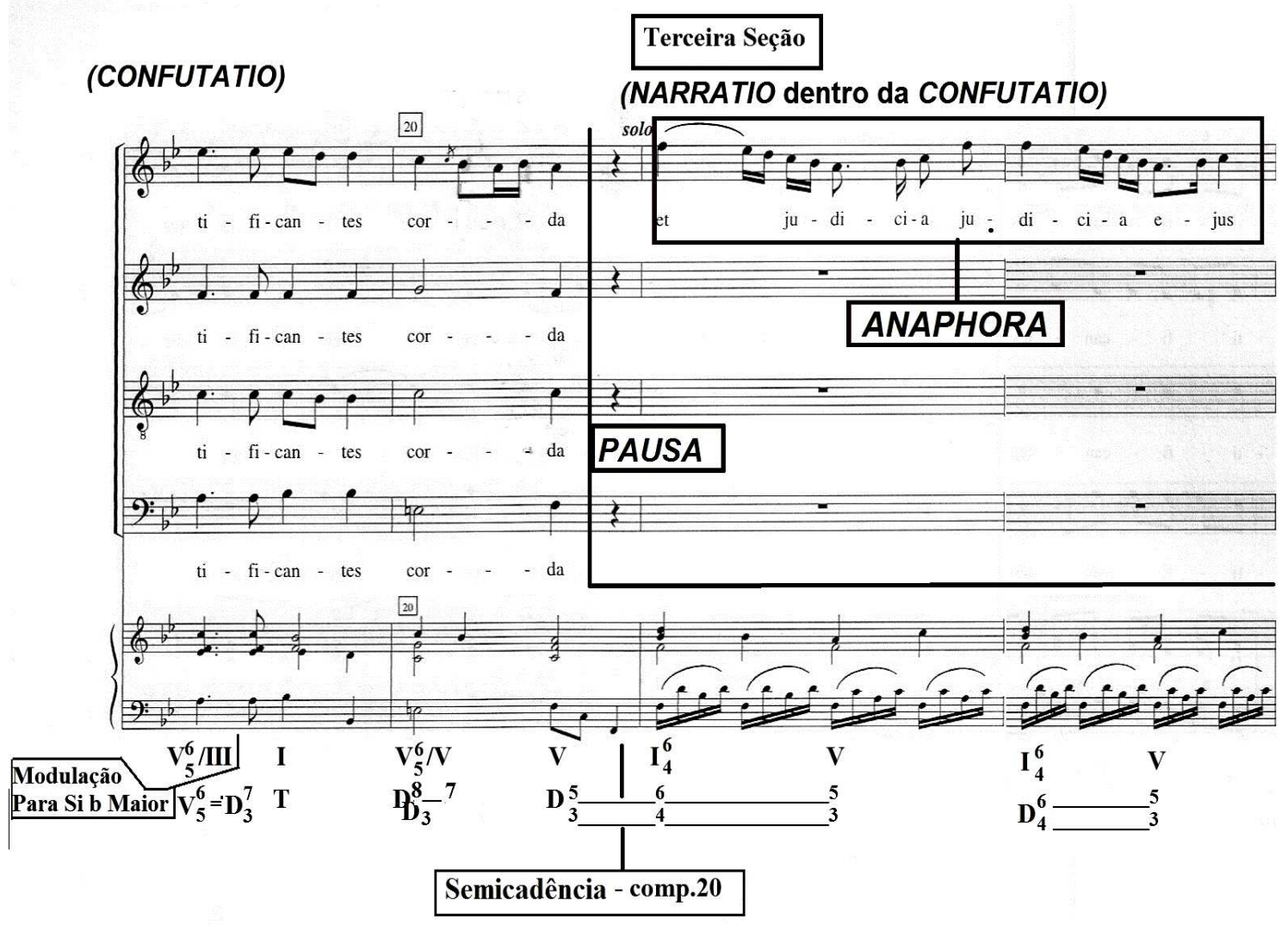

Exemplo 56: Ofertório da Missa do Terceiro Domingo da Quaresma de André da Silva Gomes- Catalogação e Organização Régis Duprat (DUPRAT, 1999, p.102).

Nota-se nesse excerto o uso da Synonimia, destacando a palavra dulciora (mais doce que), como da Pausa.

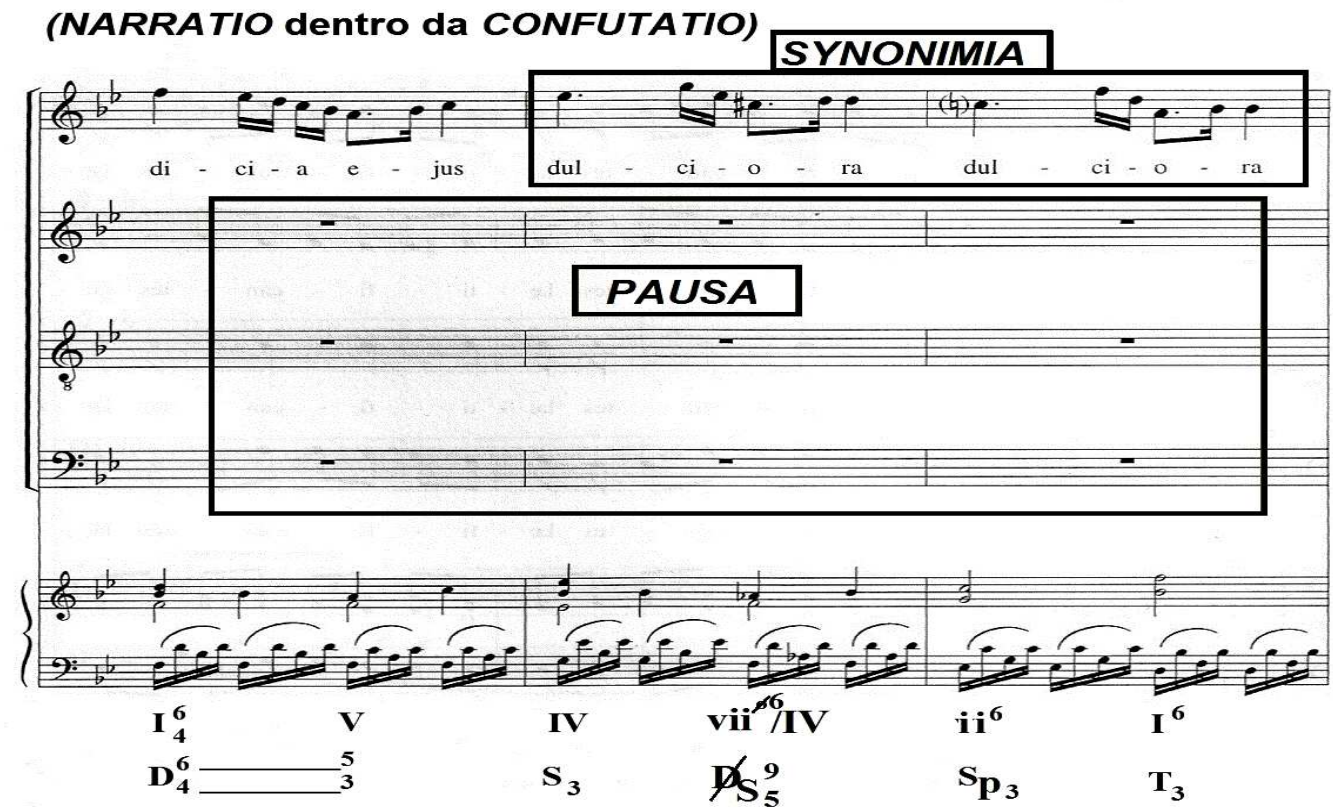

Exemplo 57: Ofertório da Missa do Terceiro Domingo da Quaresma de André da Silva Gomes- Catalogação e Organização Régis Duprat (DUPRAT, 1999, p.102). 
A Confutatio é concluída no compasso 27 com uma Cadência Autêntica Perfeita, entretanto, o autor designa a Variatio conferindo a mesma não só a função de variar os ornamentos, mas igualmente de repetir o enunciado super mel et favum ( mais que o mel e os favos), enfatizando uma parte do texto bíblico que mais doce que o mel e os favos é a justiça do Senhor.

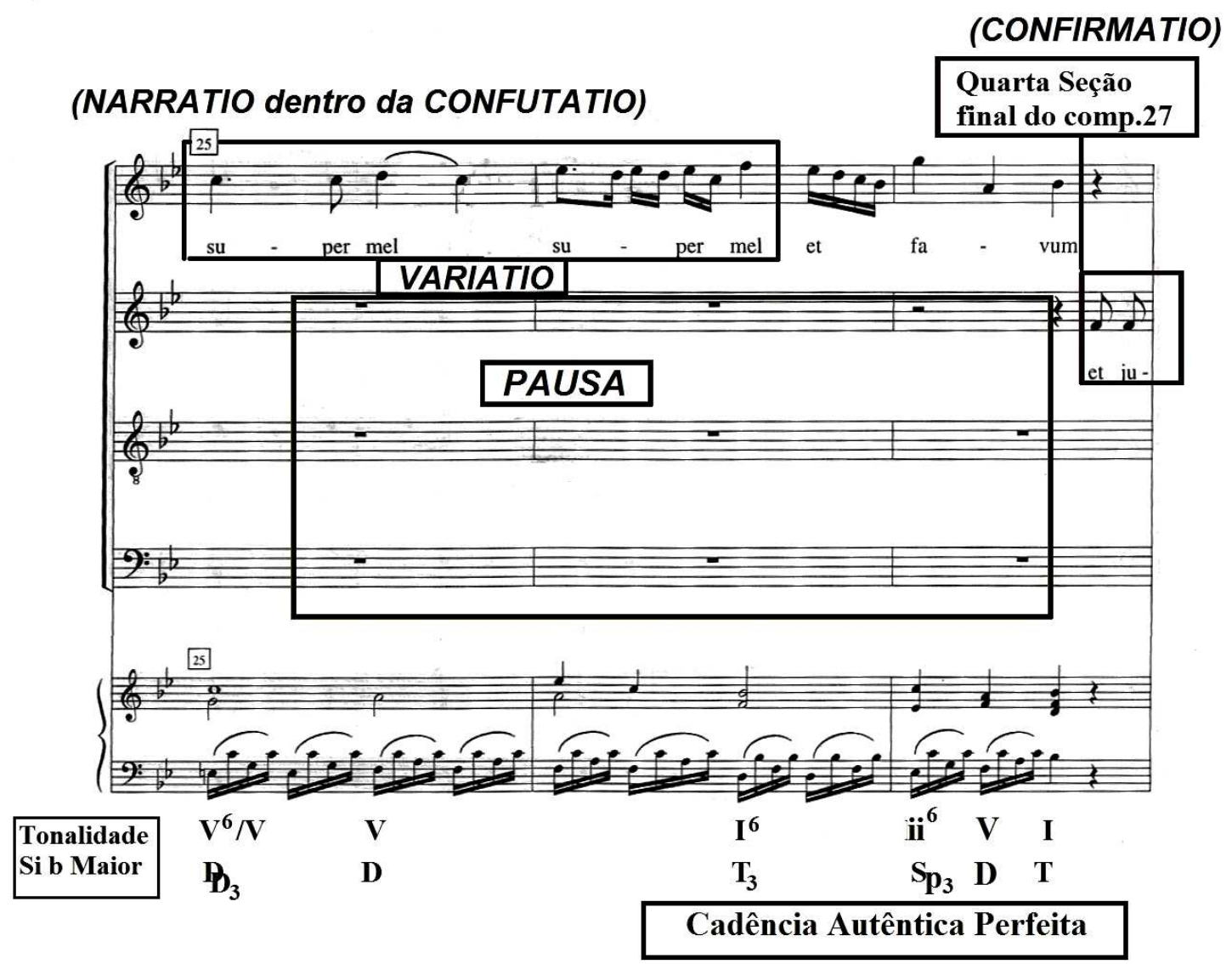

Exemplo 58: Ofertório da Missa do Terceiro Domingo da Quaresma de André da Silva Gomes- Catalogação e Organização Régis Duprat (DUPRAT, 1999, p.103).

\subsubsection{Confirmatio}

$\mathrm{Na}$ quinta parte da Dispositio são confirmadas as ideias iniciais e principais da obra, sendo repetida de maneira enfática a expressão judicia dulciosa, por meio da Epizeuxis. Similarmente, constata-se o próspero uso de Dominantes, entre os compassos 28 a 30 , contribuindo, seja na expectativa, como no auxílio dos elementos retóricos, empregados e desenvolvidos criteriosamente pelo autor. 


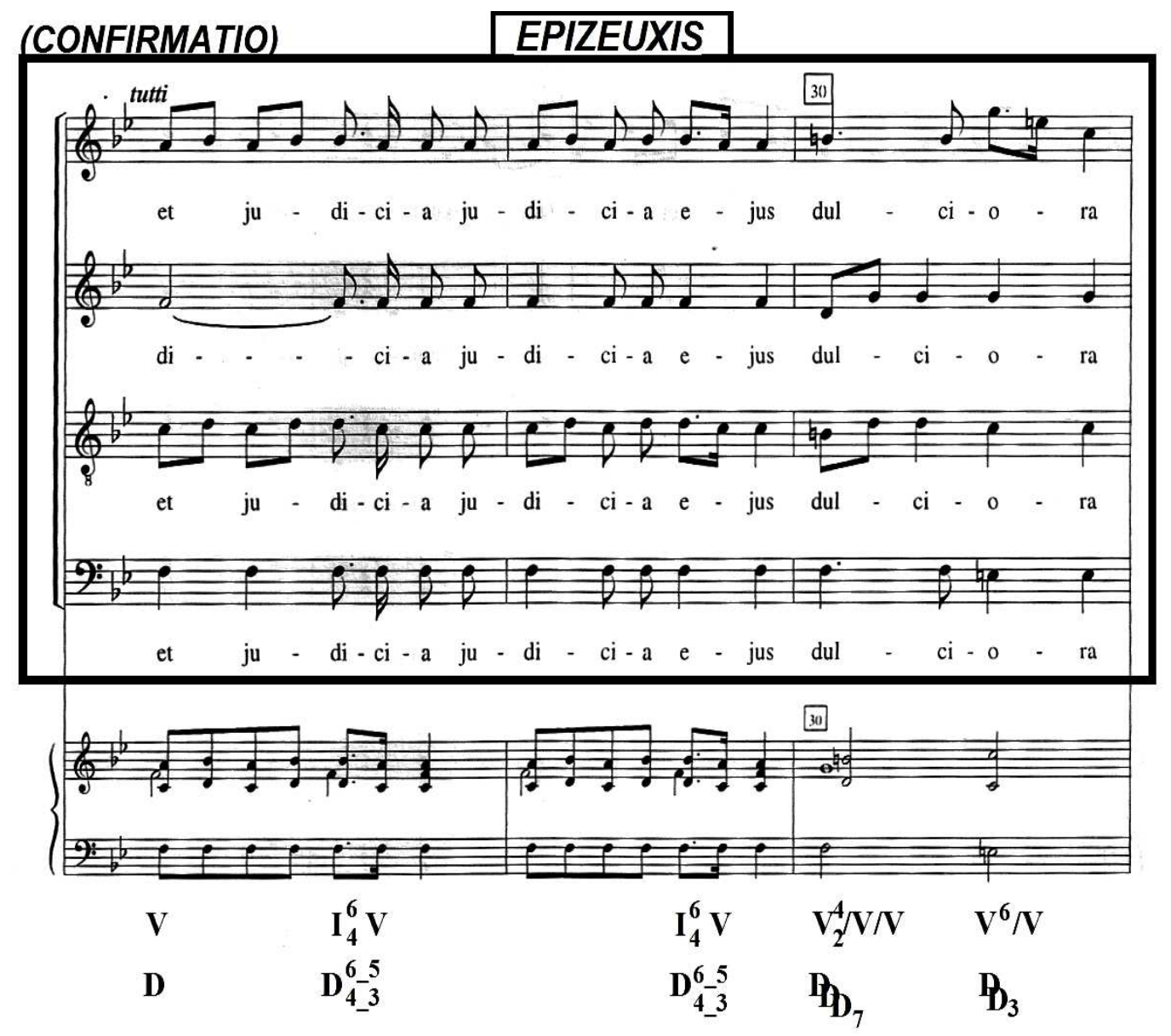

Exemplo 59: Ofertório da Missa do Terceiro Domingo da Quaresma de André da Silva Gomes- Catalogação e Organização Régis Duprat (DUPRAT, 1999, p.103).

Ainda na Confirmatio é observável a aplicação da Epizeuxis, Synaeresis e da Pausa, no entanto, nota-se a presença de duas novas figuras de interrupção e silêncio, Abruptio, que de maneira abrupta e inesperada, interrompe a melodia das vozes da contralto, tenor e baixo (favum) com pausas no compasso 33 e a Aposiopesis impondo a todas as partes um silêncio geral e simultâneo, por fim, ressalta-se a continuidade da tonalidade de $\mathrm{Si}$ bemol Maior, como o final dessa fase discursiva na Cadência Autêntica Perfeita. 


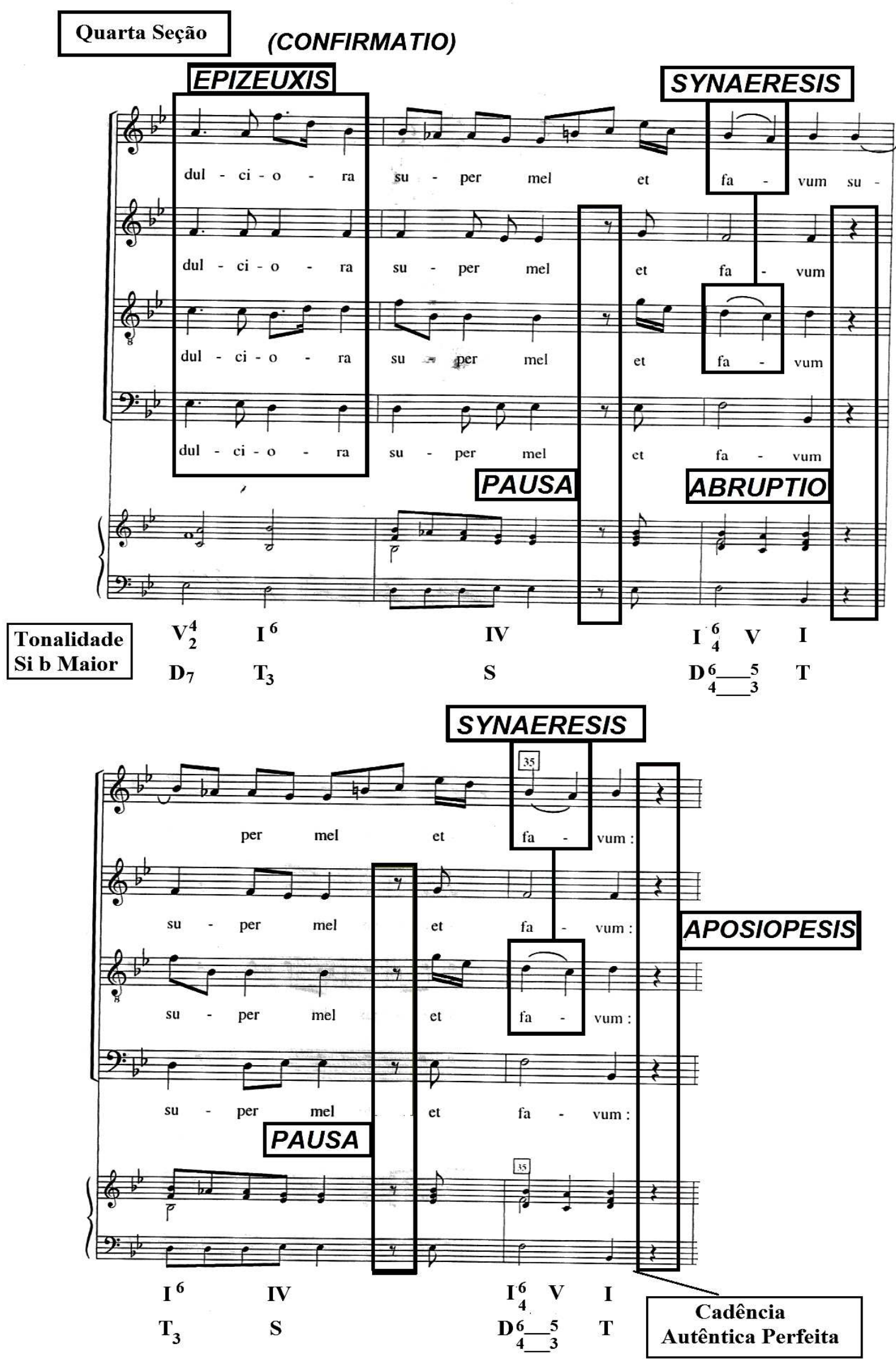

Exemplo 60: Ofertório da Missa do Terceiro Domingo da Quaresma de André da Silva Gomes- Catalogação e Organização Régis Duprat (DUPRAT, 1999, p.104). 


\subsubsection{Perotatio}

O discurso se encerra salientando a última frase do texto, Nam et servus [tuus] custodit ea (Ainda que neles atente o vosso servo). Observa-se que Silva Gomes insere duas figuras de repetição, imitação e descrição melódica, Noema e Mimesis, para enfatizar tal passagem textual, numa passagem homofônica dentro de um contexto contrapontístico. Enfim, a Perotatio é concluída tendo sido também empregadas a Aposiopesis e Synaeresis.

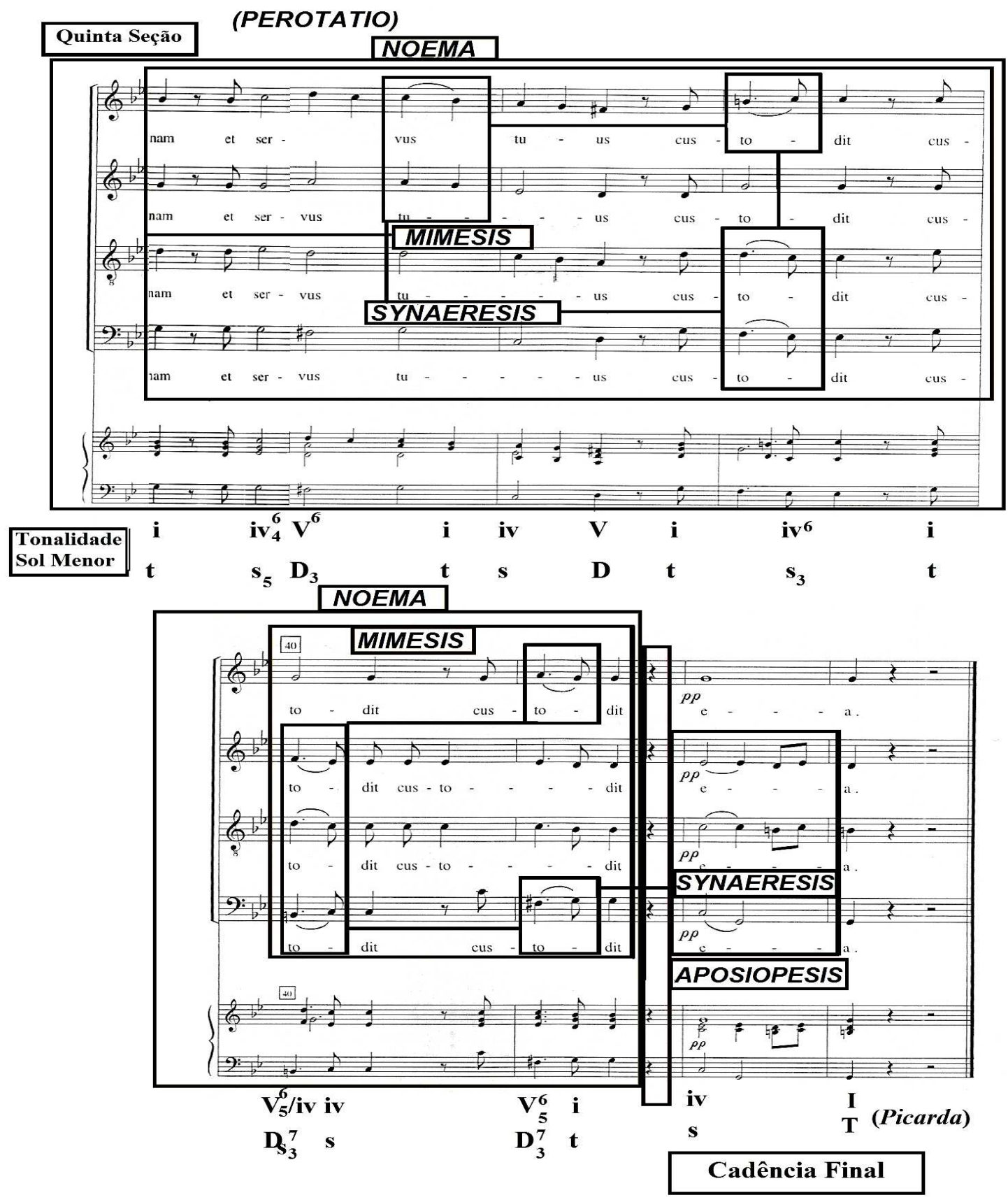

Exemplo 61: Ofertório da Missa do Terceiro Domingo da Quaresma de André da Silva Gomes- Catalogação e Organização Régis Duprat (DUPRAT, 1999, p.105). 


\subsection{Figuras observadas no Ofertório (Elocutio/Decoratio)}

\begin{tabular}{|c|c|c|c|c|}
\hline FIGURAS & & TIPO & DESCRIÇĀOO & TRATADISTA \\
\hline $\begin{array}{l}\text { ABRUPTIO } \\
\text { (BARTEL, } \\
\text { pp.168-170) }\end{array}$ & 1997, & $\begin{array}{l}\text { Interrupção e } \\
\text { Silêncio }\end{array}$ & $\begin{array}{l}\text { Uma quebra } \\
\text { súbita e } \\
\text { inesperada na } \\
\text { composição } \\
\text { musical. }\end{array}$ & $\begin{array}{l}\text { Vogt: A Abruptio } \\
\text { ocorre quando um } \\
\text { trecho musical é } \\
\text { interrompido no } \\
\text { final pela } \\
\text { colocação de } \\
\text { algumas pausas. }\end{array}$ \\
\hline $\begin{array}{l}\text { ANAPHORA } \\
\text { (BARTEL, } \\
\text { pp.184-190). }\end{array}$ & 1997, & $\begin{array}{l}\text { Repetição } \\
\text { Melódica }\end{array}$ & $\begin{array}{l}\text { (1) É uma linha } \\
\text { do baixo repetida } \\
\text { em forma de } \\
\text { solo. (2) A } \\
\text { repetição de uma } \\
\text { exposição } \\
\text { melódica sobre } \\
\text { notas e partes } \\
\text { diferentes. } \\
\text { Também pode } \\
\text { ocorrer no início } \\
\text { das repetições } \\
\text { de frases e } \\
\text { motivos em uma } \\
\text { série de } \\
\text { passagens de } \\
\text { sucessivas; (3) } \\
\text { Uma repetição } \\
\text { em geral. }\end{array}$ & $\begin{array}{l}\text { Walther: É uma } \\
\text { figura de repetição } \\
\text { e pode ocorrer de } \\
\text { duas maneiras: } \\
\text { 1. Quando uma } \\
\text { palavra é } \\
\text { repetida } \\
\text { frequentemente } \\
\text { em uma } \\
\text { composição } \\
\text { para dar maior } \\
\text { ênfase. as } \\
\text { 2. Quando graves } \\
\text { notas gã repetidas } \\
\text { são rámeras vezes } \\
\text { inúmeraso } \\
\text { (como o caso } \\
\text { das Chaconne). }\end{array}$ \\
\hline $\begin{array}{l}\text { APOSIOPESI } \\
\text { (BARTEL, } \\
\text { pp.202-206). }\end{array}$ & 1997, & $\begin{array}{l}\text { Interrupção e } \\
\text { Silêncio }\end{array}$ & $\begin{array}{l}\text { Um descanso } \\
\text { em uma ou todas } \\
\text { as vozes de uma } \\
\text { composição: } \\
\text { pausa geral. }\end{array}$ & $\begin{array}{l}\text { Walther: } \\
\text { Aposiopesis se } \\
\text { refere a uma } \\
\text { Pausa Generalis } \\
\text { ou um completo } \\
\text { silêncio em todas } \\
\text { as vozes e nas } \\
\text { partes } \\
\text { composição da } \\
\text { simultaneamente. }\end{array}$ \\
\hline $\begin{array}{l}\text { EPIZEUXIS } \\
\text { (BARTEL, } \\
\text { pp.263-265). }\end{array}$ & 1997, & $\begin{array}{l}\text { Repetição } \\
\text { Melódica }\end{array}$ & $\begin{array}{l}\text { Uma repetição } \\
\text { imediata e } \\
\text { enfática de uma } \\
\text { palavra, nota, } \\
\text { motivo ou frase. }\end{array}$ & $\begin{array}{l}\text { Walther: A } \\
\text { Epizeuxis é uma } \\
\text { figura de retórica } \\
\text { pela qual uma ou } \\
\text { mais palavras são } \\
\text { imediatamente e }\end{array}$ \\
\hline
\end{tabular}




\begin{tabular}{|c|c|c|c|}
\hline & & & $\begin{array}{l}\text { enfaticamente } \\
\text { repetidas. }\end{array}$ \\
\hline $\begin{array}{l}\text { GRADATIO } \\
\text { (BARTEL, 1997, } \\
\text { pp.220-224). }\end{array}$ & $\begin{array}{l}\text { Repetição } \\
\text { Melódica }\end{array}$ & $\begin{array}{l}\text { (1) Uma } \\
\text { sequência de } \\
\text { notas em uma só } \\
\text { voz repetida em } \\
\text { qualquer } \\
\text { tonalidade maior } \\
\text { ou menor, (2) } \\
\text { Duas vozes que } \\
\text { se deslocam em } \\
\text { movimento } \\
\text { ascendente ou } \\
\text { descendente } \\
\text { paralelo, (3) Um } \\
\text { aumento gradual } \\
\text { na intensidade e } \\
\text { altura do som. }\end{array}$ & 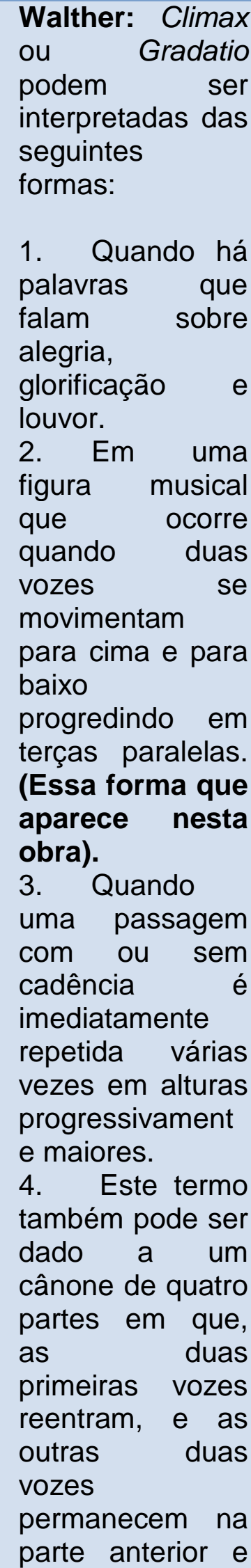 \\
\hline
\end{tabular}




\begin{tabular}{|c|c|c|c|c|}
\hline & & & & $\begin{array}{l}\text { ainda } \\
\text { harmonizam. }\end{array}$ \\
\hline $\begin{array}{l}\text { MIMESIS } \\
\text { (BARTEL, } \\
\text { pp.324-331). }\end{array}$ & 1997 & $\begin{array}{l}\text { Repetição } \\
\text { Melódica }\end{array}$ & $\begin{array}{l}\text { Uma imitação } \\
\text { aproximada em } \\
\text { vez de rigorosa } \\
\text { de um assunto } \\
\text { (sujeito) em } \\
\text { alturas } \\
\text { diferentes. }\end{array}$ & $\begin{array}{l}\text { Burmeister: } \\
\text { (Hypommentatum) } \\
\text { A Mimesis ocorre } \\
\text { quando a } \\
\text { estrutura das } \\
\text { vozes vizinhas } \\
\text { agradavelmente } \\
\text { combinadas } \\
\text { (Noema) } \\
\text { repetida por uma } \\
\text { imitação de outras } \\
\text { vozes. }\end{array}$ \\
\hline $\begin{array}{l}\text { NOEMA } \\
\text { (BARTEL, } \\
\text { p.339-342). }\end{array}$ & 1997, & $\begin{array}{l}\text { Representação } \\
\text { e Descrição }\end{array}$ & $\begin{array}{l}\text { Uma passagem } \\
\text { homofônica em } \\
\text { uma textura } \\
\text { contrapontística } \\
\text { e polifônica. }\end{array}$ & $\begin{array}{l}\text { Burmeister: A } \\
\text { Noema representa } \\
\text { o afeto harmônico, } \\
\text { onde as vozes } \\
\text { combinadas têm } \\
\text { valores e números } \\
\text { de notas } \\
\text { semelhantes. } \\
\text { Quando } \\
\text { introduzida } \\
\text { adequadamente, } \\
\text { isto é, no } \\
\text { momento certo, } \\
\text { ela afeta } \\
\text { docemente os } \\
\text { ouvidos do } \\
\text { ouvinte, } \\
\text { produzindo uma } \\
\text { sensação de } \\
\text { calma e } \\
\text { serenidade. }\end{array}$ \\
\hline $\begin{array}{l}\text { (BUELOW, } \\
\text { p.799). }\end{array}$ & 1980 & & & $\begin{array}{l}\text { Seção } \\
\text { homofônica, } \\
\text { dentro da polifonia } \\
\text { utilizada para } \\
\text { enfatizar o texto. }\end{array}$ \\
\hline $\begin{array}{l}\text { PAUSA } \\
\text { (BARTEL, } \\
\text { pp.362-365). }\end{array}$ & 1997 & $\begin{array}{l}\text { Interrupção e } \\
\text { Silêncio }\end{array}$ & $\begin{array}{l}\text { Uma pausa ou } \\
\text { descanso em } \\
\text { uma composição } \\
\text { musical. }\end{array}$ & $\begin{array}{lrr}\text { Walther: } & \text { Uma } \\
\text { figura ou figuras } \\
\text { de silêncio. Pausa } \\
\text { refere-se a } \\
\text { período um } \\
\text { repouso ou } & \text { de } \\
\text { silêncio } & & \text { na } \\
\text { música, que } & \text { é } \\
\text { indicado por } & \text { um }\end{array}$ \\
\hline
\end{tabular}




\begin{tabular}{|c|c|c|c|c|}
\hline & & & & determinado sinal. \\
\hline $\begin{array}{l}\text { SYNCOPE. } \\
\text { (BARTEL, } \\
\text { pp.396-405). }\end{array}$ & 1997 & $\begin{array}{l}\text { Dissonância e } \\
\text { Deslocamento }\end{array}$ & $\begin{array}{l}\text { Suspensão com } \\
\text { ou sem } \\
\text { dissonância } \\
\text { resultante. }\end{array}$ & $\begin{array}{l}\text { Walther: } \\
\text { Consonâncias que } \\
\text { são alteradas para } \\
\text { dissonâncias. }\end{array}$ \\
\hline $\begin{array}{l}\text { SYNAERESIS } \\
\text { (BARTEL, } \\
\text { pp.394-396). }\end{array}$ & 1997 & $\begin{array}{l}\text { Dissonância e } \\
\text { Deslocamento }\end{array}$ & $\begin{array}{l}\text { (1) Uma } \\
\text { suspensão ou } \\
\text { síncope, (2) A } \\
\text { colocação de } \\
\text { duas sílabas por } \\
\text { nota ou duas } \\
\text { notas por sílaba. }\end{array}$ & $\begin{array}{lr}\text { Vogt: } & \text { A } \\
\text { Synaeresis } & \text { ocorre } \\
\text { quando } & \text { duas } \\
\text { notas } & \text { são } \\
\text { colocadas } & \text { em } \\
\text { uma sílaba } & \text { ou } \\
\text { duas sílabas } & \text { são } \\
\text { colocadas } & \text { em } \\
\text { uma nota. } & \end{array}$ \\
\hline $\begin{array}{l}\text { SYNONYMIA } \\
\text { (BARTEL, } \\
\text { pp.405-407). }\end{array}$ & 1997 & $\begin{array}{l}\text { Repetição } \\
\text { Melódica }\end{array}$ & $\begin{array}{l}\text { É a repetição de } \\
\text { uma ideia } \\
\text { musical em } \\
\text { forma alterada } \\
\text { ou modificada. }\end{array}$ & $\begin{array}{l}\text { Walther: Um } \\
\text { compositor } \\
\text { também pode } \\
\text { empregar muito } \\
\text { bem diferentes } \\
\text { figuras retóricas } \\
\text { na elaboração de } \\
\text { um texto. Por } \\
\text { exemplo, além da } \\
\text { Epizeuxis, que é a } \\
\text { mais comum e } \\
\text { enfática, pode } \\
\text { usar, Anaphora, } \\
\text { Synonimia, } \\
\text { Epistrophe, } \\
\text { Epanalepsis e } \\
\text { assim por diante. }\end{array}$ \\
\hline $\begin{array}{l}\text { VARIATIO } \\
\text { (BARTEL, } \\
\text { pp.432-438). }\end{array}$ & 1997, & $\begin{array}{l}\text { Ornamentação } \\
\text { Melódica e } \\
\text { Harmônica }\end{array}$ & $\begin{array}{l}\text { Uma } \\
\text { ornamentação } \\
\text { de uma } \\
\text { passagem } \\
\text { melódica com } \\
\text { uma variedade } \\
\text { de } \\
\text { embelezamentos } \\
\text { (decorações). }\end{array}$ & $\begin{array}{l}\text { Printz: A palavra } \\
\text { Variatio é usada } \\
\text { de duas maneiras } \\
\text { pelos músicos, ou } \\
\text { seja, tanto no } \\
\text { sentido amplo e } \\
\text { estrito. Em um } \\
\text { sentido estrito, } \\
\text { Variatio refere-se } \\
\text { a uma alteração } \\
\text { artística } \\
\text { (figuração) de } \\
\text { uma determinada } \\
\text { passagem } \\
\text { melódica, mas em }\end{array}$ \\
\hline
\end{tabular}




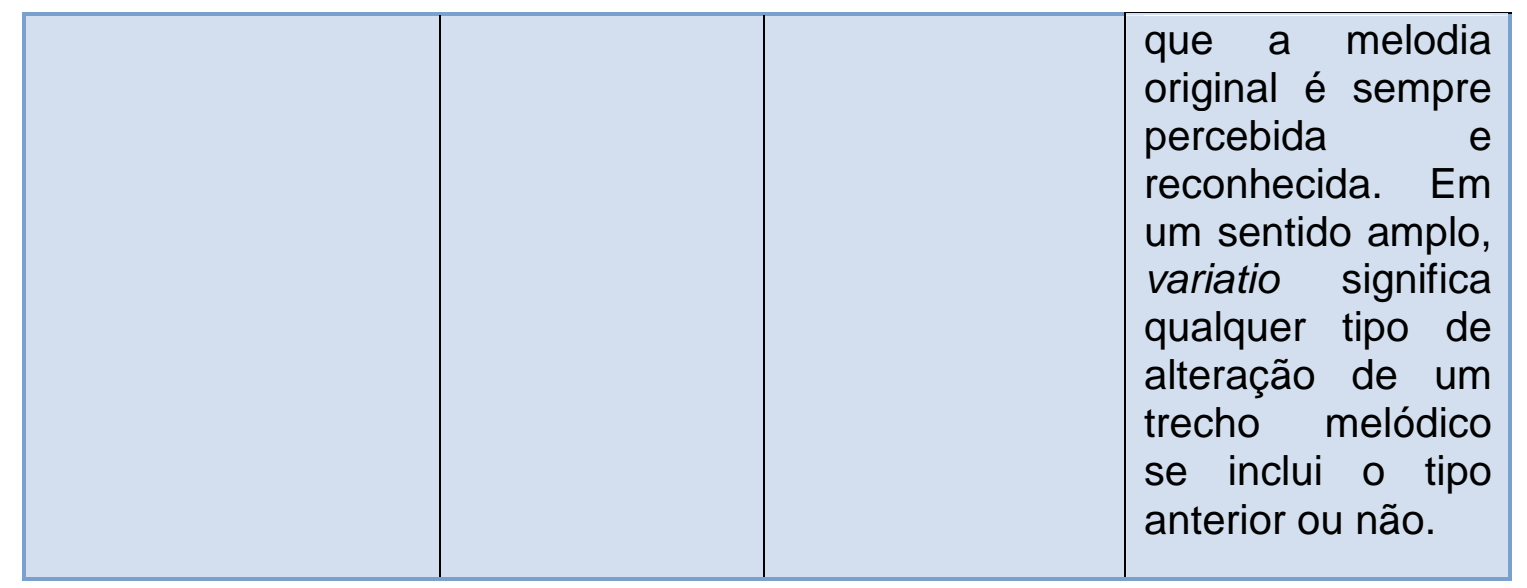

Tabela 25: Figuras encontradas no Ofertório da Missa do Terceiro Domingo da Quaresma de André da Silva Gomes

\section{Análise Harmônica}

\subsection{Curva Tonal}

Tonalidade: Sol Menor

Andamento: Adagio 4/4

Esquema de Progressões Harmônicas

\begin{tabular}{|l|c|l|}
\hline Compassos & $\begin{array}{l}\text { Função em relação a } \\
\text { tonalidade principal }\end{array}$ & Tonalidade (Acorde) \\
\hline $1-4$ & $\mathrm{t}-\mathrm{i}$ & Sol Menor \\
\hline $4-5$ & $\mathrm{~s}-\mathrm{iv}$ & Dó Menor \\
\hline $5-8$ & $\mathrm{t}-\mathrm{i}$ & Sol Menor \\
\hline 8 & $\mathrm{D}-\mathrm{V}$ & Ré Maior \\
\hline $8-12$ & $\mathrm{t}-\mathrm{i}$ & Sol Menor \\
\hline 13 & $\mathrm{sP}-\mathrm{VI}$ & Mi b Maior \\
\hline 14 & $\mathrm{~s}-\mathrm{iv}$ & Dó Menor \\
\hline 15 & $\mathrm{t}-\mathrm{i}$ & Sol Menor \\
\hline 16 & $\mathrm{D}-\mathrm{V}$ & Ré Maior \\
\hline $17-18$ & $\mathrm{t}-\mathrm{i}$ & Sol Menor \\
\hline $19-20$ & $\mathrm{D} / \mathrm{tP}-\mathrm{V} / \mathrm{III}$ & Fá Maior \\
\hline $21-23$ & $\mathrm{tP}-\mathrm{III}$ & Si b Maior \\
\hline 24 & $\mathrm{~s}-\mathrm{iV}$ & Dó Menor \\
\hline 25 & $\mathrm{D} / \mathrm{tP}-\mathrm{V} / \mathrm{III}$ & Fá Maior \\
\hline $26-29$ & $\mathrm{tP}-\mathrm{III}$ & Si b Maior \\
\hline 30 & $\mathrm{D} / \mathrm{D} / \mathrm{tP}-\mathrm{V} / \mathrm{V} / \mathrm{III}$ & Dó Maior \\
\hline 31 & $\mathrm{D} / \mathrm{tP}-\mathrm{V} / \mathrm{II}$ & Fá Maior \\
\hline 32 & $\mathrm{sP}-\mathrm{VI}$ & Mi b Maior \\
\hline $32-33$ & $\mathrm{tP}-\mathrm{III}$ & Si b Maior \\
\hline
\end{tabular}




\begin{tabular}{|l|c|l|}
\hline 34 & sP-VI & Mi b Maior \\
\hline 35 & tP-III & Si b Maior \\
\hline $36-38$ & t-i & Sol Menor \\
\hline $39-40$ & s-iv & Dó Menor \\
\hline 41 & t-i & Sol Menor \\
\hline $42-43$ & T-I (Picarda) & Sol Maior \\
\hline
\end{tabular}

Tabela 26 Curva Tonal do Ofertório da Missa do Terceiro Domingo da Quaresma

Números de compassos: 43

Regiões abordadas: 8

Variações: 25

Ritmo Harmônico: 1,72 (divisão dos números de compassos e variações)

Média ideal: (divisão dos números de compassos e regiões tonais abordadas = $5,37)$

Esquema Formal

$(1-18)(19-35)(35-43)$

$t \quad t P \quad t$

i III i

2.2. Estrutura Analítica do Ofertório: Retórica e Harmônica

\begin{tabular}{|c|c|c|c|c|c|}
\hline $\begin{array}{l}\text { RETORICA } \\
\text { DISPOSITIO }\end{array}$ & $\begin{array}{l}\text { FIGURA } \\
\text { ELOCUTIO }\end{array}$ & COMP. & $\begin{array}{l}\text { HARMÓNICA } \\
\text { SEÇÃO }\end{array}$ & TONALIDADE & FUNÇAOAO \\
\hline EXORDIUM & Pausa & 2 & 1로 Seção & Sol Menor & $t-i$ \\
\hline NARRATIO & $\begin{array}{l}\text { Pausa } \\
\text { Synonimia }\end{array}$ & $\begin{array}{l}2-11 \\
4-6 \\
\text { e } 7-11\end{array}$ & $\begin{array}{l}1^{\text {a }} \text { Seção } \\
1^{\text {a }} \text { Seção }\end{array}$ & $\begin{array}{l}\text { Sol Menor } \\
\text { Sol Menor }\end{array}$ & $\begin{array}{l}t-i \\
t-i\end{array}$ \\
\hline PROPOSITIO & $\begin{array}{l}\text { Epizeuxis } \\
\text { Synaeresis }\end{array}$ & $\begin{array}{l}11-13 \\
14\end{array}$ & $\begin{array}{l}2^{a} \text { Seção } \\
2^{\text {a }} \text { Seção }\end{array}$ & $\begin{array}{l}\text { Sol Menor } \\
\text { Sol Menor }\end{array}$ & $\begin{array}{l}t-i \\
t-i\end{array}$ \\
\hline
\end{tabular}




\begin{tabular}{|c|c|c|c|c|c|}
\hline & $\begin{array}{l}\text { Syncope } \\
\text { Pausa }\end{array}$ & $\begin{array}{l}14-15 \\
15\end{array}$ & $\begin{array}{l}2^{a} \text { Seção } \\
2^{\underline{a}} \text { Seção }\end{array}$ & $\begin{array}{l}\text { Sol Menor } \\
\text { Sol Menor }\end{array}$ & $\begin{array}{l}t-i \\
t-i\end{array}$ \\
\hline CONFUTATIO & $\begin{array}{l}\text { Gradatio } \\
\text { Pausa } \\
\text { Anaphora } \\
\text { Synonimia } \\
\text { Variatio }\end{array}$ & $\begin{array}{l}16-18 \\
20-27 \\
21-22 \\
23-24 \\
25-26\end{array}$ & 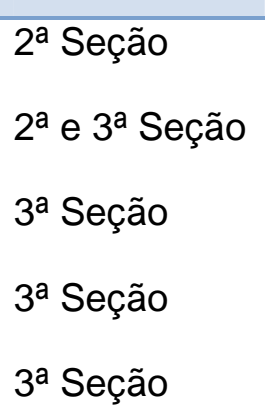 & $\begin{array}{l}\text { Sol Menor } \\
\text { Si b Maior } \\
\text { Si b Maior } \\
\text { Si b Maior } \\
\text { Si b Maior }\end{array}$ & $\begin{array}{c}t-i \\
t P-I I I \\
t P-I I I \\
t P-I I I \\
t P-I I I\end{array}$ \\
\hline CONFIRMATIO & $\begin{array}{l}\text { Epizeuxis } \\
\text { Pausa } \\
\text { Synaeresis } \\
\text { Abruptio } \\
\text { Aposiopesis }\end{array}$ & $\begin{array}{l}28-31 \\
32 \text { e } 34 \\
33 \text { e } 35 \\
33 \\
36\end{array}$ & $\begin{array}{l}4^{\text {a }} \text { Seção } \\
4^{\text {a }} \text { Seção } \\
4^{\text {a }} \text { Seção } \\
4^{\text {a }} \text { Seção } \\
\text { 4ª Seção }\end{array}$ & $\begin{array}{l}\text { Si b Maior } \\
\text { Si b Maior } \\
\text { Si b Maior } \\
\text { Si b Maior } \\
\text { Si b Maior }\end{array}$ & $\begin{array}{l}\text { tP-III } \\
\text { tP-III } \\
\text { tP-III } \\
\text { tP-III } \\
\text { tP-III }\end{array}$ \\
\hline PEROTATIO & $\begin{array}{l}\text { Noema } \\
\text { Mimesis } \\
\text { Aposiopesis } \\
\text { Synaeresis }\end{array}$ & $\begin{array}{l}36-41 \\
36-41 \\
41 \\
37 \text { e } 39 \\
41-42\end{array}$ & $\begin{array}{l}5^{\text {a }} \text { Seção } \\
5^{\text {a }} \text { Seção } \\
5^{\text {a }} \text { Seção } \\
5^{\text {a Seção }} \\
5^{\text {a Seção }}\end{array}$ & $\begin{array}{l}\text { Sol Menor } \\
\text { Sol Menor } \\
\text { Sol Menor } \\
\text { Sol Menor } \\
\text { Sol Menor }\end{array}$ & $\begin{array}{l}t-i \\
t-i \\
t-i \\
t-i \\
t-i\end{array}$ \\
\hline
\end{tabular}

Tabela 27: Estrutura analítica do Ofertório 


\subsubsection{Ofertório da Missa do Quarto Domingo da Quaresma}

\section{Estudo Semântico}

\subsection{Inventio}

Esse ofertório utiliza como epigrafe "Hino de louvor a Deus, Senhor de todas as coisas e Benfeitor de Israel" (Ps.134,3; 6/ 135,3; 6).

Laudate Dominum, quia benignus est:

Psallite Domino nomini ejus, quoniam suavis est

Omnia quaecumque voluit, facit in caelo et in terra.

[Vulgata: Laudate Dominum quia bonus Dominus

Psallite nomini ejus quoniam suave

Omnia quae voluit Dominus, fecit in caelo et in terra].

Louvai ao Senhor, porque ele é bom:

Cantai o seu nome, por que é suave

O que apraz ao Senhor ele o faz, no céu e na terra.

(SOARES, 2000, pp.80-81).

Nesse excerto, o salmista faz um encômio ao Senhor por seus atributos, em outras palavras, há um louvor direcionado a magnificência, bondade, poder e justiça de Deus para com seus servos. Este chamamento para louvar a Deus se baseia em três fatos pertinentes:

1. Deus estabeleceu um relacionamento de salvação com Israel.

2. Deus é um ser agradável, aprazível e, sobretudo, traz contentamento a seu povo.

3. Deus é onipresente, está em todo o lugar e perto de seu povo, compadecendo-se daqueles que o servem.

A ritualística do Quarto Domingo da Quaresma visa estabelecer um dialogo entre o cristão, simbolizando o filho pródigo, que, arrependido busca a remissão de seus pecados e reconciliação com seu pai, através do ato penitencial, seja por obras, orações ou jejum, enfim, o objetivo litúrgico dessa fase do Ofertório é trazer ao cristão uma reflexão para uma mudança de atitude e de vida.

No que tange a Inventio dessa obra, pode-se dizer que a mesma é escrita a oito vezes, constituída de sessenta e sete compassos, com 
andamento em Andante Moderato, na tonalidade de Dó Maior, distribuídos em sete seções, nas respectivas fases do discurso retórico.

\subsection{Locus observados na Inventio do Ofertório}

\begin{tabular}{|c|c|c|c|}
\hline INVENTIO & DESCRIÇÃO & $\begin{array}{c}\text { UTILIZAÇÃO NA } \\
\text { OBRA }\end{array}$ & $\begin{array}{l}\text { COMPASSO/ } \\
\text { VOZ }\end{array}$ \\
\hline $\begin{array}{l}\text { Locus } \\
\text { Notationis } \\
\text { (MATTHESON, } \\
\text { [1739],1954, } \\
\text { Parte II,Cap.4, } \\
\text { § 23,p.123). }\end{array}$ & $\begin{array}{l}\text { Aspecto externo } \\
\text { e desenho das } \\
\text { notas (Duração } \\
\text { das notas, } \\
\text { alteração, } \\
\text { repetição e } \\
\text { procedimentos } \\
\text { canônicos). }\end{array}$ & $\begin{array}{l}\text { Vários motivos } \\
\text { rítmicos e diferentes } \\
\text { durações de notas } \\
\text { (mínimas, mínimas } \\
\text { pontuadas, } \\
\text { semínimas, } \\
\text { semínimas } \\
\text { pontuadas, colcheias, } \\
\text { colcheias pontuadas, } \\
\text { semicolcheias, } \\
\text { repetições, ligaduras, } \\
\text { pausas, apogiatura, } \\
\text { fermata entre outros). }\end{array}$ & $\begin{array}{ll}1-3 & \text { S-A-T-B } \\
4-7 & \text { S-A-T-B } \\
7-19 & \text { S1 } \\
20-29 & \text { S-A-T-B } \\
30-37 & \text { S1 e S2 } \\
38-43 & \text { S-A-T-B } \\
44-51 & \text { S1 } \\
52-67 & \text { S-A-T-B }\end{array}$ \\
\hline $\begin{array}{l}\text { Locus } \\
\text { Oppositorum } \\
\text { (MATTHESON, } \\
\text { [1739],1954, } \\
\text { Parte II,Cap.4, } \\
\text { § 80,p.131). }\end{array}$ & $\begin{array}{l}\text { Contraste de } \\
\text { compassos, } \\
\text { movimentos } \\
\text { contrários, } \\
\text { agudos e } \\
\text { graves, lento e } \\
\text { rápido, calmo e } \\
\text { agitado. }\end{array}$ & $\begin{array}{l}\text { Movimento contrário } \\
\text { entre soprano- } 2 \text { e } \\
\text { baixo- } 2 \text {. } \\
\text { Também na contralto- } \\
2 \text { e baixo- } 2 \\
\text { soprano-1e } 2 \text { e baixo- } \\
1 \text { e } 2\end{array}$ & $\begin{array}{l}5-7 \quad \text { S2-B2 } \\
23-25 \text { S2-B2 } \\
\\
27 \quad \text { A2-B2 } \\
38-40 \quad \text { S1e 2- } \\
\text { B1 e } 2\end{array}$ \\
\hline $\begin{array}{l}\text { Locus } \\
\text { Descriptionis } \\
\text { (MATTHESON, } \\
\text { [1739],1954, } \\
\text { Parte II,Cap.4, } \\
\text { § 43,p.127). }\end{array}$ & $\begin{array}{l}\text { Disposições da } \\
\text { alma }\end{array}$ & $\begin{array}{l}\text { Celebração e } \\
\text { Exaltação (Louvai ao } \\
\text { Senhor, por que ele é } \\
\text { bom). }\end{array}$ & $\begin{array}{ll}1-3 & \text { S-A-T-B } \\
4-7 & \text { S-A-T-B } \\
7-19 & \text { S1 } \\
20-29 & \text { S-A-T-B }\end{array}$ \\
\hline $\begin{array}{l}\text { Locus } \\
\text { Comparationis } \\
\text { (MATTHESON, } \\
\text { [1739], 1954, } \\
\text { Parte II, Cap.4 } \\
\text { § 79,p.131). }\end{array}$ & $\begin{array}{l}\text { Comparações de } \\
\text { coisas } \\
\text { semelhantes ou } \\
\text { não, grandes ou } \\
\text { pequenas. }\end{array}$ & $\begin{array}{l}\text { Comparação do nome } \\
\text { de Deus com ternura } \\
\text { (Cantai o seu nome, } \\
\text { por que é suave). } \\
\text { Coisas não } \\
\text { semelhantes (Céu e } \\
\text { Terra). }\end{array}$ & $\begin{array}{ll}30-38 & \text { S1-S2 } \\
38-43 & \text { S-A-T-B }\end{array}$ \\
\hline
\end{tabular}

Tabela 28: Locus Topici encontrados no Ofertório da Missa do Quarto Domingo da Quaresma de André da Silva Gomes 


\subsection{Dispositio}

\subsubsection{Exordium}

O Ofertório da Missa do Quarto Domingo da Quaresma começa de forma intensa e ao mesmo tempo vívida e regozijante, na tonalidade de Dó Maior. Mattheson em seu tratado de 1713 para orquestra, afirma que essa tonalidade apesar de rudimentar e ousada, é bem aplicada em situações de regozijo e alegria (MATTHESON, 1713, parte III, cap.2,§ 12, apud, JANK, 2009, p.2).

André da Silva Gomes, como hábil compositor, utiliza-se dos recursos retóricos para fundamentar a primeira parte do discurso da música, inserido a Pausa nas quatro vozes da segunda parte, submetendo as mesmas a um breve silêncio, para posteriormente serem entoadas como repetição em relação às vozes da primeira parte, isto é, em alturas diferentes pelo Polyptoton. Também é empregada a Palilogia, que além de repetir as notas e palavras, dá ênfase as mesmas consubstanciando todo o sentimento de louvor e júbilo Laudate Dominum (Louvai ao Senhor).

No que tange as funções harmônicas, pode ser observada entre os compassos 1 a 4, a presença da Tônica, Subdominante e Dominante, culminando numa Cadência Plagal, no segundo tempo do quarto compasso. Já nos compassos 5 e 6, a Tônica e Dominante são trabalhadas pelo compositor de maneira enfática, mantendo diálogo não só entre si, mas igualmente com as figuras e elementos dispostos na Exordium, até sua conclusão na metade do compasso 7, na Cadência Autêntica Perfeita. 


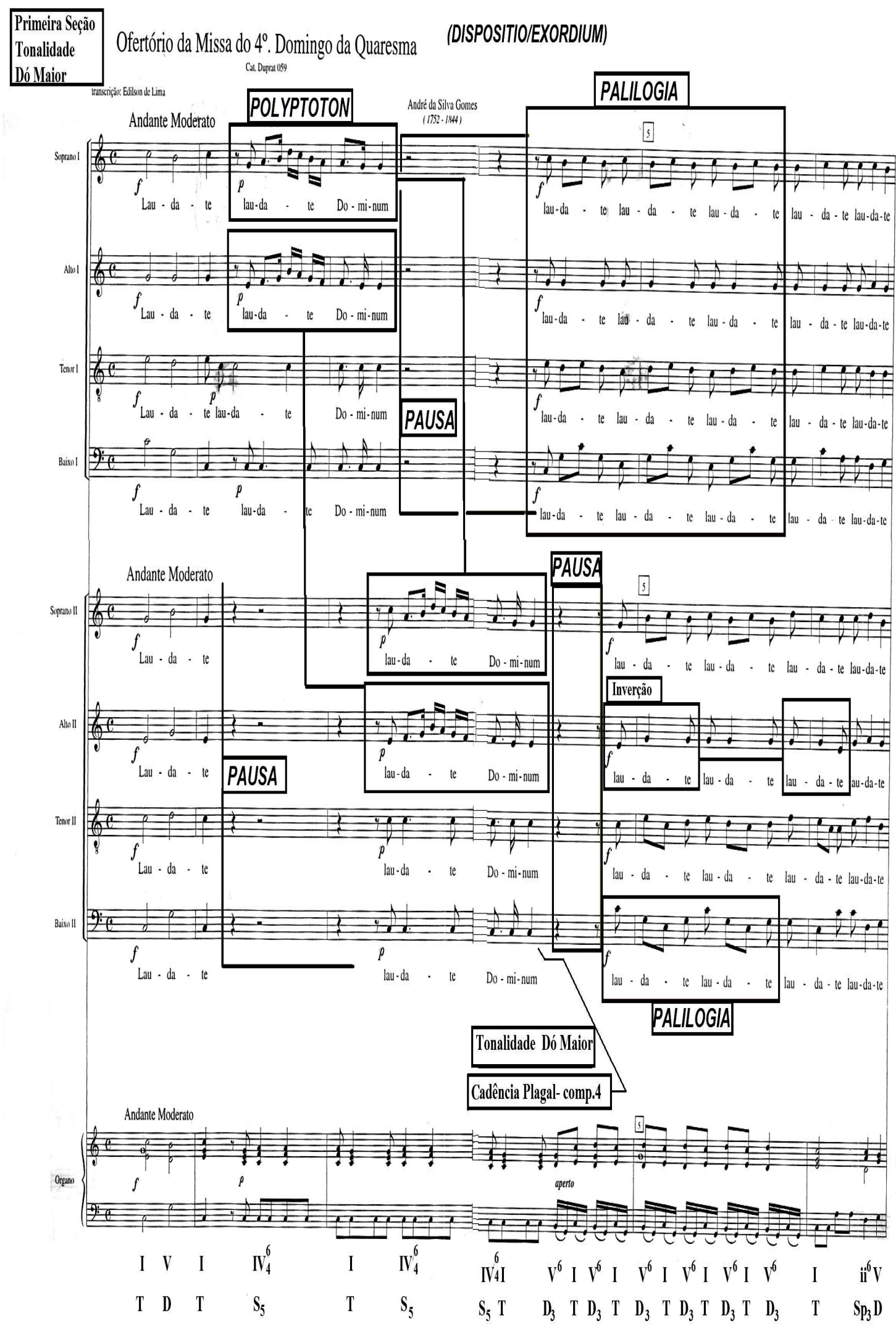

Exemplo 62: Ofertório da Missa do Quarto Domingo da Quaresma de André da Silva Gomes- Catalogação e Organização Régis Duprat (DUPRAT, 1999, pp.106-107). 


\subsubsection{Narratio}

Nesse trecho, o compositor luso-brasileiro, continua a desenvolver seu intento de atrair a atenção do ouvinte por meio da repetição e ênfase introduzindo a Synonimia e Climax, da mesma forma, procura destacar ainda mais esse afeto de alegria e unidade cristã, através da narração dos fatos na voz da soprano.

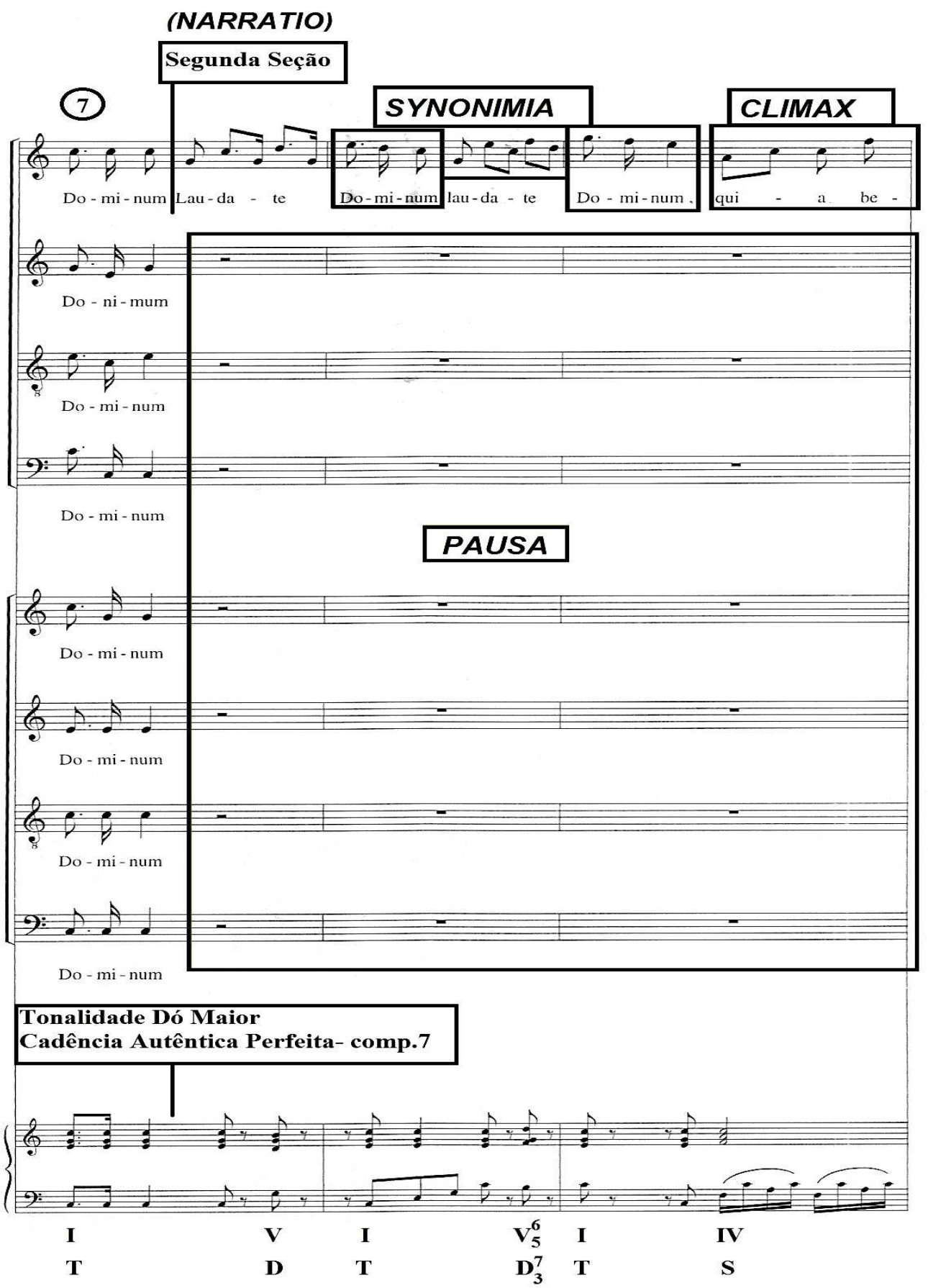

Exemplo 63: Ofertório da Missa do Quarto Domingo da Quaresma de André da Silva Gomes- Catalogação e Organização Régis Duprat (DUPRAT, 1999, p.108). 
Nos compassos 10 e 11, verifica-se a figura do Climax, cuja função é repetir em forma de sequência as notas, no entanto, em alturas diferentes e na mesma voz.

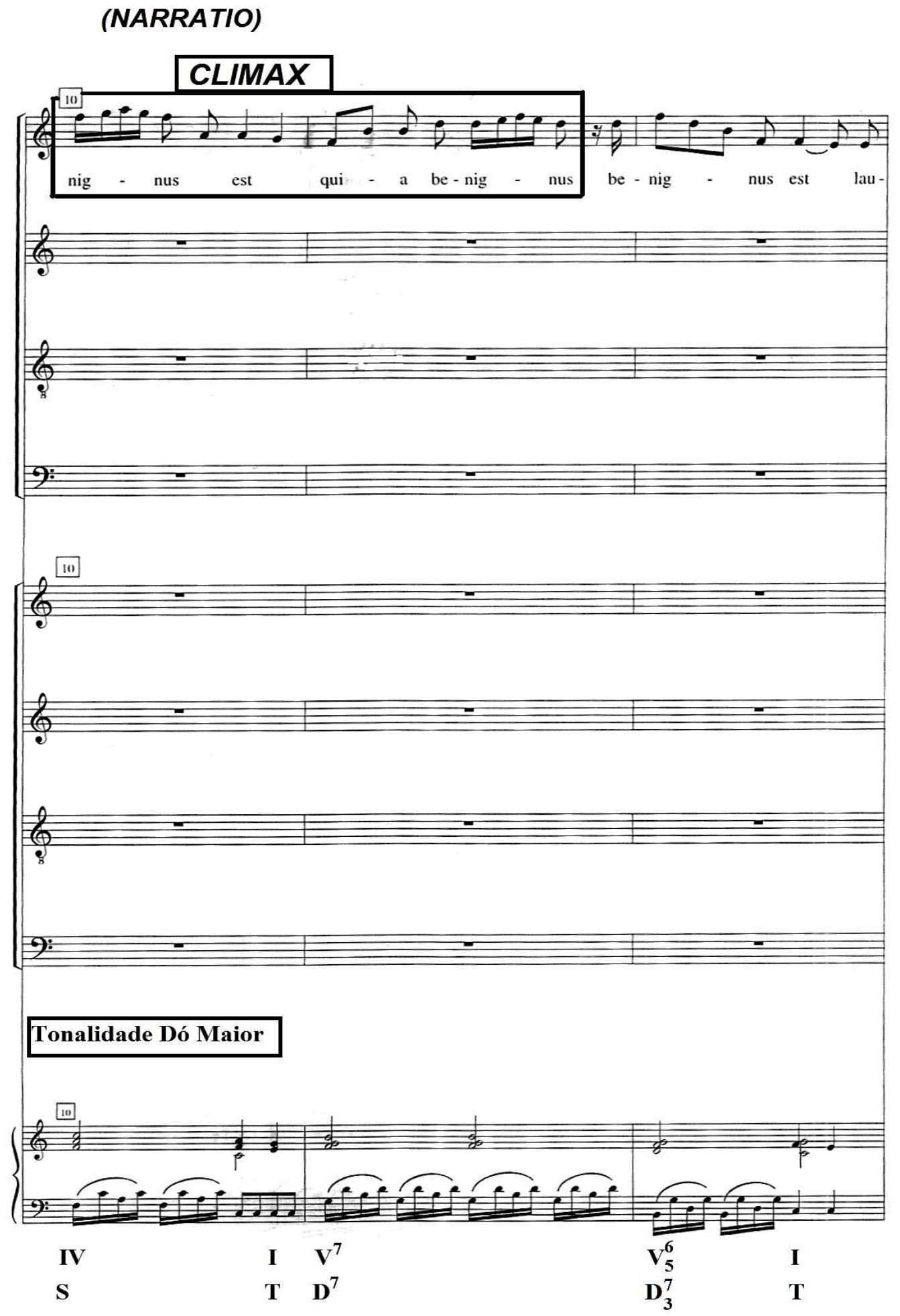

Exemplo 64: Ofertório da Missa do Quarto Domingo da Quaresma de André da Silva Gomes- Catalogação e Organização Régis Duprat (DUPRAT, 1999, p.109). 
A segunda seção e a Narratio, se encerram na tonalidade de Dó Maior, numa Cadência Autêntica Perfeita, porém, o autor insere a Variatio, objetivando-a na variação ornamental das notas.

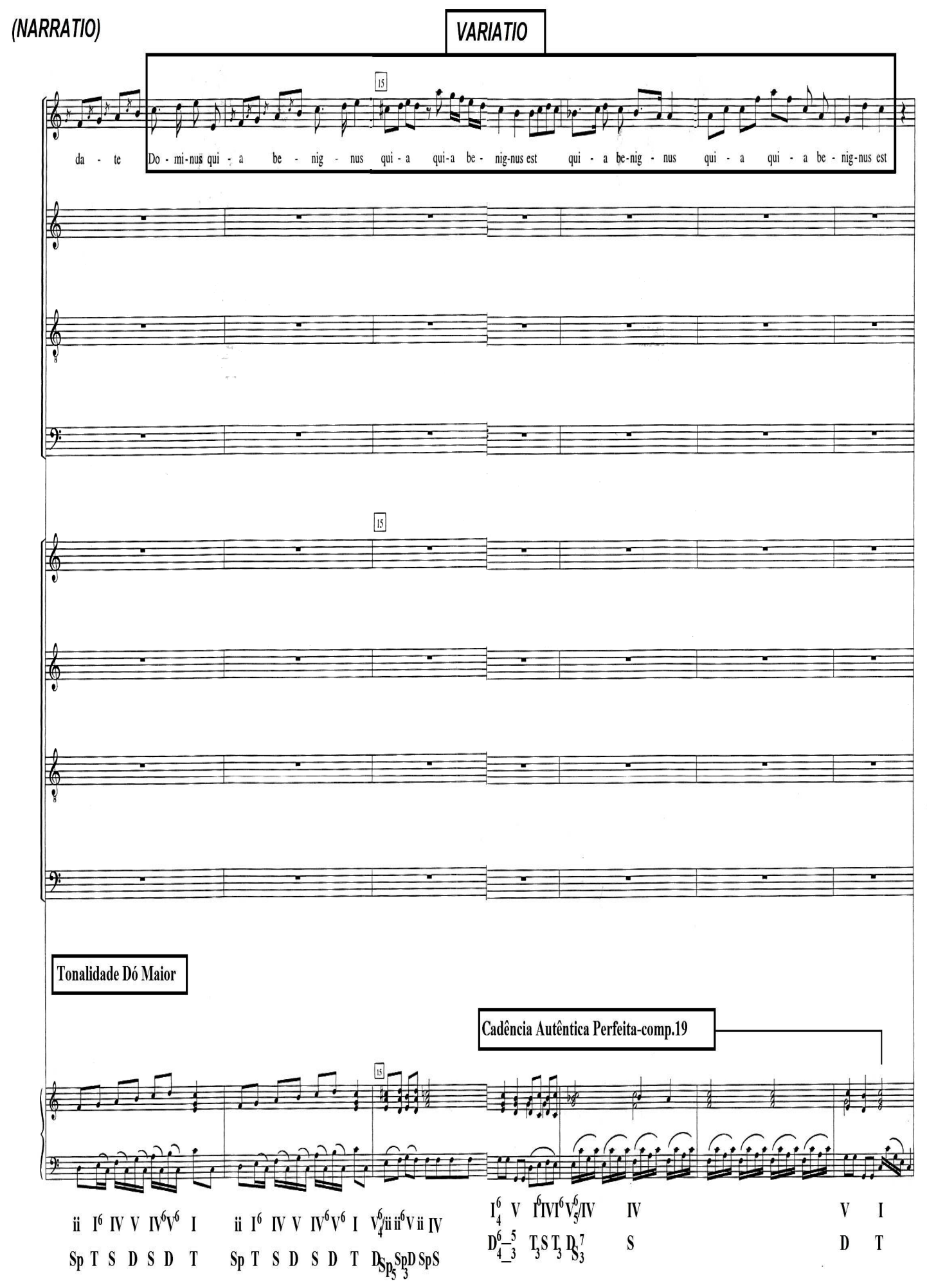

Exemplo 65: Ofertório da Missa do Quarto Domingo da Quaresma de André da Silva Gomes- Catalogação e Organização Régis Duprat (DUPRAT, 1999, pp.110-111). 


\subsubsection{Propositio}

Observam-se na Propositio, os mesmos elementos e figuras retóricas utilizadas no início do ofertório, por essa razão, acontece uma Exordium dentro da Propositio, entretanto, no compasso 25, acontece uma modulação para a tonalidade de Lá Menor.

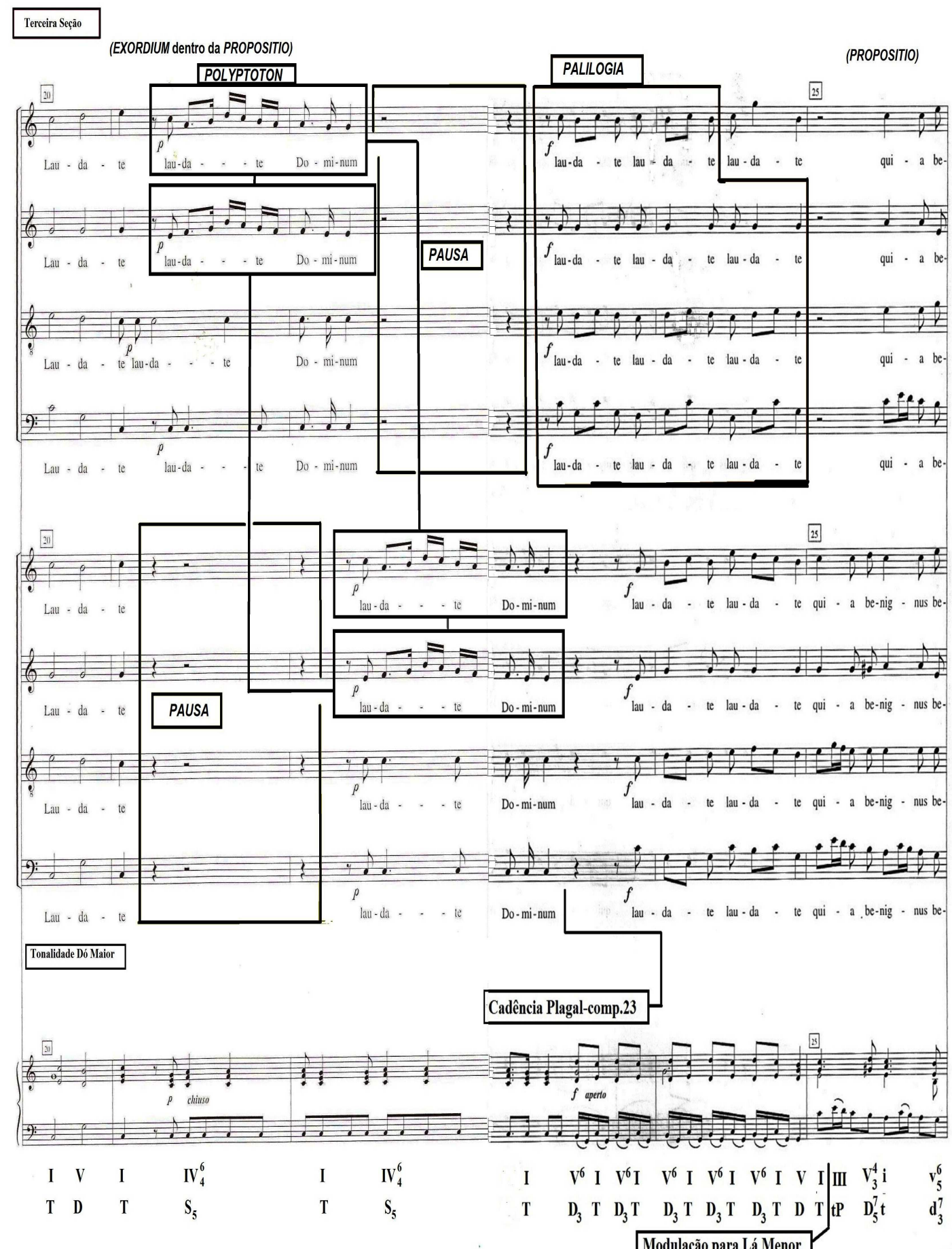

Exemplo 66: Ofertório da Missa do Quarto Domingo da Quaresma de André da Silva Gomes- Catalogação e Organização Régis Duprat (DUPRAT, 1999, pp.112-113). 
Nota-se a mesma repetição das palavras proferidas na Narratio, no entanto, em todas as vozes, também é verificável a inversão motívica nos compassos 27 e 28, como o uso da Pausa. Enfim, a terceira seção é concluída em Lá Menor, numa Cadência Autêntica Imperfeita.

(PROPOSITIO)

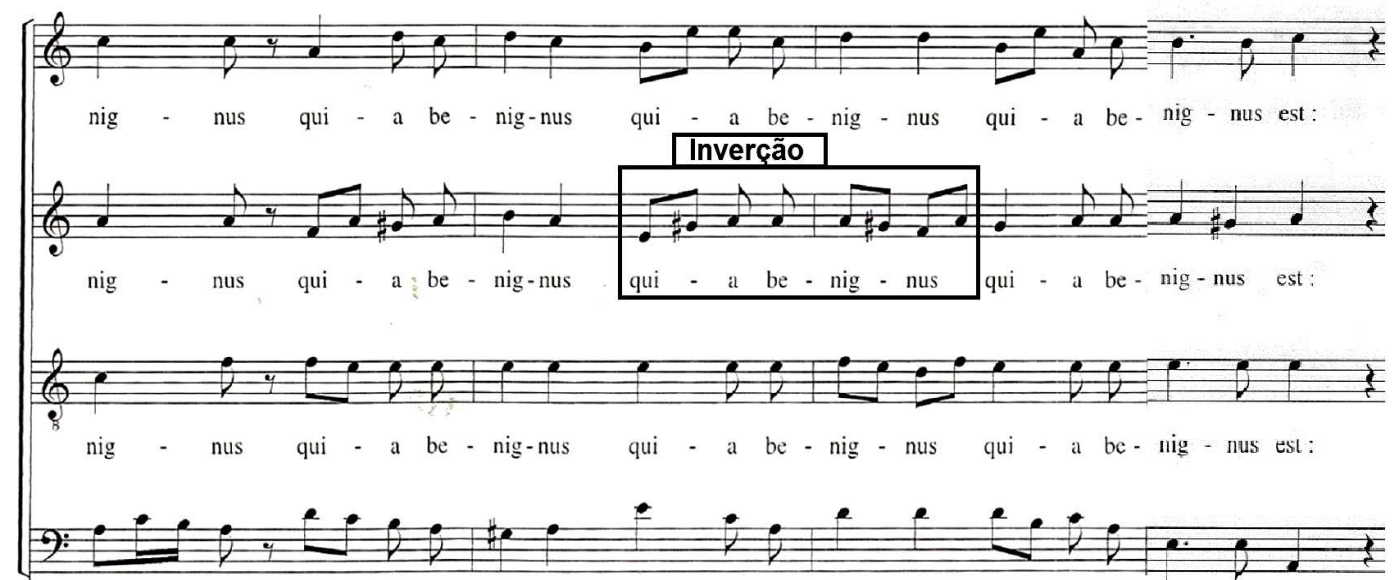

nig - nus qui - a be - nig-nus qui - a be - nig - nus qui - a be - nig - nus est:

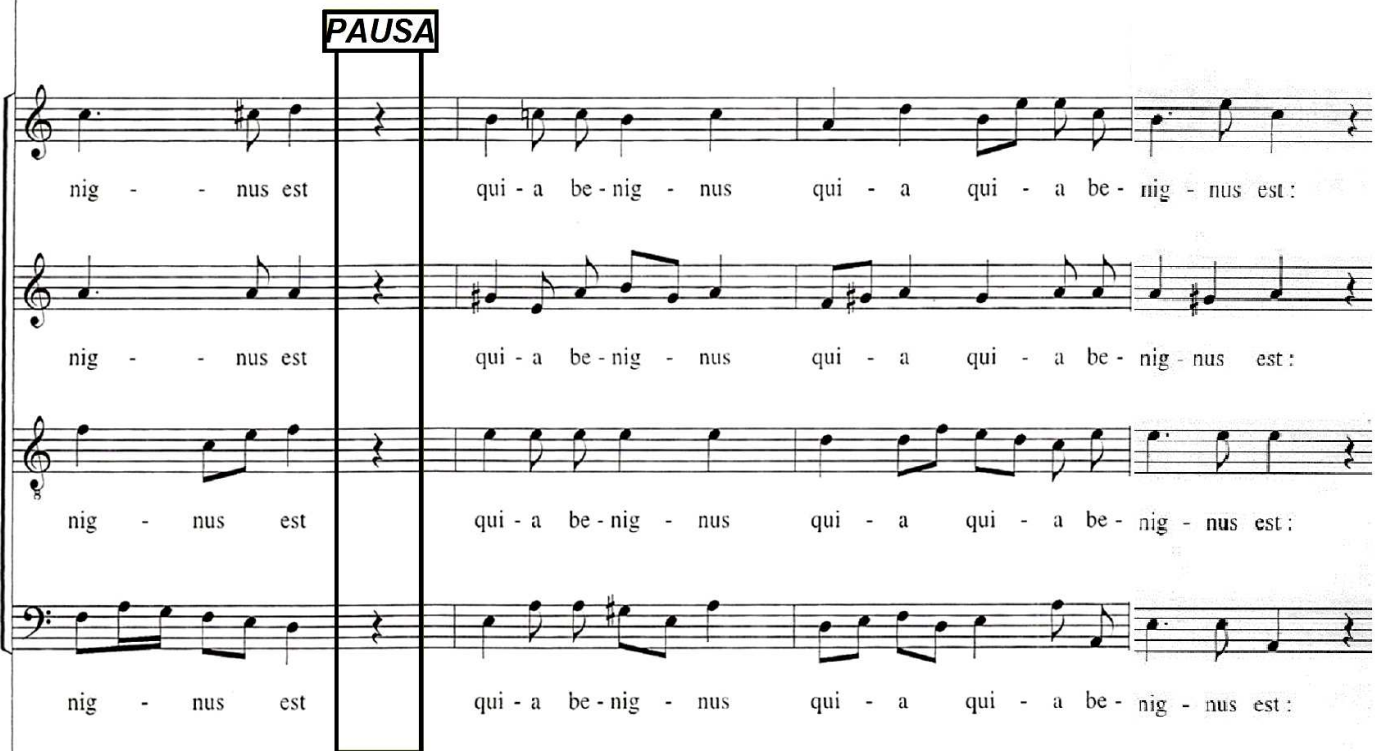

Tonalidade Lá Menor

Cadência Autêntica Imperfeita comp.29

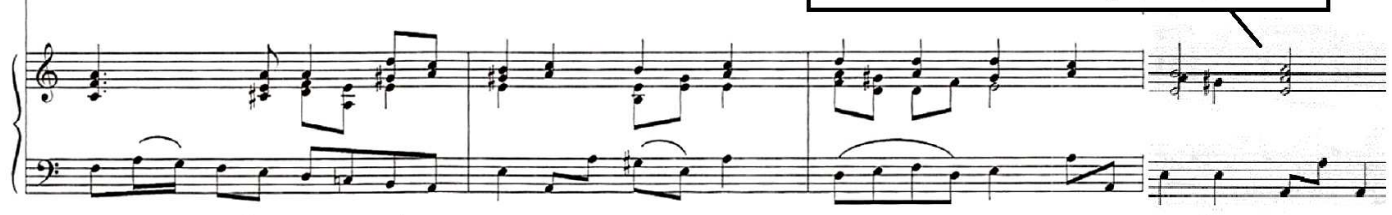

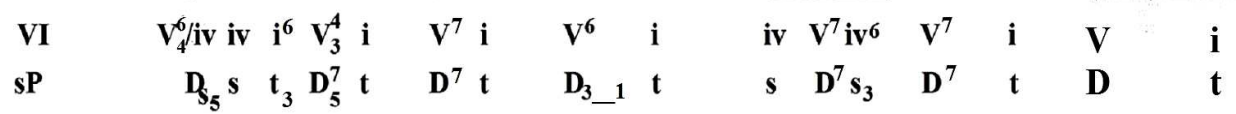

Exemplo 67: Ofertório da Missa do Quarto Domingo da Quaresma de André da Silva Gomes- Catalogação e Organização Régis Duprat (DUPRAT, 1999, pp.114-115). 


\subsubsection{Confutatio}

Depois da Aposiopesis empregada no final da seção anterior, novos elementos são apresentados na quarta seção da peça, como a Anaphora, enfatizando as palavras Psalite nominie ejus (Cantai ao seu nome), nas vozes da soprano I e II, assim caracterizando a Narratio dentro da Confutatio.

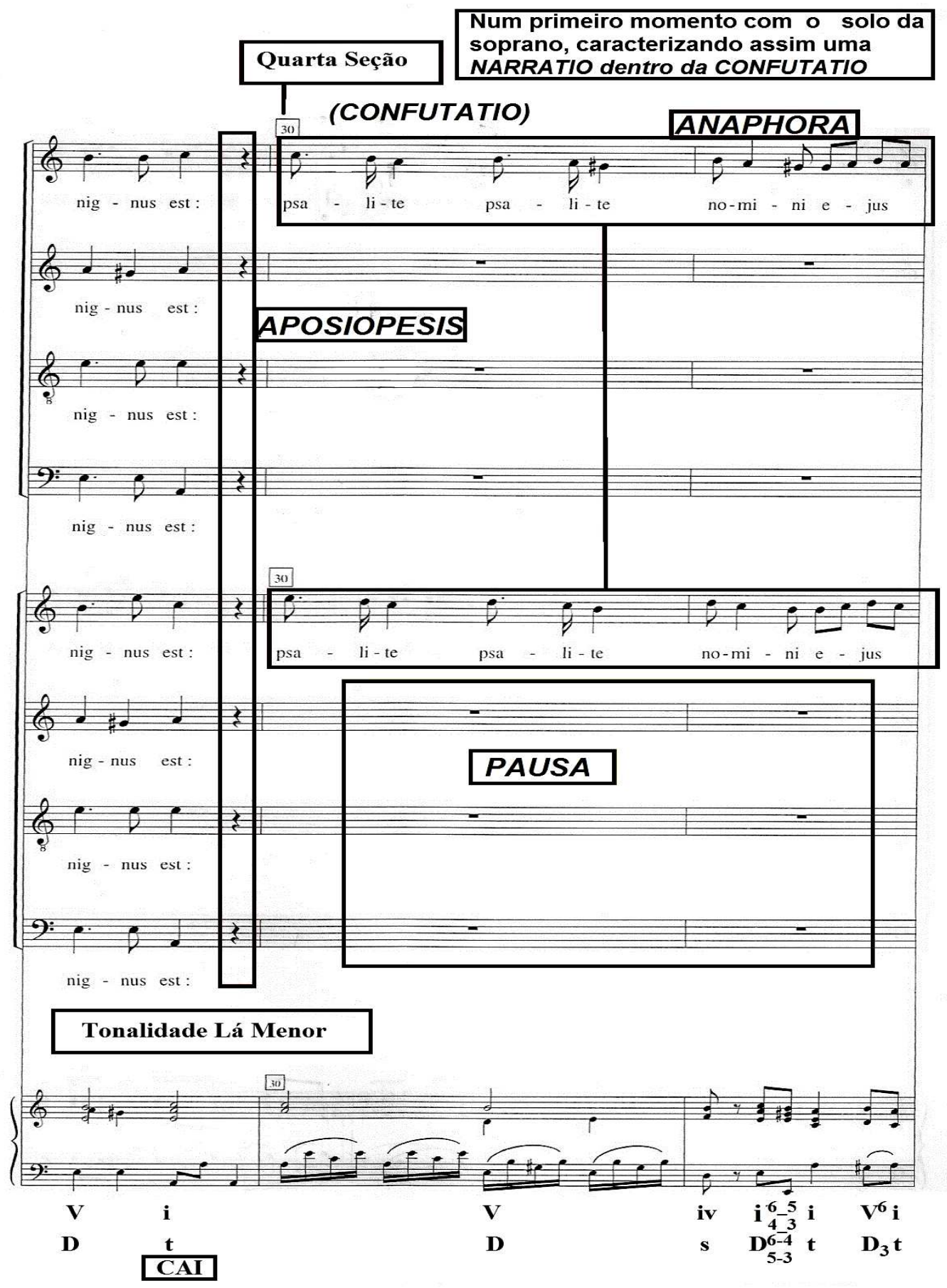

Exemplo 68: Ofertório da Missa do Quarto Domingo da Quaresma de André da Silva Gomes- Catalogação e Organização Régis Duprat (DUPRAT, 1999, p.115). 
Examina-se o uso da Synonimia nos compassos 35 e 36, repetindo a ideia musical já estabelecida de que se deve louvar ao Senhor por sua bondade e suavidade, quoniam suavis est. Similarmente, é notada uma pequena passagem cromática na soprano I, que antecede a figura de repetição, expressando de maneira suave e singela o afeto de exultação e serenidade.

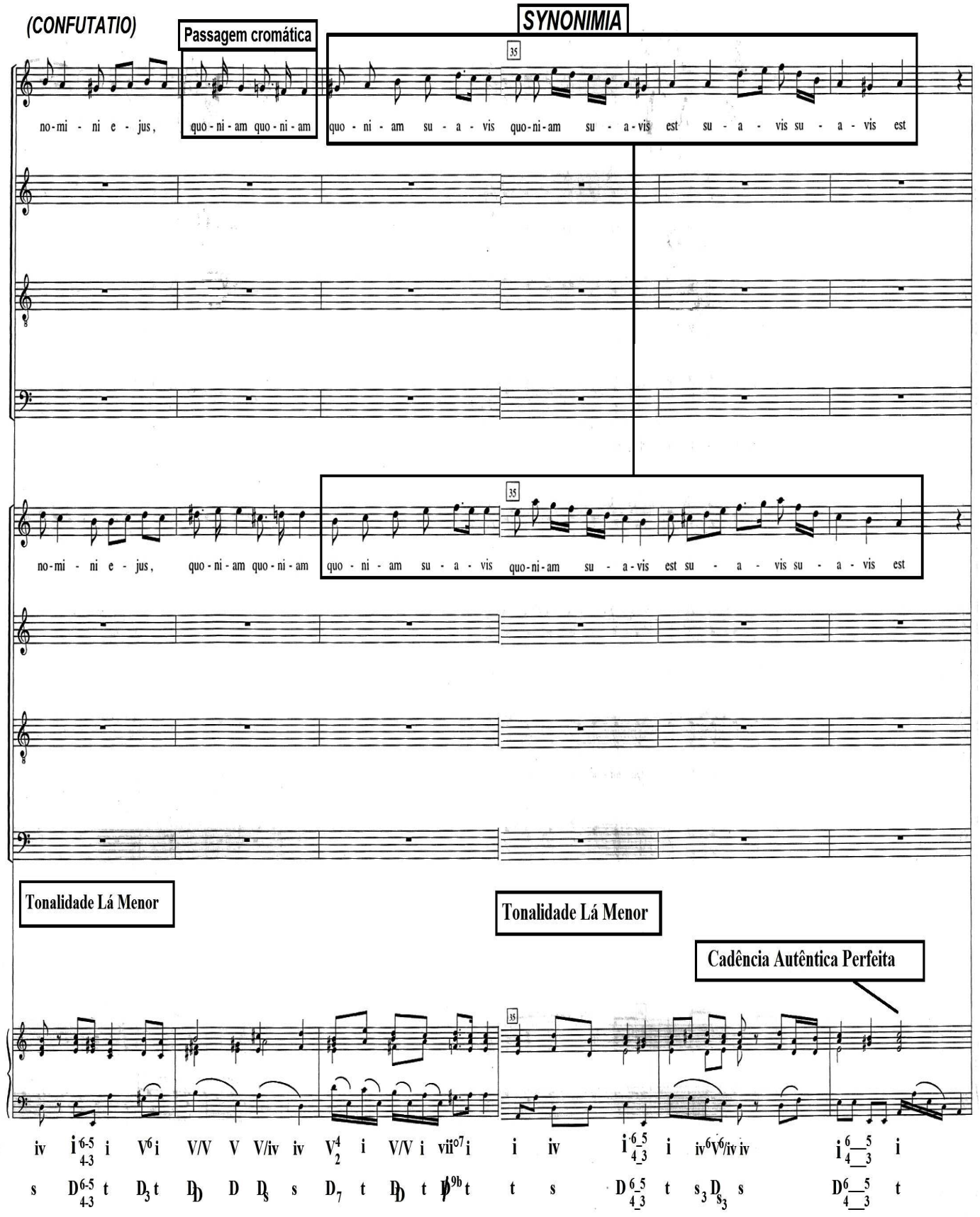

Exemplo 69: Ofertório da Missa do Quarto Domingo da Quaresma de André da Silva Gomes- Catalogação e Organização Régis Duprat (DUPRAT, 1999, pp.116-117). 
$\mathrm{Na}$ mesma senda, observa-se o emprego da Epizeuxis em todas as vozes, destacando enfaticamente que se deve louvar ao Senhor, Psalite Domino. Outra coisa a ser examinada é a modulação para a tonalidade de Dó Maior no compasso 40.

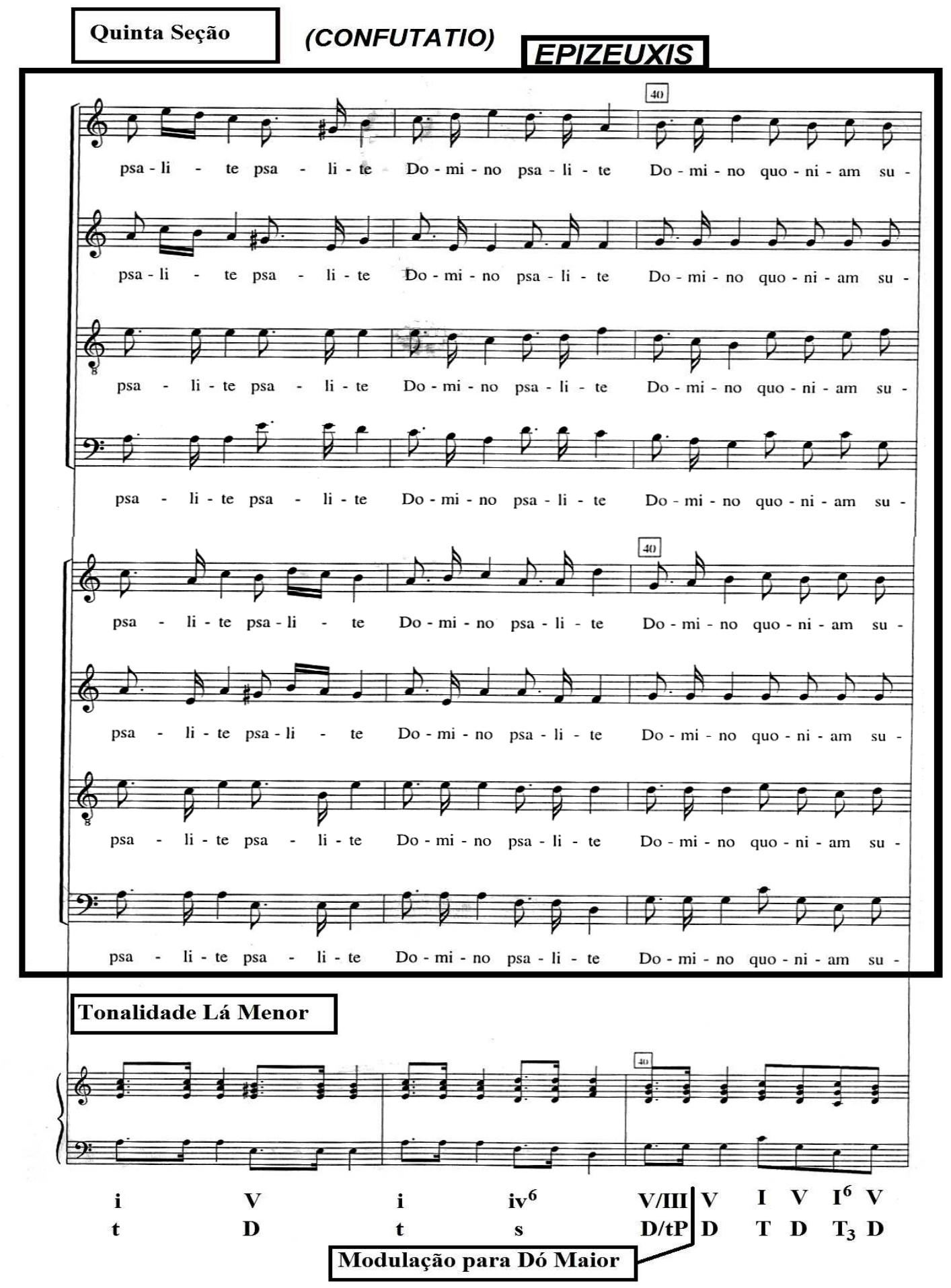

Exemplo 70: Ofertório da Missa do Quarto Domingo da Quaresma de André da Silva Gomes- Catalogação e Organização Régis Duprat (DUPRAT, 1999, p.118). 
Silva Gomes, introduz a Auxesis, repetindo uma textura homofônica em alturas diferentes, no entanto, novamente é evidenciado o emprego da Narratio dentro da Confutatio, com a aplicação da Aposiopesis e Pausa.

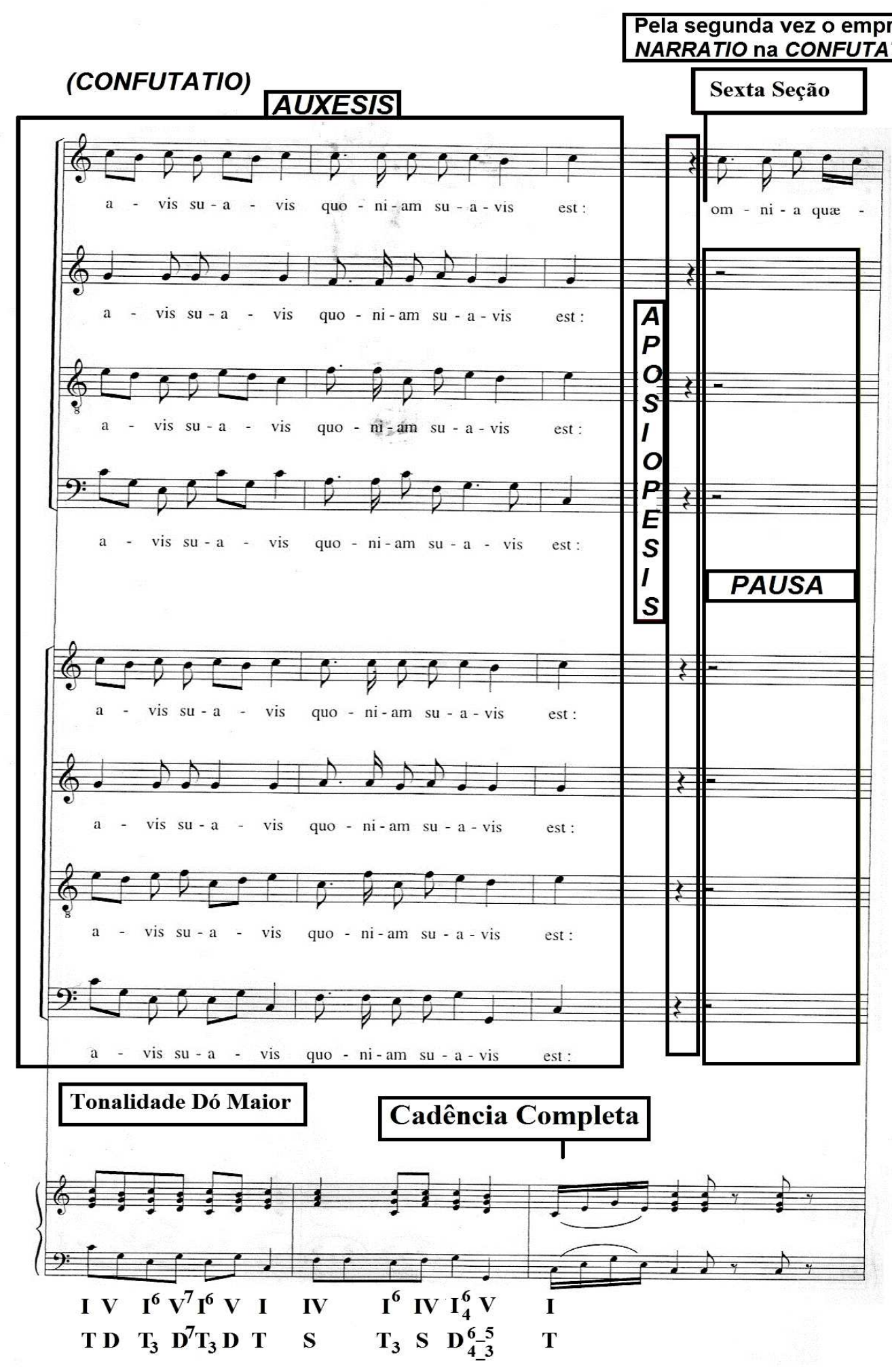

Exemplo 71: Ofertório da Missa do Quarto Domingo da Quaresma de André da Silva Gomes- Catalogação e Organização Régis Duprat (DUPRAT, 1999, p.119). 
Nessa parte, verifica-se o uso da Synonimia pelo compositor, tendo por objetivo ressaltar por meio de repetição a palavra in caelo et in terra (no céu e na terra), em outras palavras, há um forte apelo emocional ao ouvinte, representado pelo afeto de devoção e servidão a um ser que está ao mesmo tempo ascenso nas alturas, como manifesto na terra, isto é, onipresente.

Sexta Seção

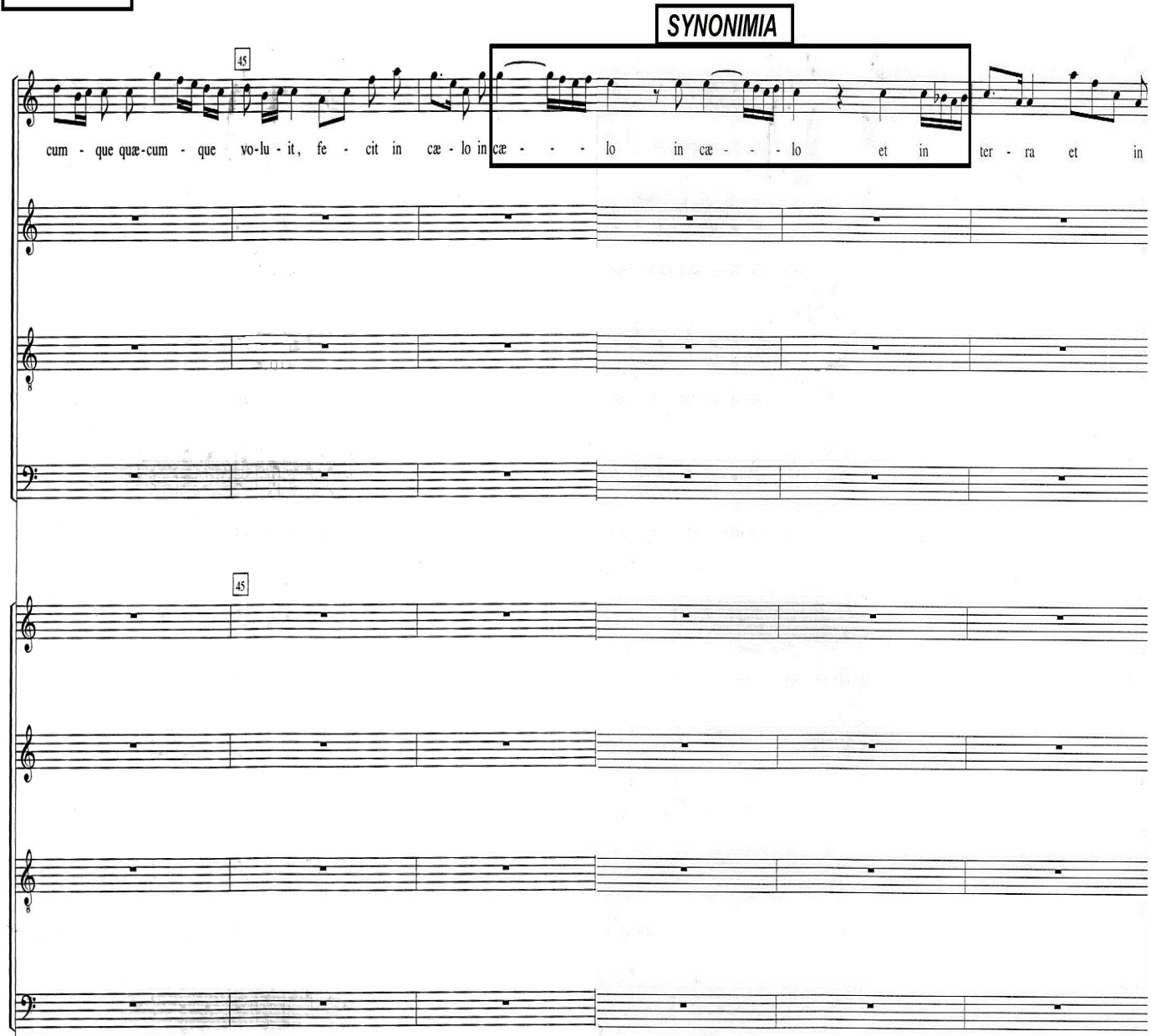

Tonalidade Dó Maior

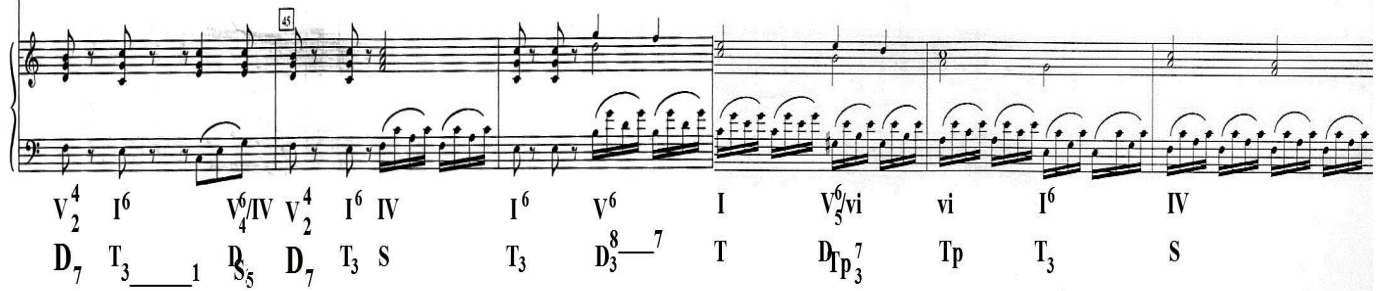

Exemplo 72: Ofertório da Missa do Quarto Domingo da Quaresma de André da Silva Gomes- Catalogação e Organização Régis Duprat (DUPRAT, 1999, pp.120-121). 


\subsubsection{Confirmatio}

A Confutatio é concluída na sexta seção em Dó Maior, no compasso 51, numa Cadência Autêntica Perfeita, igualmente, é notada a aplicação da Schematoides, destacando a palavra terra, como os mesmos intervalos e notas, todavia, com durações diferentes. Decorrente a essa conclusão, tanto a sétima seção como a Confirmatio se inicia da mesma maneira que o Exordium, entretanto, com outras palavras, Ominia quae voluit Dominus (O que apraz ao Senhor ele o faz).

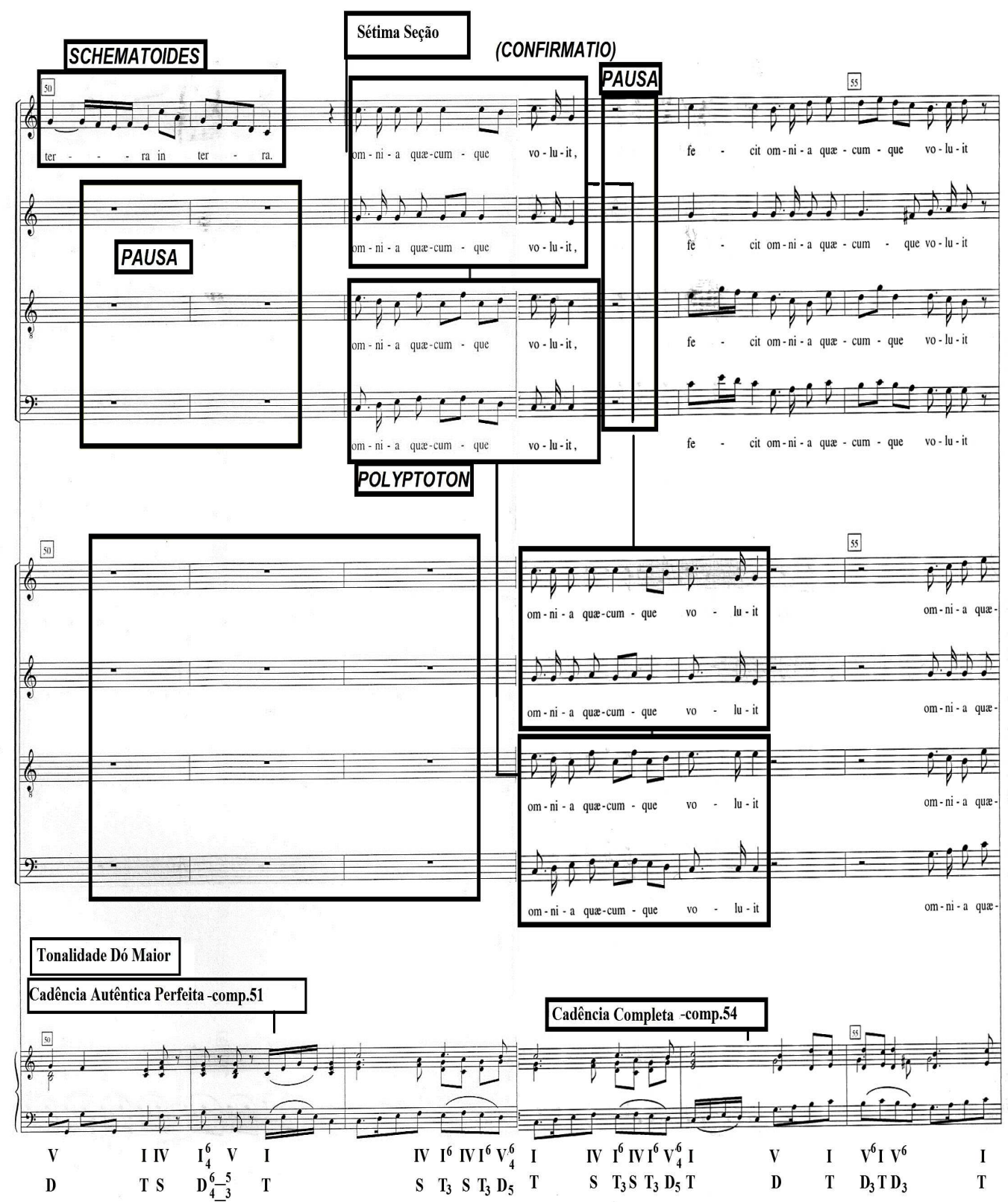

Exemplo 73: Ofertório da Missa do Quarto Domingo da Quaresma de André da Silva Gomes- Catalogação e Organização Régis Duprat (DUPRAT, 1999, pp.122-123). 
Nesse excerto, o salmista continua o seu encômio ao Senhor por seus atributos, em outras palavras, há um louvor direcionado a magnificência, bondade, poder e justiça de Deus para com seus servos, Omnia quae voluit Dominus, fecit in caelo et in terra ( $\mathrm{O}$ que apraz ao Senhor ele o faz, no céu e na terra). Enfim, por intermédio da Epizeuxis, Palilogia e Anaphora, Silva Gomes de maneira incisiva e repetitiva, confirma essa proposição.

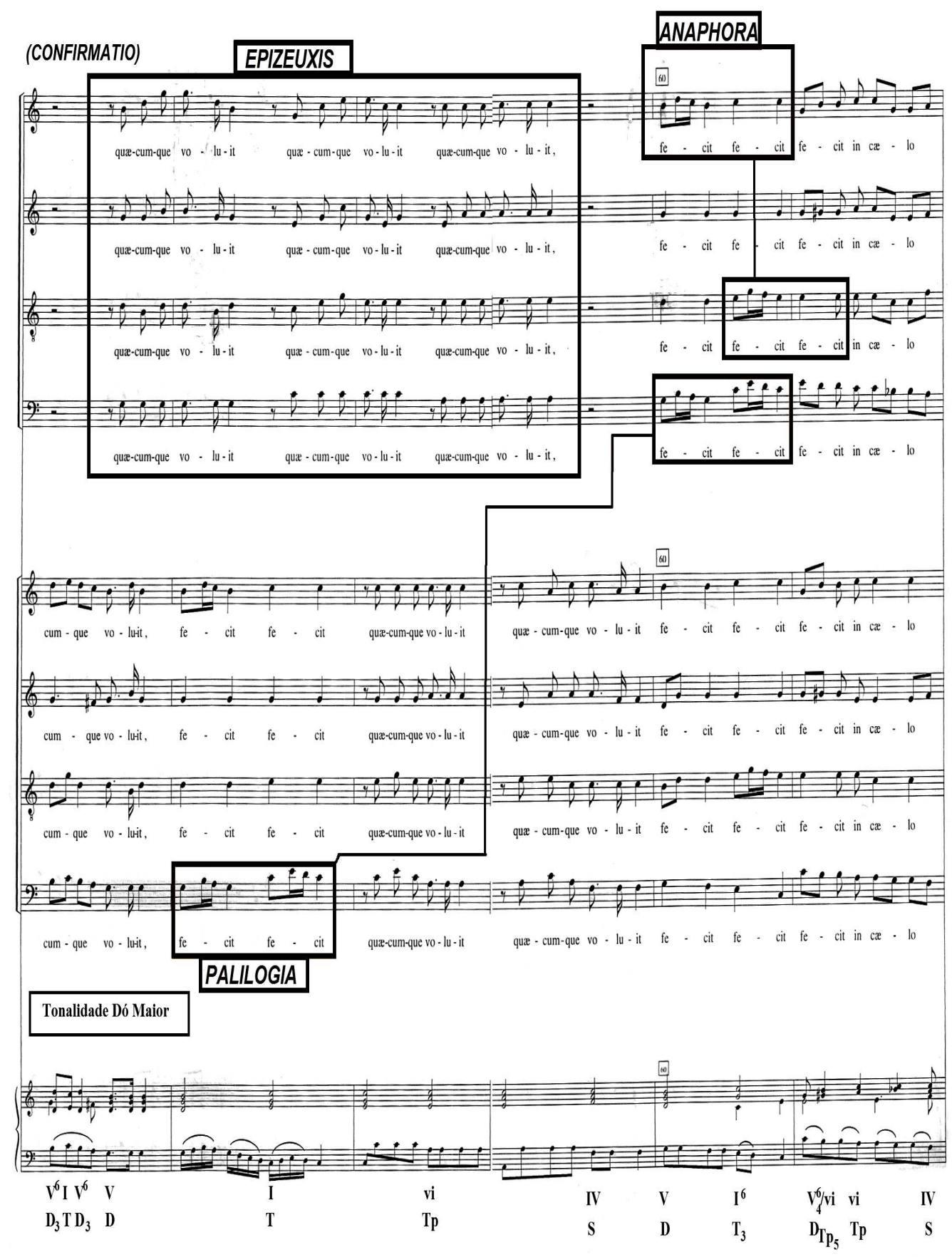

Exemplo 74: Ofertório da Missa do Quarto Domingo da Quaresma de André da Silva Gomes- Catalogação e Organização Régis Duprat (DUPRAT, 1999, pp.124-125). 


\subsubsection{Perotatio}

Na Perotatio é verificável o emprego da Noema numa passagem homofônica, também a Aposiopesis, no compasso 63, logo após a Dominante, evidenciando a Semicadência confirmando o caráter apoteótico da obra. Silva Gomes, mostra sua habilidade em adotar um processo de invenção musical realizado e elaborado na diversificação tanto da massa sonora das duas partes das vozes, seja no canto responsorial estrito ou na ordenação variada de sua disposição temporal (SOARES, 2000, p.87).

O compositor luso-brasileiro conhecedor das técnicas do contraponto, da gramática e, sobretudo da retórica, apropria-se de uma escrita cordal estrita entre os compassos 60-63, ainda na Confirmatio, a qual se consubstanciará na conclusão do discurso numa Coda, na sétima seção, em andamento Adagio, possibilitando ao autor desenvolver maior expectativa e persuasão a quem ouve, modificando a tonalidade para Dó Menor, ou seja, ele dirige o pensamento de seu auditório a terra, fazendo que o mesmo, sinta suavidade, doçura, agrado e confiança, característicos dos afetos da Laetitia, entretanto, com se estivesse próximo do céu e daquele que é aprazível, reto e justo, por meio de seu louvor e exultação. Enfim, o ofertório termina retornando de forma inesperada no último acorde para Dó Maior. 


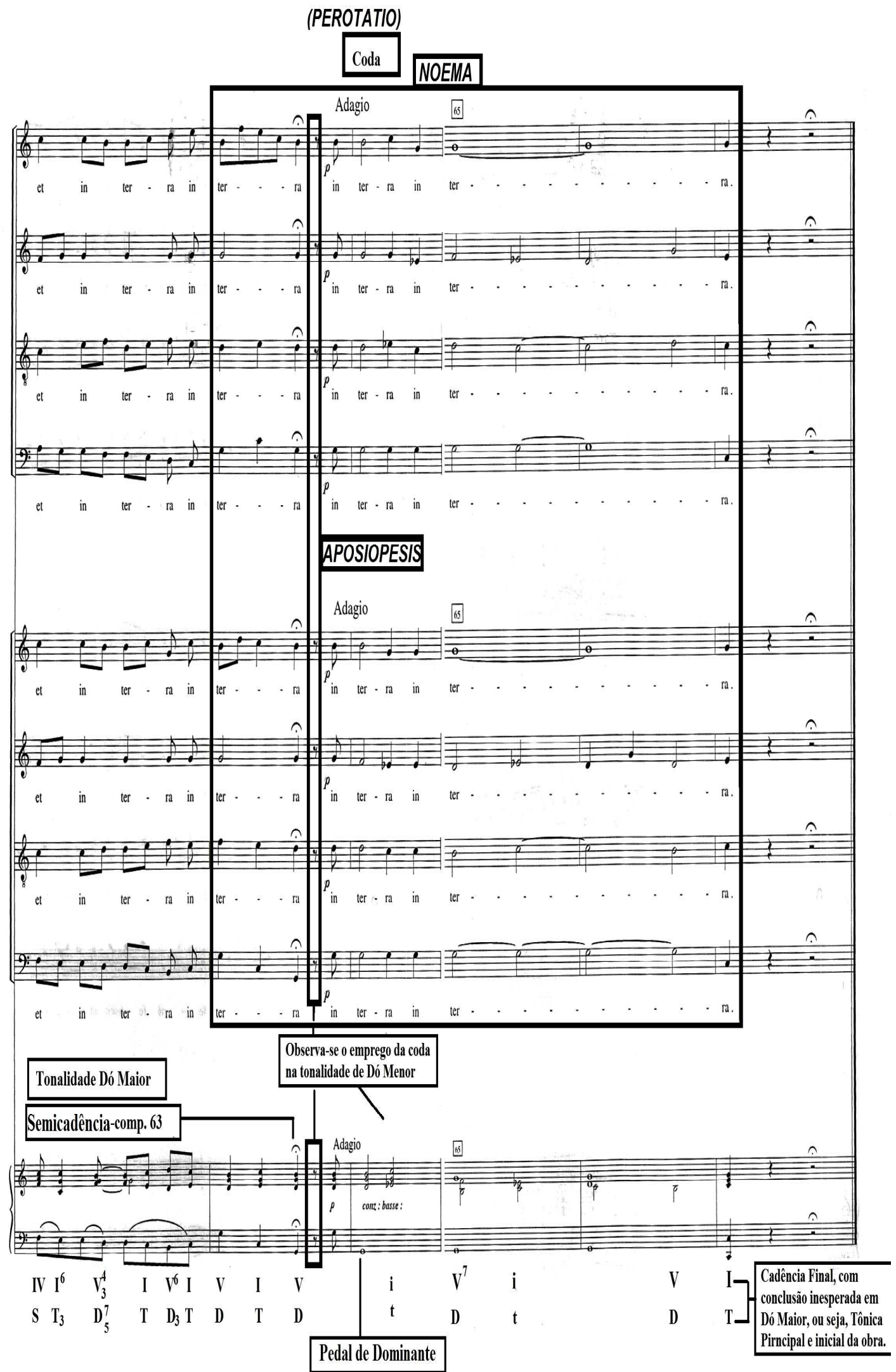

Exemplo 75: Ofertório da Missa do Quarto Domingo da Quaresma de André da Silva Gomes- Catalogação e Organização Régis Duprat (DUPRAT, 1999, pp.126-127). 


\subsection{Figuras observadas no Ofertório (Elocutio/Decoratio)}

\begin{tabular}{|c|c|c|c|}
\hline FIGURAS & TIPO & DESCRIÇÃO & TRATADISTA \\
\hline $\begin{array}{l}\text { ANAPHORA } \\
\text { (BARTEL, 1997, } \\
\text { pp.184-190). }\end{array}$ & $\begin{array}{l}\text { Repetição } \\
\text { Melódica }\end{array}$ & $\begin{array}{l}\text { (1) É uma linha } \\
\text { do baixo repetida } \\
\text { em forma de solo. } \\
\text { (2) A repetição de } \\
\text { uma exposição } \\
\text { melódica sobre } \\
\text { notas e partes } \\
\text { diferentes. } \\
\text { Também pode } \\
\text { ocorrer no início } \\
\text { das repetições de } \\
\text { frases e motivos } \\
\text { em uma série de } \\
\text { passagens } \\
\text { sucessivas; } \\
\text { Uma repetição } \\
\text { em geral. }\end{array}$ & $\begin{array}{l}\text { Walther: É uma } \\
\text { figura ra de } \\
\text { repetição e pode } \\
\text { ocorrer de duas } \\
\text { maneiras: } \\
\text { 1. Quando uma } \\
\text { palavra é } \\
\text { repetida } \\
\text { frequentement } \\
\text { e em uma } \\
\text { composição } \\
\text { para dar maior } \\
\text { ênfase. } \\
\text { 2. Quando as } \\
\text { notas graves } \\
\text { são repetidas } \\
\text { inúmeras } \\
\text { vezes (como o } \\
\text { caso das } \\
\text { Chaconne). }\end{array}$ \\
\hline $\begin{array}{l}\text { APOSIOPESIS } \\
\text { (BARTEL, 1997, } \\
\text { pp.202-206) }\end{array}$ & $\begin{array}{l}\text { Interrupção e } \\
\text { Silêncio }\end{array}$ & $\begin{array}{l}\text { Um descanso em } \\
\text { uma ou todas as } \\
\text { vozes de uma } \\
\text { composição: } \\
\text { pausa geral. }\end{array}$ & $\begin{array}{l}\text { Walther: } \\
\text { Aposiopesis se } \\
\text { refere a uma } \\
\text { pausa generalis } \\
\text { ou um completo } \\
\text { silêncio em todas } \\
\text { as vozes e nas } \\
\text { partes r da } \\
\text { composição r } \\
\text { simultaneamente. }\end{array}$ \\
\hline $\begin{array}{l}\text { AUXESIS } \\
\text { (BARTEL, 1997, pp. } \\
\text { 209-212). }\end{array}$ & $\begin{array}{l}\text { Repetição } \\
\text { Melódica }\end{array}$ & $\begin{array}{l}\text { São repetições } \\
\text { sucessivas de } \\
\text { uma passagem } \\
\text { musical. }\end{array}$ & $\begin{array}{lr}\text { Burmeister: } & \text { A } \\
\text { Auxesis ocorre } \\
\text { quando uma } \\
\text { harmonia } \\
\text { composta por } \\
\text { combinações } \\
\text { consonantes se } \\
\text { desenvolve de } \\
\text { forma crescente } \\
\text { em um texto que } \\
\text { é repetido uma, } \\
\text { duas, três ou } \\
\text { mais vezes. } \\
\text { Portanto, ela }\end{array}$ \\
\hline
\end{tabular}




\begin{tabular}{|c|c|c|c|c|}
\hline & & & & $\begin{array}{l}\text { pode ser } \\
\text { caracterizada por } \\
\text { uma elevação } \\
\text { com incremento } \\
\text { na altura de um } \\
\text { Noema repetido. }\end{array}$ \\
\hline $\begin{array}{l}\text { CLIMAX } \\
\text { (BARTEL, } \\
\text { pp.220-224). }\end{array}$ & 1997 & $\begin{array}{l}\text { Repetição } \\
\text { Melódica }\end{array}$ & $\begin{array}{l}\text { (1) Uma } \\
\text { sequência de } \\
\text { notas em uma só } \\
\text { voz repetida em } \\
\text { qualquer } \\
\text { tonalidade maior } \\
\text { ou menor, (2) } \\
\text { Duas vozes que } \\
\text { se deslocam em } \\
\text { movimento } \\
\text { ascendente ou } \\
\text { descendente } \\
\text { paralelo, (3) Um } \\
\text { aumento gradual } \\
\text { na intensidade e } \\
\text { altura do som. }\end{array}$ & $\begin{array}{l}\text { Burmeister: A } \\
\text { Climax repete } \\
\text { notas } \\
\text { semelhantes ou } \\
\text { alturas similares. } \\
\text { Kircher: } \\
\text { Climax } \\
\text { Gradatio é uma } \\
\text { passagem } \\
\text { musical } \\
\text { ascendente que é } \\
\text { frequentemente } \\
\text { utilizada em } \\
\text { afetos de amor e } \\
\text { desejo de de } \\
\text { unidade do reino } \\
\text { celestial. }\end{array}$ \\
\hline $\begin{array}{l}\text { EPIZEUXIS } \\
\text { (BARTEL, } \\
\text { pp.263-265). }\end{array}$ & 1997 & $\begin{array}{l}\text { Repetição } \\
\text { Melódica }\end{array}$ & $\begin{array}{l}\text { Uma repetição } \\
\text { imediata e } \\
\text { enfática de uma } \\
\text { palavra, nota, } \\
\text { motivo ou frase. }\end{array}$ & $\begin{array}{l}\text { Walther: A } \\
\text { Epizeuxis é uma } \\
\text { figura de retórica } \\
\text { pela qual uma ou } \\
\text { mais palavras } \\
\text { são } \\
\text { imediatamente e } \\
\text { enfaticamente } \\
\text { repetidas. }\end{array}$ \\
\hline $\begin{array}{l}\text { NOEMA } \\
\text { (BARTEL, } \\
\text { p.339-342). }\end{array}$ & 1997 & $\begin{array}{l}\text { Representação } \\
\text { e Descrição }\end{array}$ & $\begin{array}{l}\text { Uma passagem } \\
\text { homofônica em } \\
\text { uma textura } \\
\text { contrapontística e } \\
\text { polifônica. }\end{array}$ & $\begin{array}{l}\text { Burmeister: A } \\
\text { Noema } \\
\text { representa o } \\
\text { afeto harmônico, } \\
\text { onde as vozes } \\
\text { combinadas têm } \\
\text { valores e } \\
\text { números de notas } \\
\text { semelhantes. } \\
\text { Quando } \\
\text { introduzida } \\
\text { adequadamente, } \\
\text { isto é, no } \\
\text { momento certo, } \\
\text { ela afeta } \\
\text { docemente os } \\
\text { ouvidos do }\end{array}$ \\
\hline
\end{tabular}




\begin{tabular}{|c|c|c|c|}
\hline $\begin{array}{l}\text { (BUELOW, 1980, } \\
\text { p.799). }\end{array}$ & & & $\begin{array}{l}\text { ouvinte, } \\
\text { produzindo uma } \\
\text { sensação de } \\
\text { calma e } \\
\text { serenidade. } \\
\text { Seção } \\
\text { homofônica, } \\
\text { dentro da } \\
\text { polifonia utilizada } \\
\text { para enfatizar o } \\
\text { texto. }\end{array}$ \\
\hline $\begin{array}{l}\text { PALILOGIA } \\
\text { (BARTEL, 1997, } \\
\text { pp.342-344). }\end{array}$ & $\begin{array}{l}\text { Repetição } \\
\text { Melódica }\end{array}$ & \begin{tabular}{l}
\multicolumn{2}{c}{ Repetição de um } \\
tema no mesmo \\
nível de altura, \\
também pode \\
ocorrer em \\
alturas diferentes \\
na mesma ou em \\
várias vozes.
\end{tabular} & 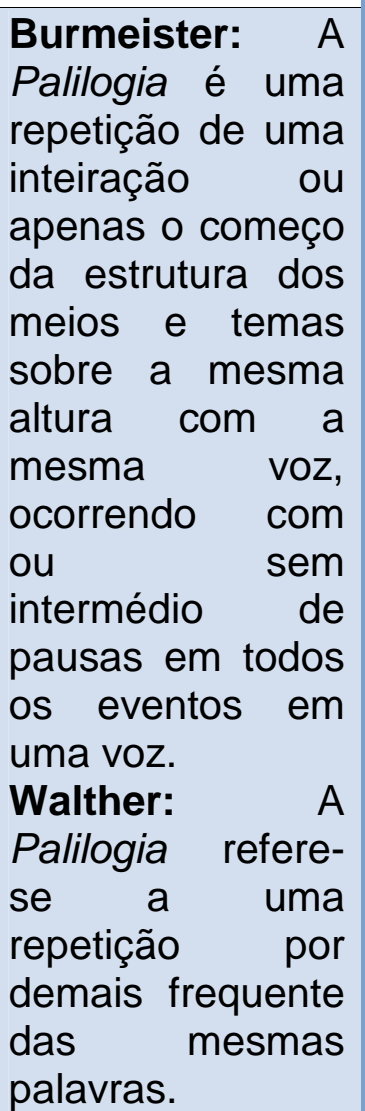 \\
\hline $\begin{array}{l}\text { PASSUS } \\
\text { DURIUSCULUS } \\
\text { (BARTEL, 1997, } \\
\text { pp.357-358) }\end{array}$ & $\begin{array}{l}\text { Dissonância e } \\
\text { Deslocamento }\end{array}$ & $\begin{array}{l}\text { Uma alteração } \\
\text { cromática } \\
\text { ascendente ou } \\
\text { descendente de } \\
\text { uma linha } \\
\text { melódica. }\end{array}$ & $\begin{array}{l}\text { Bernhard: } \\
\text { Passus } \\
\text { Duriusculus } \\
\text { dentro de uma } \\
\text { voz ocorre } \\
\text { quando a mesma } \\
\text { sobe ou desce } \\
\text { um semitom } \\
\text { menor. Estas } \\
\text { progressões } \\
\text { alguns } \\
\text { consideram como } \\
\text { cromáticas, razão } \\
\text { pela qual elas } \\
\text { podem }\end{array}$ \\
\hline
\end{tabular}




\begin{tabular}{|c|c|c|c|}
\hline & & & $\begin{array}{l}\text { movimentar-se } \\
\text { entre si. Também } \\
\text { pode ocorrer } \\
\text { nestas situações: } \\
\text { quando grau é } \\
\text { segundo grau } \\
\text { aumentado, uma } \\
\text { terça é diminuída, } \\
\text { uma quarta ou } \\
\text { quinta ó } \\
\text { aumentada ou } \\
\text { diminuída. }\end{array}$ \\
\hline $\begin{array}{l}\text { PAUSA } \\
\text { (BARTEL, } \\
\text { pp.362-365). }\end{array}$ & $\begin{array}{l}\text { Interrupção e } \\
\text { Silêncio }\end{array}$ & $\begin{array}{l}\text { Uma pausa ou } \\
\text { descanso em } \\
\text { uma composição } \\
\text { musical. }\end{array}$ & $\begin{array}{l}\text { Walther: Uma } \\
\text { figura ou figuras } \\
\text { de silêncio. } \\
\text { Pausa refere-se a } \\
\text { um período de } \\
\text { repouso ou o } \\
\text { silêncio } \\
\text { música, que é } \\
\text { indicado por um } \\
\text { determinado } \\
\text { sinal. }\end{array}$ \\
\hline $\begin{array}{l}\text { POLYPTOTON } \\
\text { (BARTEL, } 1997, \\
\text { pp.367-369). }\end{array}$ & $\begin{array}{l}\text { Repetição } \\
\text { Melódica }\end{array}$ & $\begin{array}{l}\text { A repetição de } \\
\text { uma passagem } \\
\text { melódica em } \\
\text { diferentes alturas. }\end{array}$ & \begin{tabular}{lr}
\multicolumn{2}{l}{ Vogt: Polyptoton } \\
é quando uma \\
passagem \\
repetida é \\
várias alturas.
\end{tabular} \\
\hline $\begin{array}{l}\text { SCHEMATOIDES } \\
\text { (BARTEL, } 1997, \\
\text { pp.382-384). }\end{array}$ & Diversas & $\begin{array}{l}\text { Figura que } \\
\text { reestrutura uma } \\
\text { passagem } \\
\text { anterior, quer } \\
\text { através da } \\
\text { mudança no texto } \\
\text { ou através de } \\
\text { duração aumento } \\
\text { ou diminuição. }\end{array}$ & $\begin{array}{l}\text { Printz: } \\
\text { Schematoides é } \\
\text { uma figuração } \\
\text { construída dos } \\
\text { partir } \\
\text { mesmos } \\
\text { intervalos de uma } \\
\text { determinada } \\
\text { figura, mas é } \\
\text { diferente, quer na } \\
\text { duração ou na } \\
\text { forma de } \\
\text { execução } \\
\text { mesma. da } \\
\text { A Schematoides } \\
\text { Perfectus ocorre } \\
\text { quando as notas } \\
\text { e os intervalos } \\
\text { são os mesmos } \\
\text { de uma figura, }\end{array}$ \\
\hline
\end{tabular}




\begin{tabular}{|c|c|c|c|}
\hline & & & $\begin{array}{l}\text { porém são } \\
\text { cantadas várias } \\
\text { sílabas em vez } \\
\text { de apenas uma. } \\
\text { Esta pode ser } \\
\text { encontrada } \\
\text { somente na } \\
\text { música vocal. } \\
\text { A Schematoides } \\
\text { Minus Perfectus } \\
\text { ocorre quando os } \\
\text { intervalos são os } \\
\text { mesmos, mas de } \\
\text { maior duração. } \\
\text { Magis Congruus } \\
\text { Schematoides } \\
\text { ocorre quando os } \\
\text { intervalos são os } \\
\text { mesmos, as } \\
\text { notas mais lentas } \\
\text { e ainda em igual } \\
\text { proporção com as } \\
\text { notas da figura. } \\
\text { Schematoides } \\
\text { menos } \\
\text { congruente } \\
\text { (Minus Congruus) } \\
\text { ocorre quando os } \\
\text { intervalos são os } \\
\text { mesmos de uma } \\
\text { figura, mas a } \\
\text { duração das } \\
\text { notas não é de } \\
\text { proporções iguais } \\
\text { às da figura. }\end{array}$ \\
\hline $\begin{array}{l}\text { SYNONYMIA } \\
\text { (BARTEL, 1997, } \\
\text { pp.405-407). }\end{array}$ & $\begin{array}{l}\text { Repetição } \\
\text { Melódica }\end{array}$ & $\begin{array}{l}\text { É a repetição de } \\
\text { uma ideia musical } \\
\text { em forma } \\
\text { alterada ou } \\
\text { modificada. }\end{array}$ & $\begin{array}{l}\text { Walther: Um } \\
\text { compositor } \\
\text { também pode } \\
\text { empregar muito } \\
\text { bem diferentes } \\
\text { figuras retóricas } \\
\text { na elaboração de } \\
\text { um texto. Por } \\
\text { exemplo, além da } \\
\text { Epizeuxis, que é } \\
\text { a mais comum e } \\
\text { enfática, pode } \\
\text { usar, Anaphora, } \\
\text { Synonimia, } \\
\text { Epistrophe, }\end{array}$ \\
\hline
\end{tabular}




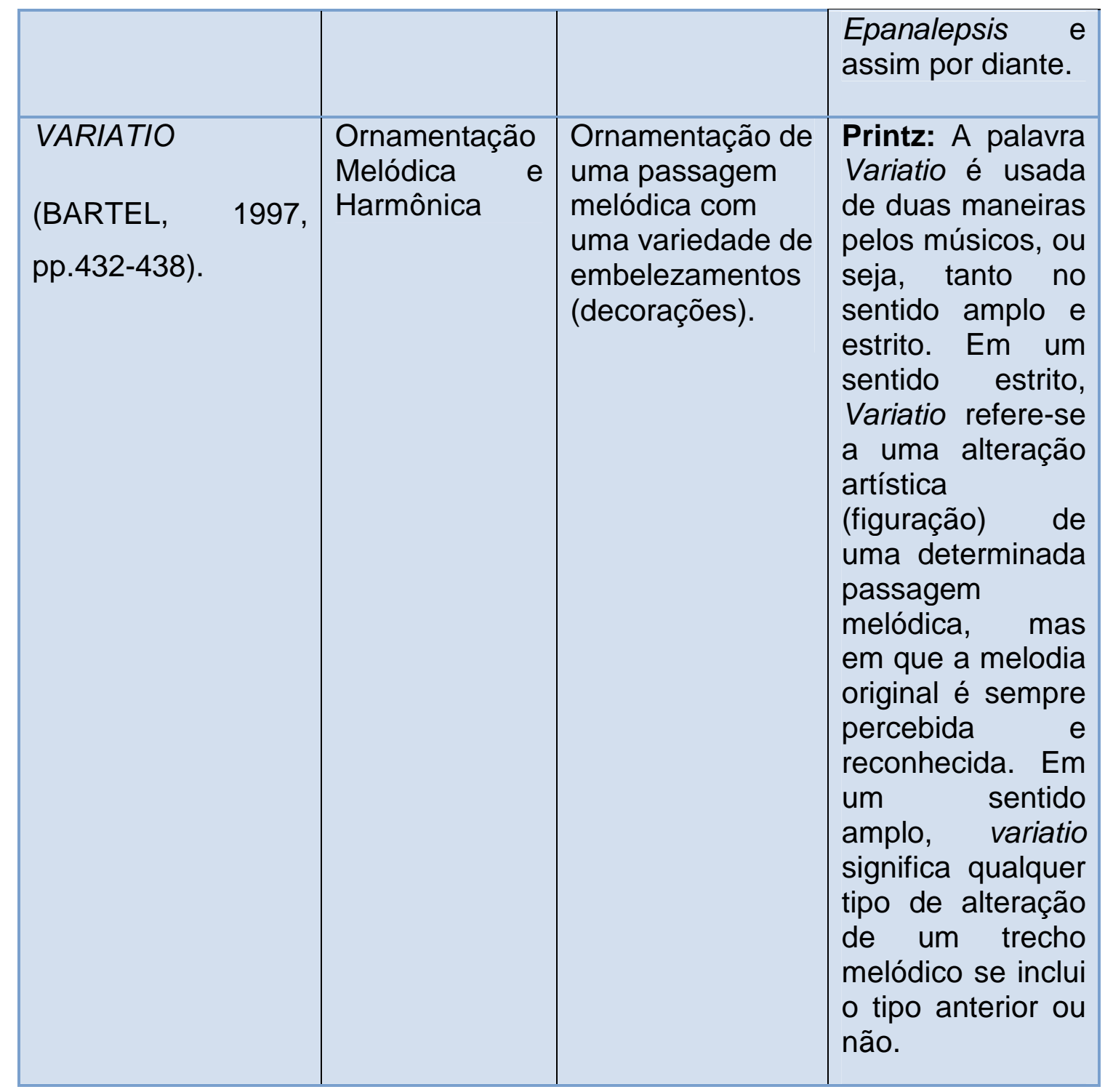

Tabela 29: Figuras encontradas no Ofertório da Missa do Quarto Domingo da Quaresma de André da Silva Gomes

\section{Análise Harmônica}

\subsection{Curva Tonal}

Tonalidade: Dó Maior

Andamento: Andante Moderato 4/4 
Esquema de Progressões Harmônicas

\begin{tabular}{|l|c|l|}
\hline Compassos & $\begin{array}{l}\text { Função em relação a } \\
\text { tonalidade principal }\end{array}$ & Tonalidade (Acorde) \\
\hline $1-14$ & $\mathrm{~T}-\mathrm{I}$ & Dó Maior \\
\hline 15 & $\mathrm{Sp}-\mathrm{ii}$ & Ré Menor \\
\hline 16 & $\mathrm{~T}-\mathrm{I}$ & Dó Maior \\
\hline $17-18$ & $\mathrm{~S}-\mathrm{IV}$ & Fá Maior \\
\hline $19-26$ & $\mathrm{~T}-\mathrm{I}$ & Dó Maior \\
\hline $26-27$ & $\mathrm{Tp}-\mathrm{vi}$ & Lá Menor \\
\hline 28 & $\mathrm{Sp}-\mathrm{ii}$ & Ré Menor \\
\hline $28-33$ & $\mathrm{Tp}-\mathrm{vi}$ & Lá Menor \\
\hline 33 & $\mathrm{D} / \mathrm{Tp}-\mathrm{V} / \mathrm{vi}$ & Mi Maior \\
\hline 33 & $\mathrm{D} / \mathrm{Sp}-\mathrm{V} / \mathrm{ii}$ & Lá Maior \\
\hline 34 & $\mathrm{D} / \mathrm{D}-\mathrm{V} / \mathrm{V}$ & Ré Maior \\
\hline $34-37$ & $\mathrm{Tp}-\mathrm{vi}$ & Lá Menor \\
\hline 37 & $\mathrm{Sp}-\mathrm{ii}$ & Ré Menor \\
\hline $37-40$ & $\mathrm{Tp}-\mathrm{vi}$ & Lá Menor \\
\hline $40-48$ & $\mathrm{~T}-\mathrm{I}$ & Dó Maior \\
\hline $49-50$ & $\mathrm{~S}-\mathrm{IV}$ & Fá Maior \\
\hline $51-56$ & $\mathrm{~T}-\mathrm{I}$ & Dó Maior \\
\hline $56-57$ & $\mathrm{D}-\mathrm{V}$ & Sol Maior \\
\hline $58-63$ & $\mathrm{~T}-\mathrm{I}$ & Dó Maior \\
\hline $64-67$ & $\mathrm{~T}-\mathrm{I}$ & Dó Menor \\
\hline 68 & Dó Maior \\
\hline
\end{tabular}

Tabela 30: Curva Tonal do Ofertório da Missa do Quarto Domingo da Quaresma

Números de compassos: 67

Regiões abordadas: 9

Variações: 21

Ritmo Harmônico: 3,19 (divisão dos números de compassos e variações)

Média ideal: (divisão dos números de compassos e regiões tonais abordadas = $7,44)$

Esquema Formal

$(1-25)(25-40)(40-63) \quad(63-67)$

$\mathrm{T} \quad \mathrm{Tp} \quad \mathrm{T} \quad \mathrm{t}$ (tonalidade homônima)

l vi l i 


\subsection{Estrutura Analítica do Ofertório: Retórica e Harmônica}

\begin{tabular}{|c|c|c|c|c|c|}
\hline $\begin{array}{l}\text { RETÓRICA } \\
\text { DISPOSITIO }\end{array}$ & $\begin{array}{l}\text { FIGURA } \\
\text { ELOCUTIO }\end{array}$ & COMP. & $\begin{array}{l}\text { HARMÔNICA } \\
\text { SEÇÃO }\end{array}$ & TONALIDADE & FUNÇÃO \\
\hline EXORDIUM & $\begin{array}{l}\text { Polyptoton } \\
\text { Pausa } \\
\text { Palilogia }\end{array}$ & $\begin{array}{l}2-4 \\
2-4 \\
4-5\end{array}$ & $\begin{array}{l}\text { 1 Seção } \\
1^{\text {a Seção }} \\
1^{\text {a Seção }}\end{array}$ & $\begin{array}{l}\text { Dó Maior } \\
\text { Dó Maior } \\
\text { Dó Maior }\end{array}$ & $\begin{array}{l}\text { T-I } \\
\text { T-I } \\
\text { T-I }\end{array}$ \\
\hline NARRATIO & $\begin{array}{l}\text { Pausa } \\
\text { Synonimia } \\
\text { Climax } \\
\text { Variatio }\end{array}$ & $\begin{array}{l}7-19 \\
\text { e } 21-23 \\
8-9 \\
9-11 \\
13-19\end{array}$ & $\begin{array}{l}2^{\text {a }} \text { Seção } \\
2^{\text {a Seção }} \\
2^{\text {a Seção }} \\
2^{\text {a Seção }}\end{array}$ & $\begin{array}{l}\text { Dó Maior } \\
\text { Dó Maior } \\
\text { Dó Maior } \\
\text { Dó Maior }\end{array}$ & $\begin{array}{l}\text { T-I } \\
\text { T-I } \\
\text { T-I }\end{array}$ \\
\hline PROPOSITIO & $\begin{array}{l}\text { Polyptoton } \\
\text { Synaeresis } \\
\text { Palilogia } \\
\text { Pausa } \\
\text { Aposiopesis }\end{array}$ & $\begin{array}{l}21-23 \\
21-23 \\
23-24 \\
26 \\
29\end{array}$ & 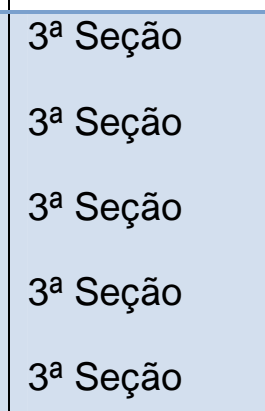 & $\begin{array}{l}\text { Dó Maior } \\
\text { Dó Maior } \\
\text { Dó Maior } \\
\text { Lá Menor } \\
\text { Lá Menor }\end{array}$ & $\begin{array}{c}\text { T-I } \\
\text { T-I } \\
\text { T-I } \\
\text { Tp-vi } \\
\text { Tp-vi }\end{array}$ \\
\hline CONFUTATIO & $\begin{array}{l}\text { Anaphora } \\
\text { Pausa } \\
\text { Synonimia } \\
\text { Epizeuxis } \\
\text { Auxesis } \\
\text { Aposiopesis } \\
\text { Schematoides }\end{array}$ & $\begin{array}{l}30-31 \\
30-37 \\
\text { e } 43-51 \\
34-37 \\
\text { e } 46-48 \\
38-40\end{array}$ & 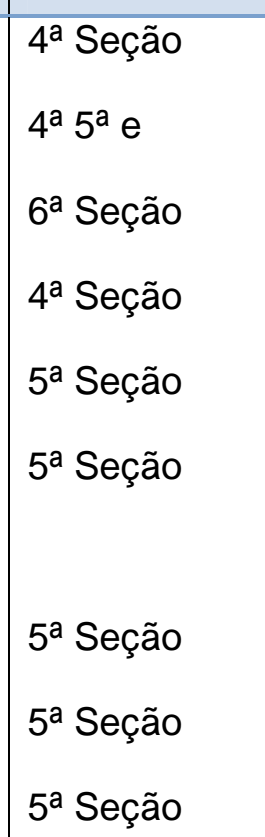 & $\begin{array}{l}\text { Lá Menor } \\
\text { Lá Menor } \\
\text { e Dó Maior } \\
\text { Lá Menor } \\
\text { Dó Maior } \\
\text { Lá Menor } \\
\text { e Dó Maior } \\
\text { Dó Maior } \\
\text { Dó Maior } \\
\text { Dó maior }\end{array}$ & $\begin{array}{l}\text { Tp-vi } \\
\text { Tp-vi } \\
\text { T-I } \\
\text { Tp-vi } \\
\text { T-I } \\
\text { Tp-vi } \\
\text { T-I } \\
\text { T-I } \\
\text { T-I } \\
\text { T-I }\end{array}$ \\
\hline CONFIRMATIO & Polyptoton & $52-54$ & 7ª Seção & Dó Maior & $\mathrm{T}-\mathrm{I}$ \\
\hline
\end{tabular}




\begin{tabular}{|c|c|c|c|c|c|}
\hline & $\begin{array}{l}\text { Pausa } \\
\text { Epizeuxis } \\
\text { Palilogia } \\
\text { Anaphora } \\
\text { Noema }\end{array}$ & $\begin{array}{l}52-53 \\
56-59 \\
57 \text { e } 60 \\
60-61 \\
63\end{array}$ & 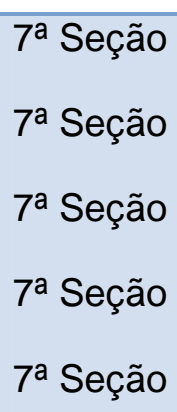 & $\begin{array}{l}\text { Dó Maior } \\
\text { Dó Maior } \\
\text { Dó Maior } \\
\text { Dó Maior } \\
\text { Dó Maior }\end{array}$ & $\begin{array}{l}\text { T-I } \\
\text { T-I } \\
\text { T-I } \\
\text { T-I } \\
\text { T-I }\end{array}$ \\
\hline PEROTATIO & $\begin{array}{l}\text { Noema } \\
\text { Aposiopesis }\end{array}$ & $\begin{array}{l}64-67 \\
63\end{array}$ & $7^{\text {a }}$ Seção & $\begin{array}{l}\text { Dó Menor } \\
\text { Dó Menor }\end{array}$ & $\begin{array}{c}t-i \\
\text { (Homo) } \\
t-i \\
\text { (Homo) }\end{array}$ \\
\hline
\end{tabular}

Tabela 31: Estrutura analítica do Ofertório 


\subsubsection{Ofertório da Missa do Primeiro Domingo do Advento}

\section{Estudo Semântico}

\subsection{Inventio}

A elaboração desta obra se dá a partir de um texto extraído dos salmos, cujo título é: Súplicas de Perdão e Libertação de Todas as Angústias (Ps. 24, 1-3/ Ps.25,1-3).

Ad te [Domine] levavi animam mean

Deus meus in te confido, nom erubescam

Neque irrideant me inimici mei

Etenim [universi] qui te expectant

[Qui se sustinent] non confundentur

A ti [Senhor] elevei minha alma

Deus meu, em ti confio, que não me envergonhe

E não se riam de mim os meus inimigos

Pois [todos os] que esperam

[Que se sustentam] em ti não serão confundidos

(SOARES, 2000, p.91).

O presente salmo retrata a oração feita pelo rei Davi, pedindo auxílio e conforto a Deus, em outras palavras, o salmista fala do intimo do seu ser, da sua condição emocional e espiritual, bem como da sua atitude. Em outras ocasiões, Davi reconhece que sua alma está angustiada (Ps.5:3/Ps.6:3), abatida (Ps.41:5/Ps.42:5) ou cheia de aflição (Ps.87:3/88:3). Todavia, ele faz uma decisão consciente a respeito do que a sua alma focalizará, isto é, resolve olhar para Deus e não para as circunstâncias. Destarte, é colocada no Senhor sua confiança em vez de ter medo dos seus inimigos (ALMEIDA, 1999, p, 852).

Desse modo, o Primeiro Domingo do Advento, simboliza para o fiel, a vigilância na espera da vinda do Senhor. Pois se deve estar preparado, por que não é sabido o momento que isso ocorrerá, por isso, a necessidade de não focalizar as dificuldades e os inimigos espirituais, sejam eles obstáculos, objeções, ansiedades, sofrimentos, angústias, desembocando numa aparente desonra ou humilhação, mas atentar-se apenas ao propósito de creditar a fé e esperança no Senhor.

Concernente à estrutura musical desse ofertório, pode-se observar, que o mesmo é composto de sessenta compassos, num Moderato Affectuozo em 
Sol Menor, dispostas em sete seções, onde Silva Gomes trará uma proposta arrojada e intrigante, despertando a curiosidade e expectativa do ouvinte, além de trabalhar com dois afetos centrais representados pela elevação e confiança e o outro pela dúvida, o que acarretará numa instabilidade harmônica na maior parte da obra.

\subsection{Locus observados na Inventio do Ofertório}

\begin{tabular}{|c|c|c|c|}
\hline INVENTIO & DESCRIÇÃO & $\begin{array}{c}\text { UTILIZAÇÃO NA } \\
\text { OBRA }\end{array}$ & $\begin{array}{l}\text { COMPASSO/ } \\
\text { VOZ }\end{array}$ \\
\hline $\begin{array}{l}\text { Locus } \\
\text { Notationis } \\
\text { (MATTHESON, } \\
\text { [1739],1954, } \\
\text { Parte II,Cap.4, } \\
\text { \$23,p.123). }\end{array}$ & $\begin{array}{l}\text { Aspecto externo } \\
\text { e desenho das } \\
\text { notas (Duração } \\
\text { das notas, } \\
\text { alteração, } \\
\text { repetição e } \\
\text { procedimentos } \\
\text { canônicos). }\end{array}$ & $\begin{array}{l}\text { Vários motivos } \\
\text { rítmicos e diferentes } \\
\text { durações de notas } \\
\text { (mínimas, mínimas } \\
\text { pontuadas, } \\
\text { semínimas,semínimas } \\
\text { pontuadas, colcheias, } \\
\text { semicolcheias } \\
\text { repetições, ligaduras, } \\
\text { apogiaturas, pausas, } \\
\text { entre outros). }\end{array}$ & $\begin{array}{ll}1-8 & S \\
9-12 & \text { S-A-T-B } \\
13-16 & \text { S-A-T-B } \\
17-59 & \text { S-A-T-B }\end{array}$ \\
\hline $\begin{array}{l}\text { Locus } \\
\text { Descriptionis } \\
\text { (MATTHESON, } \\
\text { [1739],1954, } \\
\text { Parte II,Cap.4, } \\
\text { § 43,p.127). }\end{array}$ & $\begin{array}{l}\text { Disposições da } \\
\text { alma }\end{array}$ & $\begin{array}{l}\text { Confiança, Fé (Deus } \\
\text { meu, em ti confio). } \\
\text { Vergonha, Angústia, } \\
\text { Humilhação (que não } \\
\text { me envergonhe) } \\
\text { Esperança (Pois } \\
\text { [todos os] que } \\
\text { esperam). }\end{array}$ & $\begin{array}{l}20-27 \text { S-A-T-B } \\
26-35 \text { S-A-T-B } \\
50-52 \text { S-A-T-B }\end{array}$ \\
\hline
\end{tabular}

Tabela 32: Locus Topici encontrados no Ofertório da Missa do Primeiro Domingo do Advento de André da Silva Gomes 


\subsection{Dispositio}

\subsubsection{Exordium}

O discurso é iniciado de maneira reflexiva numa súplica em forma de oração, Ad te [Domine] levavi animam mean (A ti Senhor elevei a minha alma), sendo a mesma destacada pelo solo da soprano até o compasso 12. Em meio a tal prece é trabalhada pelo autor a primeira ideia do ofertório, que é a elevação do espirito do fiel através da busca de um relacionamento com Deus, visando não só a purificação e santificação, mas a confiança para alcançar seus objetivos.

Como complemento a essas petições, o autor adiciona a Anaphora, enfatizando a palavra levavi (elevei), da mesma forma a Acciaccatura, completando o uso ornamental, acrescendo uma nota dissonante ao acorde de Dó Menor (Si bemol), logo resolvida, no compasso 3. A mesma resolução acontece em Sol Menor, da nota Lá para Sol.

No mesmo trecho, Silva Gomes, utiliza a figura da Pausa e também da Variatio, ressaltando ainda mais o caráter afetuoso da prédica animam mean (minha alma), por meio de silêncio e variação, simbolizando um momento de pergunta feito pelo suplicante, acompanhado de quietude, parecendo que não haverá resposta as suas indagações. 
Primeira Seção

Tonalidade Sol Menor Ofertório da Missa do $1^{\circ}$. Domingo do Advento
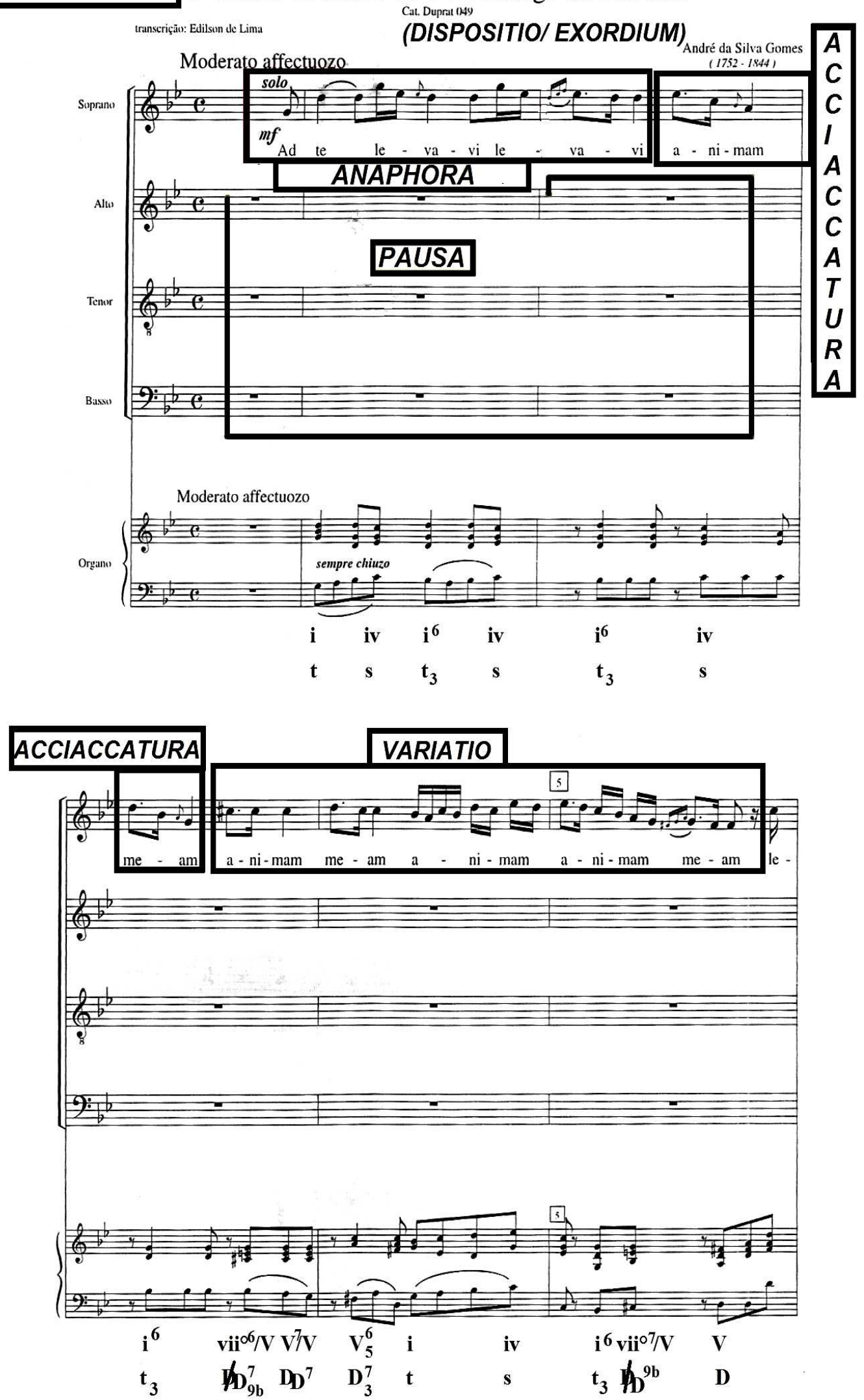

Exemplo 76: Ofertório da Missa do Primeiro Domingo do Advento de André da Silva Gomes- Catalogação e Organização Régis Duprat (DUPRAT, 1999, p.128). 
No final da primeira seção, constata-se o uso da Climax, repetindo as notas e as palavras, como a Cadência Autêntica Perfeita, já na segunda o autor insere em todas as vozes, uma das duas figuras centrais da peça, a Anabasis que acoplada a Auxesis, repete e enfatiza a expressão levavi animam mean (elevei minha alma), por meio de melodia ascendente.

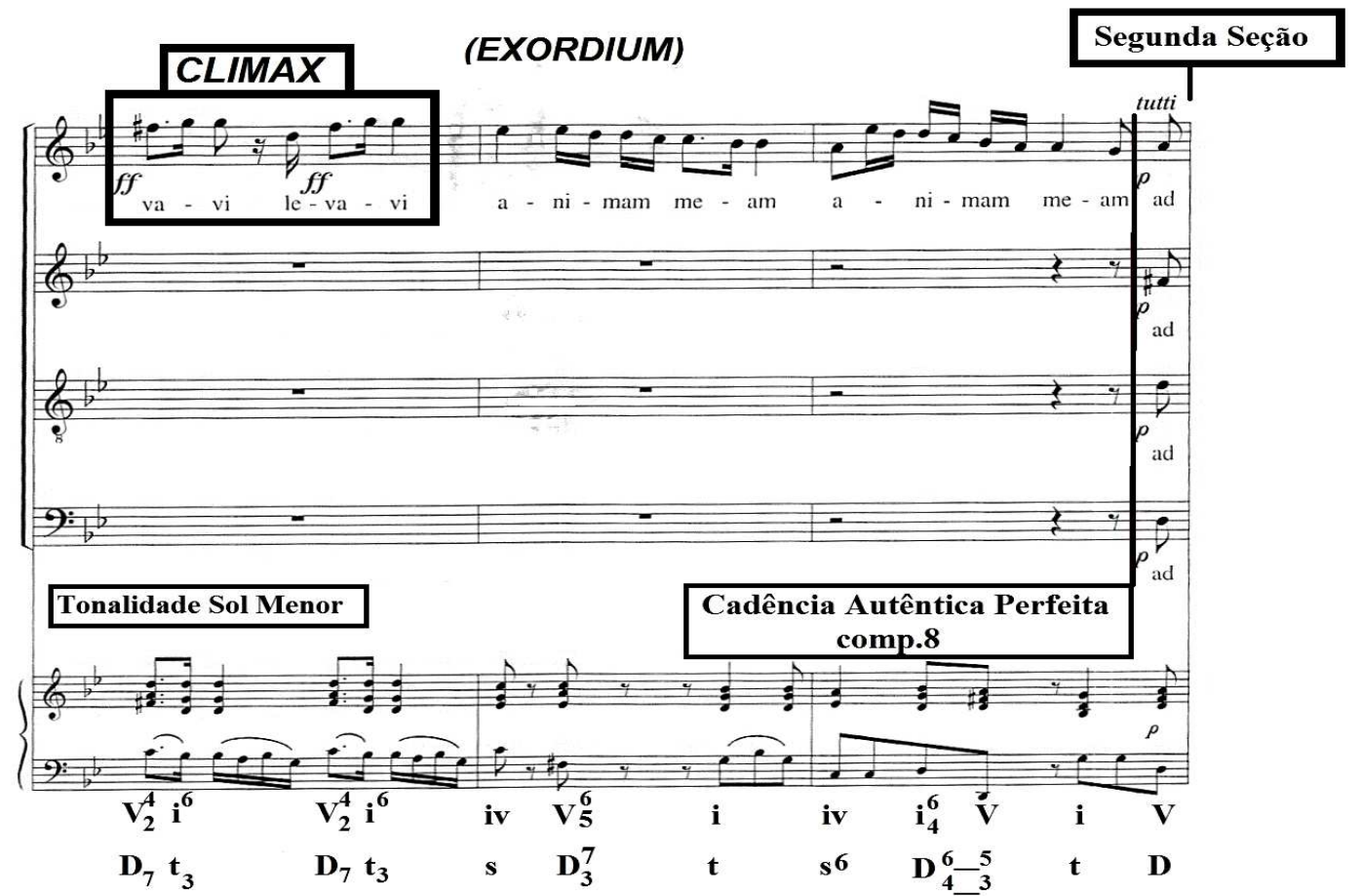

Segunda Seção

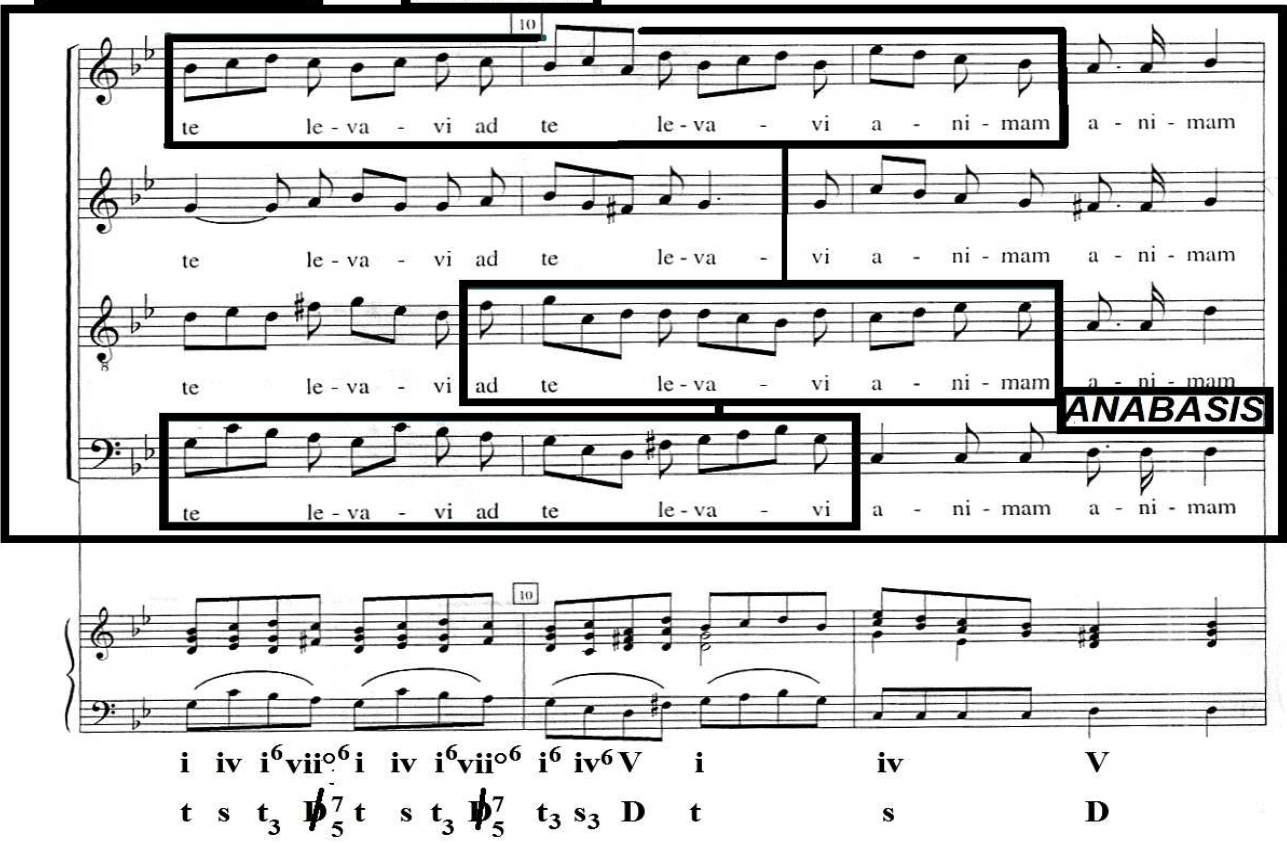

Exemplo 77: Ofertório da Missa do Primeiro Domingo do Advento de André da Silva Gomes- Catalogação e Organização Régis Duprat (DUPRAT, 1999, p.129). 


\subsubsection{Narratio}

A Narratio conserva esse sentimento de elevação e purificação, para obter êxito na inquirição do salmista, tanto é que o compositor, apropria-se dos mesmos elementos e figuras empregadas anteriormente no Exordium, contudo, ele introduz a Epizeuxis nas quatro vozes, gerando maior ênfase a petição, depois da modulação para a tonalidade de Si bemol Maior, no compasso 13.

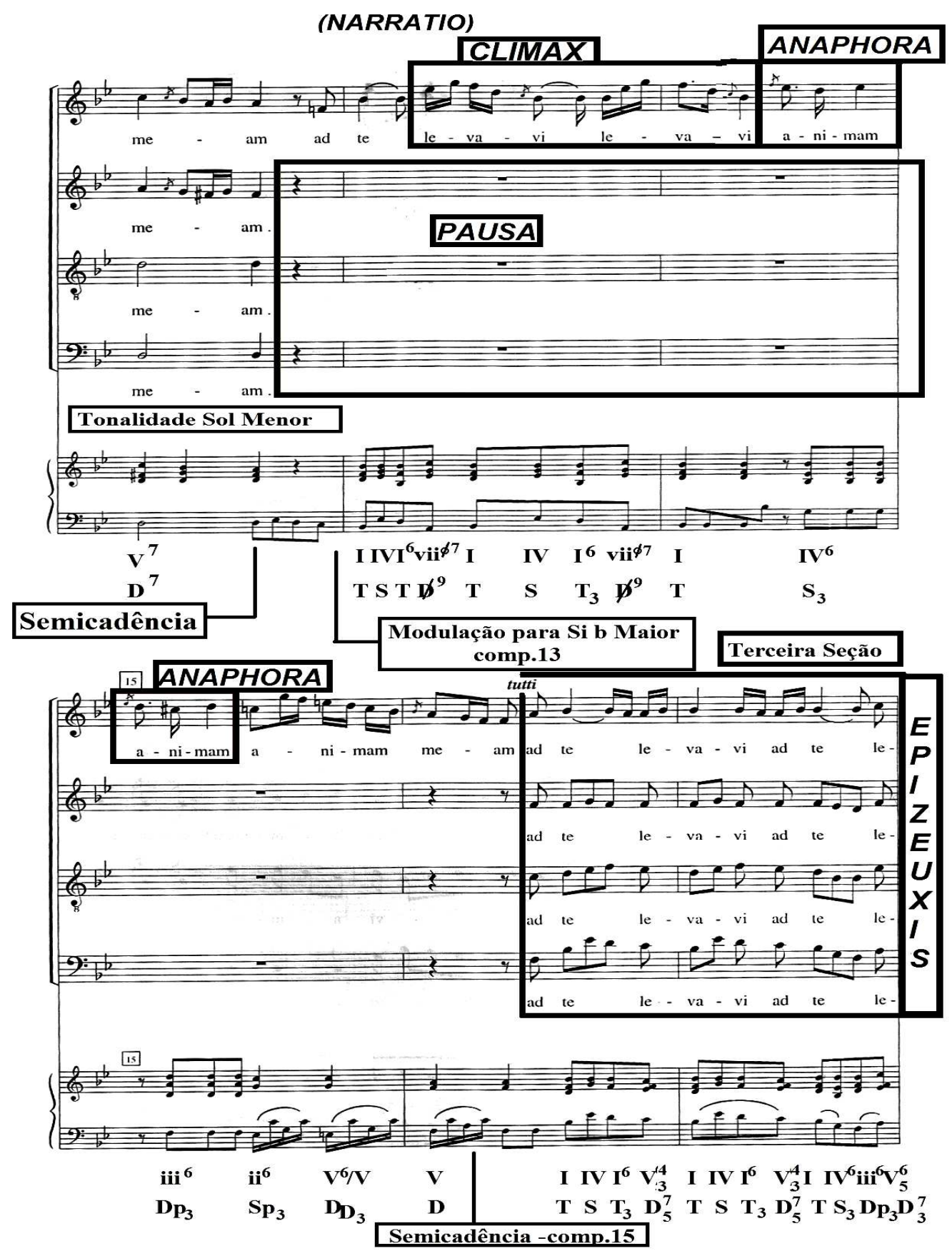

Exemplo 78: Ofertório da Missa do Primeiro Domingo do Advento de André da Silva Gomes- Catalogação e Organização Régis Duprat (DUPRAT, 1999, p.130). 
A insistência de repetir a expressão minha alma, é verificável até o fim da terceira seção, pelo emprego da Epizeuxis, no compasso 20, como a representação do afeto intentado no esforço de receber seu rogo, propiciando ao compositor a resolver essa parte numa Semicadência, criando maior expectativa ao ouvinte, por meio da tensão e suspensão do acorde da Dominante.

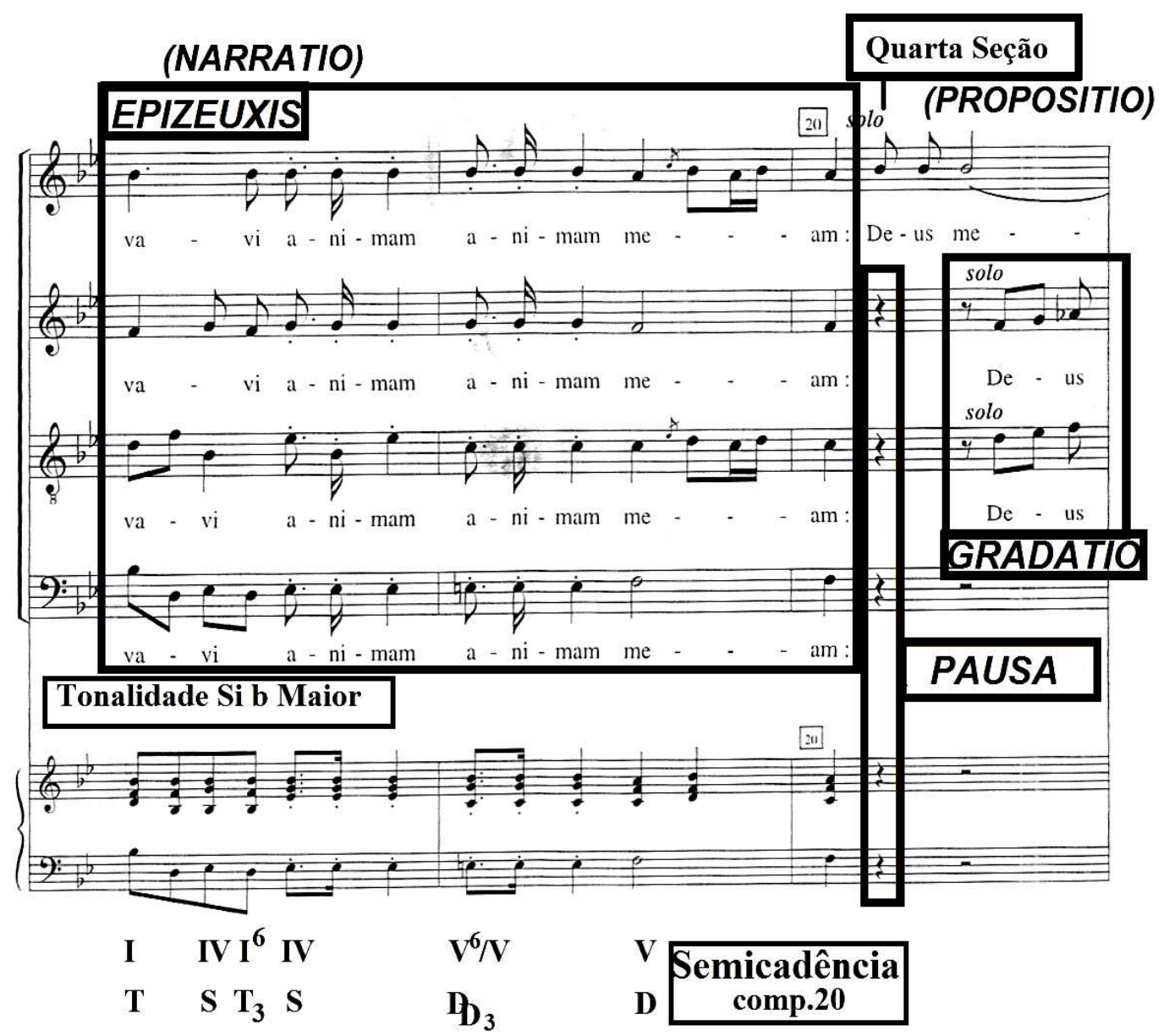

Exemplo 79: Ofertório da Missa do Primeiro Domingo do Advento de André da Silva Gomes- Catalogação e Organização Régis Duprat (DUPRAT, 1999, p.131).

\subsubsection{Propositio}

$\mathrm{Na}$ transição da terceira para quarta seção, Silva Gomes emprega a Pausa, onde as vozes da contralto, tenor e baixo, tem um momento de descanso, até a entrada da Gradatio na Propositio, nas duas vozes intermediárias, em terças paralelas, repetindo de maneira sequencial a palavra Deus, na tonalidade de Fá Menor. 


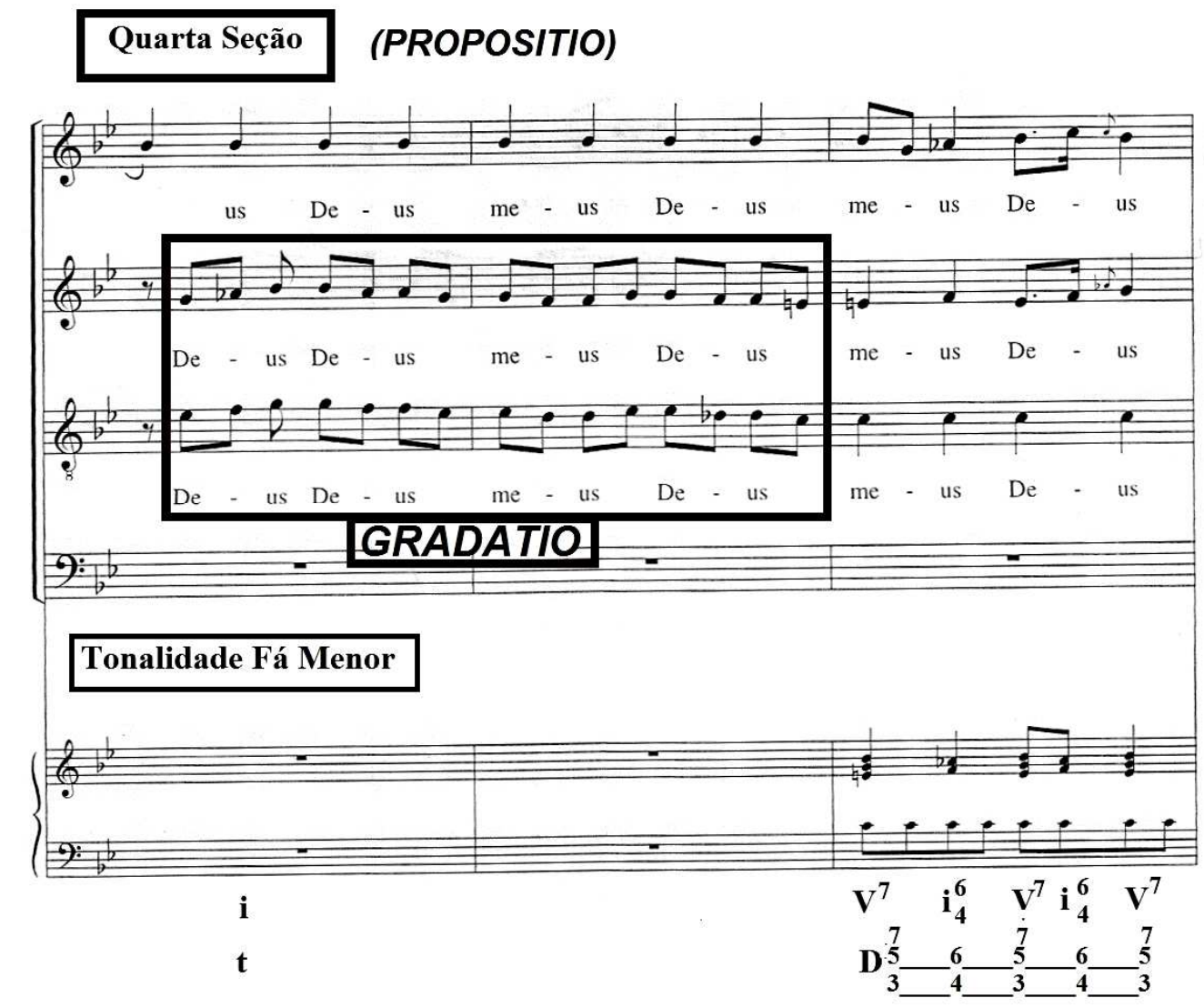

Exemplo 80: Ofertório da Missa do Primeiro Domingo do Advento de André da Silva Gomes- Catalogação e Organização Régis Duprat (DUPRAT, 1999, p.131).

A presente seção se encerra com a aplicação da Anaphora e Epizeuxis, destacando por meio de repetição o afeto de confiança, Deus meus in te confido (Deus meu em ti confio), entretanto, na transição da Propositio para Confutatio, o autor de maneira alegórica simboliza a dualidade do pathos do ser humano:

- alegria $X$ tristeza

- amor X ódio (indiferença)

- confiança X descrença

Ou seja, assim como ocorrera entre os compassos 10 a 12, no Exordium, onde a Anabasis, em passagem ascendente foi empregada juntamente com a Auxesis, expressando o afeto de júbilo, a Catabasis, outra figura central do ofertório, em passagem musical descendente, é acoplada ao Passus Duriusculus, numa carga emocional e afetiva maior que a anterior, 
expressando o desejo do peticionário em não ser envergonhado por seus inimigos, Non erubescan (Não me envergonhe) ${ }^{101}$.

(PROPOSITIO)
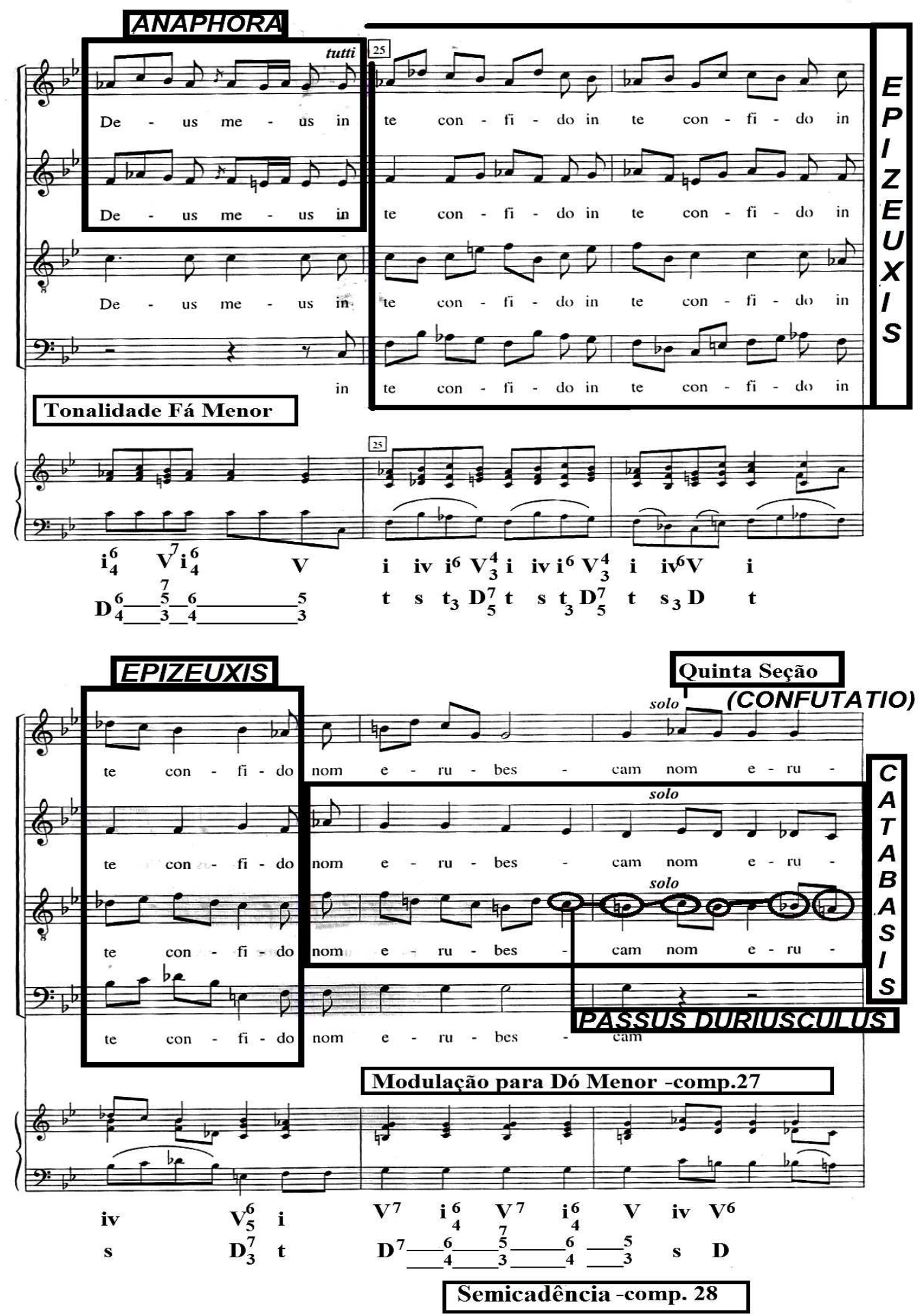

Exemplo 81: Ofertório da Missa do Primeiro Domingo do Advento de André da Silva Gomes- Catalogação e Organização Régis Duprat (DUPRAT, 1999, p.132).

${ }^{101} \mathrm{O}$ mesmo que fazer vergonha, desonrar, humilhar, sentir-se humilhado. 


\subsubsection{Confutatio}

Nota-se além dos elementos contrastantes acima descritos, a utilização da Suspiratio em todas as vozes no compasso 31, como no 33-34, na voz do baixo, suscitando em forma de suspiro a expressão não me envergonhe, como também a modulação para Dó Menor, enfim, a refutação se evidência com a Cadência de Engano, provocando curiosidade ao ouvinte em atentar para o que irá acontecer nos próximos trechos da obra, como a outra modulação para Sol Menor, no compasso 35, no final da Cadência Autêntica Perfeita.
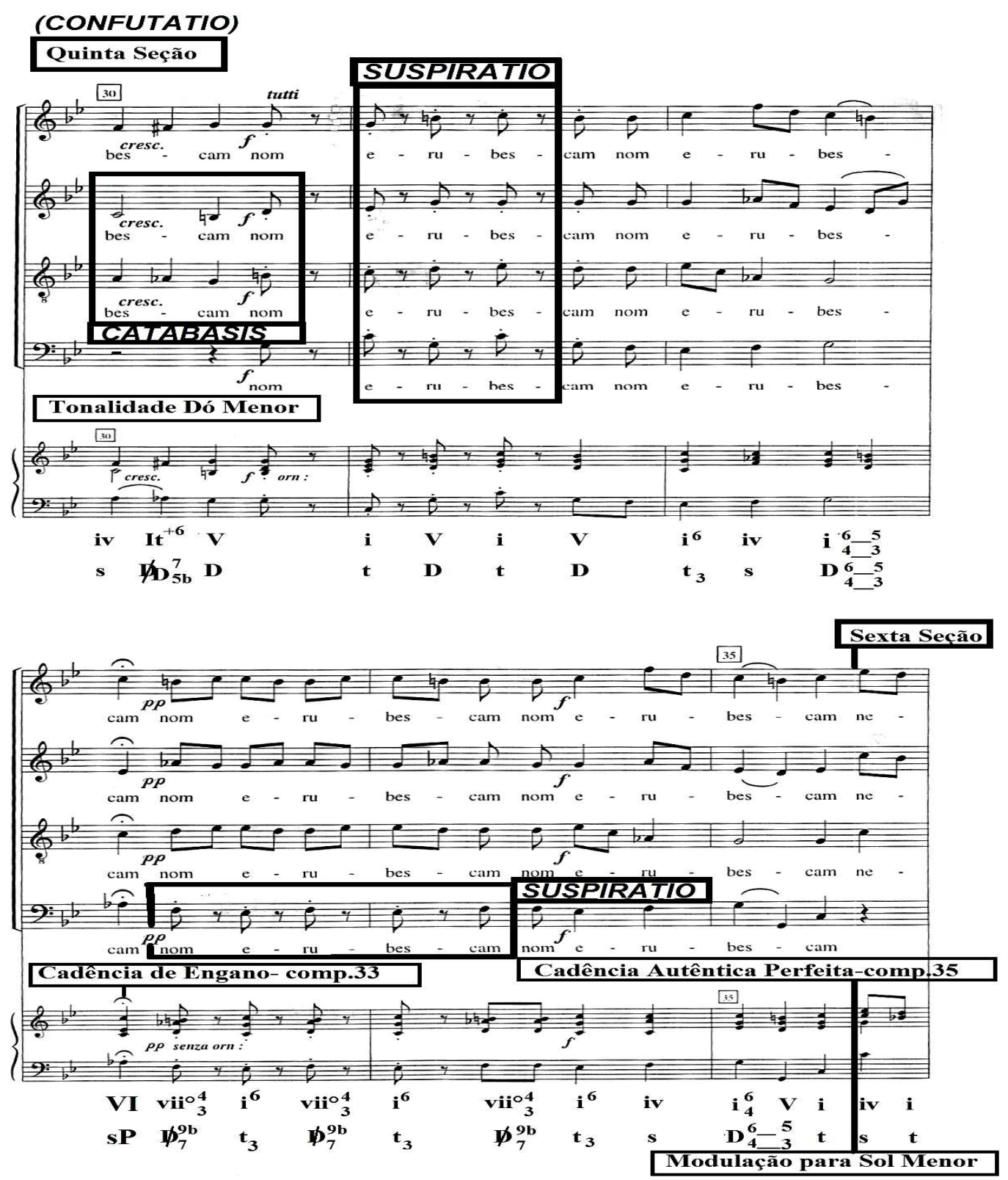

Exemplo 82: Ofertório da Missa do Primeiro Domingo do Advento de André da Silva Gomes- Catalogação e Organização Régis Duprat (DUPRAT, 1999, p.133). 
Ainda na Confutatio, é tangível o emprego de figuras de repetição melódica e de palavras, tais como Anaphora e Palilogia, Neque irrideant (Não se riam). Outro ponto a ser examinado, é a maneira em que o autor desenvolve a enunciação irrideant (rir-se), sempre entre a Tônica e Dominante, na tentativa de deixar transparecer um argumento paradoxal, do ato negativo expresso pela Tristitia e uma aparente alegria simbolizada pela Laetitia, tudo isso, na tonalidade de Sol Menor, que segundo Mattheson pode representar "suavidade, quanto contentamento, ansiedade, quanto divertimento, lamento moderado ou à alegria temperada" (MATTHESON, 1713, parte III, cap.2,§ 8, apud, JANK, 2009, p.1).
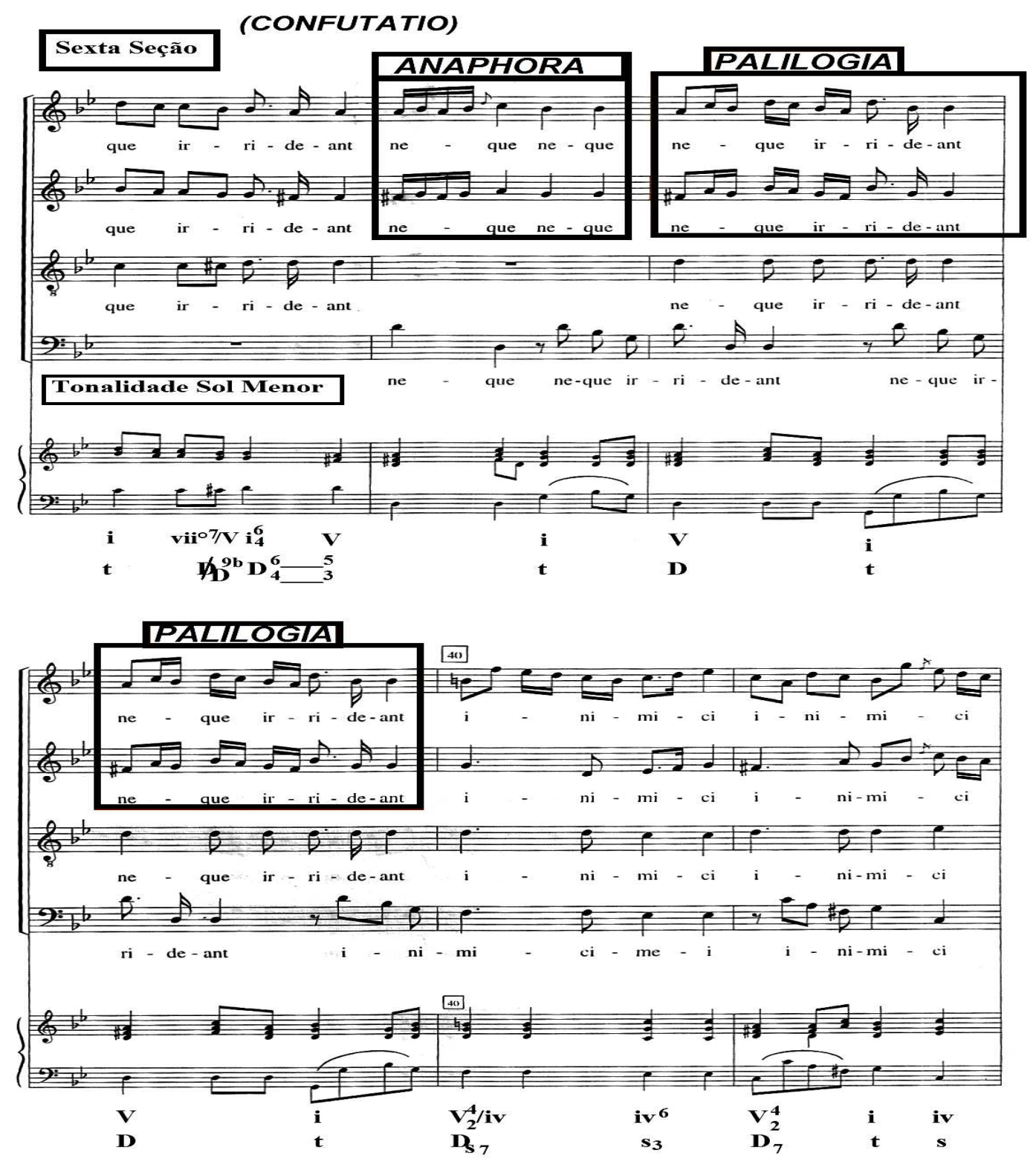

Exemplo 83: Ofertório da Missa do Primeiro Domingo do Advento de André da Silva Gomes- Catalogação e Organização Régis Duprat (DUPRAT, 1999, p.134). 
A quarta fase da Dispositio, na sexta seção, é concluída com o uso da Synaeresis e da Palilogia, igualmente é observada a modulação para Fá Maior, como o emprego da Cadência Autêntica Imperfeita.

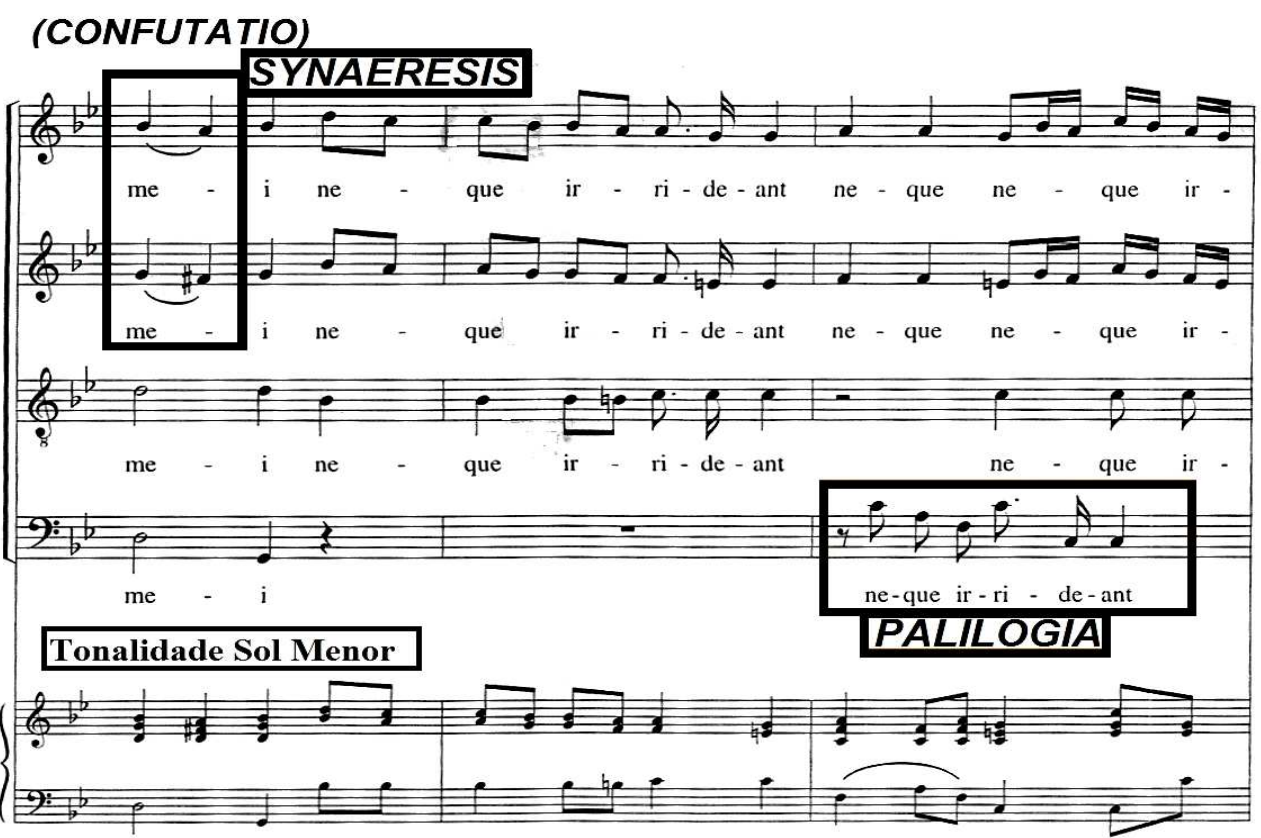

\begin{tabular}{|l|llllllll}
$\begin{array}{l}\text { Cadência } \\
\text { Autêntica }\end{array}$ & i $_{4}^{6}$ & V & i & III IV & I & V & I & V \\
Imperfeita & $D_{4}^{6}{ }_{4}^{5}$ & t & tP S & T & D & T & D
\end{tabular}

comp.42 Modulação para Fá Maior

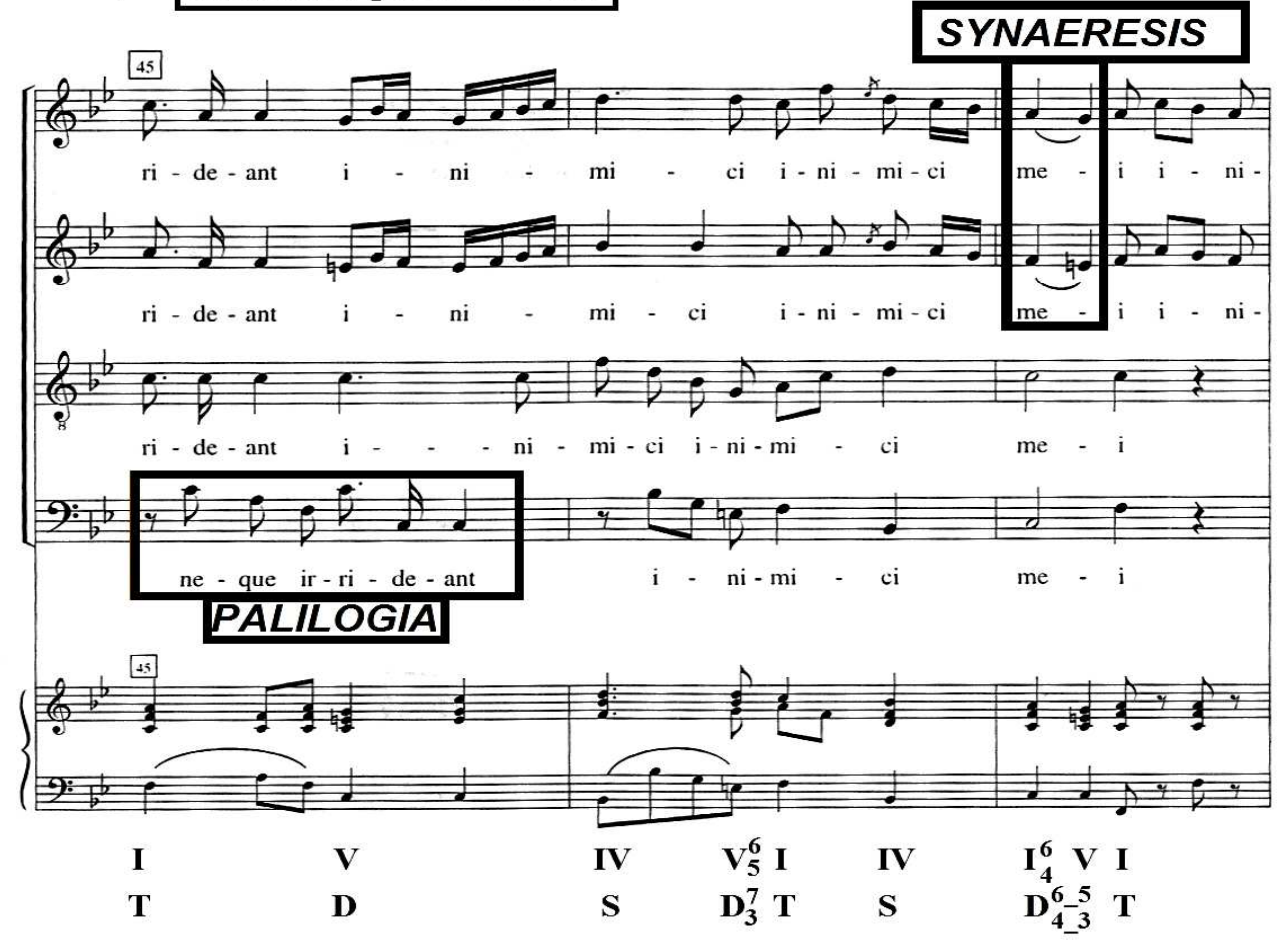

Exemplo 84: Ofertório da Missa do Primeiro Domingo do Advento de André da Silva Gomes- Catalogação e Organização Régis Duprat (DUPRAT, 1999, p.135). 


\subsubsection{Confirmatio}

$\mathrm{Na}$ Confirmatio, tem-se a continuação do emprego da Synaeresis, destacando as vozes da soprano e contralto, as quais cantam duas notas por silaba, da mesma forma, o início da sétima seção, na tonalidade de Fá Maior, no compasso 50 e por fim, se verifica o uso da Noema na condução homofônica em textura contrapontística entre os compassos 51 a 53, resultando na modulação para Fá Menor.
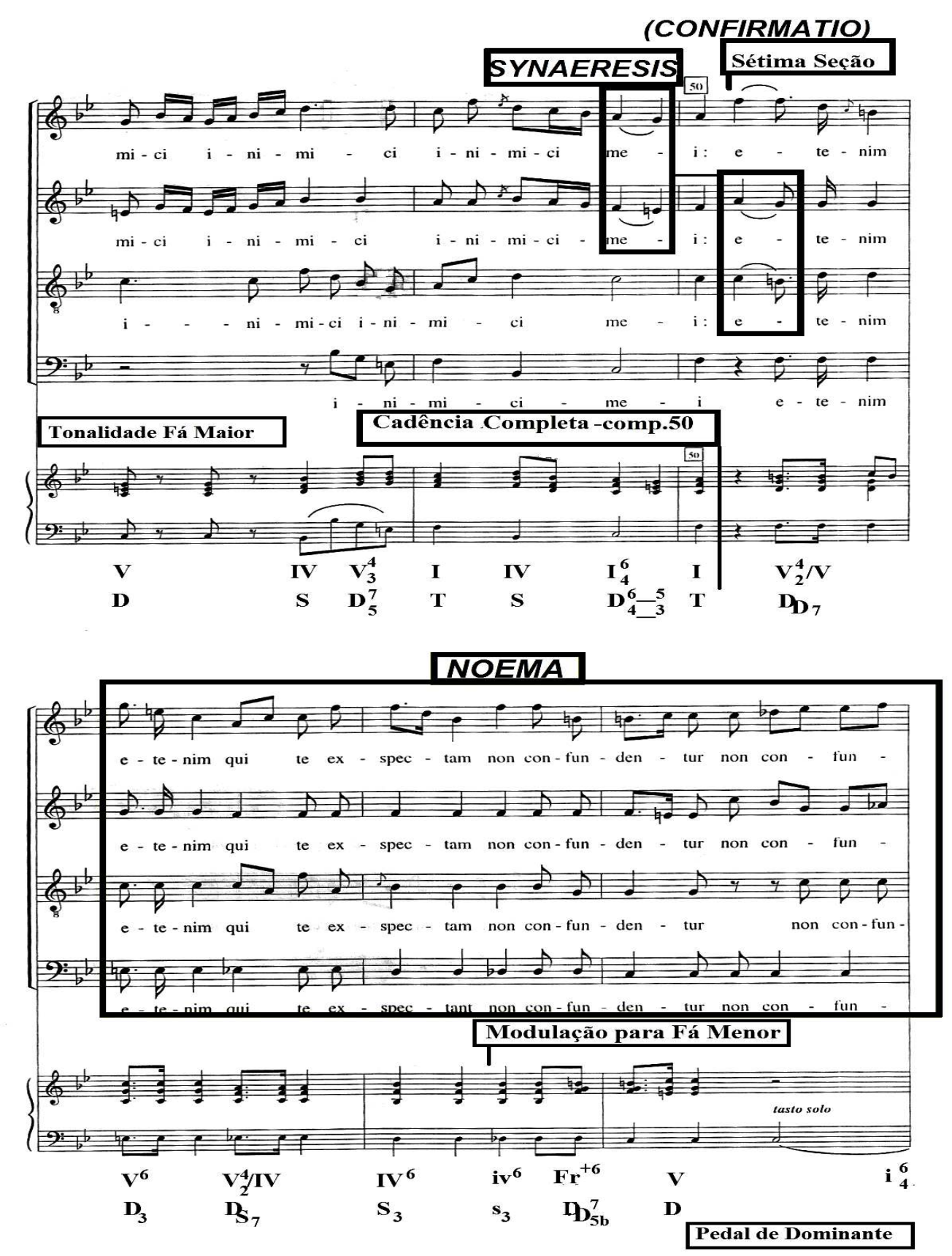

Exemplo 85: Ofertório da Missa do Primeiro Domingo do Advento de André da Silva Gomes- Catalogação e Organização Régis Duprat (DUPRAT, 1999, p.136). 
A tese inicial é confirmada desde a transição dos compassos 50 para 51 , onde é inserida a figura da Noema, em outras palavras, o afeto de confiança e esperança na obtenção de sucesso é resgatado, através da ênfase das palavras [Qui sustinent] non confundentur [Que se sustentam] em ti não serão confundidos, além do retorno para a tonalidade do princípio da obra, Sol Menor.

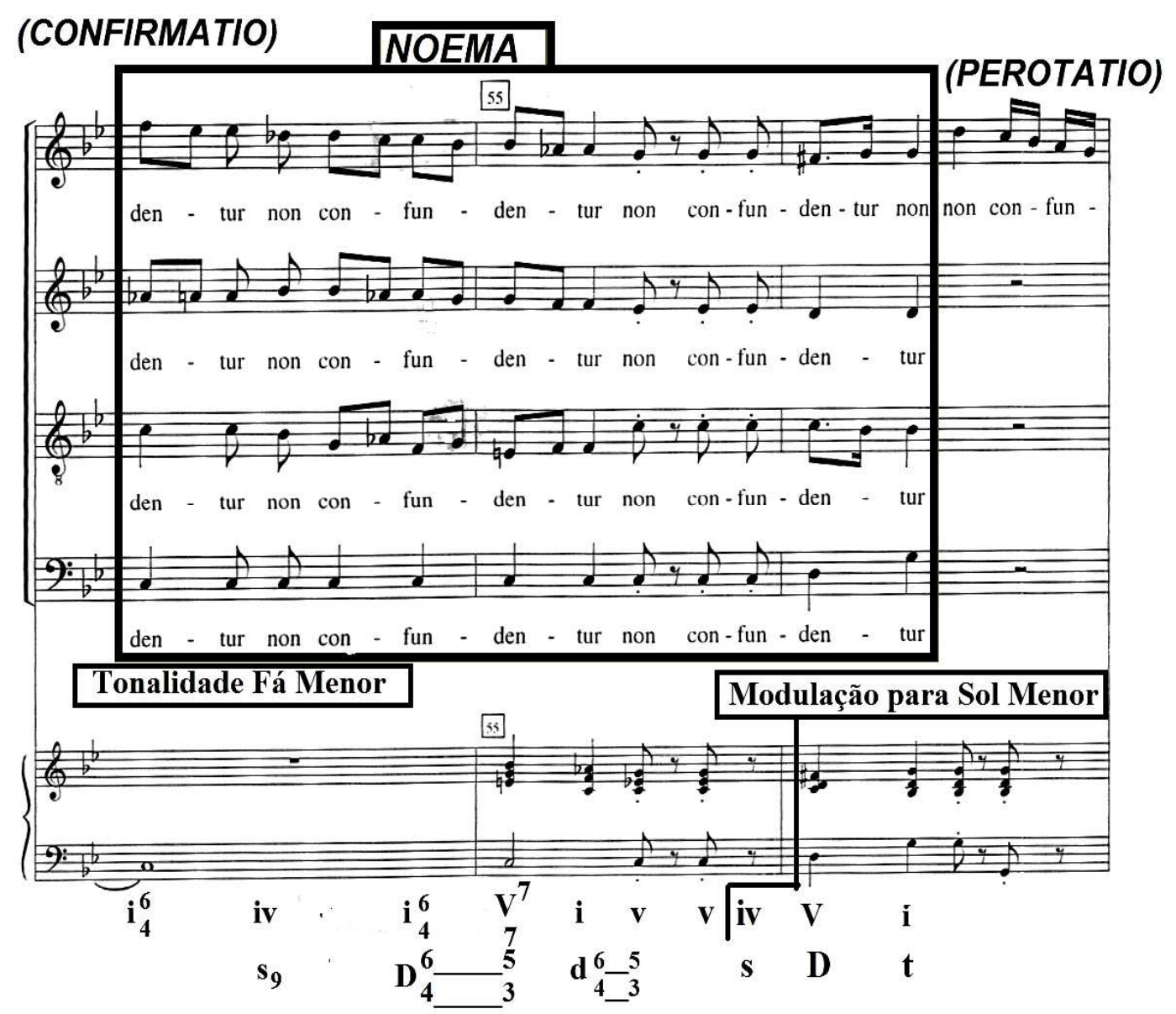

Exemplo 86: Ofertório da Missa do Primeiro Domingo do Advento de André da Silva Gomes- Catalogação e Organização Régis Duprat (DUPRAT, 1999, p.137).

\subsubsection{Perotatio}

André da Silva Gomes finaliza sua obra empregando uma nova figura, Emphasis, enfatizando pela última vez a confiança no Senhor, repetindo por três vezes a palavra não (non), expressando o momento derradeiro da oração, contrastando o afeto de devoção e confiança, através das dinâmicas, fortíssimo e pianíssimo, terminando em seguida na Cadência Final em picardia, com o acorde de Sol Maior. 


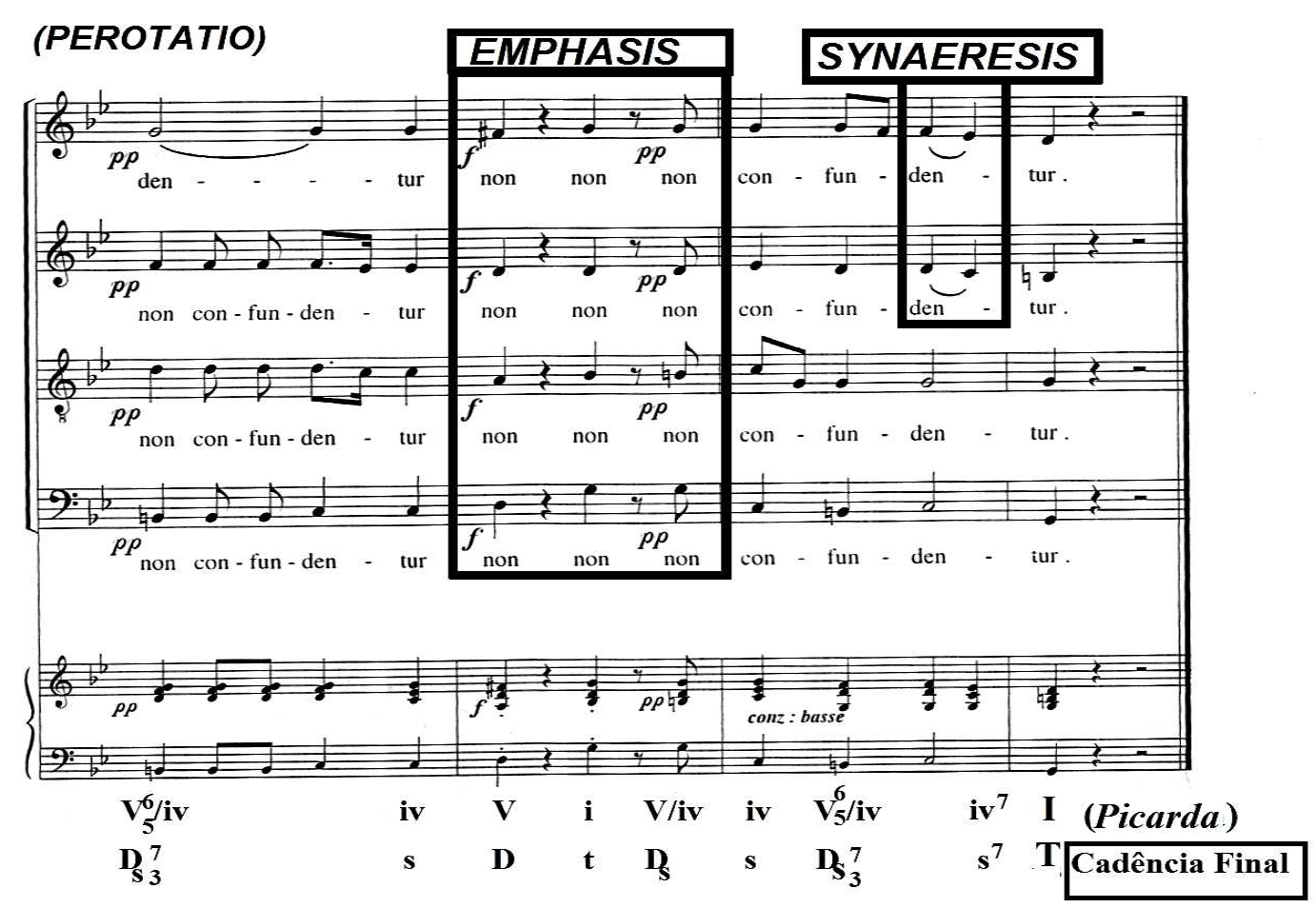

Exemplo 87: Ofertório da Missa do Primeiro Domingo do Advento de André da Silva Gomes- Catalogação e Organização Régis Duprat (DUPRAT, 1999, p.137).

\subsection{Figuras observadas no Ofertório (Elocutio/Decoratio)}

\begin{tabular}{|c|c|c|c|}
\hline FIGURAS & TIPO & DESCRIÇÃO & TRATADISTA \\
\hline $\begin{array}{l}\text { ABRUPTIO } \\
\begin{array}{l}\text { (BARTEL, 1997, } \\
\text { pp.168-170). }\end{array}\end{array}$ & $\begin{array}{l}\text { Interrupção e } \\
\text { Silêncio }\end{array}$ & $\begin{array}{l}\text { Uma quebra } \\
\text { súbita e } \\
\text { inesperada na } \\
\text { composição } \\
\text { musical. }\end{array}$ & $\begin{array}{l}\text { Vogt: A Abruptio } \\
\text { ocorre quando um } \\
\text { trecho musical é } \\
\text { interrompido no } \\
\text { final raca pela } \\
\text { colocação de } \\
\text { algumas pausas. }\end{array}$ \\
\hline $\begin{array}{l}\text { ACCIACCATURA } \\
\text { (BARTEL, } 1997, \\
\text { pp.176-178). }\end{array}$ & $\begin{array}{l}\text { Ornamentação } \\
\text { Melódica e } \\
\text { Harmônica }\end{array}$ & $\begin{array}{l}\text { Uma nota } \\
\text { dissonante, } \\
\text { adicionada ao } \\
\text { acorde, que é } \\
\text { imediatamente } \\
\text { resolvida após } \\
\text { sua execução. }\end{array}$ & $\begin{array}{l}\text { Walther: A } \\
\text { Acciaccatura } \\
\text { ocorre quando, } \\
\text { por exemplo, além } \\
\text { de tocar as notas } \\
\text { pertencentes ao } \\
\text { acorde G (d, g, b) } \\
\text { o Fá sustenido } \\
\text { também está } \\
\text { incluído tal como o } \\
\text { mordente. }\end{array}$ \\
\hline
\end{tabular}




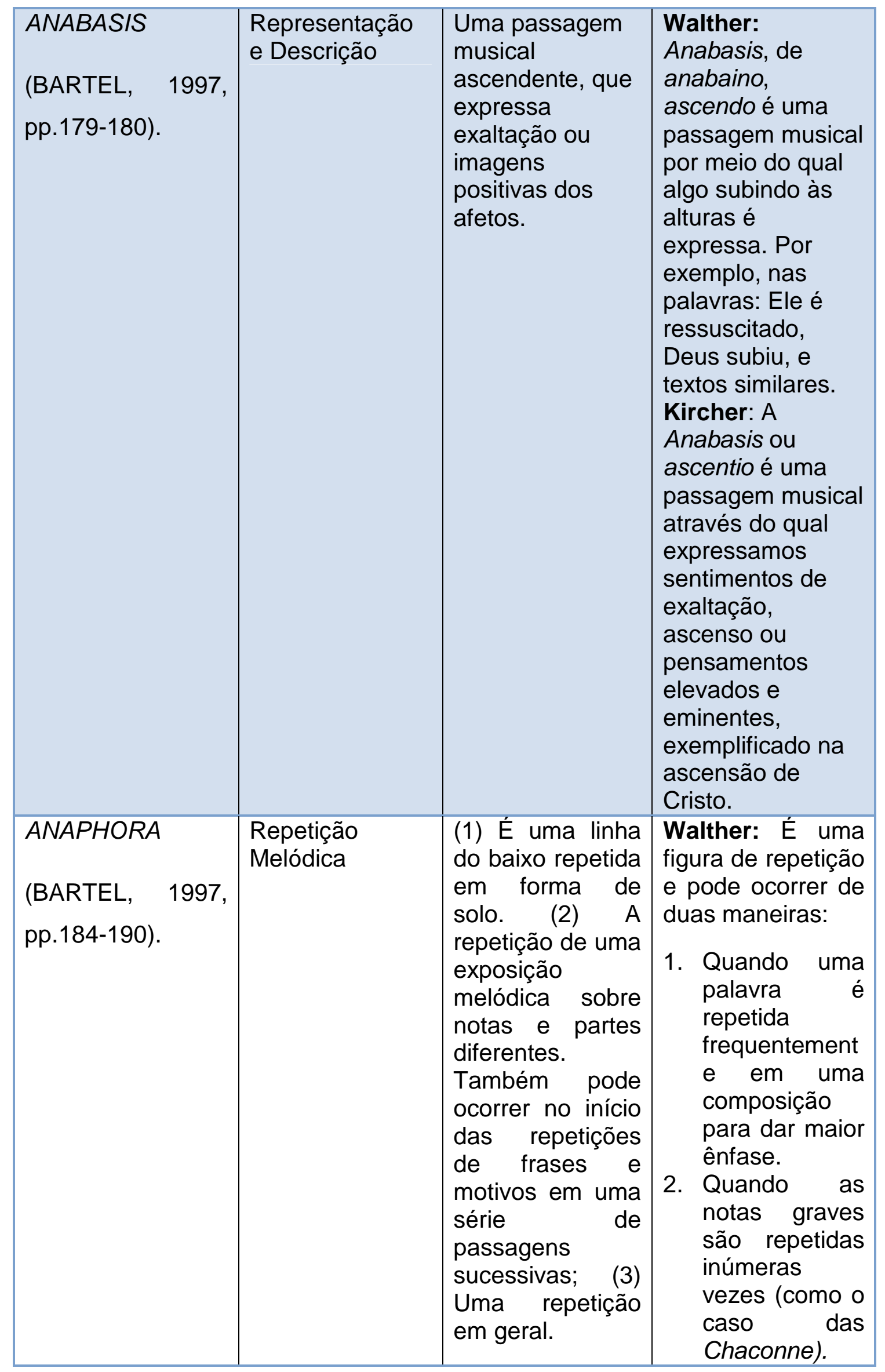




\begin{tabular}{|c|c|c|c|}
\hline $\begin{array}{l}\text { AUXESIS } \\
\text { (BARTEL, 1997, } \\
\text { pp. 209-212). }\end{array}$ & $\begin{array}{l}\text { Repetição } \\
\text { Melódica }\end{array}$ & $\begin{array}{l}\text { São repetições } \\
\text { sucessivas de } \\
\text { uma passagem } \\
\text { musical. }\end{array}$ & $\begin{array}{lr}\text { Burmeister: } & \text { A } \\
\text { Auxesis ocorre } & \\
\text { quando uma } & \text { harmonia } \\
\text { composta } & \\
\text { combinações } & \\
\text { consonantes ser } \\
\text { desenvolve de } \\
\text { forma crescente } \\
\text { em um texto que é } \\
\text { repetido uma, } \\
\text { duas, três ou mais } \\
\text { vezes Portanto, } \\
\text { ela pode ser } \\
\text { caracterizada por } \\
\text { uma elevação } \\
\text { com incremento } \\
\text { na altura de um } \\
\text { Noema repetido. }\end{array}$ \\
\hline $\begin{array}{l}\text { CATABASIS } \\
\text { (BARTEL, 1997, } \\
\text { pp.214-215). }\end{array}$ & $\begin{array}{l}\text { Representação } \\
\text { e Descrição }\end{array}$ & $\begin{array}{l}\text { Uma passagem } \\
\text { musical } \\
\text { descendente que } \\
\text { expressa } \\
\text { humildade ou } \\
\text { imagens } \\
\text { negativas dos } \\
\text { afetos. }\end{array}$ & $\begin{array}{l}\text { Janovka: } \\
\text { Catabasis ou } \\
\text { Descensus é um } \\
\text { trecho musical por } \\
\text { meio do qual } \\
\text { expressam afetos } \\
\text { opostos aos da } \\
\text { anabasis, tal como } \\
\text { a servidão, } \\
\text { humildade, } \\
\text { baixeza, } \\
\text { finalmente, a } \\
\text { veracidade, como } \\
\text { no texto: "Estou, } \\
\text { no entanto, muito } \\
\text { humilde". } \\
\text { Walther: } \\
\text { Catabasis } \\
\text { katabaiano de } \\
\text { (descendo) é uma } \\
\text { passagem musical } \\
\text { através do qual o } \\
\text { humilde } \\
\text { insignificante, são } \\
\text { representados } \\
\text { com desdenho, } \\
\text { por exemplo: "Ele" } \\
\text { desceu, "Eu sou } \\
\text { humilhado", e } \\
\text { textos similares. }\end{array}$ \\
\hline
\end{tabular}




\begin{tabular}{|c|c|c|c|}
\hline $\begin{array}{l}\text { CLIMAX } \\
\text { (BARTEL, 1997, } \\
\text { pp.220-224). }\end{array}$ & $\begin{array}{l}\text { Repetição } \\
\text { Melódica }\end{array}$ & $\begin{array}{l}\text { (1) Uma } \\
\text { sequência de } \\
\text { notas em uma só } \\
\text { voz repetida em } \\
\text { qualquer } \\
\text { tonalidade maior } \\
\text { ou menor, (2) } \\
\text { Duas vozes que } \\
\text { se deslocam em } \\
\text { movimento } \\
\text { ascendente ou } \\
\text { descendente } \\
\text { paralelo, (3) Um } \\
\text { aumento gradual } \\
\text { na intensidade e } \\
\text { altura do som. }\end{array}$ & $\begin{array}{l}\text { Burmeister: A } \\
\text { Climax repete } \\
\text { notas } \\
\text { semelhantes ou } \\
\text { alturas similares. } \\
\text { Kircher: A Climax } \\
\text { ou Gradatio é uma } \\
\text { passagem musical } \\
\text { ascendente que é } \\
\text { frequentemente } \\
\text { utilizada em afetos } \\
\text { de amor e desejo } \\
\text { de unidade do } \\
\text { reino celestial. }\end{array}$ \\
\hline $\begin{array}{l}\text { EMPHASIS } \\
\text { (BARTEL, 1997, } \\
\text { pp.251-255). }\end{array}$ & $\begin{array}{l}\text { Representação } \\
\text { e Descrição }\end{array}$ & $\begin{array}{l}\text { Um trecho ou } \\
\text { passagem } \\
\text { musical que } \\
\text { reforça ou } \\
\text { enfatiza o } \\
\text { significado do } \\
\text { texto através de } \\
\text { diversos meios. }\end{array}$ & 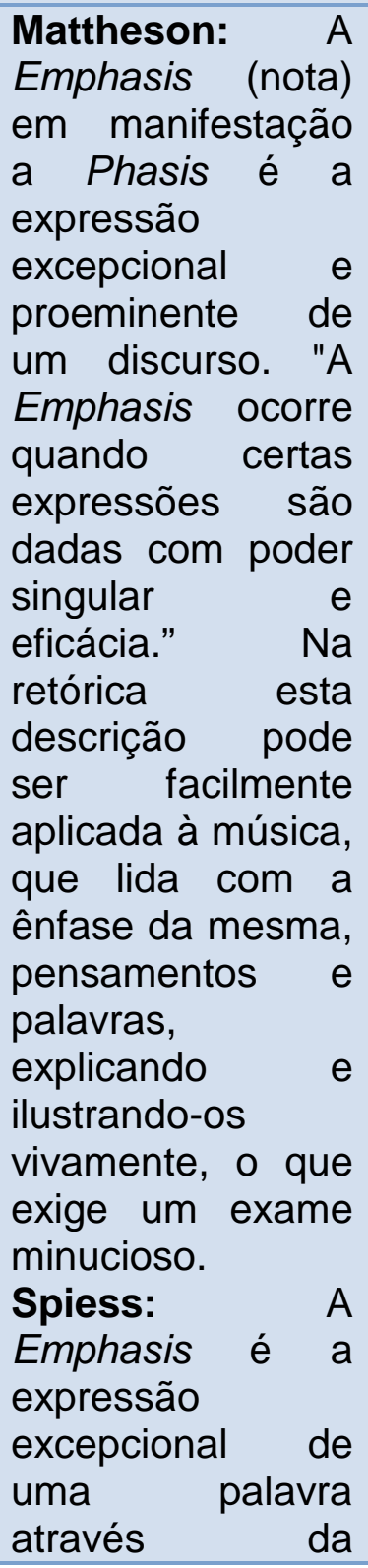 \\
\hline
\end{tabular}




\begin{tabular}{|c|c|c|c|}
\hline & & & $\begin{array}{l}\text { música, que deve } \\
\text { ser tanto inteligível } \\
\text { ou fixada pelo } \\
\text { compositor, bem } \\
\text { como hábil e } \\
\text { eficaz para } \\
\text { aquelas palavras } \\
\text { que contém o } \\
\text { conteúdo } \\
\text { excepcional, com } \\
\text { ênfase, poder, } \\
\text { força, vigor, } \\
\text { eficácia, ou vigor } \\
\text { de uma passagem } \\
\text { ou texto. }\end{array}$ \\
\hline $\begin{array}{l}\text { EPIZEUXIS } \\
\text { (BARTEL, 1997, } \\
\text { pp.263-265). }\end{array}$ & $\begin{array}{l}\text { Repetição } \\
\text { Melódica }\end{array}$ & $\begin{array}{l}\text { Uma repetição } \\
\text { imediata e } \\
\text { enfática de uma } \\
\text { palavra, nota, } \\
\text { motivo ou frase. }\end{array}$ & $\begin{array}{l}\text { Walther: A } \\
\text { Epizeuxis é uma } \\
\text { figura de retórica } \\
\text { pela qual uma ou } \\
\text { mais palavras são } \\
\text { imediatamente e } \\
\text { enfaticamente } \\
\text { repetidas. }\end{array}$ \\
\hline $\begin{array}{l}\text { GRADATIO } \\
\text { (BARTEL, 1997, } \\
\text { pp.220-224). }\end{array}$ & $\begin{array}{l}\text { Repetição } \\
\text { Melódica }\end{array}$ & $\begin{array}{l}\text { (1) Uma } \\
\text { sequência de } \\
\text { notas em uma só } \\
\text { voz repetida em } \\
\text { qualquer } \\
\text { tonalidade maior } \\
\text { ou menor, (2) } \\
\text { Duas vozes que } \\
\text { se deslocam em } \\
\text { movimento } \\
\text { ascendente ou } \\
\text { descendente } \\
\text { paralelo, (3) Um } \\
\text { aumento gradual } \\
\text { na intensidade e } \\
\text { altura do som. }\end{array}$ & 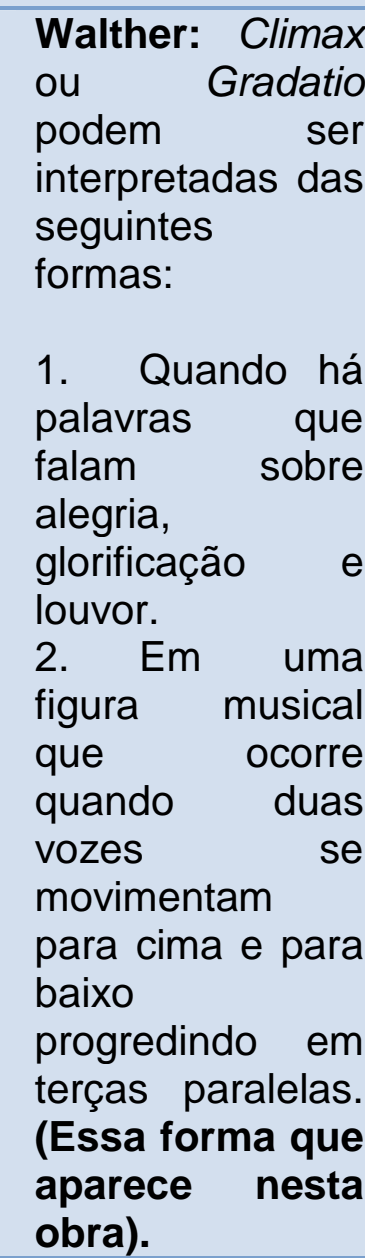 \\
\hline
\end{tabular}




\begin{tabular}{|c|c|c|c|}
\hline & & & $\begin{array}{l}\text { 3. Quando } \\
\text { uma passagem } \\
\text { com ou sem } \\
\text { cadência é } \\
\text { imediatamente } \\
\text { repetida várias } \\
\text { vezes em alturas } \\
\text { progressivament } \\
\text { e maiores. } \\
4 \text {. Este termo } \\
\text { também pode ser } \\
\text { dado a um } \\
\text { cânone de quatro } \\
\text { partes em que, } \\
\text { as dus } \\
\text { primeiras vozes } \\
\text { reentram, e as } \\
\text { outras duas } \\
\text { vozes peranecem na } \\
\text { permanecer anterior e } \\
\text { parte ante } \\
\text { ainda harmonizam. } \\
\text { haram. }\end{array}$ \\
\hline $\begin{array}{l}\text { NOEMA } \\
\text { (BARTEL, 1997, } \\
\text { p.339-342). }\end{array}$ & $\begin{array}{l}\text { Representação } \\
\text { e Descrição }\end{array}$ & $\begin{array}{l}\text { Uma passagem } \\
\text { homofônica em } \\
\text { uma textura } \\
\text { contrapontística } \\
\text { e polifônica. }\end{array}$ & $\begin{array}{l}\text { Burmeister: A } \\
\text { Noema representa } \\
\text { o afeto harmônico, } \\
\text { onde as vozes } \\
\text { combinadas têm } \\
\text { valores e números } \\
\text { de notas } \\
\text { semelhantes. } \\
\text { Quando } \\
\text { introduzida } \\
\text { adequadamente, } \\
\text { isto é, no } \\
\text { momento certo, } \\
\text { ela afeta } \\
\text { docemente os } \\
\text { ouvidos do } \\
\text { ouvinte, } \\
\text { produzindo uma } \\
\text { sensação de } \\
\text { calma e } \\
\text { serenidade. }\end{array}$ \\
\hline $\begin{array}{l}\text { (BUELOW, 1980, } \\
\text { p.799). }\end{array}$ & & & $\begin{array}{l}\text { Seção } \\
\text { homofônica, } \\
\text { dentro da polifonia } \\
\text { utilizada para } \\
\text { enfatizar o texto. }\end{array}$ \\
\hline
\end{tabular}




\begin{tabular}{|c|c|c|c|}
\hline $\begin{array}{l}\text { PALILOGIA } \\
\text { (BARTEL, 1997, } \\
\text { pp.342-344). }\end{array}$ & $\begin{array}{l}\text { Repetição } \\
\text { Melódica }\end{array}$ & $\begin{array}{l}\text { Repetição de um } \\
\text { tema no mesmo } \\
\text { nível de altura, } \\
\text { também pode } \\
\text { ocorrer em } \\
\text { alturas diferentes } \\
\text { na mesma ou em } \\
\text { várias vozes. }\end{array}$ & $\begin{array}{l}\text { Burmeister: A } \\
\text { Palilogia é uma } \\
\text { repetição de uma } \\
\text { inteiração ou } \\
\text { apenas o começo } \\
\text { da estrutura dos } \\
\text { meios e temas } \\
\text { sobre a mesma } \\
\text { altura com a } \\
\text { mesma voz, } \\
\text { ocorrendo com ou } \\
\text { sem intermédio de } \\
\text { pausas em todos } \\
\text { os eventos em } \\
\text { uma voz. } \\
\text { Walther: A } \\
\text { Palilogia refere-se } \\
\text { a uma repetição } \\
\text { por demais } \\
\text { frequente das } \\
\text { mesmas palavras. }\end{array}$ \\
\hline $\begin{array}{l}\text { PASSUS } \\
\text { DURIUSCULUS } \\
\text { (BARTEL, 1997, } \\
\text { pp.357-358) }\end{array}$ & $\begin{array}{l}\text { Dissonância e } \\
\text { Deslocamento }\end{array}$ & $\begin{array}{l}\text { Uma alteração } \\
\text { cromática } \\
\text { ascendente ou } \\
\text { descendente de } \\
\text { uma linha } \\
\text { melódica. }\end{array}$ & $\begin{array}{l}\text { Bernhard: } \\
\text { Passus } \\
\text { Duriusculus dentro } \\
\text { de uma voz ocorre } \\
\text { quando a mesma } \\
\text { sobe ou desce um } \\
\text { semitom menor. } \\
\text { Estas progressões } \\
\text { alguns } \\
\text { consideram como } \\
\text { cromáticas, razão } \\
\text { pela qual elas } \\
\text { podem } \\
\text { movimentar-se } \\
\text { entre si. Também } \\
\text { pode ocorrer } \\
\text { nestas situações: } \\
\text { quando o segundo } \\
\text { grau é } \\
\text { aumentado, uma } \\
\text { terça é diminuída, } \\
\text { uma quarta ou } \\
\begin{array}{l}\text { quinta é } \\
\text { aumentada ou } \\
\text { diminuída. }\end{array}\end{array}$ \\
\hline
\end{tabular}




\begin{tabular}{|c|c|c|c|}
\hline $\begin{array}{l}\text { PAUSA } \\
\text { (BARTEL, 1997, } \\
\text { pp.362-365). }\end{array}$ & $\begin{array}{l}\text { Interrupção e } \\
\text { Silêncio }\end{array}$ & $\begin{array}{l}\text { Pausa ou } \\
\text { descanso em } \\
\text { uma composição } \\
\text { musical. }\end{array}$ & $\begin{array}{lr}\text { Walther: } & \text { Uma } \\
\text { figura ou figuras } \\
\text { de silêncio. Pausa } \\
\text { refere-se a um } \\
\text { período } & \\
\text { repouso ou } \\
\text { silêncio } \\
\text { música, que é } \\
\text { indicado por um } \\
\text { determinado sinal. }\end{array}$ \\
\hline $\begin{array}{l}\text { POLYPTOTON } \\
\text { (BARTEL, 1997, } \\
\text { pp.367-369). }\end{array}$ & $\begin{array}{l}\text { Repetição } \\
\text { Melódica }\end{array}$ & $\begin{array}{l}\text { A repetição de } \\
\text { uma passagem } \\
\text { melódica em } \\
\text { diferentes } \\
\text { alturas. }\end{array}$ & $\begin{array}{l}\text { Vogt: Polyptoton } \\
\text { é quando uma } \\
\text { passagem é } \\
\text { repetida em várias } \\
\text { alturas. }\end{array}$ \\
\hline $\begin{array}{l}\text { SUSPIRATIO } \\
\text { (BARTEL, 1997, } \\
\text { pp. 392-394). }\end{array}$ & $\begin{array}{l}\text { Interrupção } \\
\text { Silêncio }\end{array}$ & $\begin{array}{l}\text { Expressão } \\
\text { musical de um } \\
\text { suspiro, através } \\
\text { de pausas. }\end{array}$ & $\begin{array}{l}\text { Kircher: A } \\
\text { Stenasmus ou } \\
\text { Suspiratio } \\
\text { lembram os afetos } \\
\text { naturalmente } \\
\text { expressados por } \\
\text { vários suspiros } \\
\text { criados através de } \\
\text { pausas. }\end{array}$ \\
\hline $\begin{array}{l}\text { SYNAERESIS } \\
\text { (BARTEL, 1997, } \\
\text { pp.394-396). }\end{array}$ & $\begin{array}{l}\text { Dissonância e } \\
\text { Deslocamento }\end{array}$ & $\begin{array}{l}\text { (1) Uma } \\
\text { suspensão ou } \\
\text { síncope, (2) A } \\
\text { colocação de } \\
\text { duas sílabas por } \\
\text { nota ou duas } \\
\text { notas por sílaba. }\end{array}$ & $\begin{array}{lr}\text { Vogt: } & \text { A } \\
\text { Synaeresis } & \text { ocorre } \\
\text { quando } & \text { duas } \\
\text { notas } & \text { são } \\
\text { colocadas } & \text { em } \\
\text { uma sílaba } & \text { ou } \\
\text { duas sílabas } & \text { são } \\
\text { colocadas } & \text { em } \\
\text { uma nota. }\end{array}$ \\
\hline
\end{tabular}

Tabela 33: Figuras encontradas no Ofertório da Missa do Primeiro Domingo do Advento de André da Silva Gomes

\section{Análise Harmônica}

\subsection{Curva Tonal}

Tonalidade: Sol Menor

Andamento: Moderato Affectuozo 4/4 
Esquema de Progressões Harmônicas

\begin{tabular}{|c|c|c|}
\hline Compassos & $\begin{array}{l}\text { Função em relação a } \\
\text { tonalidade principal }\end{array}$ & Tonalidade (Acorde) \\
\hline $1-3$ & $t-i$ & Sol Menor \\
\hline $3-4$ & $\mathrm{D}-\mathrm{V}$ & Ré Maior \\
\hline $4-5$ & $t-i$ & Sol Menor \\
\hline 5 & $\mathrm{D}-\mathrm{V}$ & Ré Maior \\
\hline $6-11$ & $t-i$ & Sol Menor \\
\hline 12 & D-V & Ré Maior \\
\hline $13-15$ & tP-III & Si b Maior \\
\hline $15-16$ & $\mathrm{D} / \mathrm{tP}-\mathrm{V} / \mathrm{III}$ & Fá Maior \\
\hline $16-18$ & tP-III & Si b Maior \\
\hline $19-20$ & $\mathrm{D} / \mathrm{tP}-\mathrm{V} / \mathrm{III}$ & Fá Maior \\
\hline $21-27$ & s/s- iv/iv & Fá Menor \\
\hline $28-29$ & s-iv & Dó Menor \\
\hline $29-30$ & D/s- V/iv & Sol Maior \\
\hline $31-32$ & s-iv & Dó Menor \\
\hline 33 & s/sP- iv/ii & Lá b Maior \\
\hline $33-35$ & s-iv & Dó Menor \\
\hline $35-36$ & $t-i$ & Sol Menor \\
\hline $36-37$ & $\mathrm{D}-\mathrm{V}$ & Ré Maior \\
\hline $37-39$ & $t-i$ & Sol Menor \\
\hline 40 & s-iv & Dó Menor \\
\hline $41-42$ & $t-i$ & Sol Menor \\
\hline 43 & $\mathrm{D} / \mathrm{D} / \mathrm{tP}-\mathrm{V} / \mathrm{V} / \mathrm{III}$ & Dó Maior \\
\hline $44-50$ & $\mathrm{D} / \mathrm{tP}-\mathrm{V} / \mathrm{II}$ & Fá Maior \\
\hline 51 & $\mathrm{D} / \mathrm{D} / \mathrm{tP}-\mathrm{V} / \mathrm{V} / \mathrm{III}$ & Dó Maior \\
\hline 52 & tP-III & Si b Maior \\
\hline $52-53$ & $\mathrm{D} / \mathrm{D} / \mathrm{tP}-\mathrm{V} / \mathrm{V} / \mathrm{III}$ & Dó Maior \\
\hline $53-54$ & s/s-iv/iv & Fá Menor \\
\hline 54 & s/s/s- iv/iv/iv & Si b Menor \\
\hline $54-55$ & s/s-iv/iv & Fá Menor \\
\hline 56 & $t-i$ & Sol Menor \\
\hline 57 & s-iv & Dó Menor \\
\hline 58 & $t-i$ & Sol Menor \\
\hline $58-59$ & s-iv & Dó Menor \\
\hline 60 & T-I (Picarda) & Sol Maior \\
\hline
\end{tabular}

Tabela 34: Curva Tonal do Ofertório da Missa do Primeiro Domingo do Advento

Números de compassos: 60

Regiões abordadas: 11

Variações: 34 
Ritmo Harmônico: 1,76 (divisão dos números de compassos e variações)

Média ideal: (divisão dos números de compassos e regiões tonais abordadas = $5,45)$

Esquema Formal

$(1-12)(13-20)(21-27)(27-35)(35-42)(42-52)(52-55)(55-60)$

$\begin{array}{cccccccc}\mathrm{t} & \mathrm{Tp} & \mathrm{s} / \mathrm{s} & \mathrm{s} & \mathrm{t} & \mathrm{D} / \mathrm{tP} & \mathrm{s} / \mathrm{s} & \mathrm{t} \\ \mathrm{i} & \text { III } & \text { iv/iv } & \text { iv } & \mathrm{i} & \text { V/III } & \text { iv/iv } & \mathrm{i}\end{array}$

\subsection{Estrutura Analítica do Ofertório: Retórica e Harmônica}

\begin{tabular}{|c|c|c|c|c|c|}
\hline $\begin{array}{l}\text { RETÓRICA } \\
\text { DISPOSITIO }\end{array}$ & $\begin{array}{l}\text { FIGURA } \\
\text { ELOCUTIO }\end{array}$ & COMP. & $\begin{array}{l}\text { HARMÔNICA } \\
\text { SEÇÃO }\end{array}$ & TONALIDADE & FUNÇÃO \\
\hline EXORDIUM & $\begin{array}{l}\text { Anaphora } \\
\text { Pausa } \\
\text { Acciaccatura } \\
\text { Variatio } \\
\text { Climax } \\
\text { Auxesis } \\
\text { Anabasis }\end{array}$ & $\begin{array}{l}1-2 \\
1-8 \\
\text { e } 12 \\
2-3 \\
3-5 \\
6 \\
9-11 \\
9-11\end{array}$ & 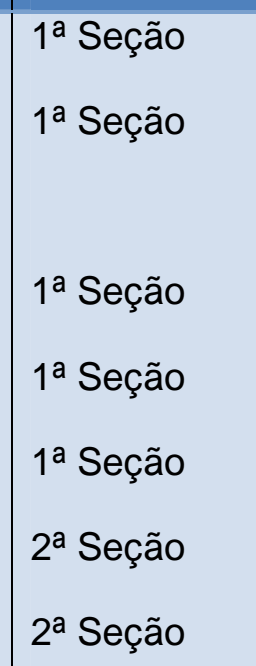 & $\begin{array}{l}\text { Sol Menor } \\
\text { Sol Menor } \\
\text { Sol Menor } \\
\text { Sol Menor } \\
\text { Sol Menor } \\
\text { Sol Menor } \\
\text { Sol Menor }\end{array}$ & $\begin{array}{l}t-i \\
t-i \\
t-i \\
t-i \\
t-i\end{array}$ \\
\hline NARRATIO & $\begin{array}{l}\text { Pausa } \\
\text { Climax } \\
\text { Anaphora } \\
\text { Epizeuxis }\end{array}$ & $\begin{array}{l}12-16 \\
13-14 \\
14-15 \\
16-20\end{array}$ & $\begin{array}{l}2^{\mathrm{a}} \text { Seção } \\
2^{\mathrm{a}} \text { Seção } \\
2^{\mathrm{a}} \text { Seção } \\
3^{\mathrm{a}} \text { Seção }\end{array}$ & $\begin{array}{l}\text { Sol Menor } \\
\text { e Si b Maior } \\
\text { Si b Maior } \\
\text { Si b Maior } \\
\text { Si b Maior }\end{array}$ & $\begin{array}{c}t-i \\
\text { tP-III } \\
\text { tP-III } \\
\text { tP-III } \\
\text { tP-III }\end{array}$ \\
\hline PROPOSITIO & $\begin{array}{l}\text { Pausa } \\
\text { Gradatio }\end{array}$ & $\begin{array}{l}20-24 \\
20-22\end{array}$ & $\begin{array}{l}4^{a} \text { Seção } \\
4^{\text {a }} \text { Seção }\end{array}$ & $\begin{array}{l}\text { Fá Menor } \\
\text { Fá Menor }\end{array}$ & $\begin{array}{l}\text { s/s-iv/iv } \\
\text { s/s-iv/iv }\end{array}$ \\
\hline
\end{tabular}




\begin{tabular}{|c|c|c|c|c|c|}
\hline & $\begin{array}{l}\text { Anaphora } \\
\text { Epizeuxis } \\
\text { Catabasis } \\
\text { Passus } \\
\text { Duriusculus }\end{array}$ & $\begin{array}{l}24 \\
25-27 \\
27-28 \\
27-28\end{array}$ & $\begin{array}{l}4^{\text {a }} \text { Seção } \\
4^{\text {a Seção }} \\
\text { 4ª Seção }^{\text {4a Seção }}\end{array}$ & $\begin{array}{l}\text { Fá Menor } \\
\text { Fá Menor } \\
\text { Dó Menor } \\
\text { Dó Menor }\end{array}$ & $\begin{array}{c}\text { s/s-iv/iv } \\
\text { s/s-iv/iv } \\
\text { s-iv } \\
\text { s-iv }\end{array}$ \\
\hline CONFUTATIO & $\begin{array}{l}\text { Catabasis } \\
\text { Passus } \\
\text { Duriusculus } \\
\text { Suspiratio } \\
\text { Anaphora } \\
\text { Palilogia } \\
\text { Synaeresis }\end{array}$ & $\begin{array}{l}28-30 \\
28-29 \\
31 \\
\text { e } 33-34 \\
37 \\
38-39 \\
\text { e } 44-45 \\
47 \text { e } 49\end{array}$ & $\begin{array}{l}\text { 5ª Seção } \\
\text { 5ª Seção } \\
\text { 5ª Seção } \\
\text { 6ª Seção } \\
\text { 6ª Seção } \\
\text { 6ª Seção }\end{array}$ & $\begin{array}{l}\text { Dó Menor } \\
\text { Dó Menor } \\
\text { Dó Menor } \\
\text { Sol Menor } \\
\text { Sol Menor } \\
\text { Fá Maior } \\
\text { Fá Maior }\end{array}$ & $\begin{array}{c}\text { s-iv } \\
\text { s-iv } \\
\text { s-iv } \\
\text { t-i } \\
\text { t-i } \\
\text { D/tP-V/III } \\
\text { D/tP-V/III }\end{array}$ \\
\hline CONFIRMATIO & $\begin{array}{l}\text { Synaeresis } \\
\text { Noema }\end{array}$ & $\begin{array}{l}50 \\
51-56\end{array}$ & $\begin{array}{l}7^{a} \text { Seção } \\
7^{\text {ạ Seção }}\end{array}$ & $\begin{array}{l}\text { Fá Menor } \\
\text { Fá Menor } \\
\text { e Sol Menor }\end{array}$ & $\begin{array}{l}\text { s/s-iv/iv } \\
\text { s/s-iv/iv } \\
\text { i-t }\end{array}$ \\
\hline PEROTATIO & $\begin{array}{l}\text { Emphasis } \\
\text { Synaeresis }\end{array}$ & $\begin{array}{l}58 \\
59\end{array}$ & $\begin{array}{l}7^{\text {ạ Seção }} \\
7^{\text {ạ Seção }}\end{array}$ & $\begin{array}{l}\text { Sol Menor } \\
\text { Sol Menor }\end{array}$ & $\begin{array}{l}t-i \\
t-i\end{array}$ \\
\hline
\end{tabular}

Tabela 35: Estrutura analítica do Ofertório 


\subsubsection{Ofertório da Missa do Segundo Domingo do Advento}

\section{Estudo Semântico}

\subsection{Inventio}

O texto do salmo "Oração pela Restauração de Israel" está presente em dois Ofertórios: para as Missas do Segundo e Terceiro Domingo do Advento. Tal excerto pode ser considerado como penitencial - onde o salmista descreve sua aflição pela indiferença de Deus com o povo de Israel.(Ps.84,7-8/Ps.85,6$7)$.

Deus tu conversus et vivificabi nos et plebs tua laetabitur in te Ostende nobis, Domine, misericordiam tuam et salutarem tuum da nobis.

Deus, não nos restituirás a vida, para que teu povo possa contigo alegrar-se? Mostra-nos tua misericórdia, Senhor, e dá-nos tua salvação!

(SOARES, 2000, p.104).

No Segundo Domingo do Advento, se faz predominante à prédica de João Batista descrita no livro de Mateus 3:3, "Voz que clama no deserto: Preparai o caminho do Senhor; endireitai as suas veredas"102 (ALMEIDA, 1999, p.1483). Essa premissa, igualmente simboliza a conjuntura contextual vivida nesse salmo na época de Moisés, quando o povo de Israel pedia a Deus para mostrar-Ihes sua compaixão e o caminho a seguir em meio ao deserto que trilhavam, tendo como objetivo a terra prometida, semelhantemente manifestada no profeta messiânico Isaías, 750 anos depois, como nos tempos de Cristo.

O referido ofertório, é concebido de trinta e nove compassos, na tonalidade de Si bemol Maior, num andamento Moderato, escrito para quatro vozes e acompanhamento instrumental, delineado em quatro seções.

\footnotetext{
102 Tal texto pode ser observado também em Isaías 40:3 "Voz do que clama no deserto: Preparai o caminho do Senhor; endireitai no ermo vereda a nosso Deus" (ALMEIDA, 1999, p.1114).
} 


\subsection{Locus observados na Inventio do Ofertório}

\begin{tabular}{|c|c|c|c|}
\hline INVENTIO & DESCRIÇÃO & $\begin{array}{c}\text { UTILIZAÇÃO NA } \\
\text { OBRA }\end{array}$ & $\begin{array}{l}\text { COMPASSO/ } \\
\text { VOZ }\end{array}$ \\
\hline $\begin{array}{l}\text { Locus } \\
\text { Notationis } \\
\text { (MATTHESON, } \\
\text { [1739],1954, } \\
\text { Parte II,Cap.4, } \\
\text { § 23,p.123). }\end{array}$ & $\begin{array}{l}\text { Aspecto } \\
\text { externo e } \\
\text { desenho das } \\
\text { notas (Duração } \\
\text { das notas, } \\
\text { alteração, } \\
\text { repetição e } \\
\text { procedimentos } \\
\text { canônicos). }\end{array}$ & $\begin{array}{l}\text { Vários motivos rítmicos } \\
\text { e diferentes durações } \\
\text { de notas (mínimas, } \\
\text { semínimas, semínimas } \\
\text { pontuadas, colcheias, } \\
\text { colcheias pontudas, } \\
\text { semicolcheias, } \\
\text { repetições, ligaduras, } \\
\text { apogiaturas, pausas, } \\
\text { entre outros). }\end{array}$ & $\begin{array}{ll}1-10 & S \\
11-39 & \text { S-A-T-B }\end{array}$ \\
\hline $\begin{array}{l}\text { Locus } \\
\text { Descriptionis } \\
\text { (MATTHESON, } \\
\text { [1739],1954, } \\
\text { Parte II,Cap.4, } \\
\S 43, \text { p.127). }\end{array}$ & $\begin{array}{l}\text { Disposições da } \\
\text { alma }\end{array}$ & $\begin{array}{l}\text { Misericórdia, } \\
\text { Compaixão (Mostra- } \\
\text { nos tua misericórdia, } \\
\text { Senhor). }\end{array}$ & 25-28 S-A-T-B \\
\hline
\end{tabular}

\subsection{Dispositio}

\subsubsection{Exordium}

$\mathrm{Na}$ introdução da exposição o autor trabalha com duas figuras retóricas, Anaphora e Pausa, a primeira tendo por característica a repetição melódica e motívica, nessa obra também manifesta nas palavras Deus tu conversus et (Deus, não nos restituirás), com ênfase na voz da soprano, a segunda promovendo descanso as outras vozes. 
Primeira Seção

Tonalidade

Si b Maior

Ofertório da Missá do $2^{\circ}$. Domingo do Advento

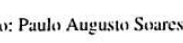

Cat. Duprat 154

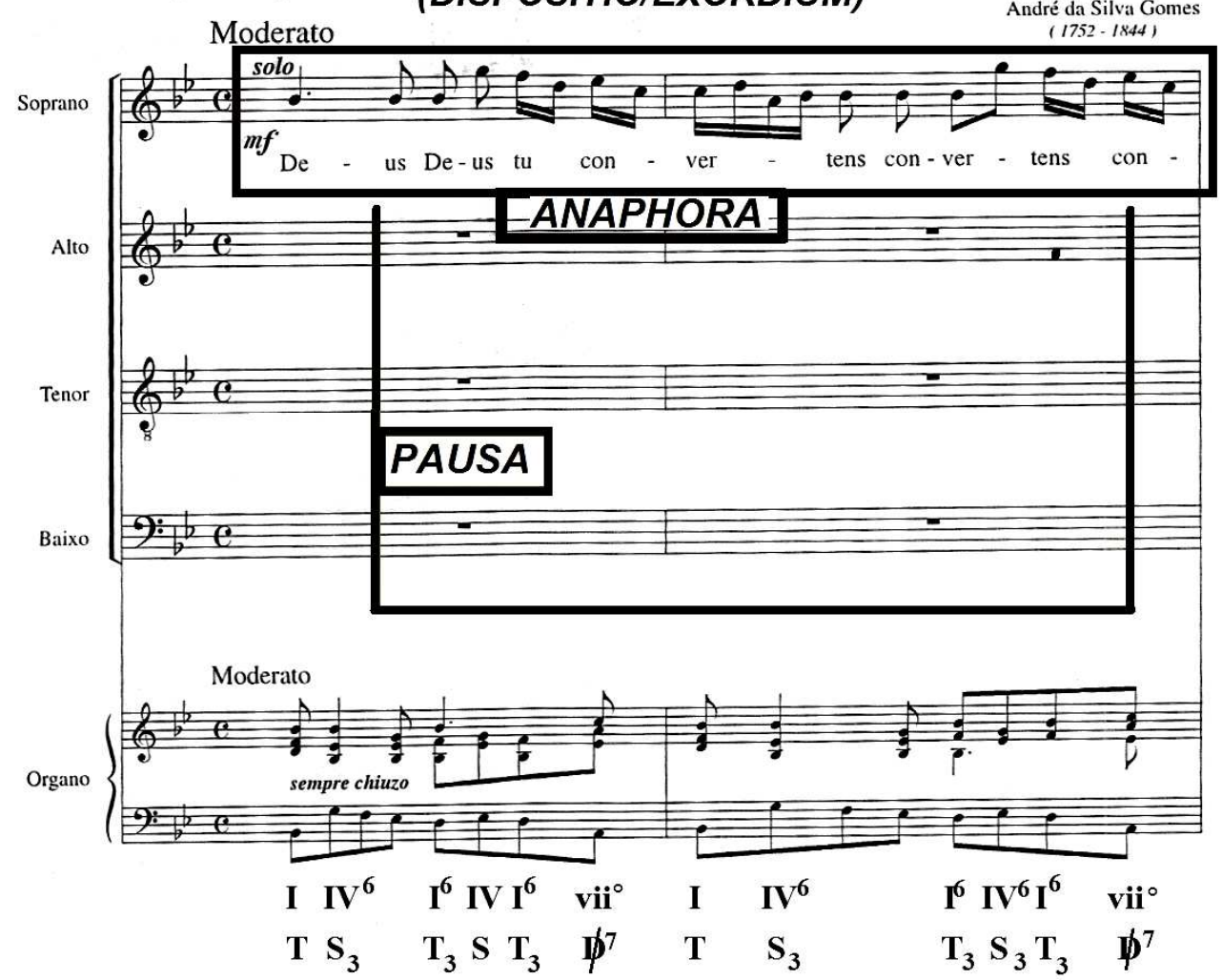

Exemplo 88: Ofertório da Missa do Segundo Domingo do Advento de André da Silva Gomes- Catalogação e Organização Régis Duprat (DUPRAT, 1999, p.138).

\subsubsection{Narratio}

Nos compassos 3 a 5, em conformidade a narração dos fatos expostos, pode-se notar a presença da Circulatio, fazendo movimento circular a cada grupo de oito notas, como também destacando a nota Dó, reforçando não só a formação de uma espécie de onda senoidal, mas perfazendo a passagem entre Tônica, Subdominante Paralela, Subdominante e Dominante. A ideia expressa nesse salmo penitencial é articulada pelo compositor por meio da figura retórica citada, onde a mesma completa o sentido da busca e objetivo traçados na petição do salmista vivificabi (preservar, restituir). 


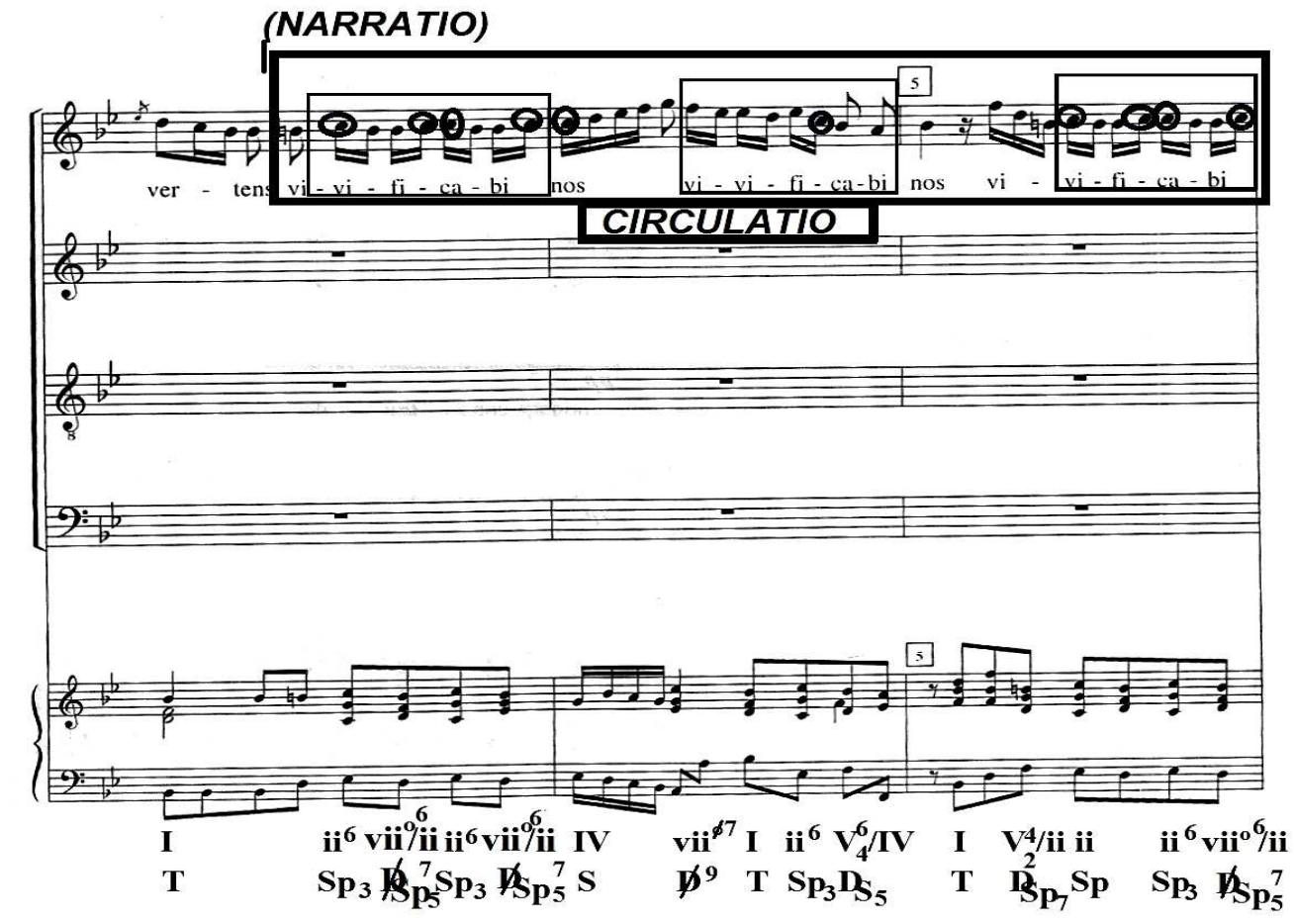

Exemplo 89: Ofertório da Missa do Segundo Domingo do Advento de André da Silva Gomes- Catalogação e Organização Régis Duprat (DUPRAT, 1999, p.138).

Novamente, são repetidas as mesmas palavras na sustentação dos argumentos anteriores, no entanto, a Tirata é utilizada em passagem escalar, por meio de figuras rápidas, tais como a colcheia e semicolcheia, de maneira vivida e brilhante pela solista, no oitavo compasso, até culminar na Cadência Autêntica Perfeita.

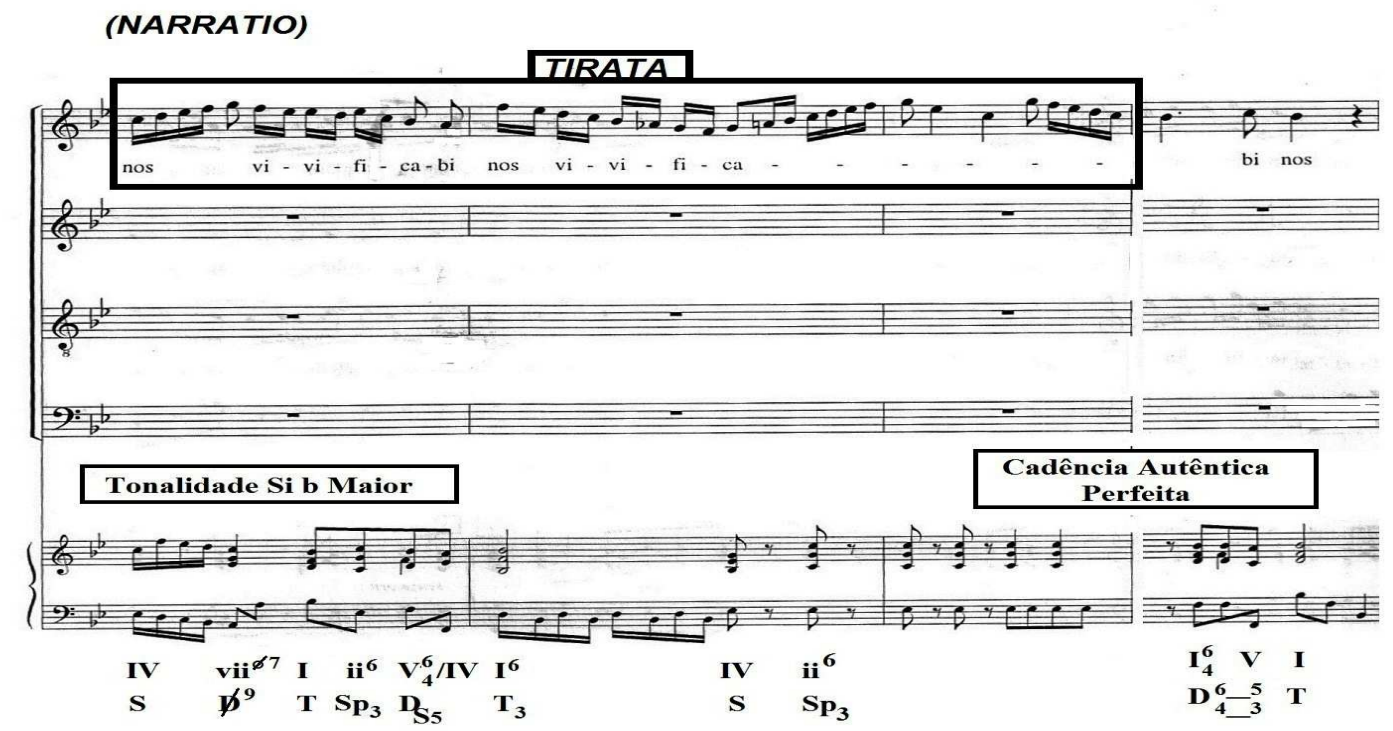

Exemplo 90: Ofertório da Missa do Segundo Domingo do Advento de André da Silva Gomes- Catalogação e Organização Régis Duprat (DUPRAT, 1999, p.139). 


\subsubsection{Propositio}

O sentimento de penitência é de novo evidenciado pela utilização da Epizeuxis, transmitindo de maneira enfática a suplica do fiel que concentra sua esperança nas ações de seu Criador, Deus tu conversus et.

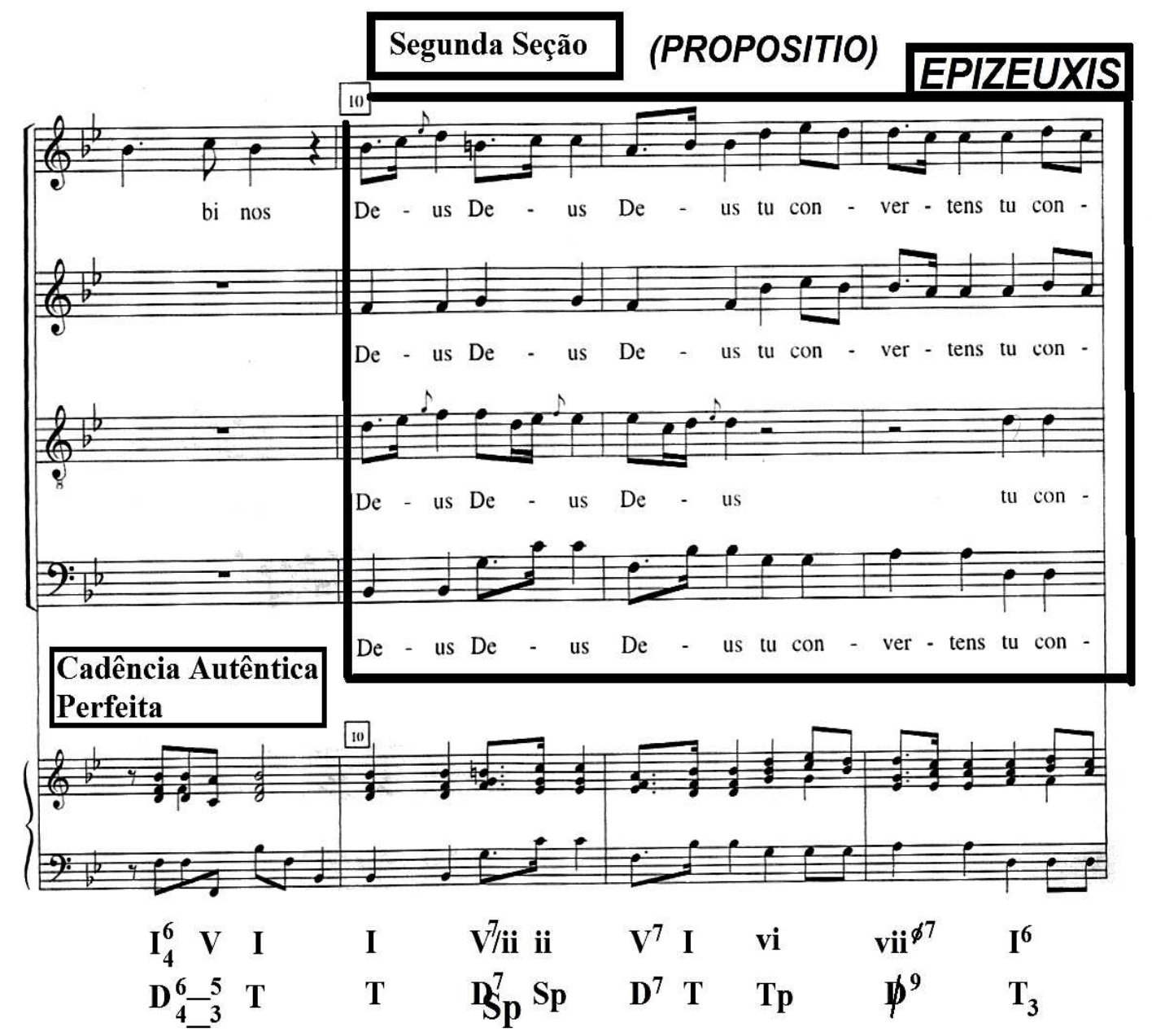

Exemplo 91: Ofertório da Missa do Segundo Domingo do Advento de André da Silva Gomes- Catalogação e Organização Régis Duprat (DUPRAT, 1999, p.139).

Na mesma tonalidade e seção, vê-se o uso da Anaphora, completando o mesmo sentido já localizado no texto, todavia, no começo do compasso 15 a Semicadência serve de transição para a nova fase da Dispositio. 


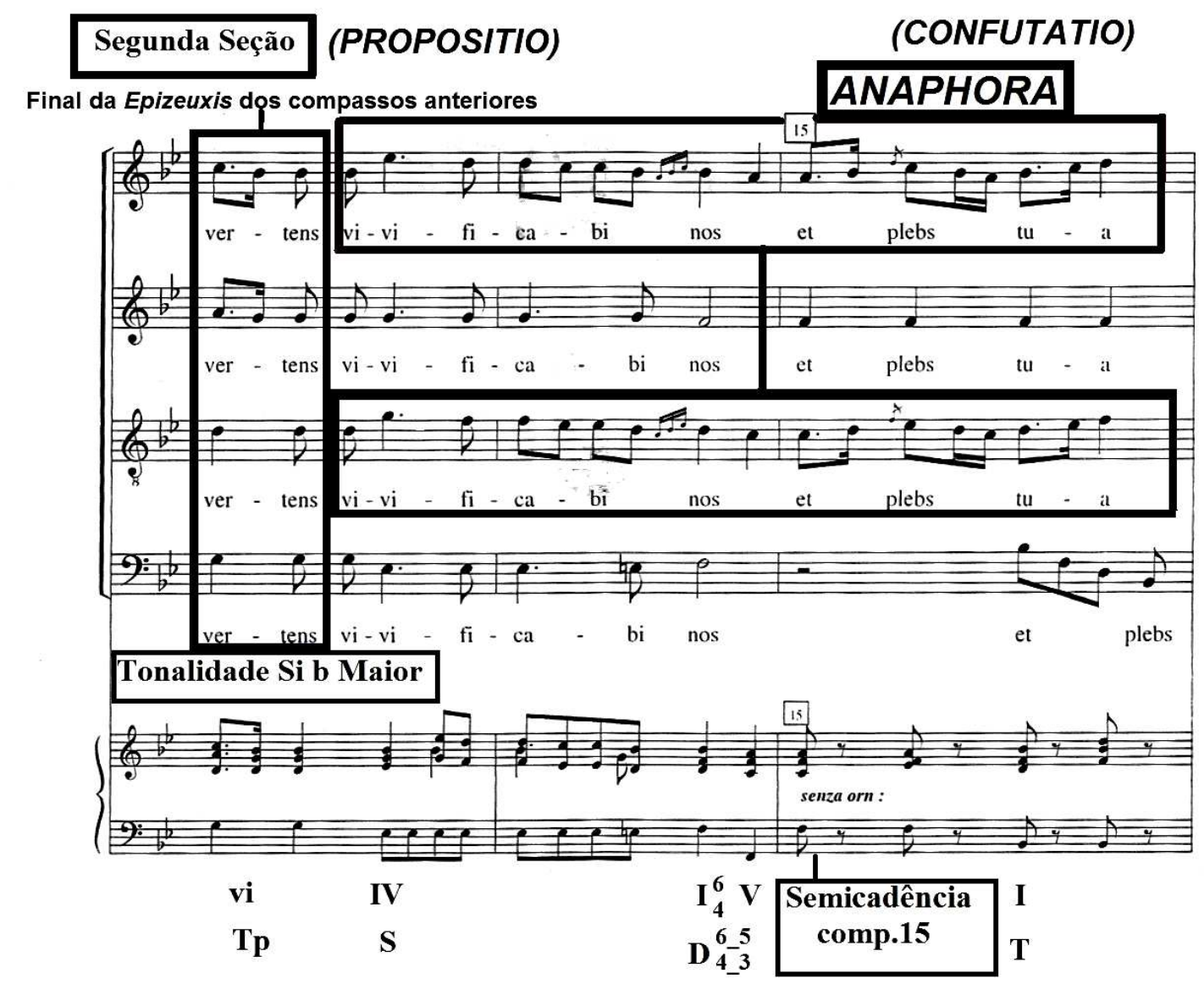

Exemplo 92: Ofertório da Missa do Segundo Domingo do Advento de André da Silva Gomes- Catalogação e Organização Régis Duprat (DUPRAT, 1999, p.140).

\subsubsection{Confutatio}

$\mathrm{Na}$ quarta parte do discurso retórico, é visível a Anaphora como a Variatio, empregada pelo autor para repetir e ao mesmo tempo destacar a esperança depositada pelo salmista em se alegrar, mesmo sem saber o caminho para onde ir, ou seja, como peculiar da Confutatio, há uma inquirição a tese suscita nas partes anteriores. 


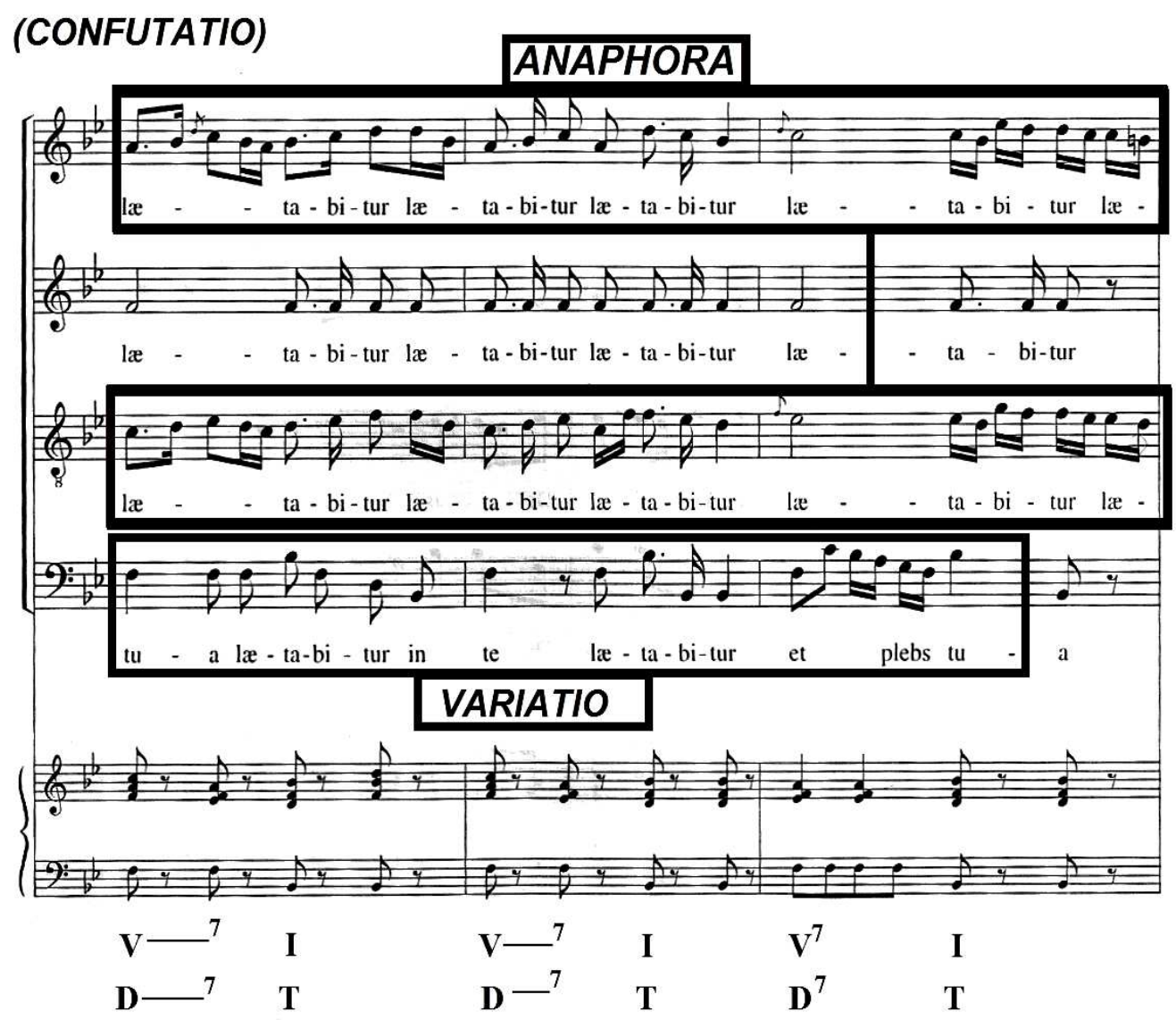

Exemplo 93: Ofertório da Missa do Segundo Domingo do Advento de André da Silva Gomes- Catalogação e Organização Régis Duprat (DUPRAT, 1999, p.140).

É claro o incremento de novos elementos retóricos na presente seção. $\mathrm{Na}$ busca de fundamentar o contraste e oposição aos argumentos apresentados desde a introdução do ofertório, Silva Gomes, emprega quatro figuras, Epizeuxis repetindo enfaticamente a expressão laetabitur, Synaeresis ressaltando a segunda voz, a qual entoa duas notas melódicas na mesma silaba, a Metabasis, cruzando as extensões da contralto e tenor e por fim, a Aposiopesis no compasso 24, instituindo um silêncio em todas as partes, logo após a Cadência Autêntica Perfeita. 

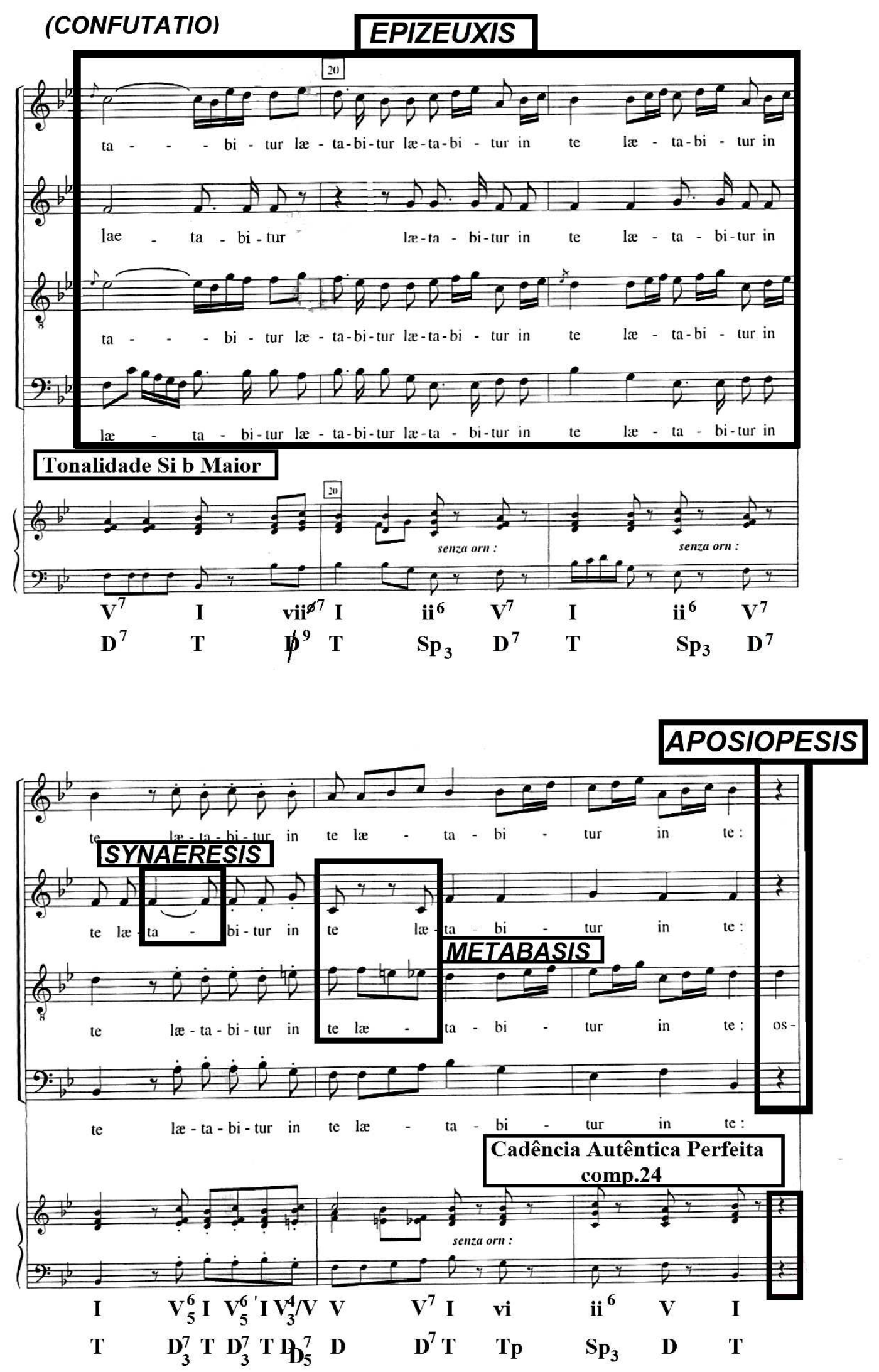

Exemplo 94: Ofertório da Missa do Segundo Domingo do Advento de André da Silva Gomes- Catalogação e Organização Régis Duprat (DUPRAT, 1999, p.141). 
Entre os compassos 25 a 29, é notada a modulação para a relativa de $\mathrm{Si}$ bemol Maior, como a clara elaboração por parte do compositor no emprego do pedal de Tônica, sustendo a passagem textual, como da Noema, objetivada a enfatizar o sentimento de compaixão demonstrado no texto, ostende nobis misericordiam tuam, apresentada uma única vez na peça, motivando forte impacto no ouvinte, o qual esteve desde o início submetido às diversas repetições dispostas tanto no salmo, quanto na música.

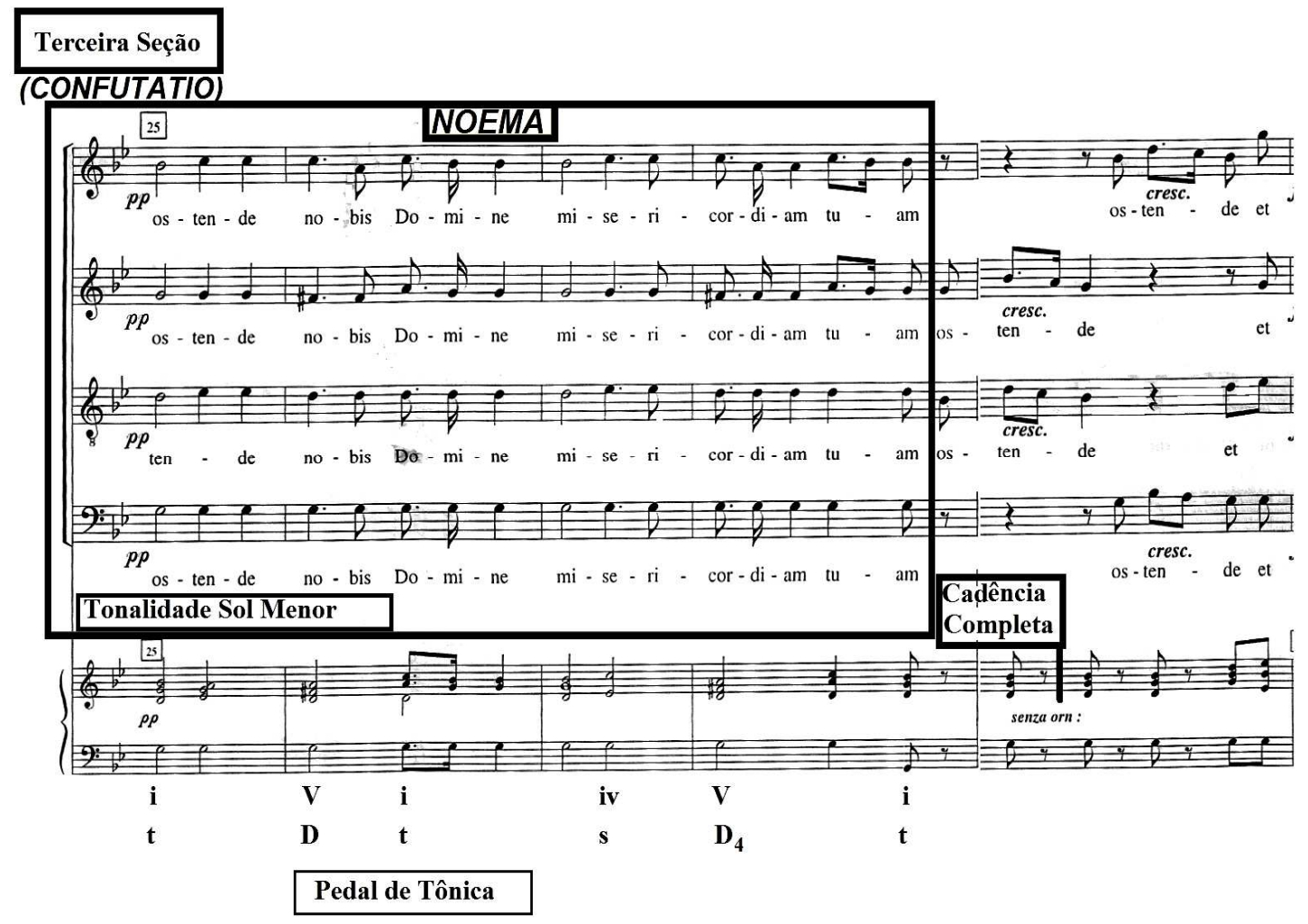

Exemplo 95: Ofertório da Missa do Segundo Domingo do Advento de André da Silva Gomes- Catalogação e Organização Régis Duprat (DUPRAT, 1999, p.142).

\subsubsection{Confirmatio}

A reiteração da ideia original é confirmada através da expressão et salutare (salvação), onde o salmista descreve sua aflição, pedido para que o Senhor, mostre sua misericórdia e o caminho pelo qual ele e seu povo devam andar, em meio a aparente indiferença. Com insistência, ao pedir a remição, nota-se um momento de humilhação, o qual caracteriza a figura da Catabasis, nos compassos 29 a 31, em linha descendente, representando o afeto depressivo, entretanto, suavizado com a modulação para a tonalidade principal da obra, isto é, Si bemol Maior. 


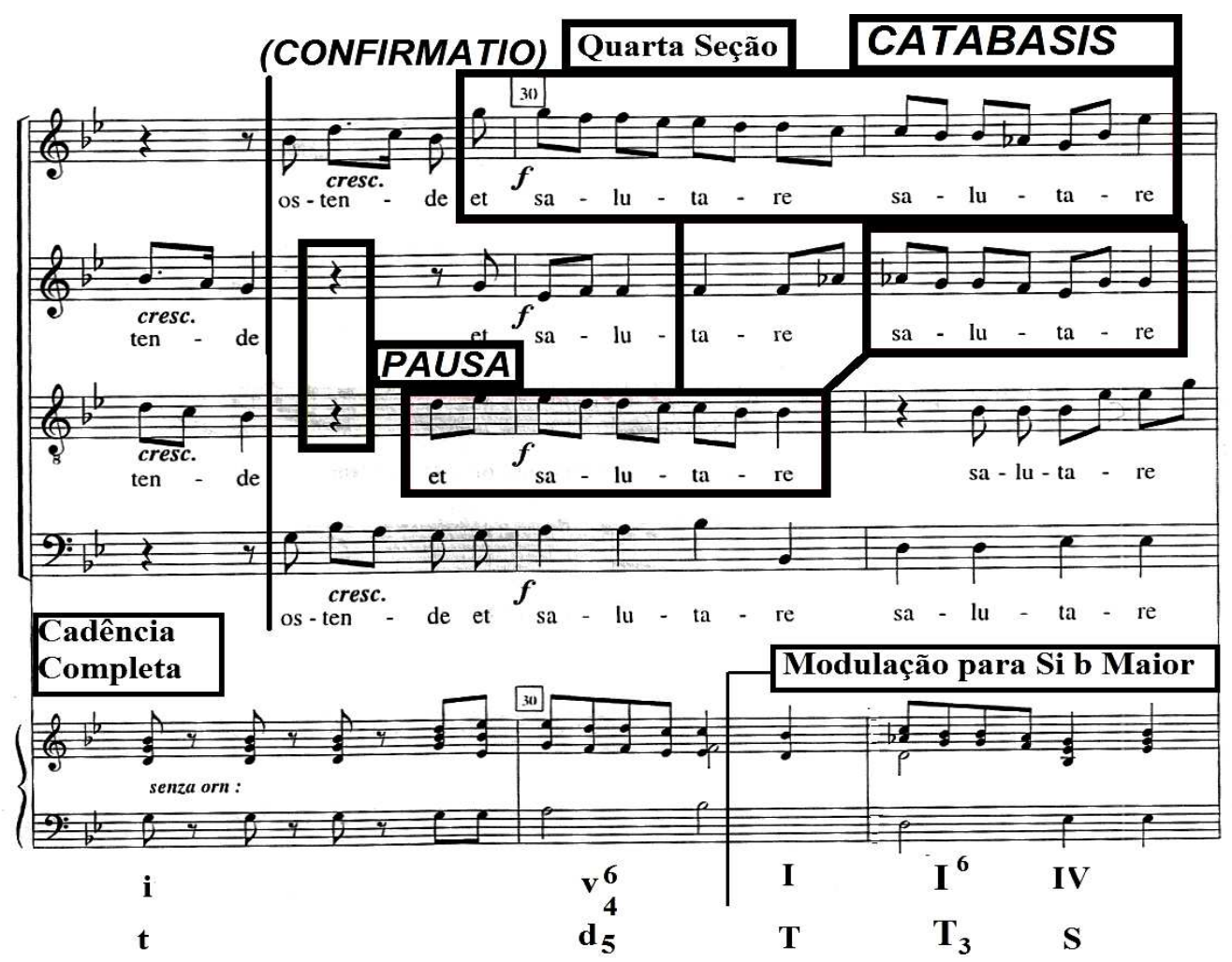

Exemplo 96: Ofertório da Missa do Segundo Domingo do Advento de André da Silva Gomes- Catalogação e Organização Régis Duprat (DUPRAT, 1999, p.142).

A utilização da Auxesis desde o compasso 32, em todas as vozes, reafirma a petição supracitada por uma solução.

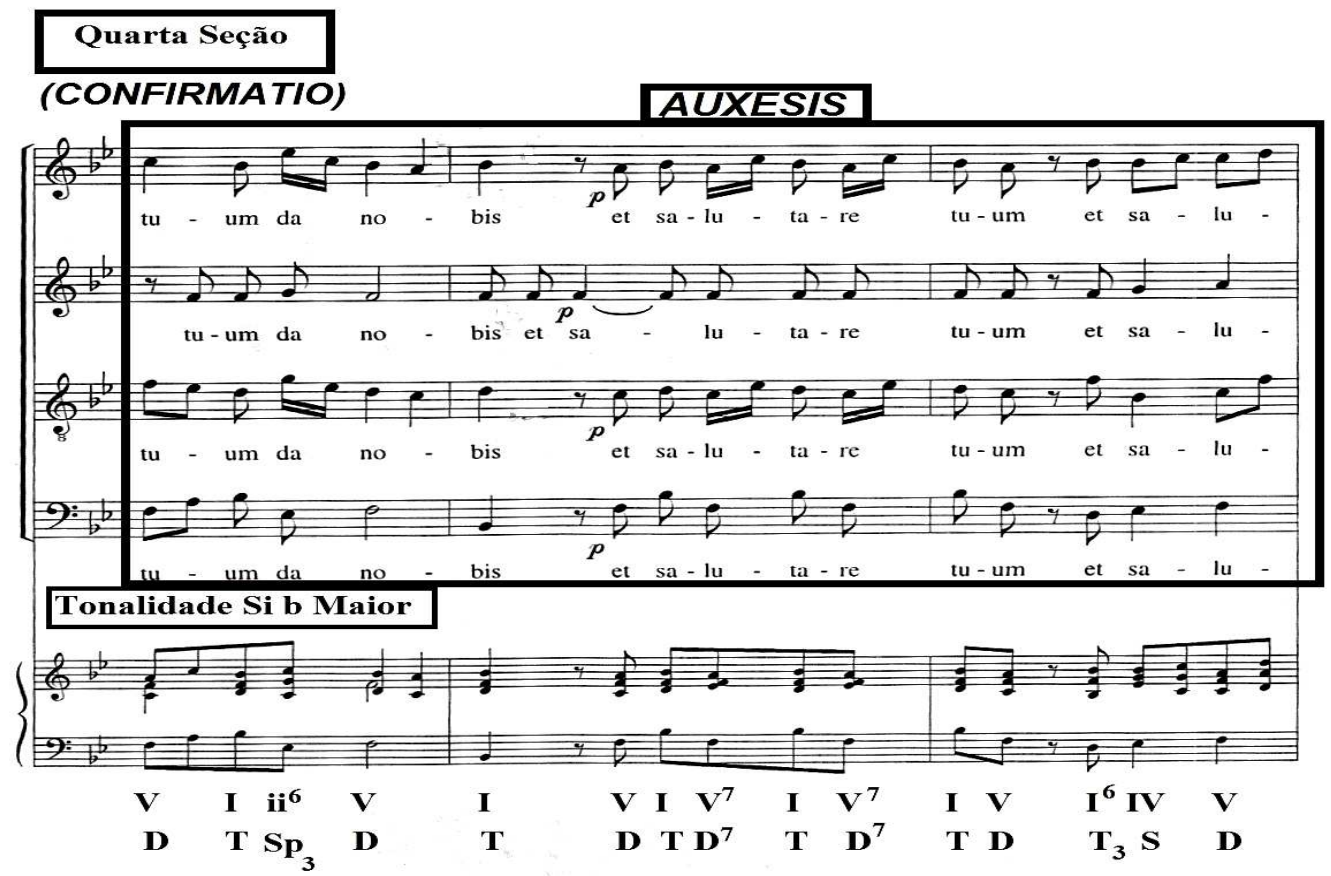

Exemplo 97: Ofertório da Missa do Segundo Domingo do Advento de André da Silva Gomes- Catalogação e Organização Régis Duprat (DUPRAT, 1999, p.143). 


\subsubsection{Perotatio}

Enfim, a Confirmatio termina numa Cadência Autêntica Perfeita, no compasso 35, sendo figura participial dessa finalização a Aposiopesis.

A Perotatio se constitui de apenas quatro compassos (36-39), onde Silva Gomes adequa a Synaeresis em todas as vozes, enfatizando a repetição da nobis, transmitindo as palavras proferidas pelo autor do salmo e ao mesmo tempo, inserindo a dinâmica pianíssimo, passando ao ouvinte a noção de suavidade, encerrando serenamente e tranquilamente a obra na Cadência Plagal.

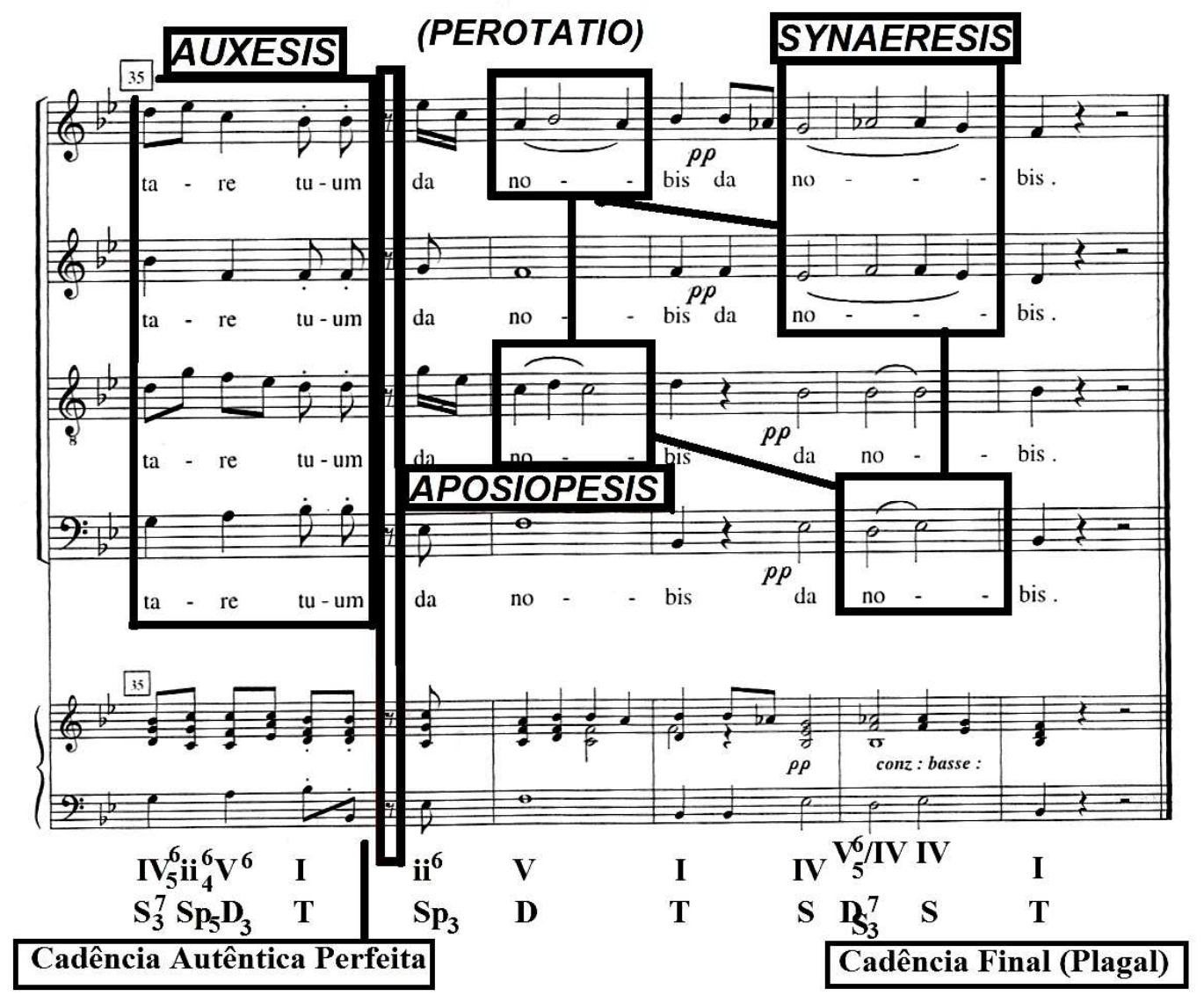

Exemplo 98: Ofertório da Missa do Segundo Domingo do Advento de André da Silva Gomes- Catalogação e Organização Régis Duprat (DUPRAT, 1999, p.143). 


\subsection{Figuras observadas no Ofertório (Elocutio/Decoratio)}

\begin{tabular}{|c|c|c|c|}
\hline FIGURAS & TIPO & DESCRIÇÃO & TRATADISTA \\
\hline $\begin{array}{l}\text { ANAPHORA } \\
\text { (BARTEL, 1997, } \\
\text { pp.184-190). }\end{array}$ & $\begin{array}{l}\text { Repetição } \\
\text { Melódica }\end{array}$ & $\begin{array}{l}\text { (1) É uma linha } \\
\text { do baixo repetida } \\
\text { em forma de solo. } \\
\text { (2) A repetição de } \\
\text { uma exposição } \\
\text { melódica sobre } \\
\text { notas e partes } \\
\text { diferentes. } \\
\text { Também pode } \\
\text { ocorrer no início } \\
\text { das repetições de } \\
\text { frases e motivos } \\
\text { em uma série de } \\
\text { passagens } \\
\text { sucessivas; (3) } \\
\text { Uma repetição } \\
\text { em geral. }\end{array}$ & $\begin{array}{lr}\text { Walther: Ér uma } \\
\text { figura } & \text { de } \\
\text { repetição e pode } \\
\text { ocorrer de duas } \\
\text { maneiras: } \\
\text { 1. Quando uma } \\
\text { palavra ra é } \\
\text { repetida rente } \\
\text { frequentemente } \\
\text { em r uma } \\
\text { composição } \\
\text { para dar maior } \\
\text { ênfase. r as } \\
\text { 2. Quando ando araves } \\
\text { notas graves } \\
\text { são repetidas } \\
\text { inúmeras vezes } \\
\text { (como o caso } \\
\text { das onne) } \\
\text { Chaconne). }\end{array}$ \\
\hline $\begin{array}{l}\text { APOSIOPESIS } \\
\text { (BARTEL, 1997, } \\
\text { pp.202-206). }\end{array}$ & $\begin{array}{l}\text { Interrupção e } \\
\text { Silêncio }\end{array}$ & $\begin{array}{l}\text { Um descanso em } \\
\text { uma ou todas as } \\
\text { vozes de uma } \\
\text { composição: } \\
\text { pausa geral. }\end{array}$ & \begin{tabular}{|lr} 
Walther: & A \\
Aposiopesis se \\
refere a uma \\
pausa generalis \\
ou um completo \\
silêncio em todas \\
as vozes e nas \\
partes r da \\
composição r \\
simultaneamente.
\end{tabular} \\
\hline $\begin{array}{l}\text { AUXESIS } \\
\text { (BARTEL, 1997, pp. } \\
\text { 209-212). }\end{array}$ & $\begin{array}{l}\text { Repetição } \\
\text { Melódica }\end{array}$ & $\begin{array}{l}\text { São repetições } \\
\text { sucessivas de } \\
\text { uma passagem } \\
\text { musical. }\end{array}$ & $\begin{array}{lr}\text { Burmeister: } & \text { A } \\
\text { Auxesis } & \text { ocorre } \\
\text { quando r uma } & \\
\text { harmonia } & \\
\text { composta } & \text { por } \\
\text { combinações } & \\
\text { consonantes } & \text { se } \\
\text { desenvolve de } & \text { dorma crescente } \\
\text { em um texto que } \\
\text { é repetido uma, } \\
\text { duas, três ou } \\
\text { mais vezes. } \\
\text { Portanto, ela }\end{array}$ \\
\hline
\end{tabular}




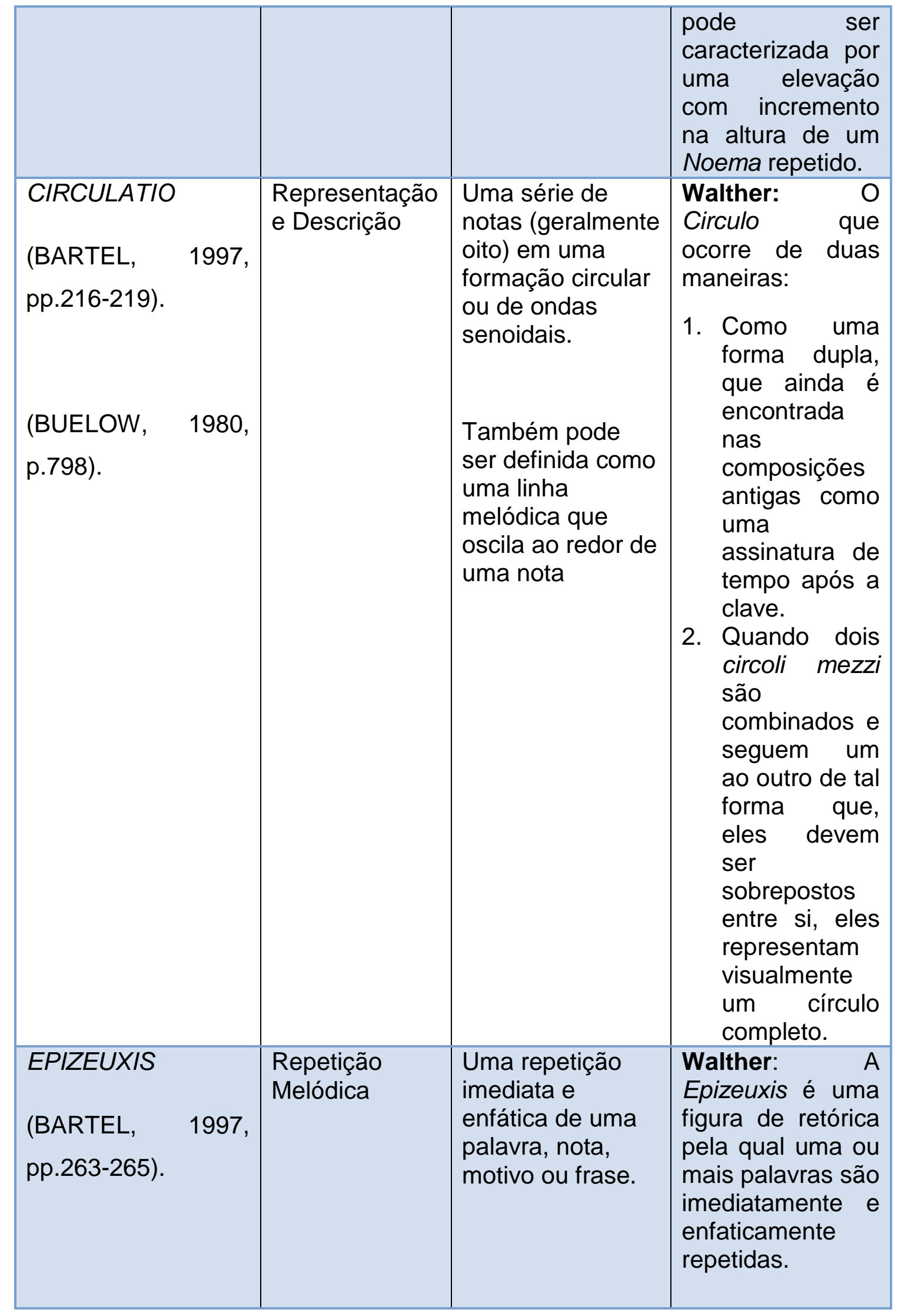




\begin{tabular}{|c|c|c|c|c|}
\hline $\begin{array}{l}\text { METABASIS } \\
\text { (BARTEL, } \\
\text { pp.319-320). }\end{array}$ & 1997, & $\begin{array}{l}\text { Representação } \\
\text { e } \\
\text { Descrição }\end{array}$ & $\begin{array}{l}\text { Cruzamento de } \\
\text { uma voz com } \\
\text { outra ou } \\
\text { cruzamento de } \\
\text { vozes. }\end{array}$ & $\begin{array}{l}\text { Spiess: A } \\
\text { Metabasis (ou } \\
\text { Diabasis, } \\
\text { Transgressio, } \\
\text { Transgression) } \\
\text { ocorre sempre } \\
\text { que uma voz } \\
\text { atravessa a outra. }\end{array}$ \\
\hline $\begin{array}{l}\text { NOEMA } \\
\text { (BARTEL, } \\
\text { p.339-342). }\end{array}$ & 2001 & $\begin{array}{l}\text { Representação } \\
\text { e Descrição }\end{array}$ & $\begin{array}{l}\text { Uma passagem } \\
\text { homofônica em } \\
\text { uma textura } \\
\text { contrapontística e } \\
\text { polifônica. }\end{array}$ & $\begin{array}{l}\text { Burmeister: A } \\
\text { Noema } \\
\text { representa o } \\
\text { afeto harmônico, } \\
\text { onde as vozes } \\
\text { combinadas têm } \\
\text { valores e } \\
\text { números de notas } \\
\text { semelhantes. } \\
\text { Quando } \\
\text { introduzida } \\
\text { adequadamente, } \\
\text { isto é, no } \\
\text { momento certo, } \\
\text { ela afeta } \\
\text { docemente os } \\
\text { ouvidos do } \\
\text { ouvinte, } \\
\text { produzindo uma } \\
\text { sensação de } \\
\text { calma e } \\
\text { serenidade. } \\
\text { Seção } \\
\text { homofônica, } \\
\text { dentro da } \\
\text { polifonia utilizada } \\
\text { para enfatizar o } \\
\text { texto. }\end{array}$ \\
\hline $\begin{array}{l}\text { PAUSA } \\
\text { (BARTEL, } \\
\text { pp.362-365). }\end{array}$ & 1997 & $\begin{array}{l}\text { Interrupção e } \\
\text { Silêncio }\end{array}$ & $\begin{array}{l}\text { Pausa } \\
\text { descanso eu } \\
\text { uma composição } \\
\text { musical }\end{array}$ & $\begin{array}{lr}\text { Walther: Uma } \\
\text { figura ou figuras } \\
\text { de silêncio. } \\
\text { Pausa refere-se a } \\
\text { um período de } \\
\text { repouso ou o } \\
\text { silêncio ro na } \\
\text { música, que é } \\
\text { indicado por um } \\
\begin{array}{lr}\text { determinado } \\
\text { sinal. }\end{array} \\
\end{array}$ \\
\hline
\end{tabular}




\begin{tabular}{|c|c|c|c|c|}
\hline $\begin{array}{l}\text { SYNAERESIs } \\
\text { (BARTEL, } \\
\text { pp.394-396). }\end{array}$ & 1997 & $\begin{array}{l}\text { Dissonância e } \\
\text { Deslocamento }\end{array}$ & $\begin{array}{l}\text { (1) Uma } \\
\text { suspensão ou } \\
\text { síncope, (2) A } \\
\text { colocação de } \\
\text { duas sílabas por } \\
\text { nota ou duas } \\
\text { notas por sílaba. }\end{array}$ & \begin{tabular}{|lr} 
Vogt: & A \\
Synaeresis & ocorre \\
quando & duas \\
notas & são \\
colocadas & em \\
uma sílaba & ou \\
duas sílabas & são \\
colocadas & em \\
uma nota. &
\end{tabular} \\
\hline $\begin{array}{l}\text { TIRATA } \\
\text { (BARTEL, } \\
\text { pp.409-412). }\end{array}$ & 1997, & $\begin{array}{l}\text { Ornamentação } \\
\text { Melódica e } \\
\text { Harmônica }\end{array}$ & $\begin{array}{l}\text { Uma passagem } \\
\text { escalar rápida } \\
\text { que mede uma } \\
\text { quarta, oitava ou } \\
\text { mais. }\end{array}$ & $\begin{array}{l}\text { Walther: Tirata } \\
\text { ou tirade significa } \\
\text { um curso ou } \\
\text { linha, que é } \\
\text { especialmente } \\
\text { um momento de } \\
\text { diversas notas } \\
\text { com a mesma } \\
\text { duração que quer } \\
\text { subir ou descer a } \\
\text { etapa. }\end{array}$ \\
\hline $\begin{array}{l}\text { VARIATIO } \\
\text { (BARTEL, } \\
\text { pp.432-438). }\end{array}$ & 1997, & $\begin{array}{l}\text { Ornamentação } \\
\text { Melódica e } \\
\text { Harmônica }\end{array}$ & $\begin{array}{l}\text { Ornamentação de } \\
\text { uma passagem } \\
\text { melódica com } \\
\text { uma variedade de } \\
\text { embelezamentos } \\
\text { (decorações). }\end{array}$ & $\begin{array}{l}\text { Printz: A palavra } \\
\text { Variatio é usada } \\
\text { de duas maneiras } \\
\text { pelos músicos, ou } \\
\text { seja, tanto no } \\
\text { sentido amplo e } \\
\text { estrito. Em um } \\
\text { sentido estrito, } \\
\text { variatio refere-se } \\
\text { a uma alteração } \\
\text { artística } \\
\text { (figuração) de } \\
\text { uma determinada } \\
\text { passagem } \\
\text { melódica, mas } \\
\text { em que a melodia } \\
\text { original é sempre } \\
\text { percebida } \\
\text { reconhecida. Em } \\
\text { um sentido } \\
\text { amplo, Variatio } \\
\text { significa qualquer } \\
\text { tipo de alteração } \\
\text { de um trecho } \\
\text { melódico se inclui } \\
\text { o tipo anterior ou } \\
\text { não. }\end{array}$ \\
\hline
\end{tabular}

Tabela 37: Figuras encontradas no Ofertório da Missa do Segundo Domingo do Advento de André da Silva Gomes 


\section{Análise Harmônica}

\subsection{Curva Tonal}

Tonalidade: Si b Maior

Andamento: Moderato 4/4

Esquema de Progressões Harmônicas

\begin{tabular}{|l|c|l|}
\hline Compassos & $\begin{array}{l}\text { Função em relação a } \\
\text { tonalidade principal }\end{array}$ & Tonalidade (Acorde) \\
\hline $1-3$ & T-I & Si b Maior \\
\hline $3-4$ & Sp-ii & Dó Menor \\
\hline $4-5$ & T-I & Si b Maior \\
\hline $5-6$ & Sp-ii & Dó Menor \\
\hline $6-7$ & T-I & Si b Maior \\
\hline $7-8$ & S-IV & Mi b Maior \\
\hline $9-10$ & T-I & Si b Maior \\
\hline 10 & Sp-ii & Dó Menor \\
\hline $11-14$ & T-I & Si b Maior \\
\hline 14 & D-V & Fá Maior \\
\hline $15-22$ & T-I & Si b Maior \\
\hline $22-23$ & D-V & Fá Maior \\
\hline $23-24$ & T-I & Si b Maior \\
\hline $25-29$ & Tp-vi & Sol Menor \\
\hline 30 & T-I & Si b Maior \\
\hline 31 & S-IV & Mi b Maior \\
\hline $32-37$ & T-I & Si b Maior \\
\hline $37-38$ & S-IV & Mi b Maior \\
\hline 39 & T-I & Si b Maior \\
\hline
\end{tabular}

Tabela 38: Curva Tonal do Ofertório da Missa do Segundo Domingo do Advento

Números de compassos: 39

Regiões abordadas: 5

Variações: 19

Ritmo Harmônico: 2,05 (divisão dos números de compassos e variações)

Média ideal: (divisão dos números de compassos e regiões tonais abordadas = $7,8)$ 
Esquema Formal

$(1-24)(25-29)(30-39)$

$\begin{array}{ccc}\text { T } & \text { Tp } & \text { T } \\ \text { I } & \text { vi } & \text { I }\end{array}$

2.2. Estrutura Analítica do Ofertório: Retórica e Harmônica

\begin{tabular}{|c|c|c|c|c|c|}
\hline $\begin{array}{l}\text { RETÓRICA } \\
\text { DISPOSITIO }\end{array}$ & $\begin{array}{l}\text { FIGURA } \\
\text { ELOCUTIO }\end{array}$ & COMP. & $\begin{array}{l}\text { HARMÔNICA } \\
\text { SEÇÃO }\end{array}$ & TONALIDADE & FUNÇÃO \\
\hline EXORDIUM & $\begin{array}{l}\text { Anaphora } \\
\text { Pausa }\end{array}$ & $\begin{array}{l}1-2 \\
1-2\end{array}$ & $\begin{array}{l}\text { 1 a Seção } \\
1 \text { a Seção }\end{array}$ & $\begin{array}{l}\text { Si b Maior } \\
\text { Si b Maior }\end{array}$ & $\begin{array}{l}T-I \\
T-I\end{array}$ \\
\hline NARRATIO & \begin{tabular}{|l} 
Pausa \\
Circulatio \\
Tirata
\end{tabular} & $\begin{array}{l}3-10 \\
3-5 \\
6-8\end{array}$ & $\begin{array}{l}1 \text { a Seção } \\
1 \text { a Seção } \\
1{ }^{a} \text { Seção }\end{array}$ & $\begin{array}{l}\text { Si b Maior } \\
\text { Si b Maior } \\
\text { Si b Maior }\end{array}$ & $\begin{array}{l}T-I \\
T-I \\
T-I\end{array}$ \\
\hline PROPOSITIO & $\begin{array}{l}\text { Epizeuxis } \\
\text { Anaphora }\end{array}$ & $\begin{array}{l}10-13 \\
13-14\end{array}$ & $\begin{array}{l}2^{\mathrm{a}} \text { Seção } \\
\text { 2 }^{\mathrm{a}} \text { Seção }\end{array}$ & $\begin{array}{l}\text { Si b Maior } \\
\text { Si b Maior }\end{array}$ & $\begin{array}{l}T-I \\
T-I\end{array}$ \\
\hline CONFUTATIO & $\begin{array}{l}\text { Anaphora } \\
\text { Variatio } \\
\text { Epizeuxis } \\
\text { Synaeresis } \\
\text { Metabasis } \\
\text { Aposiopesis } \\
\text { Noema }\end{array}$ & $\begin{array}{l}15-18 \\
16-18 \\
19-21 \\
22 \\
23 \\
24 \\
25-28\end{array}$ & 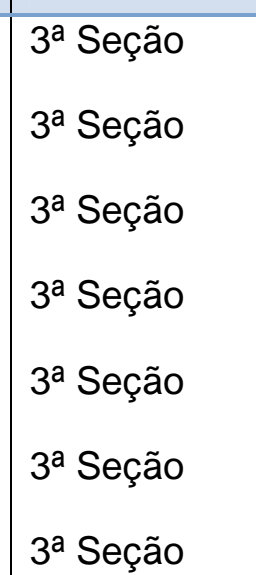 & $\begin{array}{l}\text { Si b Maior } \\
\text { Si b Maior } \\
\text { Si b Maior } \\
\text { Si b Maior } \\
\text { Si b Maior } \\
\text { Si b Maior } \\
\text { Sol Menor }\end{array}$ & $\begin{array}{l}\text { T-I } \\
T-I \\
T-I \\
T-I \\
T-I \\
T-I \\
\text { Tp-vi }\end{array}$ \\
\hline
\end{tabular}




\begin{tabular}{|l|l|l|l|l|c|}
\hline CONFIRMATIO & Pausa & 29 & $4^{\text {a }}$ Seção & Sol Menor & Tp-vi \\
& Catabasis & $29-31$ & $4^{\text {a }}$ Seção & Sol Menor & Tp-vi \\
& Auxesis & $32-35$ & $4^{\text {a }}$ Seção & Si b Maior & T-I \\
& Aposiopesis & 35 & $4^{\text {a }}$ Seção & Si b Maior & T-I \\
\hline PEROTATIO & Synaeresis & $36-38$ & $4^{\text {a }}$ Seção & Si b Maior & T-I \\
\hline
\end{tabular}

Tabela 39: Estrutura analítica do Ofertório 


\subsubsection{Ofertório da Missa do Terceiro Domingo do Advento}

\section{Estudo Semântico}

\subsection{Inventio}

Esta é a segunda obra que comtempla a oração do ofertório anterior, "Oração pela Restauração de Israel", no entanto, aqui o autor emprega novos versículos (Ps. 84.2-3/ Ps. 85.1-2), escritos desta maneira:

\section{Benedixisti Dmine terram tuam \\ Avertisti captivitatem Jacob \\ Remisisti ninquitatem plenis tuae.}

Senhor, favoreceste a tua terra,

Acabaste com o cativeiro de Jacó.

Perdoaste a culpa de teu povo [...]

(SOARES, 2000, p.114).

O excerto exposto é relacionado ao cativeiro do povo hebreu no Egito, que, em virtude de uma orientação divina comissionada por seus patriarcas, se deslocam para essa nação a procura de melhores condições de vida. A Bíblia traz em sua narrativa que Jacó, um dos patriarcas, neto de Abraão, trabalhou quatorze anos para seu tio Labão, em troca da mão de sua filha, Raquel, pelo fato de Lia a primogênita ter sido dada por esposa antes:

\footnotetext{
Ora, Labão tinha duas filhas: Lia, a mais velha, e Raquel, a mais moça. Jacó amava a Raquel e disse: "Sete anos te servirei por tua filha mais moça Raquel". [...] Concordou Jacó, e se passou a semana desta; então, Labão lhe deu por esposa Raquel, sua filha. E coabitaram. Mas Jacó amava mais a Raquel do que Lia; e continuou servindo a Labão por outros sete anos (Gênesis 29, 16; 18; 28 e 30).
}

Da união entre Jacó e Raquel, nasce José, que anos posteriores tornase governador do Egito. Em virtude disso, o patriarca migra com seu povo para esse país, todavia, com o passar dos tempos, e com um novo faraó, a futura nação israelita deixa de ser bem tratada, passando a condição de escravidão.

Tal cativeiro simboliza não só o vivido por Jacó, mas igualmente a dos cidadãos hebreus no Egito. Dessa forma Deus testa a fé seus fiéis, por meio de provações severas tendo como objetivo, preparar seu povo para novos horizontes e caminhos: a libertação do cativeiro e a terra prometida, Canaã. 
Enfim, o presente ofertório se constitui de sessenta e um compassos, na tonalidade de Si bemol Maior, com andamento Moderato, para oito vozes, distribuída em sete seções.

\subsection{Locus observados na Inventio do Ofertório}

\begin{tabular}{|c|c|c|c|}
\hline INVENTIO & DESCRIÇÃO & $\begin{array}{c}\text { UTILIZAÇÃO NA } \\
\text { OBRA }\end{array}$ & $\begin{array}{l}\text { COMPASSO/ } \\
\text { VOZ }\end{array}$ \\
\hline $\begin{array}{l}\text { Locus } \\
\text { Notationis } \\
\text { (MATTHESON, } \\
\text { [1739],1954, } \\
\text { Parte II,Cap.4, } \\
\text { § 23,p.123). }\end{array}$ & $\begin{array}{l}\text { Aspecto externo } \\
\text { e desenho das } \\
\text { notas (Duração } \\
\text { das notas, } \\
\text { alteração, } \\
\text { repetição e } \\
\text { procedimentos } \\
\text { canônicos). }\end{array}$ & $\begin{array}{l}\text { Vários motivos } \\
\text { rítmicos e diferentes } \\
\text { durações de notas } \\
\text { (semibreves, } \\
\text { mínimas, } \\
\text { semínimas, } \\
\text { semínimas } \\
\text { pontuadas, } \\
\text { colcheias, colcheias } \\
\text { pontudas, } \\
\text { semicolcheias, } \\
\text { fusas, repetições, } \\
\text { ligaduras, fermatas, } \\
\text { apogiaturas, pausas, } \\
\text { entre outros). }\end{array}$ & $\begin{array}{l}1-13 \text { Todas as } \\
\text { vozes } \\
14-21 \text { S1 e S2 } \\
22-28 \text { Todas as } \\
\text { vozes } \\
29-32 \text { S1-A1 } \\
33-38 \text { S1-A1-T1 } \\
\text { 39-61 Todas as } \\
\text { vozes }\end{array}$ \\
\hline $\begin{array}{l}\text { Locus } \\
\text { Descriptionis } \\
\text { (MATTHESON, } \\
\text { [1739],1954, } \\
\text { Parte II,Cap.4, } \\
\text { § 43,p.127). }\end{array}$ & $\begin{array}{l}\text { Disposições da } \\
\text { alma }\end{array}$ & $\begin{array}{l}\text { Perdão (Perdoaste a } \\
\text { culpa de teu povo). }\end{array}$ & $\begin{array}{l}48-61 \text { Todas as } \\
\text { vozes }\end{array}$ \\
\hline $\begin{array}{l}\text { Locus } \\
\text { Adjunctorum } \\
\text { (MATTHESON, } \\
\text { [1739] 1954, } \\
\text { Parte II, Cap.4 } \\
\S 71, \text { p. 130). }\end{array}$ & $\begin{array}{l}\text { (Representação } \\
\text { de determinados } \\
\text { personagens } \\
\text { como em: } \\
\text { ofertórios, } \\
\text { óperas } \\
\text { cantatas). }\end{array}$ & $\begin{array}{l}\text { Jacó personagem de } \\
\text { representação } \\
\text { simbólica (Acabaste } \\
\text { com o cativeiro de } \\
\text { Jacó). }\end{array}$ & $\begin{array}{l}27-39 \mathrm{~S} 1, \mathrm{~A} 1, \mathrm{~T} 1 \\
39-46 \mathrm{Em} \text { todas } \\
\text { as vozes }\end{array}$ \\
\hline
\end{tabular}

Tabela 40: Locus Topici encontrados no Ofertório da Missa do Terceiro Domingo do Advento de André da Silva Gomes 


\subsection{Dispositio}

\subsubsection{Exordium}

Tal como o Ofertório da Missa do Quarto Domingo da Quaresma, a presente obra fora escrita para oito vozes. No segundo compasso já é observável o uso da Aposiopesis, indicando um descanso a todas as vozes, da mesma forma pode-se constatar sua utilidade na resolução da primeira frase Benedixisti Domine, por meio da Cadência Plagal. Já entre os compassos 3 a 6. Silva Gomes emprega três figuras de repetição melódica, Palilogia, Anaphora e Synaeresis, a primeira enfatizando as mesmas notas e palavras, a segunda tendo como repetência as melodias entoadas pelo baixo e a terceira realçando a colocação de duas notas por silabas, complementando o início do salmo.

Outro ponto a ser verificado é o emprego da Pausa em três momentos do mesmo excerto, servindo não só de repouso as partes, mas na exploração no tratamento de caráter responsorial, por exemplo, o primeiro coro inicia uma frase e o segundo a complementa. Destarte, fica evidente a habilidade do compositor tanto na aplicação dos elementos retóricos, quanto na possibilidade de superposição dos textos apresentados, como na exploração sonora, originária dos encontros das partes durante a pronuncia concomitante das silabas, palavras e melodias. 
Ofertório da Missa do $3^{\circ}$. Domingo do Advento

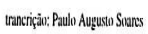
Cald Daparal (i)

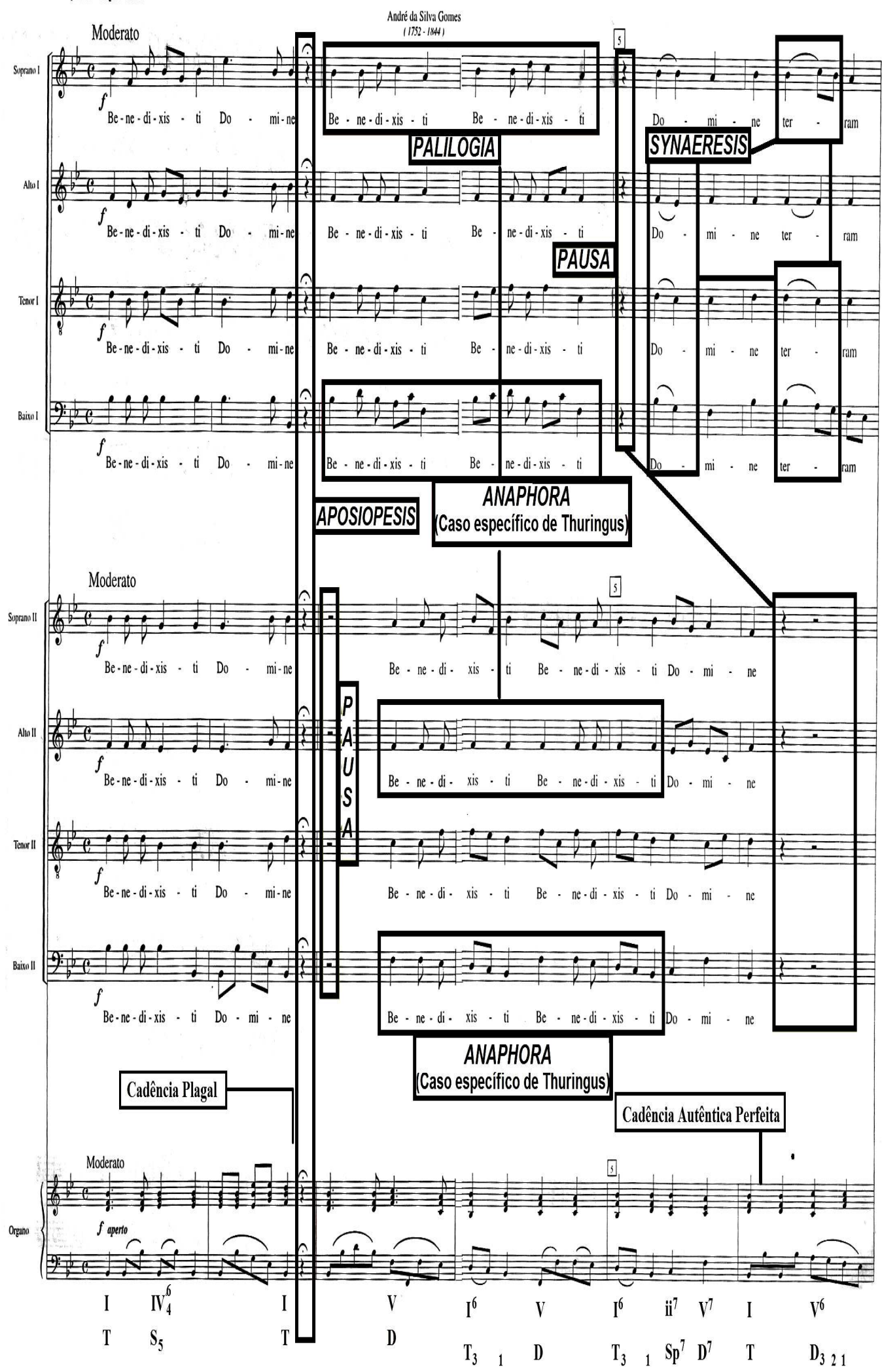

Exemplo 99: Ofertório da Missa do Terceiro Domingo do Advento de André da Silva Gomes- Catalogação e Organização Régis Duprat (DUPRAT, 1999, pp.144-145). 
No complemento da primeira parte do versículo do salmo terra tuam (tua terra), o autor utiliza-se da Pausa enfatizando ainda mais o diálogo entre as vozes (pergunta-resposta).

\section{(EXORDIUM)}

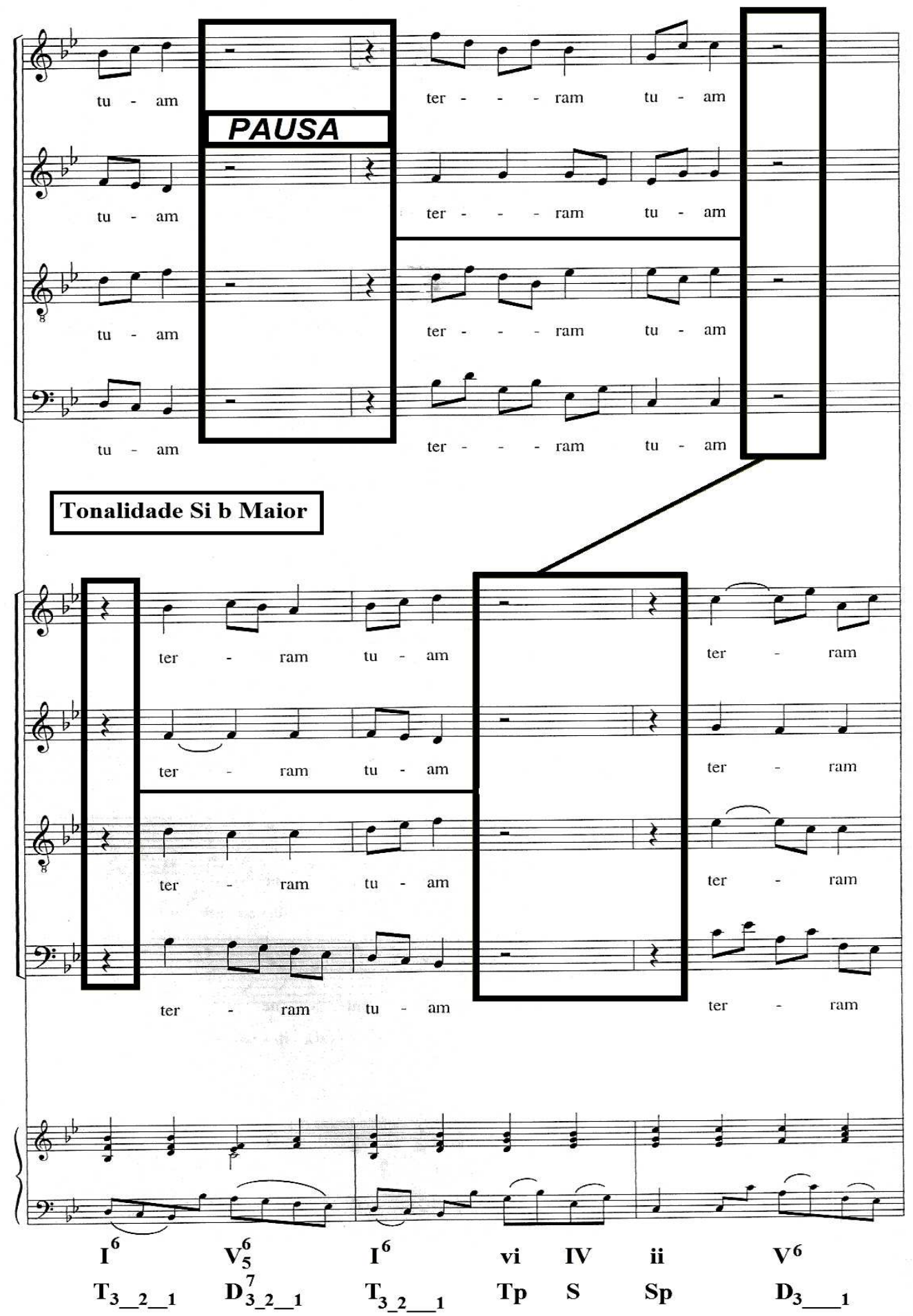

Exemplo 100: Ofertório da Missa do Terceiro Domingo do Advento de André da Silva Gomes- Catalogação e Organização Régis Duprat (DUPRAT, 1999, p.146). 
A Exordium é finalizada no compasso 13, numa Cadência Autêntica Perfeita, na tonalidade Si bemol Maior, tendo sido usadas às mesmas figuras desde o segundo compasso.

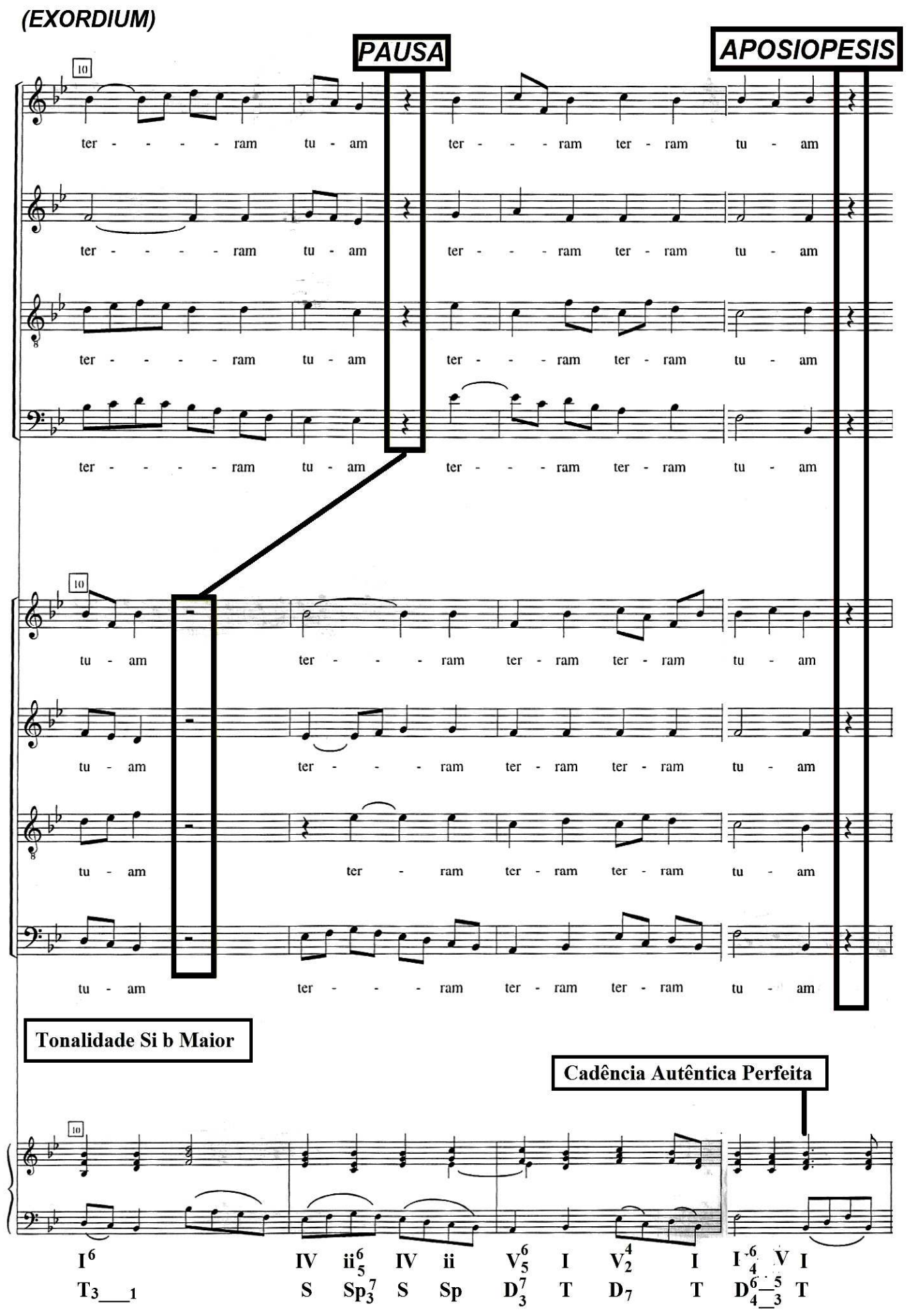

Exemplo 101: Ofertório da Missa do Terceiro Domingo do Advento de André da Silva Gomes- Catalogação e Organização Régis Duprat (DUPRAT, 1999, pp.147-148). 


\subsubsection{Narratio}

As mesmas palavras são proferidas, no entanto, o autor as trata com variedade de adornos, isto é, o mesmo aplica a Variatio, para variar a ornamentação da passagem melódica, o Climax, na repetição das palavras e das notas em alturas similares, a Circulatio, destacando a nota Ré, seja na Tônica ou na Dominante, em forma circular e, por fim, a Pausa, determinando descanso para seis vozes, deixando que a narração dos fatos iniciais sejam realizados somente pelas sopranos dos dois coros.

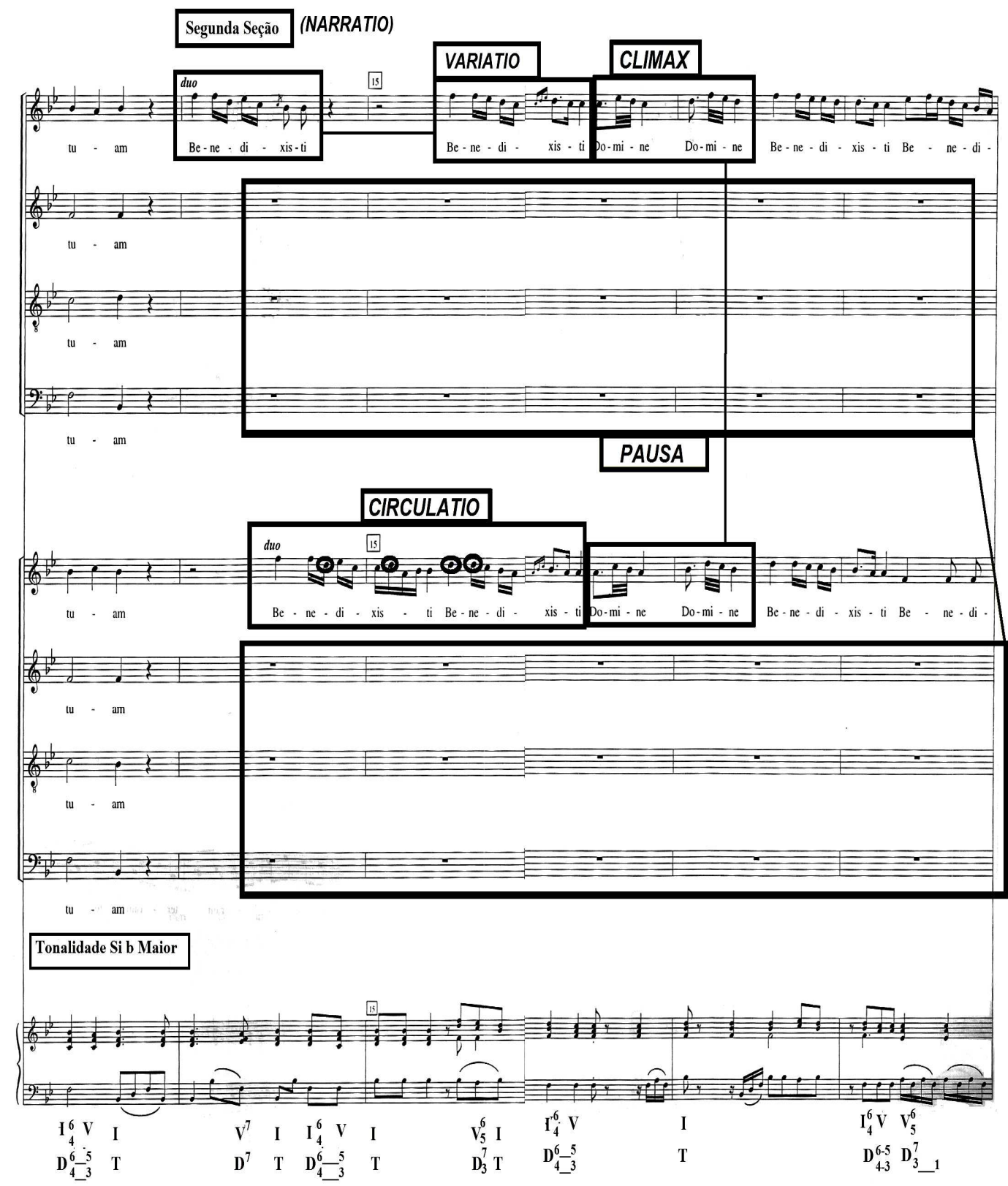

Exemplo 102: Ofertório da Missa do Terceiro Domingo do Advento de André da Silva Gomes- Catalogação e Organização Régis Duprat (DUPRAT, 1999, pp.148-149). 
Nesse trecho, vê-se o uso da Anaphora, enfatizando por meio de repetição a expressão terra tuam, além de reforçar o termino da seção, como da parte do discurso na Cadência Autêntica Perfeita.

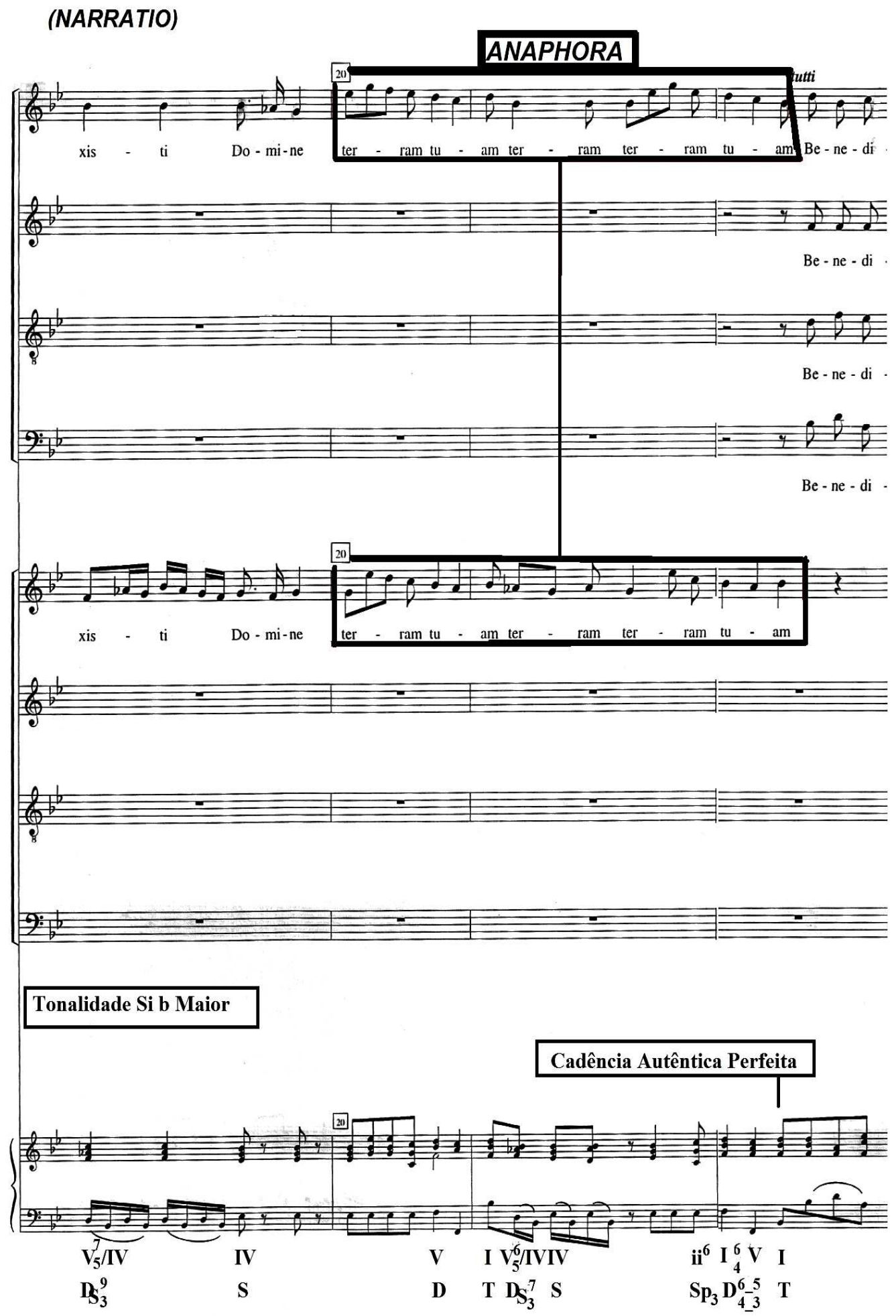

Exemplo 103: Ofertório da Missa do Terceiro Domingo do Advento de André da Silva Gomes- Catalogação e Organização Régis Duprat (DUPRAT, 1999, pp.150-151). 


\subsubsection{Propositio}

De maneira sucinta os pontos já expostos anteriormente são trabalhados pelo compositor, contudo, com a denotação da Epizeuxis repetindo enfaticamente a palavra Benedixisti, executada pelos dois coros em estilo responsorial.

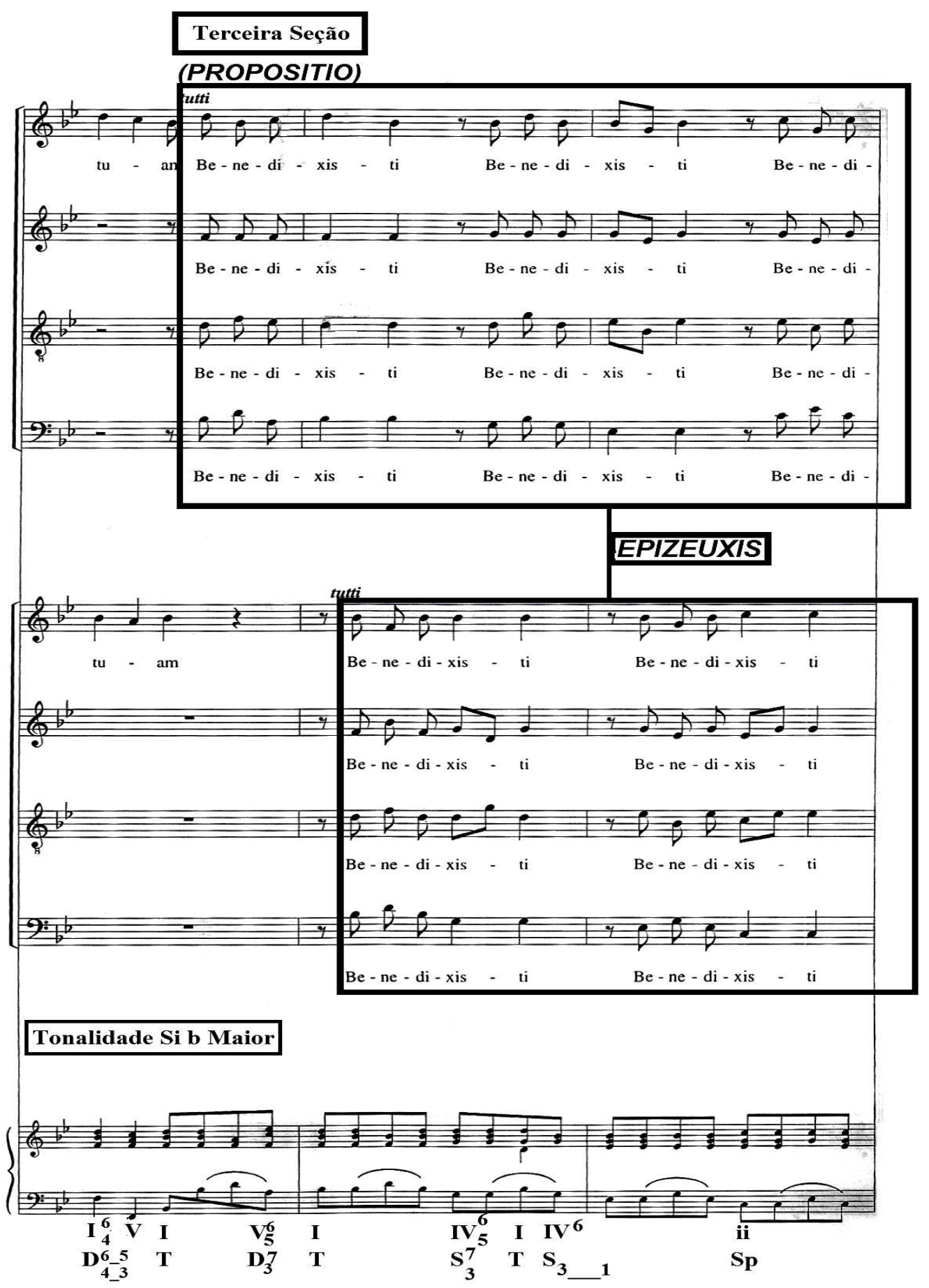

Exemplo 104: Ofertório da Missa do Terceiro Domingo do Advento de André da Silva Gomes- Catalogação e Organização Régis Duprat (DUPRAT, 1999, p.151). 
No final da Propositio, é visível a continuidade do argumento e raciocínio discursivo do autor, apresentadas nos compassos anteriores, através da utilização da Epizeuxis, porém na conclusão da primeira metade da peça é empregada a Aposiopesis, numa Semicadência, criando maior tensão e expectativa ao ouvinte.

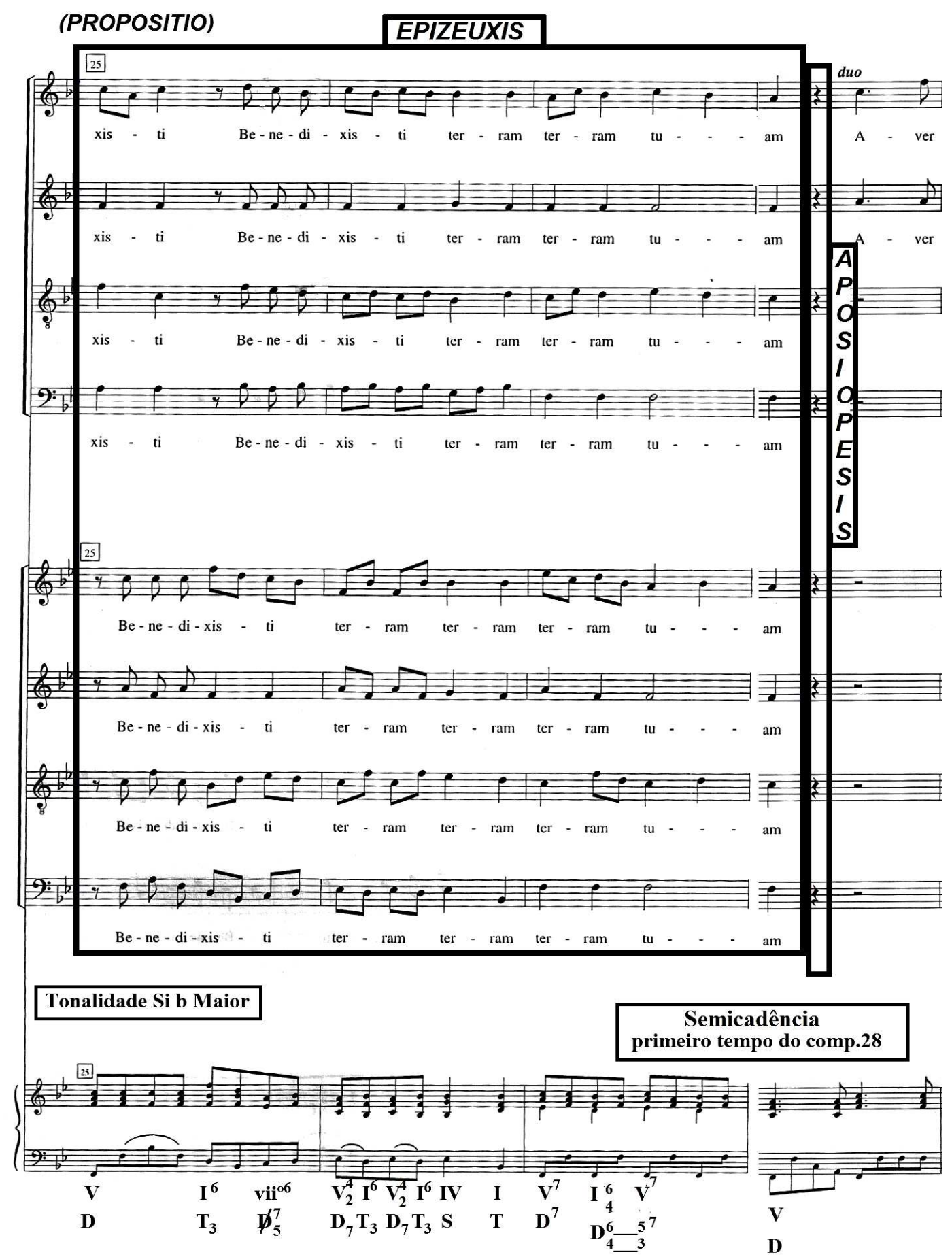

Exemplo 105: Ofertório da Missa do Terceiro Domingo do Advento de André da Silva Gomes- Catalogação e Organização Régis Duprat (DUPRAT, 1999, pp.152-153). 


\subsubsection{Confutatio}

Na segunda metade do ofertório é notada a aplicação da Anaphora e Pausa, como embasamento para o desenvolvimento da ideia exposta pelo salmista, de que o povo de Israel seria liberto da escravidão no Egito e abençoado por Deus, analogamente simbolizado pelo patriarca Jacó, Avertisti captivitatem Jacob (Acabaste com o cativeiro de Jacó). Nota-se igualmente a primeira modulação da obra para a tonalidade de Fá Maior.

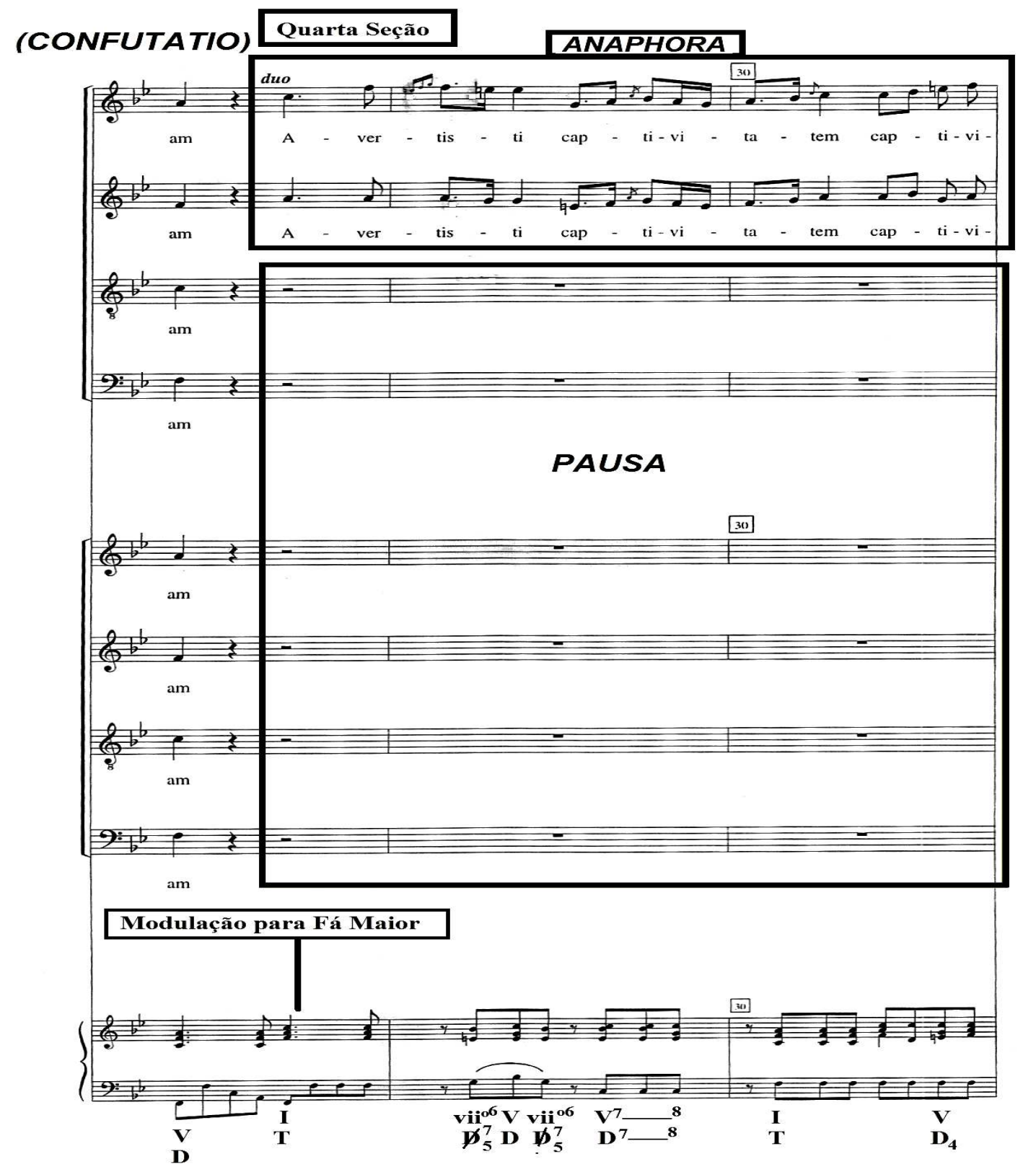

Exemplo 106: Ofertório da Missa do Terceiro Domingo do Advento de André da Silva Gomes- Catalogação e Organização Régis Duprat (DUPRAT, 1999, p.153). 
No presente excerto examina-se o emprego da Variatio e da Gradatio, como elementos característicos da Confutatio, sejam na variação da passagem ornamental melódica, quanto na repetição sequencial das notas movimentando-se em terças paralelas, culminando no contraste peculiar da referida parte do discurso, com uma modulação para a tonalidade de Fá Menor, em outras palavras, por intermédio da tensão estrutural entre as tonalidades Maior e Menor, o compositor apropria-se de um artificio de persuasão, cujo intuito é de orientar a atenção do ouvinte para a entrada do versículo já explanado desde o compasso 28.

(CONFUTATIO)

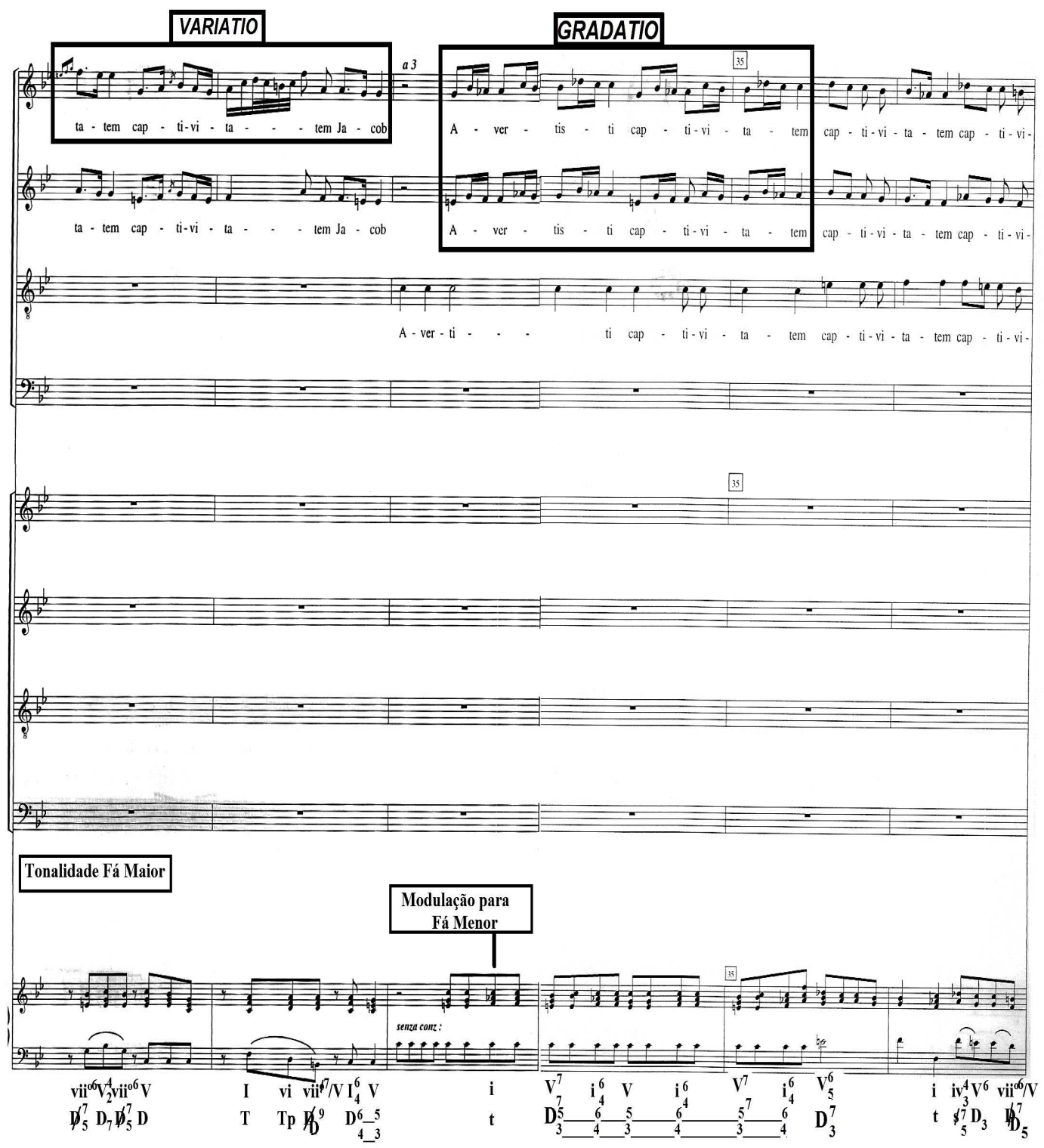

Exemplo 107: Ofertório da Missa do Terceiro Domingo do Advento de André da Silva Gomes- Catalogação e Organização Régis Duprat (DUPRAT, 1999, pp.154-155). 
Silva Gomes, continua a trabalhar com as mesmas frases textuais do começo da quarta seção do ofertório, provocando uma atmosfera de reflexão ao se referir ao cativeiro, porém, ele insere uma nova figura, Auxesis com sucessivas repetições em todas as vozes. Também, não passa despercebido, o uso da Synaeresis no compasso 38, enfatizando a silaba já executada com duas notas diferentes pela soprano e contralto, como o retorno a tonalidade de Fá Maior, pouco antes da Cadência Autêntica Imperfeita.

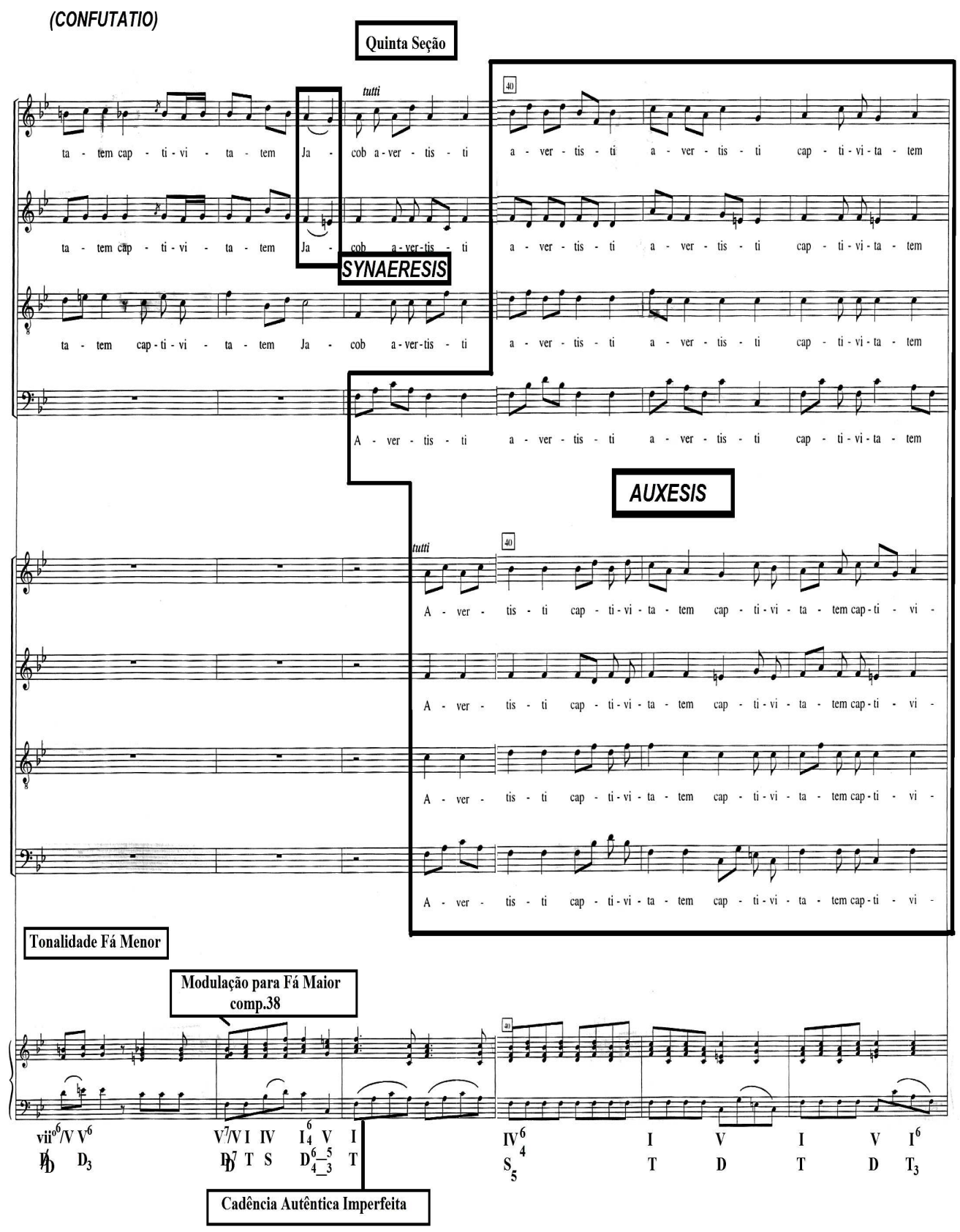

Exemplo 108: Ofertório da Missa do Terceiro Domingo do Advento de André da Silva Gomes- Catalogação e Organização Régis Duprat (DUPRAT, 1999, pp.156-157). 
A Auxesis continua a ser empregada até o fim da seção no compasso 46, perfazendo todo o sentindo do contraste entre servidão, escravidão e liberdade.
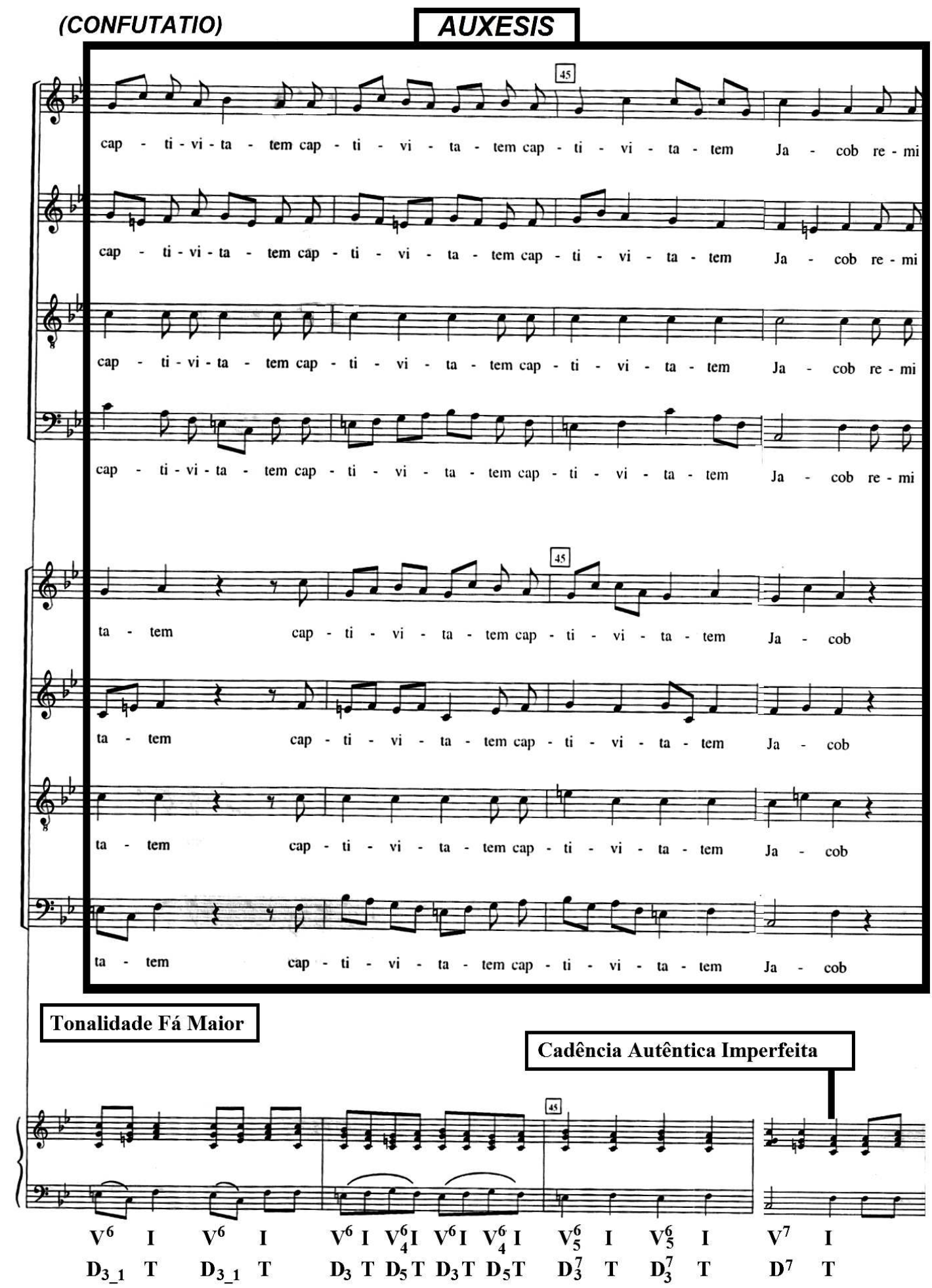

Exemplo 109: Ofertório da Missa do Terceiro Domingo do Advento de André da Silva Gomes- Catalogação e Organização Régis Duprat (DUPRAT, 1999, p.158). 


\subsubsection{Confirmatio}

A confirmação da tese inicial se dá em virtude da proposição, de que o cativeiro do povo de Israel aconteceu por causa da provação imposta pelo Senhor, entretanto, como nação escolhida, à mesma fora favorecida sendo libertada da escravidão, perdoada de seus pecados e de suas culpas, remisti iniquitatem (perdoaste a iniquidade). Tal fato é reforçado também pelo emprego das figuras de repetição melódicas, Polyptoton e Epizeuxis, assim como o retorno para a tonalidade principal da obra, Si bemol Maior, no compasso 51.

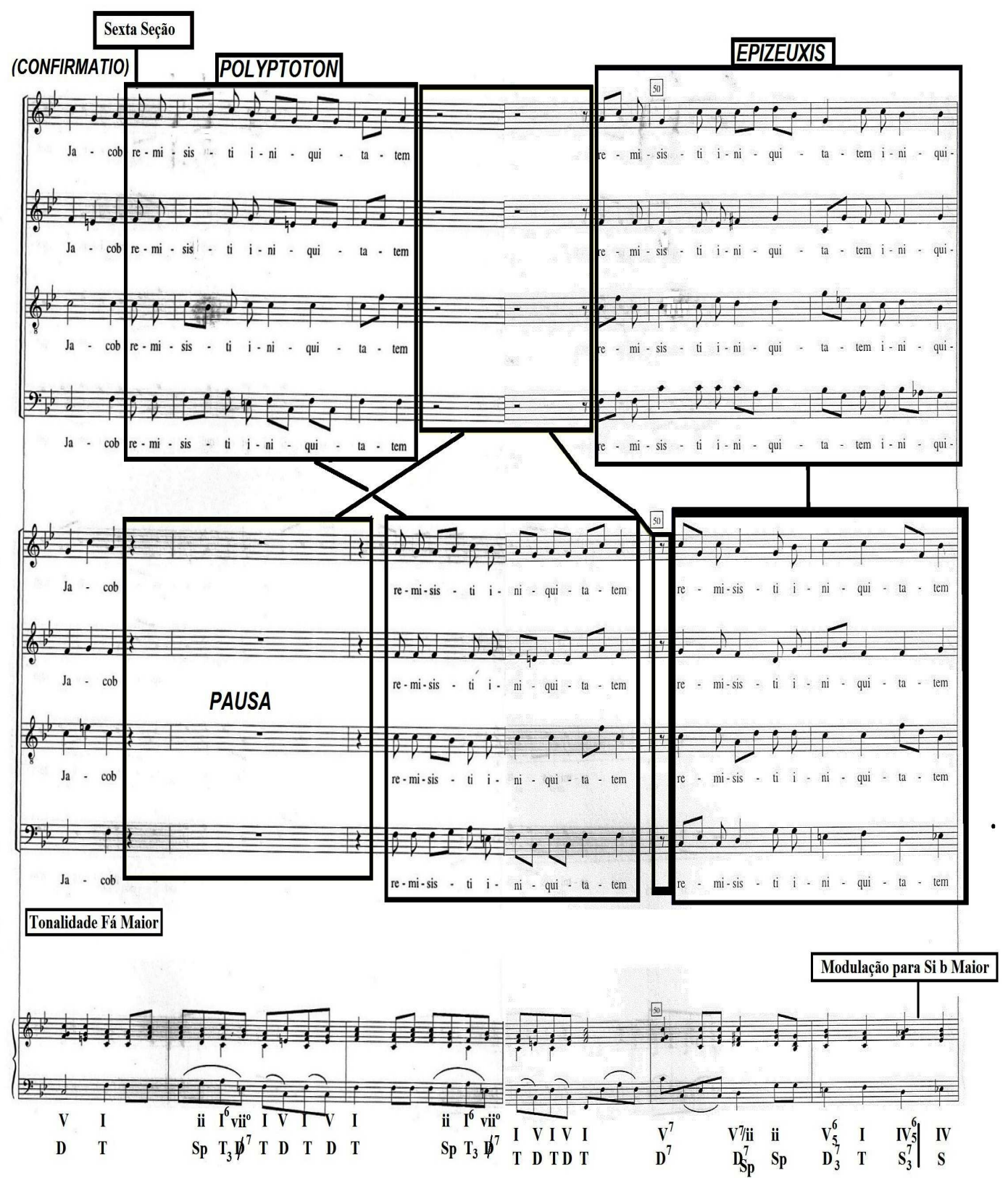

Exemplo 110: Ofertório da Missa do Terceiro Domingo do Advento de André da Silva Gomes- Catalogação e Organização Régis Duprat (DUPRAT, 1999, pp.159-160). 
$\mathrm{Na}$ última seção da peça se observa o uso da Noema na condução homofônica das vozes em textura contrapontística, como na imitação motívica, enfatizando através de repetição a palavra iniquitatem (iniquidade). Igualmente, é destaque no excerto, a aplicação de duas cadências, a Suspensiva (Semicadência), no compasso 53 e da Completa (I, IV, V, I) no compasso 57.

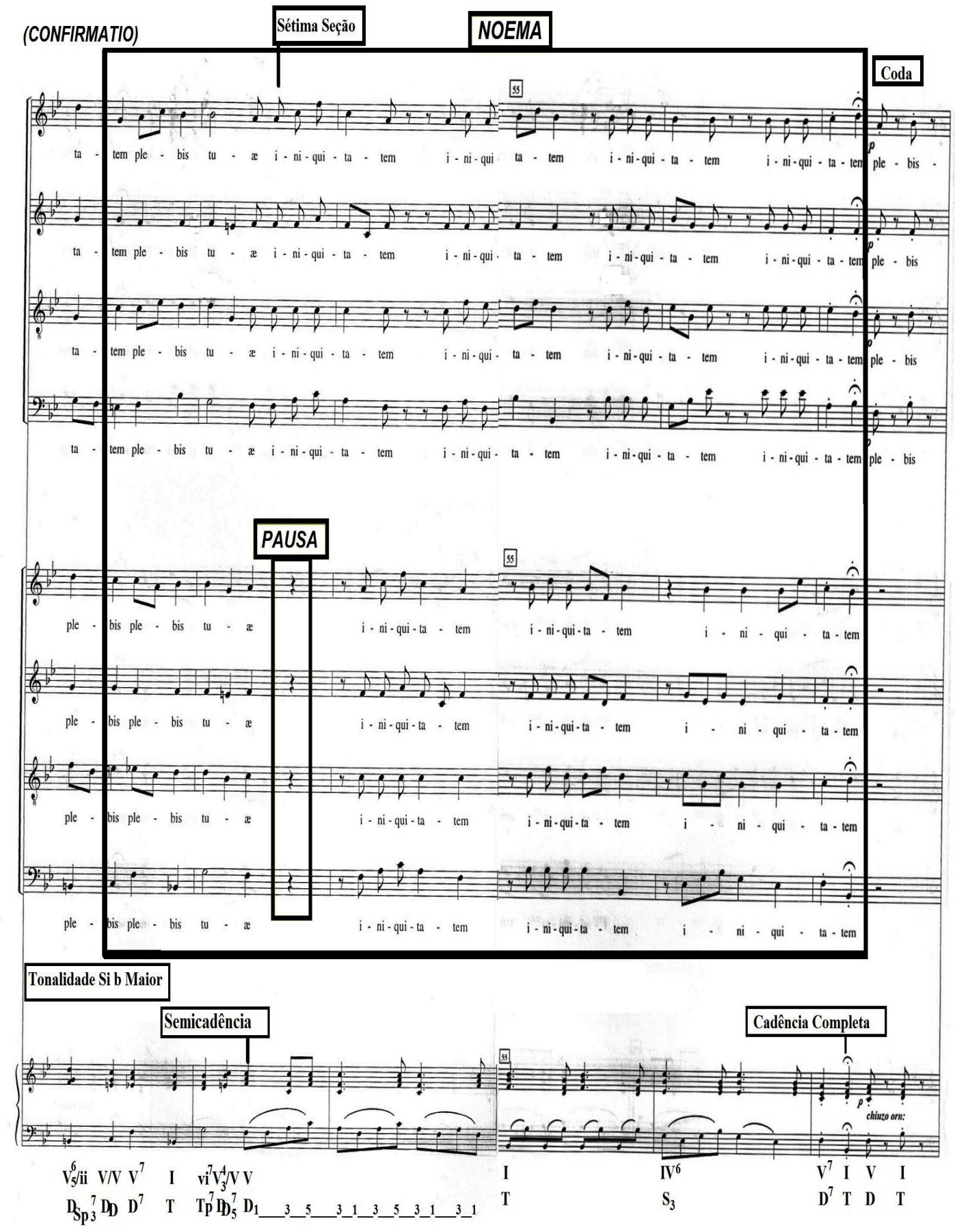

Exemplo 111: Ofertório da Missa do Terceiro Domingo do Advento de André da Silva Gomes- Catalogação e Organização Régis Duprat (DUPRAT, 1999, pp.161-162). 


\subsubsection{Perotatio}

O ofertório é finalizado com breve epílogo, onde, Silva Gomes, usa a Suspiratio para destacar a expressão plebis (povo, pessoas), fazendo analogia a nação, terra escolhida, apresentada na Exordium terram tuam (tua terra), isto é, seu povo. Outra coisa a ser observada, é a aplicação da Pausa, como da Synaeresis, a primeira como silenciando as vozes da segunda parte do coral e a outra figura ressaltando as últimas silabas da obra, na conclusão da Cadência Autêntica Perfeita.

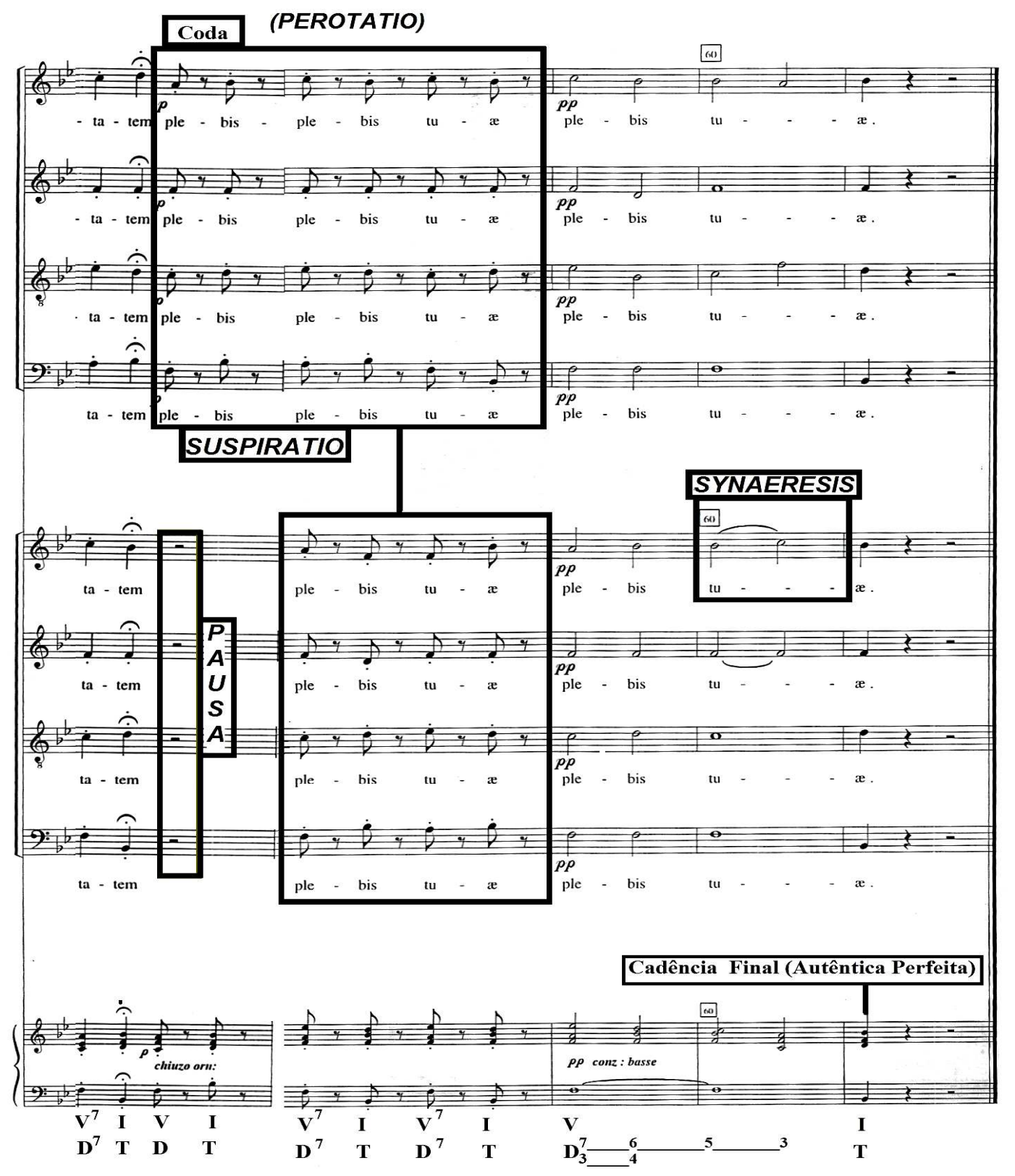

Exemplo 112: Ofertório da Missa do Terceiro Domingo do Advento de André da Silva Gomes- Catalogação e Organização Régis Duprat (DUPRAT, 1999, pp.162-163). 


\subsection{Figuras observadas no Ofertório (Elocutio/Decoratio)}

\begin{tabular}{|c|c|c|c|}
\hline FIGURAS & TIPO & DESCRIÇÃO & TRATADISTA \\
\hline $\begin{array}{l}\text { ANAPHORA } \\
\text { (BARTEL, 1997, } \\
\text { pp.184-190). }\end{array}$ & $\begin{array}{l}\text { Repetição } \\
\text { Melódica }\end{array}$ & $\begin{array}{l}\text { (1) É uma linha } \\
\text { do baixo repetida, } \\
\text { em forma de solo. } \\
\text { (2) A repetição de } \\
\text { uma exposição } \\
\text { melódica sobre } \\
\text { notas e partes } \\
\text { diferentes. } \\
\text { Também pode } \\
\text { ocorrer no início } \\
\text { das repetições de } \\
\text { frases e motivos } \\
\text { em uma série de } \\
\text { passagens } \\
\text { sucessivas; } \\
\text { Uma repetição } \\
\text { em geral. }\end{array}$ & 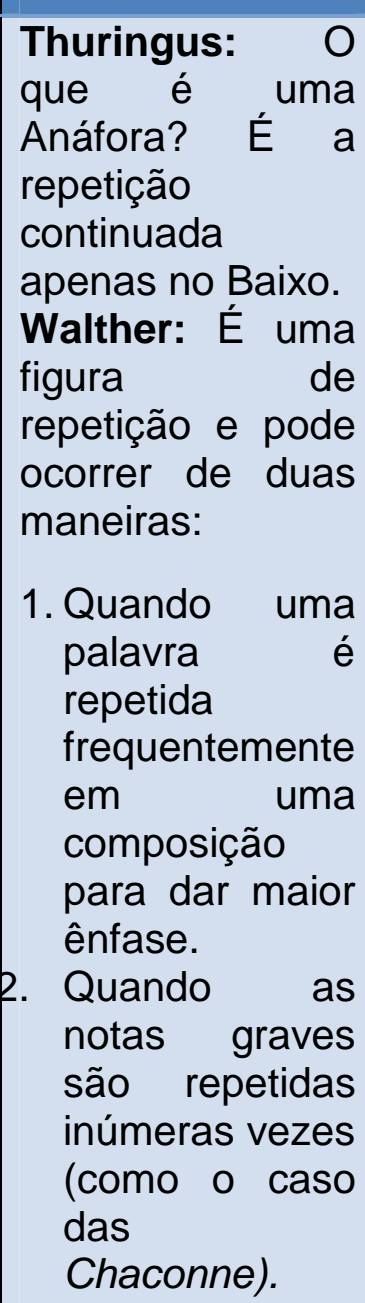 \\
\hline $\begin{array}{l}\text { APOSIOPESIS } \\
\text { (BARTEL, 1997, } \\
\text { pp.202-206) }\end{array}$ & $\begin{array}{l}\text { Interrupção e } \\
\text { Silêncio }\end{array}$ & $\begin{array}{l}\text { Um descanso em } \\
\text { uma ou todas as } \\
\text { vozes de uma } \\
\text { composição: } \\
\text { pausa geral. }\end{array}$ & $\begin{array}{l}\text { Walther: } \\
\text { Aposiopesis se } \\
\text { refere a uma } \\
\text { Pausa Generalis } \\
\text { ou um completo } \\
\text { silêncio em todas } \\
\text { as vozes e nas } \\
\text { partes r da } \\
\text { composição r } \\
\text { simultaneamente. }\end{array}$ \\
\hline $\begin{array}{l}\text { AUXESIS } \\
\text { (BARTEL, 1997, pp. } \\
\text { 209-212). }\end{array}$ & $\begin{array}{l}\text { Repetição } \\
\text { Melódica }\end{array}$ & $\begin{array}{l}\text { São repetições } \\
\text { sucessivas de } \\
\text { uma passagem } \\
\text { musical. }\end{array}$ & $\begin{array}{lr}\text { Burmeister: } & \text { A } \\
\text { Auxesis } & \text { ocorre } \\
\text { quando } & \text { uma } \\
\text { harmonia } & \\
\text { composta } & \text { por } \\
\text { combinações } & \\
\text { consonantes } & \text { se }\end{array}$ \\
\hline
\end{tabular}




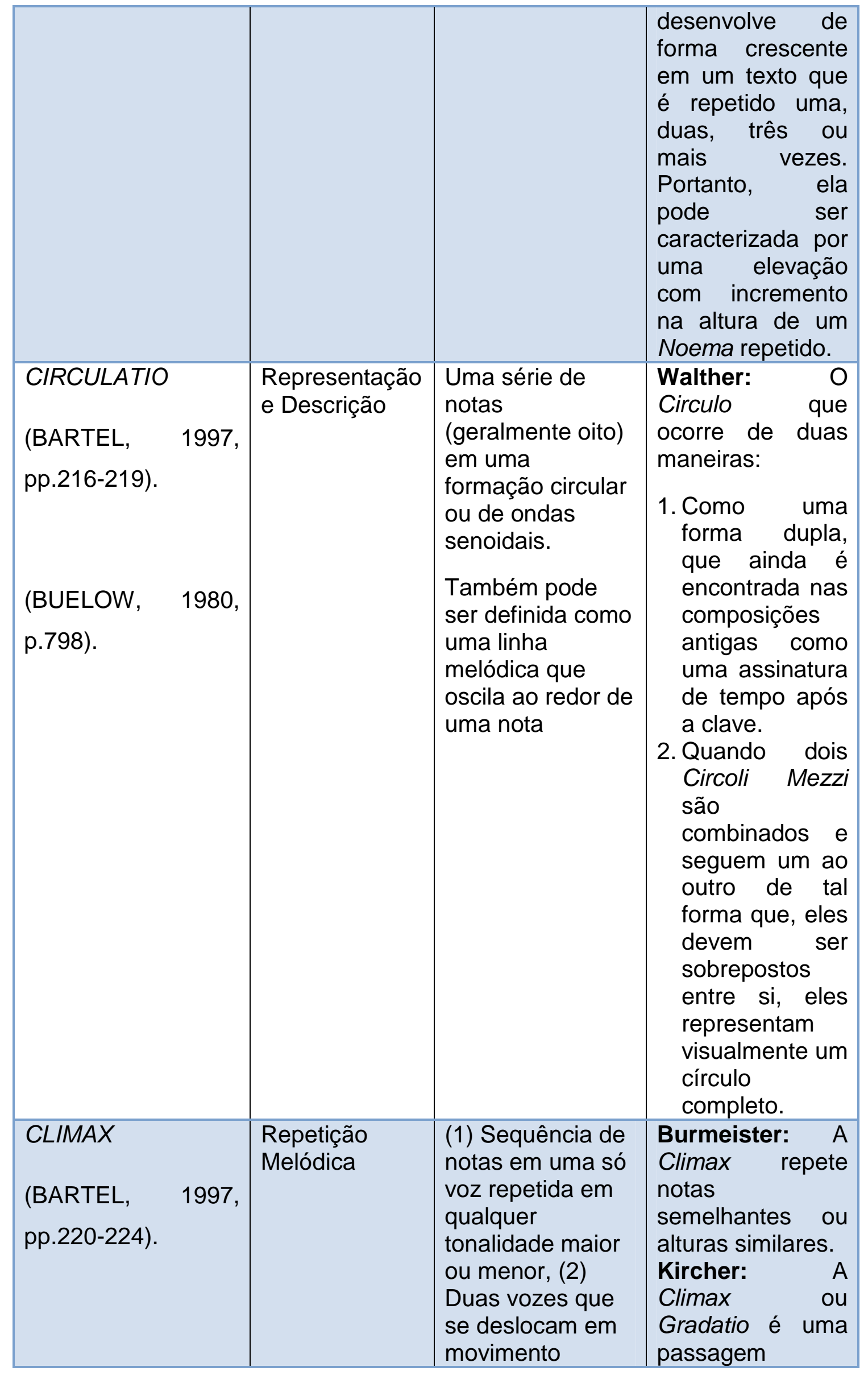




\begin{tabular}{|c|c|c|c|c|}
\hline & & & $\begin{array}{l}\text { ascendente ou } \\
\text { descendente } \\
\text { paralelo, (3) Um } \\
\text { aumento gradual } \\
\text { na intensidade e } \\
\text { altura do som. }\end{array}$ & $\begin{array}{l}\text { musical } \\
\text { ascendente que é } \\
\text { frequentemente } \\
\text { utilizada em } \\
\text { afetos de amor e } \\
\text { desejo de de } \\
\text { unidade do reino } \\
\text { celestial. }\end{array}$ \\
\hline $\begin{array}{l}\text { EPIZEUXIS } \\
\text { (BARTEL, } \\
\text { pp.263-265). }\end{array}$ & 1997 & $\begin{array}{l}\text { Repetição } \\
\text { Melódica }\end{array}$ & $\begin{array}{l}\text { Uma repetição } \\
\text { imediata e } \\
\text { enfática de uma } \\
\text { palavra, nota, } \\
\text { motivo ou frase. }\end{array}$ & $\begin{array}{l}\text { Walther: A } \\
\text { Epizeuxis é uma } \\
\text { figura de retórica } \\
\text { pela qual uma ou } \\
\text { mais palavras } \\
\text { são } \\
\text { imediatamente e } \\
\text { enfaticamente } \\
\text { repetidas. }\end{array}$ \\
\hline $\begin{array}{l}\text { GRADATIO } \\
\text { (BARTEL, } \\
\text { pp.220-224). }\end{array}$ & 1997 & $\begin{array}{l}\text { Repetição } \\
\text { Melódica }\end{array}$ & $\begin{array}{l}\text { (1) Sequência de } \\
\text { notas em uma só } \\
\text { voz repetida em } \\
\text { qualquer } \\
\text { tonalidade maior } \\
\text { ou menor, (2) } \\
\text { Duas vozes que } \\
\text { se deslocam em } \\
\text { movimento } \\
\text { ascendente ou } \\
\text { descendente } \\
\text { paralelo, (3) Um } \\
\text { aumento gradual } \\
\text { na intensidade e } \\
\text { altura do som. }\end{array}$ & $\begin{array}{l}\text { Walther: Climax } \\
\text { ou Gradatio } \\
\text { podem sor ser } \\
\text { interpretadas } \\
\text { das seguintes } \\
\text { formas: } \\
\text { 1. Quando há } \\
\text { palavras que } \\
\text { falam sobre } \\
\text { alegria, } \\
\text { glorificação } \\
\text { louvor. } \\
2 . \quad \text { Em uma } \\
\text { figura musical } \\
\text { que ocorre } \\
\text { quando duas } \\
\text { vozes se } \\
\text { movimentam } \\
\text { para cima e para } \\
\text { baixo parodindo em } \\
\text { progredindo } \\
\text { terças paralelas. } \\
\text { (Essa forma } \\
\text { que aparece } \\
\text { nesta obra). } \\
3 . \quad \text { Quando } \\
\text { uma passagem } \\
\text { com ou sem } \\
\text { cadência é } \\
\text { imediatamente } \\
\text { repetida várias }\end{array}$ \\
\hline
\end{tabular}




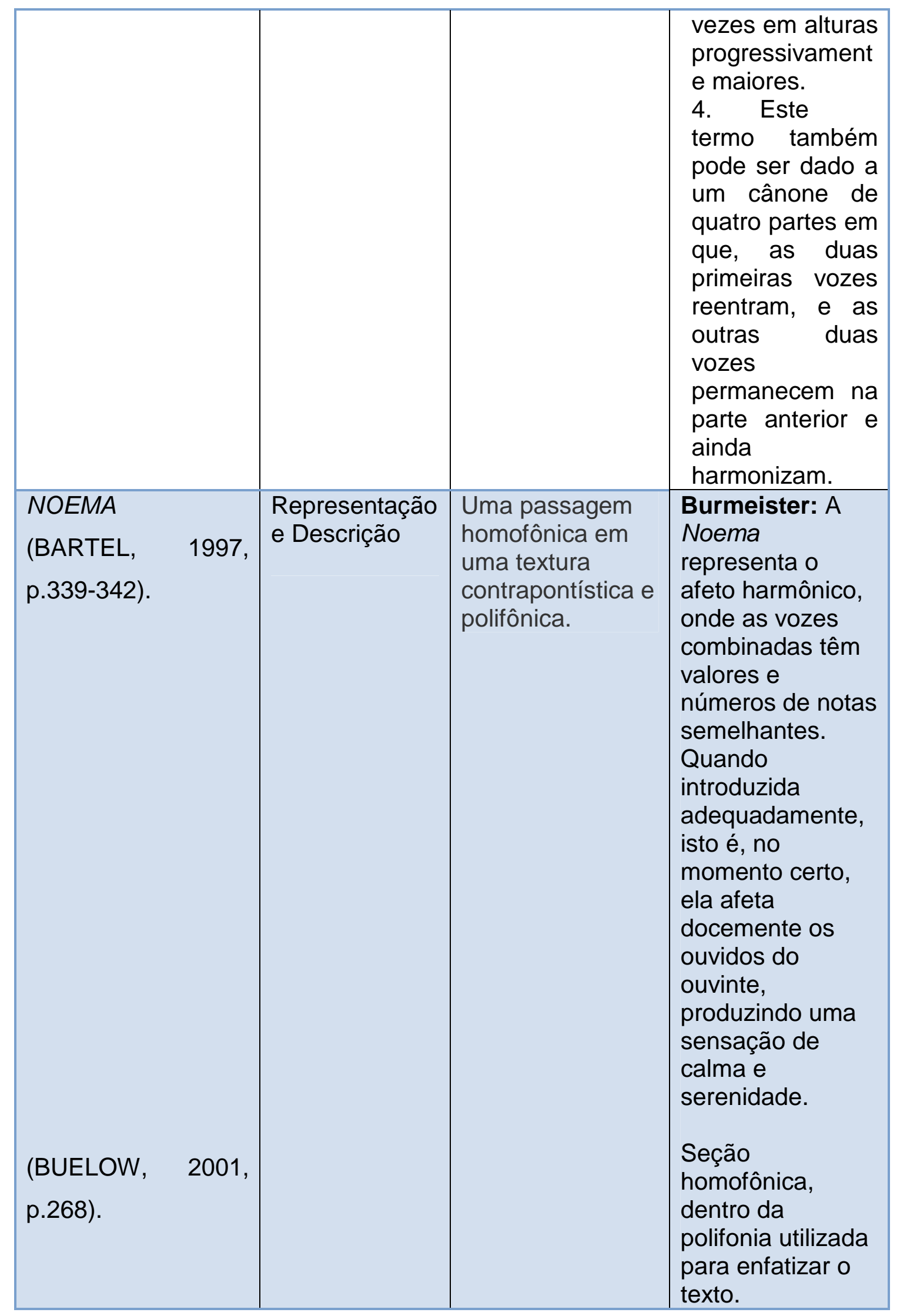




\begin{tabular}{|c|c|c|c|}
\hline $\begin{array}{l}\text { PALILOGIA } \\
\text { (BARTEL, 1997, } \\
\text { pp.342-344). }\end{array}$ & $\begin{array}{l}\text { Repetição } \\
\text { Melódica }\end{array}$ & \begin{tabular}{l}
\multicolumn{2}{c}{ Repetição de um } \\
tema no mesmo \\
nível de altura, \\
também pode \\
ocorrer em \\
alturas diferentes \\
na mesma ou em \\
várias vozes.
\end{tabular} & $\begin{array}{l}\text { Burmeister: } \\
\text { Palilogia é uma } \\
\text { repetição de uma } \\
\text { inteiração ou } \\
\text { apenas o começo } \\
\text { da estrutura dos } \\
\text { meios e temas } \\
\text { sobre a mesma } \\
\text { altura com a } \\
\text { mesma voz, } \\
\text { ocorrendo com } \\
\text { ou } \\
\text { intermédio sem de } \\
\text { pausas em todos } \\
\text { os eventos em } \\
\text { uma voz. } \\
\text { Walther: } \\
\text { Palilogia refere- } \\
\text { se a uma } \\
\text { repetição por } \\
\text { demais frequente } \\
\text { das mesmas } \\
\text { palavras. }\end{array}$ \\
\hline $\begin{array}{l}\text { PAUSA } \\
\text { (BARTEL, 1997, } \\
\text { pp.362-365). }\end{array}$ & $\begin{array}{l}\text { Interrupção e } \\
\text { Silêncio }\end{array}$ & $\begin{array}{l}\text { Pausa } \\
\text { descanso ou } \\
\text { uma composição } \\
\text { musical }\end{array}$ & $\begin{array}{l}\text { Walther: Uma } \\
\text { figura ou figuras } \\
\text { de silêncio. } \\
\text { Pausa refere-se a } \\
\text { um período de } \\
\text { repouso ou o } \\
\text { silêncio na } \\
\text { música, que é } \\
\text { indicado por um } \\
\text { determinado } \\
\text { sinal. }\end{array}$ \\
\hline $\begin{array}{l}\text { POLYPTOTON } \\
\text { (BARTEL, 1997, } \\
\text { pp.367-369). }\end{array}$ & $\begin{array}{l}\text { Repetição } \\
\text { Melódica }\end{array}$ & $\begin{array}{lr}\text { A repetição de } \\
\text { uma passagem } \\
\text { melódica em } \\
\text { diferentes alturas. }\end{array}$ & $\begin{array}{lr}\text { Vogt: } & \text { Polyptoton } \\
\text { é quando uma } & \text { passagem rem } \\
\text { repetida } & \text { em } \\
\text { várias alturas. }\end{array}$ \\
\hline $\begin{array}{l}\text { SUSPIRATIO } \\
\text { (BARTEL, 1997, pp. } \\
\text { 392-394). }\end{array}$ & $\begin{array}{l}\text { Interrupção e } \\
\text { Silêncio }\end{array}$ & $\begin{array}{l}\text { Expressão } \\
\text { musical de um } \\
\text { suspiro, através } \\
\text { de pausas. }\end{array}$ & $\begin{array}{lr}\text { Kircher: } & \text { A } \\
\text { Stenasmus } & \text { ou } \\
\text { Suspiratio } & \\
\text { lembram } & \text { os } \\
\text { afetos } & \\
\text { naturalmente } & \\
\text { expressados por } \\
\text { vários suspiros } \\
\text { criados através }\end{array}$ \\
\hline
\end{tabular}




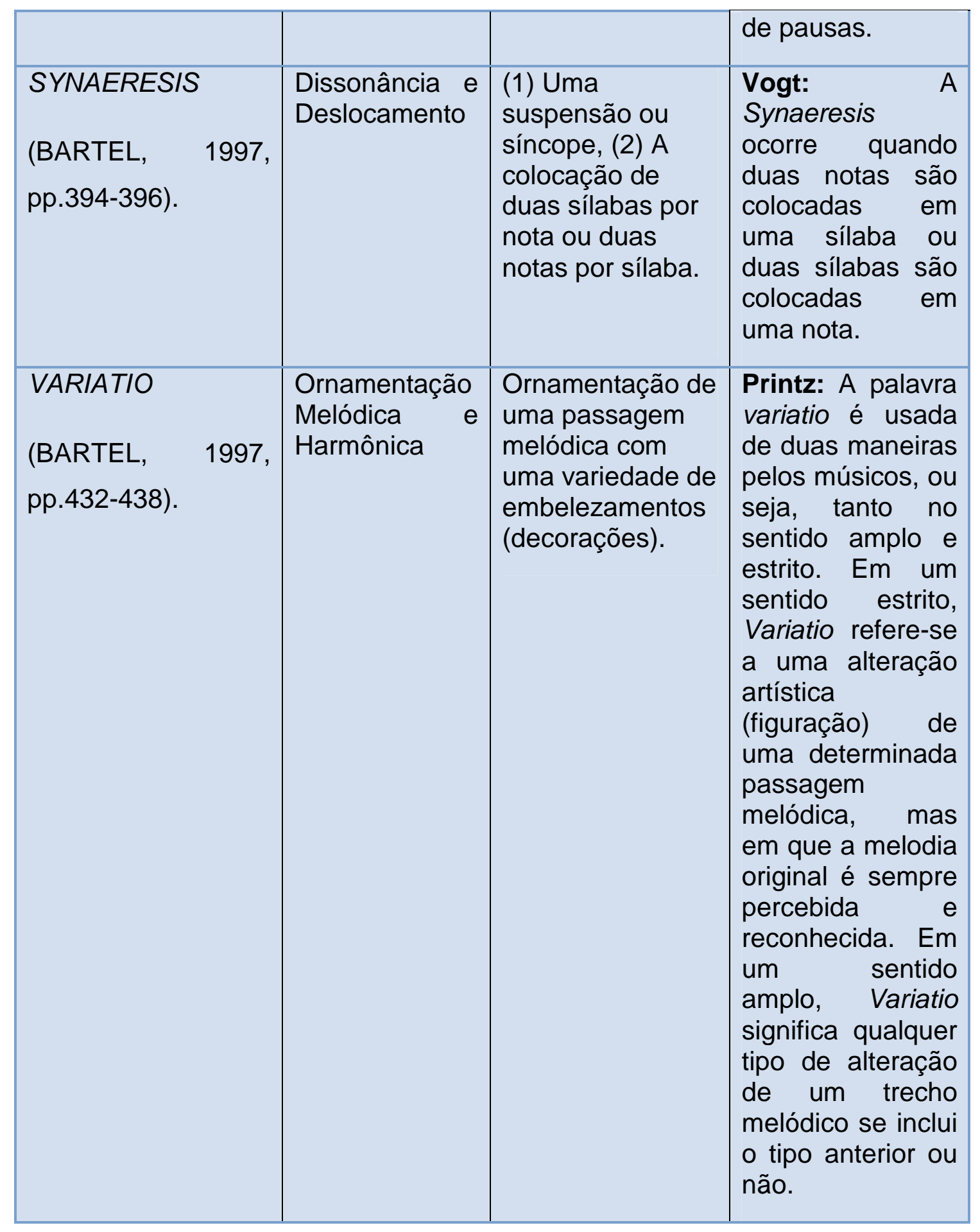

Tabela 41: Figuras encontradas no Ofertório da Missa do Terceiro Domingo do Advento de André da Silva Gomes 


\section{Análise Harmônica}

\subsection{Curva Tonal}

Tonalidade: Si b Maior

Andamento: Moderato 4/4

Esquema de Progressões Harmônicas

\begin{tabular}{|l|c|l|}
\hline Compassos & $\begin{array}{l}\text { Função em relação a } \\
\text { tonalidade principal }\end{array}$ & Tonalidade (Acorde) \\
\hline $1-18$ & T-I & Si b Maior \\
\hline $19-21$ & S-IV & Mi b Maior \\
\hline $22-26$ & T-I & Si b Maior \\
\hline $27-32$ & D-V & Fá Maior \\
\hline $33-37$ & d-v & Fá Menor \\
\hline $38-49$ & D-V & Fá Maior \\
\hline 50 & Tp-vi & Sol Menor \\
\hline 51 & D-V & Fá Maior \\
\hline 51 & S-IV & Mi b Maior \\
\hline 52 & D/D-V/V & Dó Maior \\
\hline 52 & D-V & Fá Maior \\
\hline $53-61$ & T-I & Si b Maior \\
\hline
\end{tabular}

Tabela 42: Curva Tonal do Ofertório da Missa do Terceiro Domingo do Advento

Números de compassos: 61

Regiões abordadas: 6

Variações: 12

Ritmo Harmônico: 5,08 (divisão dos números de compassos e variações)

Média ideal: (divisão dos números de compassos e regiões tonais abordadas = $10,17)$

Esquema Formal

$(1-28)(28-32)(33-37)(38-51)(51-61)$

$\begin{array}{ccccc}T & D & d & D & T \\ \text { I } & V & v & V & \text { I }\end{array}$




\subsection{Estrutura Analítica do Ofertório: Retórica e Harmônica}

\begin{tabular}{|c|c|c|c|c|c|}
\hline $\begin{array}{l}\text { RETÓRICA } \\
\text { DISPOSITIO }\end{array}$ & $\begin{array}{l}\text { FIGURA } \\
\text { ELOCUTIO }\end{array}$ & COMP. & $\begin{array}{l}\text { HARMÔNICA } \\
\text { SEÇÃO }\end{array}$ & TONALIDADE & FUNÇÃO \\
\hline EXORDIUM & $\begin{array}{l}\text { Aposiopesis } \\
\text { Pausa } \\
\text { Palilogia } \\
\text { Anaphora } \\
\text { Synaeresis }\end{array}$ & $\begin{array}{l}2 \text { e } 13 \\
3,5,6-9 \\
11 \\
3-5 \\
3-5 \\
5-6\end{array}$ & 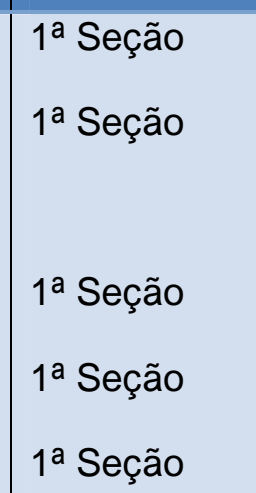 & $\begin{array}{l}\text { Si b Maior } \\
\text { Si b Maior } \\
\text { Si b Maior } \\
\text { Si b Maior } \\
\text { Si b Maior }\end{array}$ & $\begin{array}{l}\text { T-I } \\
\text { T-I } \\
\text { T-I }\end{array}$ \\
\hline NARRATIO & $\begin{array}{l}\text { Variatio } \\
\text { Climax } \\
\text { Circulatio } \\
\text { Pausa } \\
\text { Anaphora }\end{array}$ & $\begin{array}{l}14-16 \\
16-17 \\
14-16 \\
14-22 \\
20-22\end{array}$ & $\begin{array}{l}2^{\mathrm{a}} \text { Seção } \\
2^{\mathrm{a}} \text { Seção } \\
2^{\mathrm{a}} \text { Seção } \\
2^{\mathrm{a}} \text { Seção } \\
2^{\text {a }} \text { Seção }\end{array}$ & $\begin{array}{l}\text { Si b Maior } \\
\text { Si b Maior } \\
\text { Si b Maior } \\
\text { Si b Maior } \\
\text { Si b Maior }\end{array}$ & $\begin{array}{l}T-1 \\
T-I \\
T-I \\
T-I \\
T-I\end{array}$ \\
\hline PROPOSITIO & $\begin{array}{l}\text { Epizeuxis } \\
\text { Aposiopesis }\end{array}$ & $\begin{array}{l}22-28 \\
28\end{array}$ & $\begin{array}{l}3^{a} \text { Seção } \\
3^{a} \text { Seção }\end{array}$ & $\begin{array}{l}\text { Si b Maior } \\
\text { Si b Maior }\end{array}$ & $\begin{array}{l}T-1 \\
T-I\end{array}$ \\
\hline CONFUTATIO & $\begin{array}{l}\text { Anaphora } \\
\text { Pausa } \\
\text { Variatio } \\
\text { Gradatio } \\
\text { Synaeresis } \\
\text { Auxesis }\end{array}$ & $\begin{array}{l}28-30 \\
28-39 \\
31-32 \\
33-35 \\
38 \\
39-46\end{array}$ & 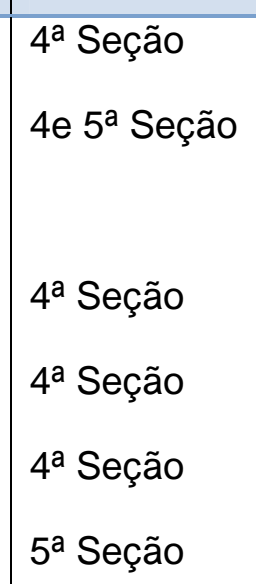 & $\begin{array}{l}\text { Fá Maior } \\
\text { Fá Maior e } \\
\text { Fá Menor } \\
\text { Fá Menor } \\
\text { Fá Menor } \\
\text { Fá Maior } \\
\text { Fá Maior }\end{array}$ & $\begin{array}{l}D-V \\
D-V \\
d-v \\
d-v \\
d-v \\
D-v \\
D-V\end{array}$ \\
\hline CONFIRMATIO & $\begin{array}{l}\text { Polyptoton } \\
\text { Pausa } \\
\text { Epizeuxis }\end{array}$ & $\begin{array}{l}46-49 \\
46-50 \\
\text { e } 53 \\
49-51\end{array}$ & $\begin{array}{l}6^{a} \text { Seção } \\
6^{a} \text { Seção } \\
6^{\text {a Seção }}\end{array}$ & $\begin{array}{l}\text { Fá Maior } \\
\text { Fá Maior } \\
\text { e Si b Maior } \\
\text { Fá Maior }\end{array}$ & $\begin{array}{l}D-V \\
D-V \\
T-I \\
D-V\end{array}$ \\
\hline
\end{tabular}




\begin{tabular}{|c|c|c|c|c|c|}
\hline & Noema & $52-57$ & 6 e $7^{a}$ Seção & $\begin{array}{l}\text { e Si b Maior } \\
\text { Si b Maior }\end{array}$ & $\begin{array}{l}\text { T-I } \\
\text { D-V }\end{array}$ \\
\hline PEROTATIO & $\begin{array}{l}\text { Suspiratio } \\
\text { Pausa } \\
\text { Synaeresis }\end{array}$ & $\begin{array}{l}57-58 \\
57 \\
60\end{array}$ & $\begin{array}{l}7^{a} \text { Seção } \\
7^{\text {ạ Seção }} \\
7^{\text {ạ Seção }}\end{array}$ & $\begin{array}{l}\text { Si b Maior } \\
\text { Si b Maior } \\
\text { Si b Maior }\end{array}$ & $\begin{array}{l}\text { T-I } \\
\text { T-I } \\
\text { T-I }\end{array}$ \\
\hline
\end{tabular}

Tabela 43: Estrutura analítica do Ofertório 


\title{
5.2.11. Ofertório da Missa da Quarta-Feira das Têmporas do Advento $^{103}$
}

\section{Estudo Semântico}

\subsection{Inventio}

O presente ofertório, diferentemente dos demais, não tem seu texto baseado no livro dos salmos e sim em um versículo extraído do livro de Isaías, "Libertação e Glória de Israel" (Is. 35,4), cuja temática é semelhante a dos textos dos salmos da qual se originaram a maioria dos ofertórios de André da Silva Gomes.

\author{
Confortamini et nolite timere \\ Ecce enim Deus noster \\ Retribuet judicium ipse veniet \\ Et salvos nos faciet \\ [Vulgata: Confortamini, et nolite timere \\ Ecce Deus vester ultionem adducet retributionis \\ Deus ipse veniet, et salvabit nos] \\ Animai-vos, e nada temais; \\ Eis o nosso Deus \\ Trará a vingança e as represarias, \\ O próprio Deus virá, e nos salvará.
}

(SOARES, 2000, p.127).

Isaías prenuncia a salvação e libertação do povo de Israel, no entanto não é precisa a data, porém, quando isso acontecesse, Deus operaria tanto na vingança, quanto na remissão, o que significa que Ele não somente salva seu povo dos inimigos físicos, mas também os livra do inimigo maior, o pecado. Nesse caso, o derradeiro cumprimento dessas palavras se dará somente quando o reino messiânico for instaurado (ALMEIDA, 1999, p.1106).

\footnotetext{
103 Indicada pelo autor, na página de rosto do manuscrito, como Offertorium in Missae Dominicae Adventus (Ofertório para o Quarto Domingo do Advento), uma investigação mais detalhada e cuidadosa deste documento revelou ter sido a obra escrita para a celebração de outra data do calendário litúrgico, isto é, a quarta-feira anterior a este domingo. É difícil de acreditar que Silva Gomes, tenha cometido um deslize desta natureza pelo fato do mesmo ser profundo conhecedor do latim litúrgico. Por esta razão, provavelmente ele se apropriou deste novo texto, em função do original, uma Ave Maria, que não vinha ao encontro às exigências de expressividade do conteúdo encontradas nos ofertórios das outras missas do período do Advento de sua autoria. Todavia, não se deve ser descartada outra hipótese, ainda que menos provável: a obra ter sido escrita para a própria quarta-feira em questão, apesar das indicações em contrário do manuscrito (SOARES, 2000, p. 126).
} 
Essa obra é composta de sessenta e dois compassos, num Moderato a quatro vozes, encerrando-se nos compassos 61 e 62, com andamento Adagio, enfatizando o caráter de esperança de salvação, trabalhados desde o princípio da obra por Silva Gomes, por fim, tudo isso distribuído em sete seções, tendo como tonalidade principal a de Si bemol Maior.

\subsection{Locus observados na Inventio do Ofertório}

\begin{tabular}{|c|c|c|c|}
\hline INVENTIO & DESCRIÇÃO & $\begin{array}{c}\text { UTILIZAÇÃO NA } \\
\text { OBRA }\end{array}$ & $\begin{array}{l}\text { COMPASSO/ } \\
\text { VOZ }\end{array}$ \\
\hline $\begin{array}{l}\text { Locus } \\
\text { Notationis } \\
\text { (MATTHESON, } \\
\text { [1739],1954, } \\
\text { Parte II,Cap.4, } \\
\text { § 23,p.123). }\end{array}$ & $\begin{array}{l}\text { Aspecto } \\
\text { externo e } \\
\text { desenho das } \\
\text { notas (Duração } \\
\text { das notas, } \\
\text { alteração, } \\
\text { repetição e } \\
\text { procedimentos } \\
\text { canônicos). }\end{array}$ & $\begin{array}{l}\text { Vários motivos rítmicos } \\
\text { e diferentes durações } \\
\text { de notas (mínimas, } \\
\text { semínimas, semínimas } \\
\text { pontuadas, colcheias, } \\
\text { colcheias pontudas, } \\
\text { semicolcheias, } \\
\text { repetições, ligaduras, } \\
\text { fermatas, apogiaturas, } \\
\text { pausas, entre outros). }\end{array}$ & $\begin{array}{l}1-4 \quad \text { S-A-T-B } \\
5-9 \quad \text { S } \\
9-12 \text { S-A-T-B } \\
13-16 \text { S } \\
16-20 \text { S-A-T-B } \\
21-24 \text { S-A } \\
25-44 \text { S-A-T-B } \\
45-46 \text { S-A } \\
47-62 \text { S-A-T-B }\end{array}$ \\
\hline $\begin{array}{l}\text { Locus } \\
\text { Oppositorum } \\
\text { (MATTHESON, } \\
\text { [1739],1954, } \\
\text { Parte II,Cap.4, } \\
\text { § 80,p.131). }\end{array}$ & $\begin{array}{l}\text { Contraste de } \\
\text { compassos, } \\
\text { movimentos } \\
\text { contrários, } \\
\text { agudos e } \\
\text { graves, lento e } \\
\text { rápido, calmo e } \\
\text { agitado. }\end{array}$ & $\begin{array}{l}\text { Movimento contrário } \\
\text { entre soprano e baixo }\end{array}$ & $27-28$ S-B \\
\hline $\begin{array}{l}\text { Locus } \\
\text { Descriptionis } \\
\text { (MATTHESON, } \\
\text { [1739],1954, } \\
\text { Parte II,Cap.4, } \\
\text { § 43,p.127). }\end{array}$ & $\begin{array}{l}\text { Disposições da } \\
\text { alma }\end{array}$ & $\begin{array}{l}\text { Ânimo, Coragem } \\
\text { (Animai-vos, e nada } \\
\text { temais) }\end{array}$ & $\begin{array}{l}1-4 \text { S-A-T-B } \\
5-9 \text { S } \\
9-12 \text { S-A-T-B } \\
13-20 \text { S-A-T-B } \\
21-32 \text { S-A-T-B }\end{array}$ \\
\hline
\end{tabular}

Tabela 44: Locus Topici encontrados no Ofertório da Missa da Quarta-feira das Têmporas do Advento de André da Silva Gomes 


\subsection{Dispositio}

\subsubsection{Exordium}

A presente seção é iniciada com o emprego da Aposiopesis, no segundo compasso, com a função de impor as partes completo silêncio, logo após a afirmação na qual se sustentará a tese do orador, Confortamini et nolite timere (Animai-vos e nada temais), enfatizando-a. Da mesma forma, se observa a aplicação do pedal de Tônica permeando todas as funções harmônicas localizadas entre os compassos 1 a 4, como o final da Exordium, na Cadência Completa.

\section{Primeira Seção- Tonalidade Si b Maior}

Ofertório da Missa da Quarta-feira das Têmporas do Advento

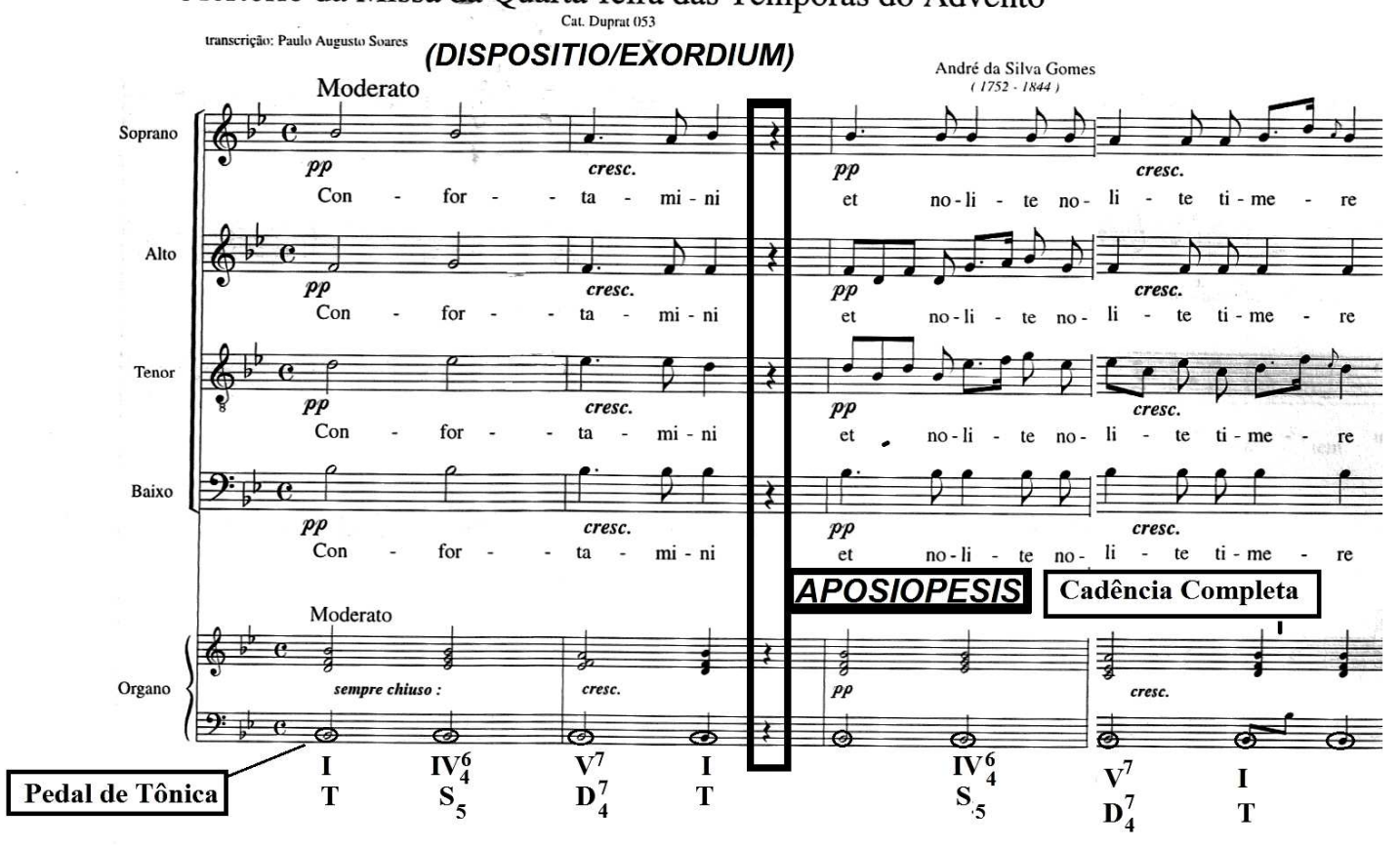

Exemplo 113: Ofertório da Missa da Quarta-feira das Têmporas do Advento de André da Silva Gomes- Catalogação e Organização Régis Duprat (DUPRAT, 1999, p.164).

\subsubsection{Narratio}

Novamente é expressa a mesma frase do começo da obra, todavia, o compositor luso-brasileiro apropria-se de recursos diferentes na concepção da presente seção, por exemplo, o uso da Pausa no estabelecimento do descanso a três vozes, auxiliando a Variatio, no solo da soprano, que por meio de suas ornamentações e variações desperta a atenção do ouvinte, como também caracteriza a narração dos fatos argumentativos da peça. 


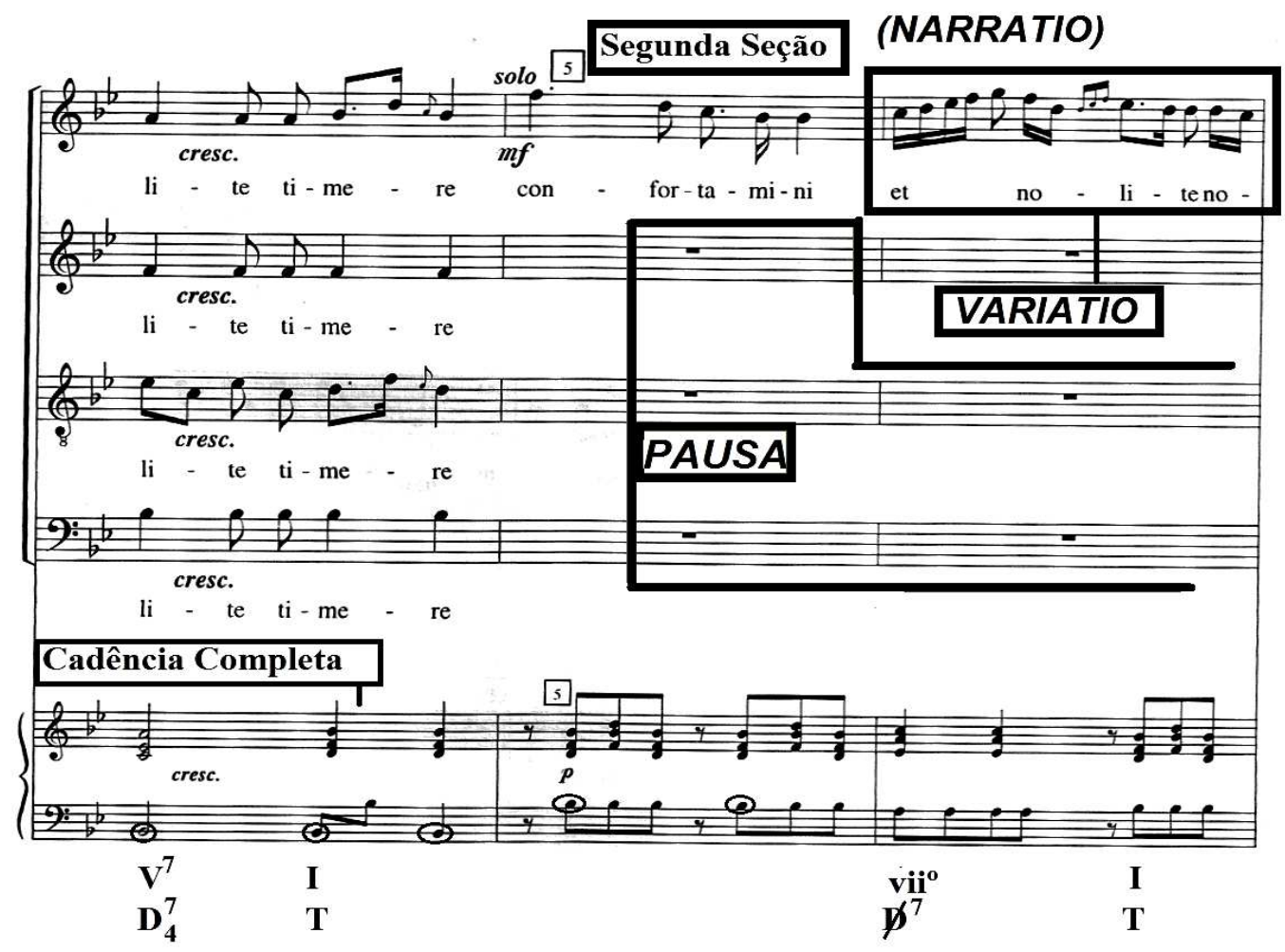

Exemplo 114: Ofertório da Missa da Quarta-feira das Têmporas do Advento de André da Silva Gomes- Catalogação e Organização Régis Duprat (DUPRAT, 1999, p.164).

Similarmente é verificável a utilização de duas figuras de repetição melódica, Anaphora e o Polyptoton, a primeira no final da Narratio e a segunda no começo da Propositio.

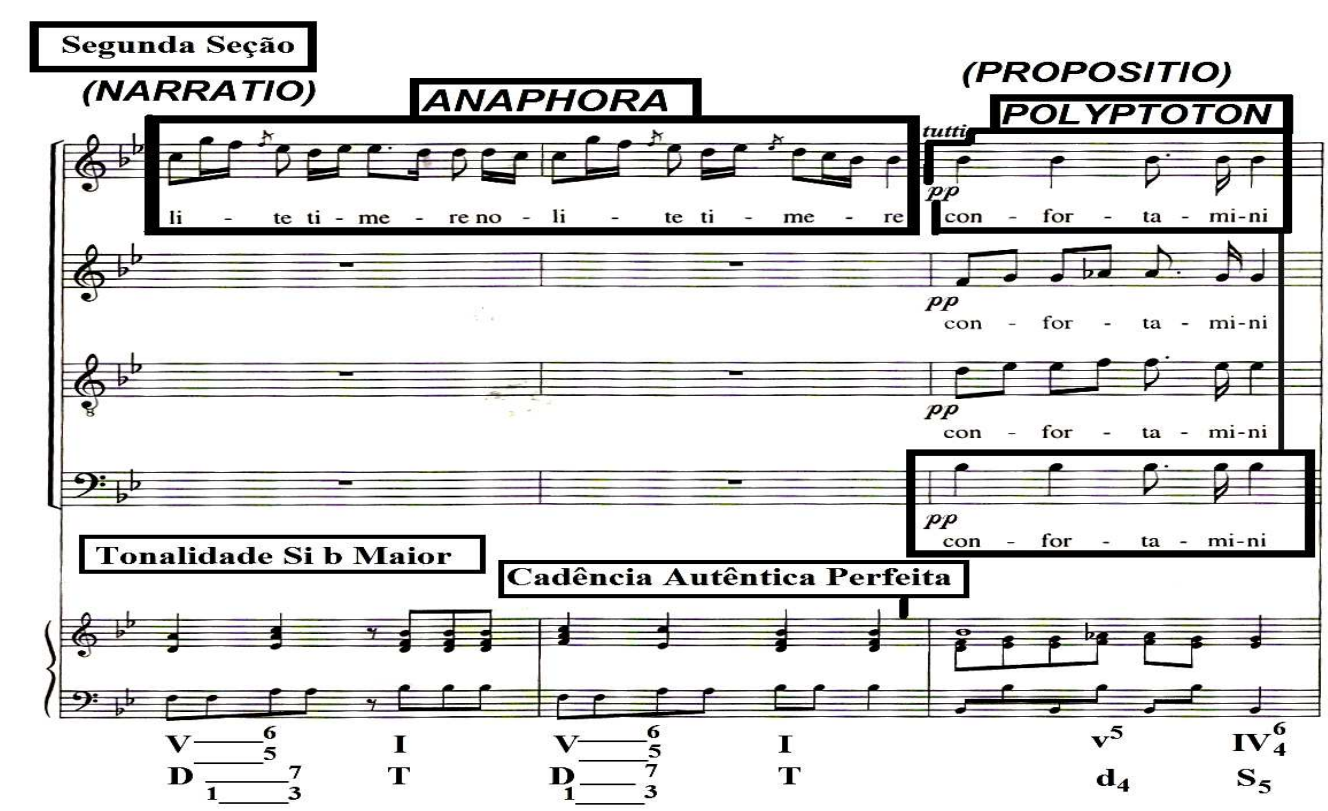

Exemplo 115: Ofertório da Missa da Quarta-feira das Têmporas do Advento de André da Silva Gomes- Catalogação e Organização Régis Duprat (DUPRAT, 1999, p.165). 


\subsubsection{Propositio}

Entre os compassos 10 e 12, nota-se a aplicação de duas novas figuras, Metabasis onde a voz da contralto cruza com a da soprano interpretando a nota Lá, enquanto a outra executa a nota Fá, e a Synonimia, que repete duas vezes a palavra et nolite, de maneira enfática completando a frase, assim como a Cadência. Por fim, pode-se notar a presença do pedal de Tônica, já introduzido pelo autor na primeira seção.

\section{(PROPOSITIO)}

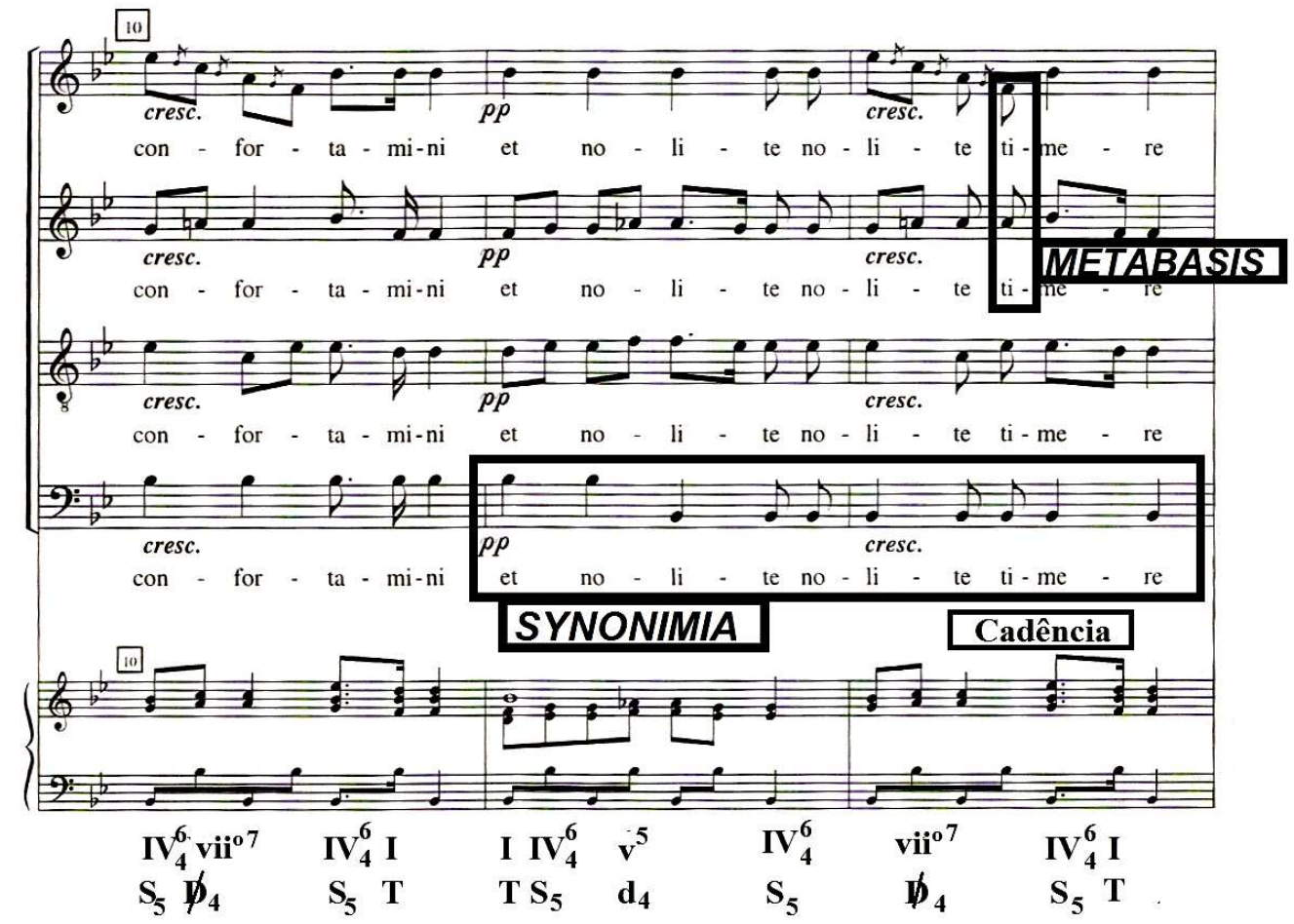

Pedal de Tônica do

compasso 9 a 12

Exemplo 116: Ofertório da Missa da Quarta-feira das Têmporas do Advento de André da Silva Gomes- Catalogação e Organização Régis Duprat (DUPRAT, 1999, p.165).

$\mathrm{Na}$ conclusão da Propositio o solo da soprano caracteriza a Narratio dentro dessa parte da Dispositio, outra vez narrando os fatos expostos desde a introdução da obra, entretanto, auxiliada pela Pausa e Anaphora, todavia na tonalidade de Fá Maior. 


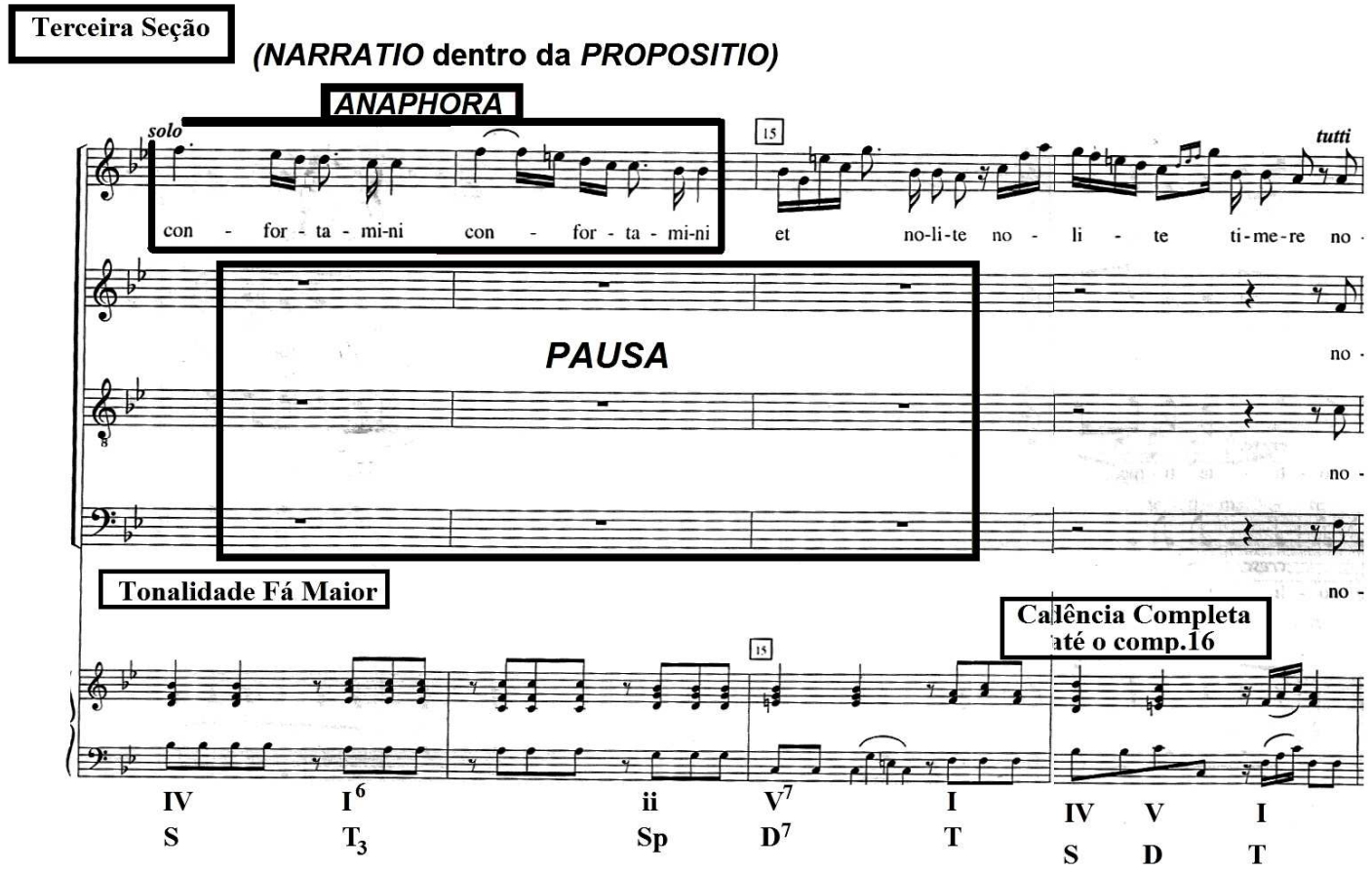

Exemplo 117: Ofertório da Missa da Quarta-feira das Têmporas do Advento de André da Silva Gomes- Catalogação e Organização Régis Duprat (DUPRAT, 1999, p.166).

\subsubsection{Confutatio}

A partir do compasso 17, vê-se a figura da Epizeuxis em todas as vozes, repetindo enfaticamente a expressão nolite, ainda corroborando a ideia de não temer, mas animai-vos no Senhor, no entanto, preparando o contraste e refutação da tese exposta anteriormente.

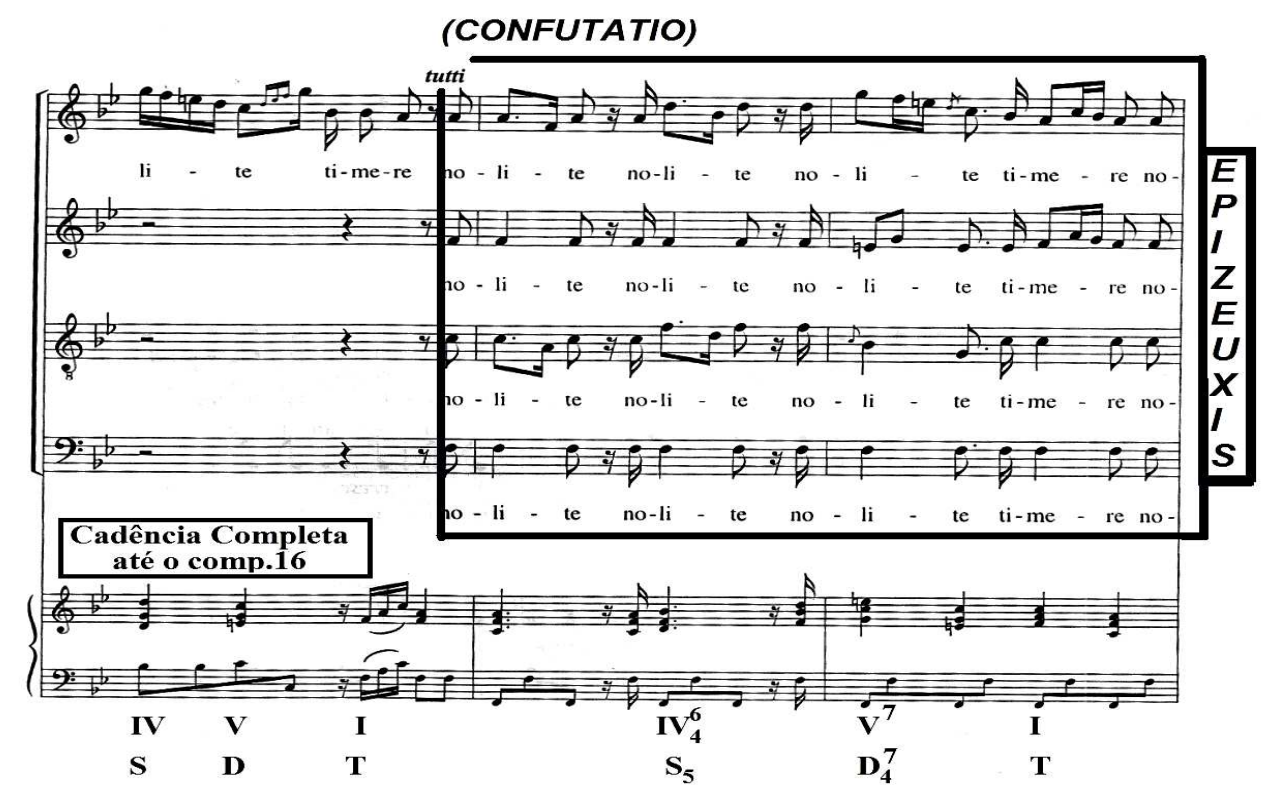

Exemplo 118: Ofertório da Missa da Quarta-feira das Têmporas do Advento de André da Silva Gomes- Catalogação e Organização Régis Duprat (DUPRAT, 1999, p.166). 
Como atributo da presente parte do discurso retórico, observou-se num primeiro momento, a continuação do uso da Epizeuxis e da Pausa pelo autor, todavia, a partir do compasso 19, é tangível a modulação para Sol Menor, isto é, a relativa de Si b Maior. Também é examinável a inserção da Semicadência entre essa passagem de mudança de tonalidade, reforçando a suspensão do acorde de tensão, no caso a Dominante, quanto à expectativa de quem ouve.

Em seguida, percebe-se o duo de apenas quatro compassos, executados pelas vozes da soprano e contralto, cuja finalidade é aprestar os mecanismos que serão adotados nos compassos posteriores, em forma de narração, caracterizando assim uma Narratio dentro da Confutatio.

Nos compassos 23 e 24, Silva Gomes aumenta o volume de contraste, com a intenção de despertar as paixões do auditório, por meio da Circulatio, destacando as notas Sol e Si bemol, trabalhadas em forma de ondas senoidais e a Gradatio, complementando o uso da figura anterior, repetindo com ênfase as mesmas palavras, em terças paralelas, logo após a resolução da Cadência Completa no compasso 24.

Enfim, a supracitada frase extraída do livro de Isaías (Animai-vos e nada temais), é desenvolvida com grande habilidade pelo autor, demostrando dessa maneira seu conhecimento acerca da disposição e elaboração das funções de cada parte integrante das seções retóricas. 

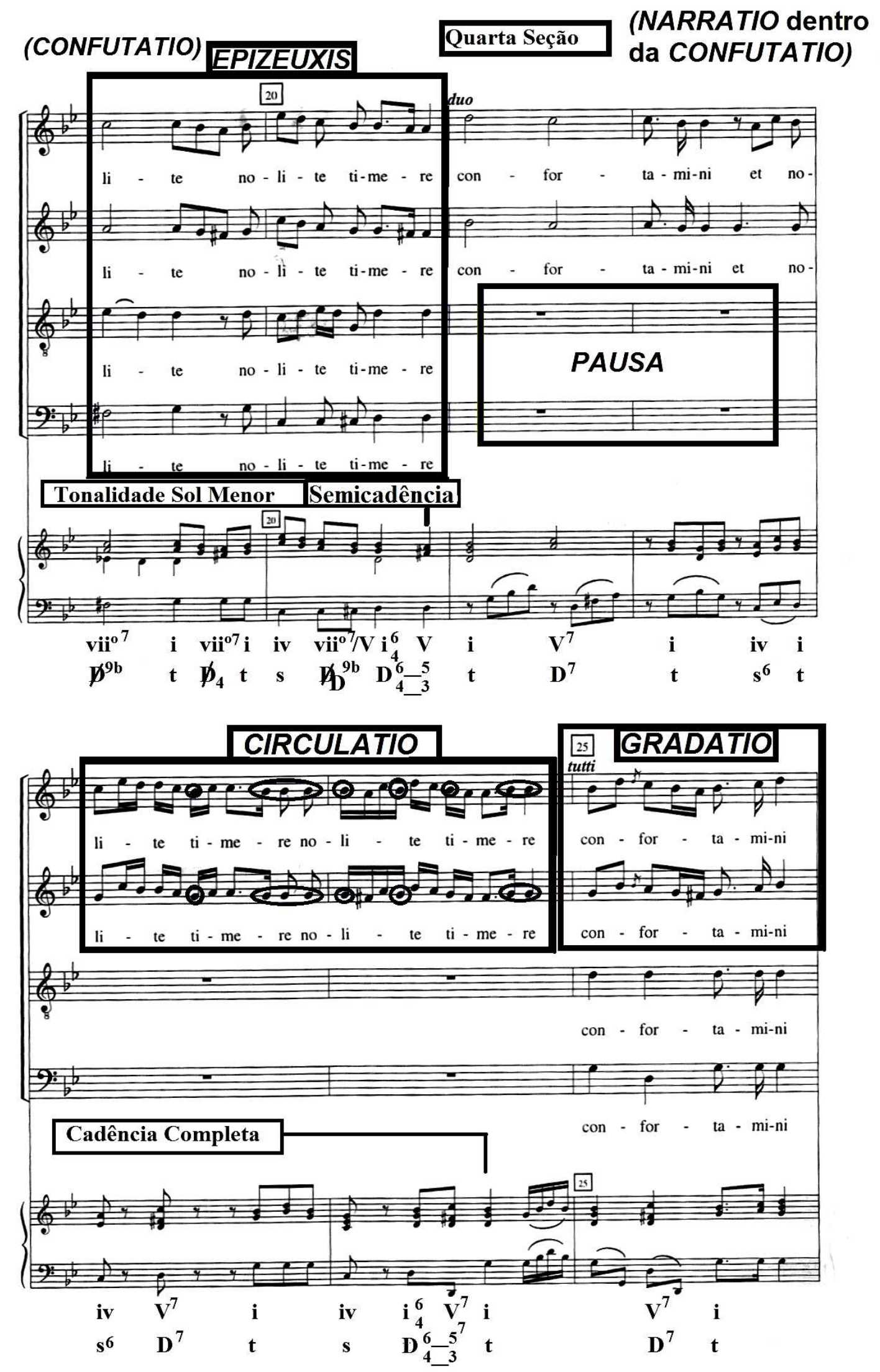

Exemplo 119: Ofertório da Missa da Quarta-feira das Têmporas do Advento de André da Silva Gomes- Catalogação e Organização Régis Duprat (DUPRAT, 1999, p.167). 
Grande é a carga afetiva aplicada pelo compositor evidenciada através da utilização da Gradatio e Auxesis, repetindo incessantemente as palavras não temais (nolite timere), além dos contrastes exercidos pelas dinâmicas forte e piano, no entanto, é destacável a figura do Saltus Duriusculus no compasso 29, na voz do baixo, executando de maneira ousada e inesperada um salto de sétima menor.
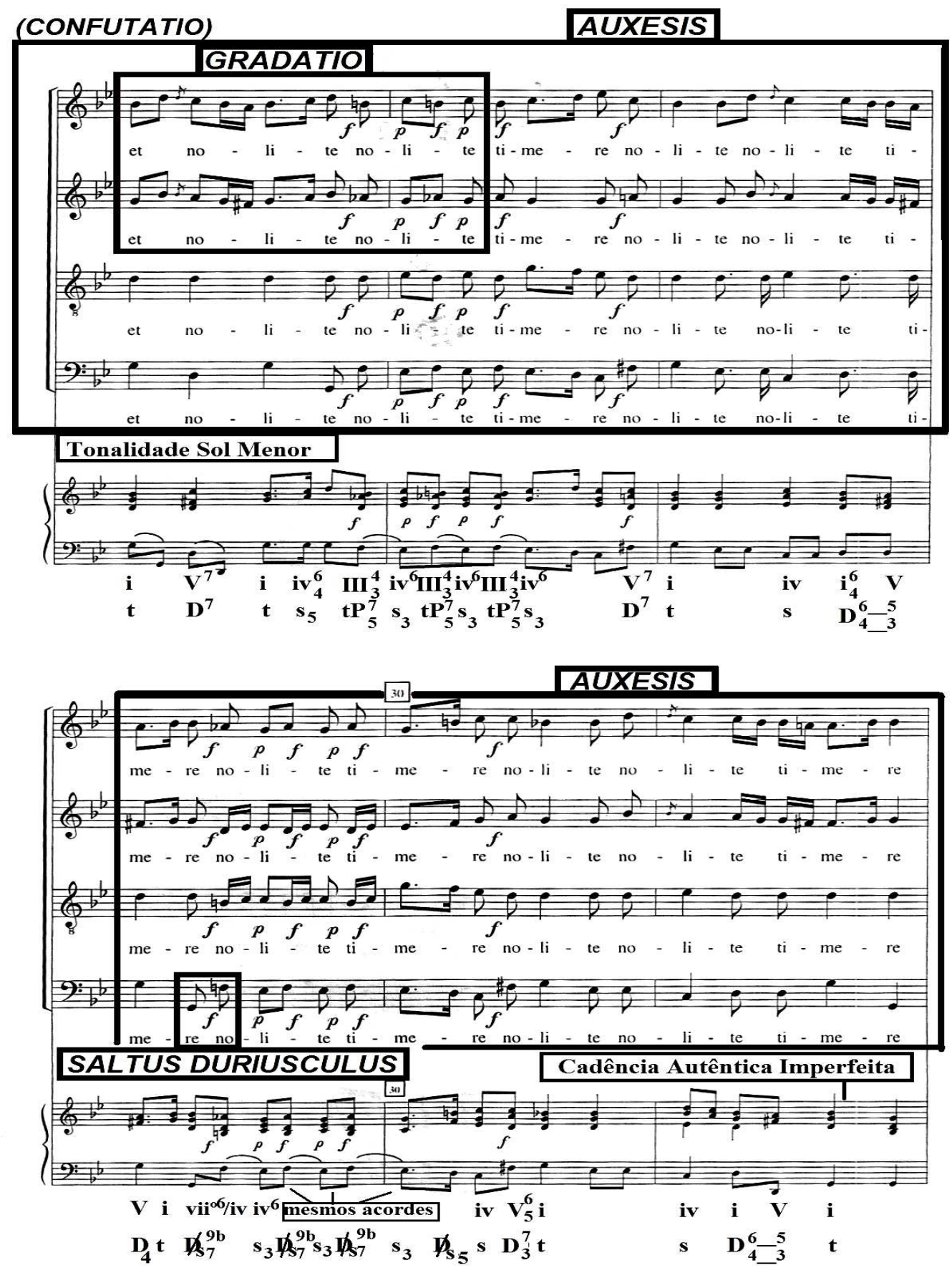

Exemplo 120: Ofertório da Missa da Quarta-feira das Têmporas do Advento de André da Silva Gomes- Catalogação e Organização Régis Duprat (DUPRAT, 1999, p.168). 
Uma nova frase é iniciada: Ecce enim Deus noster adducet retributionis (Eis que o nosso Deus trará a vingança e as represarias). Tal passagem, expõe o triunfo do povo de Israel sobre seus inimigos, os quais foram seus opressores no exilio babilônico, ou seja, o texto descrito é parte integrante do prenúncio do profeta Isaias, de que a nação israelita seria liberta do cativeiro, sob a responsabilidade do Rei Nabucodonosor ${ }^{104}$.

Conhecedor não só da gramatica latina quanto do latim litúrgico e igualmente do referido texto sacro, Silva Gomes, adota uma escrita de imitação de vozes, esta parte integrante dos parâmetros estatutários dos cânones contrapontísticos. Observa-se, que seu intento é colocar em destaque a expressão Deus, através dos recursos de escrita associados mais intimamente a obras sacras, isto é, o contraponto e a retórica, perfazendo-se conjuntamente o sentindo de representação dos afetos, sejam pelas figuras, motivos, harmonia ou instrução literária.

Nesse sentido, nota-se o emprego da Polyptoton, repetindo tanto as palavras como as melodias interpretadas em alturas diferentes, também a Metabasis, no cruzamento das vozes do tenor e baixo, a Synaeresis, enfatizando por meio da execução de duas notas em uma silaba e a Epizeuxis, repetindo a expressão retribuet, diversas vezes de maneira incisiva na Dominante de Sol Menor, terminando em suspensão na Semicadência, instigando a atenção do ouvinte a acompanhar os fatos que se sucederão ao longo do ofertório.

104 Outro profeta que também retrata esse momento de escravidão do povo de Israel na Babilônia é Jeremias. Em seu livro, a partir do sexto capítulo, já disserta sobre o que ocorreria com os hebreus por causa de seus pecados: "Por que assim diz o Senhor dos Exércitos: Esta cidade (Jerusalém), há de ser punida; só opressão há no meio dela [...] Aceita a disciplina , ó Jerusalém, para que eu não me parte de ti; para que eu não torne em assolação e terra não habitada" (Jeremias 6,6-8). 
(CONFUTATIO)
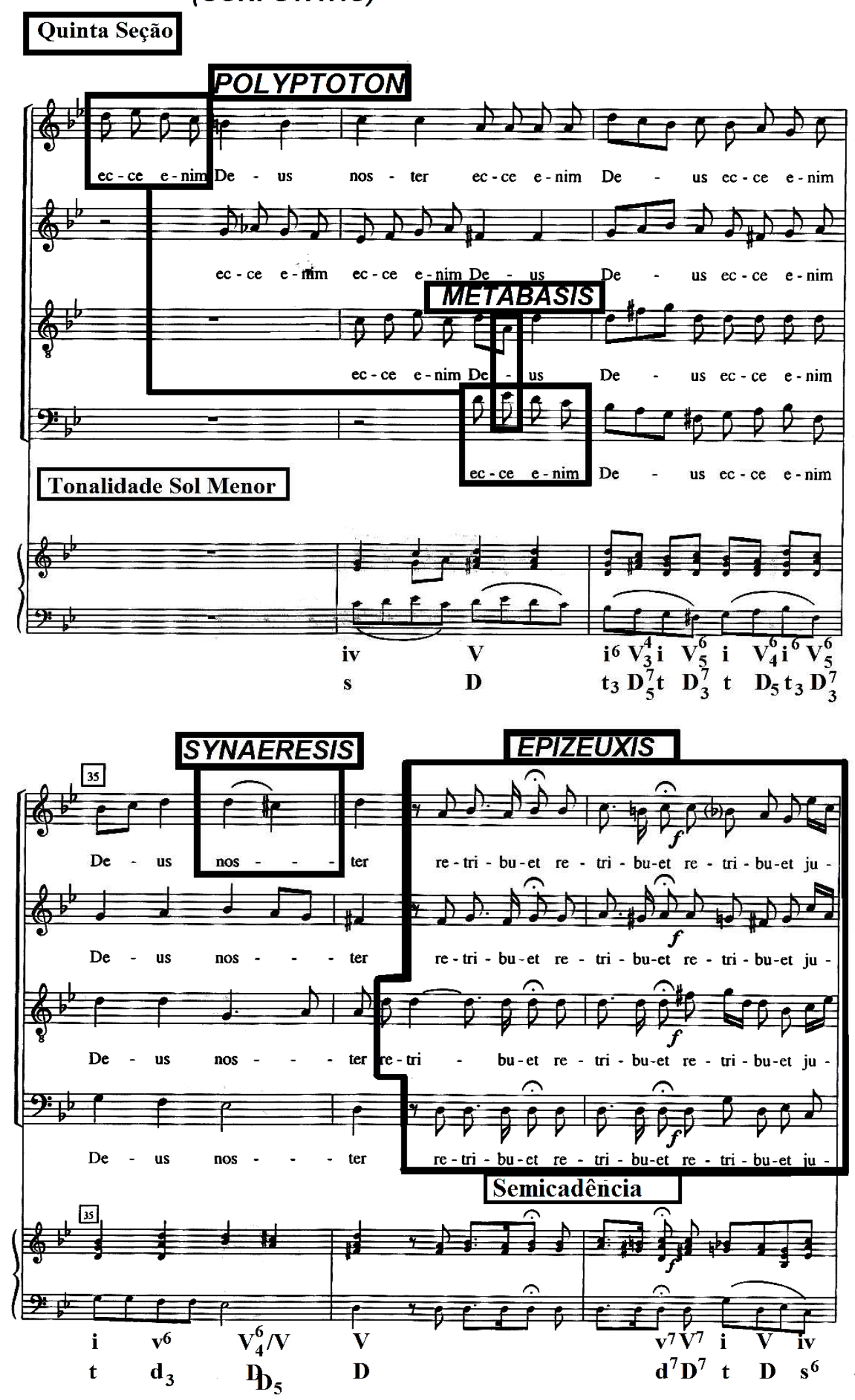

Exemplo 121: Ofertório da Missa da Quarta-feira das Têmporas do Advento de André da Silva Gomes- Catalogação e Organização Régis Duprat (DUPRAT, 1999, p.169). 
As mesmas figuras do excerto anterior são empregadas pelo autor, porém, há de se ressaltar a modulação para Si bemol Maior no compasso 40, como a Cadência Autêntica Perfeita quatro compassos depois.

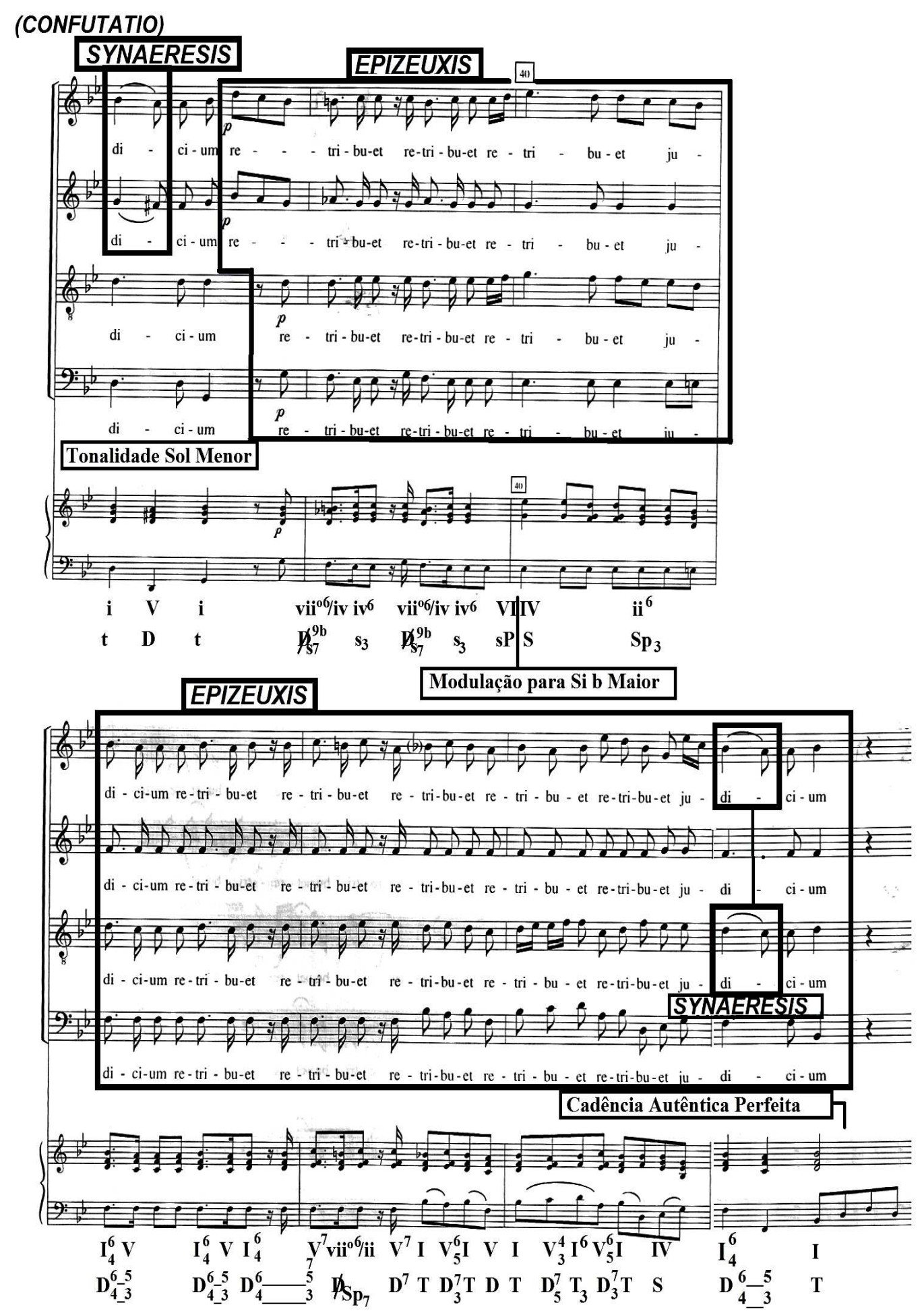

Exemplo 122: Ofertório da Missa da Quarta-feira das Têmporas do Advento de André da Silva Gomes- Catalogação e Organização Régis Duprat (DUPRAT, 1999, pp.170-171). 


\subsubsection{Confirmatio}

Na sexta seção a confirmação da tese inicial se dá por meio de figuras de repetição tanto de melodia, quanto das palavras, sejam na mesma ou em outra altura: Climax, Anaphora e Palilogia. Igualmente é notada a modulação para Dó Menor no compasso 45.

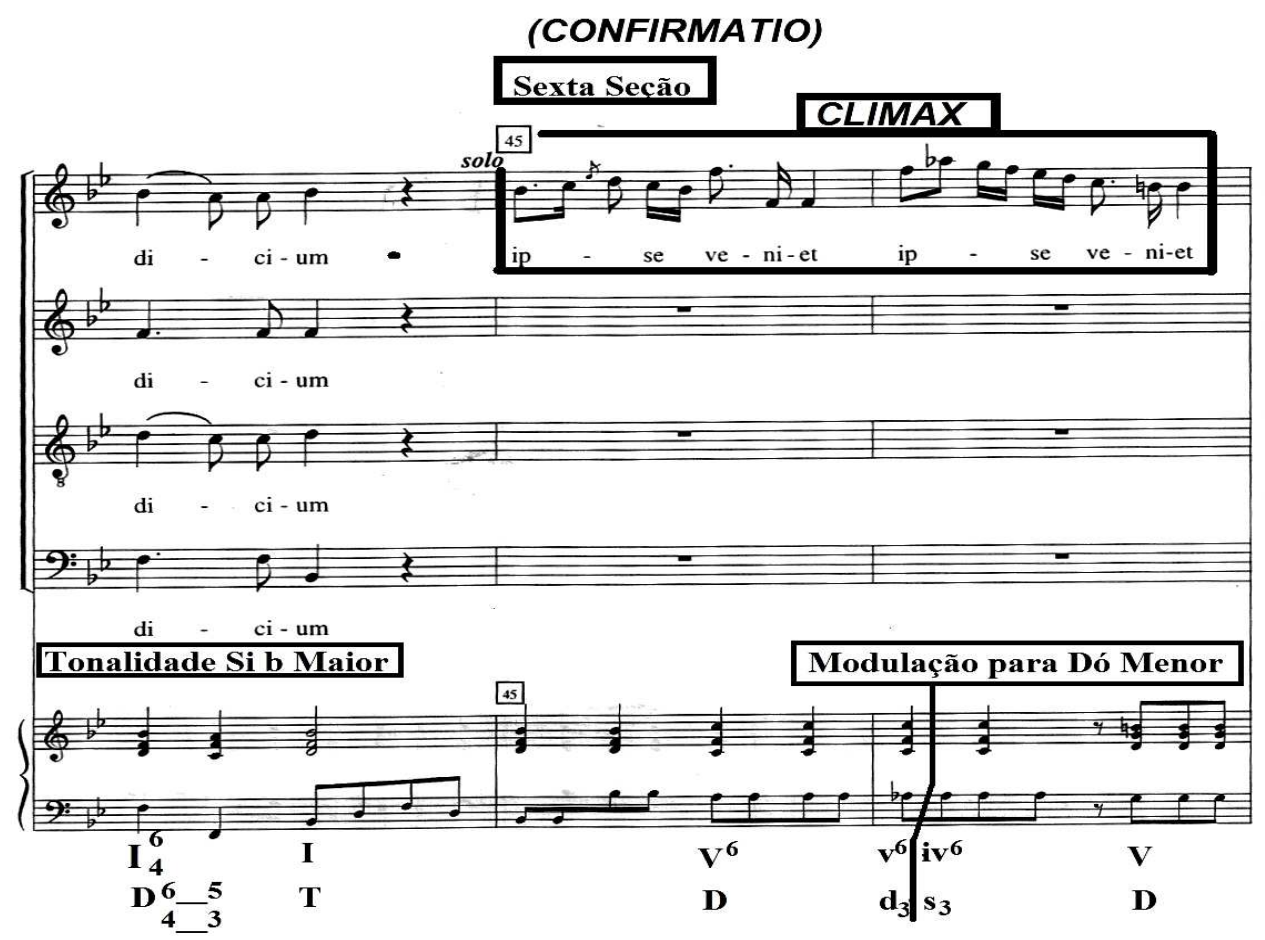

ANAPHORA

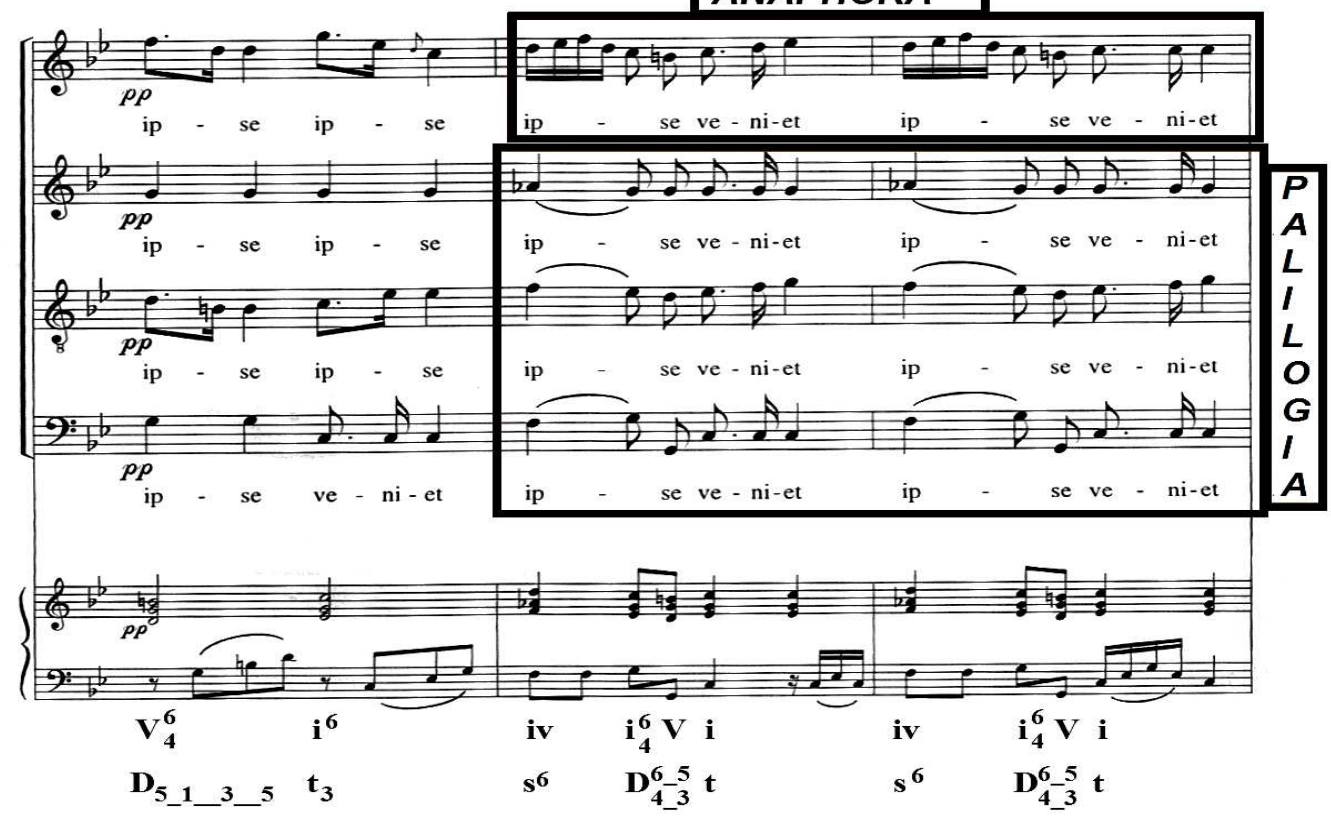

Exemplo 123: Ofertório da Missa da Quarta-feira das Têmporas do Advento de André da Silva Gomes- Catalogação e Organização Régis Duprat (DUPRAT, 1999, p.171). 
A frase ipse veniet (ele virá) é enfaticamente repetida por meio da Epizeuxis, entre os compassos 50 a 52, tendo seu fechamento na Cadência Completa.

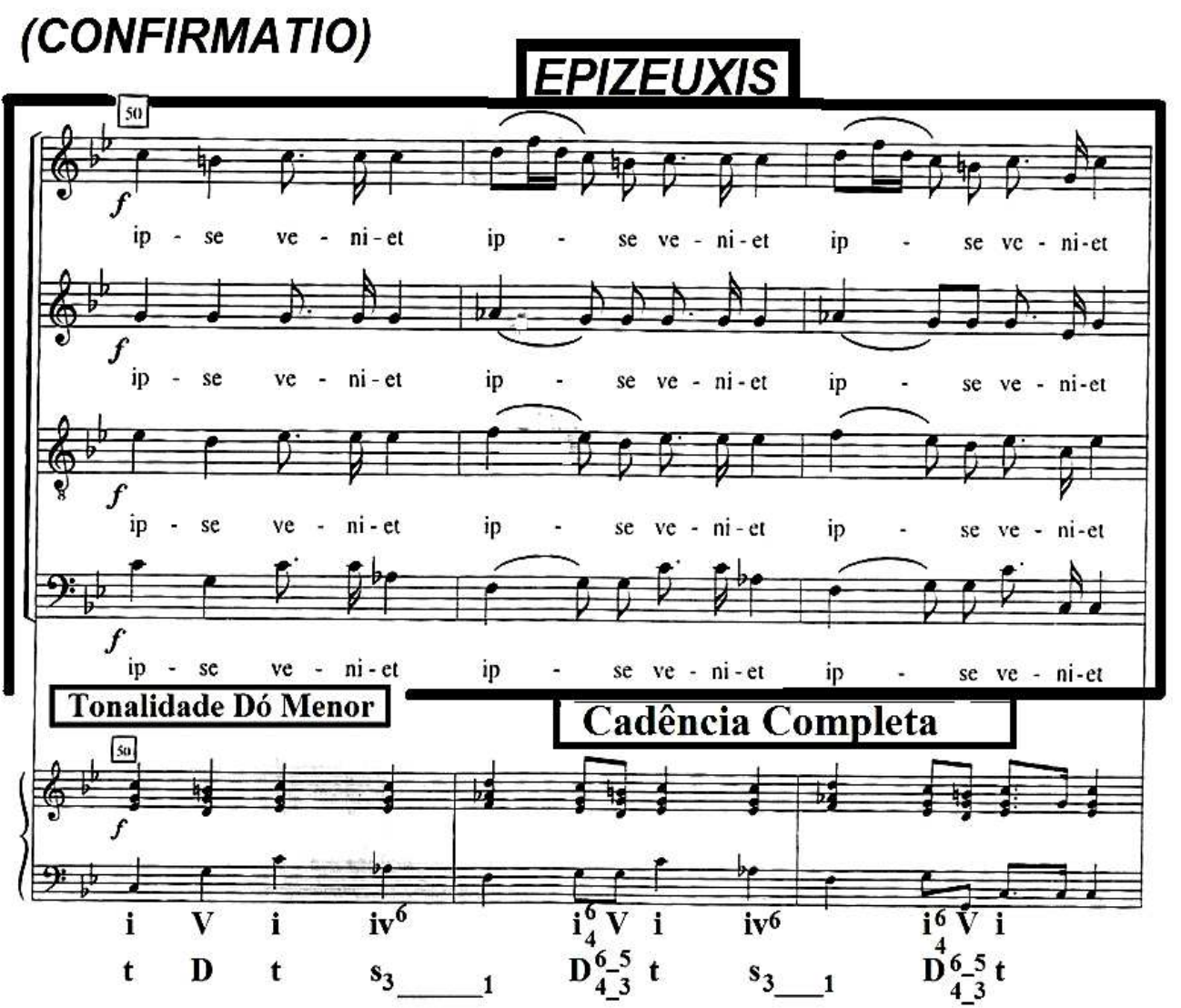

Exemplo 124: Ofertório da Missa da Quarta-feira das Têmporas do Advento de André da Silva Gomes- Catalogação e Organização Régis Duprat (DUPRAT, 1999, p.172).

\subsubsection{Perotatio}

Na sétima seção e conclusão da Dispositio o autor relembra as palavras proferidas pelo profeta messiânico, de que o povo de Israel seria vingado de sua humilhação, como regressaria de seu cativeiro no exilio babilônico para sua terra de origem, salvos por Deus: Et salvos, por meio da figura da Palilogia, enfaticamente repetida e identicamente evidenciada pelo retorno a tonalidade principal da obra, Si bemol Maior. 
(PEROTATIO)

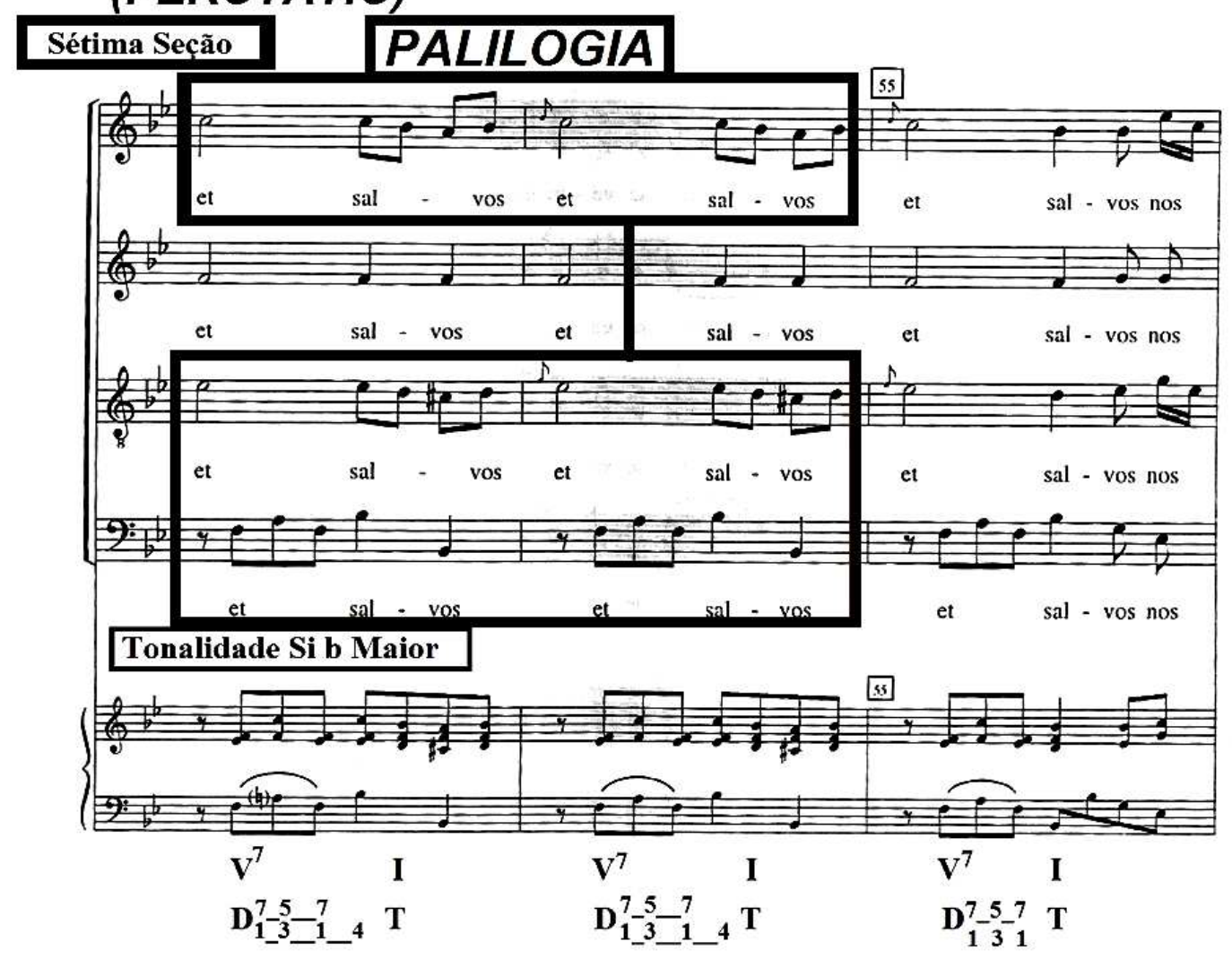

Exemplo 125: Ofertório da Missa da Quarta-feira das Têmporas do Advento de André da Silva Gomes- Catalogação e Organização Régis Duprat (DUPRAT, 1999, p.172).

A expressão Et salvos nos faciet, é utilizada até o fim da peça, todavia, em diferentes dinâmicas, tendo entre os compassos 56 a 60 um caráter suspensivo consubstanciando numa Semicadência, tendo por auxílio uma fermata, da mesma forma observa-se o emprego da Pausa em preparação no repouso e em seguida na entrada das outras vozes apoiando a soprano.

Enfim, o ofertório é concluído num pequeno Adagio, numa dinâmica pianíssimo de maneira tranquila e calma na Cadência Plagal, sendo a Synaeresis o elemento de ênfase tanto das notas, quanto do afeto de confiança na salvação. 
(PEROTATIO)
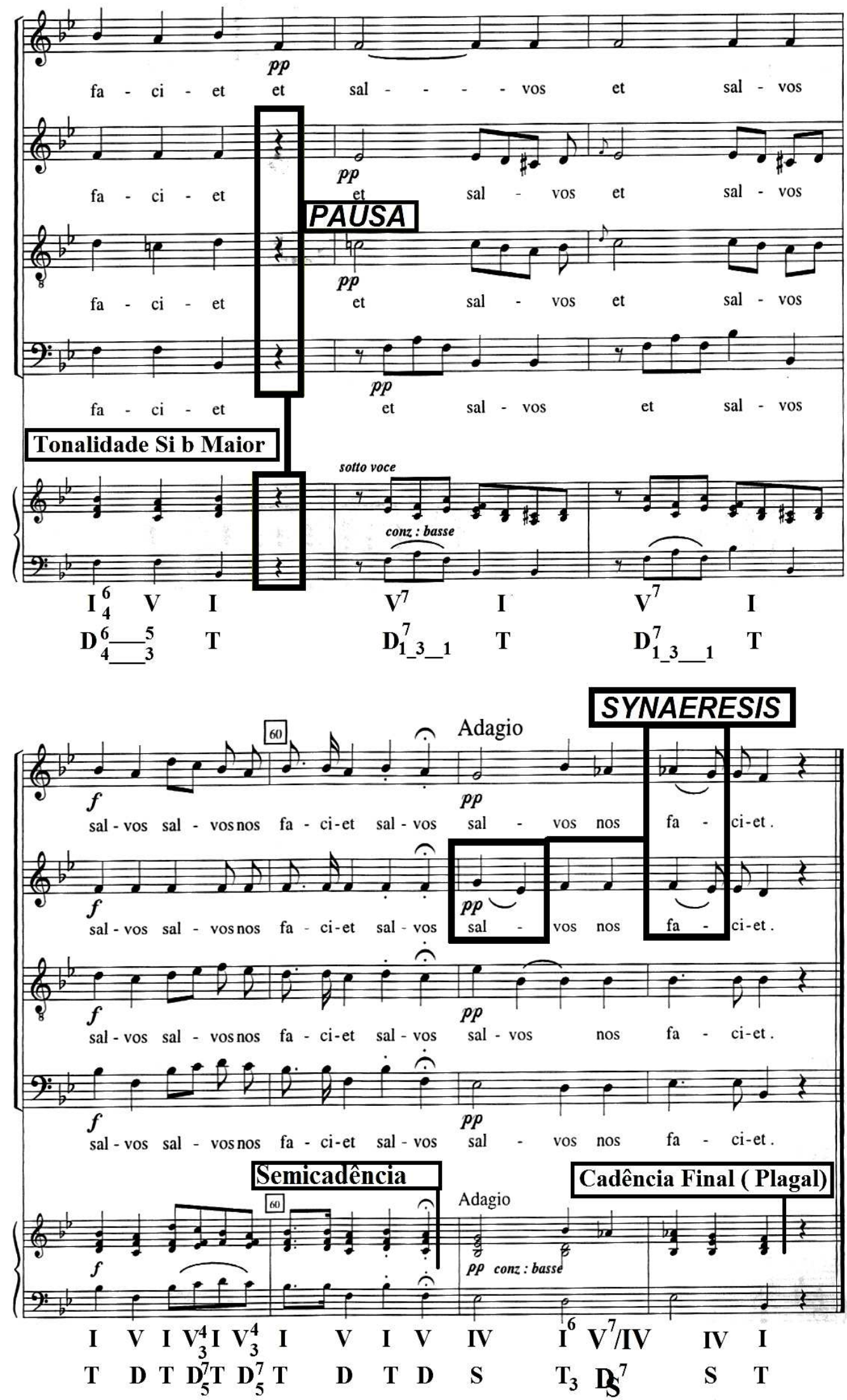

Exemplo 126: Ofertório da Missa da Quarta-feira das Têmporas do Advento de André da Silva Gomes- Catalogação e Organização Régis Duprat (DUPRAT, 1999, p.173). 


\subsection{Figuras observadas no Ofertório (Elocutio/Decoratio)}

\begin{tabular}{|c|c|c|c|}
\hline FIGURAS & TIPO & DESCRIÇÃO & TRATADISTA \\
\hline $\begin{array}{l}\text { ANAPHORA } \\
\text { (BARTEL, 1997, } \\
\text { pp.184-190). }\end{array}$ & $\begin{array}{l}\text { Repetição } \\
\text { Melódica }\end{array}$ & $\begin{array}{l}\text { (1) É uma linha } \\
\text { do baixo repetida } \\
\text { em forma de solo. } \\
\text { (2) A repetição de } \\
\text { uma exposição } \\
\text { melódica sobre } \\
\text { notas e partes } \\
\text { diferentes. } \\
\text { Também pode } \\
\text { ocorrer no início } \\
\text { das repetições de } \\
\text { frases e motivos } \\
\text { em uma série de } \\
\text { passagens } \\
\text { sucessivas; } \\
\text { Uma repetição } \\
\text { em geral. }\end{array}$ & $\begin{array}{lr}\text { Thuringus: } & \text { O } \\
\text { que é uma } \\
\text { Anáfora? É a } \\
\text { repetição } \\
\text { continuada } \\
\text { apenas no Baixo. } \\
\text { Walther: É uma } \\
\text { figura r de } \\
\text { repetição e pode } \\
\text { ocorrer de duas } \\
\text { maneiras: } \\
\text { 1. Quando uma } \\
\text { palavra é } \\
\text { repetida } \\
\text { frequentemen } \\
\text { te em uma } \\
\text { composição } \\
\text { para dar } \\
\text { maior ênfase. } \\
\text { 2. Quando as } \\
\text { notas graves } \\
\text { são repetidas } \\
\text { inúmeras } \\
\text { vezes (como } \\
\text { o caso das } \\
\text { Chaconne). }\end{array}$ \\
\hline $\begin{array}{l}\text { APOSIOPESIS } \\
\text { (BARTEL, 1997, } \\
\text { pp.202-206) }\end{array}$ & $\begin{array}{l}\text { Interrupção e } \\
\text { Silêncio }\end{array}$ & $\begin{array}{l}\text { Um descanso em } \\
\text { uma ou todas as } \\
\text { vozes de uma } \\
\text { composição: } \\
\text { pausa geral. }\end{array}$ & $\begin{array}{l}\text { Walther: } \\
\text { Aposiopesis se } \\
\text { refere a uma } \\
\text { Pausa generalis } \\
\text { ou um completo } \\
\text { silêncio em todas } \\
\text { as vozes e nas } \\
\text { partes r da } \\
\text { composição r } \\
\text { simultaneamente. }\end{array}$ \\
\hline $\begin{array}{l}\text { AUXESIS } \\
\text { (BARTEL, 1997, pp. } \\
\text { 209-212). }\end{array}$ & $\begin{array}{l}\text { Repetição } \\
\text { Melódica }\end{array}$ & $\begin{array}{l}\text { São repetições } \\
\text { sucessivas de } \\
\text { uma passagem } \\
\text { musical. }\end{array}$ & \begin{tabular}{lr}
\multicolumn{3}{l}{ Burmeister: } & A \\
Auxesis ocorre \\
quando r uma \\
harmonia & \\
composta & por \\
combinações & \\
consonantes & se \\
desenvolve & de
\end{tabular} \\
\hline
\end{tabular}




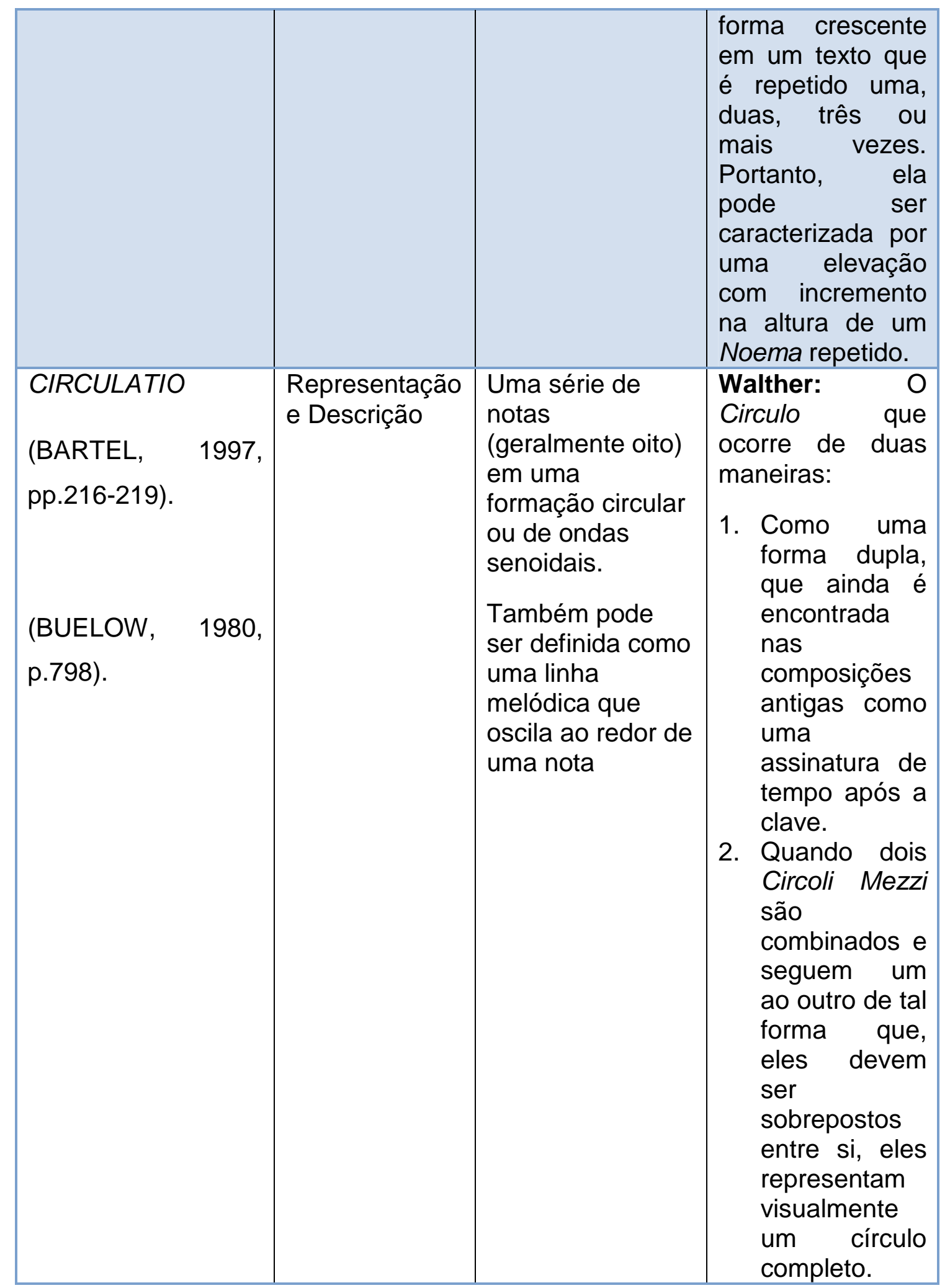




\begin{tabular}{|c|c|c|c|c|}
\hline $\begin{array}{l}\text { CLIMAX } \\
\text { (BARTEL, } \\
\text { pp.220-224). }\end{array}$ & 1997 & $\begin{array}{l}\text { Repetição } \\
\text { Melódica }\end{array}$ & $\begin{array}{l}\text { (1) Sequência de } \\
\text { notas em uma só } \\
\text { voz repetida em } \\
\text { qualquer } \\
\text { tonalidade maior } \\
\text { ou menor, (2) } \\
\text { Duas vozes que } \\
\text { se deslocam em } \\
\text { movimento } \\
\text { ascendente ou } \\
\text { descendente } \\
\text { paralelo, (3) Um } \\
\text { aumento gradual } \\
\text { na intensidade e } \\
\text { altura do som. }\end{array}$ & $\begin{array}{l}\text { Burmeister: A } \\
\text { Climax repete } \\
\text { notas } \\
\text { semelhantes ou } \\
\text { alturas similares. } \\
\text { Kircher: } \\
\text { Climax } \\
\text { Gradatio é uma } \\
\text { passagem } \\
\text { musical } \\
\text { ascendente que é } \\
\text { frequentemente } \\
\text { utilizada em } \\
\text { afetos de amor e } \\
\text { desejo de de } \\
\text { unidade do reino } \\
\text { celestial. }\end{array}$ \\
\hline $\begin{array}{l}\text { EPIZEUXIS } \\
\text { (BARTEL, } \\
\text { pp.263-265). }\end{array}$ & 1997, & $\begin{array}{l}\text { Repetição } \\
\text { Melódica }\end{array}$ & $\begin{array}{l}\text { Uma repetição } \\
\text { imediata e } \\
\text { enfática de uma } \\
\text { palavra, nota, } \\
\text { motivo ou frase. }\end{array}$ & $\begin{array}{l}\text { Walther: A } \\
\text { Epizeuxis é uma } \\
\text { figura de retórica } \\
\text { pela qual uma ou } \\
\text { mais palavras } \\
\text { são } \\
\text { imediatamente e } \\
\text { enfaticamente } \\
\text { repetidas. }\end{array}$ \\
\hline $\begin{array}{l}\text { GRADATIO } \\
\text { (BARTEL, } \\
\text { pp.220-224). }\end{array}$ & 1997 & $\begin{array}{l}\text { Repetição } \\
\text { Melódica }\end{array}$ & $\begin{array}{l}\text { (1) Sequência de } \\
\text { notas em uma só } \\
\text { voz repetida em } \\
\text { qualquer } \\
\text { tonalidade maior } \\
\text { ou menor, (2) } \\
\text { Duas vozes que } \\
\text { se deslocam em } \\
\text { movimento } \\
\text { ascendente ou } \\
\text { descendente } \\
\text { paralelo, (3) Um } \\
\text { aumento gradual } \\
\text { na intensidade e } \\
\text { altura do som. }\end{array}$ & $\begin{array}{l}\text { Walther: Climax } \\
\text { ou Gradatio } \\
\text { podem ser } \\
\text { interpretadas } \\
\text { das seguintes } \\
\text { formas: } \\
\text { 1. Quando há } \\
\text { palavras que } \\
\text { falam sobre } \\
\text { alegria, } \\
\text { glorificação e } \\
\text { louvor. } \\
2 . \quad \text { Em uma } \\
\text { figura musical } \\
\text { que ocorre } \\
\text { quando duas } \\
\text { vozes ses } \\
\text { movimentam } \\
\text { para cima e para } \\
\text { baixo } \\
\text { progredindo em } \\
\text { terças paralelas. }\end{array}$ \\
\hline
\end{tabular}




\begin{tabular}{|c|c|c|c|c|}
\hline & & & & $\begin{array}{l}\text { (Essa forma } \\
\text { que aparece } \\
\text { nesta obra). } \\
3 . \quad \text { Quando } \\
\text { uma passagem } \\
\text { com ou sem } \\
\text { cadência é } \\
\text { imediatamente } \\
\text { repetida várias } \\
\text { vezes em alturas } \\
\text { progressivament } \\
\text { e maiores. } \\
4 . \quad \text { Este } \\
\text { termo também } \\
\text { pode ser dado a } \\
\text { um cânone de } \\
\text { quatro partes em } \\
\text { que, as duas } \\
\text { primeiras vozes } \\
\text { reentram, a as } \\
\text { outras duas } \\
\text { vozes dermanece na } \\
\text { permanecem } \\
\text { parte anterior e } \\
\text { ainda } \\
\text { harmonizam. }\end{array}$ \\
\hline $\begin{array}{l}\text { METABASIS } \\
\text { (BARTEL, } \\
\text { pp.319-320). }\end{array}$ & 1997 & $\begin{array}{l}\text { Representação } \\
\text { e } \\
\text { Descrição }\end{array}$ & $\begin{array}{l}\text { Cruzamento de } \\
\text { uma voz com } \\
\text { outra ou } \\
\text { cruzamento de } \\
\text { vozes. }\end{array}$ & $\begin{array}{l}\text { Spiess: A } \\
\text { Metabasis (ou } \\
\text { Diabasis, } \\
\text { Transgressio, } \\
\text { Transgression) } \\
\text { ocorre sempre } \\
\text { que uma voz } \\
\text { atravessa a outra. }\end{array}$ \\
\hline $\begin{array}{l}\text { NOEMA } \\
\text { (BARTEL, } \\
\text { p.339-342). }\end{array}$ & 1997 & $\begin{array}{l}\text { Representação } \\
\text { e Descrição }\end{array}$ & $\begin{array}{l}\text { Uma passagem } \\
\text { homofônica em } \\
\text { uma textura } \\
\text { contrapontística e } \\
\text { polifônica. }\end{array}$ & $\begin{array}{l}\text { Burmeister: A } \\
\text { Noema } \\
\text { representa o } \\
\text { afeto harmônico, } \\
\text { onde as vozes } \\
\text { combinadas têm } \\
\text { valores e } \\
\text { números de notas } \\
\text { semelhantes. } \\
\text { Quando } \\
\text { introduzida } \\
\text { adequadamente, } \\
\text { isto é, no } \\
\text { momento certo, } \\
\text { ela afeta }\end{array}$ \\
\hline
\end{tabular}




\begin{tabular}{|c|c|c|c|c|}
\hline $\begin{array}{l}\text { (BUELOW, } \\
\text { p.799). }\end{array}$ & 1980 & & & $\begin{array}{l}\text { docemente os } \\
\text { ouvidos do } \\
\text { ouvinte, } \\
\text { produzindo uma } \\
\text { sensação de } \\
\text { calma e } \\
\text { serenidade. } \\
\text { Seção } \\
\text { homofônica, } \\
\text { dentro da } \\
\text { polifonia utilizada } \\
\text { para enfatizar o } \\
\text { texto. }\end{array}$ \\
\hline $\begin{array}{l}\text { PALILOGIA } \\
\text { (BARTEL, } \\
\text { pp.342-344). }\end{array}$ & 1997 & $\begin{array}{l}\text { Repetição } \\
\text { Melódica }\end{array}$ & \begin{tabular}{l}
\multicolumn{2}{c}{ Repetição de um } \\
tema no mesmo \\
nível de altura, \\
também pode \\
ocorrer rem \\
alturas diferentes \\
na mesma ou em \\
várias vozes.
\end{tabular} & $\begin{array}{l}\text { Burmeister: } \\
\text { Palilogia é uma } \\
\text { repetição de uma } \\
\text { inteiração ou } \\
\text { apenas o começo } \\
\text { da estrutura dos } \\
\text { meios e temas } \\
\text { sobre a mesma } \\
\text { altura com a } \\
\text { mesma voz, } \\
\text { ocorrendo com } \\
\text { ou } \\
\text { intermédio dem } \\
\text { pausas em todos } \\
\text { os eventos em } \\
\text { uma voz. } \\
\text { Walther: } \\
\text { Palilogia refere- } \\
\text { se a uma } \\
\text { repetição por } \\
\text { demais frequente } \\
\text { das mesmas } \\
\text { palavras. }\end{array}$ \\
\hline $\begin{array}{l}\text { PAUSA } \\
\text { (BARTEL, } \\
\text { pp.362-365). }\end{array}$ & 1997 & $\begin{array}{l}\text { Interrupção e } \\
\text { Silêncio }\end{array}$ & $\begin{array}{l}\text { Pausa } \quad \text { ou } \\
\text { descanso em } \\
\text { uma composição } \\
\text { musical. }\end{array}$ & $\begin{array}{l}\text { Walther: Uma } \\
\text { figura ou figuras } \\
\text { de silêncio. } \\
\text { Pausa refere-se a } \\
\text { um período de } \\
\text { repouso ou o } \\
\text { silêncio na } \\
\text { música, que é } \\
\text { indicado por um } \\
\text { determinado } \\
\text { sinal. }\end{array}$ \\
\hline
\end{tabular}




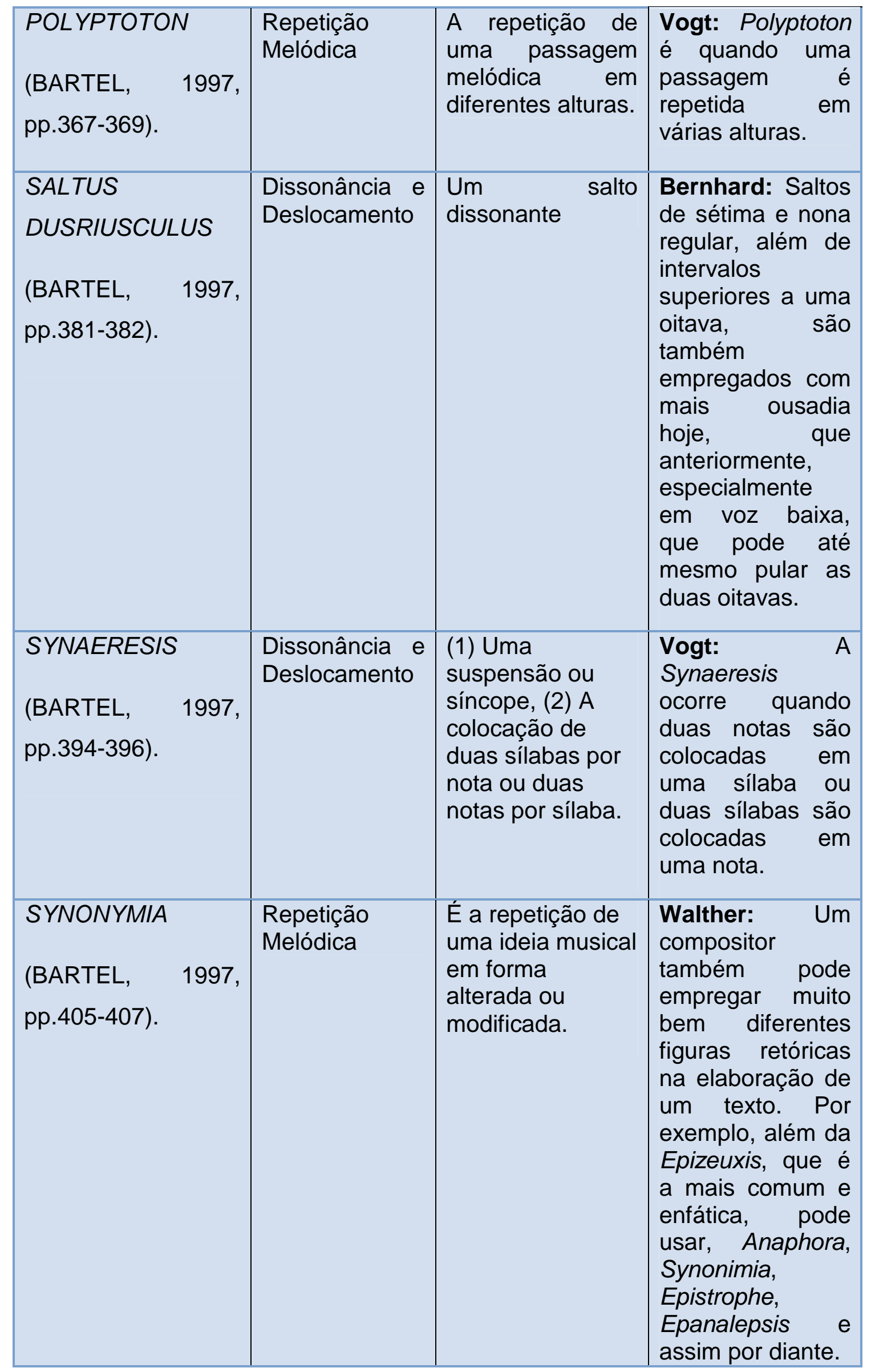




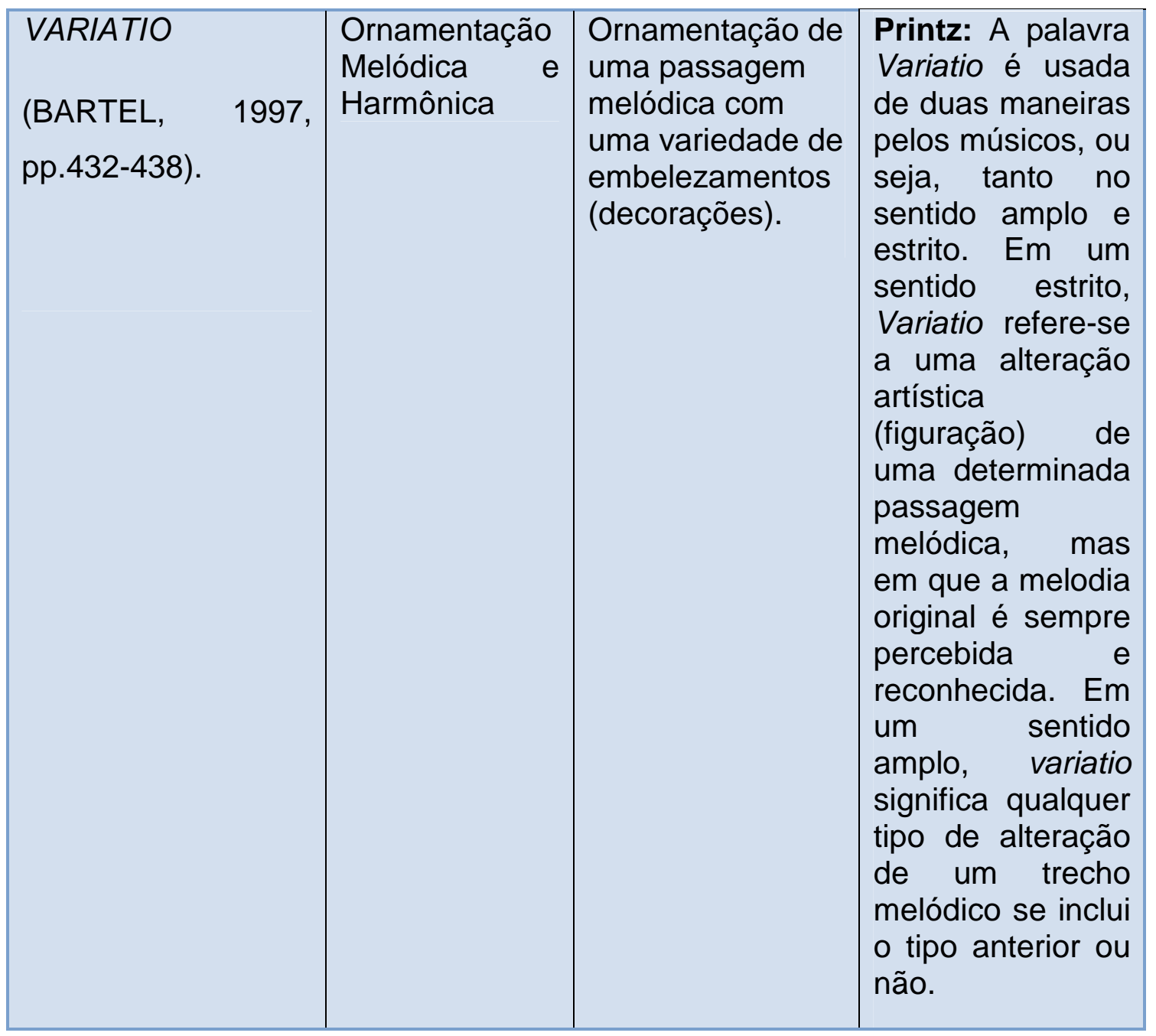

Tabela 45: Figuras encontradas no Ofertório da Missa da Quarta-feira das Têmporas do Advento de André da Silva Gomes

\section{Análise Harmônica}

\subsection{Curva Tonal}

Tonalidade: Si b Maior

Andamento: Moderato 4/4

Esquema de Progressões Harmônicas

\begin{tabular}{|l|c|l|}
\hline Compassos & $\begin{array}{l}\text { Função em relação a } \\
\text { tonalidade principal }\end{array}$ & Tonalidade (Acorde) \\
\hline $1-9$ & T-I & Si b Maior \\
\hline 9 & S-IV & Mi b Maior \\
\hline $10-11$ & T-I & Si b Maior \\
\hline 11 & S-IV & Mi b Maior \\
\hline $12-14$ & T-I & Si b Maior \\
\hline
\end{tabular}




\begin{tabular}{|l|c|l|}
\hline $15-18$ & D-V & Fá Maior \\
\hline 19 & Tp-vi & Sol Menor \\
\hline 20 & D/Tp- V/vi & Ré Maior \\
\hline $21-26$ & S-IV & Mi b Maior \\
\hline $26-27$ & Sp-ii & Dó Menor \\
\hline 28 & Tp-vi & Sol Menor \\
\hline $29-30$ & Sp-ii & Dó Menor \\
\hline $30-32$ & Tp-vi & Sol Menor \\
\hline 33 & Sp-ii & Dó Menor \\
\hline $33-35$ & Tp-vi & Sol Menor \\
\hline $35-36$ & D/Tp-V/vi & Ré Maior \\
\hline $36-38$ & Tp-vi & Sol Menor \\
\hline $39-40$ & Sp-ii & Dó Menor \\
\hline 41 & D-V & Fá Maior \\
\hline $42-45$ & T-I & Si b Maior \\
\hline $45-52$ & Sp-ii & Dó Menor \\
\hline $53-60$ & T-I & Si b Maior \\
\hline $61-62$ & S-IV & Mi b Maior \\
\hline 62 & T-I & Si b Maior \\
\hline
\end{tabular}

Tabela 46: Curva Tonal do Ofertório da Missa da Quarta-feira das Têmporas do Advento

Números de compassos: 62

Regiões abordadas: 6

Variações: 24

Ritmo Harmônico: 2,58 (divisão dos números de compassos e variações)

Média ideal: (divisão dos números de compassos e regiões tonais abordadas = 10,33)

Esquema Formal

$(1-14)(14-18)(19-40)(40-45)(45-52)(53-62)$

$\begin{array}{llllll}\text { T } & \text { D } & \text { Tp } & \text { T } & \text { Sp } & \text { T }\end{array}$

l $\quad$ V vi $\quad$ I $\quad$ ii $\quad$ I 


\subsection{Estrutura Analítica do Ofertório: Retórica e Harmônica}

\begin{tabular}{|c|c|c|c|c|c|}
\hline $\begin{array}{l}\text { RETÓRICA } \\
\text { DISPOSITIO }\end{array}$ & $\begin{array}{l}\text { FIGURA } \\
\text { ELOCUTIO }\end{array}$ & COMP. & $\begin{array}{l}\text { HARIMÔNICA } \\
\text { SEÇÃOO }\end{array}$ & TONALIDADE & FUNÇÃO \\
\hline EXORDIUM & Aposiopesis & 2 & $1^{a}$ Seção & Si b Maior & T-I \\
\hline NARRATIO & $\begin{array}{l}\text { Pausa } \\
\text { Variatio } \\
\text { Anaphora }\end{array}$ & $\begin{array}{l}6-8 \\
6 \\
7-8\end{array}$ & $\begin{array}{l}2^{\mathrm{a}} \text { Seção } \\
2^{\mathrm{a}} \text { Seção } \\
2^{\mathrm{a}} \text { Seção }\end{array}$ & $\begin{array}{l}\text { Si b Maior } \\
\text { Si b Maior } \\
\text { Si b Maior }\end{array}$ & $\begin{array}{l}T-I \\
T-I\end{array}$ \\
\hline PROPOSITIO & $\begin{array}{l}\text { Polyptoton } \\
\text { Metabasis } \\
\text { Synonimia } \\
\text { Anaphora } \\
\text { Pausa }\end{array}$ & $\begin{array}{l}9 \\
11 \\
11-12 \\
13-14 \\
13-16\end{array}$ & $\begin{array}{l}2^{\mathrm{a}} \text { Seção } \\
2^{\text {a }} \text { Seção } \\
2^{\text {a Seção }} \\
3^{\text {a Seção }} \\
3^{\text {a Seção }}\end{array}$ & $\begin{array}{l}\text { Si b Maior } \\
\text { Si b Maior } \\
\text { Si b Maior } \\
\text { Fá Maior } \\
\text { Fá Maior }\end{array}$ & $\begin{array}{l}T-I \\
T-I \\
T-I \\
D-V \\
D-V\end{array}$ \\
\hline CONFUTATIO & $\begin{array}{l}\text { Epizeuxis } \\
\text { Pausa } \\
\text { Circulatio } \\
\text { Gradatio } \\
\text { Auxesis } \\
\text { Saltus } \\
\text { Duriusculus } \\
\text { Polyptoton } \\
\text { Metabasis } \\
\text { Synaeresis }\end{array}$ & \begin{tabular}{|l}
$16-20$ \\
e $36-43$ \\
$21-24$ \\
$32-33,44$ \\
$23-24$ \\
$25-27$ \\
$26-30$ \\
29 \\
\\
$32-33$ \\
33 \\
$35,39,44$
\end{tabular} & 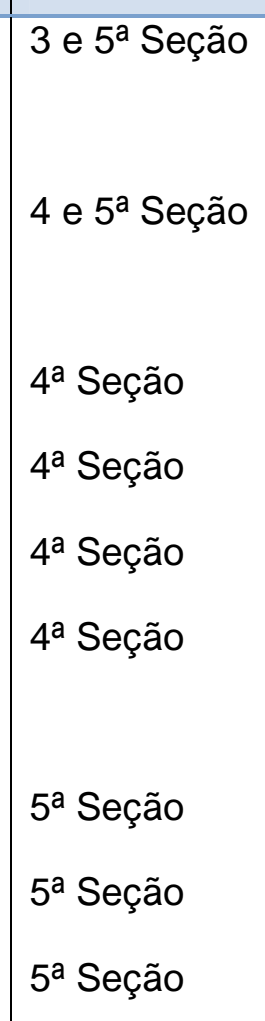 & $\begin{array}{l}\text { Fá Maior e } \\
\text { Sol Menor } \\
\text { Sol Menor e } \\
\text { Si b Maior } \\
\text { Sol Menor } \\
\text { Sol Menor } \\
\text { Sol Menor } \\
\text { Sol Menor } \\
\text { Sol Menor } \\
\text { Sol Menor } \\
\text { Sol Menor }\end{array}$ & $\begin{array}{c}\text { D-V } \\
\text { Tp-vi } \\
\text { Tp-vi } \\
\text { T-I } \\
\text { Tp-vi } \\
\text { Tp-vi } \\
\text { Tp-vi } \\
\text { Tp-vi } \\
\\
\text { Tp-vi } \\
\text { Tp-vi } \\
\text { Tp-vi }\end{array}$ \\
\hline CONFIRMATIO & $\begin{array}{l}\text { Climax } \\
\text { Anaphora } \\
\text { Palilogia }\end{array}$ & $\begin{array}{r}45-46 \\
48-49 \\
48-49\end{array}$ & 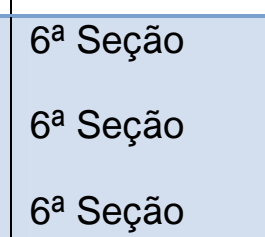 & $\begin{array}{l}\text { Dó Menor } \\
\text { Dó Menor } \\
\text { Dó Menor }\end{array}$ & $\begin{array}{l}\text { Sp-ii } \\
\text { Sp-ii } \\
\text { Sp-ii }\end{array}$ \\
\hline
\end{tabular}




\begin{tabular}{|c|c|c|c|c|c|}
\hline & Epizeuxis & $50-52$ & 6ª Seção & Dó Menor & Sp-ii \\
\hline PEROTATIO & $\begin{array}{l}\text { Palilogia } \\
\text { Pausa } \\
\text { Synaeresis }\end{array}$ & $\begin{array}{l}53-54 \\
56 \\
61-62\end{array}$ & $\begin{array}{l}7^{a} \text { Seção } \\
7^{\text {a }} \text { Seção } \\
7^{\text {ạ Seção }}\end{array}$ & $\begin{array}{l}\text { Si b Maior } \\
\text { Si b Maior } \\
\text { Si b Maior }\end{array}$ & $\begin{array}{l}\text { T-I } \\
\text { T-I } \\
\text { T-I }\end{array}$ \\
\hline
\end{tabular}

Tabela 47: Estrutura analítica do Ofertório 


\title{
5.2.12. Ofertório da Missa de Natal
}

\section{Estudo Semântico}

\subsection{Inventio}

Essa obra faz parte do subgrupo de peças desse estudo escrito em dois movimentos: o primeiro Brilhante, com sessenta e nove compassos e o segundo, num Andante, constituído de trina e nove compassos. Já o texto pertence ao livro dos Salmos (Ps.95,11 e 13/Ps.96, 11 e 13) cuja epígrafe descreve um louvor dado ao Senhor.

Laetentur caeli et exsultet terra ante faciem Domini: quoniam venit

Alegrem-se os céus e regozije a terra ante a face do Senhor, pois ele vem.

(SOARES, 2000, p.139).

O presente texto é tratado com uma técnica literária conhecida como personificação, comum nas Escrituras Sagradas, sobretudo nos livros de Salmos e Isaías. Nesse caso o salmista convida todos a regozijar-se ante a possível vinda do Senhor, simbolizado analogamente pelo Messias, isto é, o Cristo. É evidente que os três versículos são apresentados de maneira resumida na obra, sendo que em ambos pode-se observar o referido chamamento tanto para os seres vivos animados, como os inanimados, por isso a repetição deste na integra, para a compreensão contextual e de como Silva Gomes apropria-se dos recursos retóricos inserindo-os na música:

\begin{abstract}
Alegrem-se os céus, e a terra exulte; ruja o mar e a sua plenitude. Folgue-se o campo e tudo o que nele há; regozijem-se todas as arvores do bosque, na presença do Senhor, por que ele vem, vem para julgar a terra; julgará o mundo com justiça e os povos, consoante a sua fidelidade (Salmos 95,11 a 13/ 9611 a 13).
\end{abstract}

$\mathrm{Na}$ liturgia cristã, essa celebração consiste em comemorar o nascimento de Jesus, o qual simboliza a luz para iluminar seus súditos, mostrando as eles o caminho da salvação. Portanto, o Natal não é somente uma festa onde se representa um tempo de celebração e alegria, mas também simboliza a busca pela união dos fiéis, os quais devem estar unidos no amor, na fé e esperança do provir de paz, justiça e nova vida. 


\subsection{Locus observados na Inventio do Ofertório (Primeiro Movimento)}

\begin{tabular}{|c|c|c|c|}
\hline INVENTIO & DESCRIÇÃO & $\begin{array}{c}\text { UTILIZAÇÃO NA } \\
\text { OBRA }\end{array}$ & $\begin{array}{l}\text { COMPASSO/ } \\
\text { VOZ }\end{array}$ \\
\hline $\begin{array}{l}\text { Locus } \\
\text { Notationis } \\
\text { (MATTHESON, } \\
\text { [1739],1954, } \\
\text { Parte II,Cap.4, } \\
\text { § 23,p.123). }\end{array}$ & $\begin{array}{l}\text { Aspecto externo } \\
\text { e desenho das } \\
\text { notas (Duração } \\
\text { das notas, } \\
\text { alteração, } \\
\text { repetição e } \\
\text { procedimentos } \\
\text { canônicos). }\end{array}$ & $\begin{array}{l}\text { Vários motivos } \\
\text { rítmicos e diferentes } \\
\text { durações de notas } \\
\text { (mínimas, semínimas, } \\
\text { semínimas } \\
\text { pontuadas, colcheias, } \\
\text { colcheias pontuadas, } \\
\text { semicolcheias } \\
\text { repetições, ligaduras, } \\
\text { fermatas, pausas, } \\
\text { entre outros). }\end{array}$ & $\begin{array}{l}\text { 1-27 S-A-T-B } \\
28-42 \text { S } \\
43-52 \text { S-A-T-B } \\
53-58 \text { S-A-T } \\
\text { 59-69 S-A-T-B }\end{array}$ \\
\hline $\begin{array}{l}\text { Locus } \\
\text { Oppositorum } \\
\text { (MATTHESON, } \\
\text { [1739],1954, } \\
\text { Parte II,Cap.4, } \\
\text { § 80,p.131). }\end{array}$ & $\begin{array}{l}\text { Contraste de } \\
\text { compassos, } \\
\text { movimentos } \\
\text { contrários, } \\
\text { agudos e } \\
\text { graves, lento e } \\
\text { rápido, calmo e } \\
\text { agitado. }\end{array}$ & $\begin{array}{l}\text { Movimento contrário } \\
\text { entre contralto e } \\
\text { baixo. Também entre } \\
\text { soprano e baixo. }\end{array}$ & $\begin{array}{lr}2-4 & A-B \\
46-47 & S-B\end{array}$ \\
\hline $\begin{array}{l}\text { Locus } \\
\text { Descriptionis } \\
\text { (MATTHESON, } \\
\text { [1739],1954, } \\
\text { Parte II,Cap.4, } \\
\text { § 43,p.127). }\end{array}$ & $\begin{array}{l}\text { Disposições da } \\
\text { alma }\end{array}$ & $\begin{array}{l}\text { Alegria e Regozijo } \\
\text { (Alegrem-se os céus e } \\
\text { regozije a terra). }\end{array}$ & $\begin{array}{l}1-27 \text { S-A-T-B } \\
28-42 \text { S } \\
42-52 \text { S-A-T-B } \\
53-58 \text { S-A-T } \\
59-69 \text { S-A-T-B }\end{array}$ \\
\hline $\begin{array}{l}\text { (MATTHESON, } \\
\text { [1739], 1954, } \\
\text { Parte II, Cap.4 } \\
\text { § 79,p.131). }\end{array}$ & $\begin{array}{l}\text { Comparações de } \\
\text { coisas } \\
\text { semelhantes ou } \\
\text { não, grandes ou } \\
\text { pequenas. }\end{array}$ & $\begin{array}{l}\text { Comparação entre } \\
\text { coisas não } \\
\text { semelhantes: céu e } \\
\text { terra. }\end{array}$ & $\begin{array}{l}1-27 \text { S-A-T-B } \\
28-42 \text { S } \\
42-52 \text { S-A-T-B } \\
53-58 \text { S-A-T } \\
59-69 \text { S-A-T-B }\end{array}$ \\
\hline
\end{tabular}

Tabela 48: Locus Topici encontrados no Ofertório da Missa de Natal de André da Silva Gomes (Primeiro Movimento) 


\subsection{Locus observados na Inventio do Ofertório (Segundo Movimento)}

\begin{tabular}{|c|c|c|c|}
\hline INVENTIO & DESCRIÇÃO & $\begin{array}{c}\text { UTILIZAÇÃO NA } \\
\text { OBRA }\end{array}$ & $\begin{array}{l}\text { COMPASSO/ } \\
\text { VOZ }\end{array}$ \\
\hline $\begin{array}{l}\text { Locus } \\
\text { Notationis } \\
\text { (MATTHESON, } \\
\text { [1739],1954, } \\
\text { Parte II,Cap.4, } \\
\text { § 23,p.123). }\end{array}$ & $\begin{array}{l}\text { Aspecto externo } \\
\text { e desenho das } \\
\text { notas (Duração } \\
\text { das notas, } \\
\text { alteração, } \\
\text { repetição e } \\
\text { procedimentos } \\
\text { canônicos). }\end{array}$ & $\begin{array}{l}\text { Vários motivos } \\
\text { rítmicos e diferentes } \\
\text { durações de notas } \\
\text { (semibreves, } \\
\text { mínimas, mínimas } \\
\text { pontuadas, } \\
\text { semínimas, colcheias, } \\
\text { repetições, pausas, } \\
\text { ligaduras, fermata, } \\
\text { entre outros). }\end{array}$ & $\begin{array}{ll}1-2 & \text { S } \\
3-4 & \text { S-A } \\
5-6 & \text { S-A-T } \\
7-39 & \text { S-A-T-B }\end{array}$ \\
\hline $\begin{array}{l}\text { Locus } \\
\text { Oppositorum } \\
\text { (MATTHESON, } \\
\text { [1739],1954, } \\
\text { Parte II,Cap.4, } \\
\text { § 80,p.131). }\end{array}$ & $\begin{array}{l}\text { Contraste de } \\
\text { compassos, } \\
\text { movimentos } \\
\text { contrários, } \\
\text { agudos e } \\
\text { graves, lento e } \\
\text { rápido, calmo e } \\
\text { agitado. }\end{array}$ & $\begin{array}{l}\text { Movimento contrário } \\
\text { entre soprano e tenor. }\end{array}$ & $\begin{array}{l}10-\quad \text { S-B } \\
16-17 \text { S-B }\end{array}$ \\
\hline $\begin{array}{l}\text { Locus } \\
\text { Descriptionis } \\
\text { (MATTHESON, } \\
\text { [1739],1954, } \\
\text { Parte II,Cap.4, } \\
\S 43, \text { p.127). }\end{array}$ & $\begin{array}{l}\text { Disposições da } \\
\text { alma }\end{array}$ & $\begin{array}{l}\text { Esperança e } \\
\text { Confiança (Ele vem) }\end{array}$ & $\begin{array}{lr}15 & \text { S-A-T-B } \\
25-30 & \text { S-A-T-B } \\
39 & \text { S-A-T-B }\end{array}$ \\
\hline
\end{tabular}

Tabela 49: Locus Topici encontrados no Ofertório da Missa de Natal de André da Silva Gomes (Segundo Movimento) 


\subsection{Dispositio}

\subsubsection{Exordium (Primeiro Movimento)}

O Ofertório da Missa de Natal se inicia em forma de conclamação e celebração pelo nascimento do Cristo numa dinâmica forte, Laetentur. No segundo compasso, nota-se a Abruptio, determinando de maneira inesperada silêncio as vozes da contralto, tenor e baixo, na terceira silaba da primeira palavra usada no texto. Também são localizadas mais três figuras no mesmo compasso: Synaeresis, Anaphora e Palilogia, ambas empregadas pelo compositor para enfatizar o sentimento de alegria e louvor, por meio de repetições das notas, frases e silabas.

Entre os compassos 4 a 6, pode-se verificar a aplicação da Epizeuxis, destacando o chamamento do salmista para que os céus e a terra possam exultar o Senhor por sua vinda, exsultet terra, igualmente inserida no mesmo contexto é observada a utilização da Exclamatio, com um salto inesperado de sexta menor (Ré para Si bemol), numa passagem ascendente representando em forma de exclamação o afeto de satisfação e júbilo.

Enfim, os elementos retóricos utilizados nesse excerto, tal como as funções harmônicas, foram trabalhados por Silva Gomes em consonância ao texto sacro apresentado, de modo a chamar a atenção do ouvinte, seja pela ênfase, repetição ou no destaque das expressões pronunciadas melodicamente. 


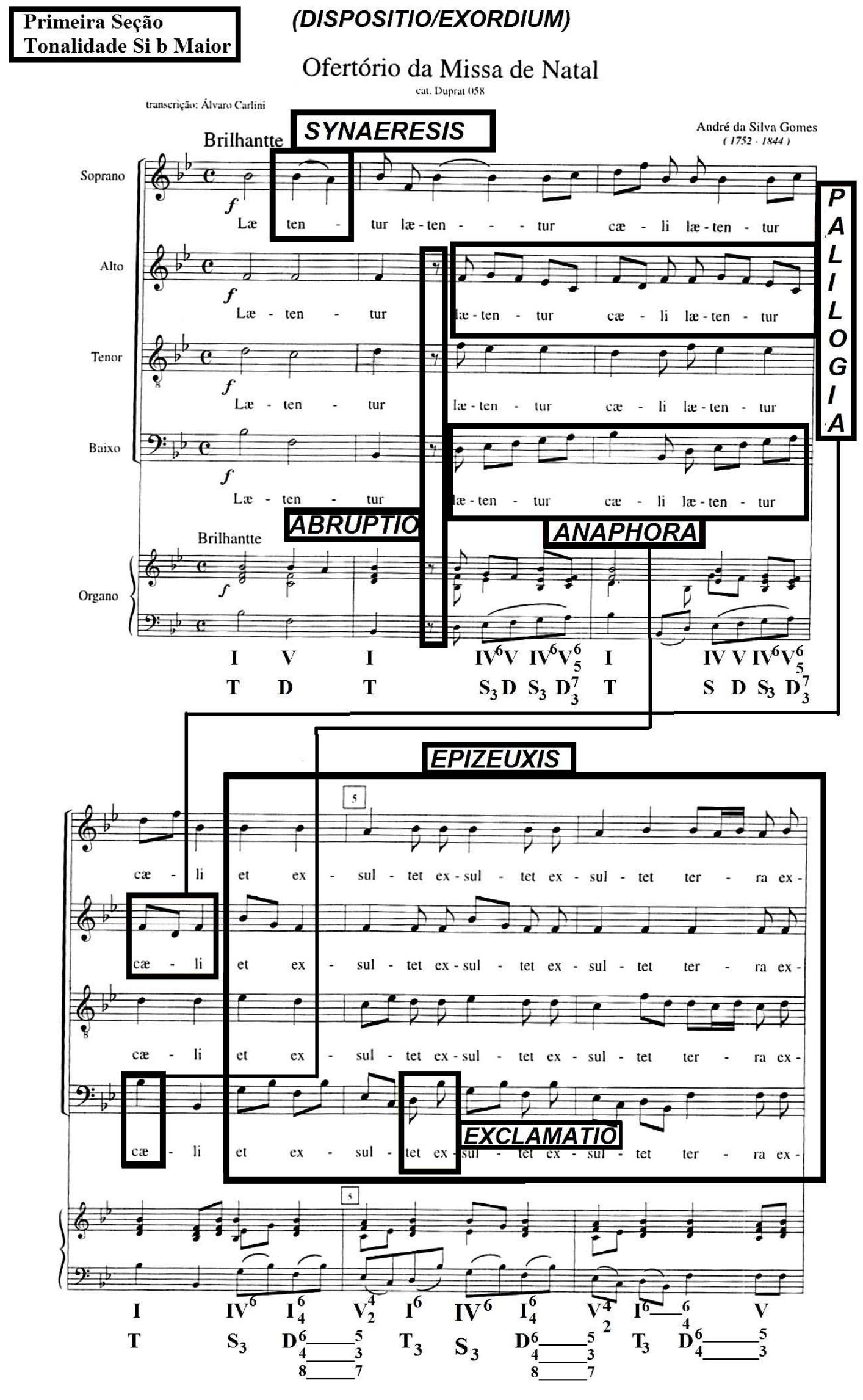

Exemplo 127: Ofertório da Missa de Natal de André da Silva Gomes- Catalogação e Organização Régis Duprat (DUPRAT, 1999, p.195). 
O mesmo procedimento é tangível no exemplo a baixo, no entanto, além da Epizeuxis, até o final dessa fase na Semicadência, já no início da outra parte do discurso o autor emprega a Circulatio destacando as notas Si bemol e Ré.
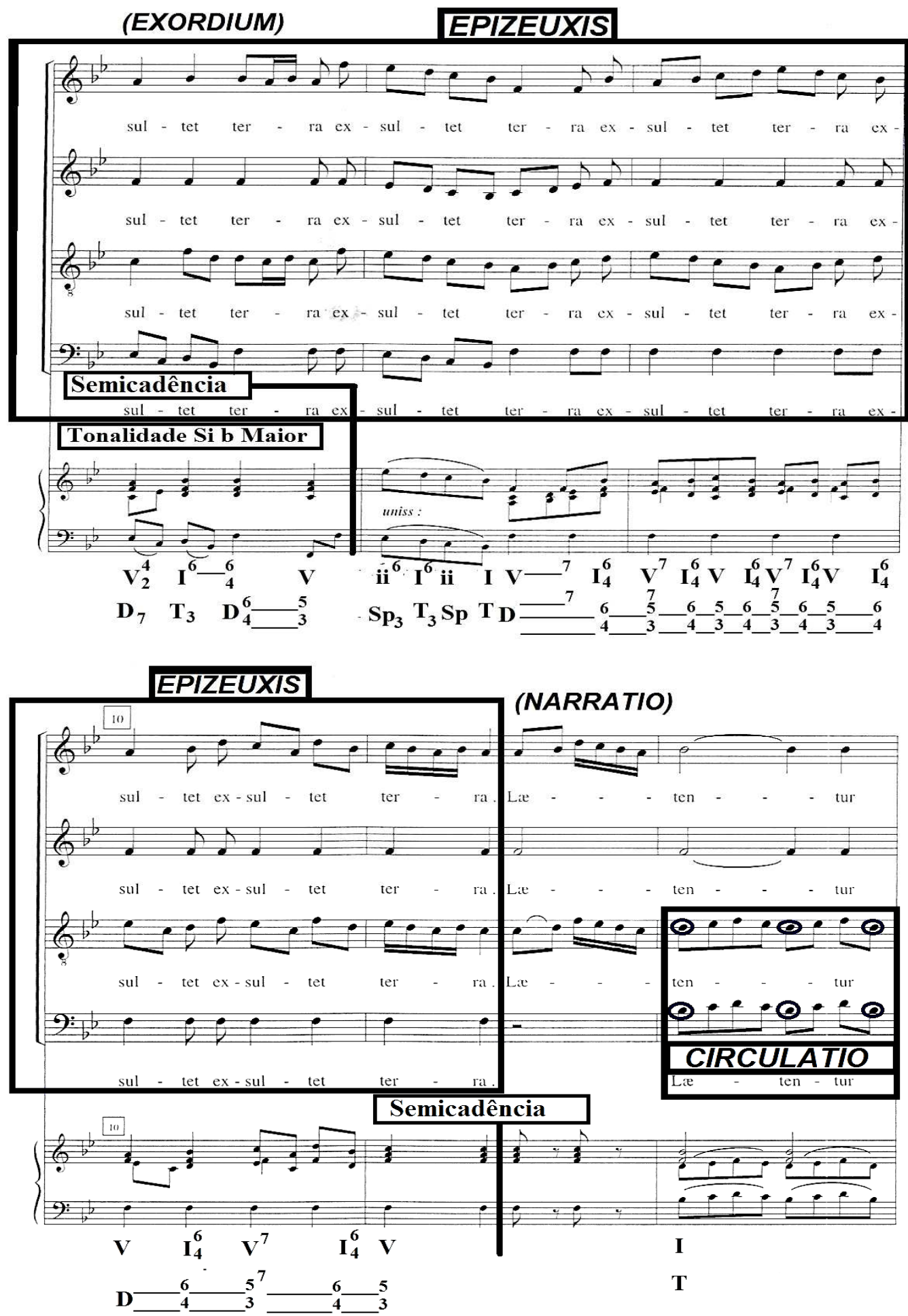

Exemplo 128: Ofertório da Missa de Natal de André da Silva Gomes- Catalogação e Organização Régis Duprat (DUPRAT, 1999, p.196). 


\subsubsection{Narratio}

A Circulatio continua sendo aplicada em forma circular ressaltando as notas Sol e Si bemol, na tonalidade de Sol Menor (outra possibilidade seria a manutenção da tonalidade de Si bemol). Semelhantemente, o autor emprega a Metabasis, evidenciando o cruzamento das vozes do tenor e baixo e Pausa na resolução da Cadência Autêntica Imperfeita, na transição para a Propositio, exercendo descanso para as vozes, enquanto a soprano entoa a silaba et, no compasso 17.
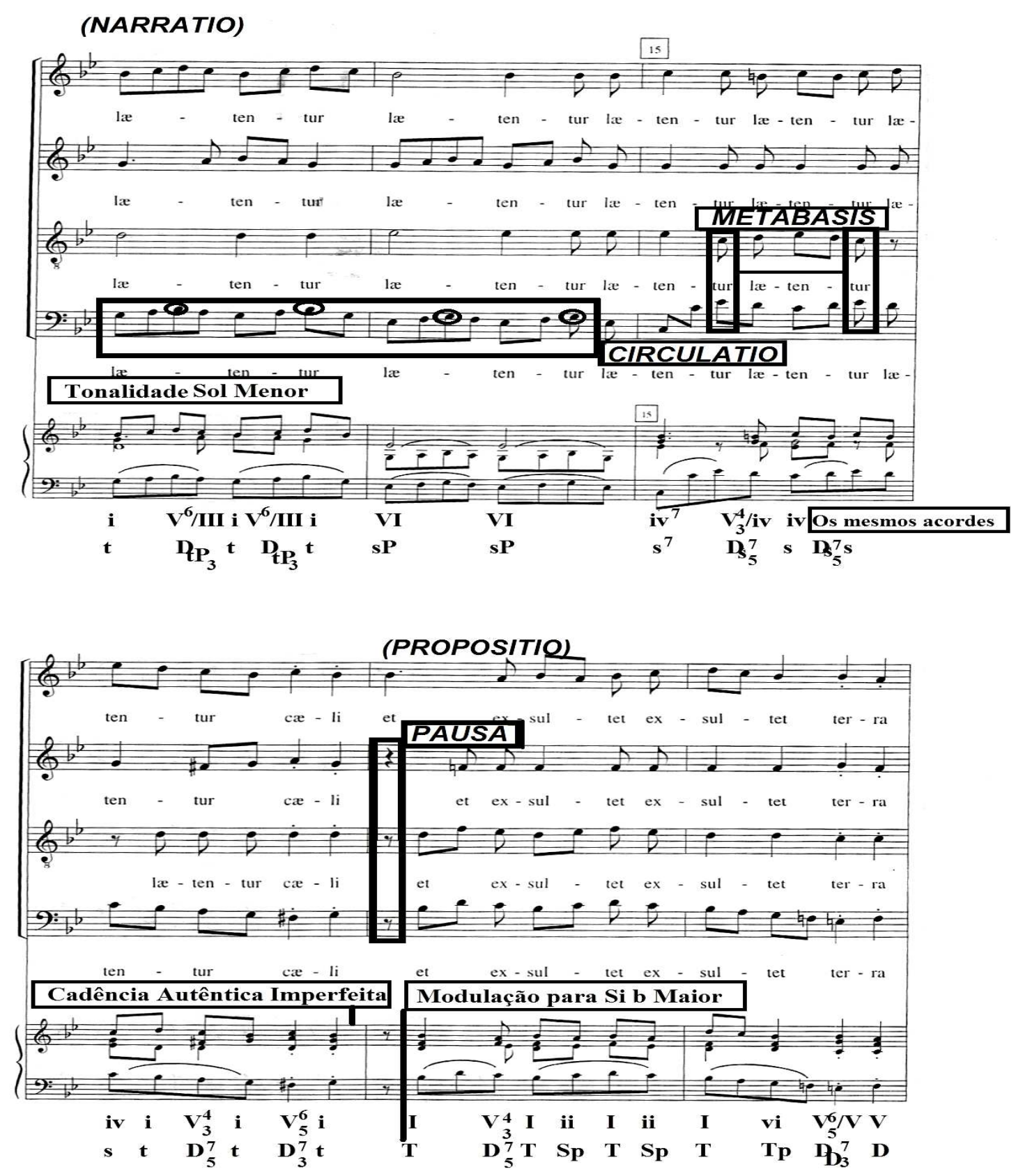

Exemplo 129: Ofertório da Missa de Natal de André da Silva Gomes- Catalogação e Organização Régis Duprat (DUPRAT, 1999, p.197). 


\subsubsection{Propositio}

$\mathrm{Na}$ Propositio continua a ser utilizada a Epizeuxis, reforçando a ideia de celebração, alegria e júbilo, através da repetição enfática da expressão exsultet terra.

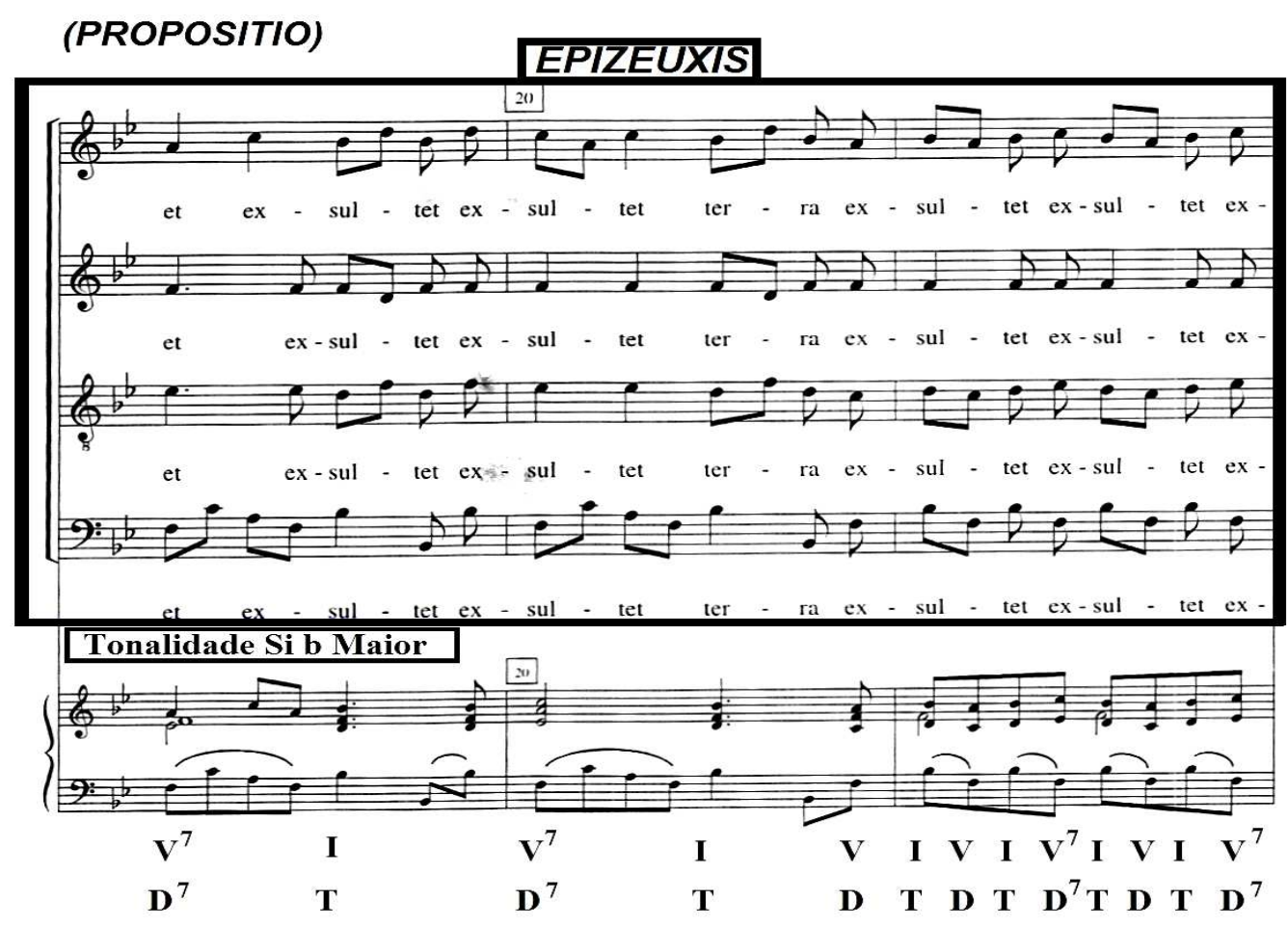

EPIZEUXIS

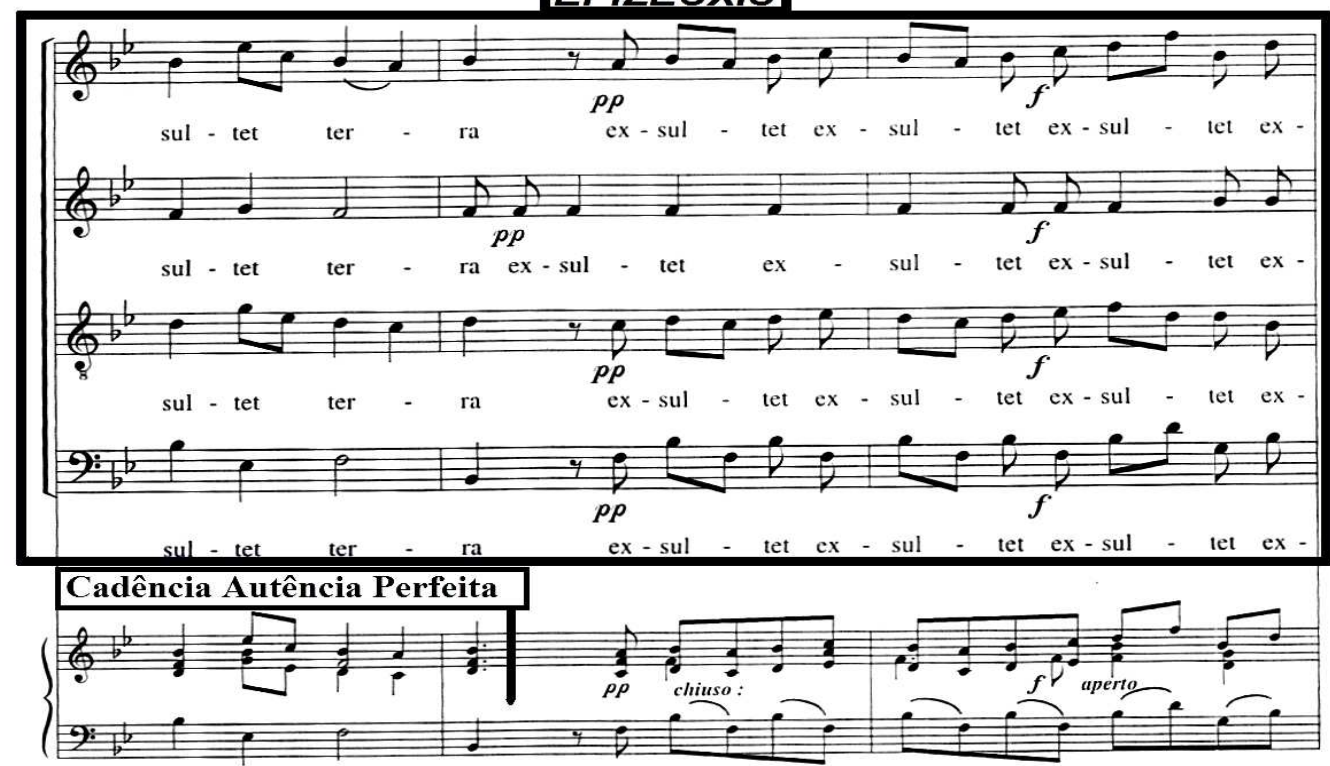
$\begin{array}{lllll}\mathrm{I} & \mathrm{IV} & \mathrm{I}_{4}^{6} & \mathrm{~V} & \mathrm{I}\end{array}$

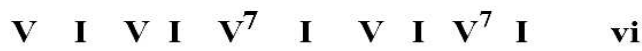
$\mathrm{T} \quad \mathrm{S} \quad \mathrm{D}_{4}^{6-5} \mathbf{3} \quad \mathrm{T}$
$\begin{array}{llllllllllllll}\mathbf{D} & \mathbf{T} & \mathbf{D} & \mathbf{T} & \mathbf{D}^{7} & \mathbf{T} & \mathbf{D} & \mathbf{T} & \mathbf{D}^{7} & \mathbf{T} & \mathbf{T p}\end{array}$

Exemplo 130: Ofertório da Missa de Natal de André da Silva Gomes- Catalogação e Organização Régis Duprat (DUPRAT, 1999, p.198). 
A presente seção se encerra com a aplicação da Synaeresis, destacando as duas notas na mesma silaba interpretada pelo tenor, nos compassos 26 e 27 e também pela Pausa nas quatro vozes, preparando a entrada do solo na parte seguinte.

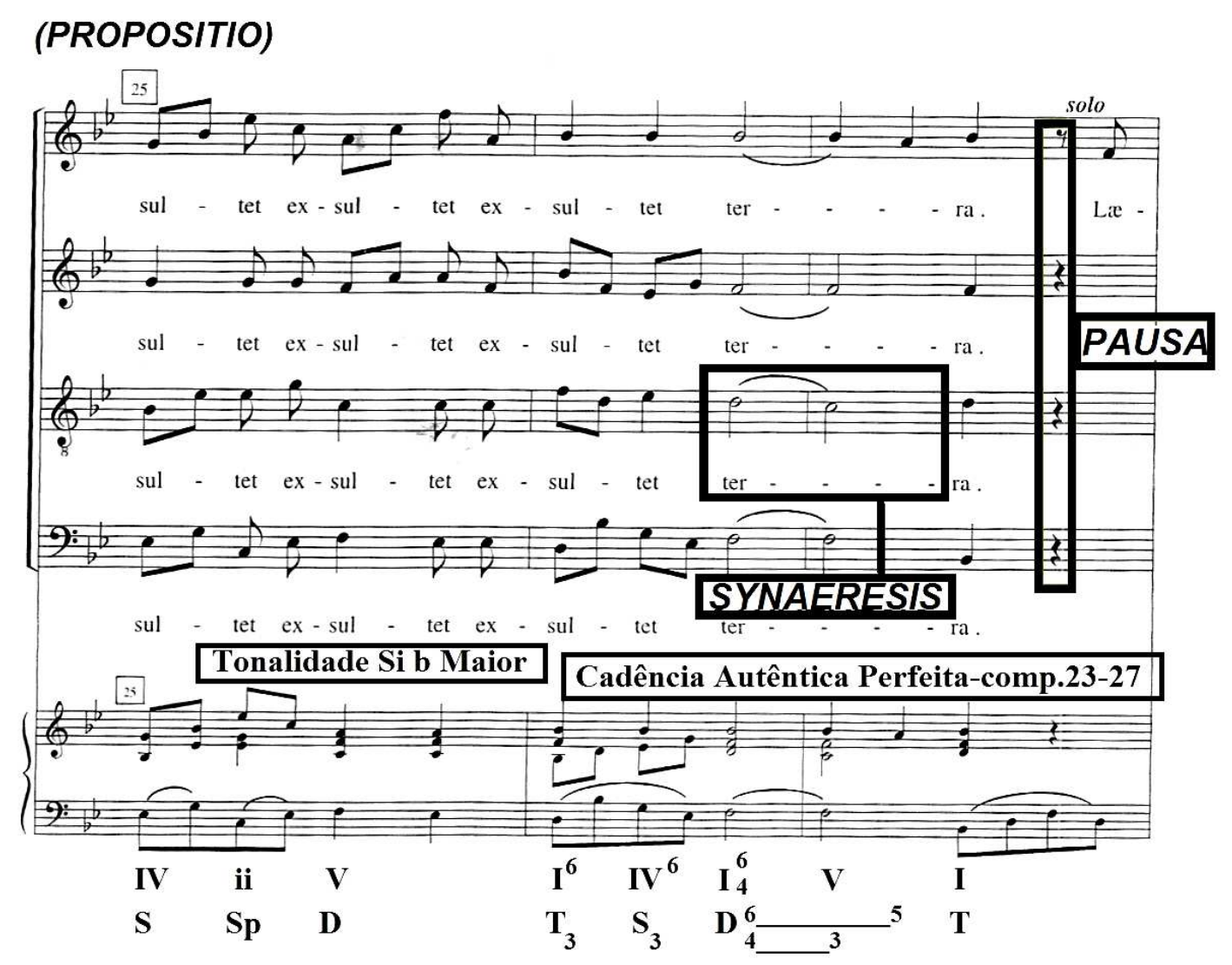

Exemplo 131: Ofertório da Missa de Natal de André da Silva Gomes- Catalogação e Organização Régis Duprat (DUPRAT, 1999, p.199).

\subsubsection{Confutatio}

Os elementos de contraste são empregos pelo compositor com intuito de impressionar o ouvinte, sejam pelas figuras, funções harmônicas, motivos, dinâmicas e afetos representados. Nesse caso, Silva Gomes, desenvolve o argumento do discurso ressaltando tanto a expressão céu e terra introduzindo a Circulatio para destacar a nota Ré, como enfatizar através da Tônica e Dominante o sobrenatural e o terreno, podendo ser interpretada não só como o louvor que os seres devam dar ao Senhor, mas também as duas naturezas de Jesus, divina e humana. Por fim, a narração dos fatos expostos, caracterizando uma Narratio dentro da Confutatio. 


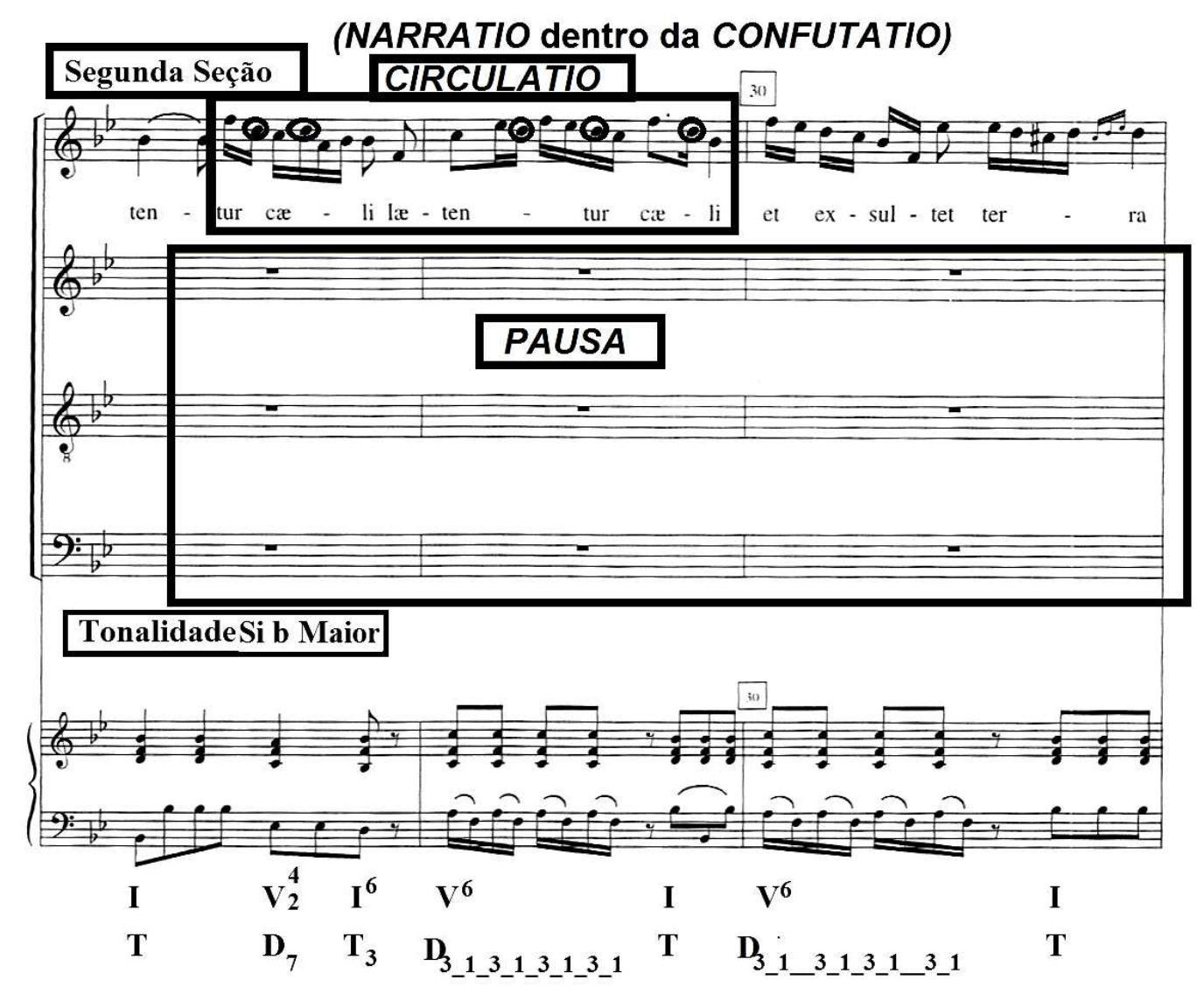

Exemplo 132: Ofertório da Missa de Natal de André da Silva Gomes- Catalogação e Organização Régis Duprat (DUPRAT, 1999, p.199).

O autor desenvolve a mesma linha de raciocínio trabalhada no excerto anterior, no entanto, empregando a figura da Synonimia juntamente com a Circulatio, salientando de maneira enfática o momento de alegria repetindo cinco vezes a expressão exsultet terra, lembrando ao auditório a relevância da natalidade de Cristo e intentando despertar o pathos de quem ouve, por meio da expectativa gerada pela suspensão do acorde de Dominante na terminação da frase em Semicadência, no compasso 35. 

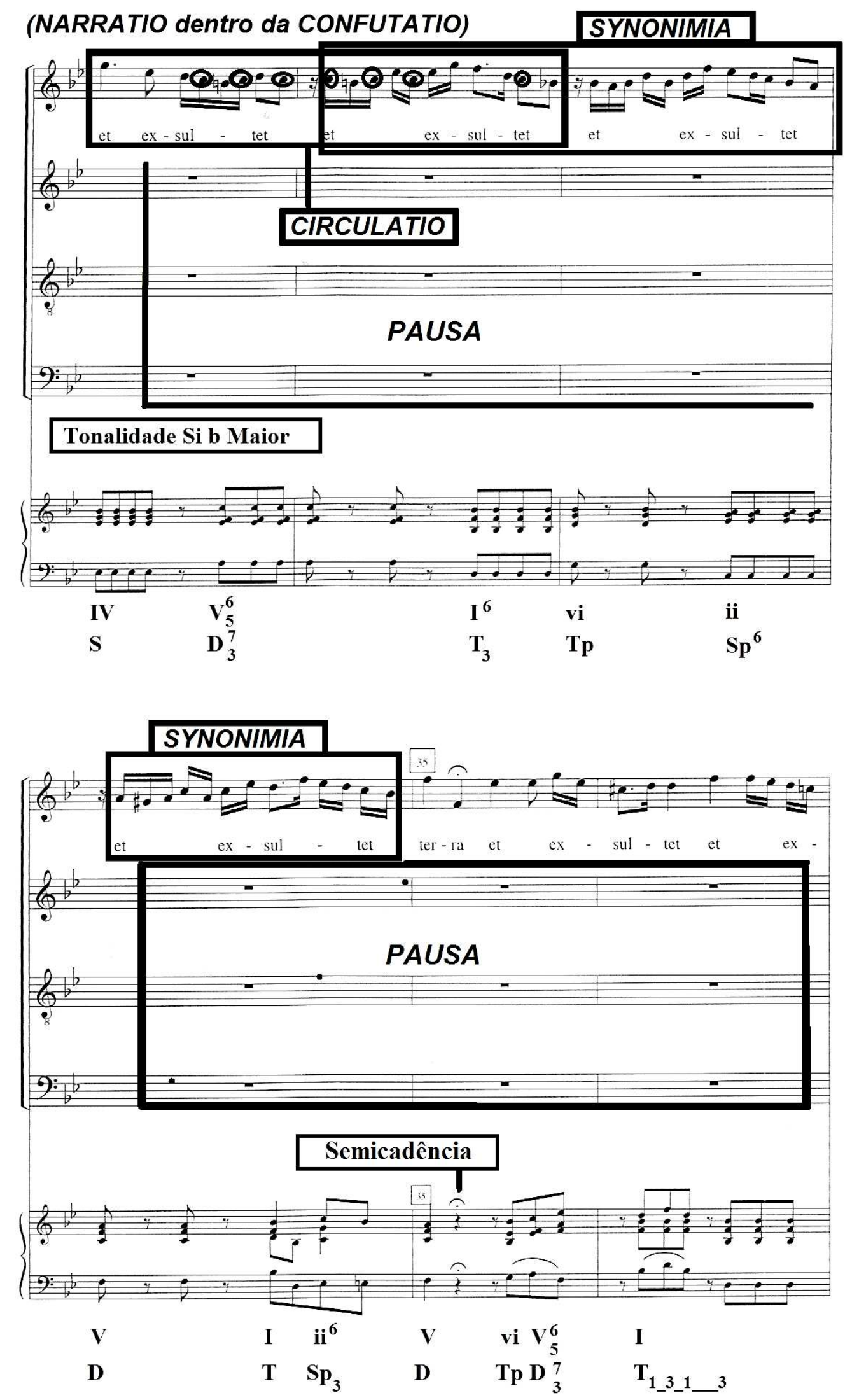

Exemplo 133: Ofertório da Missa de Natal de André da Silva Gomes- Catalogação e Organização Régis Duprat (DUPRAT, 1999, p.200). 
A Narratio dentro da Confutatio se finaliza com a utilização da Tiratanos compassos 37-38; 40-41, destacando as passagens escalares rápidas, ambas com terminação na Cadência Autêntica Perfeita.
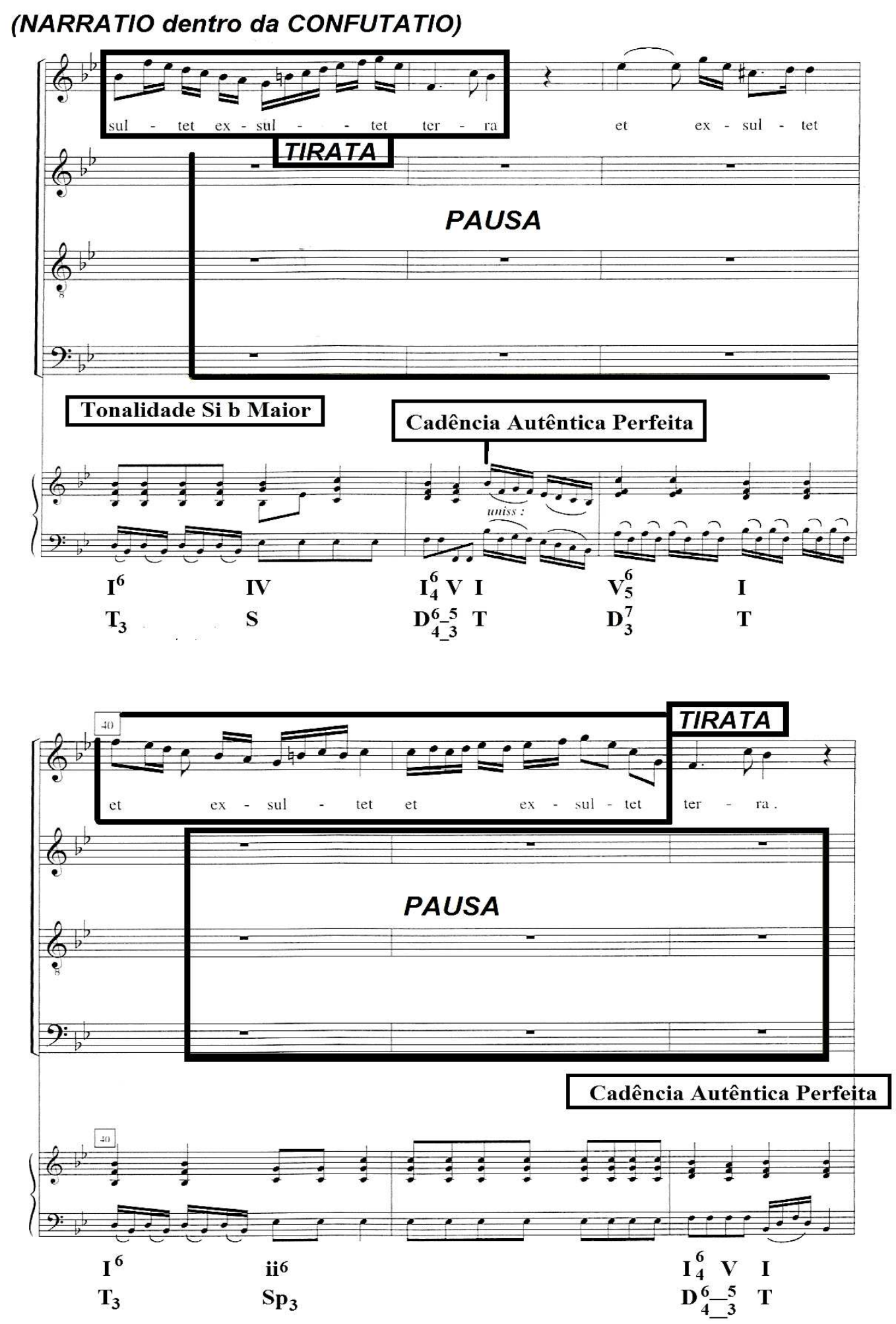

Exemplo 134: Ofertório da Missa de Natal de André da Silva Gomes- Catalogação e Organização Régis Duprat (DUPRAT, 1999, p.201). 
A atenção e expectativa do ouvinte são postas em prova pelo autor, com o incremento de três figuras de repetição melódica, Anaphora, Synaeresis e Epizeuxis. Da mesma forma, pela repetição dos mesmos materiais do começo da obra, evidenciando uma Exordium dentro da Confutatio e por fim, a aplicação da Semicadência antecipando a modulação para Fá Maior, no compasso 45.

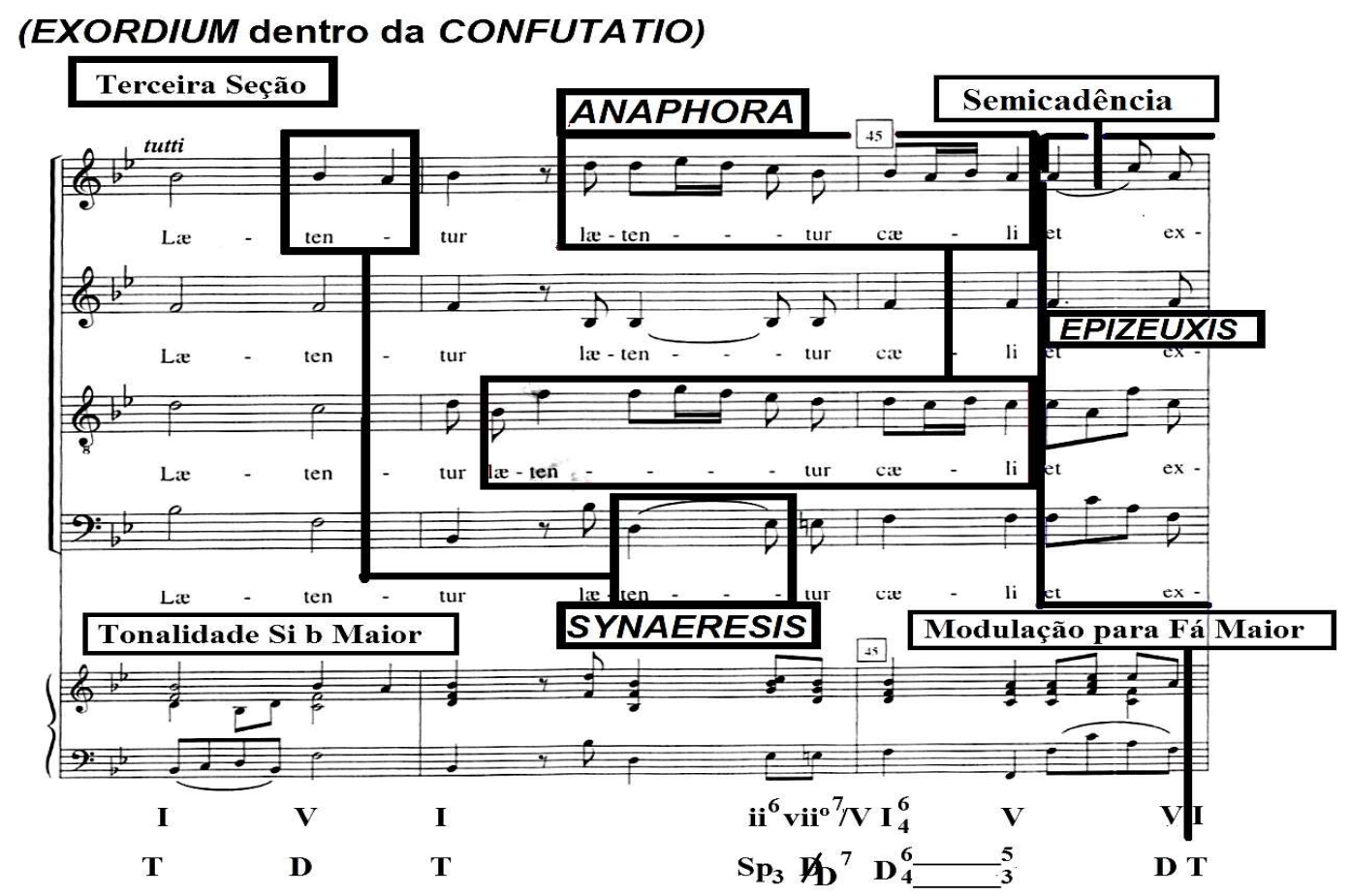

EPIZEUXIS

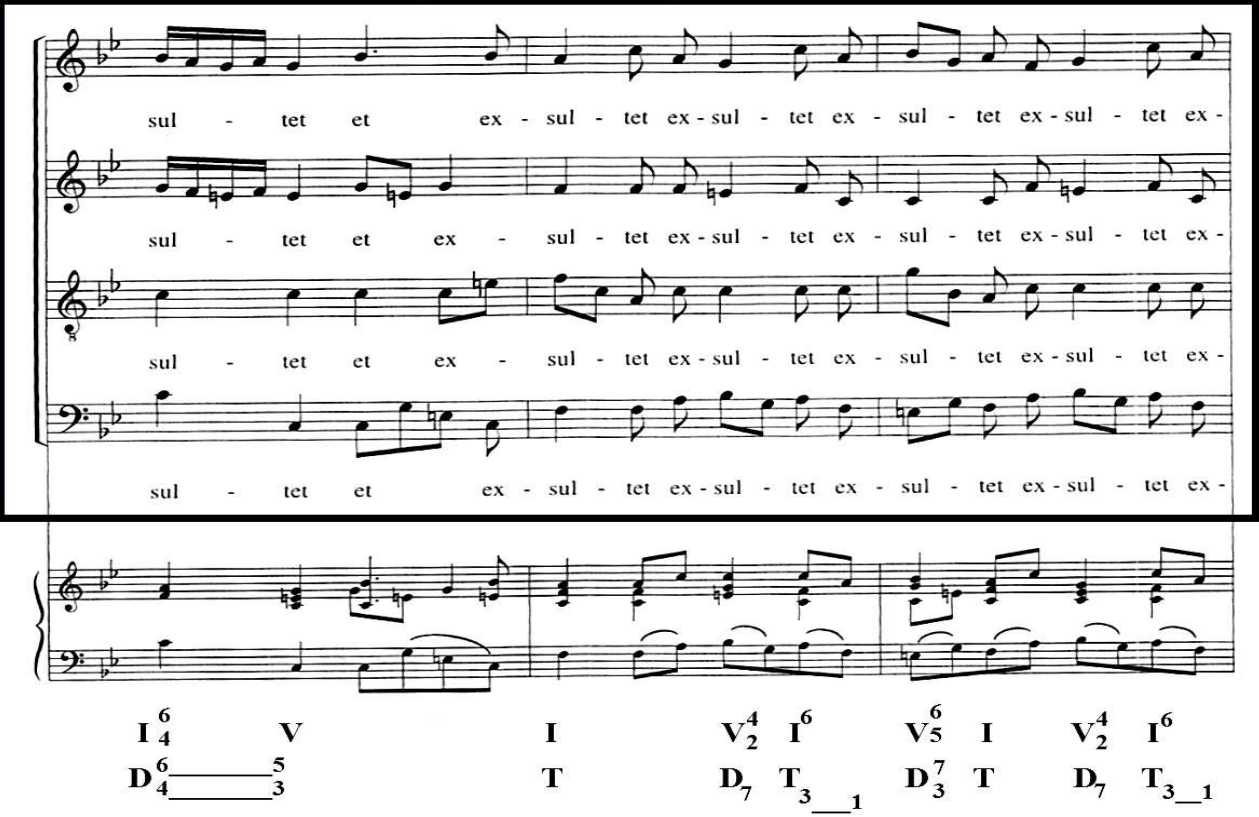

Exemplo 135: Ofertório da Missa de Natal de André da Silva Gomes- Catalogação e Organização Régis Duprat (DUPRAT, 1999, p.202). 
A Confutatio se encerra de maneira a destacar o afeto de celebração e devoção, por meio da Anaphora, Gradatio, Synaeresis e da Pausa, ambas aludindo a pessoa reverenciada (Jesus), seja pelas repetições das palavras, sequências das notas, ressaltando as notas em uma silaba ou no silêncio como ato de reflexão logo após a tensão causada pela terminação da Semicadência, no compasso 52.

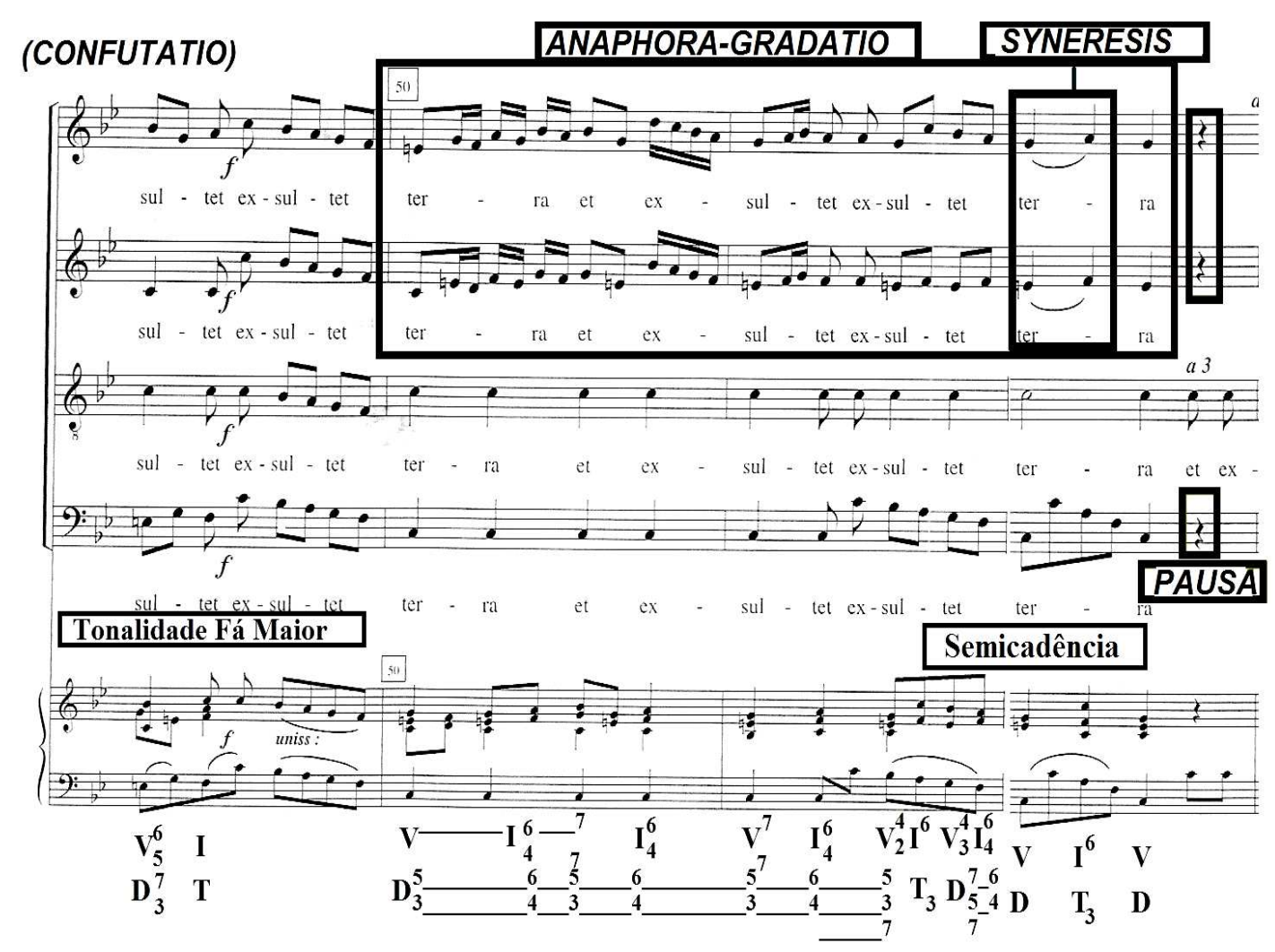

Exemplo 136: Ofertório da Missa de Natal de André da Silva Gomes- Catalogação e Organização Régis Duprat (DUPRAT, 1999, p.203).

\subsubsection{Confirmatio}

Com o uso da Gradatio, valorando o movimento das vozes da soprano e contralto por terças paralelas, repetindo as notas e as palavras, além da Pausa no baixo, verifica-se não somente as repetições das imagens, mas a confirmação das ideias iniciais da peça: que todos os seres no céu como na terra devem se alegrar e exultar o aparecimento do filho de Deus no mundo terrestre. 


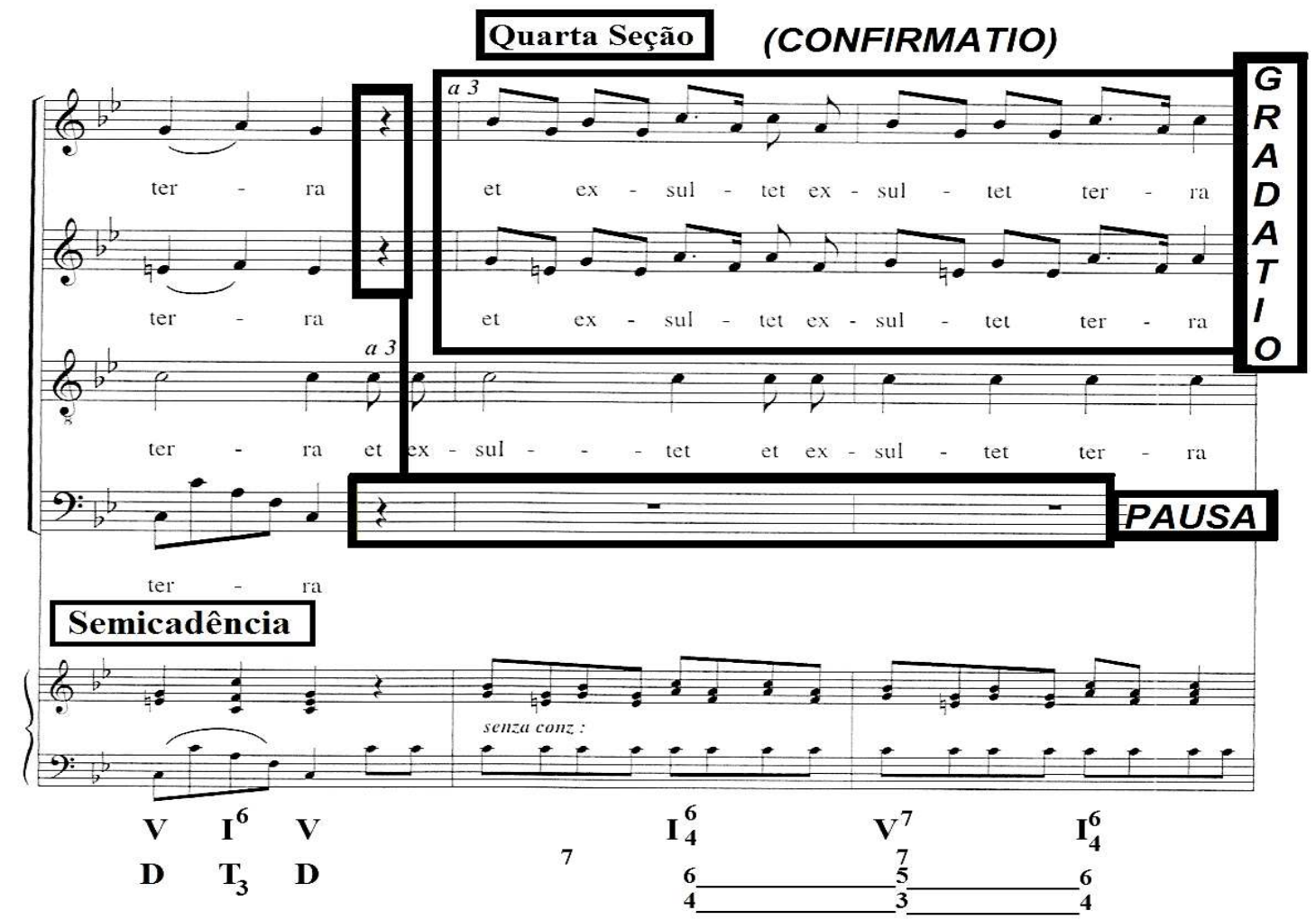

Exemplo 137: Ofertório da Missa de Natal de André da Silva Gomes- Catalogação e Organização Régis Duprat (DUPRAT, 1999, p.203).

Nota-se a abaixo os mesmos procedimentos utilizados pelo autor, seja nas figuras, quanto nas expressões.

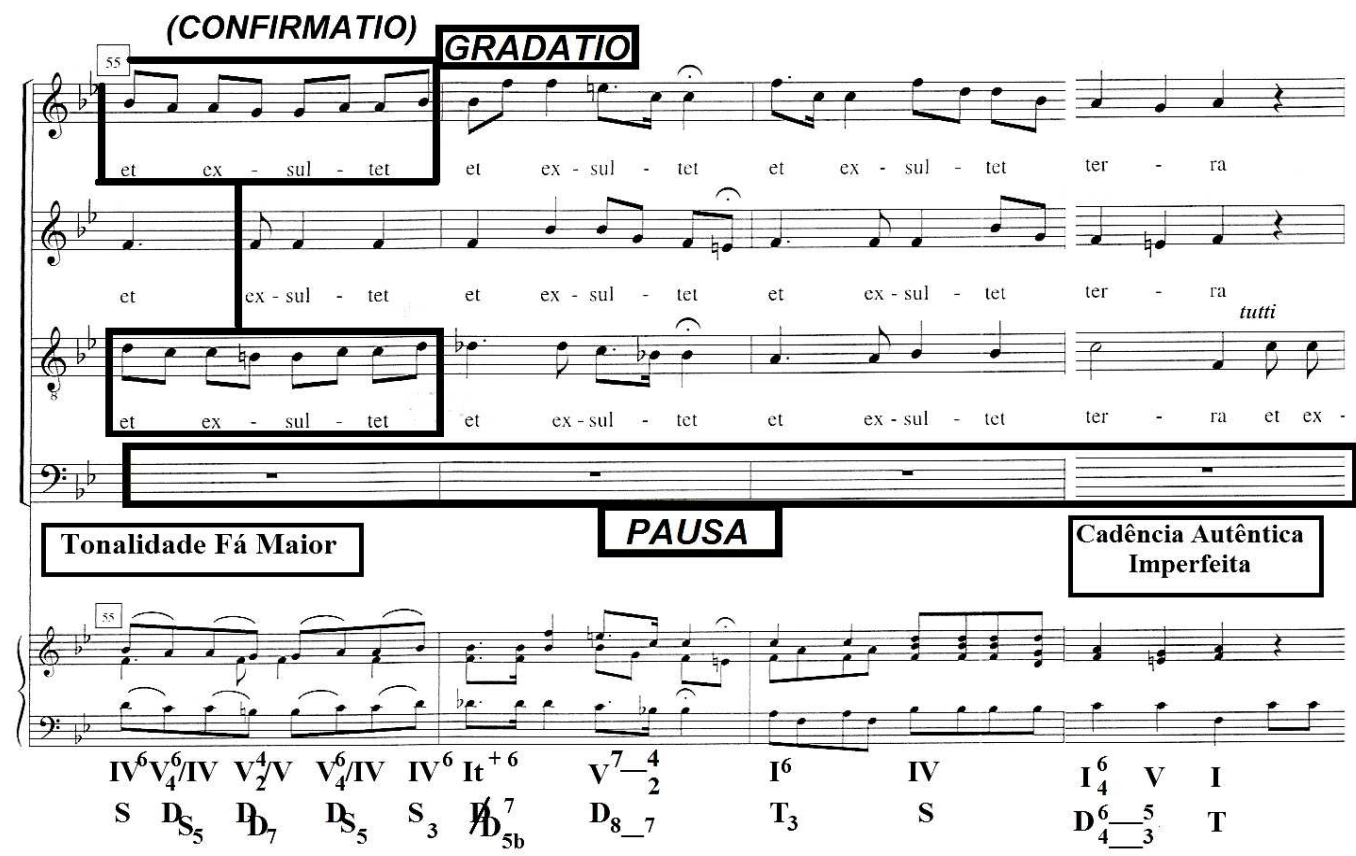

Exemplo 138: Ofertório da Missa de Natal de André da Silva Gomes- Catalogação e Organização Régis Duprat (DUPRAT, 1999, p.204). 


\subsubsection{Perotatio}

$\mathrm{Na}$ conclusão do discurso a figura central do primeiro movimento do ofertório, Epizeuxis é empregada pelo autor enfatizando com ardor o sentimento de louvação do salmista.

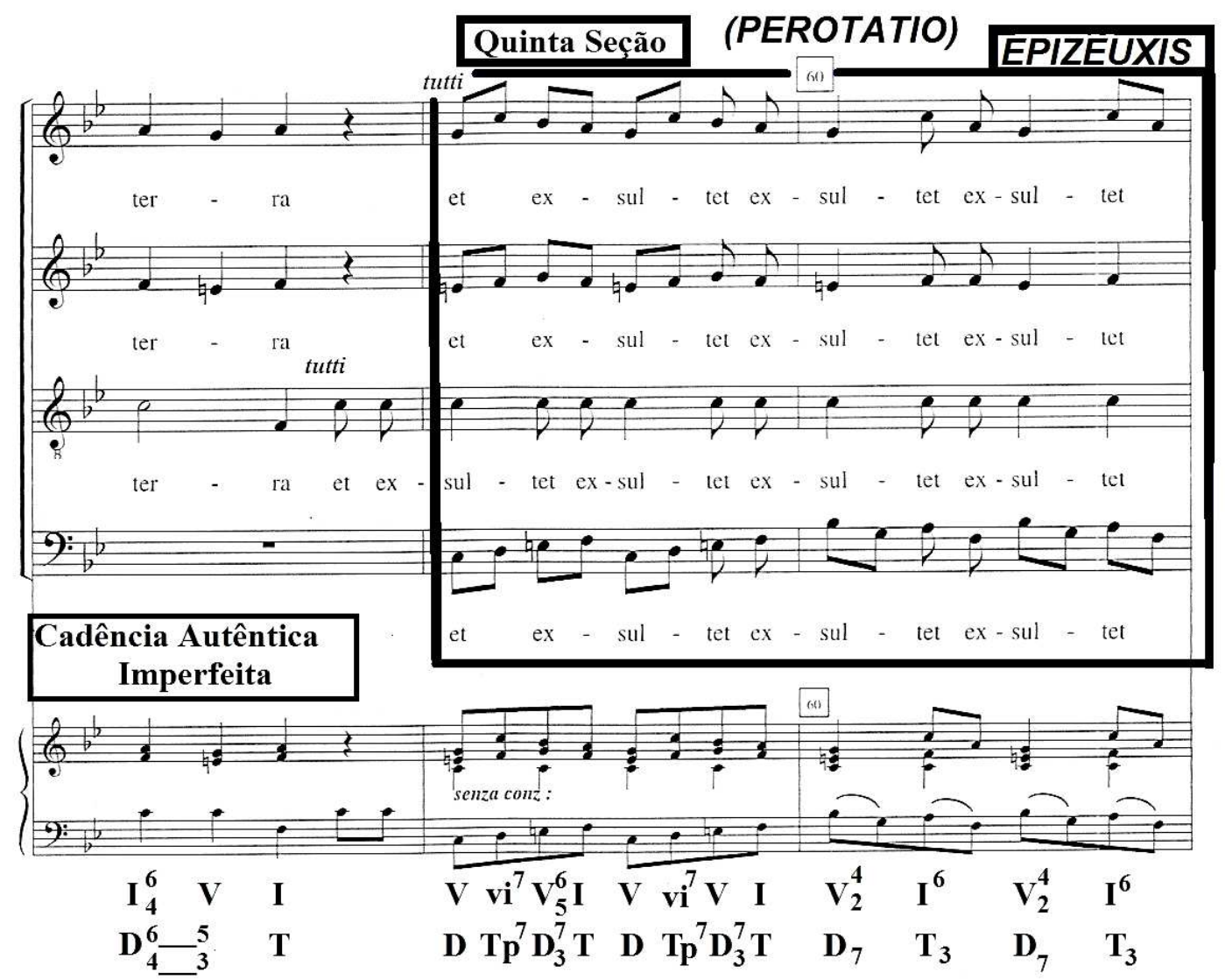
Exemplo 139: Ofertório da Missa de Natal de André da Silva Gomes- Catalogação e
Organização Régis Duprat (DUPRAT, 1999, p.204).

O ápice da repetição e intensidade de enfatizar o encômio atribuído ao Senhor, se evidencia nessa passagem de seis compassos, onde o celebrante alude nada menos que oito vezes a frase exsultet terra, em outras palavras, Silva Gomes, aplica a Epizeuxis para ressaltar esse momento de êxtase, na tonalidade inicial da obra, Si bemol Maior. 


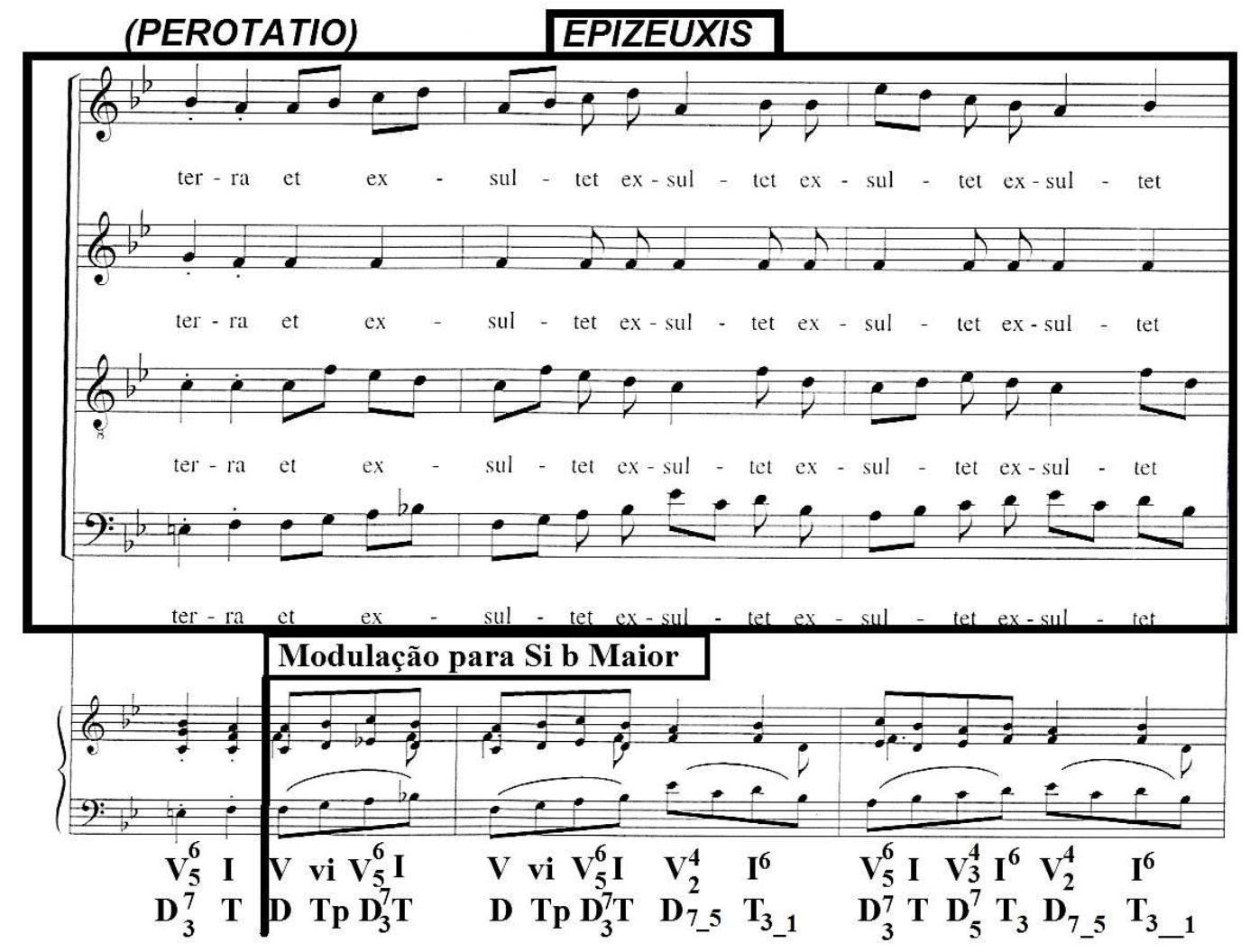

\section{EPIZEUXIS}

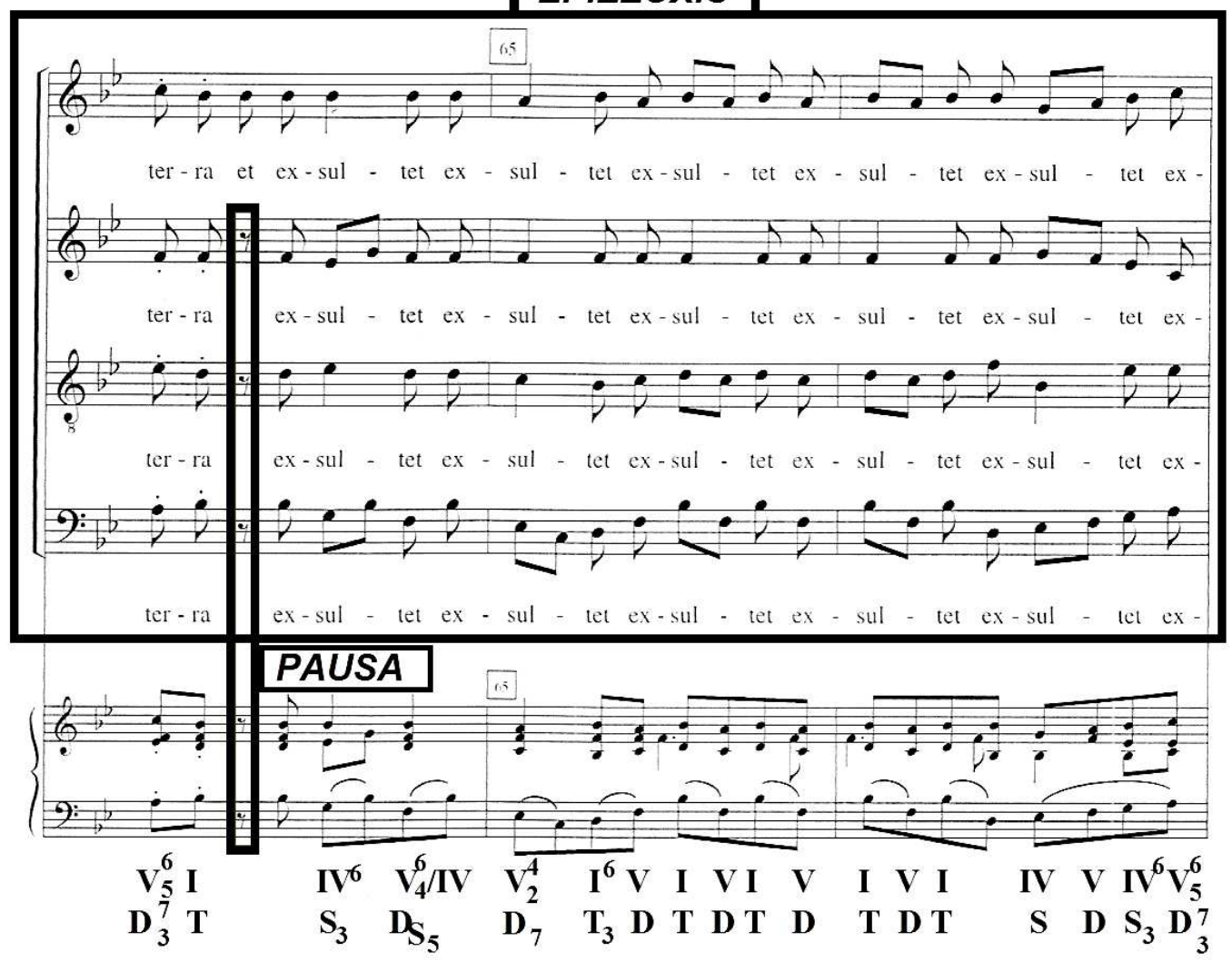

Exemplo 140: Ofertório da Missa de Natal de André da Silva Gomes- Catalogação e Organização Régis Duprat (DUPRAT, 1999, p.205). 
Em síntese, essa parte é concluída com as figuras da Epizeuxis e Synaeresis, numa Semicadência, sem resolução na Tônica provocando no ouvinte maior curiosidade e também atraindo sua atenção para o segundo movimento e desfecho da obra.

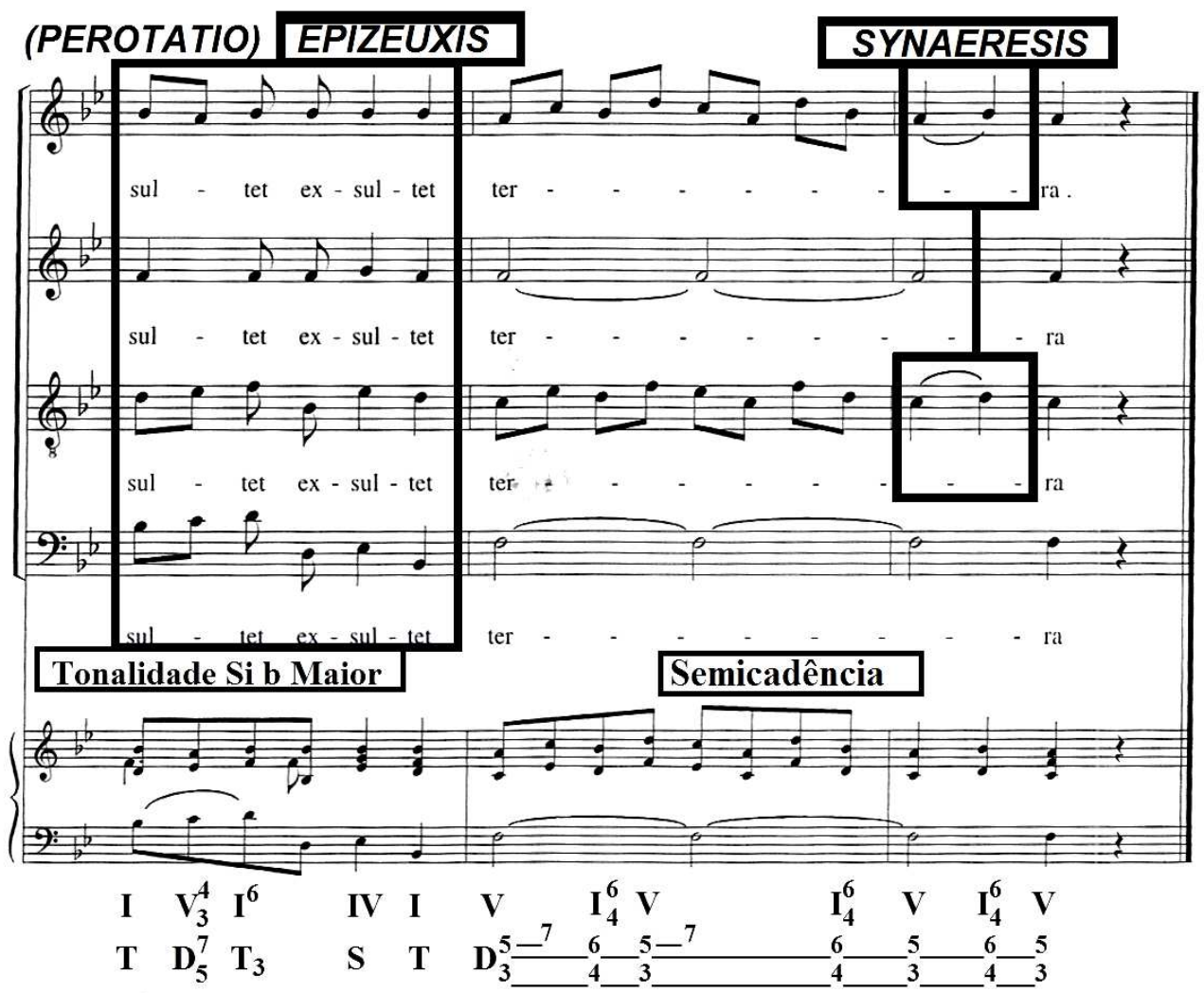

Exemplo 141: Ofertório da Missa de Natal de André da Silva Gomes- Catalogação e Organização Régis Duprat (DUPRAT, 1999, p.206).

\subsubsection{Exordium (Segundo Movimento)}

Assim como no Ofertório da Missa da Ascensão do Senhor, o segundo movimento é iniciado com entradas deslocadas das vozes em sequência a cada dois compassos, onde a expressão Ante faciem Domini é desenvolvida pelo compositor polifonicamente e com textura contrapontística. Destarte, as figuras Synaeresis, Polyptoton e Pausa completam esse sentido enfatizando tanto as palavras, quanto repetindo as notas em forma canônica. 


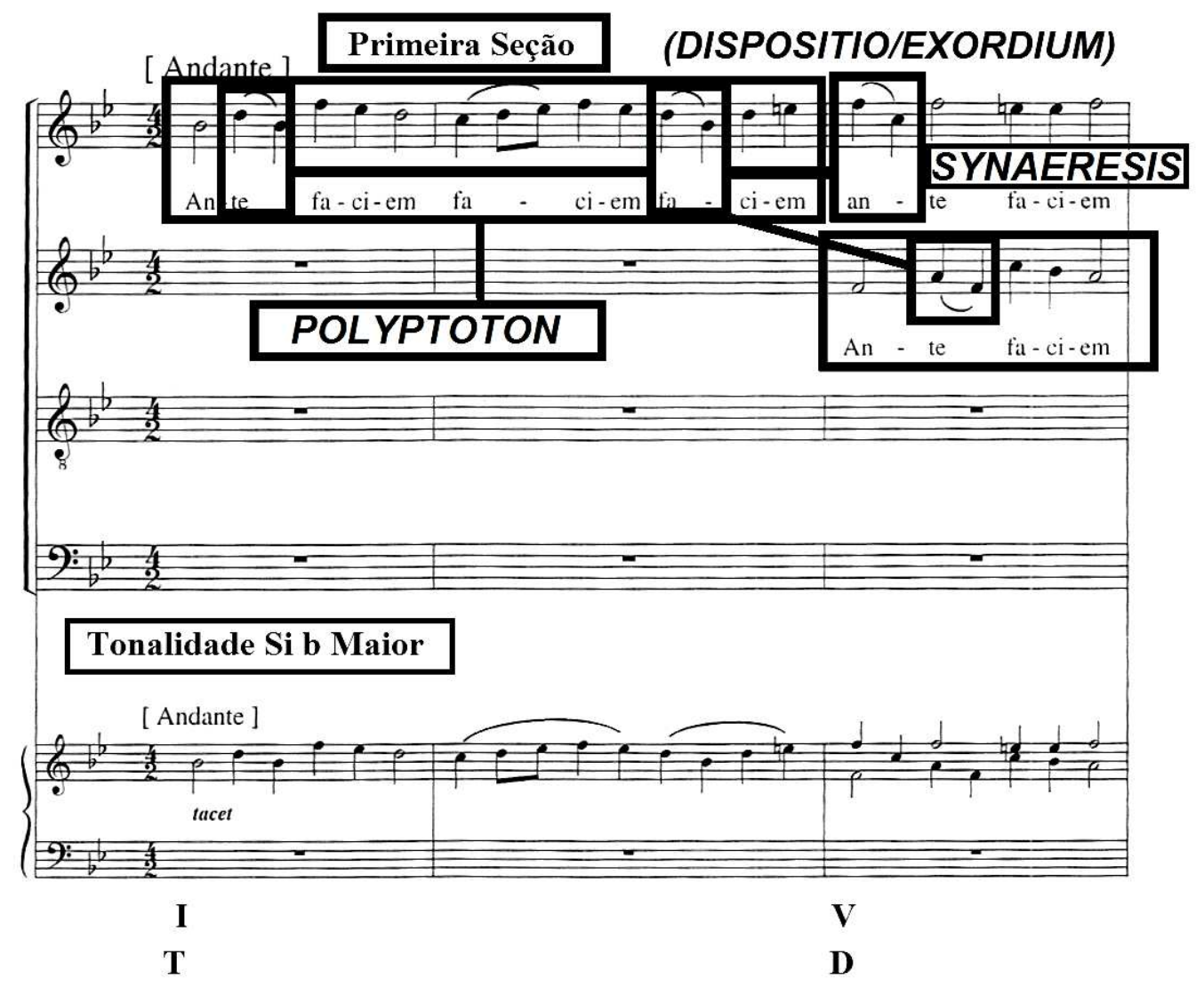

Exemplo 142: Ofertório da Missa de Natal de André da Silva Gomes- Catalogação e Organização Régis Duprat (DUPRAT, 1999, p.206).

A Exordium se encerra com as mesmas figuras e elementos utilizados no excerto anterior numa Cadência Autêntica Imperfeita. 
(EXORDIUM)
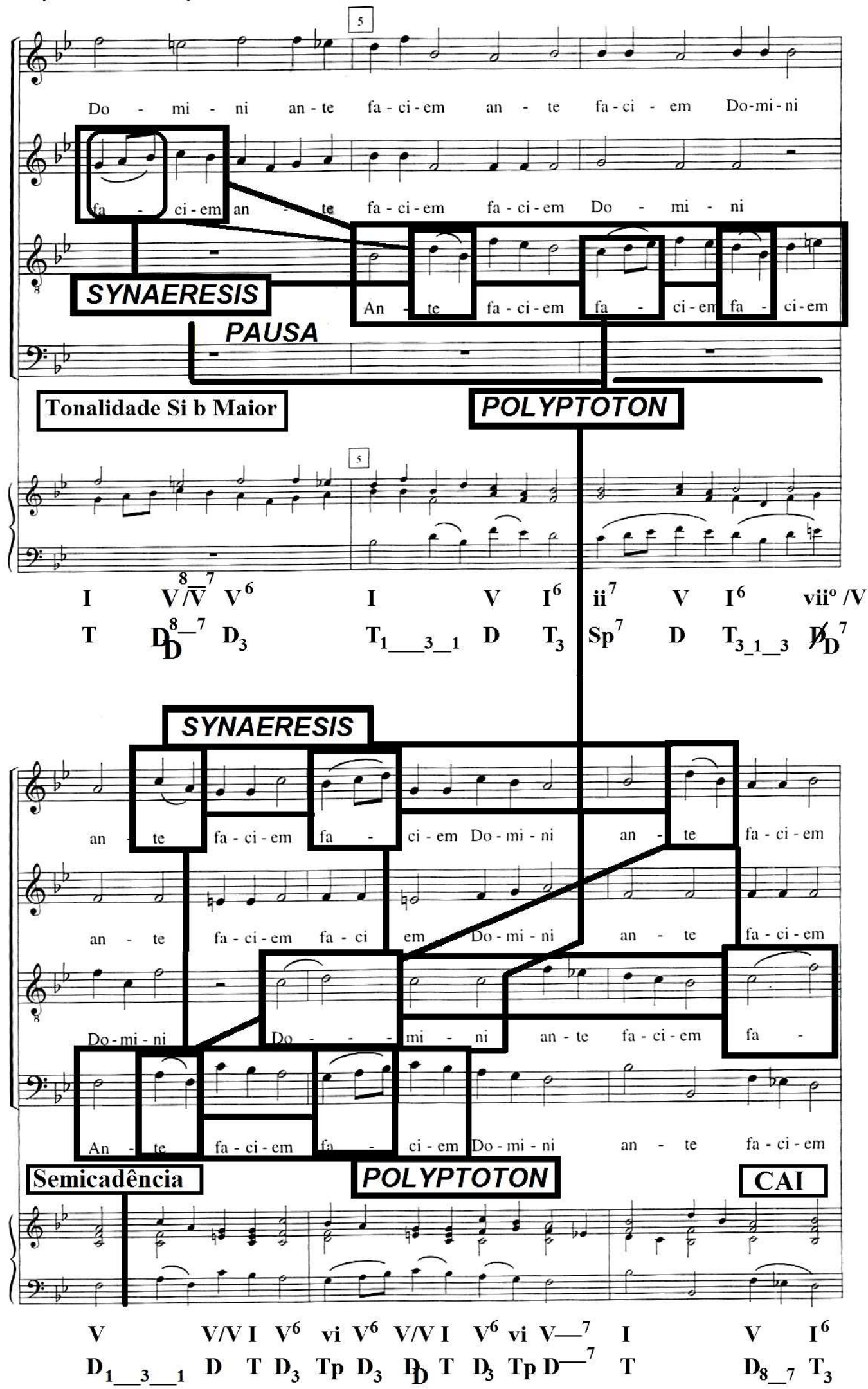

Exemplo 143: Ofertório da Missa de Natal de André da Silva Gomes- Catalogação e Organização Régis Duprat (DUPRAT, 1999, p.207). 


\subsubsection{Narratio}

No compasso 10, Silva Gomes emprega a Noema, enfatizado a passagem homofônica das vozes numa textura polifônica e contrapontística. Também, merece menção, o uso da Synaeresis, destacando a expressão faciem e quoniam venit, as quais interpretam duas notas por silaba, como das Cadências Autênticas Imperfeita e Perfeita, nos compassos 11 e 14.
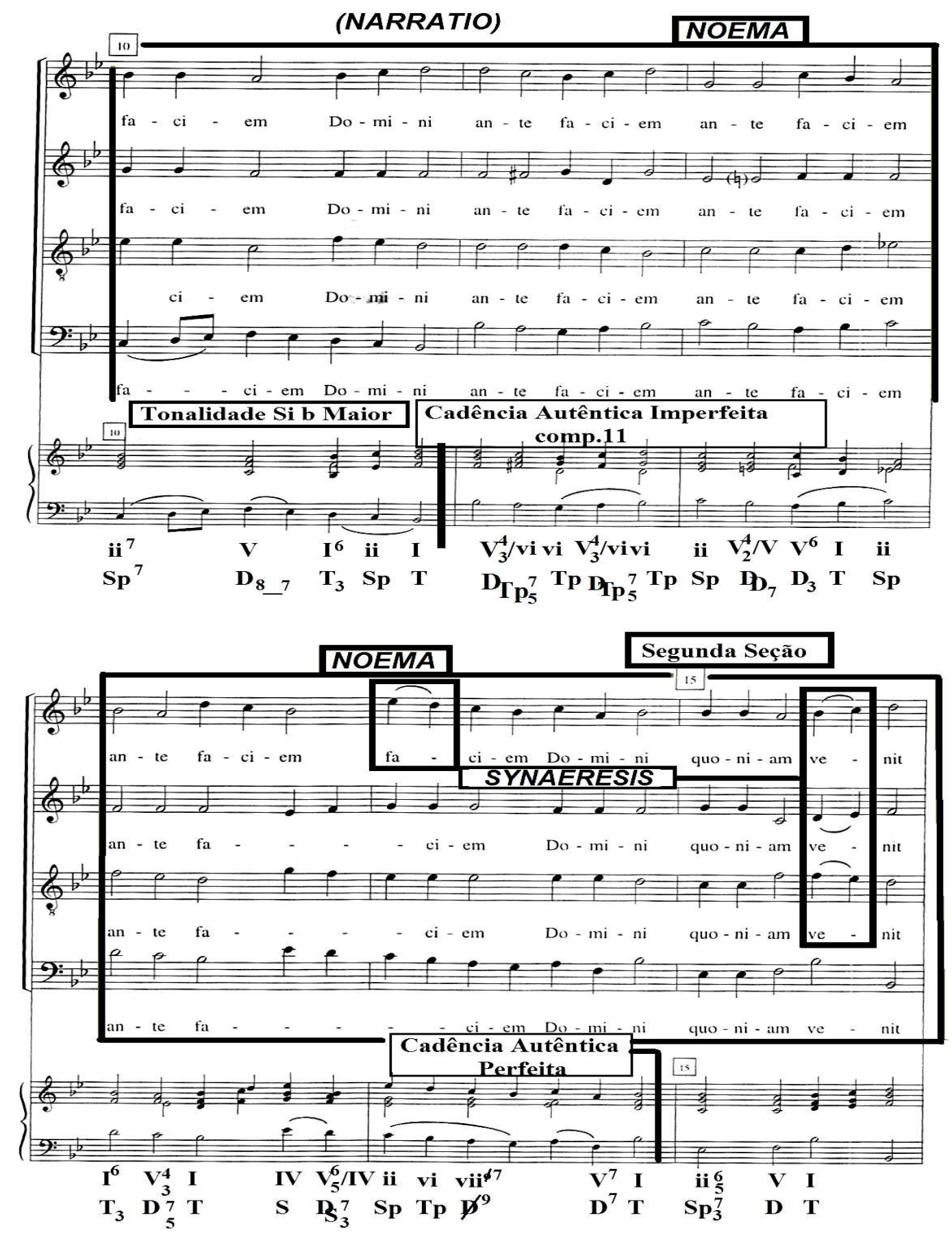

Exemplo 144: Ofertório da Missa de Natal de André da Silva Gomes- Catalogação e Organização Régis Duprat (DUPRAT, 1999, p.208). 
A Synaeresis como a Noema, são empregadas em toda Narratio, corroborando com a ideia do início desse movimento, que o Senhor vem. Igualmente são observáveis as funções usadas pelo compositor luso-brasileiro, tais como Tônica, Subdominante Paralela, Dominantes, Dominantes secundárias e a Sexta-Aumentada Francesa, que, juntamente a figuras descritas, ajudam a sustentar o discurso.
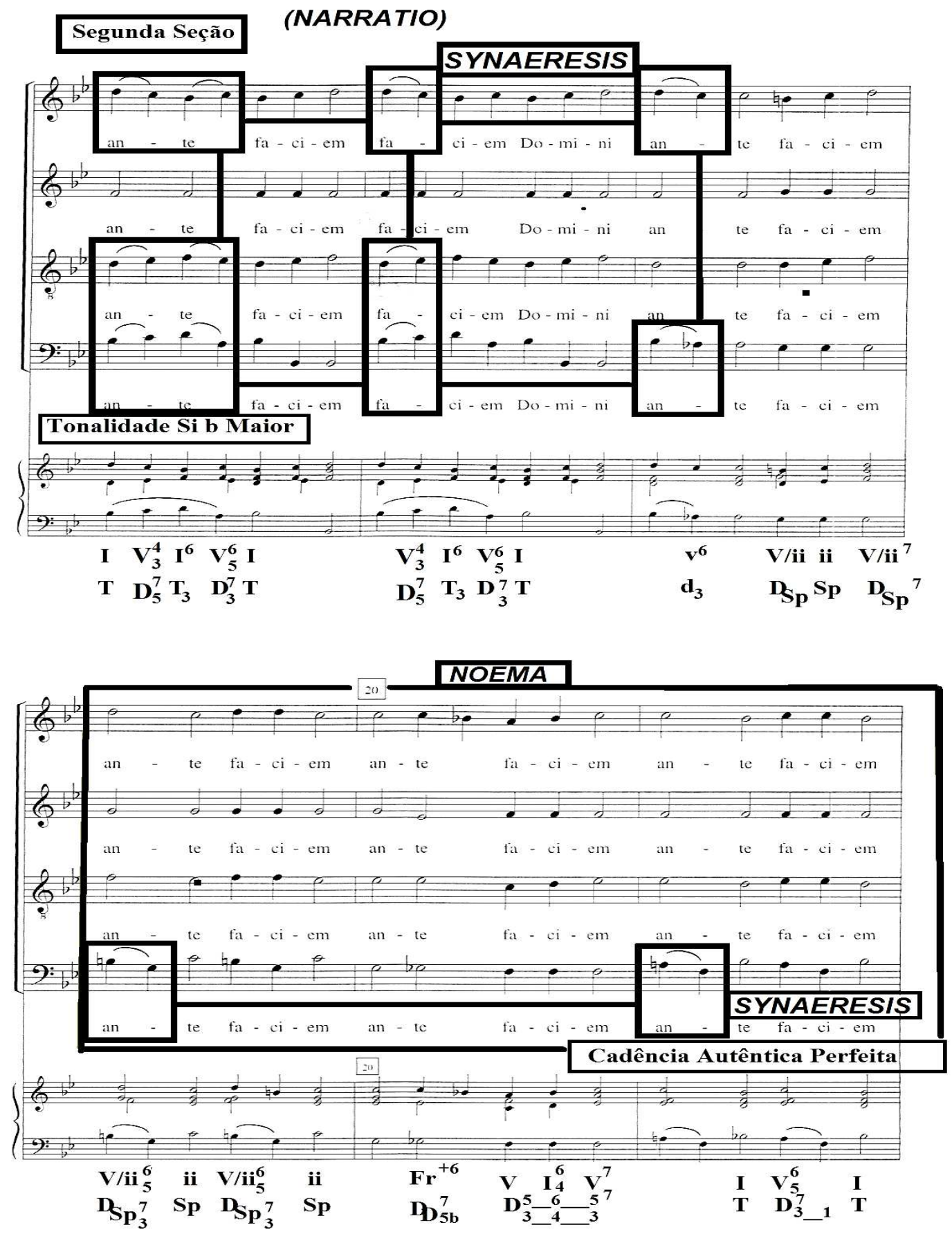

Exemplo 145: Ofertório da Missa de Natal de André da Silva Gomes- Catalogação e Organização Régis Duprat (DUPRAT, 1999, p.209). 


\subsubsection{Propositio}

A tese inicial é proferida de forma sucinta pelo autor, na mesma tonalidade e com figuras já utilizadas desde as fases anteriores, desta maneira o discurso é solidificado através das diversas repetições e ênfases.
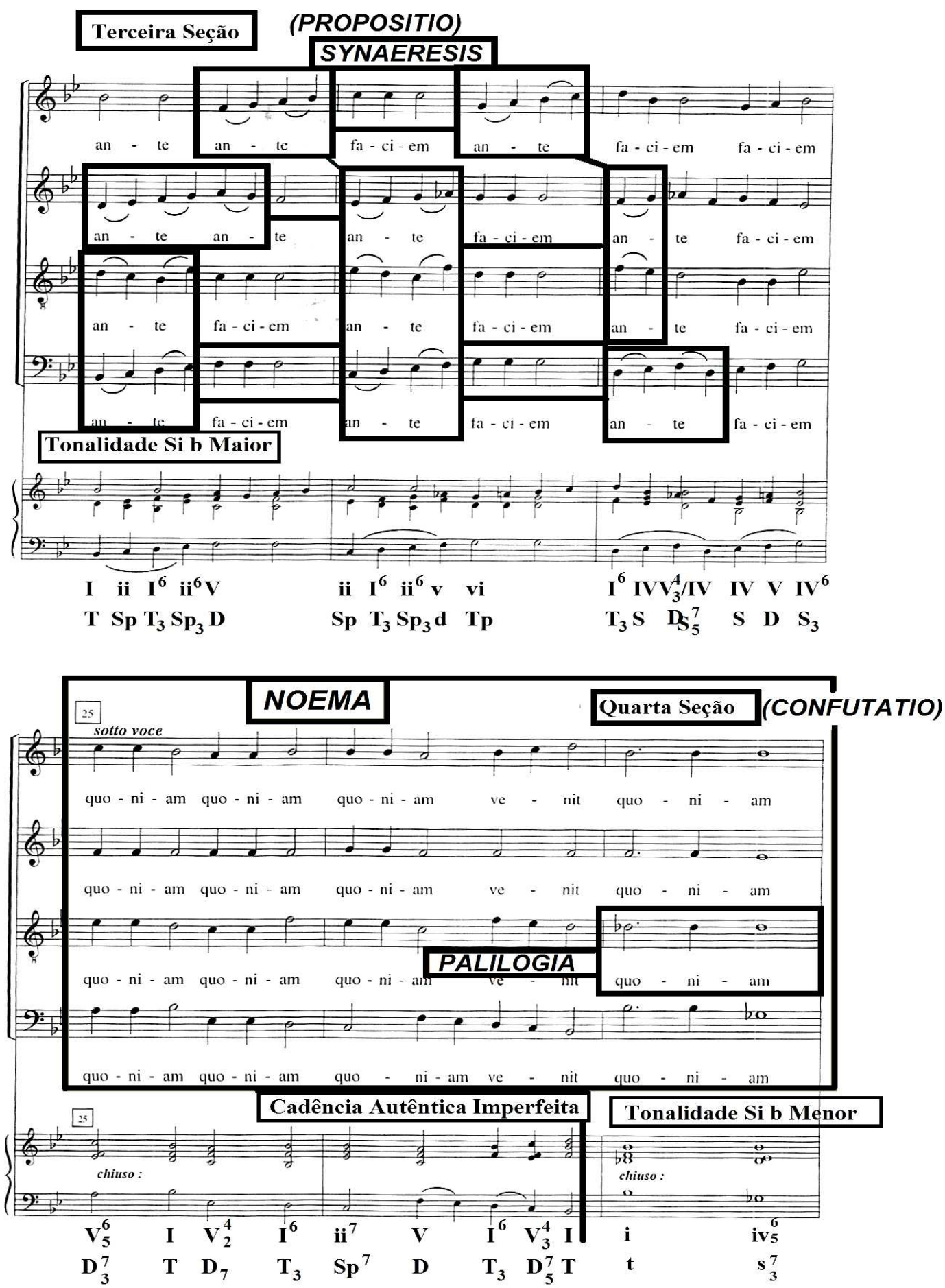

Exemplo 146: Ofertório da Missa de Natal de André da Silva Gomes- Catalogação e Organização Régis Duprat (DUPRAT, 1999, p.210). 


\subsubsection{Confutatio}

Acontece nessa seção um grande impacto, onde a progressão harmônica nos compassos 27 a início do 30, forma uma ambiência, mesmo de curta duração na tonalidade de Si bemol Menor. Tal procedimento contrastante é empregado para manter o interesse e expectativa do ouvinte em relação à obra. No mesmo contexto é verificável a empregabilidade da Synaeresis e Palilogia, enfatizando tanto a frase quoniam venit, quanto o efeito suspensivo na Dominante resultando na Semicadência.

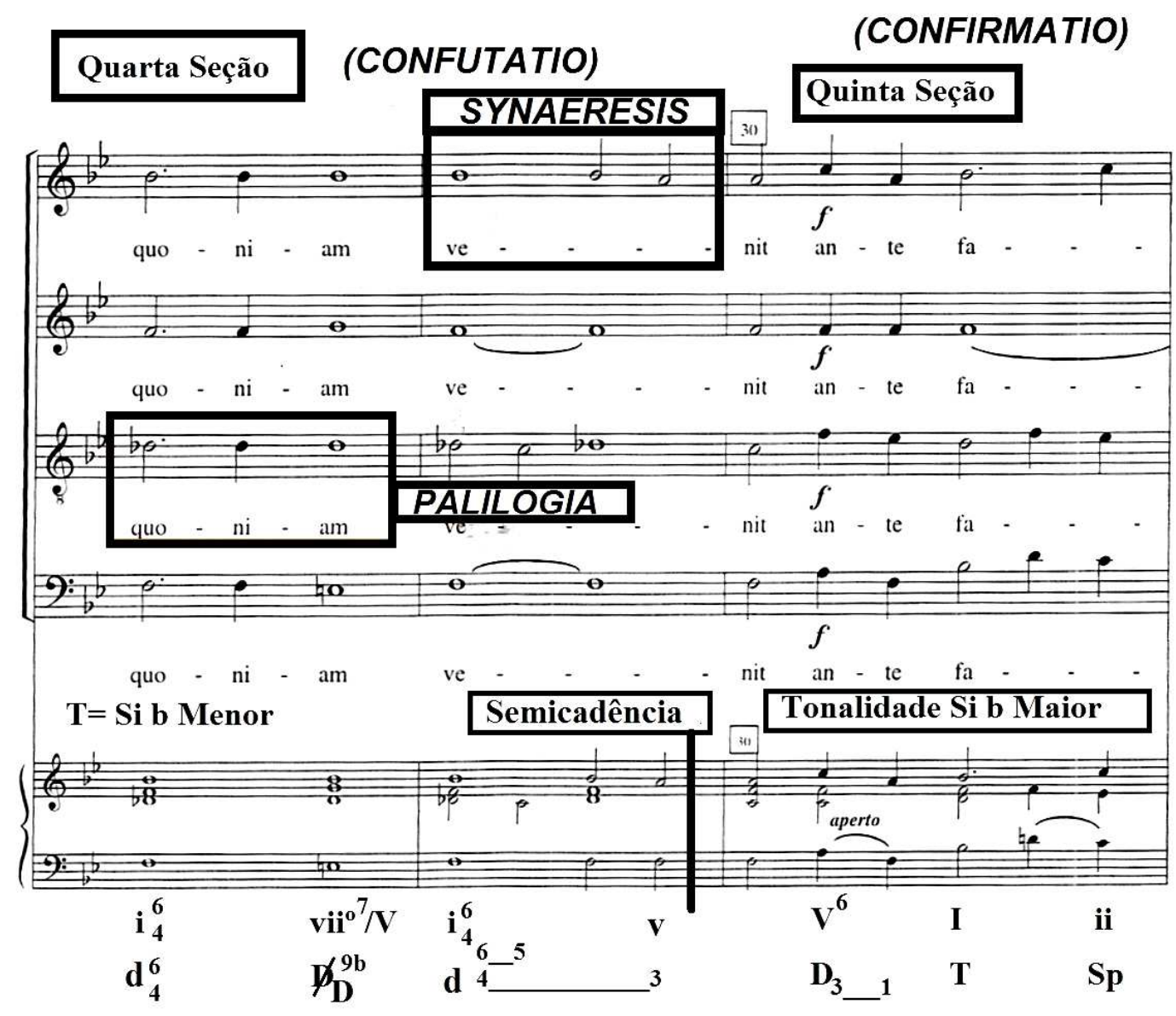

Exemplo 147: Ofertório da Missa de Natal de André da Silva Gomes- Catalogação e Organização Régis Duprat (DUPRAT, 1999, p.211).

\subsubsection{Confirmatio}

A Epizeuxis exaustivamente usada no primeiro movimento é novamente empregada pelo autor, juntamente com a Synaeresis, a mais trabalhada no segundo movimento, ressaltando por meio de repetição as funções, palavras e melodias da peça. 


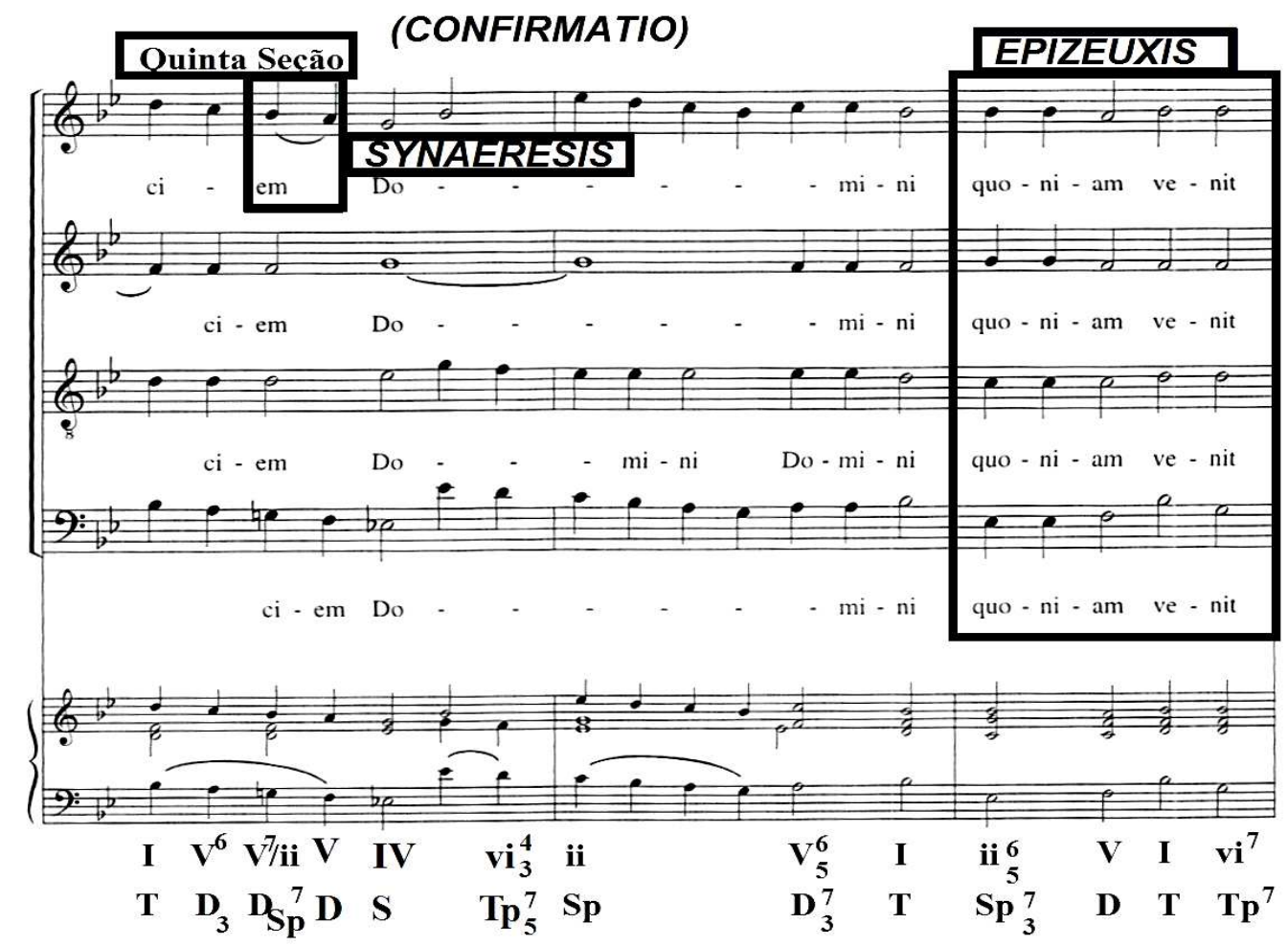

Exemplo 148: Ofertório da Missa de Natal de André da Silva Gomes- Catalogação e Organização Régis Duprat (DUPRAT, 1999, p.211).

Com a Cadência Autêntica Perfeita e o uso da Epizeuxis, é encerrada a Confirmatio, onde os argumentos preeminentes elaborados dentro da tese e discurso são confirmados.

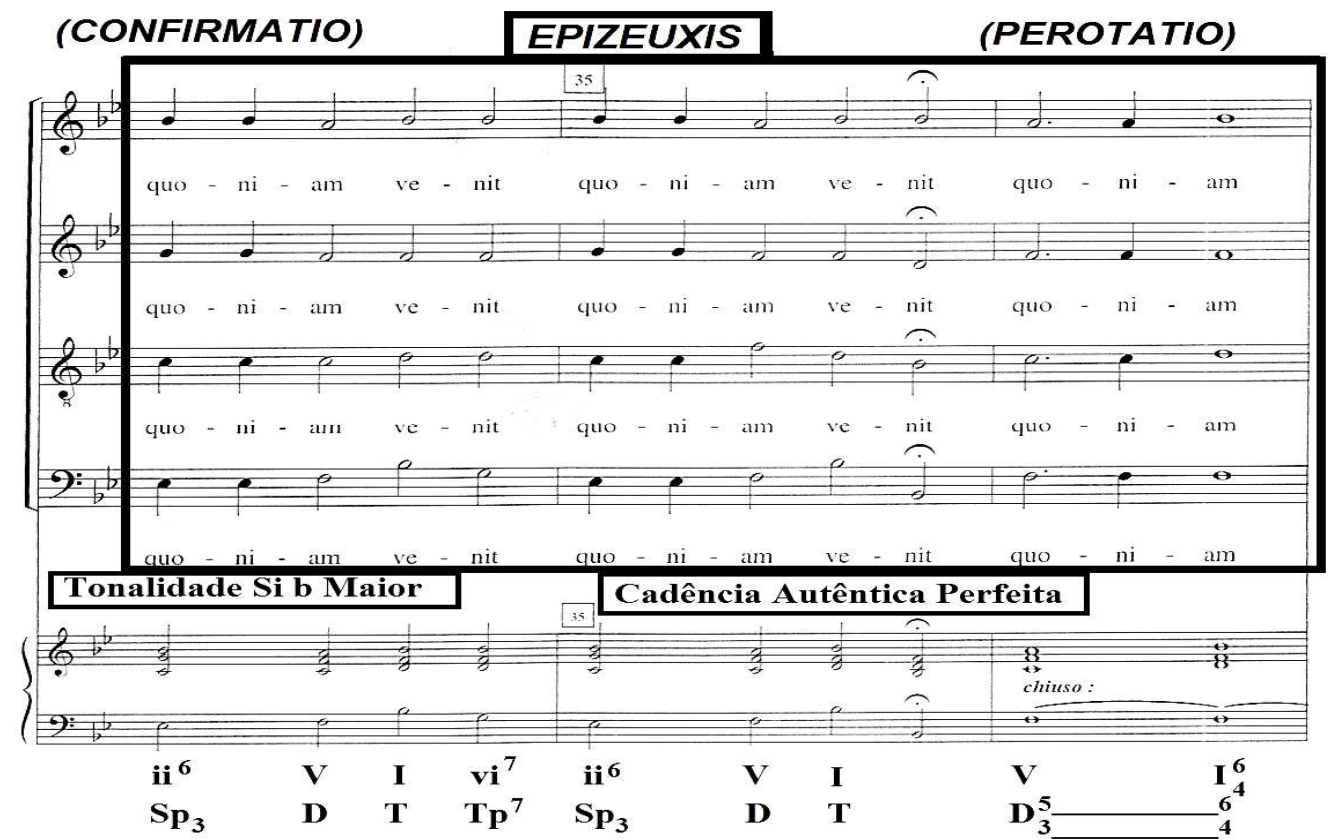

Exemplo 149: Ofertório da Missa de Natal de André da Silva Gomes- Catalogação e Organização Régis Duprat (DUPRAT, 1999, p.212). 


\subsubsection{Perotatio}

André da Silva Gomes termina o segundo movimento do Ofertório da Missa de Natal com a frase ele vem (quoniam venit), de maneira calma e tranquila, numa Cadência Autêntica Perfeita, em ressonância ao louvor, júbilo e exultação oferecidos ao nascimento de Cristo desde o começo do primeiro movimento.

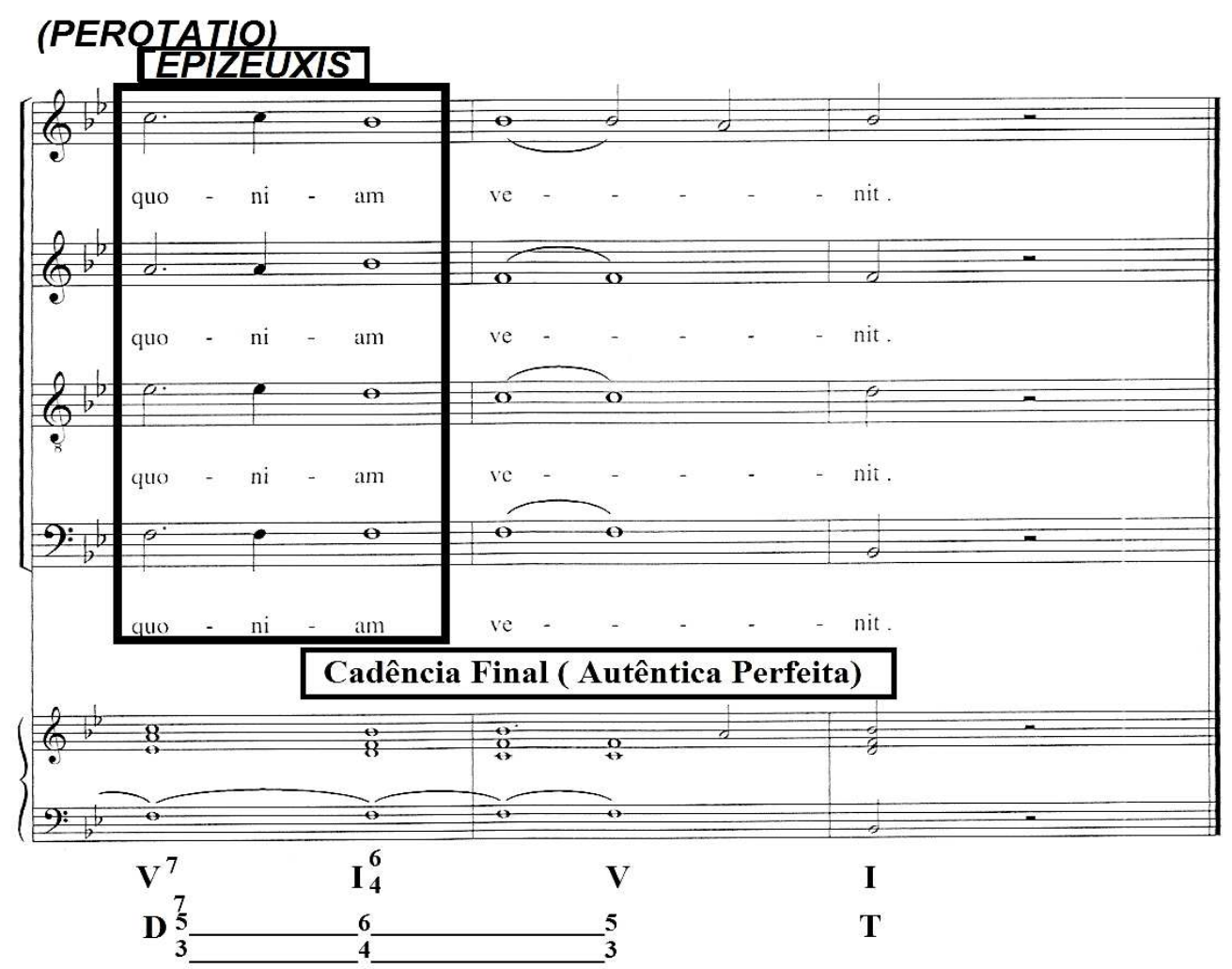

Exemplo 150: Ofertório da Missa de Natal de André da Silva Gomes- Catalogação e Organização Régis Duprat (DUPRAT, 1999, p.212).

\subsection{Figuras observadas no Ofertório (Elocutio/Decoratio)}

\begin{tabular}{|c|c|c|c|}
\hline FIGURAS & TIPO & DESCRIÇÃO & TRATADISTA \\
\hline $\begin{array}{l}\text { ABRUPTIO } \\
\text { (BARTEL, 1997, } \\
\text { pp.168-170). }\end{array}$ & $\begin{array}{l}\text { Interrupção e } \\
\text { Silêncio }\end{array}$ & $\begin{array}{l}\text { Uma quebra } \\
\text { súbita e } \\
\text { inesperada na } \\
\text { composição } \\
\text { musical. }\end{array}$ & $\begin{array}{lr}\text { Vogt: A } & \text { Abruptio } \\
\text { ocorre quando } \\
\text { um } & \text { trecho } \\
\text { musical } & \text { é } \\
\text { interrompido no } \\
\text { final } \\
\text { colocação pela } \\
\text { algumas pausas. }\end{array}$ \\
\hline
\end{tabular}




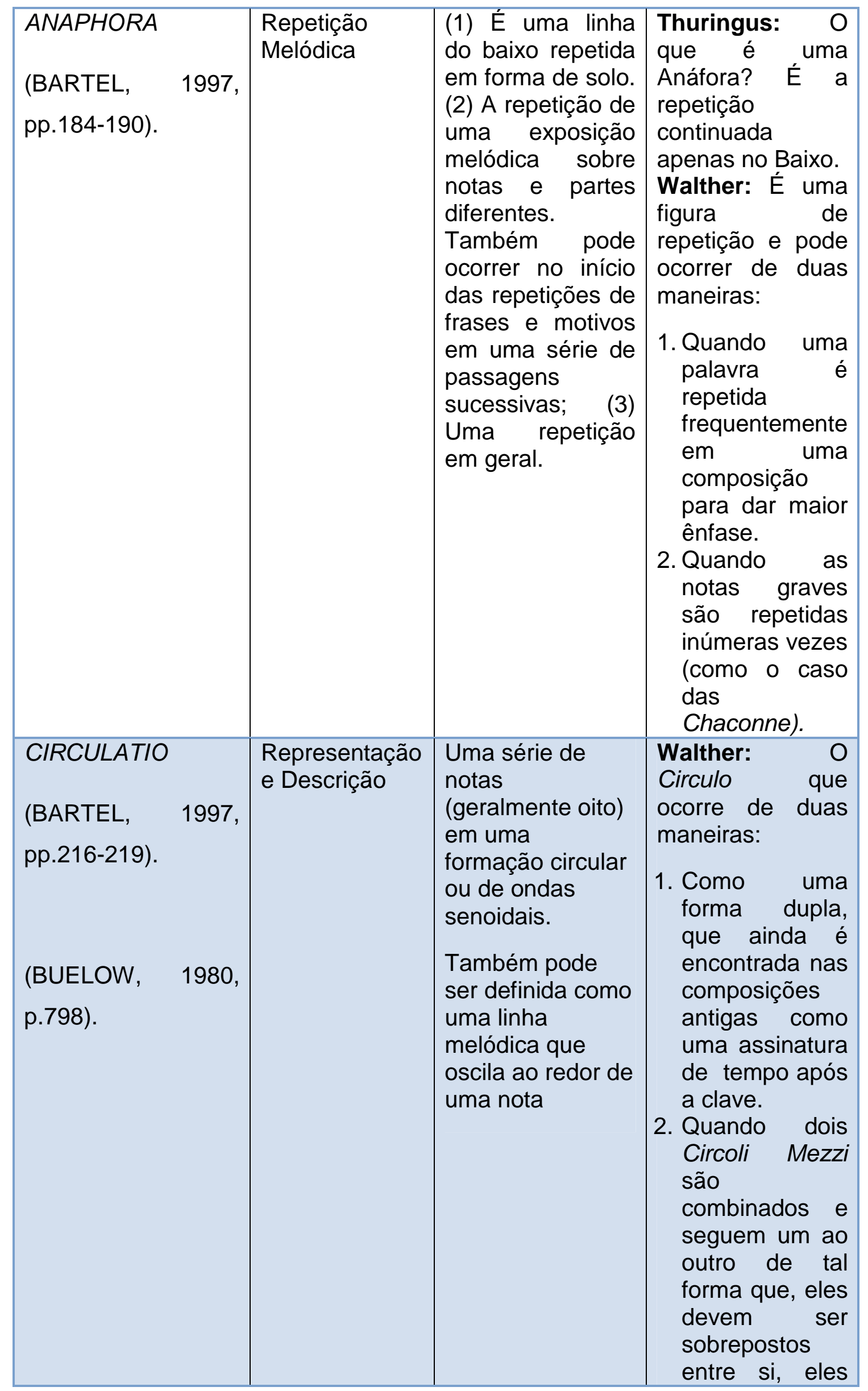




\begin{tabular}{|c|c|c|c|}
\hline & & & $\begin{array}{l}\text { representam } \\
\text { visualmente um } \\
\text { círculo } \\
\text { completo. }\end{array}$ \\
\hline $\begin{array}{l}\text { EXCLAMATIO } \\
\text { (BARTEL, } \\
\text { pp.265-269) }\end{array}$ & $\begin{array}{l}\text { Representação } \\
\text { e Descrição }\end{array}$ & $\begin{array}{l}\text { Exclamação } \\
\text { musical } \\
\text { frequentemente } \\
\text { associada com } \\
\text { uma exclamação } \\
\text { no texto. }\end{array}$ & 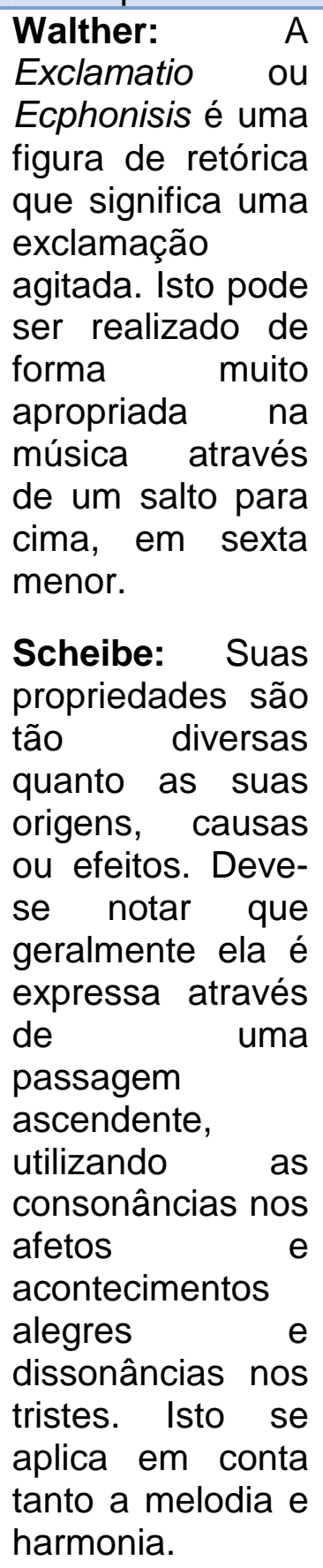 \\
\hline $\begin{array}{l}\text { EPIZEUXIS } \\
\text { (BARTEL, 1997, } \\
\text { pp.263-265). }\end{array}$ & $\begin{array}{l}\text { Repetição } \\
\text { Melódica }\end{array}$ & $\begin{array}{l}\text { Uma repetição } \\
\text { imediata e } \\
\text { enfática de uma } \\
\text { palavra, nota, } \\
\text { motivo ou frase. }\end{array}$ & $\begin{array}{l}\text { Walther: A } \\
\text { Epizeuxis é uma } \\
\text { figura de retórica } \\
\text { pela qual uma ou } \\
\text { mais palavras } \\
\text { são } \\
\text { imediatamente e } \\
\text { enfaticamente }\end{array}$ \\
\hline
\end{tabular}




\begin{tabular}{|c|c|c|c|}
\hline & & & repetidas. \\
\hline $\begin{array}{l}\text { GRADATIO } \\
\text { (BARTEL, 1997, } \\
\text { pp.220-224). }\end{array}$ & $\begin{array}{l}\text { Repetição } \\
\text { Melódica }\end{array}$ & $\begin{array}{l}\text { (1) Sequência de } \\
\text { notas em uma só } \\
\text { voz repetida em } \\
\text { qualquer } \\
\text { tonalidade maior } \\
\text { ou menor, (2) } \\
\text { Duas vozes que } \\
\text { se deslocam em } \\
\text { movimento } \\
\text { ascendente ou } \\
\text { descendente } \\
\text { paralelo, (3) Um } \\
\text { aumento gradual } \\
\text { na intensidade e } \\
\text { altura do som. }\end{array}$ & 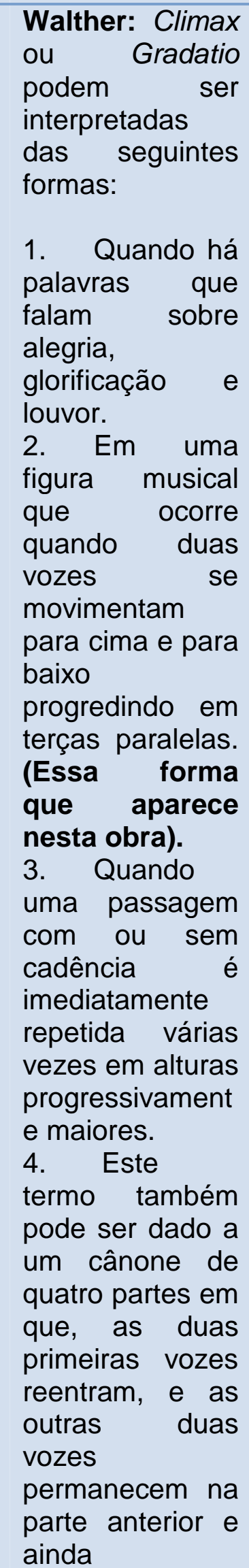 \\
\hline
\end{tabular}




\begin{tabular}{|c|c|c|c|c|}
\hline & & & & harmonizam. \\
\hline $\begin{array}{l}\text { METABASIS } \\
\text { (BARTEL, } \\
\text { pp.319-320). }\end{array}$ & 1997, & $\begin{array}{l}\text { Representação } \\
\text { e } \\
\text { Descrição }\end{array}$ & $\begin{array}{l}\text { Cruzamento de } \\
\text { uma voz com } \\
\text { outra ou } \\
\text { cruzamento de } \\
\text { vozes. }\end{array}$ & $\begin{array}{l}\text { Spiess: A } \\
\text { Metabasis (ou } \\
\text { Diabasis, } \\
\text { Transgressio, } \\
\text { Transgression) } \\
\text { ocorre sempre } \\
\text { que uma voz } \\
\text { atravessa a outra. }\end{array}$ \\
\hline $\begin{array}{l}\text { NOEMA } \\
\text { (BARTEL, } \\
\text { p.339-342). }\end{array}$ & 1997, & $\begin{array}{l}\text { Representação } \\
\text { e Descrição }\end{array}$ & $\begin{array}{l}\text { Uma passagem } \\
\text { homofônica em } \\
\text { uma textura } \\
\text { contrapontística e } \\
\text { polifônica. }\end{array}$ & $\begin{array}{l}\text { Burmeister: A } \\
\text { Noema } \\
\text { representa o } \\
\text { afeto harmônico, } \\
\text { onde as vozes } \\
\text { combinadas têm } \\
\text { valores e } \\
\text { números de notas } \\
\text { semelhantes. } \\
\text { Quando } \\
\text { introduzida } \\
\text { adequadamente, } \\
\text { isto é, no } \\
\text { momento certo, } \\
\text { ela afeta } \\
\text { docemente os } \\
\text { ouvidos do } \\
\text { ouvinte, } \\
\text { produzindo uma } \\
\text { sensação de } \\
\text { calma e } \\
\text { serenidade. } \\
\text { Seção } \\
\text { homofônica, } \\
\text { dentro da } \\
\text { polifonia utilizada } \\
\text { para enfatizar o } \\
\text { texto. }\end{array}$ \\
\hline $\begin{array}{l}\text { PALILOGIA } \\
\text { (BARTEL, } \\
\text { pp.342-344). }\end{array}$ & 1997 & $\begin{array}{l}\text { Repetição } \\
\text { Melódica }\end{array}$ & $\begin{array}{l}\text { Repetição de um } \\
\text { tema no mesmo } \\
\text { nível de altura, } \\
\text { também pode } \\
\text { ocorrer r em } \\
\text { alturas diferentes } \\
\text { na mesma ou em } \\
\text { várias vozes. }\end{array}$ & $\begin{array}{l}\text { Burmeister: } A \\
\text { Palilogia é uma } \\
\text { repetição de uma } \\
\text { inteiração ou } \\
\text { apenas o começo } \\
\text { da estrutura dos } \\
\text { meios e temas } \\
\text { sobre a mesma } \\
\text { altura com a } \\
\text { mesma voz, }\end{array}$ \\
\hline
\end{tabular}




\begin{tabular}{|c|c|c|c|}
\hline & & & $\begin{array}{lr}\text { ocorrendo } & \text { com } \\
\text { ou } & \text { sem } \\
\text { intermédio de } \\
\text { pausas em todos } \\
\text { os eventos em } \\
\text { uma voz. } \\
\text { Walther: } \\
\text { Palilogia refere- } \\
\text { se a uma } \\
\text { repetição por pr pre } \\
\text { demais frequente } \\
\text { das mesmas } \\
\text { palavras. }\end{array}$ \\
\hline $\begin{array}{l}\text { PAUSA } \\
\text { (BARTEL, 1997, } \\
\text { pp.362-365). }\end{array}$ & $\begin{array}{l}\text { Interrupção e } \\
\text { Silêncio }\end{array}$ & $\begin{array}{l}\text { Pausa } \\
\text { descanso ou } \\
\text { uma composição } \\
\text { musical. }\end{array}$ & $\begin{array}{l}\text { Walther: Uma } \\
\text { figura ou figuras } \\
\text { de silêncio. } \\
\text { Pausa refere-se a } \\
\text { um período de } \\
\text { repouso ou o } \\
\text { silêncio } \\
\text { música, que é } \\
\text { indicado por um } \\
\text { determinado } \\
\text { sinal. }\end{array}$ \\
\hline $\begin{array}{l}\text { POLYPTOTON } \\
\text { (BARTEL, 1997, } \\
\text { pp.367-369). }\end{array}$ & $\begin{array}{l}\text { Repetição } \\
\text { Melódica }\end{array}$ & $\begin{array}{l}\text { A repetição de } \\
\text { uma passagem } \\
\text { melódica em } \\
\text { diferentes alturas. }\end{array}$ & 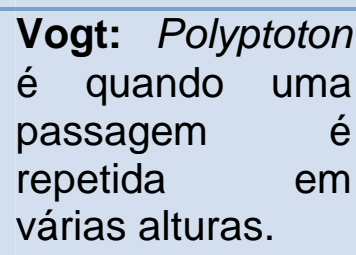 \\
\hline $\begin{array}{l}\text { SYNAERESIS } \\
\text { (BARTEL, 1997, } \\
\text { pp.394-396). }\end{array}$ & $\begin{array}{l}\text { Dissonância e } \\
\text { Deslocamento }\end{array}$ & $\begin{array}{l}\text { (1) Uma } \\
\text { suspensão ou } \\
\text { síncope, (2) A } \\
\text { colocação de } \\
\text { duas silabas por } \\
\text { nota ou duas } \\
\text { notas por sílaba. }\end{array}$ & $\begin{array}{l}\text { Vogt: } \\
\text { Synaeresis } \\
\text { ocorre quando } \\
\text { duas notas são } \\
\text { colocadas em } \\
\text { uma sílaba ou } \\
\text { duas sílabas são } \\
\text { colocadas em } \\
\text { uma nota. }\end{array}$ \\
\hline $\begin{array}{l}\text { SYNONYMIA } \\
\text { (BARTEL, 1997, } \\
\text { pp.405-407). }\end{array}$ & $\begin{array}{l}\text { Repetição } \\
\text { Melódica }\end{array}$ & $\begin{array}{l}\text { É a repetição de } \\
\text { uma ideia musical } \\
\text { em forma } \\
\text { alterada ou } \\
\text { modificada. }\end{array}$ & $\begin{array}{l}\text { Walther: Um } \\
\text { compositor } \\
\text { também pode } \\
\text { empregar muito } \\
\text { bem diferentes } \\
\text { figuras retóricas } \\
\text { na elaboração de } \\
\text { um texto. Por } \\
\text { exemplo, além da } \\
\text { Epizeuxis, que é }\end{array}$ \\
\hline
\end{tabular}




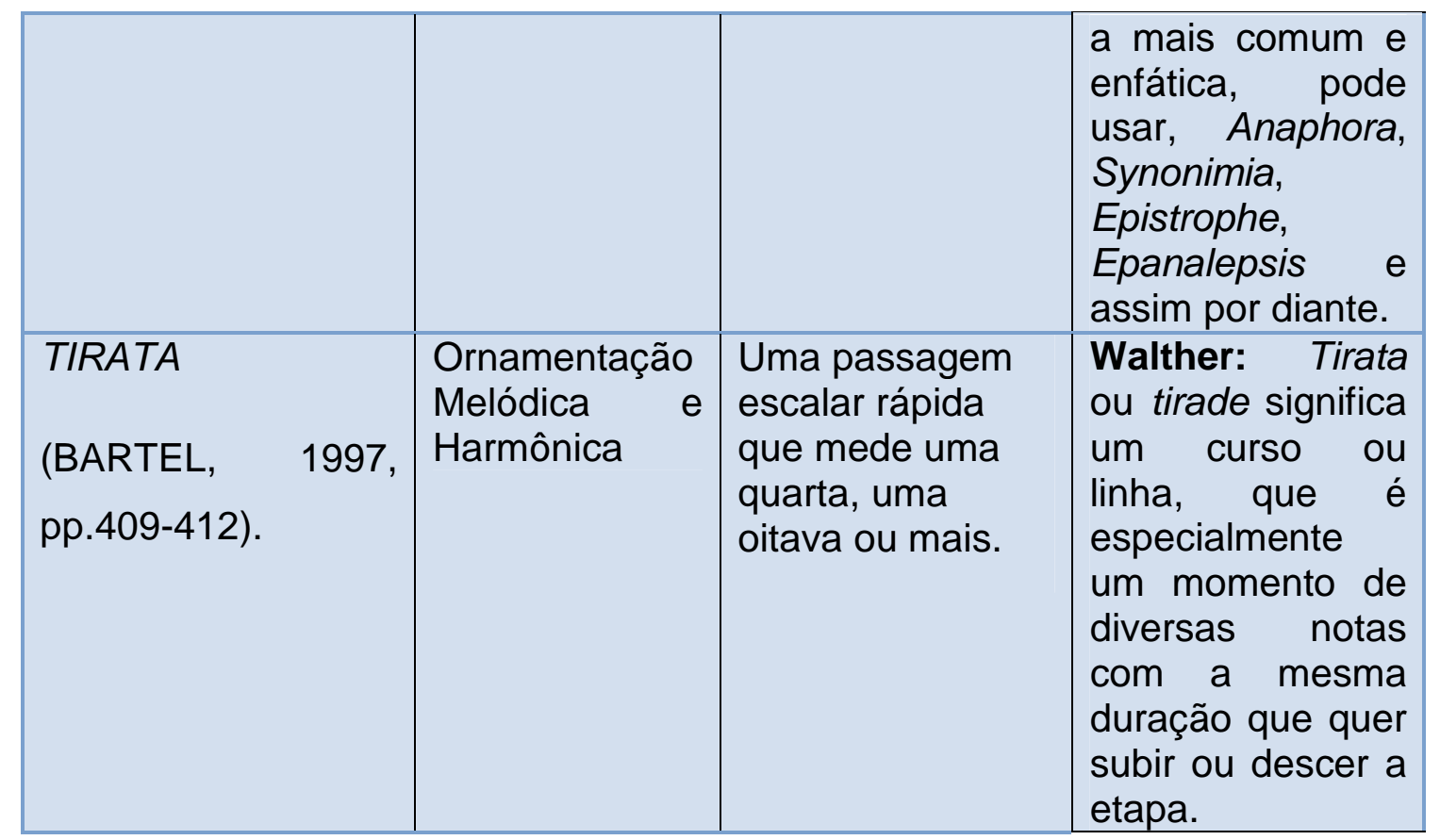

Tabela 50: Figuras encontradas no Ofertório da Missa de Natal de André da Silva Gomes

\section{Análise Harmônica}

\subsection{Curva Tonal (Primeiro Movimento)}

Tonalidade: Si b Maior

Andamento: Brilhante 4/4

Esquema de Progressões Harmônicas

\begin{tabular}{|l|c|l|}
\hline Compassos & $\begin{array}{l}\text { Função em relação a } \\
\text { tonalidade principal }\end{array}$ & Tonalidade (Acorde) \\
\hline $1-12$ & T-I & Si b Maior \\
\hline $13-14$ & Tp-vi & Sol Menor \\
\hline 15 & Sp-ii & Dó Menor \\
\hline 16 & Tp-vi & Sol Menor \\
\hline 17 & T-I & Si b Maior \\
\hline 18 & D-V & Fá Maior \\
\hline $19-34$ & T-I & Si b Maior \\
\hline $34-35$ & D-V & Fá Maior \\
\hline $36-45$ & T-I & Si b Maior \\
\hline $45-61$ & D-V & Fá Maior \\
\hline $61-69$ & T-V & Si b Maior \\
\hline
\end{tabular}

Tabela 51: Curva Tonal do Ofertório da Missa de Natal (Primeiro Movimento)

Números de compassos: 69 
Regiões abordadas: 4

Variações: 11

Ritmo Harmônico: 6,27 (divisão dos números de compassos e variações)

Média ideal: (divisão dos números de compassos e regiões tonais abordadas = $17,25)$

Esquema Formal

$(1-12)(13-16)(17-45)(45-61)(61-69)$

$\begin{array}{ccccc}\text { T } & \text { Tp } & \text { T } & \text { D } & \text { T } \\ \text { I } & \text { vi } & \text { I } & \text { V } & \text { I }\end{array}$

2.2. Estrutura Analítica do Ofertório: Retórica e Harmônica (Primeiro Movimento)

\begin{tabular}{|c|c|c|c|c|c|}
\hline $\begin{array}{l}\text { RETÓRICA } \\
\text { DISPOSITIO }\end{array}$ & $\begin{array}{l}\text { FIGURA } \\
\text { ELOCUTIO }\end{array}$ & COMP. & $\begin{array}{l}\text { HARMŌNICA } \\
\text { SEÇÃO }\end{array}$ & TONALIDADE & FUNÇÃO \\
\hline EXORDIUM & $\begin{array}{l}\text { Synaeresis } \\
\text { Abruptio } \\
\text { Palilogia } \\
\text { Anaphora } \\
\text { Epizeuxis } \\
\text { Exclamatio }\end{array}$ & $\begin{array}{l}1 \\
2 \\
2-4 \\
2-4 \\
6-11 \\
5\end{array}$ & 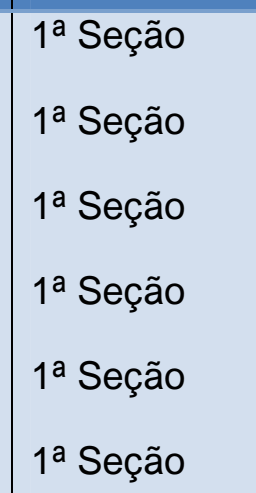 & $\begin{array}{l}\text { Si b Maior } \\
\text { Si b Maior } \\
\text { Si b Maior } \\
\text { Si b Maior } \\
\text { Si b Maior } \\
\text { Si b Maior }\end{array}$ & $\begin{array}{l}\text { T-I } \\
\text { T-I } \\
\text { T-I } \\
\text { T-I } \\
\text { T-I } \\
\text { T-I }\end{array}$ \\
\hline NARRATIO & $\begin{array}{l}\text { Circulatio } \\
\text { Metabasis }\end{array}$ & $\begin{array}{l}12-14 \\
15\end{array}$ & $\begin{array}{l}1^{a} \text { Seção } \\
1^{\text {a }} \text { Seção }\end{array}$ & $\begin{array}{l}\text { Si b Maior e } \\
\text { Sol Menor } \\
\text { Sol Menor }\end{array}$ & $\begin{array}{c}\text { T-I } \\
\text { Tp-vi } \\
\text { Tp-vi }\end{array}$ \\
\hline PROPOSITIO & $\begin{array}{l}\text { Pausa } \\
\text { Epizeuxis } \\
\text { Synaeresis }\end{array}$ & $\begin{array}{l}17 \text { e } 27 \\
19-24 \\
26-27\end{array}$ & $\begin{array}{l}1^{\text {a }} \text { Seção } \\
1^{\text {a }} \text { Seção } \\
1^{\text {a Seção }}\end{array}$ & $\begin{array}{l}\text { Si b Maior } \\
\text { Si b Maior } \\
\text { Si b Maior }\end{array}$ & $\begin{array}{l}T-I \\
T-I\end{array}$ \\
\hline
\end{tabular}




\begin{tabular}{|c|c|c|c|c|c|}
\hline CONFUTATIO & $\begin{array}{l}\text { Circulatio } \\
\text { Pausa } \\
\text { Synonimia } \\
\text { Tirata } \\
\text { Anaphora } \\
\text { Synaeresis } \\
\text { Epizeuxis } \\
\text { Gradatio }\end{array}$ & $\begin{array}{l}28-29 \\
\text { e } 32-33 \\
28-41 \\
\text { e } 53 \\
32-34 \\
37-38 \\
40-41 \\
43-44 \\
50-52 \\
43,44 \text { e } \\
52 \\
45-48\end{array}$ & 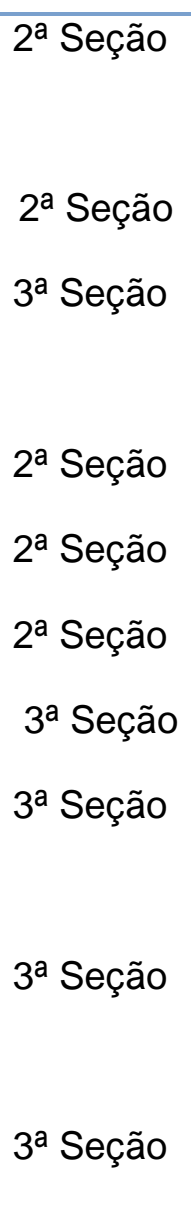 & $\begin{array}{l}\text { Si b Maior } \\
\text { Sol Menor } \\
\text { Si b Maior } \\
\text { Fá Maior } \\
\text { Si b Maior } \\
\text { Si b Maior } \\
\text { Si b Maior } \\
\text { SI b Maior } \\
\text { Fá Maior } \\
\text { Si b Maior } \\
\text { Fá Maior } \\
\text { Si b Maior } \\
\text { Fá Maior } \\
\text { Fá Maior }\end{array}$ & $\begin{array}{l}\text { T-I } \\
\text { Tp-vi } \\
\text { T-I } \\
\text { D-V } \\
\text { T-I } \\
\text { T-I } \\
\text { T-I } \\
\text { T-I } \\
\text { D-V } \\
\text { T-I } \\
\text { D-V } \\
\text { T-I } \\
\text { D-V } \\
\text { D-V }\end{array}$ \\
\hline CONFIRMATIO & $\begin{array}{l}\text { Gradatio } \\
\text { Pausa }\end{array}$ & $\begin{array}{l}53-55 \\
53-58\end{array}$ & $\begin{array}{l}4^{a} \text { Seção } \\
4^{\text {a }} \text { Seção }\end{array}$ & $\begin{array}{l}\text { Fá Maior } \\
\text { Fá Maior }\end{array}$ & $\begin{array}{l}D-V \\
D-V\end{array}$ \\
\hline PEROTATIO & $\begin{array}{l}\text { Epizeuxis } \\
\text { Pausa } \\
\text { Synaeresis }\end{array}$ & $\begin{array}{l}64 \\
69\end{array}$ & $\begin{array}{l}\text { 5ª Seção } \\
\text { 5ª Seção } \\
\text { 5ª Seção }\end{array}$ & $\begin{array}{l}\text { Fá Maior } \\
\text { e Si b Maior } \\
\text { Si b Maior } \\
\text { Si b Maior }\end{array}$ & $\begin{array}{l}\text { D-V } \\
\text { T-I } \\
\text { T-I } \\
\text { T-I }\end{array}$ \\
\hline
\end{tabular}

Tabela 52: Estrutura analítica do Ofertório (Primeiro Movimento)

\subsection{Curva Tonal (Segundo Movimento)}

Tonalidade: Si b Maior

Andamento: Andante 4/2

Esquema de Progressões Harmônicas 


\begin{tabular}{|l|c|l|}
\hline Compassos & $\begin{array}{l}\text { Função em relação a } \\
\text { tonalidade principal }\end{array}$ & Tonalidade (Acorde) \\
\hline $1-2$ & T-I & Si b Maior \\
\hline $3-4$ & D-V & Fá Maior \\
\hline $5-6$ & T-I & Si b Maior \\
\hline $6-8$ & D-V & Fá Maior \\
\hline $8-11$ & T-I & Si b Maior \\
\hline 11 & Tp-vi & Sol Menor \\
\hline 12 & D-V & Fá Maior \\
\hline 12 & Sp-ii & Dó Menor \\
\hline $12-17$ & T-I & Si b Maior \\
\hline $18-19$ & Sp-ii & Dó Menor \\
\hline $20-24$ & T-I & Si b Maior \\
\hline 24 & S-IV & Mi b Maior \\
\hline $25-26$ & T-I & Si b Maior \\
\hline $27-28$ & t-i (Tonalidade Homônima) & Si b Menor \\
\hline $28-29$ & D-V & Fá Maior \\
\hline $30-39$ & T-I & Si b Maior \\
\hline
\end{tabular}

Tabela 53: Curva Tonal do Ofertório da Missa de Natal (Segundo Movimento)

Números de compassos: 39

Regiões abordadas: 6

Variações: 16

Ritmo Harmônico: 2,43 (divisão dos números de compassos e variações)

Média ideal: (divisão dos números de compassos e regiões tonais abordadas = $6,5)$

Esquema Formal

$(1-26)(27-29)(30-39)$

$\begin{array}{lll}\mathrm{T} & \mathrm{t} & \mathrm{T}\end{array}$

i । 


\subsection{Estrutura Analítica do Ofertório: Retórica e Harmônica (Segundo Movimento)}

\begin{tabular}{|c|c|c|c|c|c|}
\hline $\begin{array}{l}\text { RETÓRICA } \\
\text { DISPOSITIO }\end{array}$ & $\begin{array}{l}\text { FIGURA } \\
\text { ELOCUTIO }\end{array}$ & COMP. & $\begin{array}{l}\text { HARMÓNICA } \\
\text { SEÇÃO }\end{array}$ & TONALIDADE & FUNÇÃO \\
\hline EXORDIUM & $\begin{array}{l}\text { Synaeresis } \\
\text { Polyptoton } \\
\text { Pausa }\end{array}$ & $\begin{array}{l}1-9 \\
1-8 \\
1-6\end{array}$ & $\begin{array}{l}1^{\text {a }} \text { Seção } \\
1^{\text {a }} \text { Seção } \\
1^{\text {a Seção }}\end{array}$ & $\begin{array}{l}\text { Si b Maior } \\
\text { Si b Maior } \\
\text { Si b Maior }\end{array}$ & $\begin{array}{l}\text { T-I } \\
\text { T-I } \\
\text { T-I }\end{array}$ \\
\hline NARRATIO & $\begin{array}{l}\text { Noema } \\
\text { Synaeresis }\end{array}$ & $\begin{array}{l}10-15 \\
19-21 \\
13,15 \\
16-18 \\
19 \text { e } 21\end{array}$ & $\begin{array}{l}2^{\text {a }} \text { Seção } \\
2^{\text {a }} \text { Seção } \\
2^{\text {a }} \text { Seção } \\
2^{\text {a }} \text { Seção } \\
2^{\text {a Seção }}\end{array}$ & $\begin{array}{l}\text { Si b Maior } \\
\text { Si b Maior } \\
\text { Si b Maior } \\
\text { Si b Maior } \\
\text { Si b Maior }\end{array}$ & $\begin{array}{l}\text { T-I } \\
\text { T-I } \\
\text { T-I } \\
\text { T-I } \\
\text { T-I }\end{array}$ \\
\hline PROPOSITIO & $\begin{array}{l}\text { Synaeresis } \\
\text { Noema }\end{array}$ & $\begin{array}{l}22-24 \\
25-26\end{array}$ & $\begin{array}{l}\text { 3ª Seção } \\
\text { 3ª Seção }\end{array}$ & $\begin{array}{l}\text { Si b Maior } \\
\text { Si b Maior }\end{array}$ & $\begin{array}{l}\text { T-I } \\
\text { T-I }\end{array}$ \\
\hline CONFUTATIO & $\begin{array}{l}\text { Noema } \\
\text { Palilogia } \\
\text { Synaeresis }\end{array}$ & $\begin{array}{l}27 \\
27-28 \\
29\end{array}$ & $\begin{array}{l}\text { 4ª Seção } \\
\text { 4ª Seção }^{\text {4ª Seção }}\end{array}$ & $\begin{array}{l}\text { Si b Menor } \\
\text { Si b Menor } \\
\text { Si b Menor }\end{array}$ & $\begin{array}{c}t-i \\
t-i \\
t-i \\
\text { (Tonal- } \\
\text { Hom). }\end{array}$ \\
\hline CONFIRMATIO & $\begin{array}{l}\text { Synaeresis } \\
\text { Epizeuxis }\end{array}$ & $\begin{array}{l}31 \\
33-35\end{array}$ & $\begin{array}{l}\text { 5ª Seção } \\
\text { 5ª Seção }\end{array}$ & $\begin{array}{l}\text { Si b Maior } \\
\text { Si b Maior }\end{array}$ & $\begin{array}{l}\text { T-I } \\
\text { T-I }\end{array}$ \\
\hline PEROTATIO & Epizeuxis & $36-37$ & $5^{\text {a }}$ Seção & Si b Maior & T-I \\
\hline
\end{tabular}

Tabela 54: Estrutura analítica do Ofertório (Segundo Movimento) 


\subsubsection{Ofertório da Missa da Ascensão do Senhor}

\section{Estudo Semântico}

\subsection{Inventio}

O Ofertório da Missa de Ascensão do Senhor é concebido por Silva Gomes em dois movimentos e seu texto foi extraído do Salmo (Ps. 46,6/47,5).

Ascendit Deus in jubilatione, Dominus in voce tubae, Alleluia.

O Senhor subiu entre as (aclamações) nações, ao som de trombeta. Aleluia.

(SOARES, 2000, p.152).

Trata-se de um salmo cuja autoria é atribuída aos filhos de Coré, e que retrata a grandeza do Senhor. Todos devem louvá-lo com as palmas e vozes de júbilo. Especialmente esse versículo tem a intenção de louvar o poderio e soberania de Deus, pois Ele é aclamado aos sons de trombeta como um verdadeiro rei que ascende sobre todos os povos e nações (SOARES; MACHADO NETO, 2011, p.394).

A celebração da Missa a Ascensão do Senhor é um acontecimento de suma importância, porque Jesus o filho de Deus que fora homem venceu 0 pecado e a morte através da sua ressurreição e posteriormente ascende aos céus, prometendo não deixar seus seguidores órfãos, enviando para substituílo o Espírito Santo ${ }^{105}$.

A Missa se divide em dez partes assim distribuídas:

\begin{tabular}{|l|l|}
\hline INTRODUÇÃOO & $\begin{array}{l}\text { Lê-se o texto base para a introdução } \\
\text { que se encontra em Atos 1:11, onde o } \\
\text { escritor dessa passagem descreve } \\
\text { um anjo a qual fala para os discípulos } \\
\text { e seguidores de Cristo, para não } \\
\text { ficarem espantados, pois Jesus que } \\
\text { está ascendendo (subindo) aos céus, } \\
\text { um dia voltará para reinar com todos }\end{array}$ \\
\hline
\end{tabular}

${ }^{105}$ João 14:16, 17, 18,19 e 20 e Atos 1:2 a 11. 
os que praticarem sua fé.

\begin{tabular}{|l|l|}
\hline ORATÓRIO & $\begin{array}{l}\text { Nessa parte, os fiéis proclamam a } \\
\text { grandiosidade de Jesus que está } \\
\text { juntamente com seu pai, Deus Jeová, } \\
\text { reinando no céu em unidade com o } \\
\text { Espírito Santo. }\end{array}$ \\
\hline ESPISTOLA & $\begin{array}{l}\text { É lido na integra a passagem de Atos } \\
1, \text { ou seja, os 11 versículos onde fala } \\
\text { da Ascensão do Senhor. }\end{array}$ \\
\hline ELELUIA & $\begin{array}{l}\text { Os Salmos 46:6 e 67:18-19 revelam } \\
\text { com júbilo a elevação de Cristo ao } \\
\text { toque da trombeta. }\end{array}$ \\
\hline PREFÁCIO DA ASCENSÃO & $\begin{array}{l}\text { Acontece um dialogo entre o } \\
\text { celebrante e os participantes onde o } \\
\text { primeiro pergunta: “O Senhor seja } \\
\text { convosco" e a congregação } \\
\text { responde: “E com vosso espírito". } \\
\text { Posteriormente é lido o evangelho } \\
\text { segundo São Marcos 16: 14 ao 20 } \\
\text { onde os fiéis respondem: "Glória a } \\
\text { vós Senhor" [grifo nosso]. }\end{array}$ \\
\hline ANTIFONA E OFERTÓRIO & $\begin{array}{l}\text { Novamente é citado o texto dos } \\
\text { Salmos 46:7, onde o cristão em forma } \\
\text { de louvor e gratidão exalta seu Rei o } \\
\text { aclamando que o mesmo é maior } \\
\text { entre todas as nações. }\end{array}$ \\
\hline $\begin{array}{l}\text { Esse é um momento de grande } \\
\text { reflexão por parte do ofertante, onde } \\
\text { este é convencido a aceitar a } \\
\text { superioridade do Senhor e ao mesmo } \\
\text { tempo celebra seus feitos poderosos. }\end{array}$ \\
Jesus é venerado e lembrado pela \\
\hline
\end{tabular}




\begin{tabular}{|l|l|}
\hline \multirow{1}{*}{$\begin{array}{l}\text { congregação por ter vencido a morte } \\
\text { através de sua ressurreição e quando } \\
\text { ascendeu para o céu, manifestou sua } \\
\text { glória a todos seus servos, fazendo } \\
\text { parte integrante e participante de seu } \\
\text { reino, como também sendo elo entre } \\
\text { seus servos terrenos e os Anjos e } \\
\text { Arcanjos que os servem no céu. }\end{array}$} \\
\hline COMUNHÃO & $\begin{array}{l}\text { No trecho dos Salmos 67:33 a 34, são } \\
\text { convidados todos os fiéis a cantarem } \\
\text { e louvarem ao Senhor que sobe no } \\
\text { mais alto dos céus. Todos estão em } \\
\text { comunhão, tendo anteriormente } \\
\text { oferecido a Trindade seu culto com } \\
\text { grande reverência. }\end{array}$ \\
\hline PóS-COMUNHÃO & $\begin{array}{l}\text { Nesse momento a congregação se } \\
\text { despede enaltecendo a unidade da } \\
\text { Trindade e também o reinado de } \\
\text { ambos que será para toda a } \\
\text { eternidade. }\end{array}$ \\
\hline
\end{tabular}

Tabela 55: Divisão Litúrgica da Missa da Ascenção do Senhor

Por fim, esse ofertório é constituído de dois movimentos, sendo o primeiro, num andamento Brilhante, com cinquenta e três compassos e o segundo em Presto, totalizado em quarenta compassos. 


\subsection{Locus observados na Inventio do Ofertório (10 Movimento)}

\begin{tabular}{|c|c|c|c|}
\hline INVENTIO & DESCRIÇÃO & $\begin{array}{c}\text { UTILIZAÇÃO NA } \\
\text { OBRA }\end{array}$ & $\begin{array}{l}\text { COMPASSO/ } \\
\text { VOZ }\end{array}$ \\
\hline $\begin{array}{l}\text { Locus } \\
\text { Notationis } \\
\text { (MATTHESON, } \\
\text { [1739],1954, } \\
\text { Parte II,Cap.4, } \\
\S 23, \text { p.123). }\end{array}$ & $\begin{array}{l}\text { Aspecto externo } \\
\text { e desenho das } \\
\text { notas (Duração } \\
\text { das notas, } \\
\text { alteração, } \\
\text { repetição e } \\
\text { procedimentos } \\
\text { canônicos). }\end{array}$ & $\begin{array}{l}\text { Vários motivos } \\
\text { rítmicos e diferentes } \\
\text { durações de notas } \\
\text { (semibreves, } \\
\text { mínimas, semínimas, } \\
\text { semínimas } \\
\text { pontuadas, colcheias, } \\
\text { semicolcheias } \\
\text { repetições, ligaduras, } \\
\text { apogiaturas, pausas, } \\
\text { entre outros). }\end{array}$ & $\begin{array}{ll}1-6 & S \\
7-25 & \text { S-A-T-B } \\
26-34 & \text { A } \\
35-53 & \text { S-A-T-B }\end{array}$ \\
\hline $\begin{array}{l}\text { Locus } \\
\text { Oppositorum } \\
\text { (MATTHESON, } \\
\text { [1739],1954, } \\
\text { Parte II,Cap.4, } \\
\S 80, p .131 \text { ). }\end{array}$ & $\begin{array}{l}\text { Contraste de } \\
\text { compassos, } \\
\text { movimentos } \\
\text { contrários, } \\
\text { agudos e } \\
\text { graves, lento e } \\
\text { rápido, calmo e } \\
\text { agitado. }\end{array}$ & $\begin{array}{l}\text { Movimento contrário } \\
\text { entre soprano e } \\
\text { contralto. Também } \\
\text { entre soprano e baixo. }\end{array}$ & $\begin{array}{l}9-10 \text { S-B } \\
14-16 \text { S-B }\end{array}$ \\
\hline $\begin{array}{l}\text { Locus } \\
\text { Descriptionis } \\
\text { (MATTHESON, } \\
\text { [1739],1954, } \\
\text { Parte II,Cap.4, } \\
\text { §43,p.127). }\end{array}$ & $\begin{array}{l}\text { Disposições da } \\
\text { alma }\end{array}$ & $\begin{array}{l}\text { Júbilo (O Senhor } \\
\text { subiu entre } \\
\text { aclamações) }\end{array}$ & $\begin{array}{l}1-2 \quad S \\
7-11 \quad \text { S-A-T-B } \\
15-19 \text { S-A-T-B } \\
25-27 \text { A } \\
35-39 \text { S-A-T-B }\end{array}$ \\
\hline
\end{tabular}

Tabela 56: Locus Topici encontrados no Ofertório da Missa da Ascenção do Senhor de André da Silva Gomes (Primeiro Movimento)

\subsection{Locus observados na Inventio do Ofertório (2을ovimento)}

\begin{tabular}{|c|c|c|c|}
\hline INVENTIO & DESCRIÇÃO & $\begin{array}{c}\text { UTILIZAÇÃO NA } \\
\text { OBRA }\end{array}$ & $\begin{array}{l}\text { COMPASSO/ } \\
\text { VOZ }\end{array}$ \\
\hline $\begin{array}{l}\text { Locus } \\
\text { Notationis } \\
\text { (MATTHESON, } \\
\text { [1739],1954, } \\
\text { Parte II,Cap.4, } \\
\text { § 23,p.123). }\end{array}$ & $\begin{array}{l}\text { Aspecto externo } \\
\text { e desenho das } \\
\text { notas (Duração } \\
\text { das notas, } \\
\text { alteração, } \\
\text { repetição e } \\
\text { procedimentos }\end{array}$ & $\begin{array}{l}\text { Vários motivos } \\
\text { rítmicos e diferentes } \\
\text { durações de notas } \\
\text { (semínimas, } \\
\text { colcheias, repetições, } \\
\text { pausas, fermata, entre } \\
\text { outros). }\end{array}$ & $\begin{array}{ll}1-2 & S \\
3 & \text { S-A } \\
4-40 & \text { S-A-T-B }\end{array}$ \\
\hline
\end{tabular}




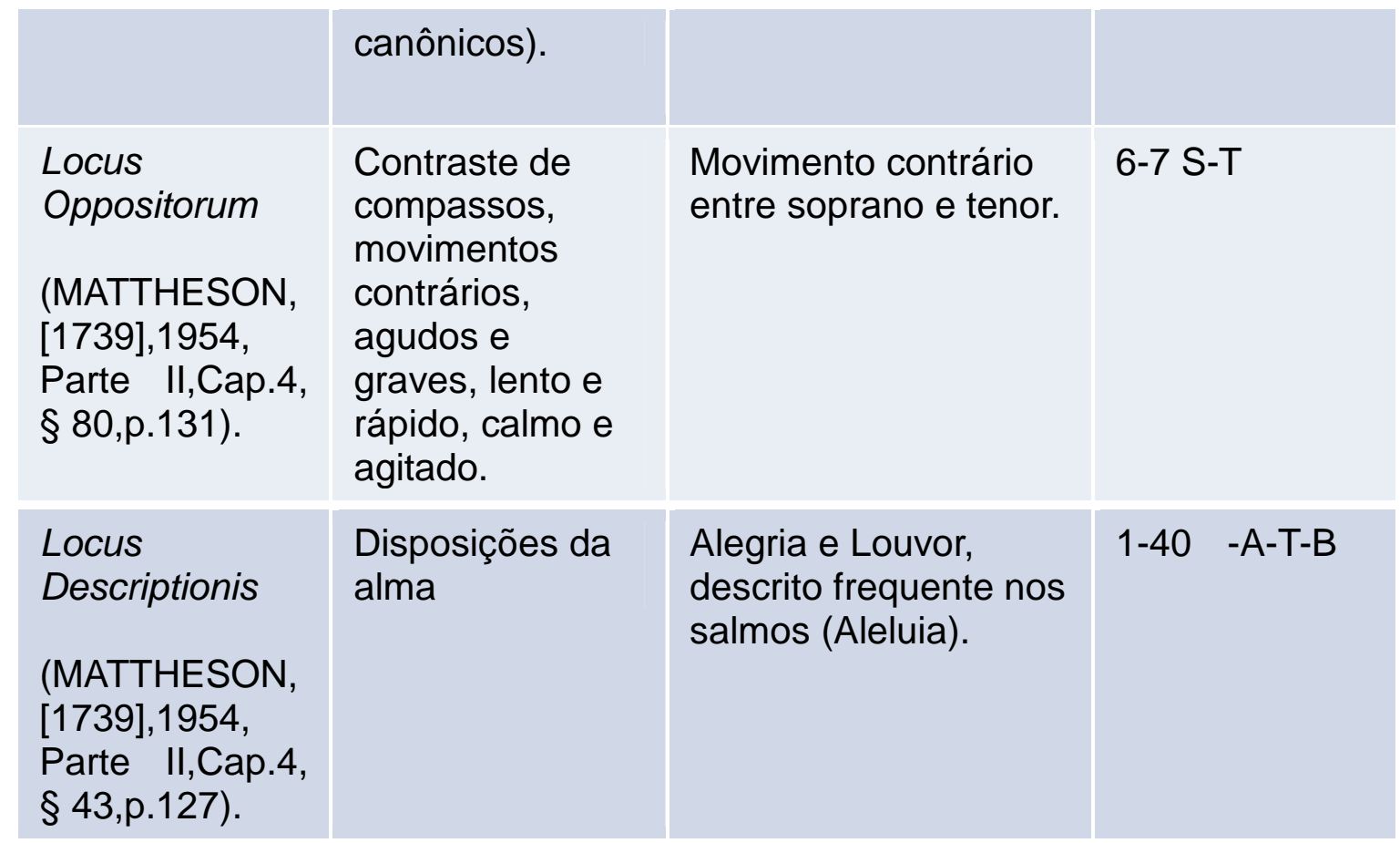

Tabela 57: Locus Topici encontrados no Ofertório da Missa da Ascenção do Senhor de André da Silva Gomes (Segundo Movimento)

\subsection{Dispositio}

\subsubsection{Exordium (Primeiro Movimento)}

É apresentado nos três primeiros compassos, onde as notas iniciais são direcionadas a ascensão do Senhor através da expressão Ascnendit Deus in jubilatione, Dominus in voce tubae, neste caso o orador introduz seu discurso proclamando a grandeza do Senhor na figura central do ofertório, Anabasis, ou seja, por meio dela se representa a exaltação e imagens positivas dos afetos, objetivando forte invocação e apelo ao ouvinte a exultação. 
Primeira Seção

Tonalidade Ré Maior

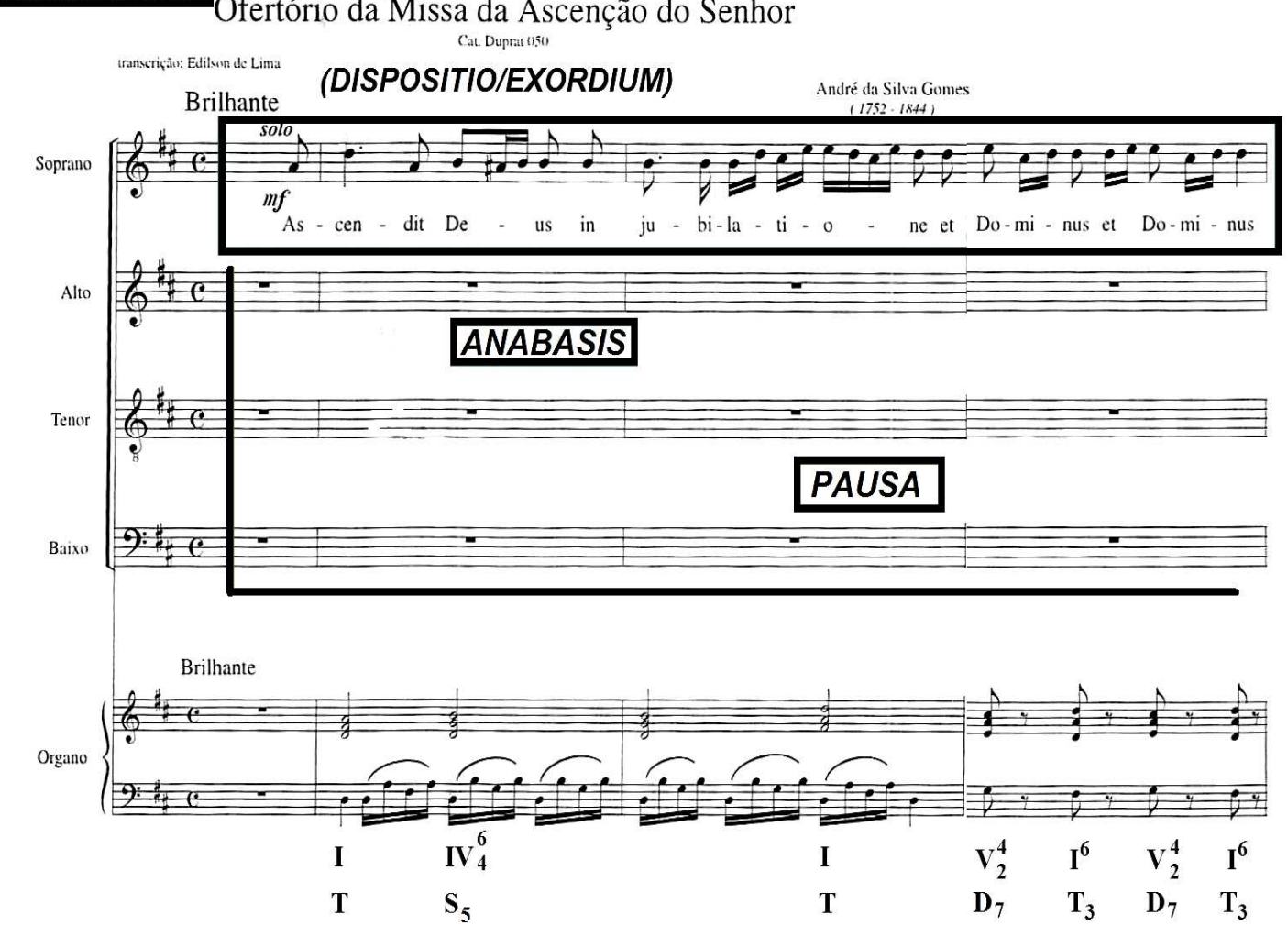

Exemplo 151: Ofertório da Missa da Ascenção do Senhor de André da Silva GomesCatalogação e Organização Régis Duprat (DUPRAT, 1999, p.183).

\subsubsection{Narratio}

Inicia-se com a inserção de duas figuras acopladas, Climax e Tirata, a primeira repetindo as notas em forma de sequência e a segunda numa passagem escalar rápida com as mesmas características da anterior, entretanto, com maior extensão. Igualmente, vê-se a Pausa, utilizada desde o começo da obra determinando o repouso das outras vozes, liberando a da soprano na continuação do argumento já disposto desde o Exordium e por fim a Cadência Autêntica Perfeita no sexto compasso. 


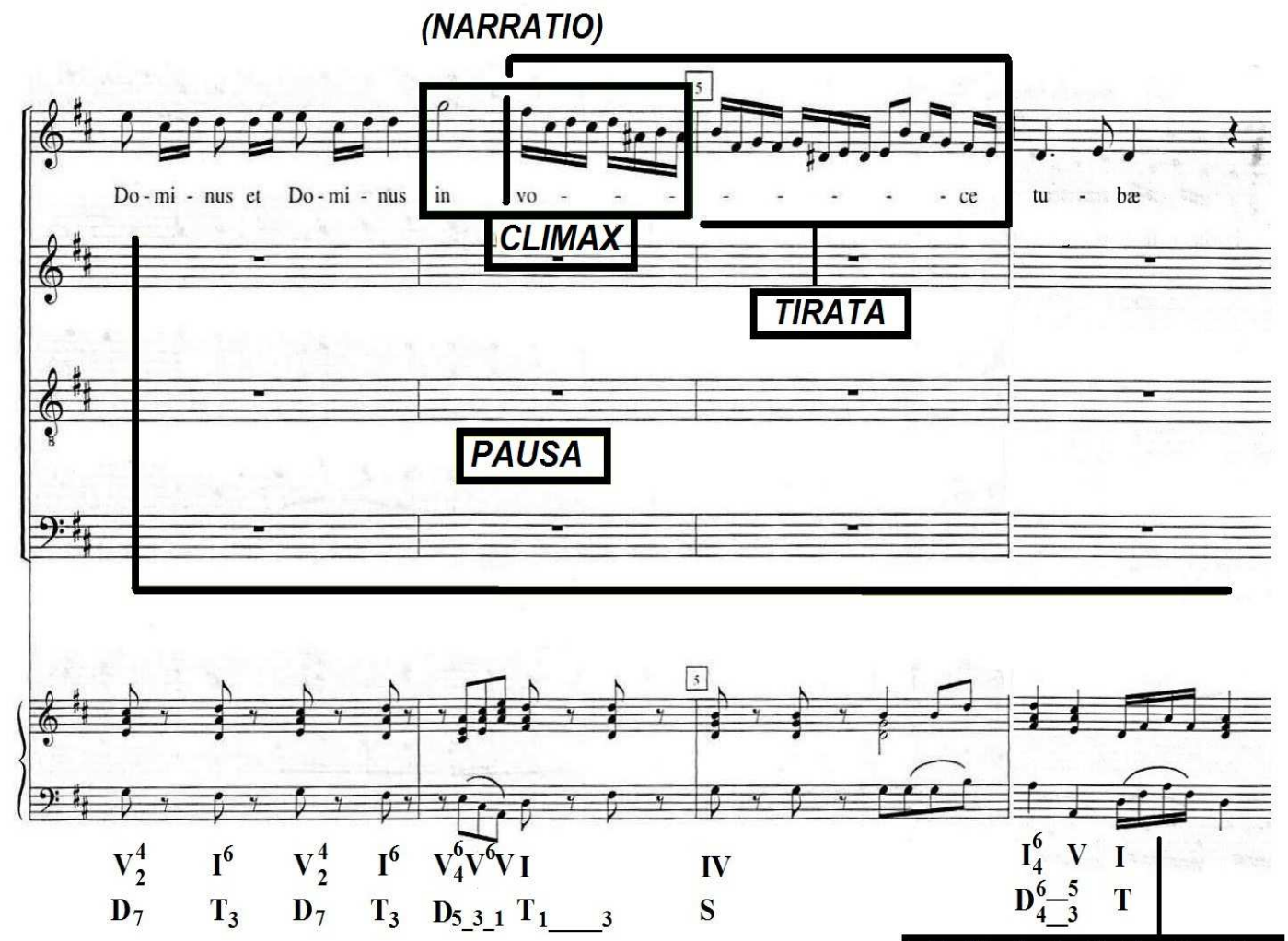

Cadência Autêntica Perfeita

Exemplo 152: Ofertório da Missa da Ascenção do Senhor de André da Silva GomesCatalogação e Organização Régis Duprat (DUPRAT, 1999, p.183).

\subsubsection{Propositio}

A mesma aclamação é visível na Propositio, onde a tese inicial é esbouçada novamente, no entanto, de maneira sucinta pelo autor e por todas as vozes. Nos compassos 7 e 8, Silva Gomes aplica a Circulatio, destacando a palavra Ascendit (subir, elevado, para cima, ascensão), como a nota Lá nas funções da Tônica e Dominante, também a Metabasis no cruzamento das vozes do tenor e baixo. Outra coisa a ser observada é o emprego da Anabasis a partir do compasso 9 , reforçando a ideia de elevação. 
(PROPOSITIO)

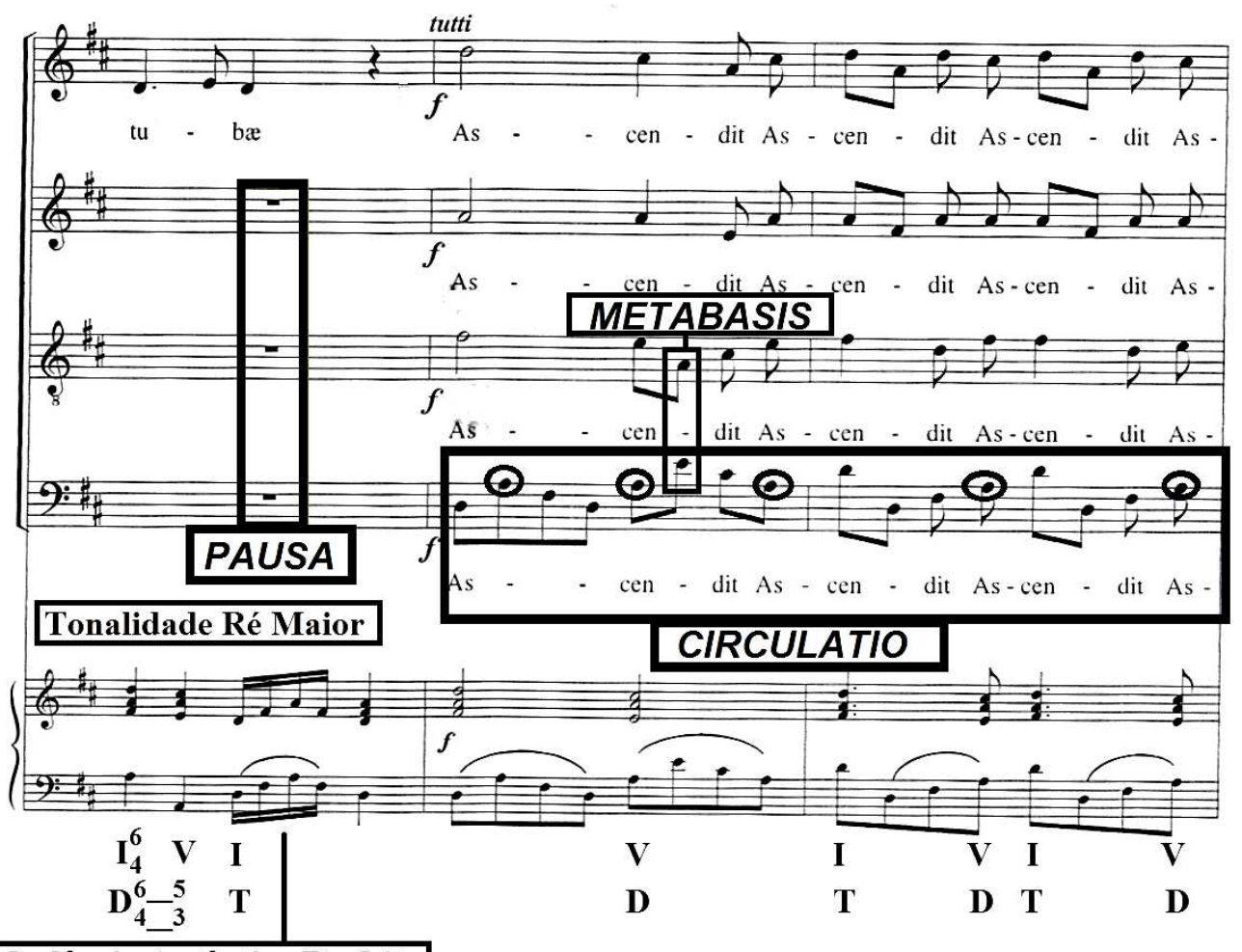

Cadência Autêntica Perfeita

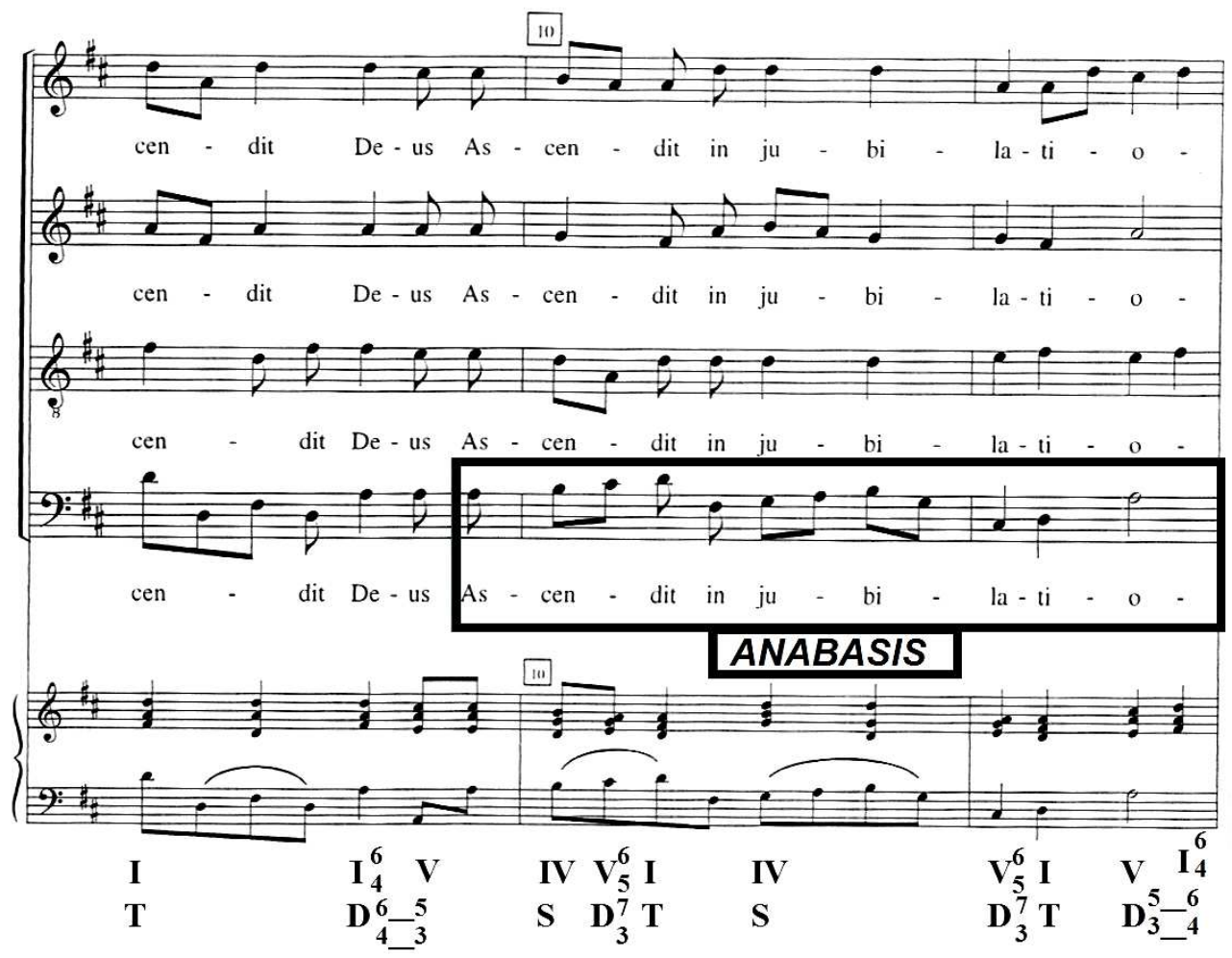

Exemplo 153: Ofertório da Missa da Ascenção do Senhor de André da Silva GomesCatalogação e Organização Régis Duprat (DUPRAT, 1999, p.184). 
Decorrente da Aposiopesis, a primeira seção e a Propositio se encerra com a introdução da Noema, destacando por meio de repetição a expressão Dominus in voce tubae, numa passagem homofônica até sua resolução no compasso 15, na Cadência Autêntica Perfeita.

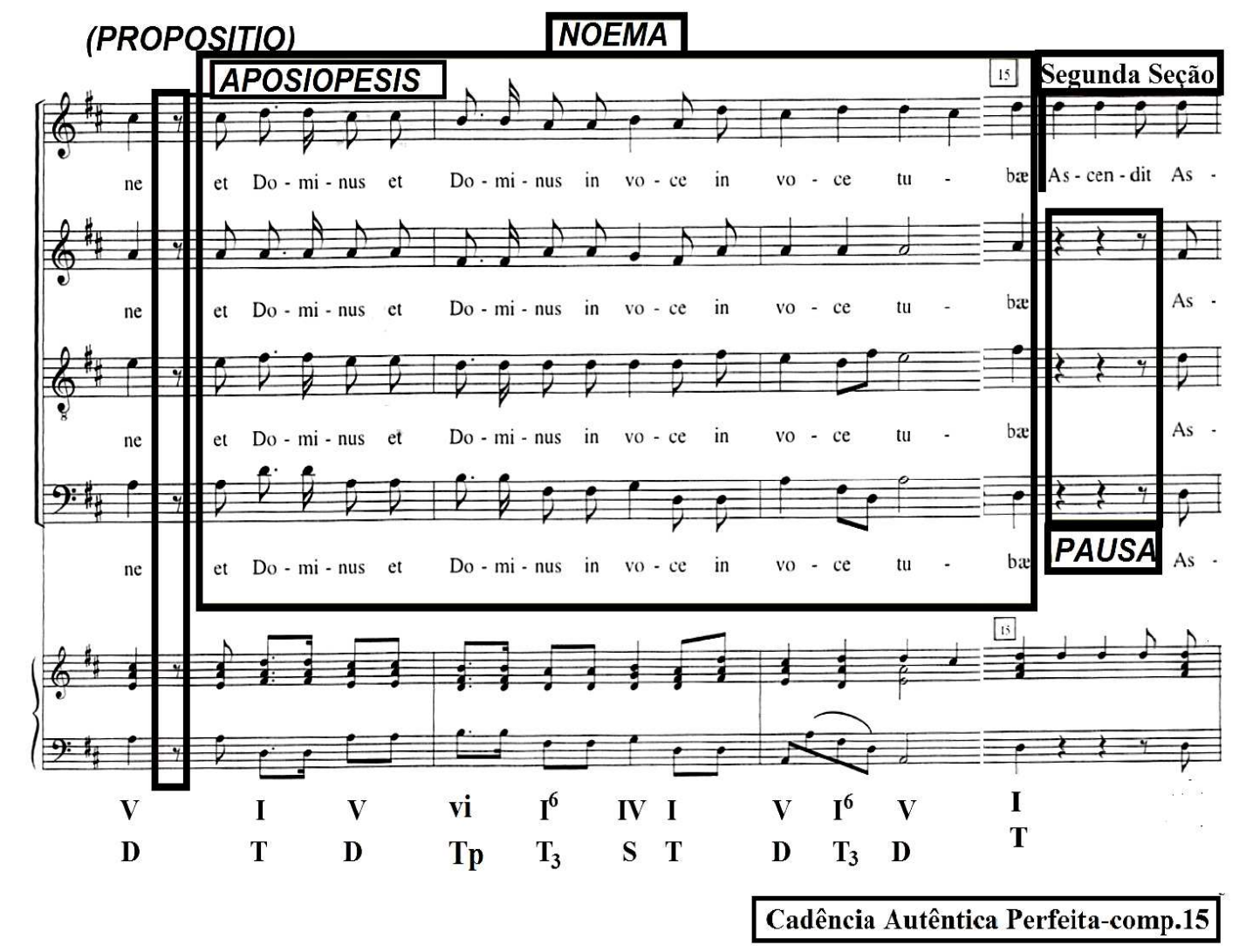
Exemplo 154: Ofertório da Missa da Ascenção do Senhor de André da Silva Gomes-
Catalogação e Organização Régis Duprat (DUPRAT, 1999, p.185).

\subsubsection{Confutatio}

Novos elementos são utilizados pelo compositor, por exemplo, a Palilogia, repetindo as mesmas palavras e notas na voz da soprano e a figura central da peça, como a Anabasis, dando sustentabilidade ao discurso, ressaltando a ascensão do Senhor, Ascendit. 


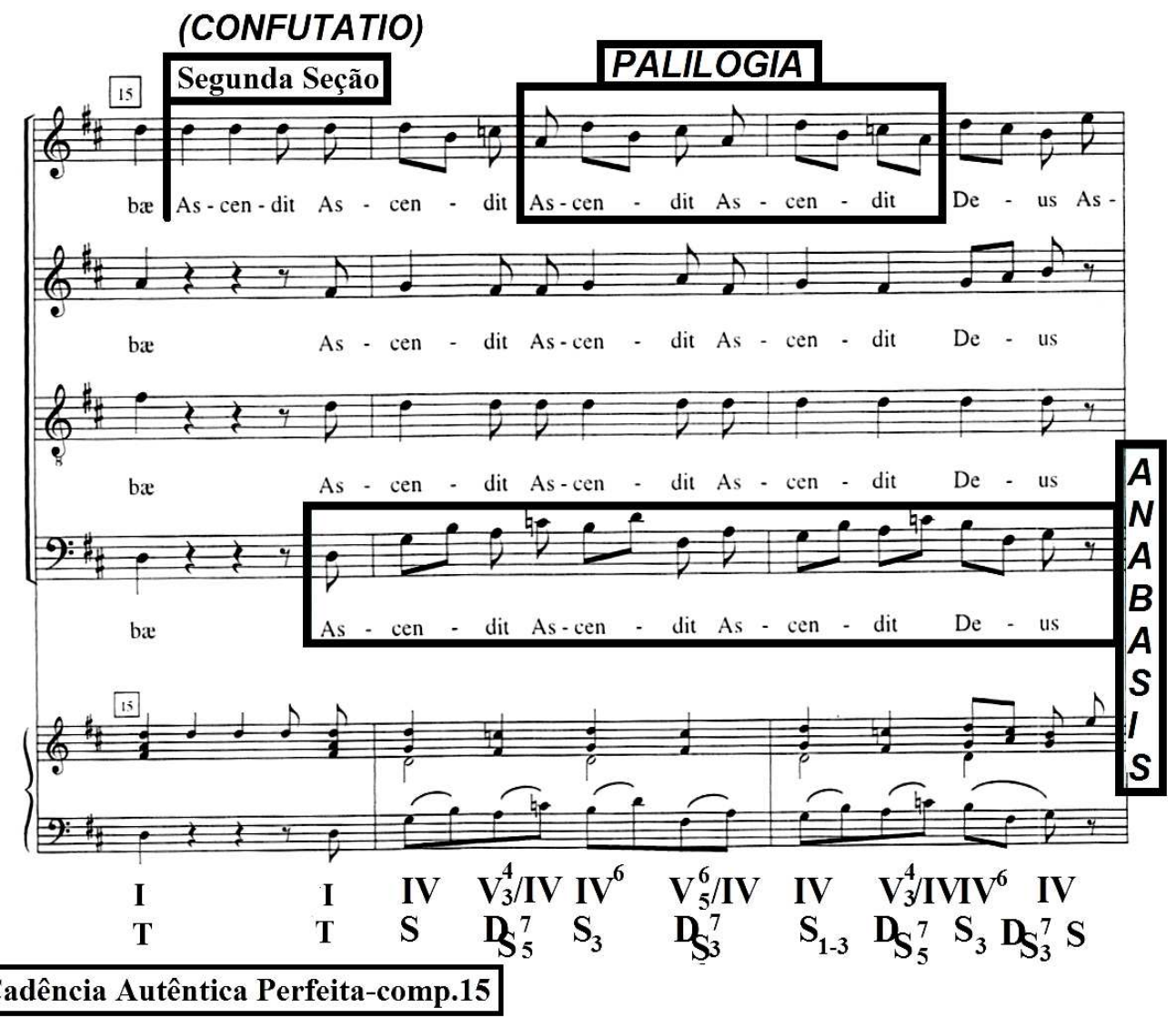

Exemplo 155: Ofertório da Missa da Ascenção do Senhor de André da Silva GomesCatalogação e Organização Régis Duprat (DUPRAT, 1999, p.185).

Observam-se duas modulações no excerto a baixo, para Lá Maior, Mi Menor e Sol Maior, além de figuras já empregadas nas seções anteriores, Anabasis e Metabasis, porém Silva Gomes reforça essas mudanças de tonalidade, inserindo a Abruptio, através de uma quebra súbita e inesperada nas vozes da contralto, tenor e baixo, a Epizeuxis, enfatizando por meio de repetição a palavra Dominus (Senhor) e a Gradatio, também repetindo as notas e palavras (in voce tubae), no entanto, em sequências e intensidade. 

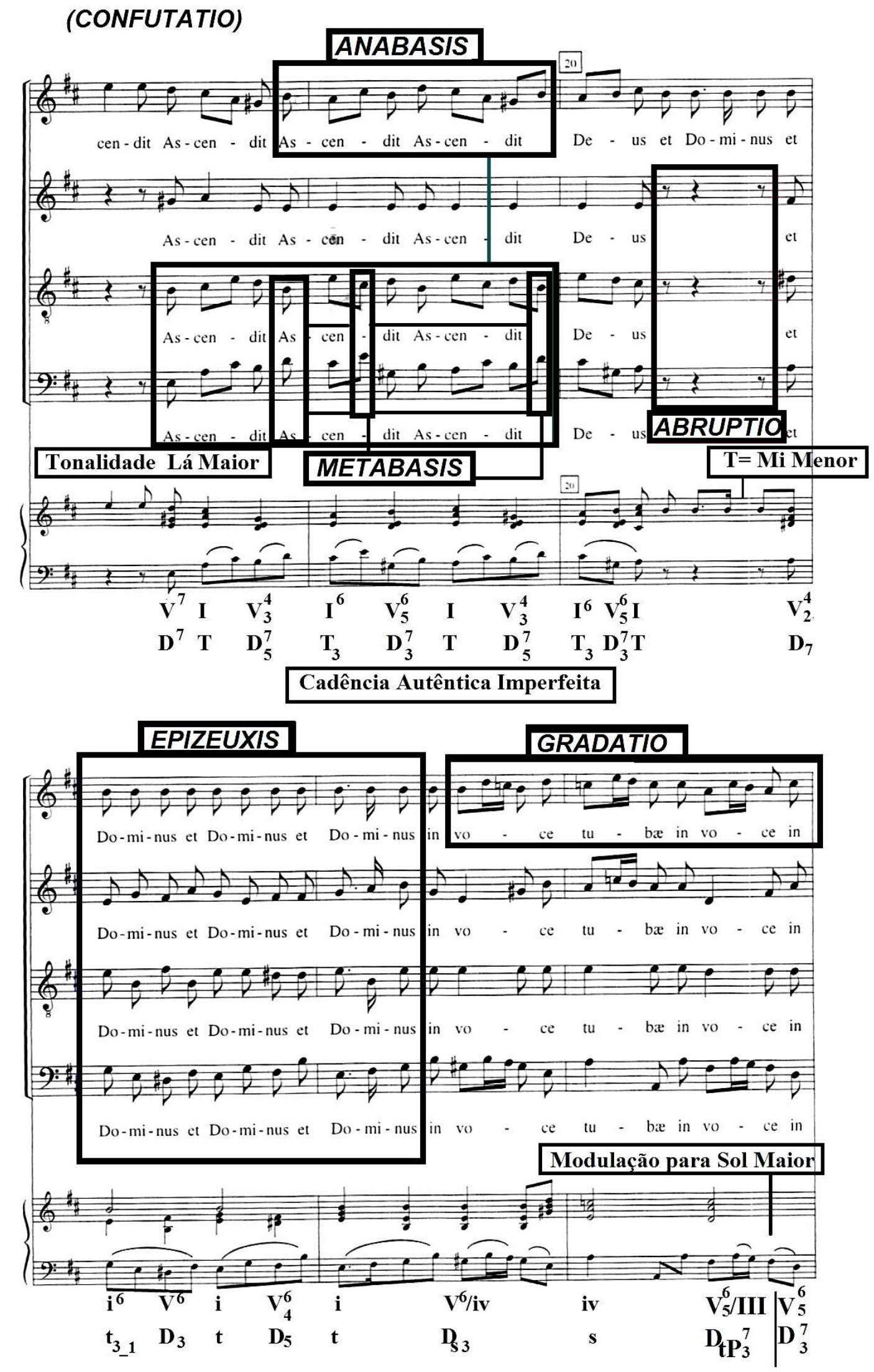

Exemplo 156: Ofertório da Missa da Ascenção do Senhor de André da Silva GomesCatalogação e Organização Régis Duprat (DUPRAT, 1999, p.186). 
A primeira parte da refutação dos fatos argumentados no discurso é finalizada no compasso 25, com uma Cadência Autêntica Imperfeita. Nos compassos seguintes, verificam-se os mesmos materiais utilizados pelo compositor desde o início da obra, como das figuras retóricas, Anabasis e Pausa, entretanto, configurados em outra fase, caracterizando um Exordium dentro da Confutatio, na tonalidade de Sol Maior.

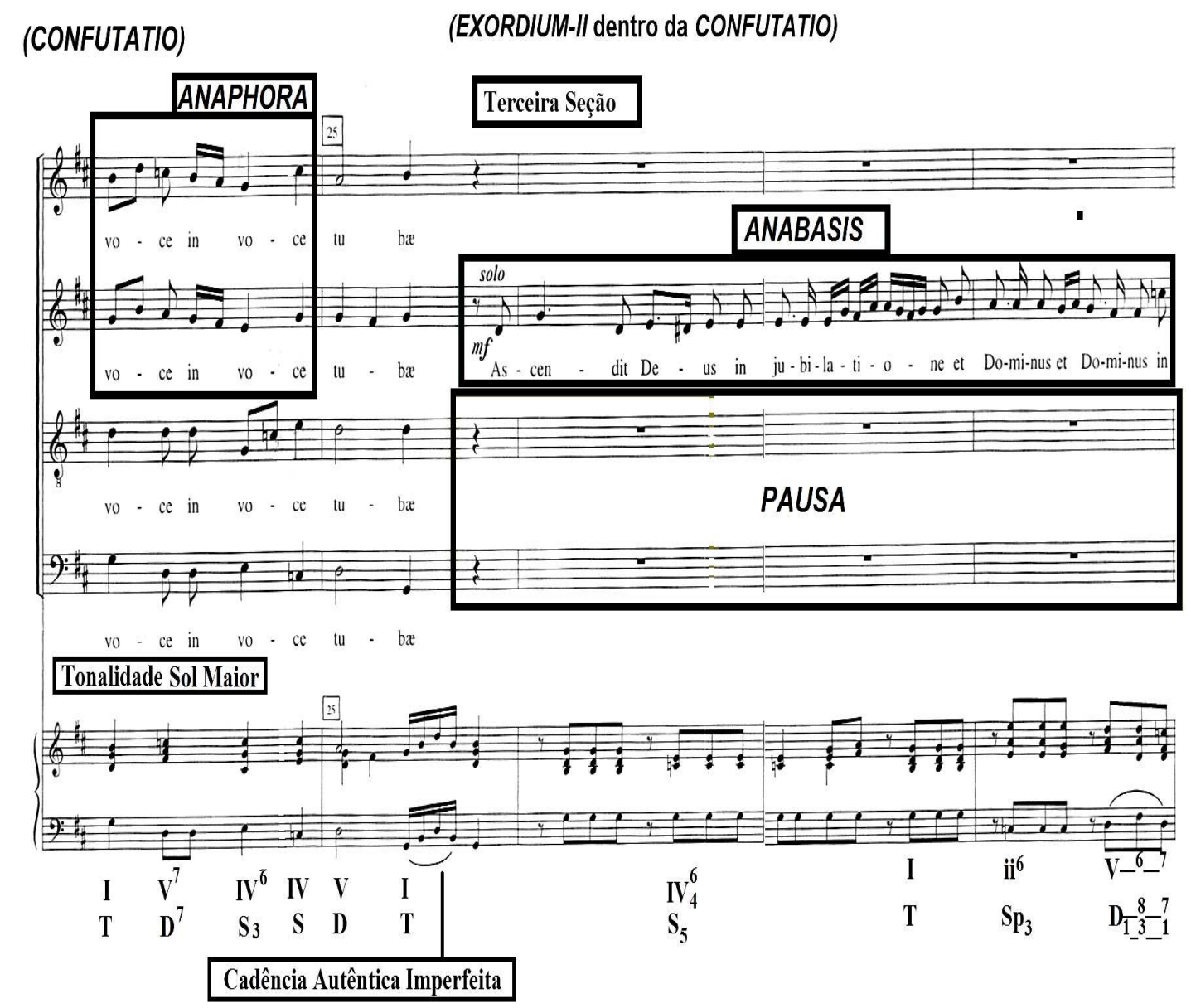

Exemplo 157: Ofertório da Missa da Ascenção do Senhor de André da Silva GomesCatalogação e Organização Régis Duprat (DUPRAT, 1999, p. 187). 
Silva Gomes dá continuidade ao seu intento de atrair a atenção do ouvinte, empregado a Circulatio, destacando as notas Sol e Sol sustenido.

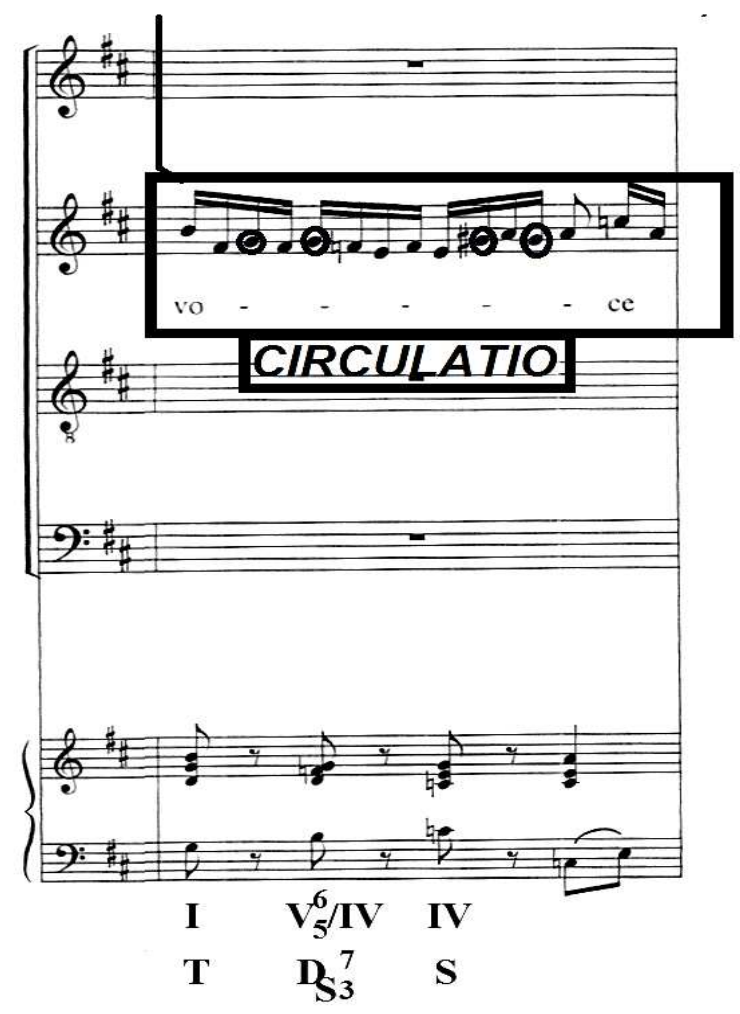

Exemplo 158: Ofertório da Missa da Ascenção do Senhor de André da Silva GomesCatalogação e Organização Régis Duprat (DUPRAT, 1999, p.187).

O autor aplica pela primeira vez no ofertório a Synonimia, repetindo as notas e enfatizando as palavras in voce tubae, interpretadas pela contralto, também examina-se a continuação do uso da Circulatio no fechamento da seção no compasso 35, numa Cadência Completa. 
(NARRATIO-II dentro da CONFUTATIO)
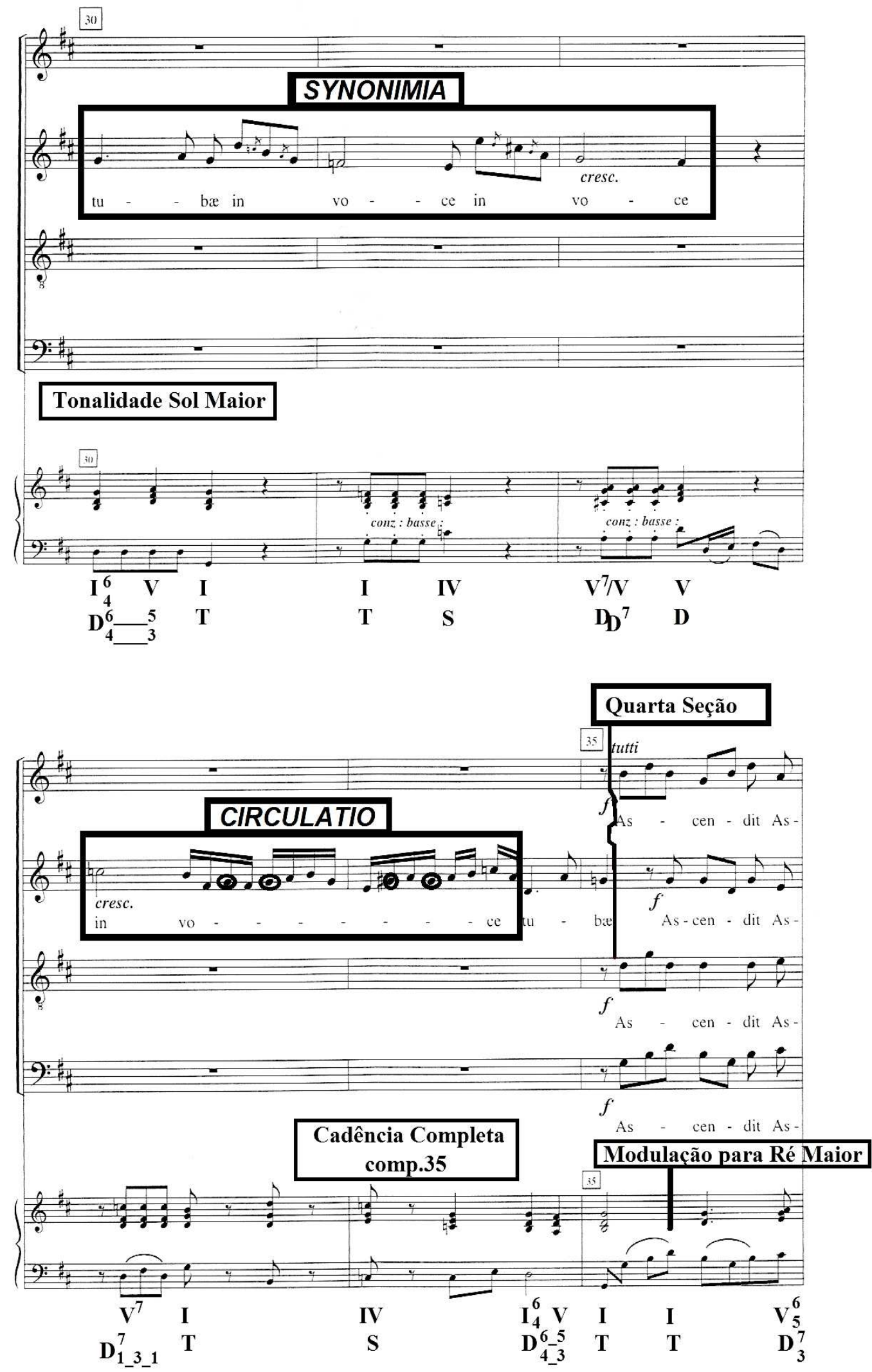

Exemplo 159: Ofertório da Missa da Ascenção do Senhor de André da Silva GomesCatalogação e Organização Régis Duprat (DUPRAT, 1999, p.188). 
Assim como ocorrera no compasso 7, o autor retorna ao argumento inicial, sustentando seu discurso com forte apelo a celebrar com júbilo a magnificência do Senhor entre aclamações, sobre as nações, Ascendit Deus in jubilatione, Dominus in voce tubae, apropriando-se dos mesmos recursos retóricos, Anabasis e Aposiopesis, porém, dentro de outra fase retórica, consubstanciando numa Propositio dentro da Confutatio. Enfim, esse artificio de refutação, contraste e modulações, como o intento de confundir e ao mesmo tempo criar expectativa a quem ouve, é finalizado com Semicadência no começo do compasso 39, aumentando ainda mais essa carga afetiva.

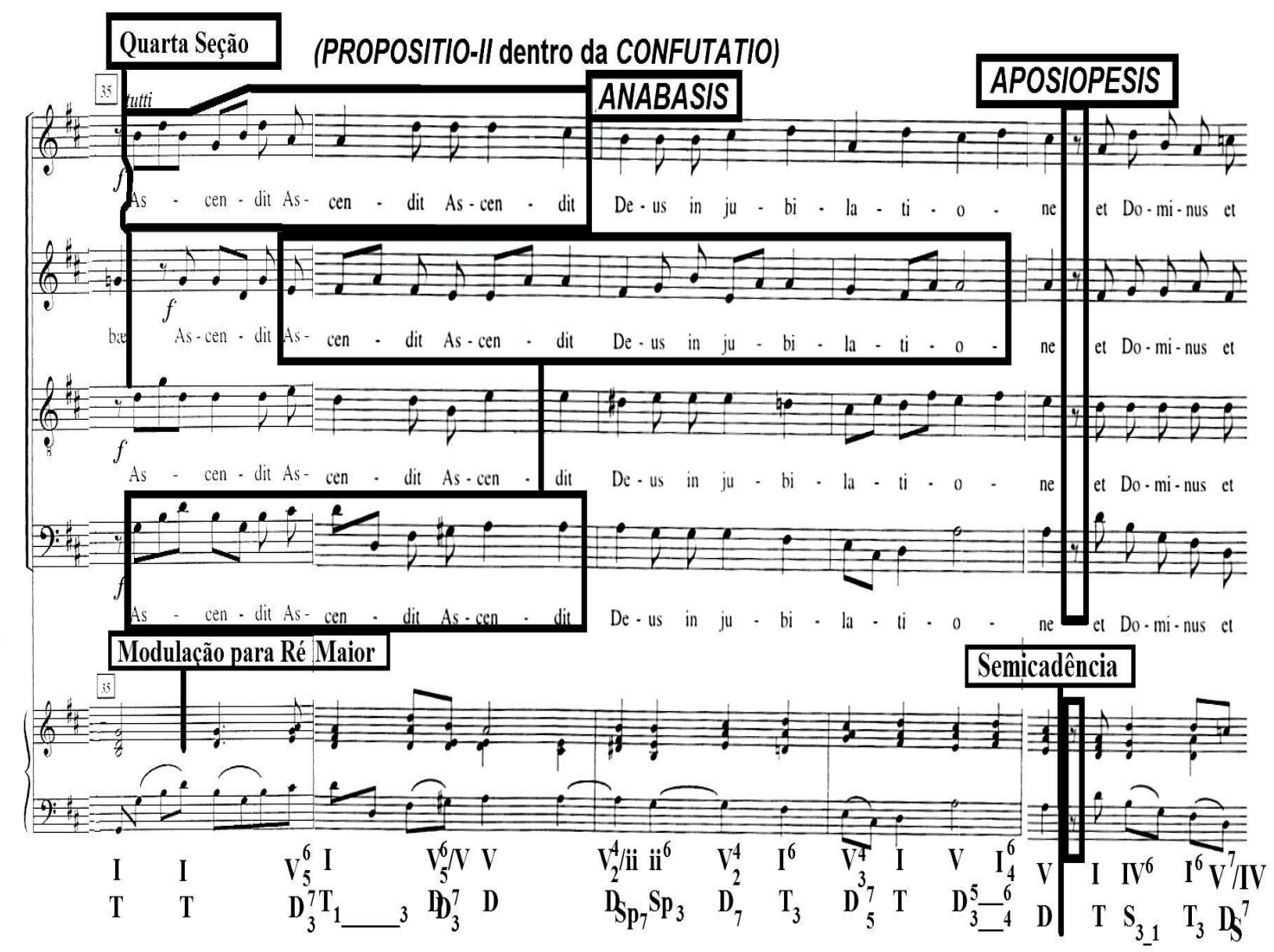

Exemplo 160: Ofertório da Missa da Ascenção do Senhor de André da Silva GomesCatalogação e Organização Régis Duprat (DUPRAT, 1999, pp.188-189).

\subsubsection{Confirmatio}

A tese se confirma com a introdução da Epizeuxis, ressaltando a grandeza do Senhor que subiu aos céus ao som de trombeta, por meio de repetições enfáticas, et Dominus in voce tubae. 


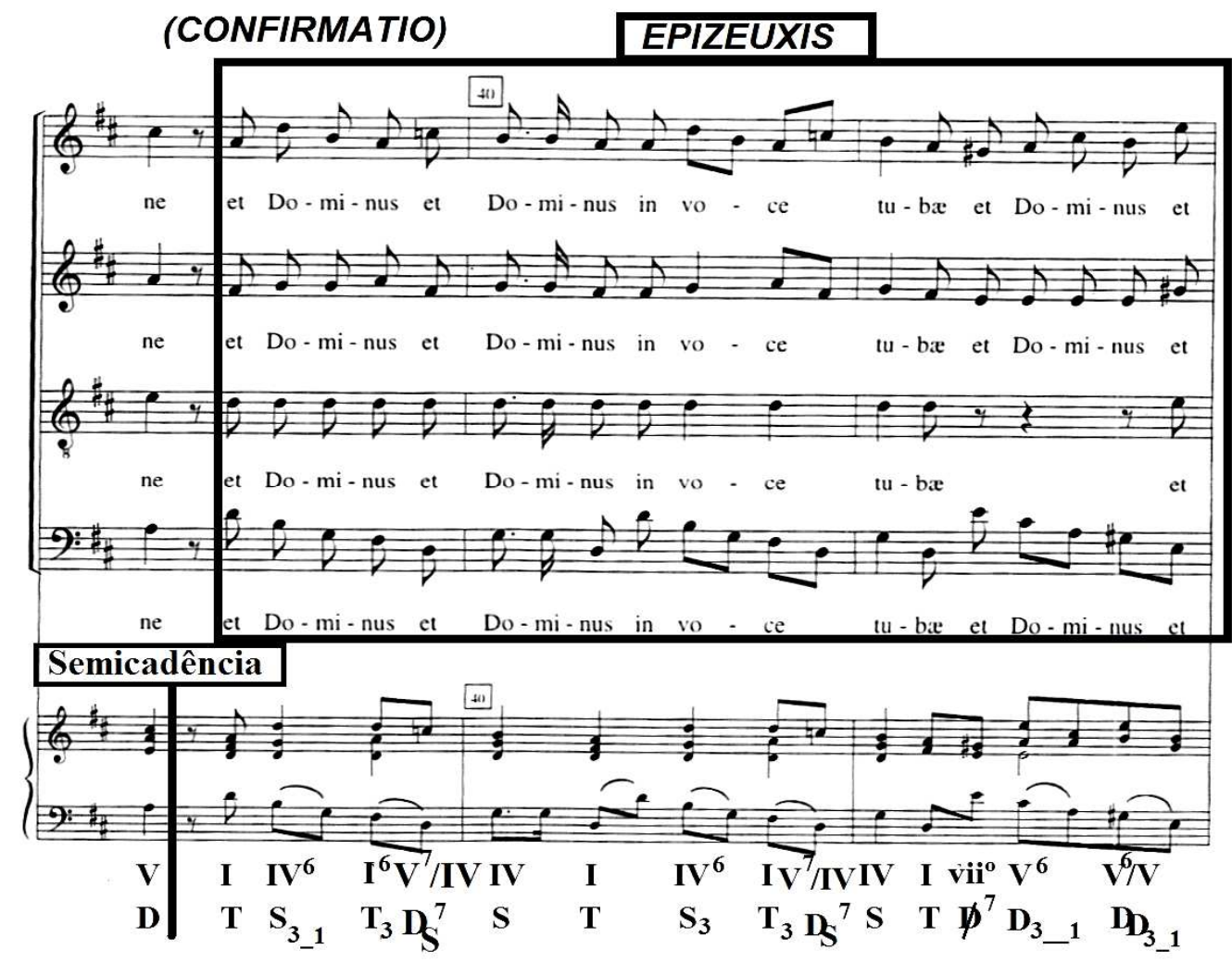

Exemplo 161: Ofertório da Missa da Ascenção do Senhor de André da Silva GomesCatalogação e Organização Régis Duprat (DUPRAT, 1999, p.189).

O emprego da Aposiopesis pelo autor finaliza essa fase, através de pausa geral, logo após a Cadência Completa.

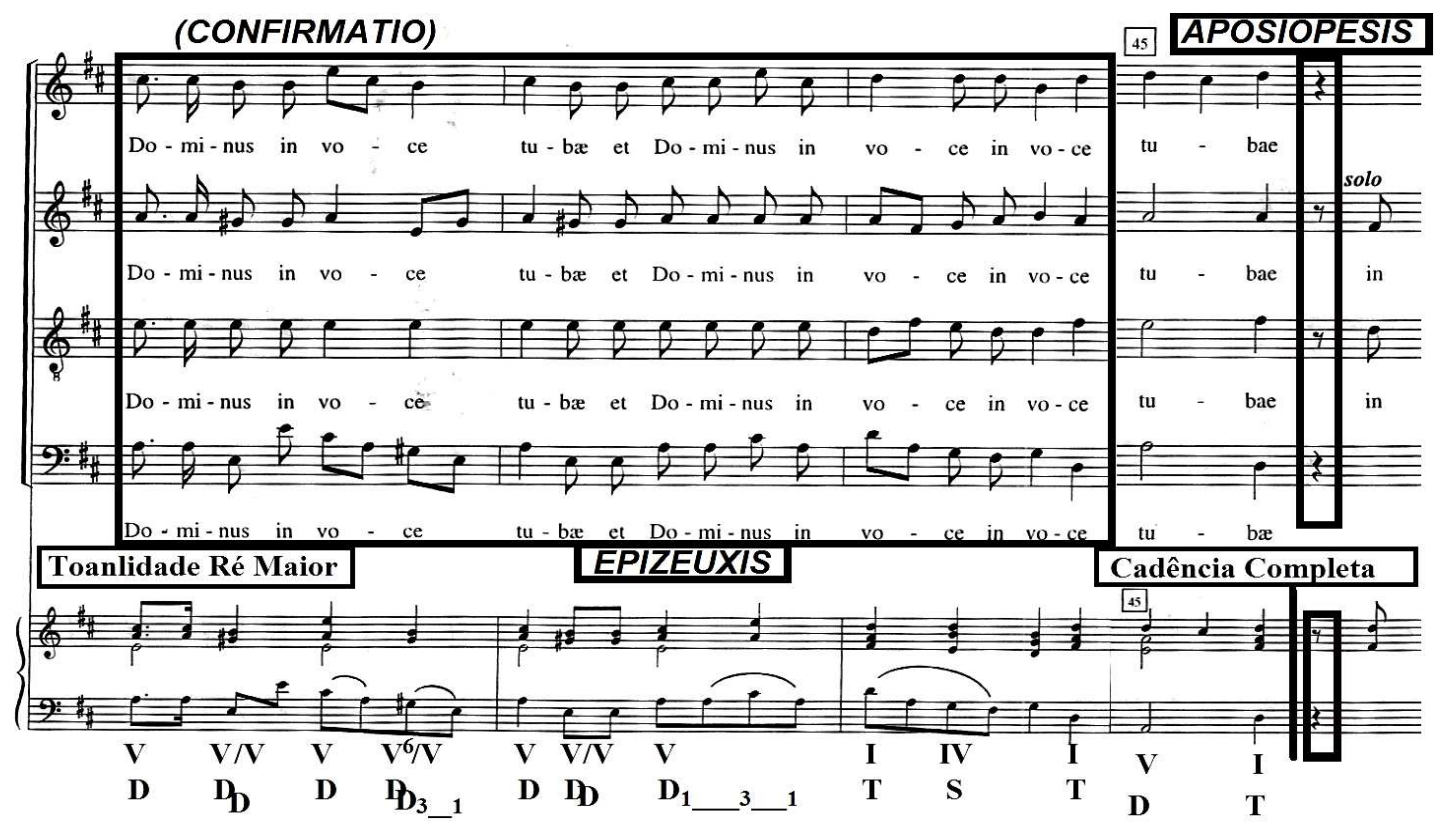

Exemplo 162: Ofertório da Missa da Ascenção do Senhor de André da Silva GomesCatalogação e Organização Régis Duprat (DUPRAT, 1999, p.190). 


\subsubsection{Perotatio}

A síntese do primeiro movimento da obra é iniciada no final do compasso 45, com solo da contralto e do tenor, com aproximadamente um compasso, sendo em seguida reforçado por todas as vozes. Nessa junção, o compositor luso-brasileiro usa a Gradatio para enfatizar tanto as notas, quanto a expressão ao som de trombeta, completando o sentido de grandeza e majestade, atribuída a Deus pelo salmista.

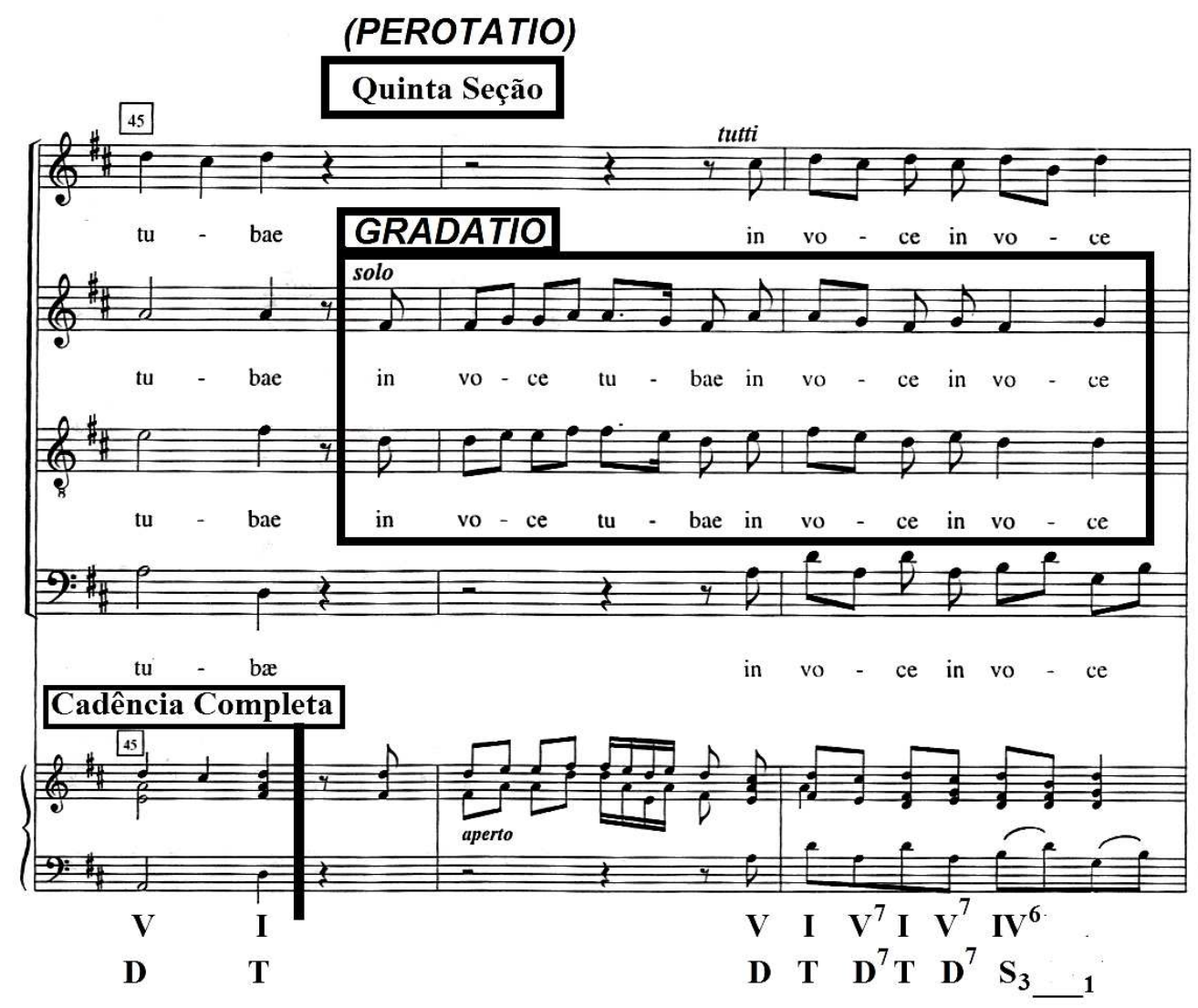

Exemplo 163: Ofertório da Missa da Ascenção do Senhor de André da Silva GomesCatalogação e Organização Régis Duprat (DUPRAT, 1999, p.190).

Com o mesmo argumento supracitado (o Senhor foi ascenso aos céus com sons de trombetas), a Perotatio é concluída na tonalidade de Ré Maior, com o emprego da Synaeresis, no compasso 48, nas vozes da contralto e tenor salientando a silaba proferida por duas notas e a Noema, destacando a passagem homofônica das partes até o compasso 53. 

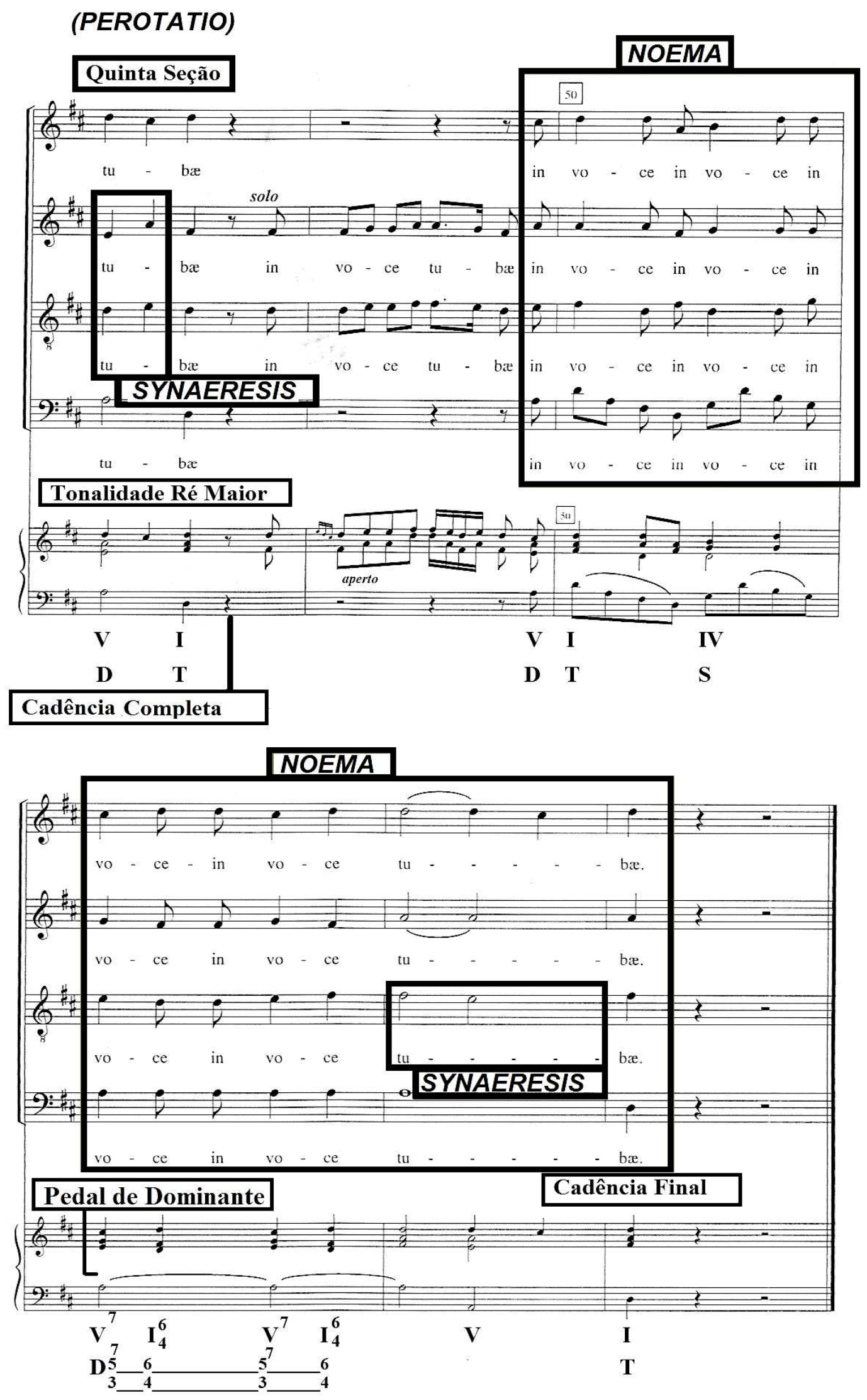

Exemplo 164: Ofertório da Missa da Ascenção do Senhor de André da Silva GomesCatalogação e Organização Régis Duprat (DUPRAT, 1999, p.191). 


\subsubsection{Exordium (Segundo Movimento)}

Segundo Paulo Augusto Soares, "esse movimento não se configura numa fuga completa por não apresentar todas as seções que the são exigidas" (SOARES, 2000, p.157). No entanto, pode-se verificar a entrada deslocada de cada voz em sequência a cada dois compassos, onde o texto Alleluia é trabalhado pelo autor, seja em polifonias, homorrítmicamente e em uníssono no final nas quatro vozes.

A referida palavra de canto e louvor (aleluia), é bem disposta por Silva Gomes nesses doze compassos do ofertório, sendo que no primeiro e terceiro, emprega duas figuras de repetição melódica: Polyptoton, que enfatiza por meio de repetição as palavras e notas em todas as alturas e vozes dessa composição e a Palilogia, com função semelhante, todavia, essa repetência se dá somente na mesma altura.

Enfim, a primeira seção e fase retórica são finalizadas na tonalidade de Ré Maior no compasso 12, numa Cadência Autêntica Perfeita cujas funções harmônicas utilizadas se detiveram entre Tônica e Dominante. 

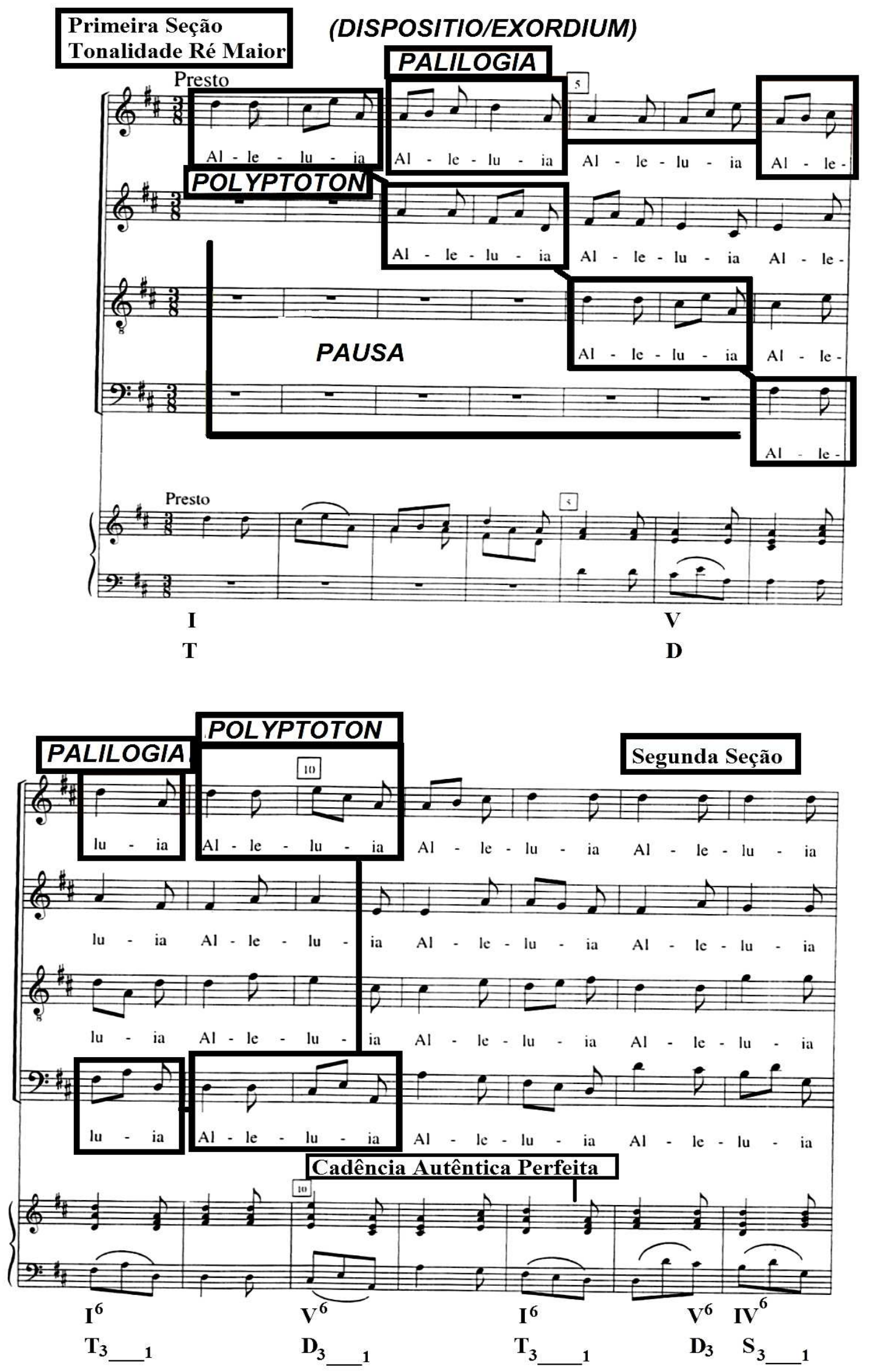

Exemplo 165: Ofertório da Missa da Ascenção do Senhor de André da Silva GomesCatalogação e Organização Régis Duprat (DUPRAT, 1999, p.192). 


\subsubsection{Narratio}

A continuidade desse encômio se aplica com a execução da narração dos fatos expostos anteriormente por todas as vozes, igualmente pelo uso da Epizeuxis, repetindo nada menos que quatro vezes a expressão central do segundo movimento, Alleuia.

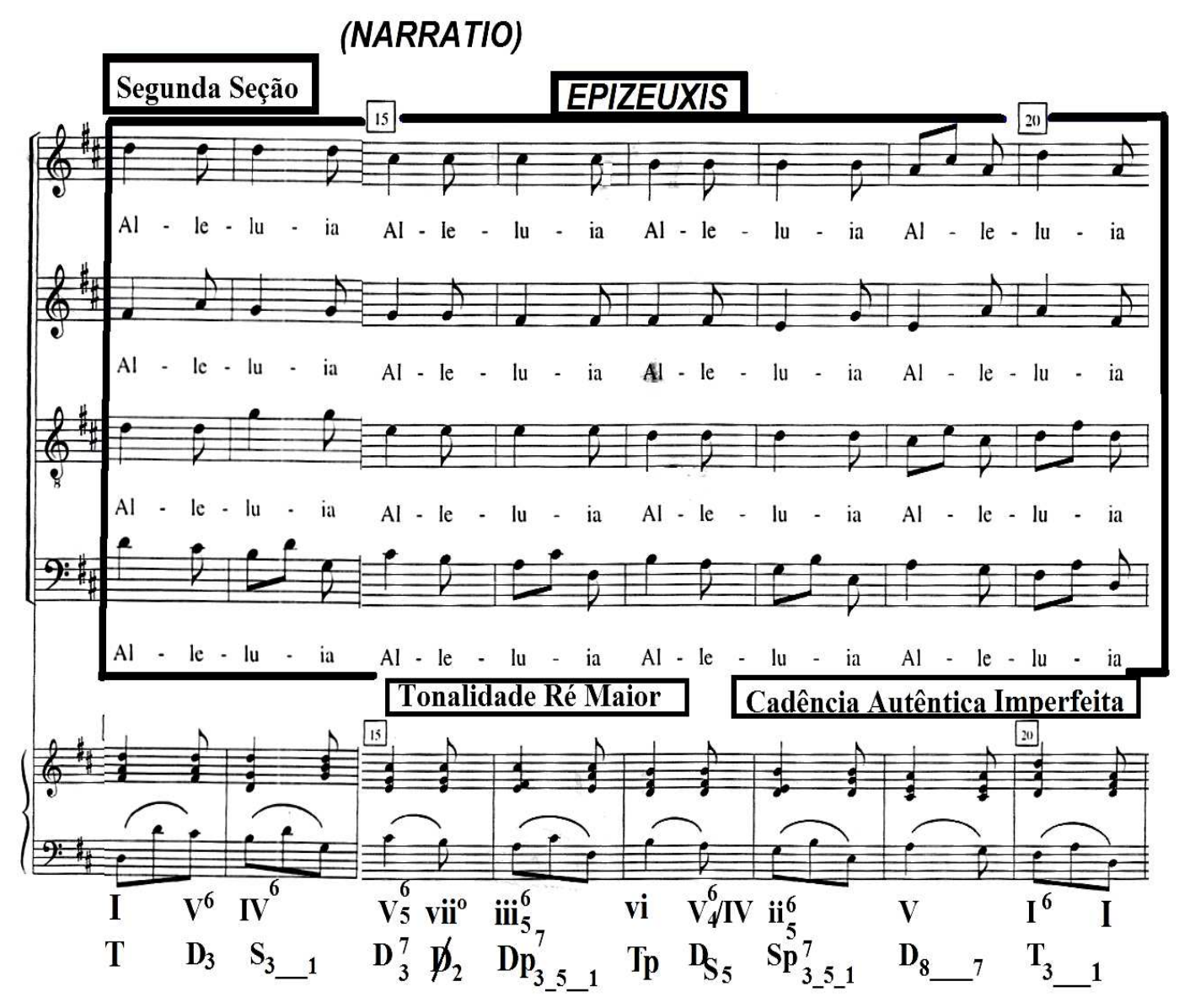

Exemplo 166: Ofertório da Missa da Ascenção do Senhor de André da Silva GomesCatalogação e Organização Régis Duprat (DUPRAT, 1999, p.193).

\subsubsection{Propositio}

A Propositio tem apenas quatro compassos, entretanto, o autor emprega a Analepsis, mantendo a coerência tanto da ênfase, como a repetição literal da seção homofônica. 


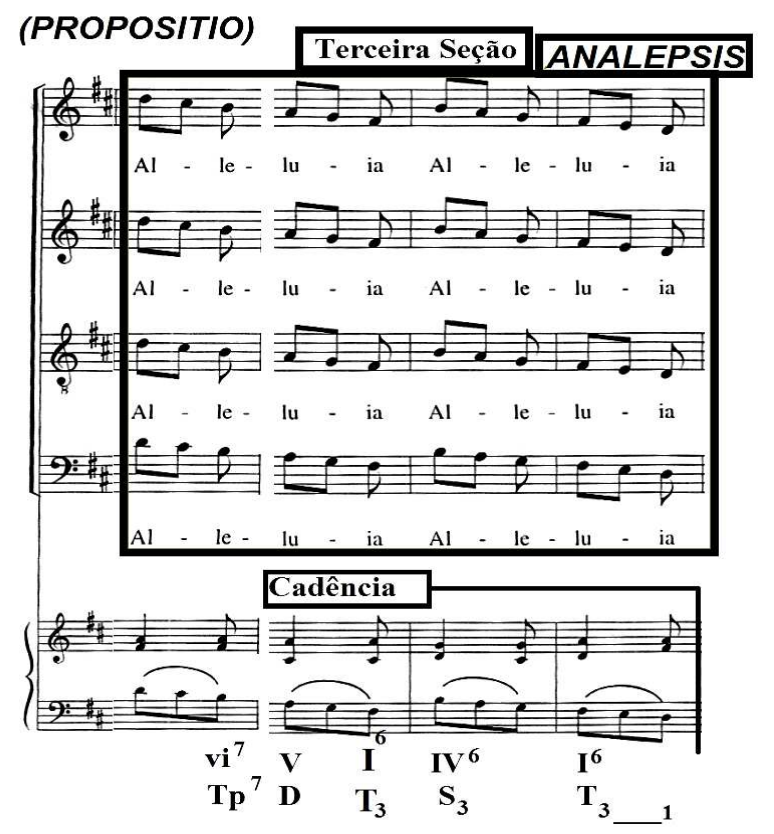

Exemplo 167: Ofertório da Missa da Ascenção do Senhor de André da Silva GomesCatalogação e Organização Régis Duprat (DUPRAT, 1999, p.983).

\subsubsection{Confutatio}

$\mathrm{Na}$ Confutatio, Silva Gomes insere a Gradatio entre os compassos 25 a 28 , aumentando a intensidade das vozes, por meio das sequências das notas repetidas.

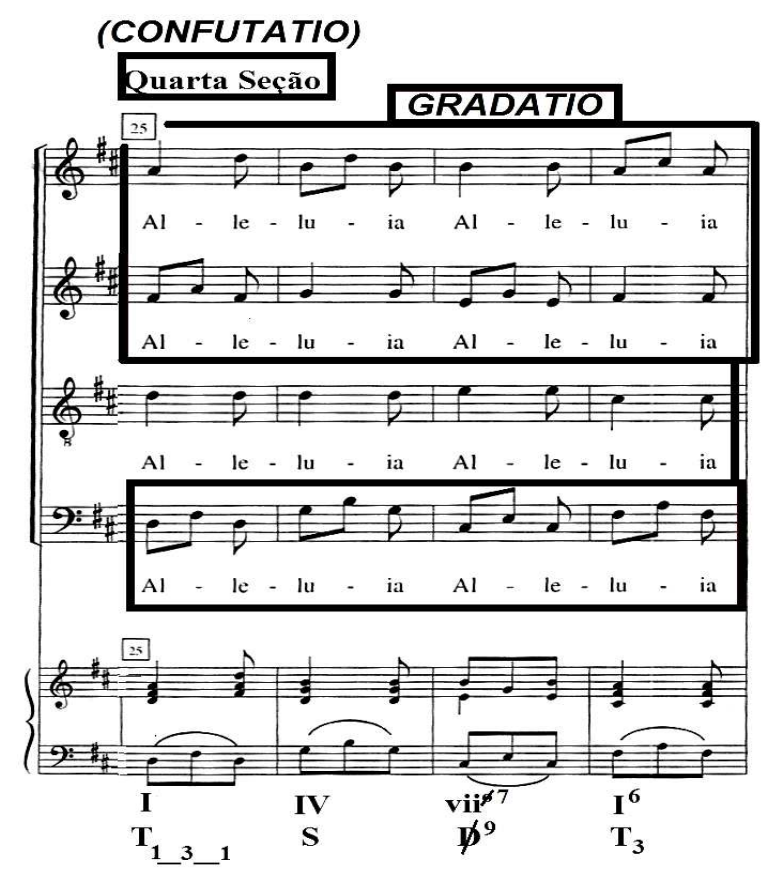

Exemplo 168: Ofertório da Missa da Ascenção do Senhor de André da Silva GomesCatalogação e Organização Régis Duprat (DUPRAT, 1999, p.193). 


\subsubsection{Confirmatio}

$\mathrm{Na}$ confirmação dos fatos, examina-se o uso da Epizeuxis repetindo enfaticamente a palavra Aleluia, assim como da fermata pela primeira vez não só nesse movimento, mas na obra. Também é observável o emprego da Cadência de Engano, a partir do compasso 30, encerrando a seção numa Subdominante, confundindo o ouvinte que esperava ouvir o fechamento da presente fase discursiva, com uma Cadência encerrada na Tônica ou Dominante, por essa razão se constitui uma Confutatio dentro da Confirmatio.

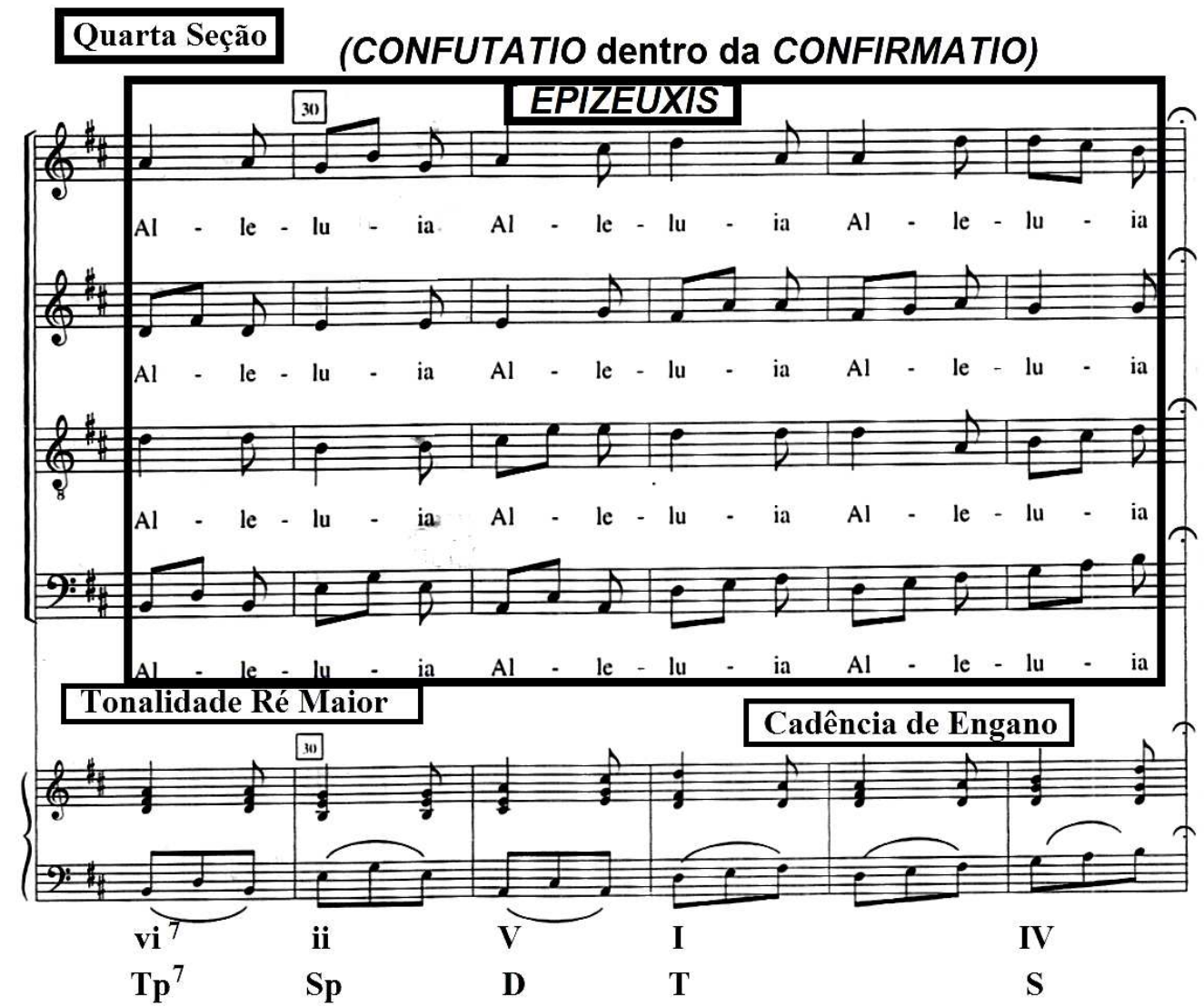

Exemplo 169: Ofertório da Missa da Ascenção do Senhor de André da Silva GomesCatalogação e Organização Régis Duprat (DUPRAT, 1999, p.1194).

\subsubsection{Perotatio}

Por fim, o discurso é concluído através do emprego da Noema que valora a repetição das palavras e notas, enfatizando a passagem homofônica das vozes até seu desfecho na Cadência Autêntica Perfeita no compasso 40. 


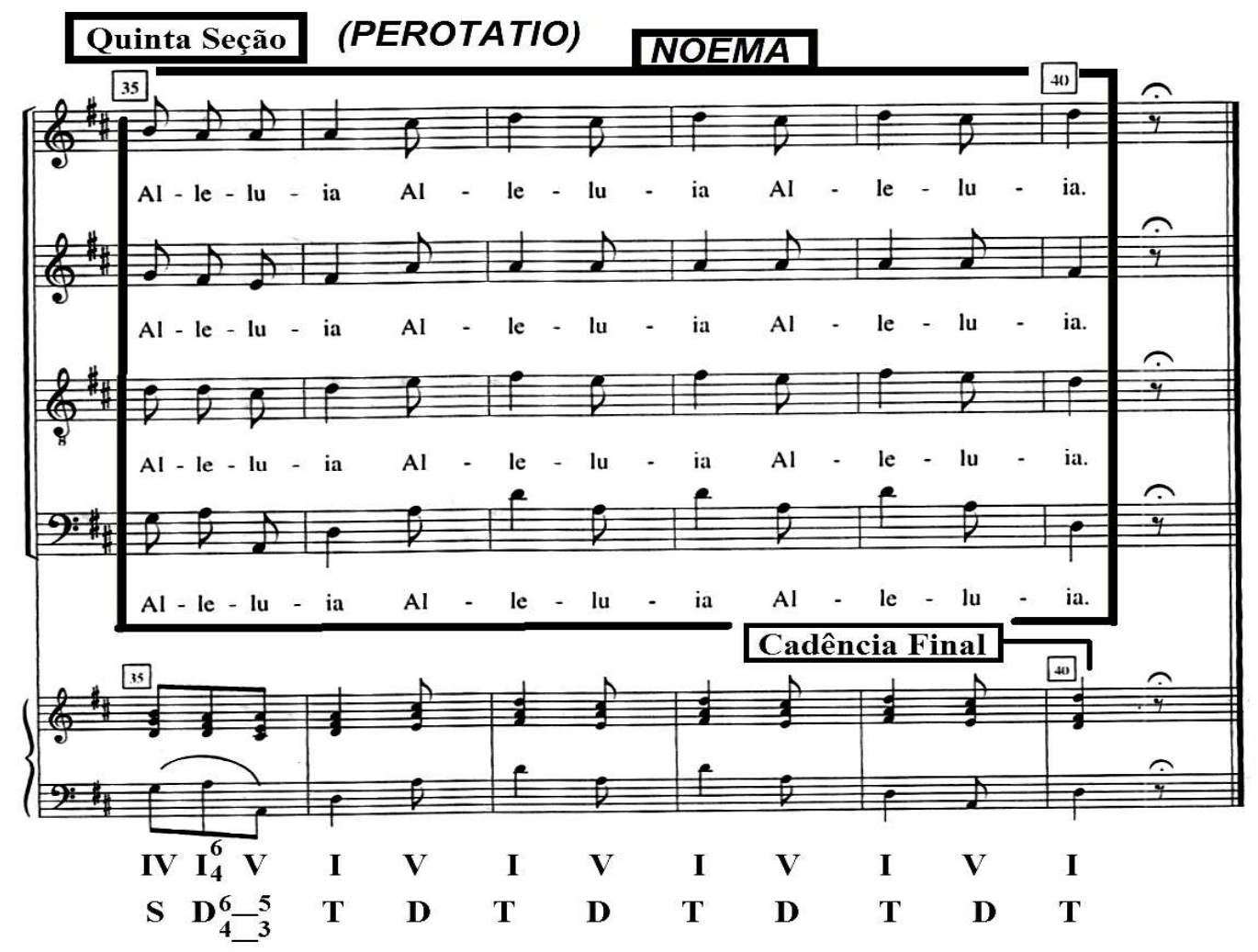

Exemplo 170: Ofertório da Missa da Ascenção do Senhor de André da Silva GomesCatalogação e Organização Régis Duprat (DUPRAT, 1999, p.194).

\subsection{Figuras observadas no Ofertório (Elocutio/Decoratio)}

\begin{tabular}{|l|l|l|l|}
\hline FIGURAS & TIPO & DESCRIÇÃO & TRATADISTA \\
\hline $\begin{array}{l}\text { ABRUPTIO } \\
\text { (BARTEL, 1997, } \\
\text { pp.168-170) }\end{array}$ & $\begin{array}{l}\text { Interrupção } \\
\text { Silêncio }\end{array}$ & $\begin{array}{l}\text { Uma quebra } \\
\text { súbita e } \\
\text { inesperada na } \\
\text { composição } \\
\text { musical. }\end{array}$ & $\begin{array}{l}\text { Vogt: A Abruptio } \\
\text { ocorre quando } \\
\text { um trecho } \\
\text { musical é } \\
\text { interrompido no } \\
\text { final pela } \\
\text { colocação de } \\
\text { algumas pausas. }\end{array}$ \\
\hline $\begin{array}{l}\text { ANABASIS } \\
\text { (BARTEL, }\end{array}$ & $\begin{array}{l}\text { Representação } \\
\text { e Descrição }\end{array}$ & $\begin{array}{l}\text { Uma passagem } \\
\text { musical } \\
\text { ascendente, que } \\
\text { expressa } \\
\text { exaltação ou } \\
\text { imagens positivas } \\
\text { dos afetos. }\end{array}$ & $\begin{array}{l}\text { Walther: } \\
\text { Anabasis, de } \\
\text { anabaino, } \\
\text { ascendo é uma } \\
\text { passagem } \\
\text { musical por meio } \\
\text { do qual algo } \\
\text { subindo às } \\
\text { alturas é } \\
\text { expressa. Por } \\
\text { exemplo, nas }\end{array}$ \\
\hline
\end{tabular}




\begin{tabular}{|c|c|c|c|}
\hline & & & $\begin{array}{l}\text { palavras: Ele é } \\
\text { ressuscitado, } \\
\text { Deus subiu, e } \\
\text { textos similares. } \\
\text { Kircher: A } \\
\text { Anabasis ou } \\
\text { Ascentio é uma } \\
\text { passagem } \\
\text { musical através } \\
\text { do qual } \\
\text { expressamos } \\
\text { sentimentos de } \\
\text { exaltação, } \\
\text { ascenso ou } \\
\text { pensamentos } \\
\text { elevados e } \\
\text { eminentes, } \\
\text { exemplificado na } \\
\text { ascensão de } \\
\text { Cristo. } \\
\end{array}$ \\
\hline $\begin{array}{l}\text { ANALEPSIS } \\
\text { (BARTEL, 1997, pp. } \\
\text { 209-212). }\end{array}$ & $\begin{array}{l}\text { Repetição } \\
\text { Harmônica; } \\
\text { Figuras de } \\
\text { Fuga }\end{array}$ & $\begin{array}{l}\text { Repetição literal } \\
\text { de uma seção } \\
\text { homofônica, ou } \\
\text { seja, de uma } \\
\text { Noema na } \\
\text { mesma altura. }\end{array}$ & $\begin{array}{l}\text { Burmeister: A } \\
\text { Analepsis é uma } \\
\text { repetição } \\
\text { imediata de uma } \\
\text { passagem } \\
\text { musical em certas } \\
\text { vozes cujas } \\
\text { sintaxes unidas } \\
\text { consistem em } \\
\text { consonâncias } \\
\text { puras. É uma } \\
\text { repetição ou } \\
\text { duplicação de } \\
\text { uma Noema e, } \\
\text { portanto, é um } \\
\text { ornamento } \\
\text { relacionado a ela. }\end{array}$ \\
\hline $\begin{array}{l}\text { ANAPHORA } \\
\text { (BARTEL, 1997, } \\
\text { pp.184-190). }\end{array}$ & $\begin{array}{l}\text { Repetição } \\
\text { Melódica }\end{array}$ & $\begin{array}{l}\text { (1) É uma linha } \\
\text { do baixo repetida } \\
\text { em forma de solo. } \\
\text { (2) A repetição de } \\
\text { uma exposição } \\
\text { melódica sobre } \\
\text { notas e partes } \\
\text { diferentes. } \\
\text { Também pode } \\
\text { ocorrer no início } \\
\text { das repetições de } \\
\text { frases e motivos } \\
\text { em uma série de }\end{array}$ & $\begin{array}{lr}\text { Thuringus: } & \text { O } \\
\text { que é } & \text { uma } \\
\text { Anáfora? É } & \text { a } \\
\text { repetição } & \\
\text { continuada } \\
\text { apenas no Baixo. } \\
\text { Walther: Ér uma } \\
\text { figura } & \text { de } \\
\text { repetição e pode } \\
\text { ocorrer de duas } \\
\text { maneiras: } \\
\text { 1. Quando } \\
\end{array}$ \\
\hline
\end{tabular}




\begin{tabular}{|c|c|c|c|}
\hline & & $\begin{array}{l}\text { passagens } \\
\text { sucessivas; (3) } \\
\text { Uma repetição } \\
\text { em geral. }\end{array}$ & $\begin{array}{l}\text { palavra é } \\
\text { repetida } \\
\text { frequentemente } \\
\text { em uma } \\
\text { composição } \\
\text { para dar maior } \\
\text { ênfase. } \\
\text { 2. Quando as } \\
\text { notas graves } \\
\text { são repetidas } \\
\text { inúmeras } \\
\text { vezes (como } \\
\text { o caso das } \\
\text { Chaconne). }\end{array}$ \\
\hline $\begin{array}{l}\text { APOSIOPESIS } \\
\text { (BARTEL, } \\
\text { pp.202-206). }\end{array}$ & $\begin{array}{l}\text { Interrupção e } \\
\text { Silêncio }\end{array}$ & $\begin{array}{l}\text { Um descanso em } \\
\text { uma ou todas as } \\
\text { vozes de uma } \\
\text { composição: } \\
\text { pausa geral. }\end{array}$ & $\begin{array}{lr}\text { Walther: } & \text { A } \\
\text { Aposiopesis se } \\
\text { refere a uma } \\
\text { Pausa generalis } \\
\text { ou um completo } \\
\text { silêncio em todas } \\
\text { as vozes e nas } \\
\text { partes ra } \\
\text { composição da } \\
\text { simultaneamente. }\end{array}$ \\
\hline $\begin{array}{l}\text { CIRCULATIO } \\
\text { (BARTEL, 1997, } \\
\text { pp.216-219). } \\
\text { (BUELOW, 1980, } \\
\text { p.798). }\end{array}$ & $\begin{array}{l}\text { Representação } \\
\text { e Descrição }\end{array}$ & $\begin{array}{l}\text { Uma série de } \\
\text { notas } \\
\text { (geralmente oito) } \\
\text { em uma } \\
\text { formação circular } \\
\text { ou de ondas } \\
\text { senoidais. } \\
\text { Também pode } \\
\text { ser definida como } \\
\text { uma linha } \\
\text { melódica que } \\
\text { oscila ao redor de } \\
\text { uma nota }\end{array}$ & $\begin{array}{l}\text { Walther: } \\
\text { Circulo que } \\
\text { ocorre de duas } \\
\text { maneiras: } \\
\text { 1. Como uma } \\
\text { forma dupla, } \\
\text { que ainda é } \\
\text { encontrada nas } \\
\text { composições } \\
\text { antigas como } \\
\text { uma assinatura } \\
\text { de tempo após } \\
\text { a clave. } \\
\text { 2. Quando dois } \\
\text { Circoli Mezzi } \\
\text { são } \\
\text { combinados e } \\
\text { seguem um ao } \\
\text { outro de tal } \\
\text { forma que, eles } \\
\text { devem ser } \\
\text { sobrepostos } \\
\text { entre si, eles } \\
\text { representam } \\
\text { visualmente um }\end{array}$ \\
\hline
\end{tabular}




\begin{tabular}{|c|c|c|c|c|}
\hline & & & & $\begin{array}{l}\text { círculo } \\
\text { completo. }\end{array}$ \\
\hline $\begin{array}{l}\text { CLIMAX } \\
\text { (BARTEL, } \\
\text { pp.220-224). }\end{array}$ & 1997, & $\begin{array}{l}\text { Repetição } \\
\text { Melódica }\end{array}$ & $\begin{array}{l}\text { (1) Sequência de } \\
\text { notas em uma só } \\
\text { voz repetida em } \\
\text { qualquer } \\
\text { tonalidade maior } \\
\text { ou menor, (2) } \\
\text { Duas vozes que } \\
\text { se deslocam em } \\
\text { movimento } \\
\text { ascendente ou } \\
\text { descendente } \\
\text { paralelo, (3) Um } \\
\text { aumento gradual } \\
\text { na intensidade e } \\
\text { altura do som. }\end{array}$ & $\begin{array}{l}\text { Burmeister: A } \\
\text { Climax repete } \\
\text { notas semelhantes ou } \\
\text { semel } \\
\text { alturas similares. } \\
\text { Kircher: } \\
\text { Climax } \\
\text { Gradatio é uma } \\
\text { passagem } \\
\text { musical } \\
\text { ascendente que é } \\
\text { frequentemente } \\
\text { utilizada em } \\
\text { afetos de amor e } \\
\text { desejo de } \\
\text { unidade do reino } \\
\text { celestial. }\end{array}$ \\
\hline $\begin{array}{l}\text { EPIZEUXIS } \\
\text { (BARTEL, } \\
\text { pp.263-265). }\end{array}$ & 1997, & $\begin{array}{l}\text { Repetição } \\
\text { Melódica }\end{array}$ & $\begin{array}{l}\text { Uma repetição } \\
\text { imediata e } \\
\text { enfática de uma } \\
\text { palavra, nota, } \\
\text { motivo ou frase. }\end{array}$ & $\begin{array}{l}\text { Walther: A } \\
\text { Epizeuxis é uma } \\
\text { figura de retórica } \\
\text { pela qual uma ou } \\
\text { mais palavras } \\
\text { são } \\
\text { imediatamente e } \\
\text { enfaticamente } \\
\text { repetidas. }\end{array}$ \\
\hline $\begin{array}{l}\text { GRADATIO } \\
\text { (BARTEL, } \\
\text { pp.220-224). }\end{array}$ & 1997, & $\begin{array}{l}\text { Repetição } \\
\text { Melódica }\end{array}$ & $\begin{array}{l}\text { (1) Sequência de } \\
\text { notas em uma só } \\
\text { voz repetida em } \\
\text { qualquer } \\
\text { tonalidade maior } \\
\text { ou menor, (2) } \\
\text { Duas vozes que } \\
\text { se deslocam em } \\
\text { movimento } \\
\text { ascendente ou } \\
\text { descendente } \\
\text { paralelo, (3) Um } \\
\text { aumento gradual } \\
\text { na intensidade e } \\
\text { altura do som. }\end{array}$ & $\begin{array}{l}\text { Walther: Climax } \\
\text { ou Gradatio } \\
\text { podem ser } \\
\text { interpretadas } \\
\text { das seguintes } \\
\text { formas: } \\
\text { 1. Quando há } \\
\text { palavras que } \\
\text { falam sobre } \\
\text { alegria, } \\
\text { glorificação e } \\
\text { louvor. } \\
2 . \quad \text { Em uma } \\
\text { figura musical } \\
\text { que ocorre } \\
\text { quando duas } \\
\text { vozes se } \\
\text { movimentam } \\
\text { para cima e para } \\
\text { baixo }\end{array}$ \\
\hline
\end{tabular}




\begin{tabular}{|c|c|c|c|}
\hline & & & $\begin{array}{l}\text { progredindo em } \\
\text { terças paralelas. } \\
\text { (Essa forma } \\
\text { que aparece } \\
\text { nesta obra). } \\
\text { 3. Quando } \\
\text { uma passagem } \\
\text { com ou sem } \\
\text { cadência é é } \\
\text { imediatamente } \\
\text { repetida várias } \\
\text { vezes em alturas } \\
\text { progressivament } \\
\text { e maiores. } \\
4 . \quad \text { Este } \\
\text { termo também } \\
\text { pode ser dado a } \\
\text { um cânone de } \\
\text { quatro partes em } \\
\text { que, as duas } \\
\text { primeiras vozes } \\
\text { reentram, as as } \\
\text { outras duas } \\
\text { vozes nermanecem na } \\
\text { permananterior e } \\
\text { parte anter } \\
\text { ainda } \\
\text { harmonizam. }\end{array}$ \\
\hline $\begin{array}{l}\text { METABASIS } \\
\text { (BARTEL, 1997, } \\
\text { pp.319-320). }\end{array}$ & $\begin{array}{l}\text { Representação } \\
\text { e } \\
\text { Descrição }\end{array}$ & $\begin{array}{l}\text { Cruzamento de } \\
\text { uma voz com } \\
\text { outra ou } \\
\text { cruzamento de } \\
\text { vozes. }\end{array}$ & $\begin{array}{l}\text { Spiess: A } \\
\text { Metabasis (ou } \\
\text { Diabasis, } \\
\text { Transgressio, } \\
\text { Transgression) } \\
\text { ocorre sempre } \\
\text { que uma voz } \\
\text { atravessa a outra. }\end{array}$ \\
\hline $\begin{array}{l}\text { NOEMA } \\
\text { (BARTEL, 1997, } \\
\text { p.339-342). }\end{array}$ & $\begin{array}{l}\text { Representação } \\
\text { e Descrição }\end{array}$ & $\begin{array}{l}\text { Uma passagem } \\
\text { homofônica em } \\
\text { uma textura } \\
\text { contrapontística e } \\
\text { polifônica. }\end{array}$ & $\begin{array}{l}\text { Burmeister: A } \\
\text { Noema } \\
\text { representa o } \\
\text { afeto harmônico, } \\
\text { onde as vozes } \\
\text { combinadas têm } \\
\text { valores e } \\
\text { números de notas } \\
\text { semelhantes. } \\
\text { Quando } \\
\text { introduzida } \\
\text { adequadamente, } \\
\text { isto é, no }\end{array}$ \\
\hline
\end{tabular}




\begin{tabular}{|c|c|c|c|c|}
\hline $\begin{array}{l}\text { (BUELOW, } \\
\text { р.799). }\end{array}$ & 1980 & & & $\begin{array}{l}\text { momento certo, } \\
\text { ela afeta } \\
\text { docemente os } \\
\text { ouvidos do } \\
\text { ouvinte, } \\
\text { produzindo uma } \\
\text { sensação de } \\
\text { calma e } \\
\text { serenidade. } \\
\text { Seção } \\
\text { homofônica, } \\
\text { dentro da } \\
\text { polifonia utilizada } \\
\text { para enfatizar o } \\
\text { texto. }\end{array}$ \\
\hline $\begin{array}{l}\text { PALILOGIA } \\
\text { (BARTEL, } \\
\text { pp.342-344). }\end{array}$ & 1997 & $\begin{array}{l}\text { Repetição } \\
\text { Melódica }\end{array}$ & $\begin{array}{l}\text { Repetição de um } \\
\text { tema no mesmo } \\
\text { nível de altura, } \\
\text { também pode } \\
\text { ocorrer em } \\
\text { alturas diferentes } \\
\text { na mesma ou em } \\
\text { várias vozes. }\end{array}$ & $\begin{array}{l}\text { Burmeister: } \\
\text { Palilogia é uma } \\
\text { repetição de uma } \\
\text { inteiração ou } \\
\text { apenas o começo } \\
\text { da estrutura dos } \\
\text { meios e temas } \\
\text { sobre a mesma } \\
\text { altura com a } \\
\text { mesma voz, } \\
\text { ocorrendo com } \\
\text { ou } \\
\text { intermédio dem } \\
\text { pausas em todos } \\
\text { os eventos em } \\
\text { uma voz. } \\
\text { Walther: } \\
\text { Palilogia refere- } \\
\text { se a uma } \\
\text { repetição por } \\
\text { demais frequente } \\
\text { das mesmas } \\
\text { palavras. }\end{array}$ \\
\hline $\begin{array}{l}\text { PAUSA } \\
\text { (BARTEL, } \\
\text { pp.362-365). }\end{array}$ & 1997 & $\begin{array}{l}\text { Interrupção e } \\
\text { Silêncio }\end{array}$ & $\begin{array}{lr}\text { Pausa } & \text { ou } \\
\text { descanso em } & \text { em } \\
\text { uma composição } \\
\text { musical }\end{array}$ & $\begin{array}{l}\text { Walther: Uma } \\
\text { figura ou figuras } \\
\text { de } \text { silêncio. } \\
\text { Pausa refere-se a } \\
\text { um período de } \\
\text { repouso ou o } \\
\text { silêncio na } \\
\text { música, que é } \\
\text { indicado por um } \\
\text { determinado } \\
\text { sinal. }\end{array}$ \\
\hline
\end{tabular}




\begin{tabular}{|c|c|c|c|c|}
\hline $\begin{array}{l}\text { (BARTEL, } \\
\text { pp.367-369). }\end{array}$ & 1997 & $\begin{array}{l}\text { Repetição } \\
\text { Melódica }\end{array}$ & $\begin{array}{l}\text { A repetição de } \\
\text { uma passagem } \\
\text { melódica em } \\
\text { diferentes alturas. }\end{array}$ & 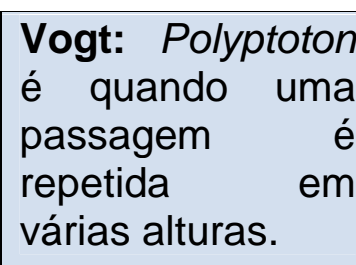 \\
\hline $\begin{array}{l}\text { SYNAERESIS } \\
\text { (BARTEL, } \\
\text { pp.394-396). }\end{array}$ & 1997, & $\begin{array}{l}\text { Dissonância e } \\
\text { Deslocamento }\end{array}$ & $\begin{array}{l}\text { (1) Uma } \\
\text { suspensão ou } \\
\text { síncope, (2) A } \\
\text { colocação de } \\
\text { duas sílabas por } \\
\text { nota ou duas } \\
\text { notas por sílaba. }\end{array}$ & $\begin{array}{l}\text { Vogt: } \\
\text { Synaeresis } \\
\text { ocorre quando } \\
\text { duas notas são } \\
\text { colocadas em } \\
\text { uma sílaba ou } \\
\text { duas sílabas são } \\
\text { colocadas em } \\
\text { uma nota. }\end{array}$ \\
\hline $\begin{array}{l}\text { SYNONYMIA } \\
\text { (BARTEL, } \\
\text { pp.405-407). }\end{array}$ & 1997, & $\begin{array}{l}\text { Repetição } \\
\text { Melódica }\end{array}$ & $\begin{array}{l}\text { É a repetição de } \\
\text { uma ideia musical } \\
\text { em forma } \\
\text { alterada ou } \\
\text { modificada. }\end{array}$ & $\begin{array}{l}\text { Walther: Um } \\
\text { compositor } \\
\text { também pode } \\
\text { empregar muito } \\
\text { bem diferentes } \\
\text { figuras retóricas } \\
\text { na elaboração de } \\
\text { um texto. Por } \\
\text { exemplo, além da } \\
\text { Epizeuxis, que é } \\
\text { a mais comum e } \\
\text { enfática, pode } \\
\text { usar, Anaphora, } \\
\text { Synonimia, } \\
\text { Epistrophe, } \\
\text { Epanalepsis e } \\
\text { assim por diante. }\end{array}$ \\
\hline $\begin{array}{l}\text { TIRATA } \\
\text { (BARTEL, } \\
\text { pp.409-412). }\end{array}$ & 1997, & $\begin{array}{l}\text { Ornamentação } \\
\text { Melódica e } \\
\text { Harmônica }\end{array}$ & $\begin{array}{l}\text { Uma passagem } \\
\text { escalar rápida } \\
\text { que mede uma } \\
\text { quarta, uma } \\
\text { oitava ou mais. }\end{array}$ & $\begin{array}{l}\text { Walther: Tirata } \\
\text { ou tirade significa } \\
\text { um curso ou } \\
\text { linha, que é } \\
\text { especialmente } \\
\text { um momento de } \\
\text { diversas notas } \\
\text { com a mesma } \\
\text { duração que quer } \\
\text { subir ou descer a } \\
\text { etapa. }\end{array}$ \\
\hline
\end{tabular}

Tabela 58: Figuras encontradas no Ofertório da Missa da Ascenção do Senhor de André da Silva Gomes 


\section{Análise Harmônica}

\subsection{Curva Tonal (Primeiro Movimento)}

Tonalidade: Ré Maior

Andamento: Brilhante 4/4

Esquema de Progressões Harmônicas

\begin{tabular}{|l|c|l|}
\hline Compassos & $\begin{array}{l}\text { Função em relação a } \\
\text { tonalidade principal }\end{array}$ & Tonalidade (Acorde) \\
\hline $1-15$ & T-I & Ré Maior \\
\hline $16-17$ & S & Sol Maior \\
\hline $18-20$ & Sp-V & Lá Maior \\
\hline $20-22$ & Sp/S-ii/IV & Mi Menor \\
\hline $22-23$ & S-IV & Lá Menor \\
\hline $23-30$ & S/S-IV/IV & Sol Maior \\
\hline 31 & D-V & Ré Maior \\
\hline $31-32$ & S-IV & Sol Maior \\
\hline $33-35$ & T-I & Ré Maior \\
\hline 35 & D-V & Lá Maior \\
\hline 36 & Sp-ii & Mi Menor \\
\hline 37 & S-IV & Sol Maior \\
\hline $37-41$ & D-V & Lá Maior \\
\hline $41-43$ & T-I & Ré Maior \\
\hline $44-53$ & &
\end{tabular}

Tabela 59: Curva Tonal do Ofertório da Missa da Ascenção do Senhor (Primeiro Movimento)

Números de compassos: 53

Regiões abordadas: 6

Variações: 15

Ritmo Harmônico: 3,53 (divisão dos números de compassos e variações)

Média ideal: (divisão dos números de compassos e regiões tonais abordadas = 8,83)

Esquema Formal

$(1-17)(18-20)(20-23)(23-35)(35-53)$ 
D $\quad$ Sp $\quad$ S $\quad$ T

I V ii IV I

2.2. Estrutura Analítica do Ofertório: Retórica e Harmônica (Primeiro Movimento)

\begin{tabular}{|c|c|c|c|c|c|}
\hline $\begin{array}{l}\text { RETÓRICA } \\
\text { DISPOSITIO }\end{array}$ & $\begin{array}{l}\text { FIGURA } \\
\text { ELOCUTIO }\end{array}$ & COMP. & $\begin{array}{l}\text { HARMÔNICA } \\
\text { SEÇÃO }\end{array}$ & TONALIDADE & FUNÇÃO \\
\hline EXORDIUM & $\begin{array}{l}\text { Anabasis } \\
\text { Pausa }\end{array}$ & $\begin{array}{l}1-3 \\
1-3\end{array}$ & $\begin{array}{l}1^{a} \text { Seção } \\
1 \text { a Seção }\end{array}$ & $\begin{array}{l}\text { Ré Maior } \\
\text { Ré Maior }\end{array}$ & $\begin{array}{l}T-I \\
T-I\end{array}$ \\
\hline NARRATIO & $\begin{array}{l}\text { Pausa } \\
\text { Climax } \\
\text { Tirata }\end{array}$ & $\begin{array}{l}4-6 \\
4 \\
4-5\end{array}$ & $\begin{array}{l}1^{\text {a }} \text { Seção } \\
1^{\text {a }} \text { Seção } \\
1^{\text {a }} \text { Seção }\end{array}$ & $\begin{array}{l}\text { Ré Maior } \\
\text { Ré Maior } \\
\text { Ré Maior }\end{array}$ & $\begin{array}{l}T-I \\
T-I \\
T-I\end{array}$ \\
\hline PROPOSITIO & $\begin{array}{l}\text { Metabasis } \\
\text { Circulatio } \\
\text { Anabasis } \\
\text { Aposiopesis } \\
\text { Noema }\end{array}$ & $\begin{array}{l}7 \\
7-8 \\
9-11 \\
12 \\
12-15\end{array}$ & 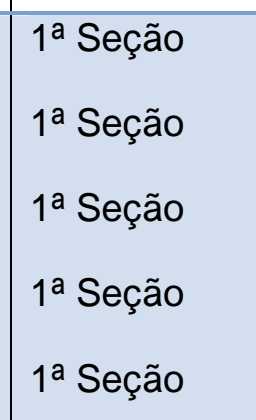 & $\begin{array}{l}\text { Ré Maior } \\
\text { Ré Maior } \\
\text { Ré Maior } \\
\text { Ré Maior } \\
\text { Ré Maior }\end{array}$ & $\begin{array}{l}T-I \\
T-1 \\
T-I \\
T-1 \\
T-I\end{array}$ \\
\hline CONFUTATIO & $\begin{array}{l}\text { Palilogia } \\
\text { Anabasis }\end{array}$ & $\begin{array}{l}15,18 \\
25,34 \\
13 \\
15-19 \\
25-28 \\
35-38 \\
18-19 \\
20\end{array}$ & 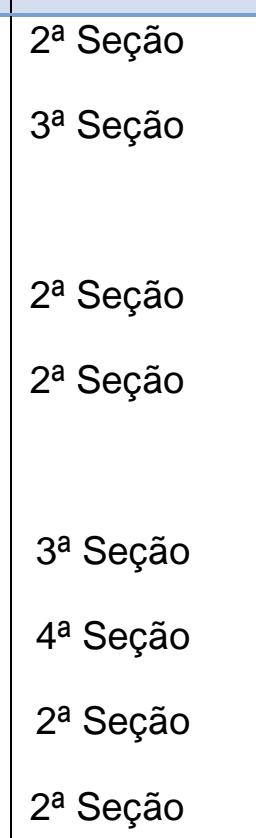 & $\begin{array}{l}\text { Ré Maior } \\
\text { Lá Maior } \\
\text { Sol Maior } \\
\text { Ré Maior } \\
\text { Ré Maior } \\
\text { Lá Maior } \\
\text { Sol Maior } \\
\text { Ré Maior } \\
\text { Lá Maior } \\
\text { Mi Menor }\end{array}$ & $\begin{array}{l}\text { T-I } \\
\text { D-V } \\
\text { S-IV } \\
\text { T-I } \\
\text { T-I } \\
\text { D-V } \\
\text { S-V } \\
\text { T-I } \\
\text { D-V } \\
\text { Sp-ii }\end{array}$ \\
\hline
\end{tabular}




\begin{tabular}{|c|c|c|c|c|c|}
\hline & $\begin{array}{l}\text { Epizeuxis } \\
\text { Gradatio } \\
\text { Circulatio } \\
\text { Synonimia } \\
\text { Aposiopesis }\end{array}$ & $\begin{array}{l}21-22 \\
22-24 \\
29 \\
33-34 \\
30-32 \\
39\end{array}$ & $\begin{array}{l}2^{\text {a Seção }} \\
2^{\text {a Seção }} \\
3^{\text {a Seção }} \\
3^{\text {a Seção }} \\
3^{\text {a Seção }} \\
4^{\text {a Seção }}\end{array}$ & $\begin{array}{l}\text { Mi Menor } \\
\text { Mi Menor } \\
\text { e Sol Maior } \\
\text { Sol Maior } \\
\text { Sol Maior } \\
\text { Sol Maior } \\
\text { Ré Maior }\end{array}$ & $\begin{array}{l}\text { Sp-ii } \\
\text { Sp-ii } \\
\text { S-IV } \\
\text { S-IV } \\
\text { S-IV } \\
\text { S-IV } \\
\text { T-I }\end{array}$ \\
\hline CONFIRMATIO & $\begin{array}{l}\text { Epizeuxis } \\
\text { Aposiopesis }\end{array}$ & $\begin{array}{l}39-44 \\
45\end{array}$ & $\begin{array}{l}4^{a} \text { Seção } \\
4^{\text {a }} \text { Seção }\end{array}$ & $\begin{array}{l}\text { Ré Maior } \\
\text { Ré Maior }\end{array}$ & $\begin{array}{l}\text { T-I } \\
\text { T-I }\end{array}$ \\
\hline PEROTATIO & $\begin{array}{l}\text { Gradatio } \\
\text { Synaeresis } \\
\text { Noema }\end{array}$ & $\begin{array}{l}45-47 \\
48 \text { e } 52 \\
49-53\end{array}$ & $\begin{array}{l}5^{\text {a }} \text { Seção } \\
\text { 5ª Seção }^{\text {5a Seção }}\end{array}$ & $\begin{array}{l}\text { Ré Maior } \\
\text { Ré Maior } \\
\text { Ré Maior }\end{array}$ & $\begin{array}{l}\text { T-I } \\
\text { T-I } \\
\text { T-I }\end{array}$ \\
\hline
\end{tabular}

Tabela 60: Estrutura analítica do Ofertório (Primeiro Movimento)

\subsection{Curva Tonal (Segundo Movimento)}

Tonalidade: Ré Maior

Andamento: Presto 3/8

Esquema de Progressões Harmônicas

\begin{tabular}{|l|c|l|}
\hline Compassos & $\begin{array}{l}\text { Função em relação a } \\
\text { tonalidade principal }\end{array}$ & Tonalidade (Acorde) \\
\hline $1-40$ & T-I & Ré Maior \\
\hline
\end{tabular}

Tabela 61: Curva Tonal do Ofertório da Missa da Ascenção do Senhor (Segundo Movimento)

Números de compassos: 40

Regiões abordadas: 1

Variações: 1

Ritmo Harmônico: 40 (divisão dos números de compassos e variações) 
Média ideal: (divisão dos números de compassos e regiões tonais abordadas = 40)

Esquema Formal

$\mathrm{T}$

\subsection{Estrutura Analítica do Ofertório: Retórica e Harmônica (Segundo Movimento)}

\begin{tabular}{|c|c|c|c|c|c|}
\hline $\begin{array}{l}\text { RETÓRICA } \\
\text { DISPOSITIO }\end{array}$ & $\begin{array}{l}\text { FIGURA } \\
\text { ELOCUTIO }\end{array}$ & COMP. & $\begin{array}{l}\text { HARMÔNICA } \\
\text { SEÇÃO }\end{array}$ & TONALIDADE & FUNÇÃO \\
\hline EXORDIUM & $\begin{array}{l}\text { Polyptoton } \\
\text { Pausa } \\
\text { Palilogia }\end{array}$ & $\begin{array}{l}1-10 \\
1-6 \\
3-4 \\
6-7\end{array}$ & $\begin{array}{l}1^{\text {a }} \text { Seção } \\
1^{\text {a }} \text { Seção } \\
1^{\text {a }} \text { Seção } \\
1^{\text {a }} \text { Seção }\end{array}$ & $\begin{array}{l}\text { Ré Maior } \\
\text { Ré Maior } \\
\text { Ré Maior } \\
\text { Ré Maior }\end{array}$ & $\begin{array}{l}T-I \\
T-I \\
T-I \\
T-I\end{array}$ \\
\hline NARRATIO & Epizeuxis & $13-20$ & 2 Seção & Ré Maior & T-I \\
\hline PROPOSITIO & Analepsis & $22-24$ & 2 e $3^{a}$ Seção & Ré Maior & T-I \\
\hline CONFUTATIO & Gradatio & $25-28$ & 4ª Seção & Ré Maior & T-I \\
\hline CONFIRMATIO & Epizeuxis & $29-34$ & 4ª Seção & Ré Maior & T-I \\
\hline PEROTATIO & Noema & $35-40$ & $5^{\text {a Seção }}$ & Ré Maior & $T-1$ \\
\hline
\end{tabular}

Tabela 62: Estrutura analítica do Ofertório (Segundo Movimento) 


\subsubsection{Ofertório da Missa da Conversão de São Paulo Apóstolo}

\section{Estudo Semântico}

\subsection{Inventio}

A presente obra é parte integrante dos ofertórios escritos em dois movimentos, Brilhante e Vivo, já seu texto é extraído dos salmos (Ps.138,117/139, 1-17) cujo título é: Deus Onisciente, Onipotente e Onipresente, que tudo vê.

Mihi autem nimis honorati sunt amici tui, Deus: nimis confortatus est principatus eorum

Como são difíceis de compreender, ó Deus, os vossos desígnios!

(SOARES, 2000, p.161).

A passagem descrita acima mostra um Deus que examina o coração e mente para descobrir tudo a respeito do ser humano: sua verdadeira personalidade, fantasias e motivos ocultos. Paralelamente, Daniel faz uma oração em forma de revelação ressaltando os mesmos atributos dados a Deus relatos por Davi:

Seja bendito o nome de Deus, de eternidade a eternidade, por que Dele é a sabedoria e o poder; é ele quem muda o tempo e as estações; remove reis e estabelece reis; Ele dá sabedoria aos sábios e entendimento aos inteligentes. Revela o profundo e o escondido; conhece o que está em trevas, e com ele mora a luz (Daniel 2,20-22).

Nesse contexto, se insere a conversão do apóstolo São Paulo, considerado por muitos como um dos maiores escritores da Bíblia e do cristianismo primitivo, cujas obras perfazem parte considerável do Novo Testamento. Segundo a teologia o referido discípulo de Jesus, anteriormente era conhecido como Saulo, aquele que teve como tutor e orientador Gamaliel, rabino da sinagoga e reconhecido doutor da lei. Anterior a sua decisão pelo cristianismo, o apóstolo perseguia os primeiros discípulos de Cristo, justificando que os mesmos eram hereges, ou seja, realizavam feitos em nome de Jesus, como curar, ajudar na libertação das pessoas, professava a elas a salvação por 
meio do filho de Maria, sendo que tais manifestações e ordenanças, só caberiam ao Senhor de Israel.

Todavia, o supracitado apóstolo foi incumbido de fiscalizar as ações dos cristãos na cidade de Damasco (hoje capital da Síria), quando para sua surpresa teve um encontro com a segunda pessoa da Trindade, que também sendo Deus tudo sabe, conhece e vê:

\begin{abstract}
Saulo, respirando ainda ameaças e morte contra os discípulos do Senhor, dirigiu-se ao sumo sacerdote e the pediu cartas para as sinagogas de Damasco, a fim que, caso achasse alguns que eram do caminho, assim homens como mulheres, os levasse presos para Jerusalém. Seguindo estrada fora, ao aproximar-se de Damasco, subitamente uma luz do céu brilhou ao seu redor e, caindo por terra, ouviu uma voz que Ihe dizia: "Saulo, Saulo, por que me persegues?". Então ele perguntou que és tu, Senhor? E então veio a resposta: " Eu sou Jesus, a quem tu persegues; mas levanta-te e entra na cidade, onde te dirão o que te convém fazer" (Atos 9,1-6).
\end{abstract}

Enfim, todo esse sentimento de devoção, respeito, temor e da não compreensão dos designíos do soberano dos céus, são laborados por Silva Gomes na presente obra em sessenta compassos no primeiro movimento e cinquenta no segundo, através de elementos e figuras retóricas, representando os afetos inerentes às paixões, lógica e confiança da alma humana.

\title{
1.2. Locus observados na Inventio do Ofertório (1ํMovimento)
}

\begin{tabular}{|c|c|c|c|}
\hline INVENTIO & DESCRIÇÃO & $\begin{array}{c}\text { UTILIZAÇÃO NA } \\
\text { OBRA }\end{array}$ & $\begin{array}{l}\text { COMPASSO/ } \\
\text { VOZ }\end{array}$ \\
\hline $\begin{array}{l}\text { Locus } \\
\text { Notationis } \\
\text { (MATTHESON, } \\
\text { [1739],1954, } \\
\text { Parte II,Cap.4, } \\
\S 23, \text { p.123). }\end{array}$ & $\begin{array}{l}\text { Aspecto } \\
\text { externo e } \\
\text { desenho das } \\
\text { notas (Duração } \\
\text { das notas, } \\
\text { alteração, } \\
\text { repetição e } \\
\text { procedimentos } \\
\text { canônicos). }\end{array}$ & $\begin{array}{l}\text { Vários motivos rítmicos } \\
\text { e diferentes durações } \\
\text { de notas } \\
\text { (míminas,semínimas, } \\
\text { semínimas pontuadas, } \\
\text { colcheias, colcheias } \\
\text { pontuadas, } \\
\text { semicolcheias } \\
\text { repetições, } \\
\text { apogiaturas, ligaduras, } \\
\text { pausas, entre outros). }\end{array}$ & $\begin{array}{l}1-9 \text { S-A-T-B } \\
10-18 \text { S-A } \\
18-33 \text { S-A-T-B } \\
34-42 \text { S-A } \\
42-60 \text { S-A-T-B }\end{array}$ \\
\hline
\end{tabular}




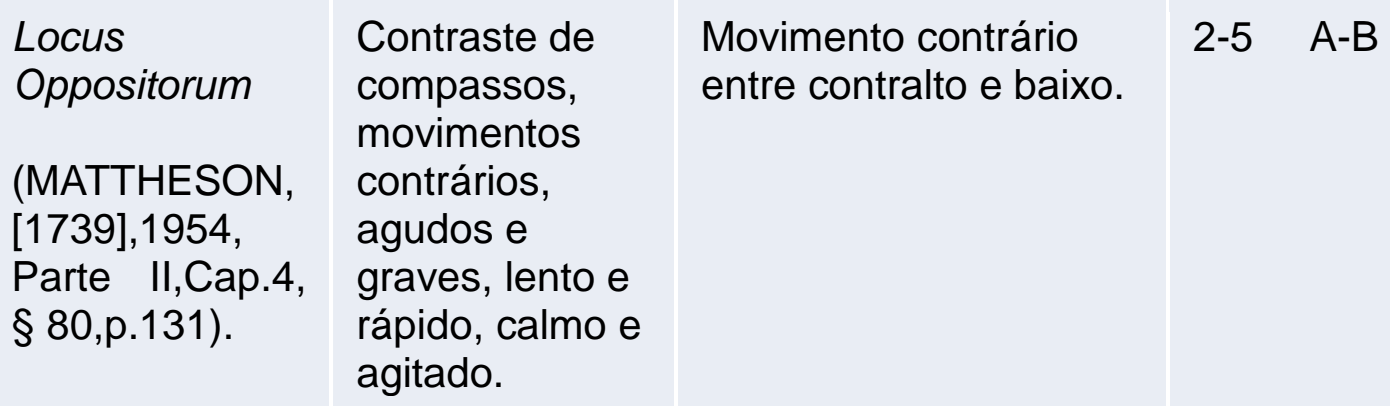

Tabela 63: Locus Topici encontrados no Ofertório da Missa da Conversão de São Paulo Apóstolo de André da Silva Gomes (Primeiro Movimento)

\subsection{Locus observados na Inventio do Ofertório (2o Movimento)}

\begin{tabular}{|c|c|c|c|}
\hline INVENTIO & DESCRIÇÃO & $\begin{array}{c}\text { UTILIZAÇÃO NA } \\
\text { OBRA }\end{array}$ & $\begin{array}{l}\text { COMPASSO/ } \\
\text { VOZ }\end{array}$ \\
\hline $\begin{array}{l}\text { Locus } \\
\text { Notationis } \\
\text { (MATTHESON, } \\
\text { [1739],1954, } \\
\text { Parte II,Cap.4, } \\
\text { § 23,p.123). }\end{array}$ & $\begin{array}{l}\text { Aspecto externo } \\
\text { e desenho das } \\
\text { notas (Duração } \\
\text { das notas, } \\
\text { alteração, } \\
\text { repetição e } \\
\text { procedimentos } \\
\text { canônicos). }\end{array}$ & $\begin{array}{l}\text { Vários motivos } \\
\text { rítmicos e diferentes } \\
\text { durações de notas } \\
\text { (semibreves, } \\
\text { mínimas, mínimas } \\
\text { pontuadas, } \\
\text { semínimas, colcheias, } \\
\text { repetições, pausas, } \\
\text { ligaduras, entre } \\
\text { outros). }\end{array}$ & $\begin{array}{ll}1-4 & S \\
5-8 & \text { S-A } \\
9-12 & \text { S-A-T } \\
13-50 & \text { S-A-T-B }\end{array}$ \\
\hline $\begin{array}{l}\text { Locus } \\
\text { Oppositorum } \\
\text { (MATTHESON, } \\
\text { [1739],1954, } \\
\text { Parte II,Cap.4, } \\
\text { § 80,p.131). }\end{array}$ & $\begin{array}{l}\text { Contraste de } \\
\text { compassos, } \\
\text { movimentos } \\
\text { contrários, } \\
\text { agudos e } \\
\text { graves, lento e } \\
\text { rápido, calmo e } \\
\text { agitado. }\end{array}$ & $\begin{array}{l}\text { Movimento contrário } \\
\text { entre soprano e } \\
\text { contralto. } \\
\text { Também entre } \\
\text { soprano e contralto, } \\
\text { contralto e baixo e } \\
\text { soprano e tenor. } \\
\text { Por fim, movimento } \\
\text { contrário entre } \\
\text { soprano e baixo. }\end{array}$ & $\begin{array}{l}7 \quad \text { S-A } \\
28-30 \text { S-A-T-B }\end{array}$ \\
\hline
\end{tabular}

Tabela 64: Locus Topici encontrados no Ofertório da Missa da Conversão de São Paulo Apóstolo de André da Silva Gomes (Segundo Movimento) 


\subsection{Dispositio}

\subsubsection{Exordium (Primeiro Movimento)}

André da Silva Gomes emprega desde o segundo compasso a Palilogia, ressaltando a repetição da expressão autem minis, porém, entre essa figura o compositor insere outra de interrupção e silêncio, Aposiopesis, promovendo descanso geral a todas as vozes, em auxílio a respiração das mesmas. Também se examina o uso da Pausa na voz do tenor e do baixo, no compasso 6, logo após a Semicadência.

\section{Primeira Seção-Tonalidade Sol Maior}

Ofertório da Missa da Conversão de São Paulo Apóstolo
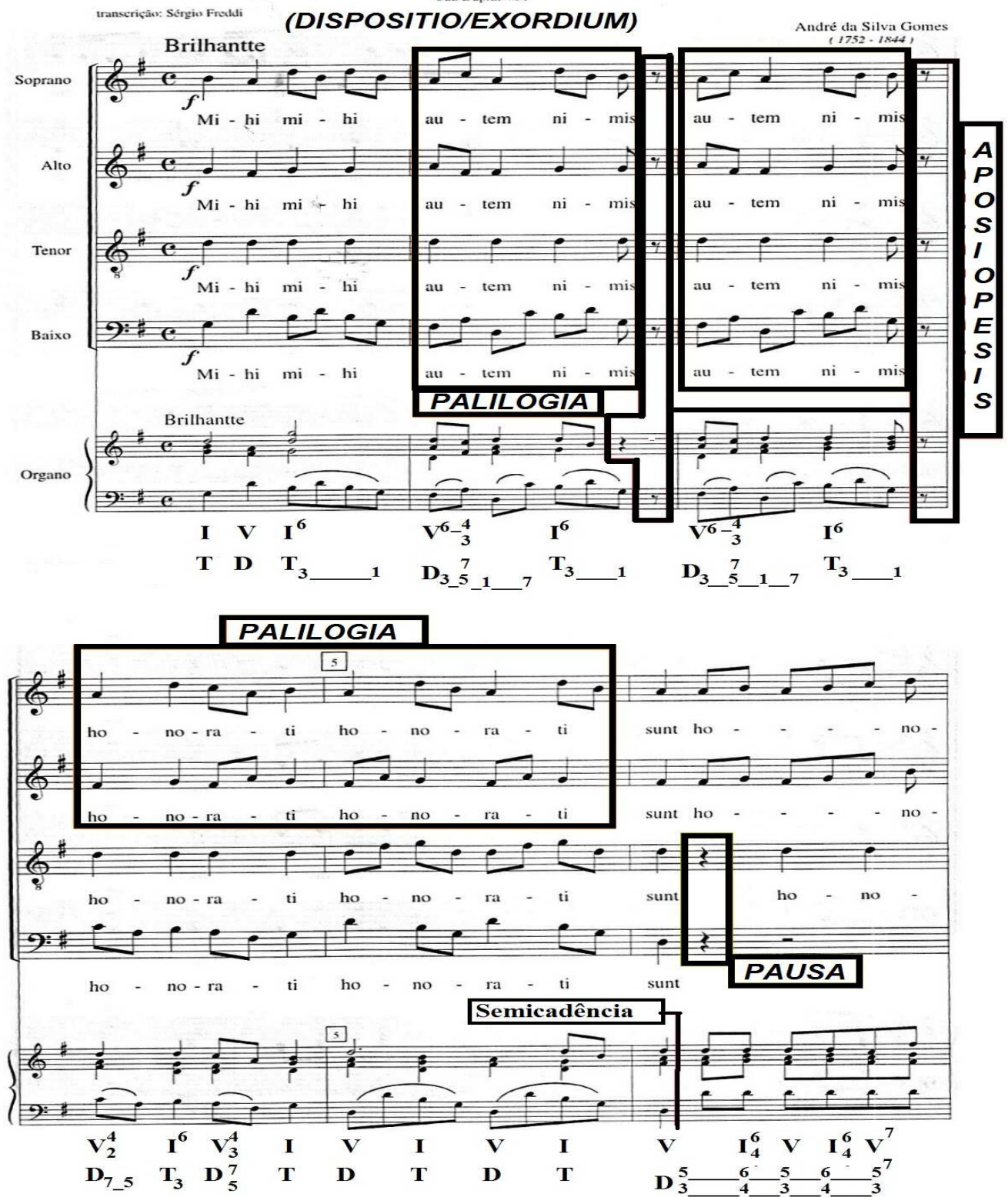

Exemplo 171: Ofertório da Missa da Conversão de São Paulo Apóstolo de André da Silva Gomes- Catalogação e Organização Régis Duprat (DUPRAT, 1999, p.220). 
No excerto a baixo o autor continua a utilizar a Pausa, valorizando o final da frase e da Cadência Autêntica Perfeita.

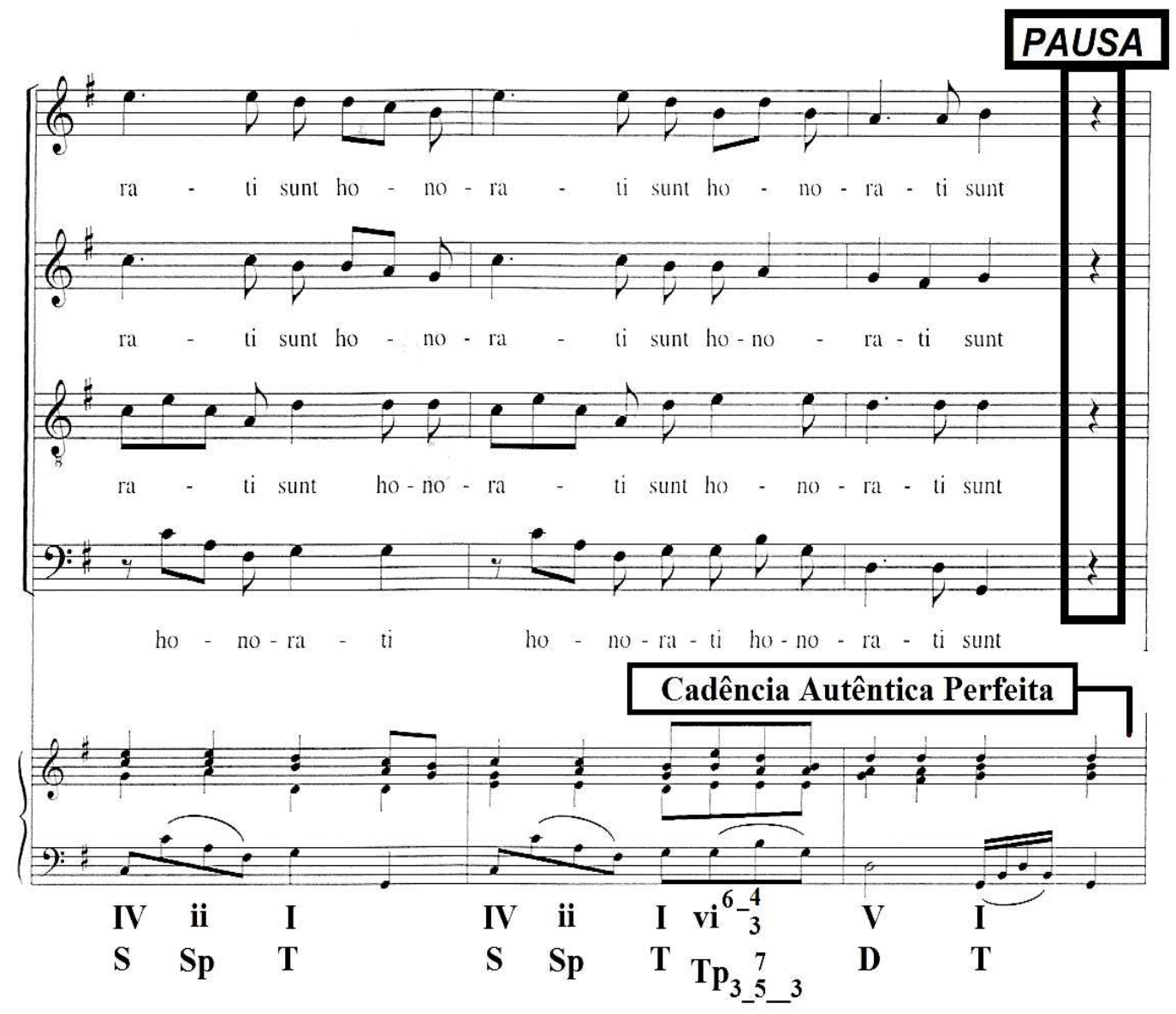

Exemplo 172: Ofertório da Missa da Conversão de São Paulo Apóstolo de André da Silva Gomes- Catalogação e Organização Régis Duprat (DUPRAT, 1999, p.221).

\subsubsection{Narratio}

Reforçando a afirmação da seção anterior, Silva Gomes, aplica a Gradatio estabelecendo maior intensidade na argumentação desenvolvida pelo salmista, que os designíos do Senhor são difíceis de compreensão, projetandoa em terças paralelas, na soprano e contralto. 


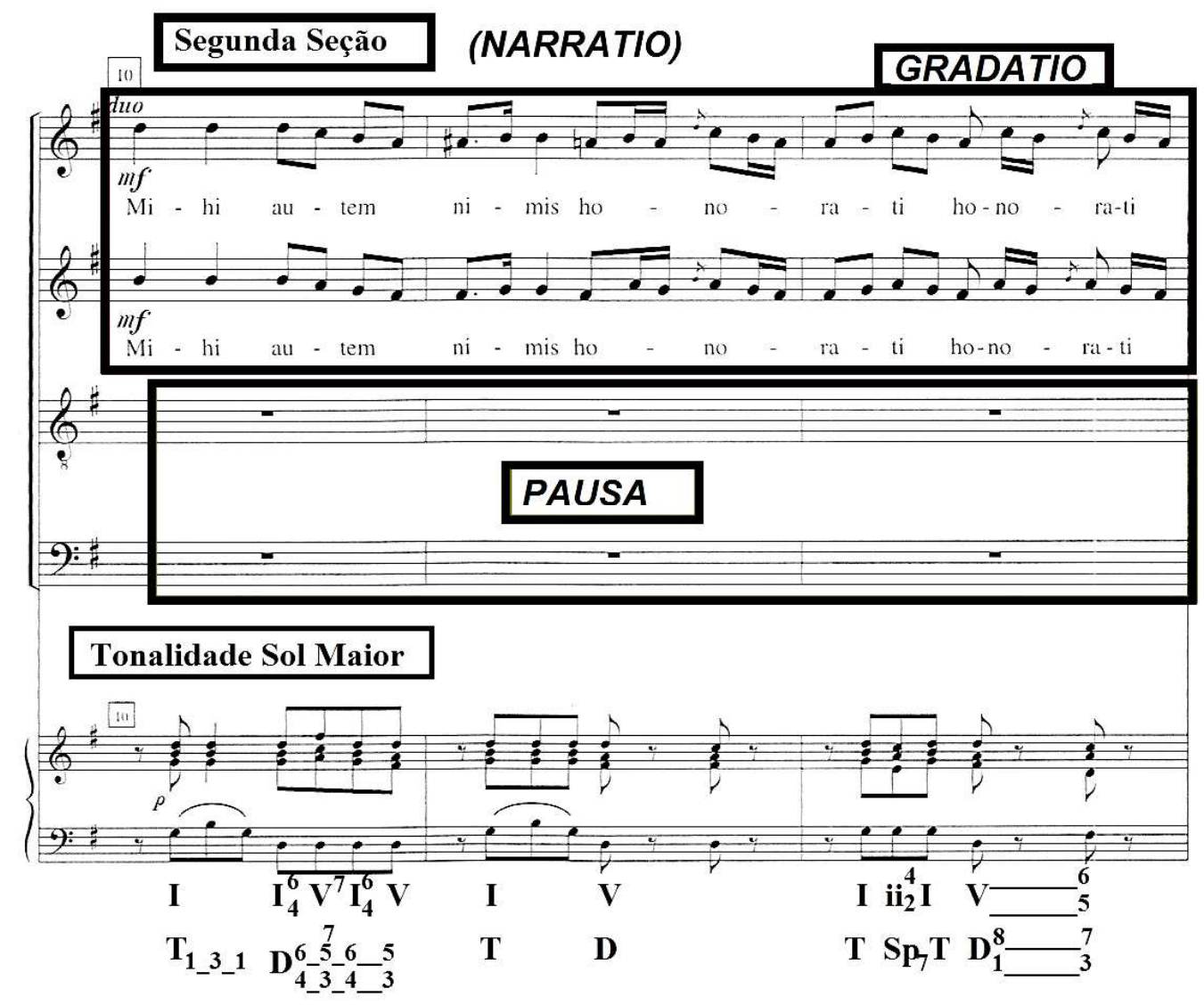

Exemplo 173: Ofertório da Missa da Conversão de São Paulo Apóstolo de André da Silva Gomes- Catalogação e Organização Régis Duprat (DUPRAT, 1999, p.221).

O contraste entre solo e tutti chega ao seu ápice entre os compassos 13 a 18, tendo como elementos adotados na clarificação da exposição dos fatos, a Gradatio e Synaeresis, que, de forma insistente juntamente com a Pausa destaca tanto a repetição da palavra amici, quanto na focalização das silabas.

Da mesma forma é observável o acompanhamento instrumental, movimentando-se por várias regiões funcionais em relação à tonalidade de Sol Maior, tais como, Tônica, Dominante, Subdominante, Subdominante Paralela, Tônica Paralela, Dominante da Subdominante Paralela, demonstrando a habilidade do compositor tanto no contraponto, quanto na disposição dos mecanismos harmônicos e retóricos. 

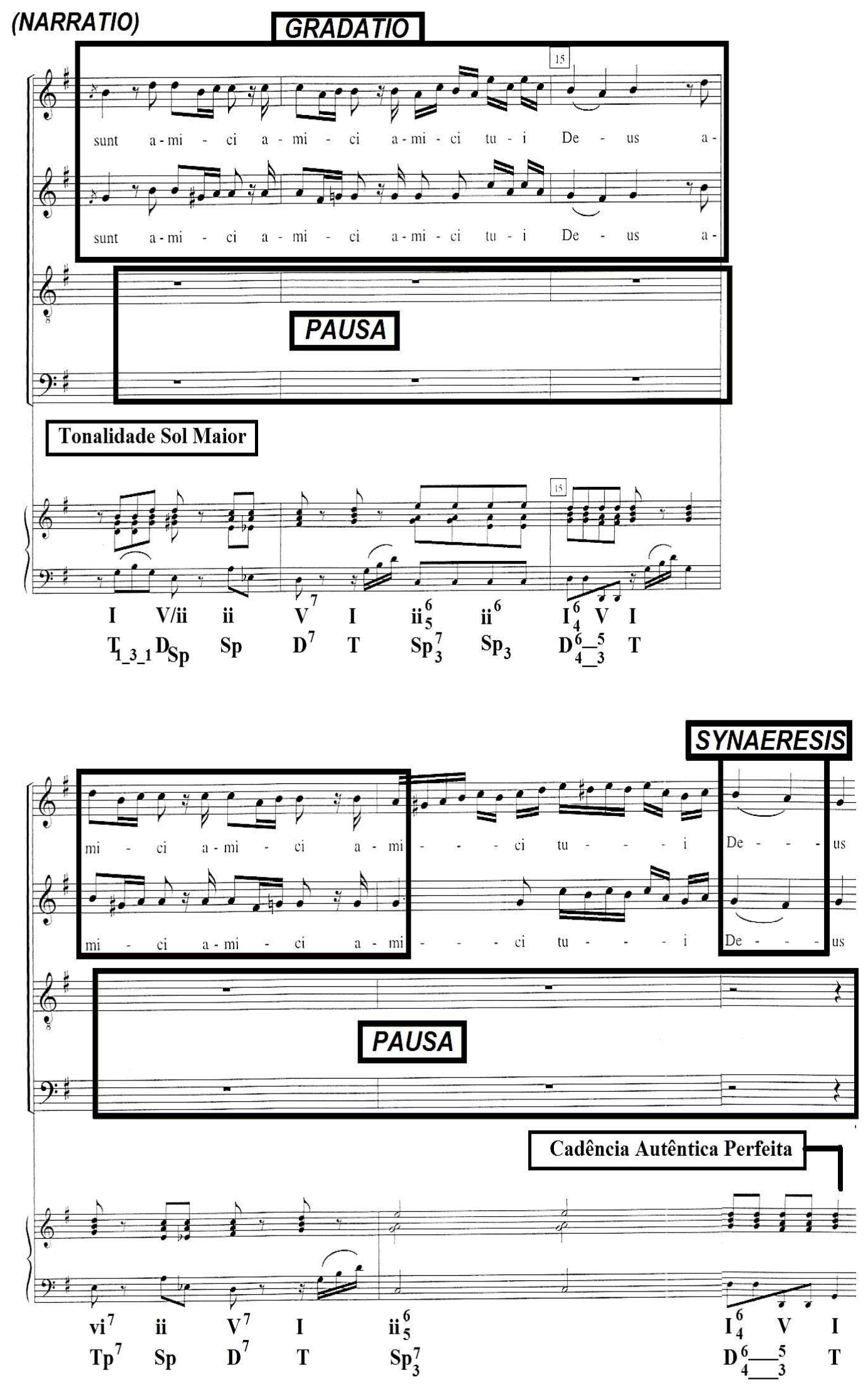

Exemplo 174: Ofertório da Missa da Conversão de São Paulo Apóstolo de André da Silva Gomes- Catalogação e Organização Régis Duprat (DUPRAT, 1999, pp.222-223). 


\subsubsection{Propositio}

A peça prossegue conservando a tese inicial, todavia, na transição do compasso 19 para o 20, acontece uma modulação para Ré Maior, ou seja, a Dominante da tonalidade principal da obra. Já no que tange as figuras, Silva Gomes aplica a Pausa, deslocando o tenor e baixo na execução da palavra amici e a Metabasis, no cruzamento da extensão das mesmas vozes.
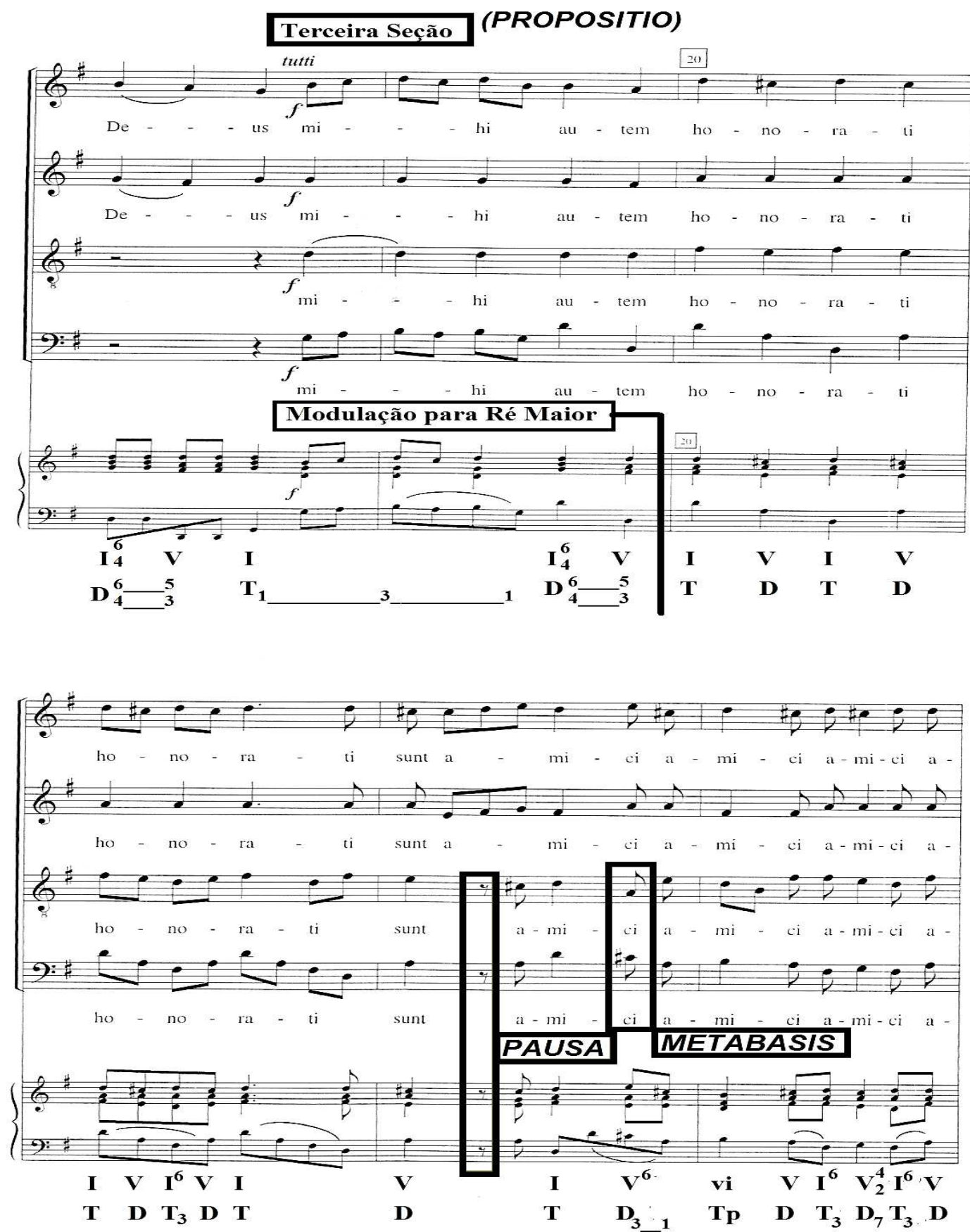

Exemplo 175: Ofertório da Missa da Conversão de São Paulo Apóstolo de André da Silva Gomes- Catalogação e Organização Régis Duprat (DUPRAT, 1999, p.223). 
A Propositio é encerrada num acorde de suspensão na Semicadência, direcionando o ouvinte a próxima parte do discurso, que é o ponto culminante do ofertório, tendo como figuras a Synaeresis e Pausa.

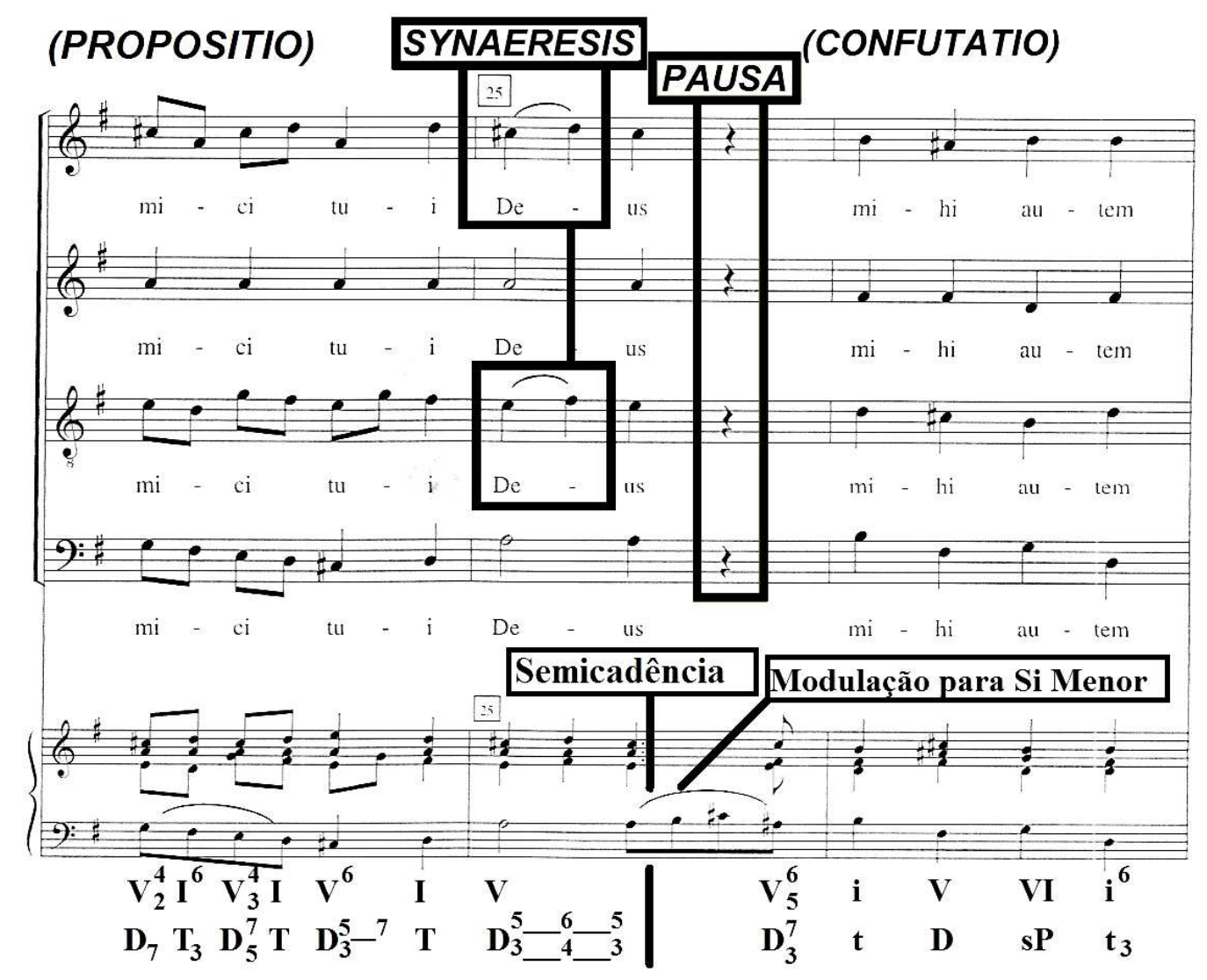

Exemplo 176: Ofertório da Missa da Conversão de São Paulo Apóstolo de André da Silva Gomes- Catalogação e Organização Régis Duprat (DUPRAT, 1999, p.224).

\subsubsection{Confutatio}

Consolidando a terceira seção, obtêm-se uma nova tonalidade, $\mathrm{Si}$ Menor, através do deslocamento harmônico inesperado. Em manutenção as objeções aos fatos desde então apresentados, o autor desenvolve sua contestação introduzindo além da Aposiopesis, a Epizeuxis repetindo de maneira enfática a expressão já trabalhada exaustivamente nas outras partes da obra. 


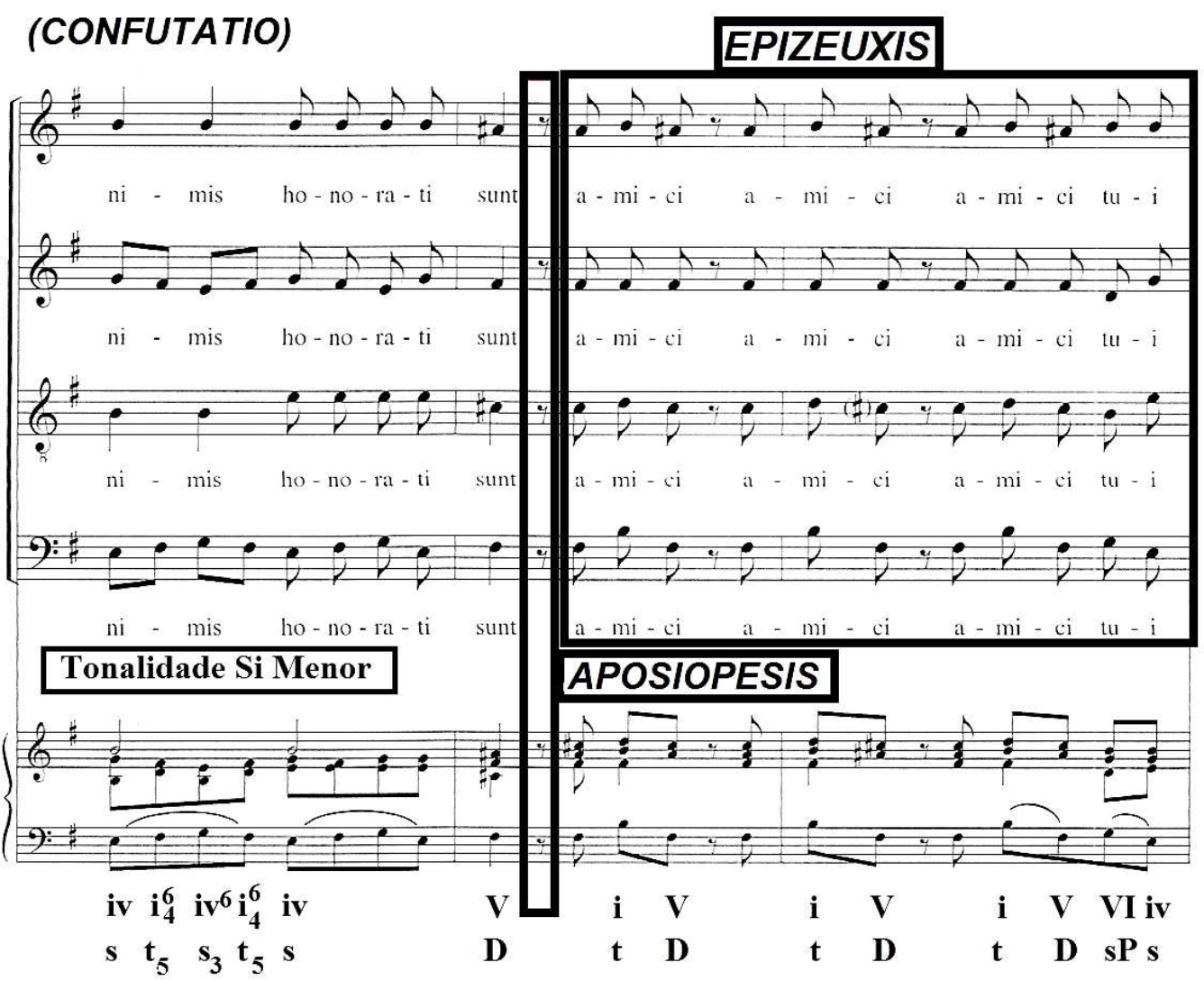

Exemplo 177: Ofertório da Missa da Conversão de São Paulo Apóstolo de André da Silva Gomes- Catalogação e Organização Régis Duprat (DUPRAT, 1999, p.224).

O compositor continua a estimular a atenção do ouvinte fornecendo a ele, as mesmas figuras utilizadas no trecho anterior, entretanto, o conduzindo a um desvio da sua orientação lógica em voltar para a tonalidade de Ré Maior, permanecendo em Si Menor. Semelhantemente é destacável o uso da Pausa na resolução da Cadência Autêntica Perfeita nos compassos 33, em todas as partes, como no 34, nas vozes do tenor e baixo, destacando as melodias agudas da soprano e contralto que retomam a narração do discurso, isto é, uma Narratio dentro da Confutatio. 


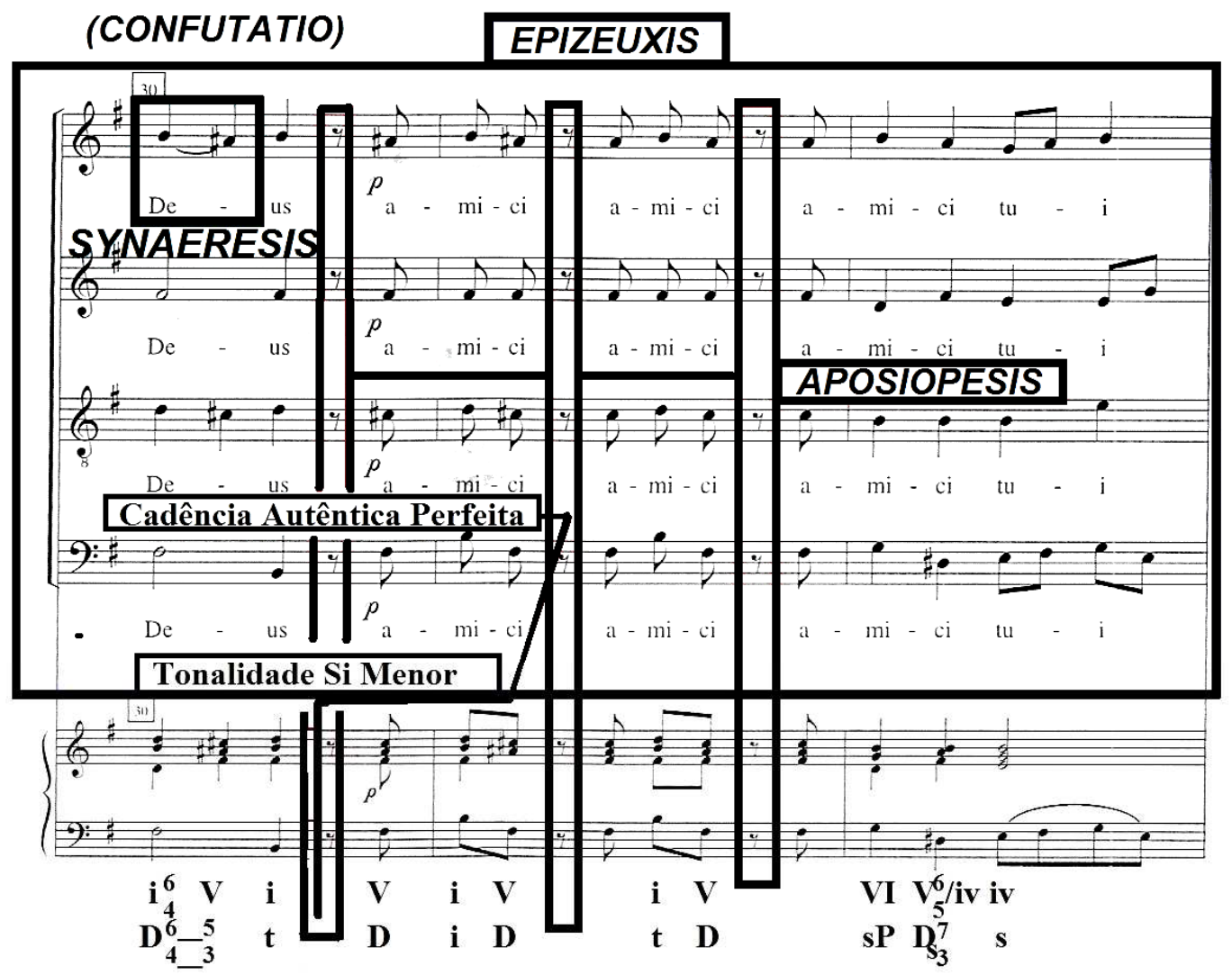

(NARRATIO dentro da CONFUTATIO)

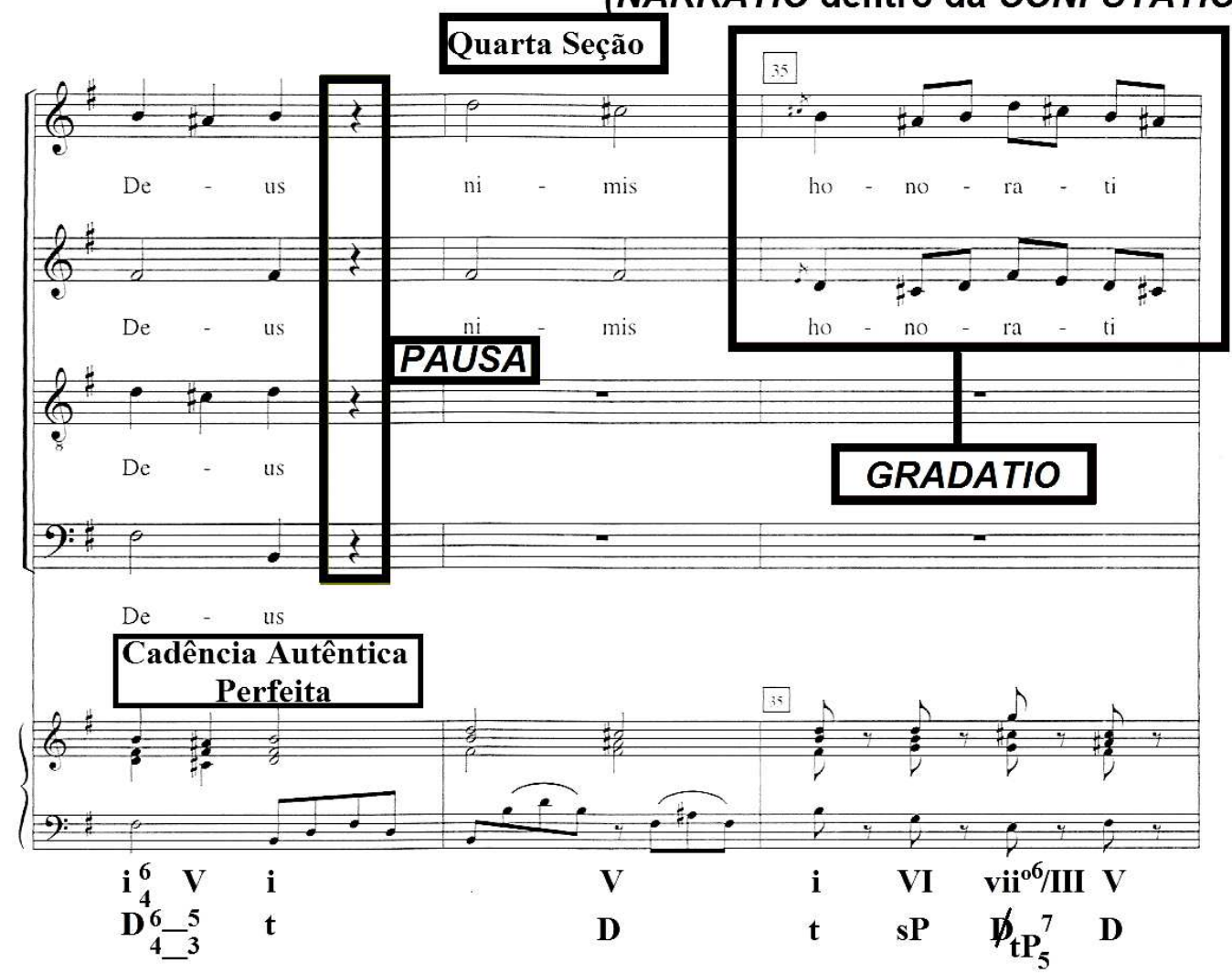

Exemplo 178: Ofertório da Missa da Conversão de São Paulo Apóstolo de André da Silva Gomes- Catalogação e Organização Régis Duprat (DUPRAT, 1999, p.225). 
Nota-se o procedimento semelhante ao aplicado na Narratio, dos compassos 10 a 18, no entanto com emprego da colcheia em vez de semicolcheia, na expressão honorati sunt amici tui, ou seja, aumentação motívica, além de sua terminação numa Cadência Completa.
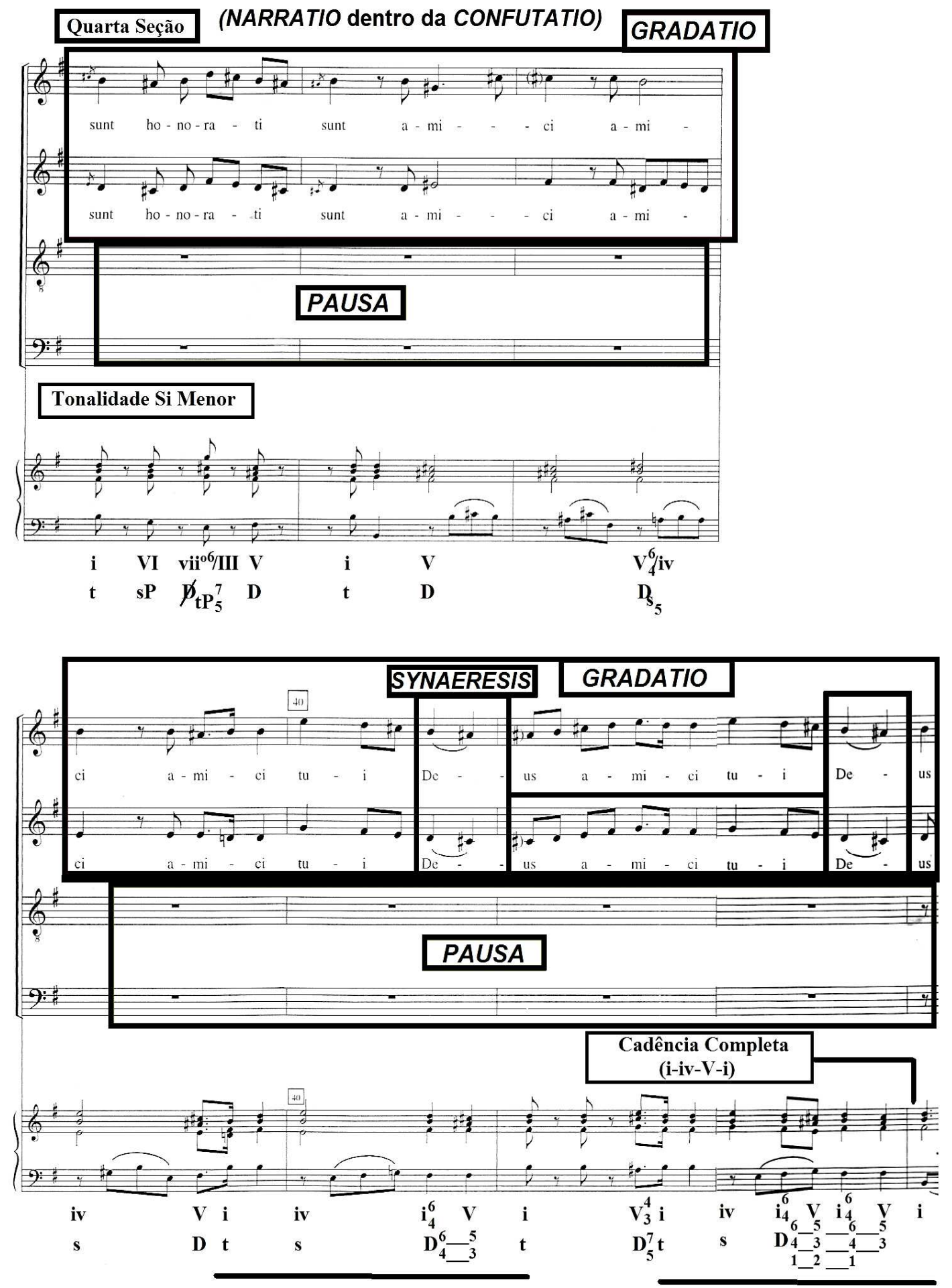

Exemplo 179: Ofertório da Missa da Conversão de São Paulo Apóstolo de André da Silva Gomes- Catalogação e Organização Régis Duprat (DUPRAT, 1999, p.226-227). 


\subsubsection{Confirmatio}

A tese se confirma através do tutti, pronunciando a frase mais trabalhada pelo autor amici tui, Deus, repetida quatro vezes pela figura da Epizeuxis.

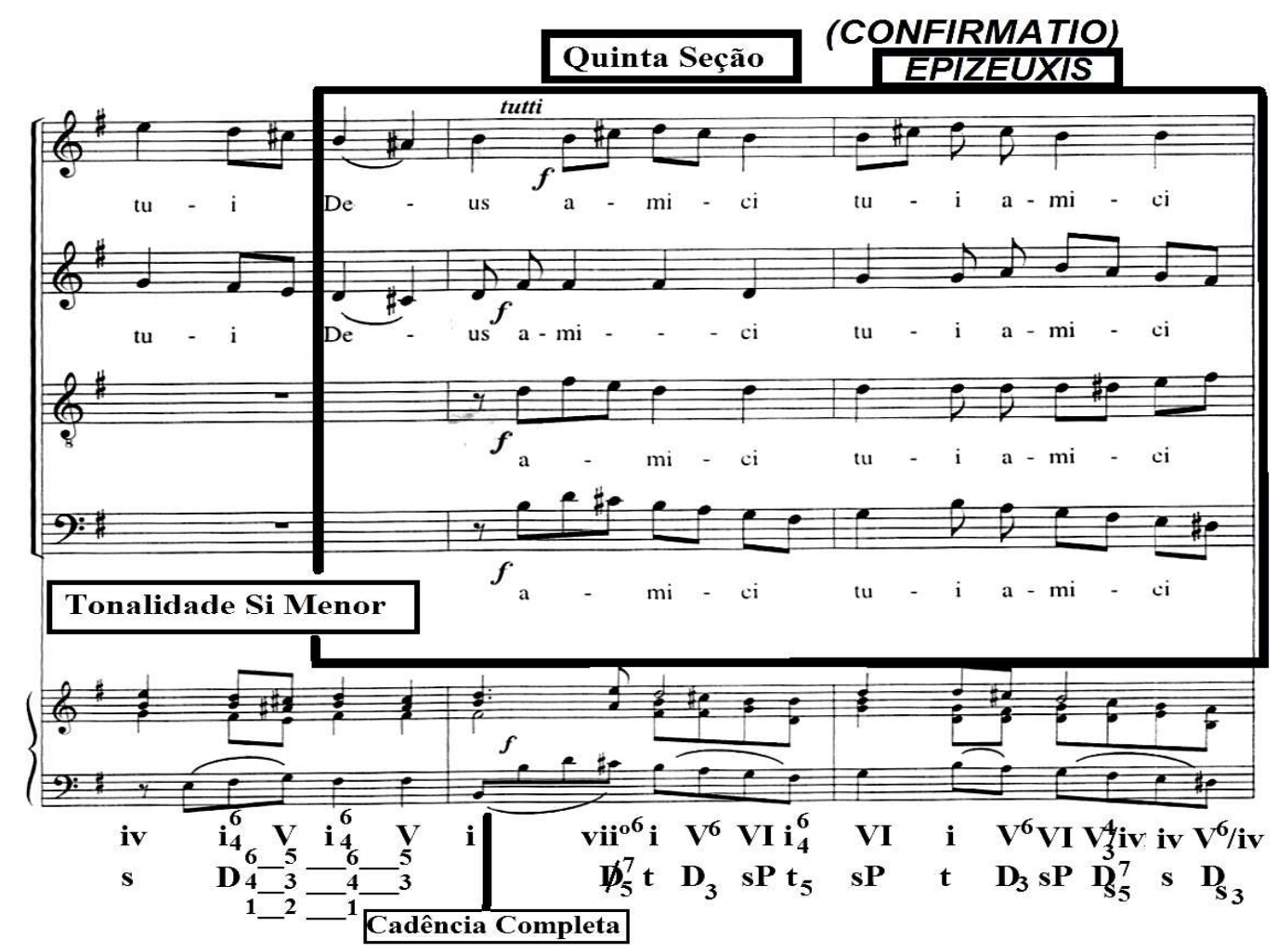

EPIZEUXIS

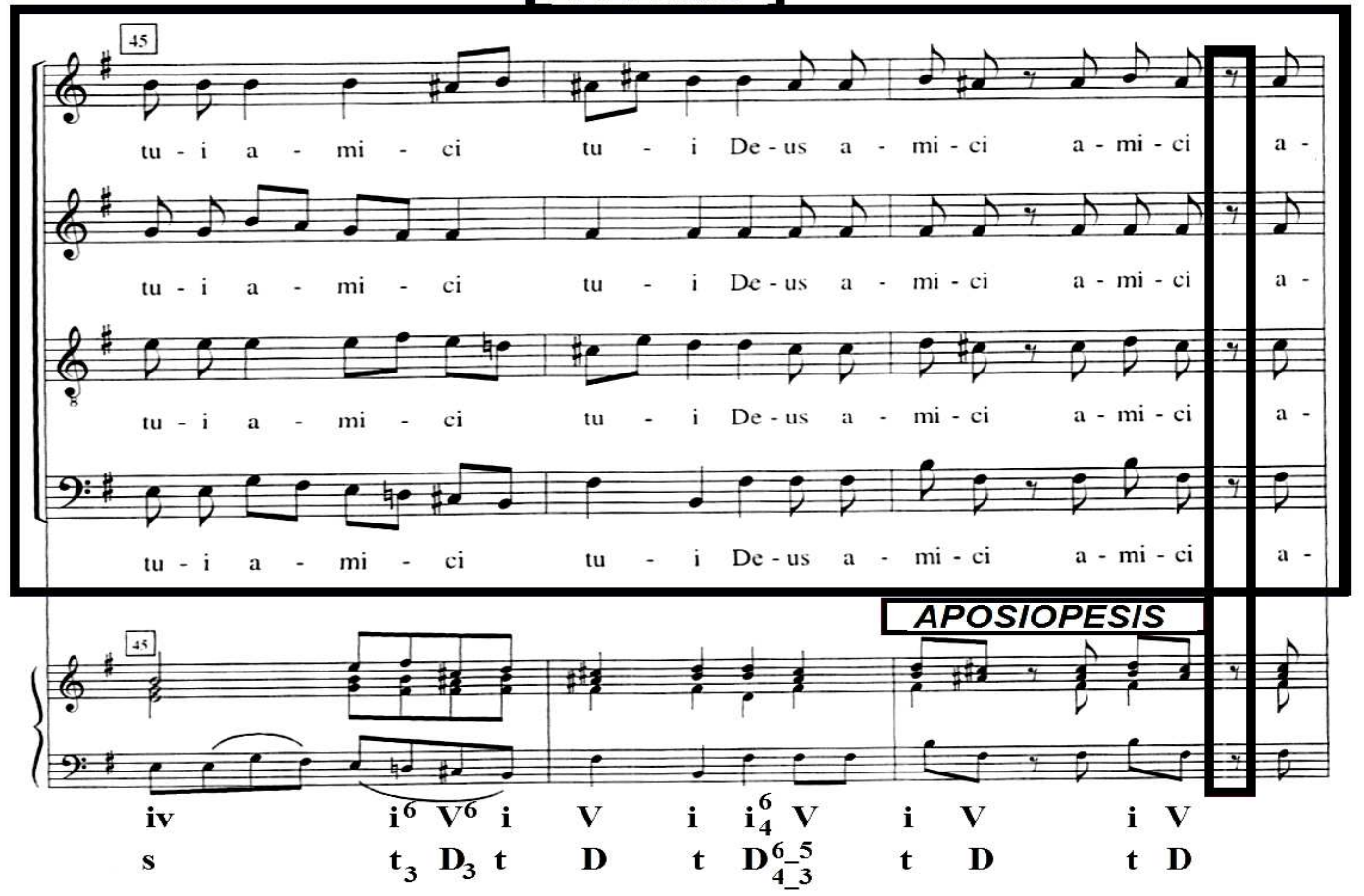

Exemplo 180: Ofertório da Missa da Conversão de São Paulo Apóstolo de André da Silva Gomes- Catalogação e Organização Régis Duprat (DUPRAT, 1999, p.227). 
Numa Cadência Autêntica Perfeita, a quinta parte da Dispositio é finalizada tendo como elemento de destaque a Synaeresis.

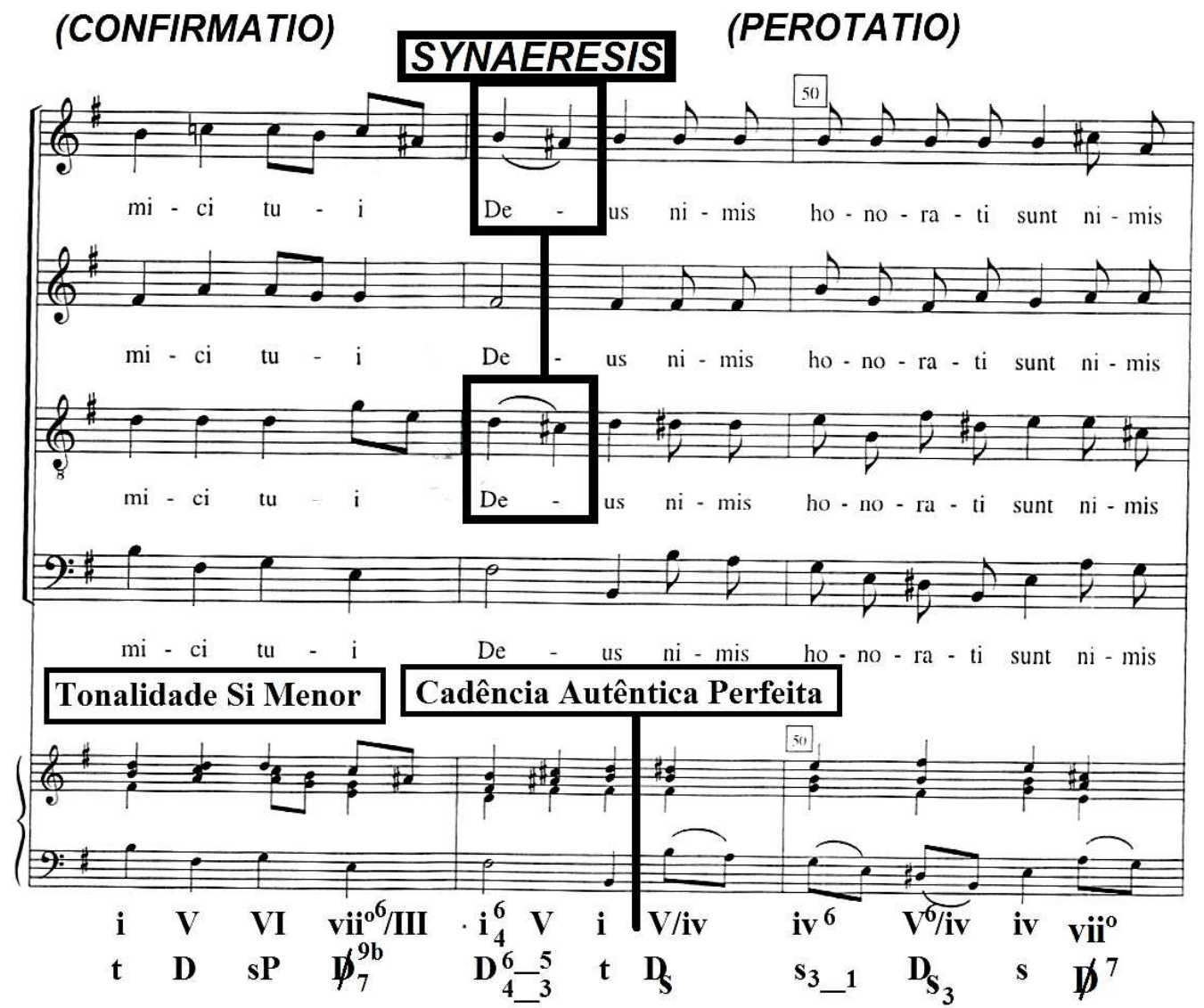

Exemplo 181: Ofertório da Missa da Conversão de São Paulo Apóstolo de André da Silva Gomes- Catalogação e Organização Régis Duprat (DUPRAT, 1999, p.228).

\subsubsection{Perotatio}

A conclusão do primeiro movimento começa com a expressão honorati sunt, sendo resolvida no compasso 51, numa Pausa, a qual preparará o retorno à tonalidade de Sol Maior, a mesma utilizada na parte introdutória da peça. 


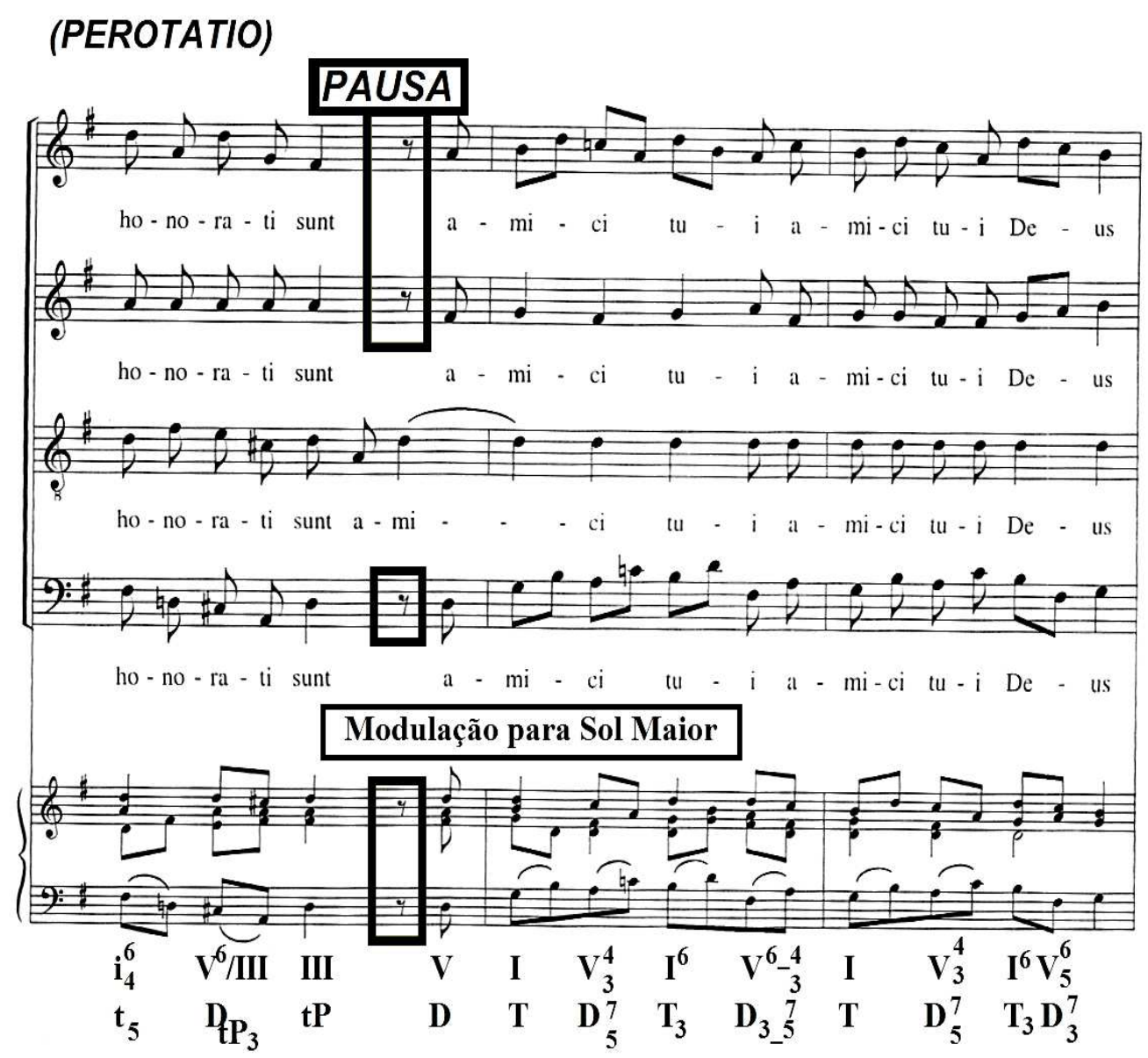

Exemplo 182: Ofertório da Missa da Conversão de São Paulo Apóstolo de André da Silva Gomes- Catalogação e Organização Régis Duprat (DUPRAT, 1999, p.228).

A Synaeresis continua a ser usada entre os compassos 54,56 na soprano e contralto e 59 , também no tenor, destacando principalmente as duas notas entoando a primeira silaba da palavra Deus, no entanto, também é verificável o uso da Aposiopesis determinando as vozes um momento de breve silêncio, além de ressaltar a respiração entre a expressão amici, auxiliando num primeiro momento a retomada da mesma, como na resolução da Semicadência, para depois concluir na Coda com duração mais longa das notas, num rallentando, aplicado pelo autor em preparação ao segundo movimento. 
(PEROTATIO)
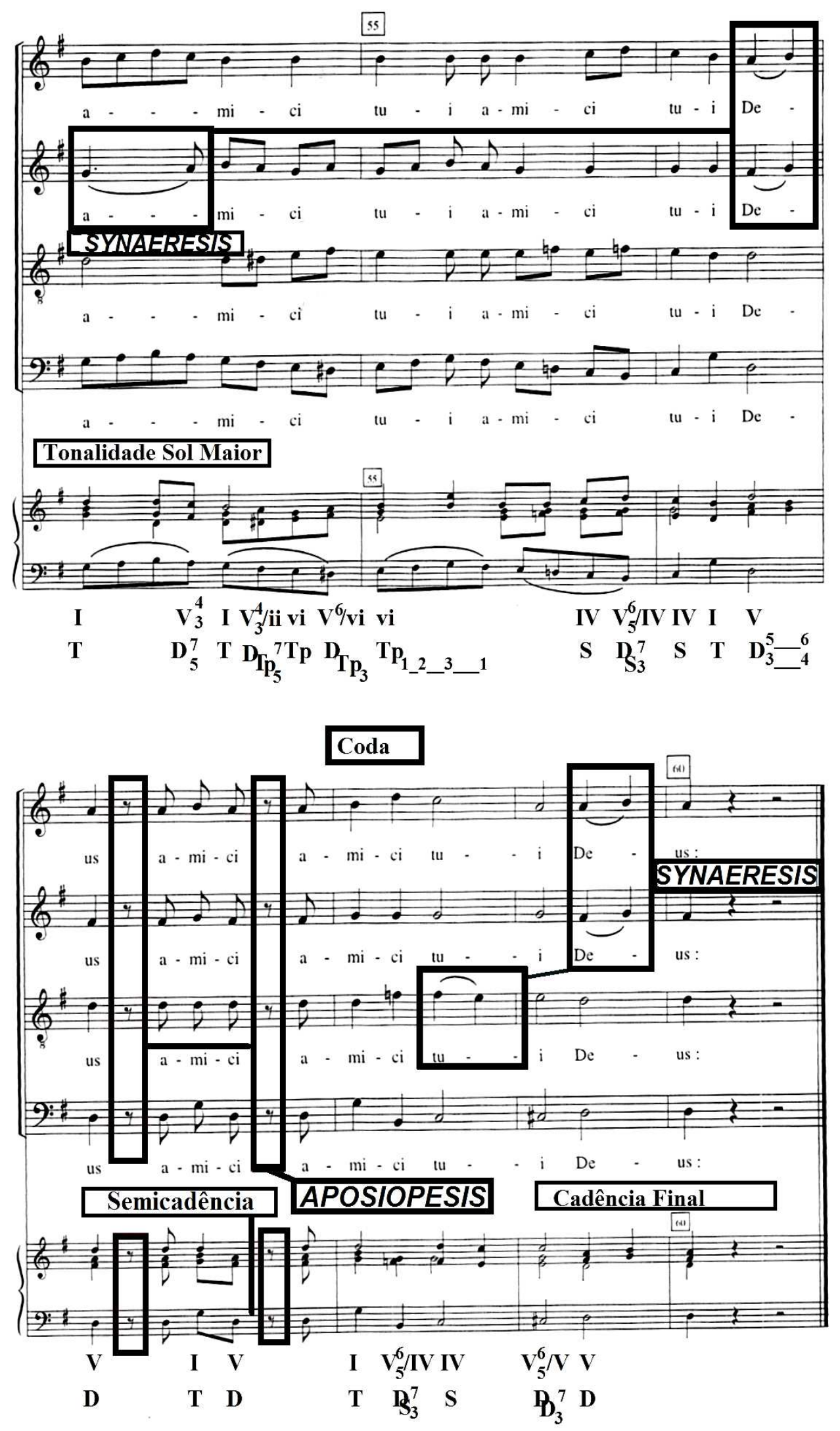

Exemplo 183: Ofertório da Missa da Conversão de São Paulo Apóstolo de André da Silva Gomes- Catalogação e Organização Régis Duprat (DUPRAT, 1999, p.229). 


\subsubsection{Exordium (Segundo Movimento)}

Em sua Arte Explicada de Contraponto, André da Silva Gomes apresenta o esquema inicial da exposição de uma Fuga detalhadamente, ressaltando que o motivo, tema, tenção e passo contidos na mesma devem ser constituídos de três partes ou condições, Princípio, Meio e Fim. Sendo o Princípio iniciado na primeira ou quinta nota ou corda do tom, conforme a entrada do motivo. O Meio considera-se a nota, em que a voz começa a infletir o tom ou a primeira nota. O Fim sempre é considerado na nota em que a voz forma Cláusula ou Cadência, para finalizar na nota em que ao mesmo tempo principia a voz sua competidora, que a segue (SILVA GOMES, apud, DUPRAT, et al, 1998, p.175).

Ele continua seu raciocínio salientando que numa Fuga, cuja tonalidade esta estabelecida em Sol Maior, pode ser iniciada com a quinta de seu tom, em outras palavras, a primeira voz terá início com a nota Ré. Já a voz consequente principia no primeiro tom, Sol e por fim, se emprega à nota Ré inferior, cujo espaço é justamente de uma quarta, completando e cumprindo o artificio peculiar desse gênero musical (SILVA GOMES, apud, DUPRAT, et al, 1998 pp.175-176).

Enfim, o compositor luso-brasileiro mostra seu domínio na arte do contraponto, assim como na construção ordenada do discurso, disposto desde o Exordium do presente movimento deste ofertório. 

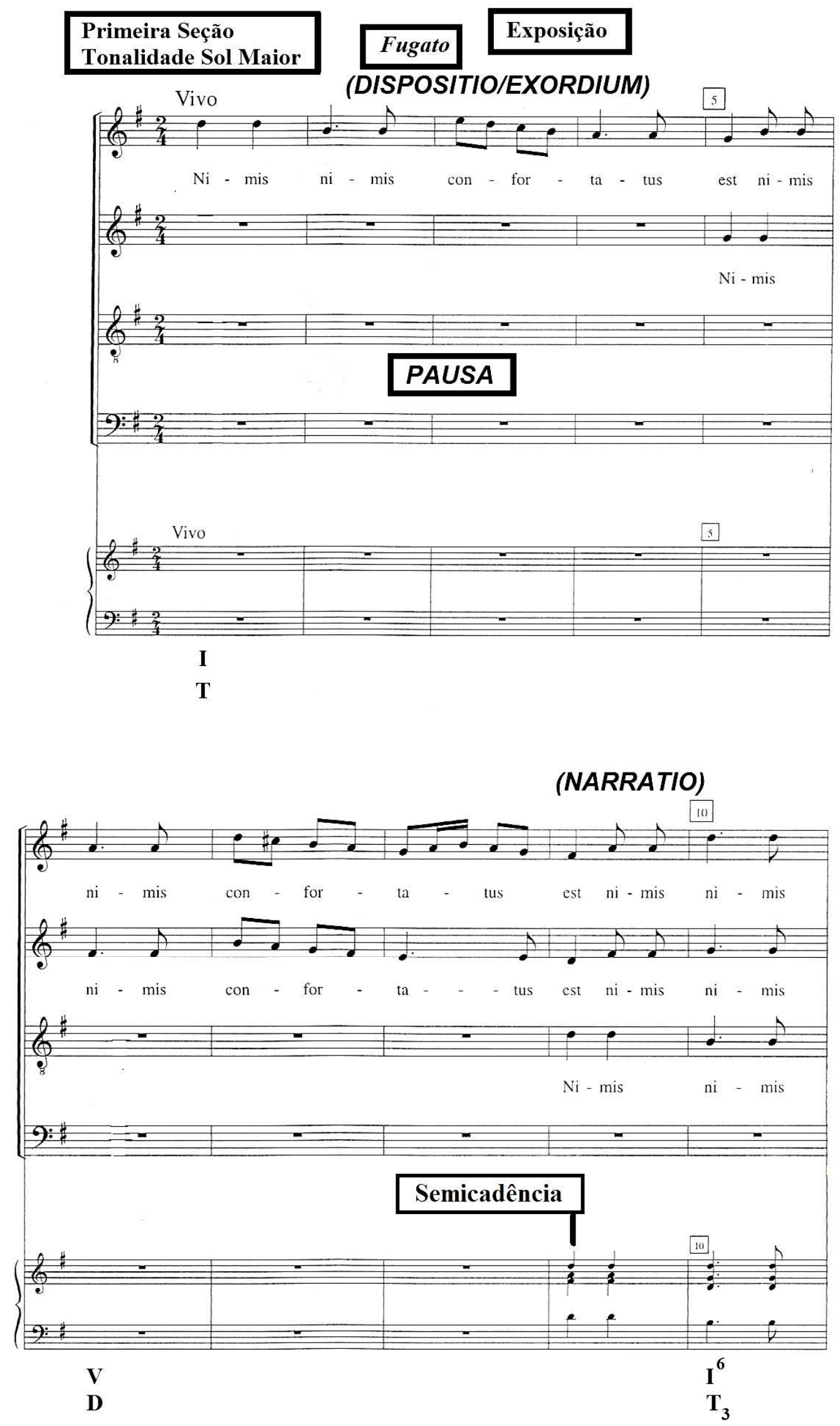

Exemplo 184: Ofertório da Missa da Conversão de São Paulo Apóstolo de André da Silva Gomes- Catalogação e Organização Régis Duprat (DUPRAT, 1999, p.230). 


\subsubsection{Narratio}

Na segunda parte discursiva, o autor aplica a Noema para ressaltar tanto a passagem homofônica das vozes na textura contrapontística, como na enfatização da expressão nimis confortatus est. Igualmente pode-se notar o uso da Cadência Autêntica Perfeita no compasso 13.

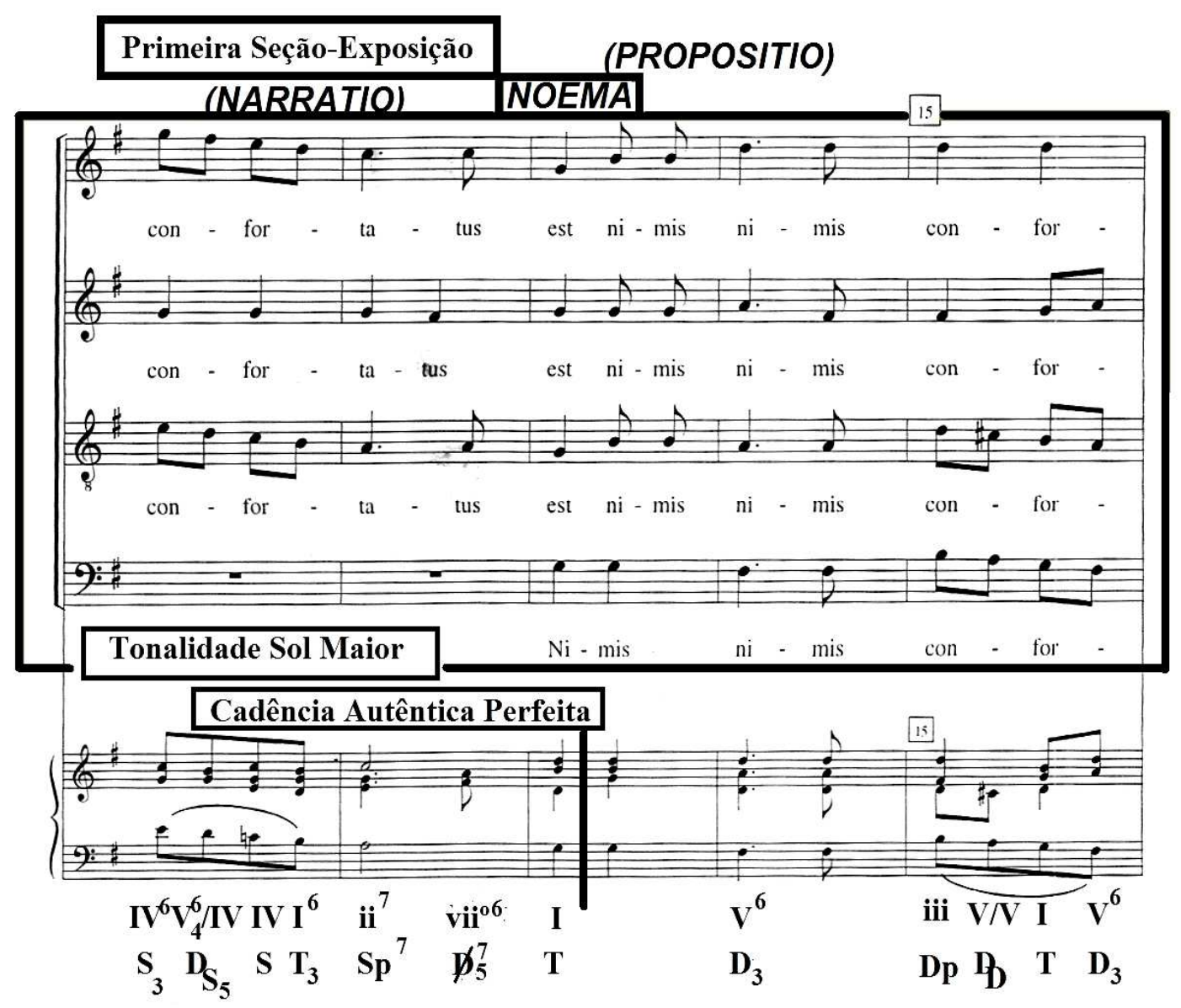

Exemplo 185: Ofertório da Missa da Conversão de São Paulo Apóstolo de André da Silva Gomes- Catalogação e Organização Régis Duprat (DUPRAT, 1999, p.2231).

\subsubsection{Propositio}

Na presente parte da Dispositio, a Noema é empregada pelo autor com a intenção de reforçar o argumento central da obra, que os caminhos e designíos de Deus são difíceis de serem compreendidos pelos humanos, ou seja, assim como Paulo outrora perseguidor dos cristãos foi escolhido para seguir e propagar a palavra de Deus, provocando incompreensão dos próprios seguidores de Cristo. 


\section{(PROPOSITIO) NOEMA}

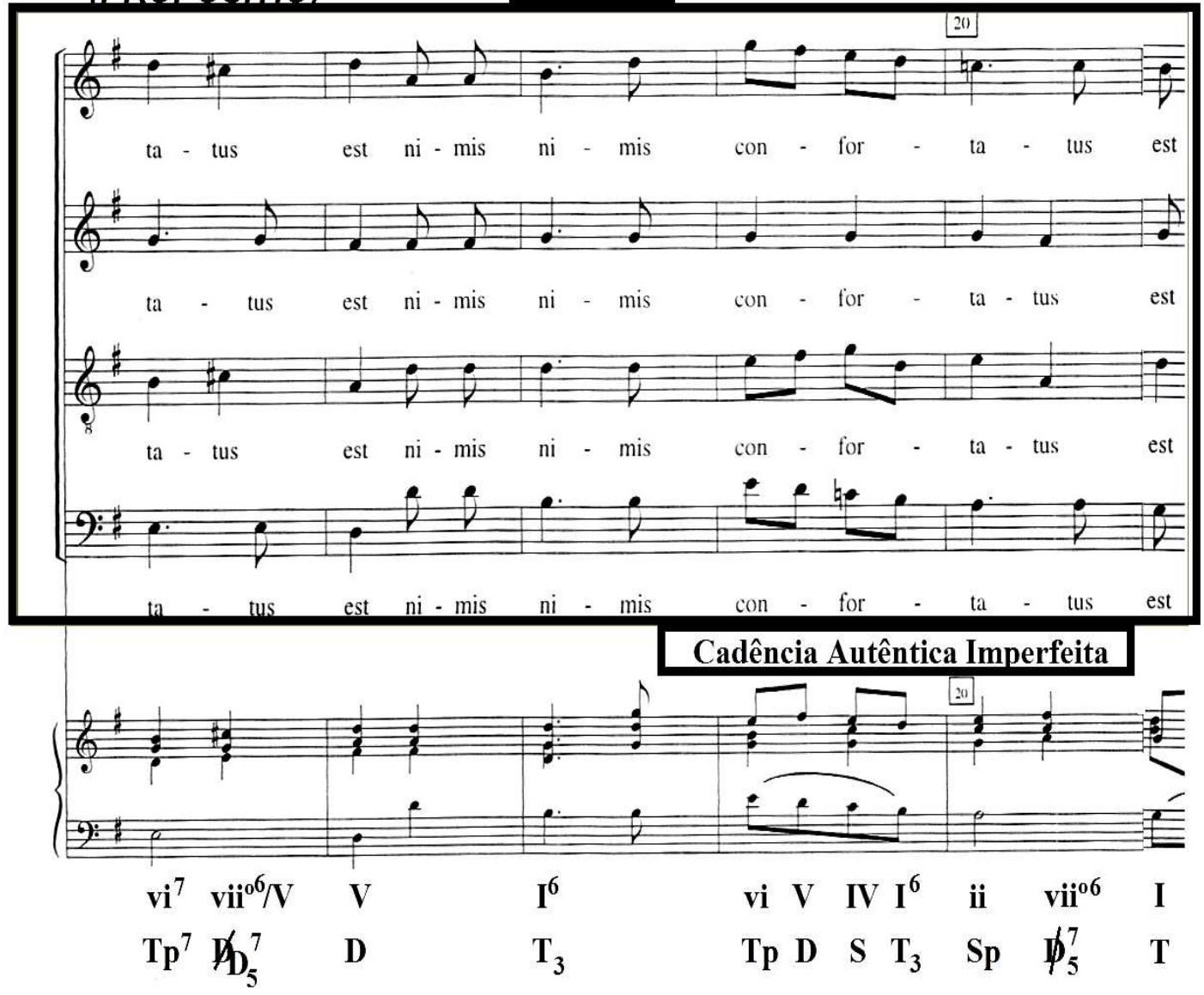

Exemplo 186: Ofertório da Missa da Conversão de São Paulo Apóstolo de André da Silva Gomes- Catalogação e Organização Régis Duprat (DUPRAT, 1999, pp.231-232).

\subsubsection{Confutatio}

Os materiais e elementos de contraste são localizados através das modulações para Si Menor e Ré Maior, também se têm a aplicabilidade da Synaeresis, destacando as notas descendentes Si e Lá sustenido na voz da contralto e Ré e Dó sustenido no tenor (compasso 28), como a Auxesis em repetição sucessivas da passagem musical. 

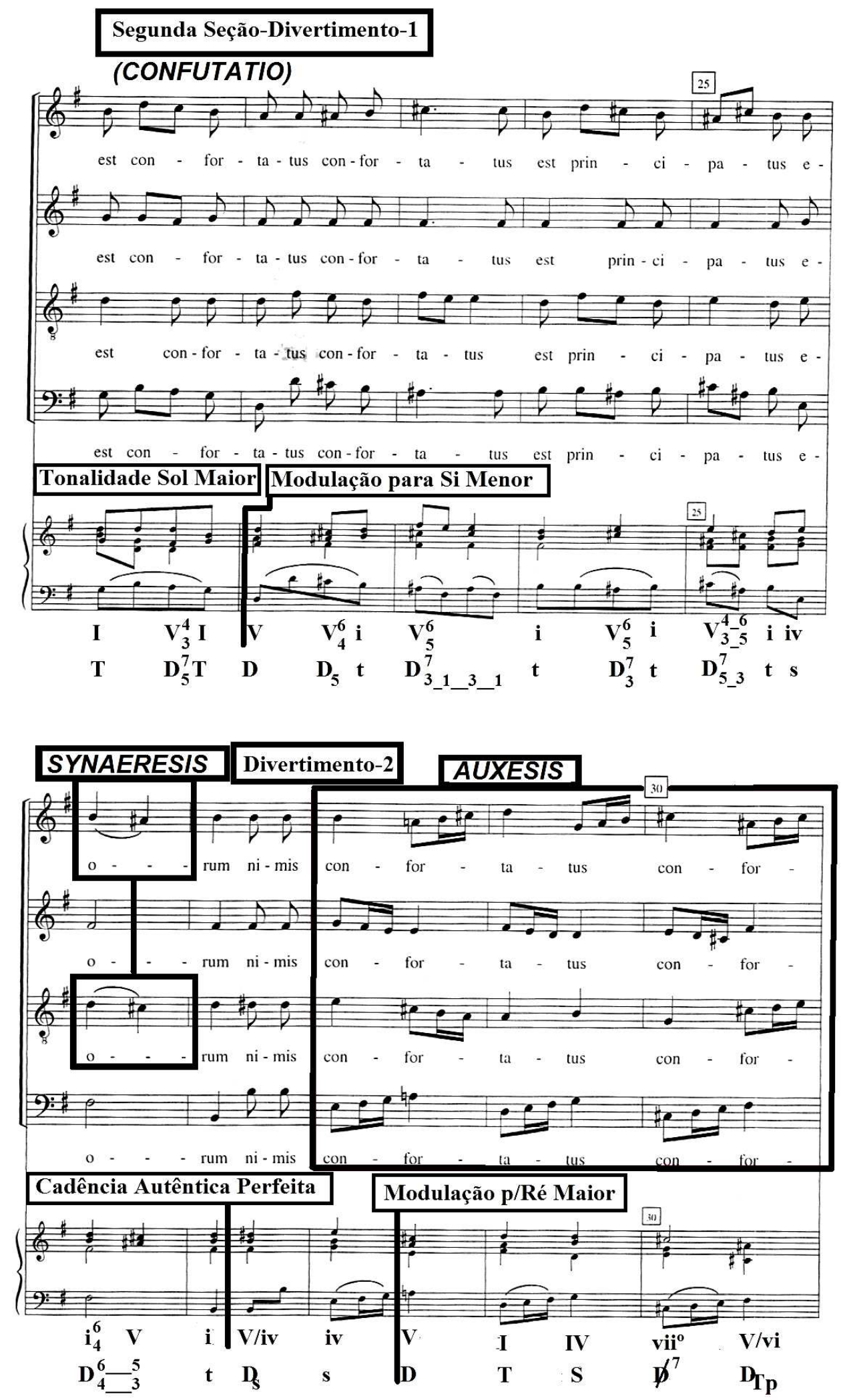

Exemplo 187: Ofertório da Missa da Conversão de São Paulo Apóstolo de André da Silva Gomes- Catalogação e Organização Régis Duprat (DUPRAT, 1999, p.232). 
Silva Gomes incrementa mais uma nova figura na peça, Metabasis, cruzando a extensão de entoação do tenor e baixo. Por fim, se observa a resolução da Confutatio na Cadência Autêntica Perfeita.

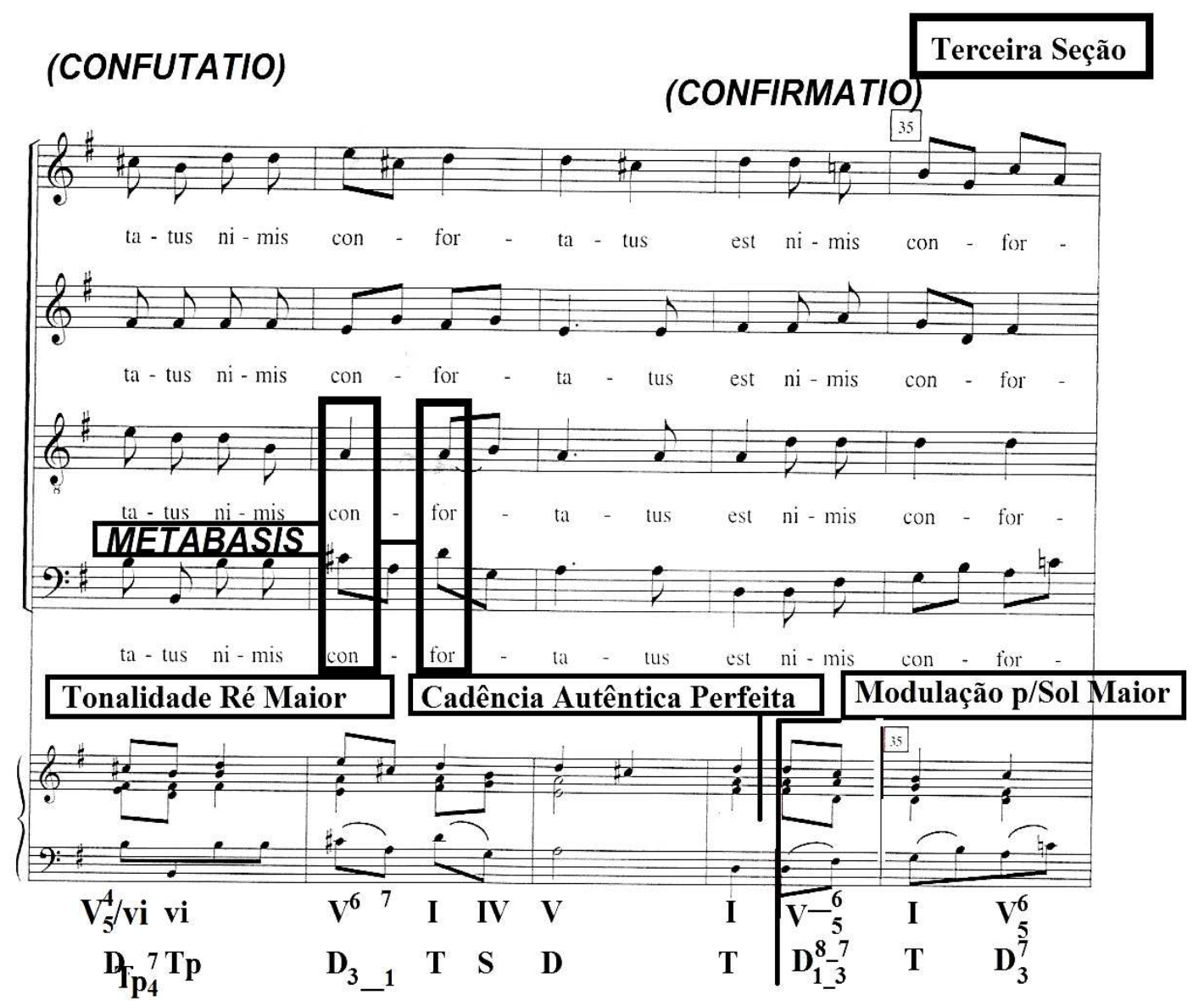

Exemplo 188: Ofertório da Missa da Conversão de São Paulo Apóstolo de André da Silva Gomes- Catalogação e Organização Régis Duprat (DUPRAT, 1999, p.233).

\subsubsection{Confirmatio}

O argumento inicial do Fugato é confirmado com o retorno à tonalidade de Sol Maior, isto é, a principal da peça. Em síntese, a Confirmatio é concretizada numa Cadência Autêntica Imperfeita em preparação a conclusão do discurso. Já no começo da seção seguinte se examina o uso da Circulatio para destacar a nota Sol em movimentos como de um circulo, sempre direcionadas a ela. 


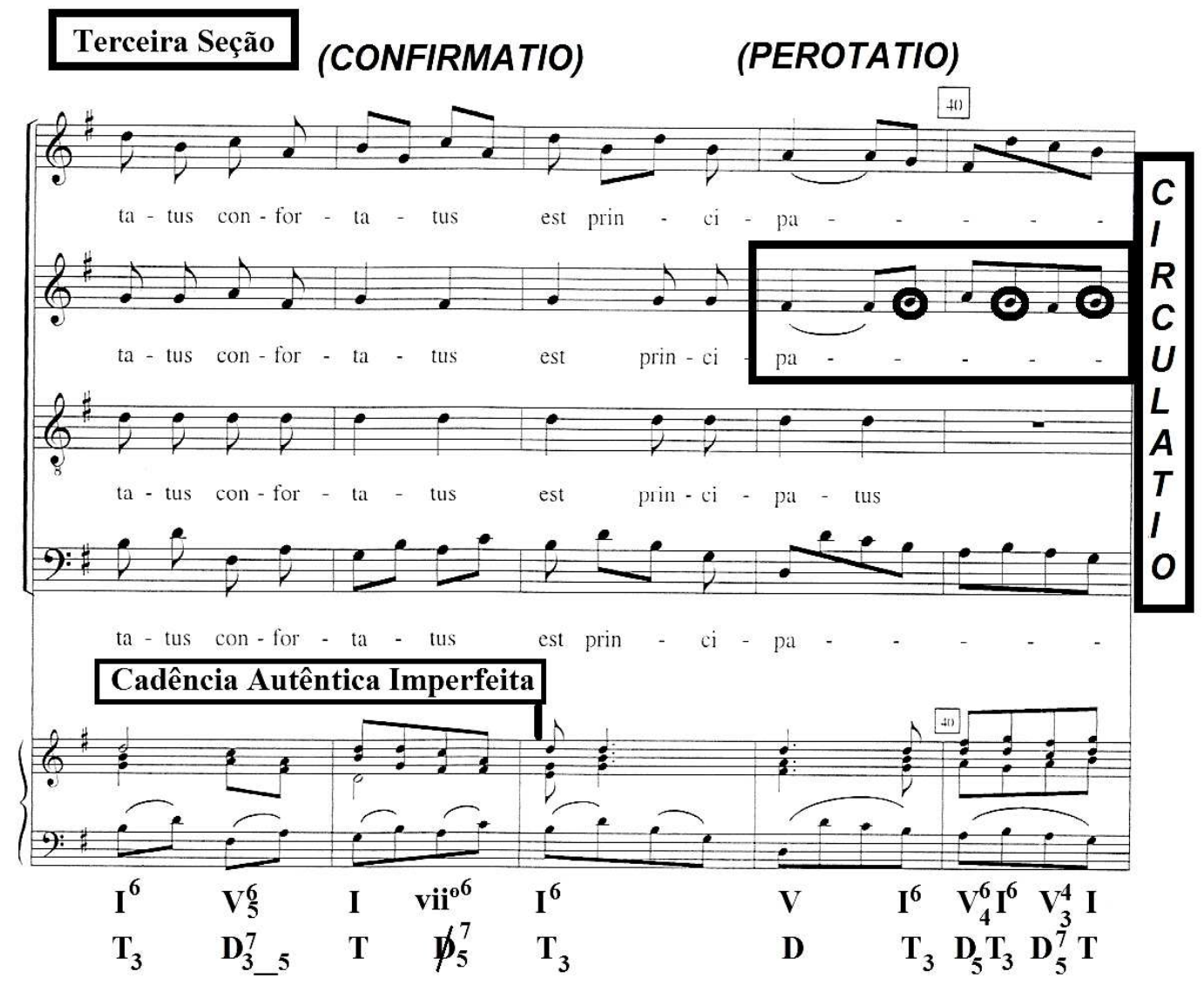

Exemplo 189: Ofertório da Missa da Conversão de São Paulo Apóstolo de André da Silva Gomes- Catalogação e Organização Régis Duprat (DUPRAT, 1999, p.234).

\subsubsection{Perotatio}

O ofertório se encerra com o uso da Circulatio nos mesmos atributos do trecho anterior, também da Pausa, delimitando as entradas das vozes por meio de interrupção e silêncio e a Synaeresis, enfatizando a expressão orum, nas vozes da soprano e contralto.

Enfim, Silva Gomes como mestre na arte do contraponto e da composição, aplica o Pedal de Dominante do compasso 42, até o final da obra na Cadência Final, para enfatizar e ressaltar a importância das introduções sucessivas das vozes juntamente com as figuras citadas no parágrafo anterior. 

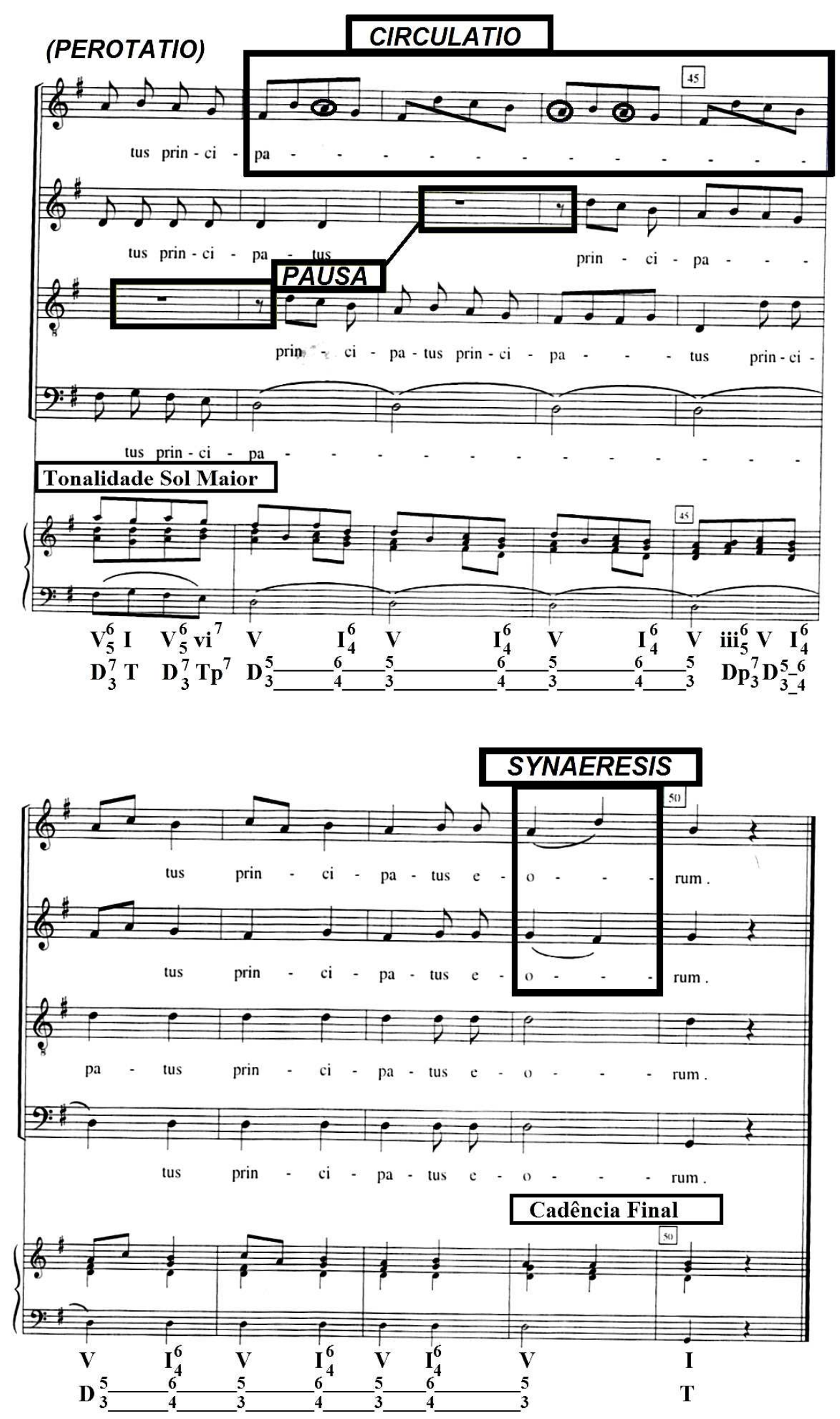

Exemplo 190: Ofertório da Missa da Conversão de São Paulo Apóstolo de André da Silva Gomes- Catalogação e Organização Régis Duprat (DUPRAT, 1999, p.234). 
1.5. Figuras observadas no Ofertório (Elocutio/Decoratio)

\begin{tabular}{|c|c|c|c|}
\hline FIGURAS & TIPO & DESCRIÇÃO & TRATADISTA \\
\hline $\begin{array}{l}\text { AUXESIS } \\
\text { (BARTEL, 1997, pp. } \\
\text { 209-212). }\end{array}$ & $\begin{array}{l}\text { Repetição } \\
\text { Melódica }\end{array}$ & $\begin{array}{l}\text { São repetições } \\
\text { sucessivas de } \\
\text { uma passagem } \\
\text { musical. }\end{array}$ & $\begin{array}{lr}\text { Burmeister: A } \\
\text { Auxesis ocorre } \\
\text { quando uma } \\
\text { harmonia } \\
\text { composta por } \\
\text { combinações } \\
\text { consonantes se } \\
\text { desenvolve de } \\
\text { forma crescente } \\
\text { em um texto que é } \\
\text { repetido uma, } \\
\text { duas, três ou mais } \\
\text { vezes. Portanto, } \\
\text { ela pode ser } \\
\text { caracterizada por } \\
\text { uma elevação } \\
\text { com incremento } \\
\text { na altura de um } \\
\text { Noema repetido. }\end{array}$ \\
\hline $\begin{array}{l}\text { APOSIOPESIS } \\
\text { (BARTEL, 1997, } \\
\text { pp.202-206). }\end{array}$ & $\begin{array}{l}\text { Interrupção } \\
\text { Silêncio }\end{array}$ & $\begin{array}{l}\text { Um descanso } \\
\text { em uma ou todas } \\
\text { as vozes de uma } \\
\text { composição: } \\
\text { pausa geral. }\end{array}$ & 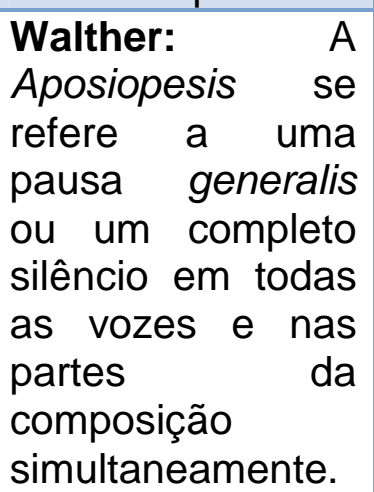 \\
\hline $\begin{array}{l}\text { CIRCULATIO } \\
\text { (BARTEL, 1997, }\end{array}$ & $\begin{array}{l}\text { Representação } \\
\text { e Descrição }\end{array}$ & $\begin{array}{l}\text { Uma série de } \\
\text { notas } \\
\text { (geralmente oito) }\end{array}$ & $\begin{array}{l}\text { Walther: } \\
\text { Circulo que ocorre } \\
\text { de duas maneiras: }\end{array}$ \\
\hline $\begin{array}{l}\text { (BUELOW, } 1980, \\
\text { p.798). }\end{array}$ & & $\begin{array}{l}\text { em uma } \\
\text { formação circular } \\
\text { ou de ondas } \\
\text { senoidais. } \\
\text { Também pode } \\
\text { ser definida } \\
\text { como uma linha } \\
\text { melódica que } \\
\text { oscila ao redor } \\
\text { de uma nota }\end{array}$ & $\begin{array}{l}\text { 1. Como uma } \\
\text { forma dupla, } \\
\text { que ainda é } \\
\text { encontrada } \\
\text { nas } \\
\text { composições } \\
\text { antigas como } \\
\text { uma } \\
\text { assinatura de } \\
\text { tempo após a } \\
\text { clave. } \\
\text { 2. Quando dois }\end{array}$ \\
\hline
\end{tabular}




\begin{tabular}{|c|c|c|c|c|}
\hline & & & & $\begin{array}{l}\text { Circoli Mezzi } \\
\text { são } \\
\text { combinados e } \\
\text { seguem um ao } \\
\text { outro de tal } \\
\text { forma que, } \\
\text { eles devem } \\
\text { ser } \\
\text { sobrepostos } \\
\text { entre si, eles } \\
\text { representam } \\
\text { visualmente } \\
\text { um círculo } \\
\text { completo. }\end{array}$ \\
\hline $\begin{array}{l}\text { EPIZEUXIS } \\
\text { (BARTEL, } \\
\text { pp.263-265). }\end{array}$ & 1997 & $\begin{array}{l}\text { Repetição } \\
\text { Melódica }\end{array}$ & $\begin{array}{l}\text { Uma repetição } \\
\text { imediata e } \\
\text { enfática de uma } \\
\text { palavra, nota, } \\
\text { motivo ou frase. }\end{array}$ & $\begin{array}{l}\text { Walther: A } \\
\text { Epizeuxis é uma } \\
\text { figura de retórica } \\
\text { pela qual uma ou } \\
\text { mais palavras são } \\
\text { imediatamente e } \\
\text { enfaticamente } \\
\text { repetidas. }\end{array}$ \\
\hline $\begin{array}{l}\text { GRADATIO } \\
\text { (BARTEL, } \\
\text { pp.220-224). }\end{array}$ & 1997 & $\begin{array}{l}\text { Repetição } \\
\text { Melódica }\end{array}$ & $\begin{array}{l}\text { (1) Sequência de } \\
\text { notas em uma só } \\
\text { voz repetida em } \\
\text { qualquer } \\
\text { tonalidade maior } \\
\text { ou menor, (2) } \\
\text { Duas vozes que } \\
\text { se deslocam em } \\
\text { movimento } \\
\text { ascendente ou } \\
\text { descendente } \\
\text { paralelo, (3) Um } \\
\text { aumento gradual } \\
\text { na intensidade e } \\
\text { altura do som. }\end{array}$ & 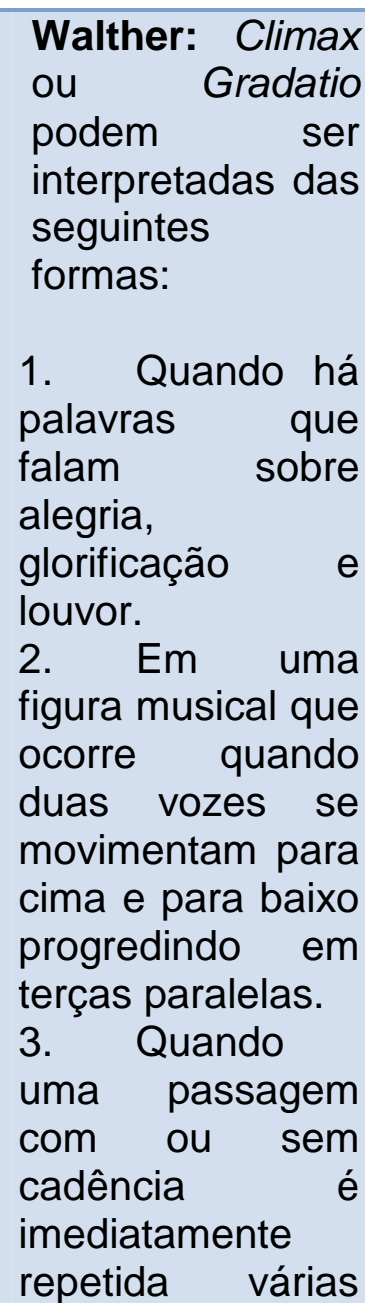 \\
\hline
\end{tabular}




\begin{tabular}{|c|c|c|c|c|}
\hline & & & & $\begin{array}{l}\text { vezes em alturas } \\
\text { progressivamente } \\
\text { maiores. } \\
4 \text {. Este termo } \\
\text { também pode ser } \\
\text { dado a um } \\
\text { cânone de quatro } \\
\text { partes em que, as } \\
\text { duas primeiras } \\
\text { vozes reentram, e } \\
\text { as outras duas } \\
\text { vozes } \\
\text { permanecem na } \\
\text { parte anterior e } \\
\text { ainda } \\
\text { harmonizam. }\end{array}$ \\
\hline $\begin{array}{l}\text { METABASIS } \\
\text { (BARTEL, } \\
\text { pp.319-320). }\end{array}$ & 1997 & $\begin{array}{l}\text { Representação } \\
\text { e } \\
\text { Descrição }\end{array}$ & $\begin{array}{l}\text { Cruzamento de } \\
\text { uma voz com } \\
\text { outra ou } \\
\text { cruzamento de } \\
\text { vozes. }\end{array}$ & $\begin{array}{l}\text { Spiess: A } \\
\text { Metabasis (ou } \\
\text { Diabasis, } \\
\text { Transgressio, } \\
\text { Transgression) } \\
\text { ocorre sempre } \\
\text { que uma voz } \\
\text { atravessa a outra. }\end{array}$ \\
\hline $\begin{array}{l}\text { NOEMA } \\
\text { (BARTEL, } \\
\text { p.339-342). }\end{array}$ & 1997 & $\begin{array}{l}\text { Representação } \\
\text { e Descrição }\end{array}$ & $\begin{array}{l}\text { Uma passagem } \\
\text { homofônica em } \\
\text { uma textura } \\
\text { contrapontística } \\
\text { e polifônica. }\end{array}$ & $\begin{array}{l}\text { Burmeister: A } \\
\text { Noema representa } \\
\text { o afeto harmônico, } \\
\text { onde as vozes } \\
\text { combinadas têm } \\
\text { valores e números } \\
\text { de notas } \\
\text { semelhantes. } \\
\text { Quando } \\
\text { introduzida } \\
\text { adequadamente, } \\
\text { isto é, no } \\
\text { momento certo, } \\
\text { ela afeta } \\
\text { docemente os } \\
\text { ouvidos do } \\
\text { ouvinte, } \\
\text { produzindo uma } \\
\text { sensação de } \\
\text { calma e } \\
\text { serenidade. }\end{array}$ \\
\hline $\begin{array}{l}\text { (BUELOW, } \\
\text { p.799). }\end{array}$ & 1980 & & & $\begin{array}{l}\text { Seção } \\
\text { homofônica, } \\
\text { dentro da polifonia }\end{array}$ \\
\hline
\end{tabular}




\begin{tabular}{|c|c|c|c|c|}
\hline & & & & $\begin{array}{l}\text { utilizada para } \\
\text { enfatizar o texto. }\end{array}$ \\
\hline $\begin{array}{l}\text { PALILOGIA } \\
\text { (BARTEL, } \\
\text { pp.342-344). }\end{array}$ & 1997, & $\begin{array}{l}\text { Repetição } \\
\text { Melódica }\end{array}$ & $\begin{array}{l}\text { Repetição de } \\
\text { um tema no } \\
\text { mesmo nível de } \\
\text { altura, também } \\
\text { pode ocorrer em } \\
\text { alturas diferentes } \\
\text { na mesma ou em } \\
\text { várias vozes. }\end{array}$ & 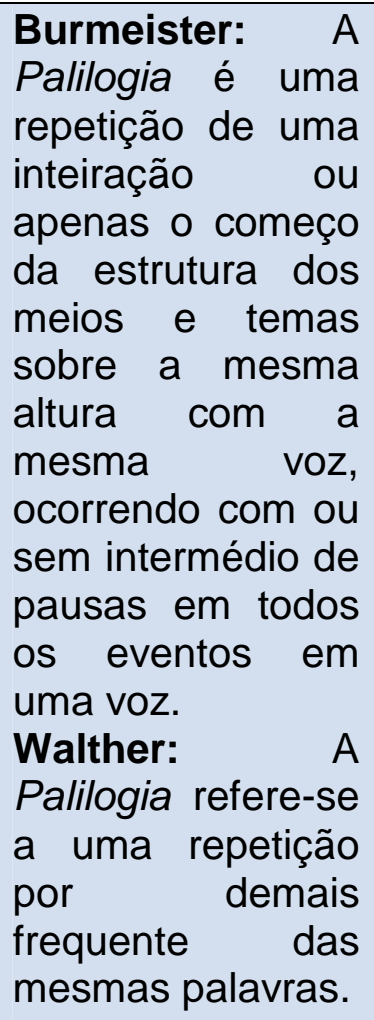 \\
\hline $\begin{array}{l}\text { PAUSA } \\
\text { (BARTEL, } \\
\text { pp.362-365). }\end{array}$ & 1997 & $\begin{array}{l}\text { Interrupção e } \\
\text { Silêncio }\end{array}$ & $\begin{array}{lr}\text { Pausa } & \text { ou } \\
\text { descanso } & \text { em } \\
\text { uma composição } \\
\text { musical }\end{array}$ & $\begin{array}{lrr}\text { Walther: } & \text { Uma } \\
\text { figura ou } & \text { figuras } \\
\text { de silêncio. Estas } \\
\text { se referem à } \\
\text { pausa. } & \text { Pausa } \\
\text { refere-se a um } \\
\text { período } & & \text { de } \\
\text { repouso ou } & \text { o } \\
\text { silêncio } & & \text { na } \\
\text { música, que é } \\
\text { indicado por um } \\
\text { determinado sinal. }\end{array}$ \\
\hline $\begin{array}{l}\text { SYNAERESIS } \\
\text { (BARTEL, } \\
\text { pp.394-396). }\end{array}$ & 1997 & $\begin{array}{l}\text { Dissonância e } \\
\text { Deslocamento }\end{array}$ & $\begin{array}{l}\text { (1) Uma } \\
\text { suspensão ou } \\
\text { síncope, (2) A } \\
\text { colocação de } \\
\text { duas sílabas por } \\
\text { nota ou duas } \\
\text { notas por sílaba. }\end{array}$ & $\begin{array}{lr}\text { Vogt: } & \text { A } \\
\text { Synaeresis } & \text { ocorre } \\
\text { quando } & \text { duas } \\
\text { notas } & \text { são } \\
\text { colocadas } & \text { em } \\
\text { uma sílaba } & \text { ou } \\
\text { duas sílabas } & \text { são } \\
\text { colocadas } & \text { em } \\
\text { uma nota. } & \end{array}$ \\
\hline
\end{tabular}

Tabela 65: Figuras encontradas no Ofertório da Missa da Conversão de São Paulo Apóstolo de André da Silva Gomes 


\section{Análise Harmônica}

\subsection{Curva Tonal (Primeiro Movimento)}

Tonalidade: Sol Maior

Andamento: Brilhante 4/4

Esquema de Progressões Harmônicas

\begin{tabular}{|l|c|l|}
\hline Compassos & $\begin{array}{l}\text { Função em relação a } \\
\text { tonalidade principal }\end{array}$ & Tonalidade (Acorde) \\
\hline $1-13$ & T-I & Sol Maior \\
\hline 13 & Sp-ii & Lá Menor \\
\hline $14-15$ & T-I & Sol Maior \\
\hline 16 & Sp-ii & Lá Menor \\
\hline $16-19$ & T-I & Sol Maior \\
\hline $20-25$ & D-V & Ré Maior \\
\hline $25-31$ & Dp-iii & Si Menor \\
\hline 32 & Tp-vi & Mi Menor \\
\hline $32-35$ & Dp-iii & Si Menor \\
\hline 35 & D-V & Ré Maior \\
\hline $35-36$ & Dp-iii & Si Menor \\
\hline 36 & D-V & Ré Maior \\
\hline $36-37$ & Dp-iii & Si Menor \\
\hline $37-38$ & D/Dp-V/iii & Fá \# Maior \\
\hline 38 & D/Tp-V/vi & Si Maior \\
\hline 39 & D/Sp-V/ii & Mi Maior \\
\hline $39-43$ & Dp-iii & Si Menor \\
\hline $44-45$ & Tp-vi & Mi Menor \\
\hline $45-48$ & Dp-iii & Si Menor \\
\hline 48 & T-I & Sol Maior \\
\hline $48-49$ & Dp-iii & Si Menor \\
\hline $49-50$ & Tp-vi & Mi Menor \\
\hline 51 & D-V & Ré Maior \\
\hline $52-54$ & T-I & Sol Maior \\
\hline $54-55$ & Tp-vi & Mi Menor \\
\hline $55-56$ & S-IV & Dó Maior \\
\hline 57 & T-I & Sol Maior \\
\hline 58 & S-IV & Dó Maior \\
\hline $59-60$ & T-I & Ré Maior \\
\hline & & \\
\hline
\end{tabular}

Tabela 66: Curva Tonal do Ofertório da Missa da Conversão de São Paulo Apóstolo (Primeiro Movimento) 
Números de compassos: 60

Regiões abordadas: 9

Variações: 29

Ritmo Harmônico: 2,07(divisão dos números de compassos e variações)

Média ideal: (divisão dos números de compassos e regiões tonais abordadas = $6,67)$

Esquema Formal

$(1-19)(20-25)(25-51)(51-60)$

T D D $\quad$ D $\quad$-D

I V iii I-V

2.2. Estrutura Analítica do Ofertório: Retórica e Harmônica (Primeiro Movimento)

\begin{tabular}{|c|c|c|c|c|c|}
\hline $\begin{array}{l}\text { RETÓRICA } \\
\text { DISPOSITIO }\end{array}$ & $\begin{array}{l}\text { FIGURA } \\
\text { ELOCUTIO }\end{array}$ & COMP. & $\begin{array}{l}\text { HARMÓNICA } \\
\text { SEÇÃO }\end{array}$ & TONALIDADE & FUNÇĀO \\
\hline EXORDIUM & $\begin{array}{l}\text { Palilogia } \\
\text { Aposiopesis } \\
\text { Pausa }\end{array}$ & $\begin{array}{l}2-5 \\
2-3 \\
6 \text { e } 9\end{array}$ & $\begin{array}{l}1 \text { a Seção } \\
1 \text { a Seção } \\
1{ }^{\text {a Seção }}\end{array}$ & $\begin{array}{l}\text { Sol Maior } \\
\text { Sol Maior } \\
\text { Sol Maior }\end{array}$ & $\begin{array}{l}T-I \\
T-I \\
T-I\end{array}$ \\
\hline NARRATIO & $\begin{array}{l}\text { Gradatio } \\
\text { Pausa } \\
\text { Synaeresis }\end{array}$ & $\begin{array}{l}10-17 \\
10-18 \\
18\end{array}$ & $\begin{array}{l}2^{\mathrm{a}} \text { Seção } \\
2^{\mathrm{a}} \text { Seção } \\
2^{\mathrm{a}} \text { Seção }\end{array}$ & $\begin{array}{l}\text { Sol Maior } \\
\text { Sol Maior } \\
\text { Sol Maior }\end{array}$ & $\begin{array}{l}T-I \\
T-I \\
T-I\end{array}$ \\
\hline PROPOSITIO & $\begin{array}{l}\text { Pausa } \\
\text { Metabasis } \\
\text { Synaeresis }\end{array}$ & $\begin{array}{l}22 \text { e } 25 \\
22 \\
25\end{array}$ & $\begin{array}{l}3^{a} \text { Seção } \\
3^{\text {a Seção }} \\
3^{\text {a Seção }}\end{array}$ & $\begin{array}{l}\text { Ré Maior } \\
\text { Ré Maior } \\
\text { Ré Maior }\end{array}$ & $\begin{array}{l}D-V \\
D-V \\
D-V\end{array}$ \\
\hline CONFUTATIO & Aposiopesis & $\begin{array}{l}28 \\
30-31\end{array}$ & 3 a Seção & Si Menor & $\begin{array}{l}\text { Dp-iii } \\
D-V\end{array}$ \\
\hline
\end{tabular}




\begin{tabular}{|c|c|c|c|c|c|}
\hline & $\begin{array}{l}\text { Epizeuxis } \\
\text { Synaeresis } \\
\text { Pausa } \\
\text { Gradatio }\end{array}$ & $\begin{array}{l}28-32 \\
30 \\
42 \text { e } 42 \\
33-43 \\
35-43\end{array}$ & 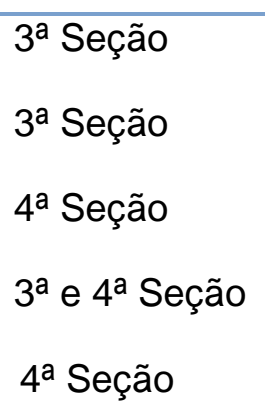 & $\begin{array}{l}\text { Si Menor } \\
\text { Si Menor } \\
\text { Si Menor } \\
\text { Si Menor } \\
\text { Si Menor }\end{array}$ & $\begin{array}{l}\text { Dp-iii } \\
\text { Dp-iii } \\
\text { Dp-iii } \\
\text { Dp-iii } \\
\text { Dp-iii }\end{array}$ \\
\hline CONFIRMATIO & $\begin{array}{l}\text { Epizeuxis } \\
\text { Aposiopesis } \\
\text { Synaeresis }\end{array}$ & $\begin{array}{l}43-47 \\
47\end{array}$ & 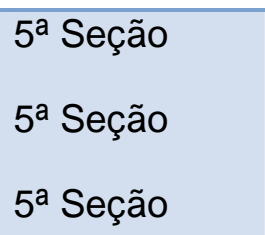 & $\begin{array}{l}\text { Si Menor } \\
\text { Si Menor } \\
\text { Si Menor }\end{array}$ & $\begin{array}{l}\text { Dp-iii } \\
\text { Dp-iii } \\
\text { Dp-iii }\end{array}$ \\
\hline PEROTATIO & $\begin{array}{l}\text { Pausa } \\
\text { Synaeresis } \\
\text { Aposiopesis }\end{array}$ & $\begin{array}{l}52 \\
54 \text { e } 57 \\
59-60 \\
58\end{array}$ & $\begin{array}{l}5^{\text {a }} \text { Seção } \\
\text { 5ª Seção }^{\text {5a Seção }} \\
5^{\text {a Seção }}\end{array}$ & $\begin{array}{l}\text { Sol Maior } \\
\text { Sol Maior } \\
\text { Sol Maior } \\
\text { Sol Maior }\end{array}$ & $\begin{array}{l}\text { T-I } \\
\text { T-I } \\
\text { T-I } \\
\text { T-I }\end{array}$ \\
\hline
\end{tabular}

Tabela 67: Estrutura analítica do Ofertório (Primeiro Movimento)

\subsection{Curva Tonal (Segundo Movimento)}

Tonalidade: Ré Maior

Andamento: Fugato Vivo Presto 2/4

Esquema de Progressões Harmônicas

\begin{tabular}{|l|c|l|}
\hline Compassos & $\begin{array}{l}\text { Função em relação a } \\
\text { tonalidade principal }\end{array}$ & Tonalidade (Acorde) \\
\hline $1-15$ & T-I & Sol Maior \\
\hline $16-17$ & D-V & Ré Maior \\
\hline $17-22$ & T-I & Sol Maior \\
\hline $22-27$ & Dp-iii & Si Menor \\
\hline $28-29$ & D-V & Ré Maior \\
\hline 29 & T-I & Sol Maior \\
\hline $30-31$ & Dp-iii & Si Menor \\
\hline $32-34$ & D-V & Ré Maior \\
\hline $35-50$ & T-I & Sol Maior \\
\hline
\end{tabular}

Tabela 68: Curva Tonal do Ofertório da Missa da Conversão de São Paulo Apóstolo (Segundo Movimento)

Números de compassos: 50 
Regiões abordadas: 4

Variações: 10

Ritmo Harmônico: 5 (divisão dos números de compassos e variações)

Média ideal: (divisão dos números de compassos e regiões tonais abordadas = $12,5)$

Esquema Formal

$(1-21)(22-27)(27-34)(35-50)$

$\begin{array}{cccc}\text { T } & \text { Dp } & \text { D } & \text { T } \\ \text { I } & \text { iii } & \text { V } & \text { I }\end{array}$

2.4. Estrutura Analítica do Ofertório: Retórica e Harmônica (Segundo Movimento)

\begin{tabular}{|c|c|c|c|c|c|}
\hline $\begin{array}{l}\text { RETÓRICA } \\
\text { DISPOSITIO }\end{array}$ & $\begin{array}{l}\text { FIGURA } \\
\text { ELOCUTIO }\end{array}$ & COMP. & $\begin{array}{l}\text { HARMÔNICA } \\
\text { SEÇÃOO }\end{array}$ & TONALIDADE & FUNÇÃO \\
\hline EXORDIUM & Pausa & $1-9$ & 1a Seção & Sol Maior & T-I \\
\hline NARRATIO & $\begin{array}{l}\text { Pausa } \\
\text { Noema }\end{array}$ & $\begin{array}{l}9-12 \\
11-13\end{array}$ & $\begin{array}{l}\text { 1ํa Seção } \\
\text { 1ª Seção }\end{array}$ & $\begin{array}{l}\text { Sol Maior } \\
\text { Sol Maior }\end{array}$ & $\begin{array}{l}\text { T-I } \\
\text { T-I }\end{array}$ \\
\hline PROPOSITIO & Noema & $13-21$ & 2 a Seção & Sol Maior & T-I \\
\hline CONFUTATIO & $\begin{array}{l}\text { Synaeresis } \\
\text { Auxesis } \\
\text { Metabasis }\end{array}$ & $\begin{array}{l}26 \\
28-30 \\
32\end{array}$ & $\begin{array}{l}2^{a} \text { Seção } \\
2^{\text {a }} \text { Seção } \\
2^{\text {a }} \text { Seção }\end{array}$ & $\begin{array}{l}\text { Si Menor } \\
\text { Ré Maior } \\
\text { Ré Maior }\end{array}$ & $\begin{array}{l}\text { Dp-iii } \\
D-V \\
D-V\end{array}$ \\
\hline CONFIRMATIO & Circulatio & $39-40$ & 3ำ Seção & Sol Maior & T-I \\
\hline PEROTATIO & $\begin{array}{l}\text { Circulatio } \\
\text { Pausa } \\
\text { Synaeresis }\end{array}$ & $\begin{array}{l}43-45 \\
41-44 \\
49\end{array}$ & $\begin{array}{l}\text { 3ª Seção } \\
\text { 3ª Seção } \\
\text { 3ª Seção }\end{array}$ & $\begin{array}{l}\text { Sol Maior } \\
\text { Sol Maior } \\
\text { Sol Maior }\end{array}$ & $\begin{array}{l}\text { T-I } \\
\text { T-I } \\
\text { T-I }\end{array}$ \\
\hline
\end{tabular}

Tabela 69: Estrutura analítica do Ofertório (Segundo Movimento) 


\section{CONCLUSÃO}

Procurou-se nesta dissertação, observar a utilização de elementos retóricos nos Ofertórios de André da Silva Gomes, e, para tanto, buscou-se, dispor neste trabalho, três vertentes metodológicas que se complementam. A primeira, baseada em investigações dos contextos históricos ocorridos desde a civilização greco-romana até o primeiro quartel do século XIX, passando pelos diversos tratadistas e compositores que corroboraram para a sistematização da retórica como disciplina, além de sua inserção na música; a segunda, estabelecendo o vínculo do compositor luso-brasileiro com a tradição retórica portuguesa, a qual influenciou sua formação; por último, foi realizada uma observação criteriosa e minuciosa, apropriando-se de ferramentas analíticas adequadas. Portanto, sendo expostos esses três objetivos, desenvolvidos em ordem cronológica, ao longo dessa conclusão.

Parte integrante do Trivium, a retórica auxilia o orador desde a Antiguidade para atrair a atenção do público de forma persuasiva, através de discursos eloquentes, seja em praças públicas, nos auditórios políticos e jurídicos, tendo por finalidade a adesão dos ouvintes à tese apresentada (GUIMARÃES, 2004, p.145). Nesse sentido, o elemento emocional torna-se fator crucial na edificação do discurso retórico. Não obstante, na música Barroca e início do Classicismo, mecanismos retóricos eram adotados pelos compositores, visando clarificar a significação dos enunciados musicais, por meio de recursos alegóricos utilizados para dar expressão e sentimento às palavras e música, isto é, ethos, pathos e logos, eram representados pelas figuras retóricas.

Efetivamente, essas figuras e elementos retóricos inseridos na música incluem grande quantidade de fenômenos musicais como repetições, desenvolvimentos, imitações, descrições, acordes, repetições de acordes, ornamentos, notas, seções de transição, contrastes, interrupções, silêncios, modificações dos timbres, condução das melodias, preparação das dissonâncias, posição e altura das notas, ou seja, existe um discurso altamente organizado pelos compositores com o intuito de convencer e induzir o ouvinte para um plano espiritual (CANO, 2000, pp.109-110).

Autores como Cláudio Monteverdi (1567-1643), Heinrich Schultz (15851672), Dietrich Buxtehude (1637-1707), Marc-Antonie Charpentier (1643-1704), 
Henry Purcell (1659-1695), Antônio Vivaldi (1678-1741), George Friedrich Haendel (1685-1759), Johann Sebastian Bach (1685-1750), Giovanni Battista Pergolesi (1710-1736), Carl Phillip Emanuel Bach (1714-1788), até mesmo Joseph Haydn (1732-1809), Wolfgang Amadeus Mozart (1756-1791) e Ludwig van Beethoven (1770-1827) aplicaram esses importantes recursos em suas obras, sendo que os três últimos as usavam sobretudo na música sacra. Por exemplo, Purcell divide em três partes (Exordium, Medium e Finis) o discurso da Abertura da Música para o Funeral da Rainha Maria II, igualmente aplica figuras de repetição melódica, tais como Epizeuxis e Anaphora, para enfatizar tanto o pesar quanto a devoção pela soberana inglesa. Por sua vez, Bach, no Magnificat utiliza, no início de seu terceiro movimento, a figura da Catabasis, reiterando a frase Humilitaten que pode ser traduzido como humilde, ou seja, o autor reforça a ideia de submissão, já em sua Cantata o․ 31- Der Hinmel lacht, die Erde jubilieret utiliza a figura da Anabasis com o intuito de júbilo e exultação ao Senhor.

Já a padronização e sistematização retórico-musicais deram-se por meio de inúmeros tratadistas, dentre eles podem ser destacados: Joachim Burmeister (1564-1629) que se preocupou em relacionar teoria, poética e prática, estabelecendo analogia com as figuras de retórica; Johannes Nucius (1556-1620) estudou a fundo as figuras retóricas na música sacra em seu tempo, Johannes Luppius (1585-1612) que considerava Luca Marenzio (15531599) e Orlando di Lasso (1532-1594) os grandes mestres que utilizavam elementos retóricos inseridos em suas obras, em plena Renascença; Marin Mersenne (1588-1648), figura crucial na transição do Renascimento para o Barroco, contribuiu relacionando a música às outras ciências; Athanasius Kircher (1601-1680), o qual estabelece síntese sobre as músicas alemãs e italianas do século XVII, introduzindo o termo Musica Phatetica ao descobrir a natureza afetiva da música com os princípios da disciplina retórica e, por último, podem ser citados dois grandes pesquisadores: Johann Mattheson (1681-1764) compositor, crítico e teórico musical, e Johann Nikolaus Forkel (1749-1818), considerado fundador da musicologia moderna (CANO, 2000, pp.251-261).

Seguindo a mesma senda doutrinária, Silva Gomes revela que o compositor bem instruído deve elaborar com diligência as ideias que serão 
dispostas na obra musical, tendo como base a imitação de sábios mestres, além dos preceitos contidos na Faculdade Retórica e Poética:

[...] não poderão avançar um dilatado terreno sem que sejam acompanhados, ajustados e socorridos pelos ótimos exemplares de insignes Mestres [...] Revela, pois, saber manejar, define um empréstimo de ideias de pensamentos, de sentimentos e passagens dos escolhidos exemplares que nos propomos a imitar ou aproximando-os ou diferenciando-os, ou diminuindo ou aumentando, os quais preceitos, próprios da Faculdade Retórica e Poética, nos quais supomos o nosso aluno de Composição de Música bem instruído, como preparatórios desta Faculdade que tratamos; por isto deixamos aqui de os explicar [grifos nossos] (SILVA GOMES, apud DUPRAT et al, 1998, pp.179-180).

Em outra passagem da Arte Explicada de Contraponto (como visto no tópico 4.3), André faz repetidas alusões à importância da instrução literária e, mais especificamente, da oratória na formação do compositor. Com isso, busca repetir na Colônia o saber contrapontístico obtido em seus anos de estudo junto ao Seminário Patriarcal de Lisboa, em outras palavras, ele referencia que o compositor, instruído como o filósofo, tem que estar apto a distinguir e a empregar os elementos retóricos em uma obra, tendo como partes integrantes a invenção das ideias (Inventio), disposição elaborada (Dispositio) e as figuras (Elocutio) (SILVA GOMES, apud DUPRAT, et al, 1998, pp.17-18). Enfim, tal instrução é necessária para construção de uma exposição sólida e eficaz.

Embora não haja referência de tratados retórico-musicais ou dos cânones de música poética alemã, tais como de Listenius (1537), Burmeister (1599/1606), Nucius (1613), Kircher (1650), Ahle (1697), Vogt (1719), Mattheson (1721/1739), Walter (1732), Scheibe (1737), Spiess (1745) e Forkel (1788-1801,1792), entre outros, não exprime que no mestre de capela faltasse à sapiência e cabedal necessários para a elaboração e constituição da retórica em suas peças, primeiro, como afirma Ana Paixão (2008):

A relação entre música, gramática, retórica e poética não se limita à teoria alemã, podendo-se encontrar a mesma relação em quadros teórico-musicais italianos, franceses ou flamengos, mesmo não apresentando a indicação de música poética, adaptam terminologias ou técnicas literárias para o domínio musical, sobretudo ao logo do período Barroco. Por exemplo, os tratados de Jacobus Faber Stapulensis (1500), Gioseffo Zarlino (1562), René Descartes (1618), Jean Joachim Quantz (1752) (PAIXÃO, 2008, pp.32-35). 
Segundo, por Portugal possuir tradição na transmissão da retórica, na esfera deliberativa, politica e especialmente religiosa, desde os primórdios da Idade Média, até a transição para o Classicismo. Porquanto, é notório que as obras sacras do compositor luso-brasileiro se baseavam em textos bíblicos, repletos de alegorias, metáforas e simbolismos, produzidos com habilidade e domínio, pelo fato de ter sido professor de Gramática Latina, disciplina essa ensinada na sua formação, no país lusitano, associada à retórica. Fato verificável no seu Tratado, onde ele explica a inserção dessas duas disciplinas no processo composicional:

Os adjetivos 'docente' e 'utente' são, respectivamente, formas principais dos verbos latinos doceo, docui, doctum, (instruir, ensinar); e utor, usus, uti (usar, servir-se). Nota-se que André da Silva Gomes preferiu atribuir à harmonia um significado bastante peculiar. $\mathrm{O}$ termo é empregado como um elemento comum ou mediador: a doutrina utente, ou seja, a composição, serve-se dos preceitos da doutrina docente, o contraponto. Seguindo seu raciocínio a analogia com a faculdade retórica torna-se evidente: [...] aqui se examina o contraponto relativo à parte da invenção e a composição relativa à disposição e à elocução (LANDI, 2007, p.32).

Portanto, as orientações de André da Silva Gomes em sua Arte Explicada de Contraponto demonstram sua proficuidade e proficiência sobre 0 assunto. Pois, como bem salienta Santo Agostinho, a transmissão dessa arte não é exclusiva de uma escola ou nação, ela é inerente ao ser humano, podendo ser aprendida, conhecida e assimilada por nações diferentes, de modos diversificados. (AGOSTINHO, [397-426] 2002, livro III, cap.29 § 40, p.185).

Em síntese, ao examinar a tradição e o contexto histórico-social, no qual estava inserido o compositor luso-brasileiro, pode-se evidenciar sua consciência na aplicação desses recursos retóricos, pois é sabido que o mesmo era um artista de considerável erudição, que acompanhava atentamente os progressos da ciência e da música, deixando transparecer em sua obra o pleno conhecimento acerca da arte da eloquência, o que desvela sua sólida formação, onde a Retórica é tida como "um saber interdisciplinar no sentido pleno da palavra, na medida em que se afirmou como arte de pensar e arte de comunicar o pensamento" (ARISTÓTELES [ALEXANDRE JUNIOR], 2005 p. 11). 
No que tange aos ofertórios, objeto de nossa pesquisa, pode-se afirmar que através de análises minuciosas, foram localizadas diversas figuras e elementos de retórica aplicados em suas estruturas, relacionadas ao texto e à música, assim como nas funções harmônicas e no contraponto.

Por exemplo, no Ofertório da Missa de Ascenção do Senhor, Silva Gomes emprega como figura central a Anabasis, diferentemente do Ofertório da Missa do Primeiro Domingo do Advento onde ele utiliza a figura da Catabasis, fazendo um apelo ao ouvinte de humilhação e subordinação ao Senhor, já no anterior o apelo é de júbilo, alegria e reconhecimento da superioridade e majestade do Senhor.

Ainda dissertando sobre o Ofertório da Missa do Primeiro Domingo do Advento, há de se ressaltar que o quarto mestre de capela da Sé de São Paulo apresenta com propriedade essas duas figuras em dois momentos distintos: no final da primeira seção no Exordium, logo após o uso da Climax, com resolução na Cadência Autêntica Perfeita (compasso 8), a Anabasis que, acoplada a Auxesis, repete e enfatiza a expressão levavi animam mean (elevei minha alma), por meio de melodia ascendente. E na transição da Propositio para Confutatio, onde a Catabasis também é unida ao Passus Duriusculus numa carga emocional e afetiva maior que a anterior, expressando o desejo do peticionário em não ser envergonhado por seus inimigos Non erubescan (Não me envergonhe), numa melodia descendente.

Nos Ofertórios do Primeiro, Segundo, Terceiro e Quarto Domingo da Missa da Quaresma, vê-se que seus textos são todos originários do livro de Salmos, entretanto, com mensagens, afetos, Locus e figuras aplicadas em diferentes situações. Na primeira música o autor trabalha e adapta cada elemento buscando consonância à ideia de proteção e segurança, na segunda peça desenvolve sua aplicabilidade num contexto onde é ressaltada a palavra de Deus como bússola e fundamento para o cristão, apropriando-se da Circulatio, Anaphora, Palilogia, Epizeuxis, Variatio, Synonimia, Synaeresis e Pausa, entre outras figuras, no terceiro Ofertório, dispondo cada seção e parte do discurso corroborando a afirmação do salmista de que os preceitos do Senhor são justos e, por fim, na quarta, onde ele expõe em oito vozes na tonalidade de Dó Maior, utiliza a Palilogia e o Polyptoton, valorando tanto as repetições das palavras e notas quanto o afeto de devoção e regozijo. 
Quanto aos Ofertórios da Missa do Segundo, Terceiro Domingo e da Quarta-feira das Têmporas do Advento, nota-se que eles foram elaborados pelo compositor na tonalidade de Si bemol Maior, da mesma forma se observa o emprego da Auxesis e Synaeresis nas três composições, porém, o Ofertório da Missa do Terceiro Domingo do Advento fora escrito para oito vozes com tratamento de caráter responsorial e o da Missa da Quarta-feira é baseado não no livro de Salmos, mas sim em Isaías.

Nos demais Ofertórios, da Missa de Quarta-feira de Cinzas, Domingo da Paixão e de Ramos, Silva Gomes dispõe dos mecanismos retóricos como fundamentação de sua tese e argumentação, onde cada palavra, nota, acorde, função, Cadência, seção, figura, parte discursiva e fase são diligentemente organizadas.

Já nas obras constituídas de dois movimentos, Ofertório da Missa de Natal, Ascenção do Senhor e da Conversão de São Paulo o Apóstolo, encontram-se em tonalidades diferentes, Si bemol Maior, Ré Maior e Sol Maior, no entanto, as mesmas têm em comum o fato de seus respectivos segundos movimentos serem escritos em cânones, em forma de imitação.

Semelhantemente, é observável o uso daquela que, segundo Johann Ahle, é a figura mais comum, usada por vários compositores nas suas peças: a Epizeuxis nos quatorze ofertórios, seja em repetições das notas, motivos, frases, expressões e palavras, enfatizando-as.

Portanto, no Ofertório que é um dos segmentos do ritual da missa cristã, acontece uma reflexão e, ao mesmo tempo, se desenvolve a ação de fé do fiel, realizada anteriormente à Eucaristia, ou seja, nele está o fundamento de maior significância entre a entrega de Cristo que se sacrifica, ofertando sua vida pelo pecador e o cristão, que apresentam seus préstimos de gratidão a Deus, oferecendo seu louvor. Todo esse intento de dedicação plena se dá por meio de uma expressão do afeto que é trabalhado pelo autor ao longo das diversas seções de cada obra. Analogamente, os elementos e as figuras retóricas aplicadas dentro da Inventio, Dispositio e Elocutio (Decoratio) foram devidamente dispostos e ordenados, conforme o contexto de cada peça, isto é, contextualizadas diante das circunstâncias e particularidades do discurso, assim caracterizando o conhecimento e domínio do compositor. 


\section{REFERÊNCIAS BIBLIOGRAFICAS}

ABBAGNANO, Nicola. Dicionário de Filosofia. Tradução Alfredo Bosi. 2ª Edição. São Paulo: Martins Fontes, 1998.1030 p.

AFFONSO, Rodrigo Cardoso. Um Estudo sobre a Relação TextoMúsica: os Ofícios Fúnebres de José Mauricio Nunes Garcia. 156 f. Dissertação (Mestrado em Música) Programa de Pós-Graduação em Música, Centro de Letras e Artes, Universidade do Estado do Rio de Janeiro (UNIRIO), Rio de Janeiro, 2005.

AGOSTINHO, Santo. A Doutrina Cristã: Manual de exegese e formação cristã. São Paulo: Editora Paulus, 2002. 284 p.

ALEGRIA, José Augusto. Frei Manuel Cardoso compositor português (1566-1650). 1 1 Edição. Lisboa: Biblioteca Breve vol. 75. Instituto de Cultura e Língua Portuguesa, 1983. 98p.

. Polifonistas Portugueses. $1^{1 \underline{a}}$ Edição. Lisboa:

Biblioteca Breve vol. 86. Instituto de Cultura e Língua Portuguesa, 1984.121p.

O ensino e prática na música nas Sés de Portugal (da Reconquista aos fins do século XVI). 1' Edição. Lisboa: Biblioteca Breve vol.101. Instituto de Cultura e Língua Portuguesa, 1985. 142 p.

ALMEIDA, João Ferreira de. Bíblia de Estudo Pentecostal. 2ª Edição. Rio de Janeiro: Casa Publicadora das Assembléias de Deus, 1996. 2.160 p.

Bíblia Sagrada com Concordância. 12 Edição. São Paulo: Editora Vida, 1999. 1.302 p.

Bíblia de Estudo Vida. 2ª Edição. São Paulo: Editora Vida, 1999. 2.134 p.

Bíblia de Estudo de Genebra. São

Paulo: Editora Cultura Cristã (Sociedade Bíblica do Brasil), 1999.1710 p. 
AMARAL, llídio. Nótulas Históricas sobre os primeiros tempos da Academia das Ciências de Lisboa. Artigo. Lisboa: Academia de Letras de Lisboa Classe de Letras, 2009. 34 p. Disponível em: http://s1.acadciencias.pt/files/Mem\%C3\%B3rias/ll\%C3\%ADdio\%20do\%20Amaral/n\%C3\%B3 tulas\%20hist\%C3\%B3ricas.pdf Acessado em: 28 de Maio de 2010.

AMBIEL. Áurea Helena de Jesus. "LAMENTATIONES JEREMIAE PROPHETAE" DE ORLANDO DI LASSO: a aplicação da quinta categoria analítica de Joachim Burmeister. $436 \mathrm{f}$ Tese (Doutorado em Música) Instituto de Artes, IA, Universidade Estadual de Campinas (UNICAMP), Campinas, 2010. Disponível em: http://cutter.unicamp.br/document/?code $=000615946$ Acessado em: 16 de Julho de 2010.

"Lamentiones Jeremiae Prophetae" de Orlando Di Lasso: algumas figuras retórico-musicais na Lamentatio Prima Prima Diei (Feria Quinta In Coena Domin). Revista Acadêmica de Música Per Musi, Belo Horizonte, vol.18, pp.77-89, 2008. Disponível em: http://www.musica.ufmg.br/permusi/port/numeros/18/num18 cap 09.pdf Acessado em: 16 de Janeiro de 2010.

AMOSSY, Ruth (org.). Imagens de Si no Discurso - A Construção do Ethos. 1르 Edição. São Paulo: Editora Contexto, 2005. 205 p.

ANDRADE, Mário. Padre Jesuíno do Monte Carmelo. São Paulo: Livraria Martins Fontes, 1963. 273 p.

ANTUNES, Jorge. Anáfora, Epístrofe e Poliptóton identificação de figuras de linguagem na música eletroacústica, no âmbito da retórica e da eloqüência, com base em significações do tipo "persuasão". Caderno de Semiótica Aplicada vol.4 o․ 1, Junho, 2006, pp.1-9. Disponível em: http://200.145.78.103/index.php/casa/article/view/598/0 Acessado em: 13 de Novembro de 2009.

ARAÚJO, Fabiano. Prelúdio e Fuga $V$ em Ré menor do Cravo bem Temperado, Livro-I, BWV 848, de Johan Sebastian Bach- Uma análise retórico-musical. Estudando a Semântica das Paixões. Programa de Pós- 
Graduação em Música da Universidade Federal de Minas Gerais (UFMG), Belo Horizonte, 2005, pp.21-32. Disponível em: http://www.musica.ufmg.br/textos/cdsemantica/04Fabiano.pdf. Acessado em: 17 de dezembro de 2009.

ARISTÓTELES. Arte Retórica e Arte Poética. Tradução de Antônio Pinto de Carvalho. Rio de Janeiro: Edições de Ouro, s/d. 290 p. Ética à Nicômaco. Tradução Leonel Vallandro e Gerd Bornheim, Coleção Os Pensadores vol.IV Editora Abril Cultural, São Paulo, 1984. $330 \mathrm{p}$.

Retórica. Prefácio e Introdução Manuel Alexandre Júnior, Tradução e Notas Manuel Alexandre Júnior, Paulo Farmhouse Alberto e Abel do Nascimento Pena. 2 ${ }^{\text {a }}$ Edição. Lisboa, Centro de Filosofia da Universidade de Lisboa, Imprensa Nacional-Casa da Moeda, 2005.318 p.

ASSUMPÇÃO, S. E. M. Ascendência Retórica das Formas Musicais. 141 f Dissertação (Mestrado em Música). Programa de Pós-Graduação em Música, Escola de Comunicações e Artes, Universidade de São Paulo (USP), São Paulo, 2007.

BANDEIRA, José Ramos. Universidade de Coimbra: Edifícios do Corpo Central e Casa dos Melos vol.2. Coimbra: Coimbra Editora, 1947.310 p.

BARROS, Cassiano de Almeida. A orientação retórica no processo de composição do classicismo, observada a partir do tratado VERSCH EINER ANLEITUNG ZUR COMPOSITION (1782-1793) de H.C.Koch. $131 \mathrm{f}$. Dissertação (Mestrado em Música) Instituto de Artes, IA, Universidade Estadual de Campinas (UNICAMP), Campinas, 2006. Disponível em: http://libdigi.unicamp.br/document/?code=vtls000380274 Acessado em: 22 de Setembro de 2009.

BARTEL, Dietrich. Musica Poetica: musical-rhetorical figures in Germany Barroque music. Lincoln: University of Nebraska Press, 1997. 471 p. 
BEGHIN, Tom \& Sander M. Goldberg (orgs.) Haydn and the performance of rhetoric. Chicago: University of Chicago Press, 2007. 366 p.

BENITEZ, Vincent "Musical-Rhetorical Figures in the Orgelbüchlein of J. S. Bach," in Bach 18: pp. 3-21, 1987.

BERISTÁIN, Helena. Diccionário de Retórica y Poética. 7ª Edição: México. Universidade Nacional Autônoma do México, Editorial Porrua S.A, 1995. $510 \mathrm{p}$.

BINDER, Fernando; CASTAGNA, P. A. Teoria Musical no Brasil: 17341854. I Simpósio Latino- Americano de Musicologia, Curitiba, Janeiro de 1997. Curitiba: Fundação Cultural de Curitiba, 1998. pp. 198-217. Disponível em: http://people.ufpr.br/ budasz/CD10.pdf Acessado em: 02 de Abril de 2010.

BONDS, Marc Evans. Wordless Rhetoric. Musical Form and Metaphor of the Oration. Cambridge: Harvard University Press, 1991. 237 p.

BORÉM, Fausto \& LIMA, C.N. Heroe, Egrégio, para contrabaixo e cravo: aspectos didáticos e interpretativos em uma transição de uma cantata do repertório colonial brasileiro. Revista Acadêmica de Música - Per Musi, Belo Horizonte, vol.18, pp.40-51, 2008. Disponível em: http://www.musica.ufmg.br/permusi/port/numeros/18/Num18 cap 05.pdf Acessado em: 10 de Outubro de 2009.

BUELOW, George. J. Rhetoric and Music. The New Grove Dictionary of Music and Musicians. Ed.Sadie, S., Londres: Macmillan, 1980 vol.15, pp.793-803.

Rhetoric and Music. The New Grove Dictionary of Music and Musicians. Ed.Sadie, S., Tyrrell, J. , New York: Oxford University Press Published, INC, 2001 vol. 21, pp.260 - 275.

BUKOZFER, Manfred. La Música em lá época Barroca, de Monteverdi a Bach. 3ª Edição. Madrid: Alianza Editorial, 2002. 524 p. 
BURMEISTER, Joachim. Musical Poetics. Translated, with Introduction and Notes by Benito V. Rivera. Claude Palisca (org.). New Haven and London: Yale University Press, 1993. 306 p.

CALAFETE, Pedro. A disciplina de "Filosofia em Portugal" e o seu ensino nas universidades portuguesas. Revista Cervantes. Madri, vol.7, pp.19 2002.

Disponível

em:

http://www.cervantesvirtual.com/servlet/SirveObras/1248208868235151186584 6/203034 3.pdf Acessado em: 07 de Junho de 2010.

CANO, Rubén López. Música y Retórica en el Barroco. México, D.F: Gráfica da Universidade Nacional Autônoma do México, 2000, vol.1. 207 p. Disponível: http://www.geocties.com/lopezcano/Articulos/MRB/02.PrimeiraParte.pdf Acessado em: 17 de Maio de 2009.

\section{. Exemplos Musicais de Figuras Retóricas.}

México, DF: Gráfica da Universidade Nacional Autônoma do México, 2000. 30 p.

Disponível

em:

http://www.geocities.com/lopezcano/Articulos/MRB/04.ejemplos1.pdf Acessado em 22 de Maio de 2009.

CARDOSO, André. A Música na Corte de D. João VI, 1808-1821. São Paulo: Editora Martins Fontes, 2008. 281p.

CARVALHO, Maria do Socorro Fernandes de. Poesia e Agudeza em Portugal. 269 f. Tese (Doutorado em Literatura Portuguesa). Programa de Pós-Graduação de Teoria e História dos Estudos da Linguagem, Universidade Estadual de Campinas (UNICAMP), Campinas, 2004. Disponível em: http://libdigi.unicamp.br/document/?code=vtls000318262 Acessado em: 18 de Abril de 2010.

CASTAGNA, P. A. Sagrado e profano na música mineira e paulista da primeira metade do século XVIII. In: II Simpósio Latino-Americano de Musicologia, 1999, Curitiba. Anais. Curitiba: Fundação Cultural de Curitiba, 1998. pp. 97-125. Disponível em: http://people.ufpr.br/ budasz/CD08.pdf Acessado em 10 de Abril de 2010. 
. O 'Estilo Antigo' no Brasil, nos Séculos XVIII e XIX.

In: I Colóquio Internacional a Música no Brasil Colonial, Lisboa, Outubro de 2000. Anais. Lisboa: Fundação Calouste Gulbenkian, 2001. pp.171-215.

CASTRO, Aníbal Pinto de. Retórica e Teorização Literária em Portugal: do humanismo ao neoclassicismo. 2a Edição Lisboa: Impressa Nacional- Casa da Moeda, 2008. 756 p.

CHASIN, Ibaney. O canto dos Afetos: um dizer humanista. São Paulo: Perspectiva, 2004. 190 p.

CíCERO, Marco Tulio. De Claris Oratoribus Liber qui Dicitur Brutus. Edição Carlos Peter. Leipzig: Sumptibus Fr.Chr. Guil. Vogelii. 1839. 298 p.

De Oratore. $4^{\text {a }}$ Edição Cambridge: Harvard University Press, 1967. 524 p.

Retórica a Herênio. Tradução e Introdução. Ana Paula Celestino Faria. São Paulo: Hedra, 2005.315 p.

CIVRA, Ferruccio. (1991) Musica poetica: introduzione alla retorica musicale. Torino: UTET, 1991. $215 \mathrm{p}$.

COLLISANI, Amalia. Musica e Simboli. Sallerio Editora, Palermo: $1988.192 \mathrm{p}$.

CORBI, Fernando Marín. Figuras, Gesto, Afeto e Retórica na Música. NASSARE: Revista Aragonesa de Musicologia. Insituición "Fernando el Católico". Zaragoza, Vol. XXIII no. 1, pp.11-52. 2007.

COSTA, R.B. O Baixo contínuo no "officio de defuntos" de Lobo de Mesquita.172 f. (Dissertação em Música), Programa de Pós- Graduação da Escola de Música da Universidade Federal de Minas Gerais (UFMG). Belo Horizonte, $2006 . \quad$ Disponível em

http://www.dominiopublico.gov.br/download/texto/cp022514.pdf Acessado em : 18 de Fevereiro de 2011. 
CROWL, Harry. La Música en el Brasil Colonial antes de La llegada de La corte de D.João VI. Revista Textos do Brasil (Ministério das Relações Exteriores). Brasília, vol.12, pp.24-31. 2006. Disponível em: http://www.mre.gov.br/dc/espanol/textos/revistaesp12-mat1-2.pdf Acessado em: 17 de Abril de 2010.

DADISMAN, George. Some Observations on Dispositio and Elocutio in Bach's Wir eilen mit schwachen, doch emsigen Schritten from BWV 78» 2008. http://www.musicapoetica.net/bachbwv78.htm Acessado em 18 de Setembro de 2009.

DAVIS, John. Dicionário da Bíblia. 5ª Edição. Rio de Janeiro: Casa Publicadora Batista, 1977.

DICIONÁRIO GROVE DE MÚSICA; Edição Concisa. Rio de Janeiro: Jorge Zahar Editor Ldta, 1994. 1050 p.

DOTTORI, M. Ut Rhetorica Musica: análise do moteto $O$ Vos Omnes a dois coros, de Manoel Dias de Oliveira. Revista Música, São Paulo, vol. 3, n. 1, pp. 53-69. 1992.

DUPRAT, Régis. O Estanco da Música no Brasil Colonial. Yearbook. University of Texas Press. Vol.4, pp. 98-109. 1968.

Música na Matriz e Sé de São Paulo Colonial. Anuário Interamericano de Investigacion Musical, University of Texas. Astin, Vol.11, pp.8-68, 1975.

Garimpo Musical. São Paulo: Editora Novas Metas, 1985. $181 \mathrm{p}$. Evolução da Historiografia Musical Brasileira. Revista da Associação Nacional de Pesquisa e Pós-Graduação em Música (ANPPOM). Rio de Janeiro, №. 1, 1989. pp.32-36. Disponível em: http://www.anppom.com.br/opus/opus1/opus1-3.pdf Acessado em: 02 de Abril de 2010.

Música na Sé de São Paulo Colonial. São Paulo: Editora Paulus, 1995. $231 \mathrm{p}$. 
Música Sacra Paulista. Marília (SP): Editora Empresa Unimar, 1999. $308 \mathrm{p}$.

. O Estanco da Música no Brasil Colonial. In: Neide Marcondes; Manoel Lello Belloto. (Org.). Labirintos e Nós: imagem ibérica em terras da América. São Paulo: Editora Unesp, 1999, v., pp. 53-74.

Síntese e Monografia na História da Música Brasileira.

Revista da Associação Nacional de Pesquisa e Pós-Graduação em Música (ANPPOM). Salvador 1999. pp.1-16. Disponível em: http://www.anppom.com.br/anais/anaiscongresso anppom 1999/ANPPOM\%2 099/CONFEREN/RDUPRAT.PDF Acessado em: 16 de Junho de 2010.

Musicologia e Interpretação: Teoria e Prática. Guarujá, Revista Eletrônica de Divulgação Científica. Faculdade de Ciências e Letras Don Domenico, Vol.1/2, pp. 29-38. 2001. Disponível em: http://www.faculdadedondomenico.edu.br/revista don/musicologia ed1.pdf Acessado em: 03 de Junho de 2010.

A Música Sacra no Brasil colonial e imperial. Revista do Patrimônio Histórico e Artístico Nacional, Brasília vol. 29, pp. 243-255, 2001. Disponível em: http://www.iphan.gov.br/revistadopatrimonio Acessado em: 03 de Junho de 2010.

DUPRAT, Régis et al. A "Arte Explicada de Contraponto" de André da Silva Gomes. São Paulo: Arte \& Ciência, 1998. $192 p$

DURAN, Maria Regina da Cruz. Retórica e Eloqüência no Rio de Janeiro: 1759-1834.195 f. Tese (Doutorado em História) Faculdade de História, Direito e Serviço Social da Universidade Estadual Paulista Júlio de Mesquita Filho (UNESP), Franca, 2009. Disponível em: http://www.franca.unesp.br/poshistoria/Maria\%20Renata.pdf Acessado em: 12 de Março de 2010.

ESTEVES, José Manuel Vasconcelos. Ironia e Argumentação. Série Estudos da Comunicação. Lisboa: Livros LabCom, 2009. 136 p. 
FAVERO, L. L. Relações de poder no Brasil colônia: línguas gerais $x$ língua portuguesa. In: VIII ENI> e II SIACD, 2008, São Paulo. Anais do II Simpósio Internacional de Análise Crítica do Discurso e VIII Encontro Nacional de Interação em Linguagem Verbal e Não-Verbal. 2008. vol.01, pp.1-9. Disponível em:

http://www.fflch.usp.br/dlcv/enil/pdf/Artigo Leonor Lopes Favero.pdf Acessado em: 06 de Abril de 2010.

FERNANDES, Cristina. O sistema produtivo da música sacra em Portugal nos finais do Antigo Regime: a Capela Real e a Patriarcal entre 1750 e 1807. Tese 555 f. (Doutorado em Musicologia) Unidade de Investigação em Música e Musicologia, Universidade de Évora (UE), Évora, 2009.

FERREIRA, Aurélio Buarque de Holanda. Dicionário Aurélio Século XXI. Rio de Janeiro: Editora Nova Fronteira, 2001. 790 p.

\section{Novo Dicionário da Língua}

Portuguesa. 3ª Edição. Curitiba: Editora Positivo, 2004. 2120 p.

FERREIRA dos SANTOS, Mário. Curso de Oratória e Retórica. São Paulo: 9ª Edição, Livraria e Editora Logos, 1962. 232 p.

FERREIRA, Ivone. De uma retórica da persuasão para uma retórica da

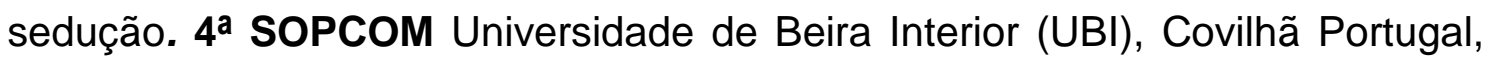
2005, pp.1820-1827. Disponível em: http://www.bocc.ubi.pt/pag/ferreira-ivoneretorica-persuasao-retorica-seducao.pdf Acessado em: 12 de Novembro de 2009.

FERREIRA, Valéria Maria Pena. Retórica das Lágrimas: sermões e orações fúnebres na Bahia do século XVII. $274 \mathrm{f}$. Tese (Doutorado em Letras) Programa de Pós- Graduação do Curso de Letras da Universidade Federal de Minas Gerais (UFMG), 2007. Disponível em: http://www.bibliotecadigital.ufmg.br/dspace/bitstream/1843/ECAP76LKJS/1/vers o da tese definitiva.pdf Acessado dia 10 de Março de 2010. 
FUBINI, Enrico. La Estética Música desde La Antigüedad hasta EI Siglo XX. 13ª Edição. Madrid: Alianza musical, 2002. 600 p.

GALLO, Alberto. História de la música; el Medievo. Madrid: Tuner Música, 1986, vol.3. 148 p.

GARCIA, A. S. Retórica: A Função Heurística da Linguagem. I Simpósio de Estudos Filológicos e Lingüísticos. Periódico. Circulo Fluminense de Estudos Filológicos (CiFEFiL), Faculdade de Formação de Professores (FFP) Universidade Estadual do Rio de Janeiro (UERJ), Rio de Janeiro, pp.1-9, 2008. Disponível em: http://www.filologia.org.br/revista Acessado em: 11 de Março de 2011.

GIRON, Luís Antonio. Minoridade Crítica- A Ópera e o teatro nos folhetins da Corte. Rio de Janeiro: Ediouro; São Paulo: Edusp, 2004. 415 p.

GROUT, Donald \& PALISCA, Claude. História da Música Ocidental. $4^{\text {a }}$ Edição. Lisboa: Editora Gradavia, 2007. 759 p.

GUIMARÃES, Elisa. Figuras e Retórica e Argumentação. In: MOSCA, Lineide do Lago Salvador. Retóricas de Ontem e de Hoje. $3^{\text {a }}$ Edição. São Paulo: Associação Editorial Humanistas, 2004. pp. 145-160.

HANSEN, J. A. Alegoria: Construção e Interpretação da Metáfora. São Paulo/Campinas: Hedra/Editora Unicamp, 2006. 320 p.

HOUAISS, Antônio. Dicionário Houaiss da Língua Portuguesa. Rio de Janeiro : Objetiva, 2001. 2922 p.

Dicionário Houaiss da Língua Portuguesa. Rio de Janeiro: Objetiva, 2009. 1986 p.

HOLLER, M. T. Uma história de cantares de Sion na terra dos brasis: a música na atuação dos jesuítas na América Portuguesa (15491759). 950 f. Tese (Doutorado em Música). Instituto de Artes, IA, Universidade Estadual de Campinas (UNICAMP), Campinas, 2006. Disponível em: http://libdigi.unicamp.br/document/?code=vtls000382848 Acessado em: 24 de Abril de 2010. 
JALÔTO, Fernando Miguel Marques; FALCÃO, José Antônio; COSTA, José Bruno da. V Festival de Música Sacra do Baixo Alentejo: Terras sem Sombra do Velho ao Novo Mundo. Revista, Lisboa e Beja: Artes das Musas e Departamento do Patrimônio Histórico e Artístico da Diocese de Beja 2009, $105 \mathrm{p}$.

JANK, Helena. E chorou amargamente... ; Figuras retórico- musicais e a expressão de extremo pesar... (Resumo). In: XVII Congresso da ANPPOM (Associação Nacional de Pesquisa e Pós-Graduação em Música), 2007, Anais, Brasília, 2007, vol.17, pp.1-11. Disponível em: http://www.anppom.com.br/anais/anaiscongresso anppom 2007/musicologia/ musicol HJank.pdf. Acessado em 15 de Março de 2009. - Tradução do tratado Das Neueröffnete Orchestre de Johann Mattheson (1713), Parte III, Cap.2. 2009, pp.1-6.

JAPIASSÚ, Hilton e MARCONDES, Danilo. Dicionário Básico de Filosofia. 3ª Edição. Rio de Janeiro: Editora Jorge Zahar, 1999. 296 p.

KIEFER, Bruno. História da Música Brasileira, dos Primórdios ao início do Século XX. Porto Alegre: Editora Movimento, 1977. 140 p.

LANDI, Márcio Spartaco. Lições de Contraponto segundo a Arte Explicada de André da Silva Gomes. Fortaleza: Expressão Gráfica e Editora, $2006.288 \mathrm{p}$.

LANGE, Francisco Curt. A organização musical durante o período colonial brasileiro. Coimbra: V Colóquio internacional de estudos lusobrasileiros, 1966. $106 \mathrm{p}$.

LAUSBERG Heinrich. Elementos de Retórica Literária. 5aㅡ Ed. Lisboa: Fundação Calouste Gulbernkian, 2004. 294 p.

LEONI, Aldo Luiz. Os que vivem da arte da música: Vila Rica, século XVIII. 184 f. Dissertação (Mestrado em História Social), Instituto de Filosofia, Ciências e História, IFCH da Universidade Estadual de Campinas (UNICAMP), Campinas, 2007, Disponível em: 
http://libdigi.unicamp.br/document/?code=vtls000415282 Acessado em: 06 de Junho de 2010.

LOPES-GRAÇA, Fernando. A Música Portuguesa e os seus Problemas- III. Lisboa: Edições Cosmos, 1973. 320 p.

LUCAS, Mônica Isabel. Humor e Agudeza nos Quartetos de Cordas Op.33 de Joseph Haydn. 273 f. Tese (Doutorado em Música). Instituto de Artes, IA, Universidade Estadual de Campinas (UNICAMP), Campinas, 2005. Disponível em: http://libdigi.unicamp.br/document/?code=vtls000391815 Acessado em: 18 de Julho de 2009.

. Origem das idéias de imitação e linguagem musical. In: Imitação e linguagem na música instrumental setecentista. São Paulo: FFLCH, 2007. pp.1-26.

Retórica e Estética na música no século XVIII. Revista ArtCultura (UFU), Uberlândia, vol. 9, pp. 223-234. 2007.

MACEDO, José Marcos Mariani de. A Palavra Ofertada: Uma análise retórica e formal dos hinos gregos e da tradição hínica grega e indiana. 310 f. Tese (Doutorado em Letras Clássicas). Departamento de Letras Clássicas e Vernáculas da Faculdade de Filosofia, Letras e Ciências Humanas da Universidade de São Paulo (USP), São Paulo, 2007, Disponível em: http://www.teses.usp.br/teses/disponiveis/8/8143/tde-13022008-110231/ Acessado em: 18 de Novembro de 2009.

MACHADO NETO, Diósnio. Administrando a festa: Música e lluminismo no Brasil colonial. $470 \mathrm{f}$. Tese (Doutorado em Musicologia). Programa de Pós-Graduação em Música, Escola de Comunicações e Artes (ECA), Universidade de São Paulo (USP), São Paulo, 2008, Disponível em: http://www.teses.usp.br/teses/disponiveis/27/27140/tde-05072009-230904/ Acessado em: 10 de Julho de 2009.

A censura das "luzes" na capela da Sé paulista, em 1774: modelos políticos, modelos musicais. In: XV Jornadas Argentinas de Musicología, 2010, Córdoba - Argentina. XV Jornadas 
Argentinas de Musicologia - Musica y Política - Resúmenes. Córdoba: sd, 2010. vol. $1 . \quad$ pp. 62-63. Disponível em: http://xa.yimg.com/kg/groups/17912635/525319024/name/Libro+Reusmenes++AAM-INM-UNC.pdf Acessado em: 16 de Março de 2011.

. Em vão vigiam as sentinelas: cânones e rupturas na historiografia musical brasileira sobre o período colonial. 322 f. Tese (Livre-Docência).Faculdade de Filosofia, Ciências e Letras (FFCLRP), Universidade de São Paulo (USP), Ribeirão Preto, 2011.

MACIEL, Ruy Homem de Mello. A forma sonata em descontinuidades e bifurcações. 422 f. Tese (Doutorado em Música). Programa de PósGraduação em Música, Escola de Comunicações e Artes, Universidade de São Paulo (USP), São Paulo, 2010, Disponível em: http://www.teses.usp.br/teses/disponiveis/27/27158/tde-10112010140659/en.php Acessado em: 21 de Dezembro de 2010.

MARIZ, Vasco. História da Música no Brasil. 6a Edição. Rio de Janeiro: Editora Nova Fronteira, 2005. 550 p.

MARROQUÍN, Lucía Díaz. La retórica de los afectos. Zaragoza: Estudios de Literatura 110 DeMusica 13, 2008. 330 p.

MATTHESON, Johann. Der Volkommene Capellmeister. Fac-simile do original de 1739 (Hamburg: Crsitian Herold). Kassel: Basel: Bärenreiter Verlag, 1954. $484 \mathrm{p}$.

. Der Volkommene Cappelmeister. FaksimileNachdruck herausgegeben von Margarete Reimann. Kassel und Basel: Bärenreiter - Verlag,1965.500 p.

MICHES, Urich. Atlas da Música. Madri: Alianza Musical Editorial, 1992, vol. 1. 286 p.

Atlas da Música do Barroco a Atualidade. Lisboa: Editora Gradavia, 2007, vol. 2.304 p. 
MONTEIRO, Donald Bueno. Música Religiosa no Brasil Colonial. Fides Reformata XIV São Paulo, №. 1, pp.75-100. 2009. Disponível em: http://www.mackenzie.br/fileadmin/Mantenedora/CPAJ/revista/Fides v14 n1 a rtigo-4.pdf Acessado em: 12 de Março de 2010.

MONTEIRO, Maurício. Música na Corte do Brasil: Entre Apolo e Dionísio 1808 - 1821 Revista Textos do Brasil (Ministério das Relações Exteriores). Brasília, vol.12, pp.32-39. 2006. Disponível em: http://www.mre.gov.br/dc/textos/revista12-mat4.pdf Acessado em 30 de Março de 2010.

NERY, Rui Vieira. O Olhar Exterior: Os Retratos dos Viajantes estrangeiros como fontes para o Estudo da Vida Musical Luso-Brasileira nos Finais do Antigo Regime. In: NERY, Rui Vieira (coord.) I Colóquio Internacional a Música no Brasil Colonial, Lisboa, Outubro de 2000. Lisboa: Fundação Calouste Gulbenkian, 2001, pp.72-91.

Espaço Profano e Espaço Sagrado na Música Luso-Brasileira do Século XVIII. Revista Música, São Paulo, vol. 11, pp.11-28, 2006.

OLIVERIA, André Luiz Muniz. O Magnificat de Johann Sebastian Bach: uma leitura à luz do seu significado retórico musical. 142 f. Dissertação (Mestrado em Artes) Instituto de Artes, IA, Universidade Estadual de Campinas (UNICAMP), Campinas, $2006 . \quad$ Disponível em: http://libdigi.unicamp.br/document/?code=vtls000275735 Acessado em: 11 de Março de 2010.

O uso de Figuras de Retórica Musical no Magnificat de Johann Sebastian Bach. In: XVI Congresso da Associação Nacional de Pesquisa e Pós-Graduação em Música (ANPPOM) Anais, Brasília, 2006. vol.16, pp.360-364. Disponível em: http://www.anppom.com.br/anais/anaiscongresso anppom 2006/CDROM/CO M/04 Com Musicologia/sessao02/04COM MusHist 0205-079.pdf Acessado em: 25 de Junho de 2009. 
OLVEIRA, L.F; MANZOLLI, J. Uma Visão Paradigmática do Significado Musical e Seus Recentes Desdobramentos. In: XVII Congresso da ANPPOM (Associação Nacional de Pesquisa e Pós-Graduação em Música), 2007, Anais, Brasília, 2007, vol.17, pp.1-13. Disponível em: http:/www.anppom.com.br/anais/anaiscongresso anppom 2007/semiotica/se miot LFOliveira JManzolli.pdf Acessado em: 17 de Outubro de 2009.

PACHECO, A. J. V. Música profana ocasional e poder no Império LusoBrasileiro. Claves (João Pessoa. Impresso), vol. 7, pp. 23-32, 2009. Disponível em: http://www.cchla.ufpb.br/claves/pdf/claves07/claves 7 musica profana.pdf Acessado em: 20 de Abril de 2010.

PAIXÃO, Ana Margarida Madeira Minhós. Retórica e Técnicas de Escrita Literárias e Musicais em Portugal entre os séculos XVII-XIX-vol. 1.390 f. Tese (Doutorado em Literatura Comparada) Programa em Estudos Comparatistas da Faculdade de Letras da Universidade de Lisboa em CoTutela na Univerisade de Nice Sophia Antipolis (França), Lisboa e Nice, 2008.

. Retórica e Técnicas de

Escrita Literárias e Musicais em Portugal entre os séculos XVII-XIX-vol. 2. 209 f. (Doutorado em Literatura Comparada) Anexos e Listas de Figuras. Programa em Estudos Comparatistas da Faculdade de Letras da Universidade de Lisboa em Co-Tutela na Univerisade de Nice Sophia Antipolis (França), Lisboa e Nice, 2008.

PASSOS, Henrique Romaniello. Vieira e Bach: uma retórica do espelhamento. 112 f. Dissertação (Mestrado em Literatura) Programa de PósGraduação do Curso de Letras da Universidade Federal de Minas Gerais (UFMG), $2006 . \quad$ Disponível em: http://www.bibliotecadigital.ufmg.br/dspace/bitstream/1843/ALDR6WEHSE/1/disserta o vers o agrupada pdf. Acessado em: 16 de Junho de 2009.

PERSONE, Pedro. As Obras 'Non Mesurés' para Cravo, Explicadas Segundo as Leis da Retórica. 160 f. Dissertação (Mestrado em Artes) 
Instituto de Artes, IA, Universidade Estadual de Campinas (UNICAMP), Campinas, $1996 . \quad$ Disponível em: http://libdigi.unicamp.br/document/?code=vtls000111845 Acessado em: 16 de Junho de 2010.

PLATÃO. A República. Trad. Enrico Corvisieri. São Paulo: Editora Nova Cultural, 1997. 259 p.

PLEBE, Armando. Breve História da Retórica Antiga. São Paulo: Editora Pedagógica e Universitária Ldta/ EPU, 1978. 108 p.

POLASTRE, Cláudia Aparecida. A música na cidade de São Paulo, 1765-1822. 255 f.Tese (Doutorado em Ciências Sociais)- Programa de PósGraduação em História Social do Departamento de História da Faculdade de Filosofia, Letras e Ciências Humanas da Universidade de São Paulo, USP, São Paulo, 2008.2 Disponível em: http://www.teses.usp.br/teses/disponiveis/8/8138/tde-13042009-154843/es.php Acessado em: 19 de Outubro de 2010.

REBOUL, Olivier. Introdução à Retórica. Tradução de Ivone Castilho Benedetti. 2ª Edição. São Paulo: Ed. Martins Fontes, 2000.253 p.

RICCIARDI, Rubens Russomano. Manoel Dias de Oliveira; Um compositor brasileiro em tempos coloniais-documentos e partituras. $142 \mathrm{f}$ + anexos. Tese (Doutorado em Artes)- Pós-Graduação em Música, Escola de Comunicações e Artes, ECA, Universidade de São Paulo, USP, São Paulo, 2000.

RODRIGUES, A.C. Análise de alguns aspectos retórico-musicais de "Domine, Deus, Agnus Dei" do Glória RV 545 de Antônio Vivaldi. Música Hodie. Programa de Pós-Graduação de Música da Universidade Federal de Minas Gerais (UFMG), Belo Horizonte, vol.6 №. 1. pp. 35-49, 2001. Disponível em: http://revistas.ufg.br/index.php/musica/article/view/1848/1755 Acessado em 17 de Setembro de 2009.

RODRIGUES, M. M. luminismo e Contra-lluminismo. In: Seminário Superior de Literatura Portuguesa, 2004, Rio de Janeiro. Anais. Cadernos da 
ABF, 2004. vol. IV. p. 116-131. Disponível em: http://www.filologia.org.br/abf/vol4/num1-08.htm Acessado em: 26 de Julho de 2010.

ROSEN, Charles El Estilo Clássico (Haydn, Mozart e Beethoven), Madrid- 3aㅡ Edição- Madrid: Alianza Musical Editorial S.A, 1999. 467 p.

SANTOS, Zulmira C. Entre a "doutrina" e a retórica: os tratados sobre os Quatro Novíssimos (1622) de Frei António Rosado O.P. In: Os “Últimos Fins” na Cultura Ibérica (XV-XVIII) Revista da Faculdade de Letras, Línguas e Literaturas, Universidade do Porto, Porto, pp.161-172,1997. Disponível em: http://repositorio-aberto.up.pt/bitstream/10216/8184/2/artigo5751.pdf Acessado em: 13 de Abril de 2010.

SCHREINER, C. Psalmo de anjinhos bem xibantes: representações musicais no salmo Laudate pueri (1813) de José Maurício Nunes Garcia. 96 f. Dissertação (Mestrado em Música) Programa de Pós-Graduação em Música, Universidade Federal da Bahia (UFBA), Salvador, 2008.

SHIBATA, Ricardo Hiroyuki. Retórica e Teorização na carta "a el -rei D. João” de Sá de Miranda.115 f. Dissertação (Mestrado em Letras) Instituto de Linguagem da Universidade Estadual de Campinas (UNICAMP), Campinas, 1996. Disponível em: http://libdigi.unicamp.br/document/?code=vtls000110440 Acessado em 19 de Outubro de 2010.

SILVA, C. H. Virtudes e vícios em Aristóteles e Tomás de Aquino: oposição e prudência. In: IV Colóquio do CPA - Política e Ética na Antigüidade Clássica, 1998, Campinas. Boletim do CPA, 1998. vol. 5/6. pp. 129-140. Disponível em: http://www.ifch.unicamp.br/cpa/boletim/boletim05/08silva.pdf Acessado em: 24 de Junho de 2010.

SILVA, Flávio Mateus da. "Behold a virgin shall conceive e $O$ thou that tellest good tidigns" -do oratório- "O Messias" de George Friedrich HaendelUma análise retórico-musical. Estudando a Semântica das Paixões. Programa de Pós-Graduação em Música da Universidade Federal de Minas Gerais (UFMG), Belo Horizonte, 2005, pp.33-49. Disponível em: 
http://www.musica.ufmg.br/textos/cdsemantica/05Flávio.pdf Acessado em 17 de Setembro de 2009.

SILVESTRE, João Paulo. A Informação Retórica no Vocabulário Portuguez e Latino (1712-1728) de Rafael Bluteau: da descrição à Composição Literária. In: Retórica. Actas do I Congresso Virtual do Departamento de Literaturas Românicas, Faculdade de Letras da Universidade de Lisboa 2005, Anais, Lisboa, 2005, pp.1-14. Disponível em: http://clp.dlc.ua.pt/Publicacoes/informacao retorica vocabulario.pdf Acessado em: 22 de Janeiro de 2010.

SOARES, Eliel Almeida; NOVAES, Ronaldo. Figuras de Retórica no Ofertório da Missa do Primeiro Domingo da Quaresma de André da Silva Gomes. VIII SEMPEM (Seminário Nacional de Pesquisa em Música) 2008. Anais. Programa de Pós-Graduação Stricto Sensu da Escola de Música e Artes Cênicas da Universidade Federal de Goiás (UFG), Goiânia: Editora Vieira, vol.8, 2008, pp.101-110. Disponível em: http://www.musica.ufg.br/mestrado/anais/anais\%20do\%20VIII\%20Sempem/SE MPEM on-line2008.pdf Acessado em 22 de Maio de 2009. Utilização de Figuras de Retórica na Harmonia de André da Silva Gomes. In: I Encontro de Iniciação Científica em Musicologia- ECA-USP. 2009. Anais. Ribeirão Preto. III Encontro de Musicologia de Ribeirão Preto- vol. 03.2009, pp. 1-9.

SOARES, Eliel Almeida; MACHADO NETO, Diósnio. A Aplicação de Figuras e Elementos Retóricos em Dois Ofertórios de André da Silva Gomes. DAPesquisa, v. 4, p. 391-403, 2011. Disponível em: http://www.ceart.udesc.br/dapesquisa/files/03MUSICA Eliel Almeida Soares2 212.pdf Acessado em: 09 de Março de 2012.

SOARES, Paulo Augusto. Os Ofertórios de André da Silva Gomes. 183 f. Dissertação (Mestrado em Artes). Instituto de Artes, Universidade Estadual Paulista Júlio de Mesquita Filho (UNESP) São Paulo, 2000.

SOTUYO BLANCO, Pablo. Modelos Pré-Composicionais nas Lamentações de Jeremias no Brasil.301f. Tese (Doutorado em Música) 
Programa de Pós-Graduação em Música, Universidade Federal da Bahia (UFBA), Salvador, $2003 . \quad$ Disponível em: http://www2.ufba.br/ psotuyo/dir/artigos/Tese\%20PSB\%20\%20MPCLamBrasil\%20-\%20UFBA\%202003 Acessado em: 02 de Abril de 2010.

SOUZA, Euridiana Silva. Allemande-gigueé: Análise retórica de danças barrocas das Suítes francesas BWV 813 e 816, de Johann Sebastian Bach. Estudando a Semântica das Paixões. Programa de Pós-Graduação em Música da Universidade Federal de Minas Gerais (UFMG), Belo Horizonte, 2005, pp.14-20. Disponível em: http://www.musica.ufmg.br/textos/cdsemantica/03Euridiana.pdf Acessado em 17 de Setembro de 2009.

SOUZA, Militza Franco e. Uma análise musical do Adágio ma non tanto da Sonata em Mi Maior, BWV 1035 de Johann Sebastian Bach; Sob a luz da retórica música barroca. Estudando a Semântica das Paixões. Programa de Pós-Graduação em Música da Universidade Federal de Minas Gerais (UFMG), Belo Horizonte, 2005, pp.70-79. Disponível em: http://www.musica.ufmg.br/textos/cdsemantica/07Militza.pdf Acessado em 18 de Setembro de 2009.

TOLEDO, B. L. Essência e Alcance das Manifestações Barrocas no Universo Luso-Brasileiro. Revista Música, São Paulo, vol. 11, pp.29-44, 2006.

TONI, F.C (Org.); DUPRAT, Régis; VOLPE, M.A. Recitativo e Ária para José Mascarenhas. São Paulo: EDUSP, 2000. 178 p.

VAZ, H. C. de Lima, Escritos de Filosofia VII- Raízes da Modernidade. São Paulo: Edições Loyola, 2002. 291 p. (Coleção Filosofia$55)$.

VERNEY, Luís Antônio. O Verdadeiro Método de Estudar para ser Útil. Vol.1 Valensa [Nápoles]: Oficina de Antonio Balle [Genaro e Vicenzo Muzio], 1746. 322 p. 
VIANA, Rosane. Análise retórica e fenomenológica do recitativo e ária "Lascia cdío pianga" da ópera "Rinaldo" de George Friedrich Haendel. Estudando a Semântica das Paixões. Programa de Pós-Graduação em Música da Universidade Federal de Minas Gerais (UFMG), Belo Horizonte, 2005, pp.80-88. Disponível em: http://www.musica.ufmg.br/textos/cdsemantica/08Rosane.pdf Acessado em 18 de Setembro de 2009.

VIDAL, João Vicente. A Idéia do ‘Clássico'no classicismo. Retórica e Música no Final do Século XVIII. 171f. Dissertação de (Mestrado em Música). Escola de Música: Centro de Letras e Artes, Universidade Federal do Rio de Janeiro (UFRJ) Rio de Janeiro, 2002.

VIEIRA, Enesto. Diccionário Biográphico de Músicos Portuguezes. História e Bibliographia da Música em Portugal. vol.1 Lisboa: Mattos, Moreira \& Pinheiro, 1900.559 p.

\section{Diccionário Biográphico de Músicos Portuguezes.}

História e Bibliographia da Música em Portugal. vol. 2 Lisboa: Mattos, Moreira \& Pinheiro, $1900.519 p$.

ZARLINO, Gioseffo. Le Istitutioni Harmoniche. Reimpressão da edição de 1558.Trnaslations Program of the National Endowment for the Humanities, an independent federal agency, Yale University,1983.150 p.

\subsection{Sites Pesquisados}

José Mauricio Nunes Garcia

http://www.arqnet.pt/dicionario/garciajosemauricio.html Acessado em 30 de Março de 2010.

\section{Figuras de Retórica na Música}

Disponível em: http://figurasretoricomusicais.com Acessado em: 18 de Setembro de 2009. 


\section{Textos sobre Retórica Musical}

Disponível em: http://www.retoricamusical.com/home-1 Acessado em: 20 de Março de 2010.

Sobre História da Música Luso-Brasileira

Disponível em: http://www.caravelas.com.pt/Portugues.htm Acessado em 12 de Janeiro de 2010.

\section{Elementos de Retórica}

Disponível em: http://www.radames.manosso.nom.br/retorica Acessado em: 18 de Novembro de 2009. 